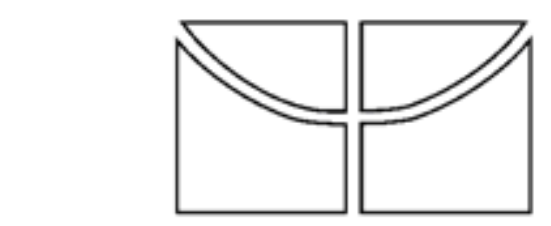

UNIVERSIDADE DE BRASÍLIA

FACULDADE DE COMUNICAÇÃO

PROGRAMA DE PÓS-GRADUAÇÃO

LINHA IMAGEM E SOM

CIRO INÁCIO MARCONDES

\title{
Uma poética do cinema silencioso
}

- Brasília, 2016 - 


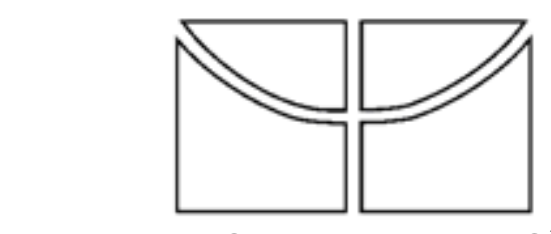

UNIVERSIDADE DE BRASÍLIA

FACULDADE DE COMUNICAÇÃO

PROGRAMA DE PÓS-GRADUAÇÃO

LINHA IMAGEM E SOM

CIRO INÁCIO MARCONDES

\section{Uma poética do cinema silencioso}

Tese apresentada ao Programa de PósGraduação em Comunicação da Universidade de Brasília/UnB como parte dos requisitos para a obtenção do título de Doutor em Comunicação Social, pela linha de Imagem e Som.

Orientador: Prof. Dr. Gustavo de Castro e Silva 


\section{CIRO INÁCIO MARCONDES}

\section{UMA POÉTICA DO CINEMA SILENCIOSO}

Tese apresentada ao Programa de Pós-Graduação em Comunicação Social da

Universidade de Brasília, e defendida sob avaliação da Banca Examinadora constituída por:

Prof. Dr. Gustavo de Castro e Silva

Orientador

Universidade de Brasília

Profa. Dra. Gabriela Freitas

Membro Interno

Universidade de Brasília

Prof. Dr. Sérgio Rizo

Membro Interno

Universidade de Brasília

Prof. Dr. Alexsandro Galeno Araujo Dantas

Membro Externo

Universidade Federal do Rio Grande do Norte

Profa. Dra. Florence Marie Dravet

Membro Externo

Universidade Católica de Brasília

Profa. Dra. Susana Dobal

Suplente

Universidade de Brasília 
Para Isabel Tarrisse, a melhor escolha da minha vida. Teu ser-poesia foi a maior inspiração para encontrar os caminhos deste texto.

Para João Rafael, meu sobrinho: uma vida em estado de poesia te aguarda. 


\section{AGRADECIMENTOS}

Ao meu orientador Gustavo de Castro, um humanista de primeira ordem que rompe as fronteiras entre a filosofia e a poesia e propõe um pensamento que celebra o lirismo como componente fundamental do entendimento do mundo. Obrigado pela mestria e pela amizade.

\section{A Alberto da Silva, Nancy Berthier e os pesquisadores do Centre de} Recherches Interdisciplinaires sur les Mondes Ibériques Contemporains (CRIMIC), em Paris IV - Sorbonne, que ofereceram tão imensa ajuda em Paris, abrindo e mostrando os caminhos para a fantástica experiência intelectual que vivi lá.

Aos professores e funcionários do PPG-COM da Faculdade de Comunicação da Universidade de Brasília, aos membros da linha de pesquisa Imagem e Som e aos pesquisadores do grupo Com Versações. Obrigado por compartilharem um ambiente intelectual estimulante e fértil, em que pude desenvolver minhas ideias livre e pacientemente.

À minha família: minha mãe Zulma, meu pai Luiz, meus irmãos João, Guga e Marcos, minhas cunhadas Ana e Vi. Obrigado por acreditarem em mim neste tempo todo.

A Raoni Vasconcelos e Béata Sitarek, meus queridos irmãos na França.

Aos amigos e colegas pesquisadores que, cada um em seu momento, me ajudaram a cimentar as ideias deste texto: André Costa, Adalberto Müller, 
Pablo Gonçalo, Thomaz Simões, Luiza Spínola, Alex Vidigal, Raimundo Lima, Maurício Fonteles, Ludimila Menezes, Fábio Crispim.

Aos amigos de sempre: não sou nada sem vocês. Suelem Jobim, Thiago Garcia, Chico Mozart, Claytinho, Davi Mattos, Santiago Mourão, Leonardo Menezes, Pedro Brandt, Ulisses Xavier, Gustavo Freitas, Andrea Dutra, Leonardo Messias, André Schmidt, Pollyanna Carvalho e meu afilhado Horácio.

À Vanessa de Moraes e ao Victor Cruzeiro, pela força na reta final.

Aos meus alunos na UnB, no IESB e no UniProjeção durante todos estes anos. Estou convicto de que a prática docente é indistinguível da minha prática como pesquisador, e uma coisa alimenta a outra a partir do contato com estudantes de todas as graduações.

E à CAPES/REUNI, pelo fomento às minhas ideias. 
Silêncio por favor

Enquanto esqueço um pouco

a dor no peito

Não diga nada

sobre meus defeitos

E não me lembro mais

quem me deixou assim

Hoje eu quero apenas

Uma pausa de mil compassos

Para ver as meninas

E nada mais nos braços

Só este amor

assim descontraído

Quem sabe de tudo não fale

Quem não sabe nada se cale

Se for preciso eu repito

Porque hoje eu vou fazer

Ao meu jeito eu vou fazer

um samba sobre o infinito

- Paulinho da Viola
No que é visto deve haver apenas o que é visto, no que é escutado deve haver apenas o que é escutado, no que é sentido (cheiro, gosto e tato) deve haver apenas o que é sentido, no que é pensado deve haver apenas o que é pensado.

- atribuído ao Buda (sutra Udana I)

POESIA

um

gato tenso

tocaiando o silêncio

- Orides Fontela 


\section{RESUMO}

MARCONDES, Ciro Inácio. Uma poética do cinema silencioso. 2016. 354f. Tese (Doutorado em Comunicação) - Curso de Pós-Graduação em Comunicação Social, Universidade de Brasília, 2016.

Orientador: Prof. Dr. Gustavo de Castro e Silva Defesa: 23/09/16

Este trabalho se propõe a elaborar uma poética do cinema silencioso a partir de elementos básicos constituintes deste cinema: a imagem, o silêncio e a poesia. Entre seus objetivos principais estão investigar a natureza das relações mediáticas entre som e silêncio, fala e silêncio, escrita e silêncio, imagem e palavra. O que ocorre, na percepção humana, quando um medium (a banda sonora) é retirado de outro medium (o cinema sonoro), gerando, por antecipação, o cinema silencioso? Trabalhamos com a hipótese de que o silêncio técnico do filme, associado a propriedades específicas da imagem, gera uma frequência (um medium que ocorre não na materialidade, mas na percepção) poética, mergulhando o espectador em estado cognitivo diferente. Neste caso, portanto, a poesia não é forma literária ou artística, mas sim ontologia. Para realizar esta investigação foram adotados alguns procedimentos metodológicos: o "hologramático", que prevê um corpus e um material de investigação policêntricos; o "fragmento", que encerra o conteúdo em pequenas porções dispersas, mas completas em si; a "iconologia dos movimentos", para se pensar a história da arte por meio das relações entre imagens; o "método erótico", que valoriza a aproximação entre sujeito e objeto; e a "razão poética", meta-método que propõe uma heurística por meio da poesia. Através deste procedimento, investigamos inúmeros filmes silenciosos e também sonoros, como $O$ vagabundo, Os vampiros, $O$ boulevard do crime, $O$ gabinete das figuras de cera, Ivan o terrível, Moana with sound, A ponte, Fantômas, Retrato de um homem jovem, entre outros. Como a poesia se adapta diferentemente em cada contexto mediático, cada análise constituiu um universo em si de cruzamento dos temas principais do trabalho. Isso também justifica a presença de análises dos pintores René Magritte e Claude Monet. Circundando os temas por meio desta investigação hologramática, chegamos à ideia de que a frequência poética se manifesta de maneira semelhante em media que compartilham a imagem e o silêncio, como a pintura e o cinema silencioso, e que todos eles fazem parte de um mesmo fenômeno de percepção.

Palavras-chave: Cinema silencioso; Poesia; Imagem; Silêncio; medium; pintura 


\section{ABSTRACT}

This study aims to develop the poetics of silent cinema guided by the basic constituent elements of these films: image, silence and poetry. Among its main objectives are investigate the nature of media relations between sound and silence, speech and silence, writing and silence, and image and word. What happens, in a human perception, when a medium (the soundtrack) is taken from another medium (the sound cinema), generating, in advance, the silent cinema? Our hypothesis is that the technical silence of the movie, associated with specific properties of the image, generates a frequency (a medium that occurs not in matter, but in perception) which is poetic, plunging the viewer into a different cognitive state of mind. In this case, therefore, poetry is not a literary or artistic form, but ontology. To conduct this research we adopted certain methodological procedures: the "holographic", which provides polycentric corpus and research material; the "fragment", which disposes the content in small dispersed portions, but complete in itself; the "iconology of movements", to think about the history of art through the relationships between images; the "erotic" method, which values the rapprochement between subject and object; and the "poetic reason", a metamethod proposing heuristics through poetry. Through this procedure, we investigated numerous silent and also sound films, such as The vagabond, The vampires, The children of paradise, Waxworks, Ivan the terrible, Moana with sound, The bridge, Fantômas, Portrait of a young man, among others. As poetry adapts differently to each media context, each analysis was a universe in itself crossing the main themes of the work. This also justifies the presence of the analysis of the painters René Magritte and Claude Monet. Surrounding the issues through this hologramatic research, we came to the idea that the poetic frequence often manifests itself in a similar manner in the media which shares image and silence, like painting and silent cinema, and that they are all part of the same perception phenomenon.

Keywords: Silent Cinema; Poetry; Image; Silence; medium; painting 


\section{LISTA DE FIGURAS}

Figura 1 - Fotograma de Nosferatu (F.W. Murnau, 1922) - 19

Figura 2 - Fotograma de Limite (Mário Peixoto, 1931) - 20

Figura 3 - Quadro "confuso" em Carlitos e Mabel se casam (Charlie Chaplin, 1914) -49

Figura 4 - Roscoe Arbuckle em Dois heróis (Mack Sennet, 1914) - 50

Figura 5 - Charlie Chaplin e Eric Campbell em Rua da paz (Charles Chaplin, 1917) - 51

Figura 6 - Fotograma de Página de loucura (Teinosuke Kinugasa, 1926) - 56

Figura 7 - Fotograma de Dois heróis (Mack Sennet, 1914) - 60

Figuras 8 e 9 - Fotogramas de O vagabundo (Charles Chaplin, 1915) - 62

Figuras 10, 11 e 12 - Fotogramas de Os vampiros - A cabeça decepada (Louis Feuillade, 1915) - 67-68

Figura 13 - Fotograma de A roda (Abel Gance, 1923) - 77

Figuras 14, 15, 16 e 17 - Fotogramas de Os vampiros - $O$ anel que mata (Louis Feuillade, 1915) - 79-80

Figuras 18 e 19 - Musidora atua como Irma Vep em Os vampiros - $O$ anel que mata (Louis Feuillade, 1915) - 80

Figura 20 - Intertítulos em Aurora (F.W. Murnau, 1927) - 89

Figura 21 - Intertítulos em $A$ greve (S. Eisenstein, 1925) - 89

Figura 22 - Fotograma de Os vampiros - O criptograma vermelho (Louis Feuillade, 1915) - 93

Figura 23 - Stacia Napierkowska atua em Os vampiros - O criptograma vermelho (Louis Feuillade, 1915) - 93

Figura 24 - Fotograma de Nosferatu (F.W. Murnau, 1922) - 93

Figuras 25, 26 e 27 - Respectivamente, fotogramas de Limite (Mário Peixoto, 1931), Terra (Aleksandr Dovjenko, 1930) e Homem de Aran (Robert Flaherty, 1934) - 99-100 
Figura 28 - Fotograma de Ivan, o terrível Parte 1 (Sergei Eisenstein, 1944) 106

Figura 29 - Nikolai Cherkasov atua em Ivan, o terrível Parte 1 (Sergei Eisenstein, 1944) - 108

Figuras 30 e 31 - Fotogramas de Moana (Robert Flaherty, 1926) - 112-113

Figura 32 - Isto não é uma maçã (René Magritte, 1964) - 118

Figuras 33 e 34 - Fotogramas de Nanook, o esquimó (Roberto Flaherty, 1922) $-134-135$

Figura 35 - Plano geral de O boulevard do crime (Marcel Carné, 1945) - 142

Figura 36 - Arletti interpreta Garance em O boulevard do crime (Marcel Carné, 1945) -142

Figura 37 - Fotograma de O boulevard do crime (Marcel Carné, 1945) - 144

Figuras 38 e 39 - Jean-Louis Barrault interpreta Baptiste em O boulevard do crime (Marcel Carné, 1945) - 147

Figuras 40 e 41 - Fotogramas de O boulevard do crime (Marcel Carné, 1945) 148

Figuras 42 a 45 - Barrault faz sua performance de mímica em $O$ boulevard do crime (Marcel Carné, 1945) - 150

Figura 46 - Fotograma de O boulevard do crime (Marcel Carné, 1945) - 156

Figuras 47 a 50 - Performance em O boulevard do crime (Marcel Carné, 1945) $-160$

Figuras 51 a 57 - Fotogramas de O gabinete das figuras de cera (Paul Leni, 1924) $-169-180$

Figura 58 - O primeiro plano em O grande assalto de trem (Edwin S. Porter, 1903) - 183

Figura 59 - Fotograma de The big swallow (James Williamson, 1901) - 184

Figuras 60 a 65 - Fotogramas de A ponte (Joris Ivens, 1928) - 195-199

Figura 66 - Os dois mistérios, René Magritte, 1966 - 204

Figura 67 - Reprodução proibida, René Magritte, 1937 - 205

Figura 68 - A condição humana, René Magritte, 1935 - 208 
Figura 69 - Mise-en-scène em Fantômas - à sombra da guilhotina (Louis Feuillade, 1913) - 211

Figura 70 - O assassino ameaçado, René Magritte, 1926 - 211

Figura 71 - René Navarre e os mil disfarces de Fantômas - à sombra da guilhotina (Louis Feuillade, 1913) - 214

Figura 72 - Fotograma de Fantômas - à sombra da guilhotina (Louis Feuillade, 1913) -215

Figura 73 - Perspicácia, René Magritte, 1936 - 217

Figura 74 - Ligações perigosas, 1926 - 219

Figura 75, 76 e 77 - Fotogramas de Fantômas - à sombra da guilhotina (Louis Feuillade, 1913) - 224

Figura 78 - O espelho vivo, René Magritte, 1928 - 227

Figura 79 - A interpretação dos sonhos, René Magritte, 1930 - 228

Figura 80 - As imagens e as palavras, René Magritte, 1929 - 231

Figura 81 - Claude Monet por Félix Nadar, 1899 - 234

Figura 82 - O lago, a ponte japonesa e os jardins de Giverny - 235

Figura 83 - Claude Monet por Sacha Guitry, 1918 - 237

Figura 84 - Autorretrato fotográfico de Claude Monet. Cerca de 1905 - 237

Figuras 85 a 87 - Série de telas retratando a estação de Saint-Lazare. Anos 1970. Claude Monet - 239-240

Figuras 88 e 89 - A série das catedrais de Rouen. Claude Monet. 1894-1895 242-243

Figura 90 - Uma das telas de nenúfares de Monet - 245

Figura 91 - Fotograma de Themis (Dwinell Grant, 1940) - 248

Figura 92 - Fotograma de H20 (Ralph Steiner, 1929) - 248

Figuras 93 e 94 - os salões com os painéis de Monet no Musée de l'Orangerie $-251$

Figura 95 - Manhã, Claude Monet, entre 1914-1926 - 257

Figura 96 - As nuvens, Claude Monet, entre 1914-1926 - 258 
Figura 97 - O sol se pondo, Claude Monet, entre 1914-1926 - 259

Figura 98 - Nebulosa de Rosetta - 260

Figura 99 - Simulação do movimento aleatório de partículas em colisão - 260

Figura 100 - Imagem de fundo de micro-ondas cósmicas fotografadas pelo observatório Planck a partir do espaço sideral - 260

Figura 101 - Reflexos verdes, Claude Monet, entre 1914-1926 - 261

Figuras 102, 103 e 104 - A manhã com salgueiros, A manhã clara com salgueiros e Os dois salgueiros. Claude Monet, entre 1914-1926 - 265

Figura 105 - Reflexos de árvores, Claude Monet, entre 1914-1926 - 268

Figura 106 - Fotograma de The life and death of 9413 - A Hollywood extra (1928, Slavo Vorkapitch e Robert Florey) - 272

Figura 107 - Fotograma de Rose Hobart (Joseph Cornell, 1936) - 273

Figuras 108 e 109 - Fotogramas de Children's party (Joseph Cornell, 1938) e Cotillion (Joseph Cornell, 1938) - 274-275

Figura 110 - Fotograma de A Day in Santa Fe (Lynn Rigs, 1931) - 276

Figuras 111 e 112 - Fotogramas de 24 dollar island (Robert Flaherty, 1926) 278

Figura 113 - Henwar Rodakiewicz - 280

Figuras 114, 115, 116, 117, 118, 119 e 120 - Fotogramas de Retrato de um homem jovem (Henwar Rodakiewicz, 1931) - 285-287 


\section{SUMÁRIO}

1. Introdução - 17

2. O terceiro vértice: cinema silencioso e poesia - 37

2.1 Primeiramente, a respeito de Chaplin - 37

2.2 Os vampiros: pequenas metonímias de imagem, movimento, presença e poesia - 61

2.2.1

Um vampiro escala um prédio e o cinema silencioso é inaugurado - 61

2.2.2 A interferência de um medium: palavra versus imagem - 76

2.2.3 A poesia redime o medium -89

2.3 Grito e Som - 97

2.3.1 Skrik -97

2.3.2 Ivan, o terrível e uma ubiquidade sonora e espacial - 105

2.3.3 Moana with sound... e com silêncio - 108

$3 \quad$ Mutações do silêncio - 115

3.1 Duas Dicotomias - 115

3.1.1 Um problema de terminologia -115

3.1.2 O silêncio ao redor -118

3.2 O boulevard do crime: o silêncio demarca a fala - 139

3.3 O gabinete das figuras de cera: escrevendo imagens a partir do silêncio - 165 
$4 \quad$ Inventário de imagens silenciosas - 181

4.1 Imagem e objeto -181

4.1.1 Revisão da fotogenia -181

4.1.2 A ponte: objeto indecidível - 193

4.2 O cinema silencioso de Magritte - 201

4.2.1 Imagem, abismo e ficção - 201

4.2.2 Imagem, corpo e palavra - 217

$5 \quad$ Nefelibatas: autorretrato em silêncio - 233

5.1 Autorretratos -233

5.1.1 A cinética de Claude Monet - 233

5.1.2 A série de painéis decorativos do museu de Orangerie - 244

5.1.3 Estrada para Retrato de um homem jovem - 268

5.1.4 Nefelomancia e outras coisas mais em Retrato de um homem jovem, de Henwar Rodakiewicz - 282

5.1.5 Nuvens -289

5.2 Abstração e silêncio a partir de Monet e Rodakiewicz - 293

5.2.1 Silêncio e alucinação -293

5.2.2 Silêncio e abstração - 305

5.2.3 Zen e razão poética -315

Considerações finais - 332 
Referências - 339

Filmografia incluída no pen drive - 353 


\title{
1 INTRODUÇÃo
}

\begin{abstract}
... la pluralidad de poemas no niega, sino afirma, la unidad de la poesía - Octavio Paz ${ }^{1}$
A rigor, o conceito de um poema científico é tão absurdo quanto o de uma ciência poética - Friedrich

Schlegel
\end{abstract}

Este trabalho é, antes de qualquer coisa, um trabalho sobre poesia. Este é seu corolário. Se vamos partir para investigar, conforme está bem descrito em seu título, o cinema silencioso, isto ocorre porque este cinema, antes alvo principal de análise, se tornou menor que o seu corolário. Antes de pensarmos em uma definição e uma etiologia para este cinema (ou melhor: estes cinemas), é preciso pensar no que motivou a investigação em primeiro lugar. O que ocorreu para deflagrar as cataratas de significação e ao mesmo tempo de paradoxo (em levas, ondas fortes) que nos induziram a associar, com veemência, dois temas tão díspares, desencontrados, que parecem não olhar um para outro? O que tem este cinema de poético, para dele se originar uma poética? O que é este cinema? O que são estes cinemas? E, é claro, assevera-se a pergunta difícil, irrespondível, mas inevitável: o que é a poesia? Ou poesias. O trabalho de se entrecruzar todas as poesias com todos os cinemas silenciosos, antes de (ao contrário do que parece) ser totalizante, é uma atitude de completa dispersão fragmentária. Não existe um cinema silencioso, assim como não existe uma poesia. Ainda assim, estes conceitos estão aí, circulam no imaginário, sobrevivem em pedaços, em espirais fractais, se interconectam por meio de seus inúmeros, detalhados aspectos. As redes de relações entre eles, se às vezes não se encontram, se às vezes se encaixam com precisão matemática, e se às vezes se contradizem com produzindo conflito, estão aí para que se pesquem possibilidades de sinergias, pontes neurais, sinapses de conhecimento.

Não haverá aqui um capítulo procurando definir a poesia. Só o poético a pode definir e, quando isto se efetiva, tanto a poesia quanto a definição se desfazem, se reconfiguram. A poesia tem a capacidade de se transformar a cada olhar individual. É

\footnotetext{
1“A pluralidade de poemas não nega, senão afirma, a unidade da poesia” (tradução nossa).
} 
um objeto quântico, uma impossibilidade racional que se materializa no corpo do mundo, das coisas, do pensamento e do entendimento humano. Antes de qualquer coisa, parece ser um princípio, no sentido mais arcaico que esta palavra pode carregar. Do Latim: principium (origem, causa própria, início). Antes de princípio, arqué (do Grego antigo: $\dot{\alpha} \rho \chi \eta ́):$ princípio que está contido no ser de todas as coisas. Portanto, para os que procuram um local para a poesia como forma literária, é hora de abandonar as esperanças. A poesia, neste trabalho, aparece como uma forma de ontologia. Suas possibilidades de investida no mundo aparecem nas coisas mais gerais, imensas, comuns a tudo o que existe. Ao mesmo tempo, sua dispersão fragmentária a torna um tropo muito peculiar, adaptável aos contextos mais específicos, detalhistas e mínimos. O paradoxo marca a poesia enquanto arqué (como marca toda e qualquer arqué) e, para se pensar esta relação, é preciso ter um olho na ordem e outro na desordem. Um na luz, e outro na sombra.

Não haverá aqui, da mesma forma, um capítulo procurando definir o cinema silencioso. Para isso existe uma miríade de estudos aplicados em historiografia do cinema. Não há definição, sabemos. Estes cinemas atravessam quatro décadas, estão submetidos a contextos complexos de ordem econômica, histórica, tecnológica, social e estética. Cada possível recombinação entre estes fatores gera um novo cinema e, por conseguinte, uma nova poesia. Cada investida que faremos neste período é uma rede lançada no mar de possíveis entrecruzamentos destes elementos todos. A cada rede que volta da maré teremos uma fauna diferente de animais simbólicos. Fosse a rede lançada outro dia, por outras pessoas, em outras condições marítimas, teríamos outros animais. É uma condição inexorável do pensamento, a de capturar apenas o fragmento. Além das condições atmosféricas e da braveza eventual do mar a que nos estamos lançando, há também a natureza da rede. Cada uma delas (e há tantas) captura animais diferentes. Não podemos falar sobre os peixes que pescamos neste momento, mas podemos falar da escolha da rede.

Por que cinema silencioso e poesia, em primeiro lugar? Pode ter sido o vislumbre da imagem vampírica de Nosferatu (Nosferatu, eine Symphonie des Grauens, F.W. Murnau, 1922, FIG.01), aos 14 anos. Antes disso, o cinema era uma coisa. Depois, não se transformou em outra coisa. Renasceu. Este novo parto tem a ver com o tema vampírico do filme. Todo filme silencioso é um filme de terror, de certa forma, porque 
está ressuscitando pessoas mortas. Cada imagem deste cinema é um aviso de nossa impermanência, é um sinal da ambiguidade da morte e, é claro, da ambiguidade da eternidade. O eterno e o perecível são ouroboros, e se transfiguram nestas imagens técnicas que sobrevivem para nós, resilientes, antigas mas ao mesmo tempo sempre renováveis. Este cinema, vampírico, possui o dom da pestilência: se ele nos toca, acaba nos transformando nele próprio.

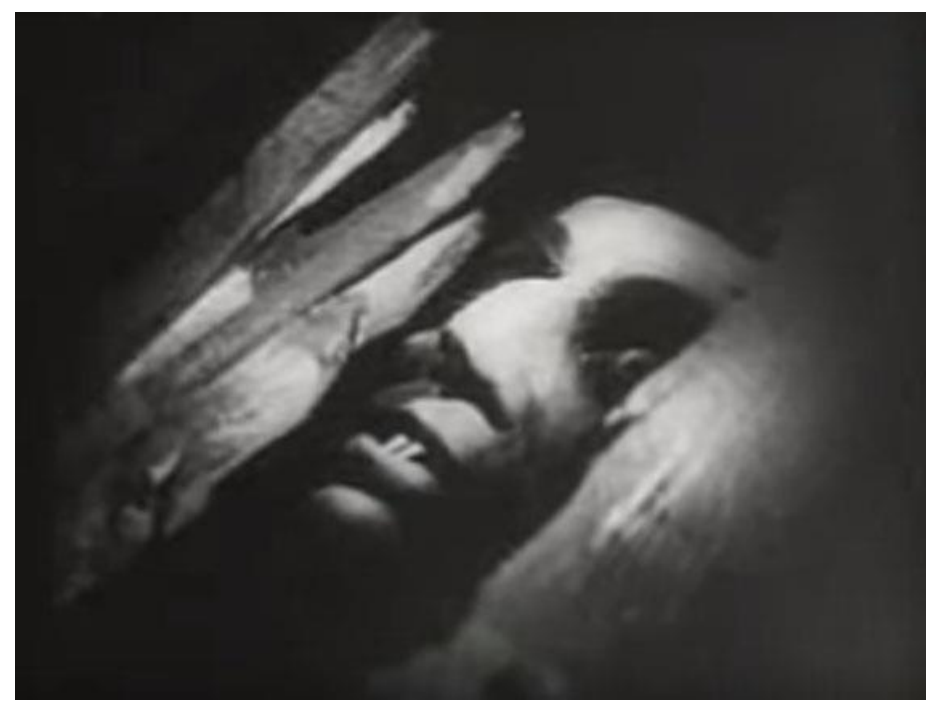

Figura 1

Pode também ter sido com Limite (Mário Peixoto, 1931, FIG.02), aos 21, filme brasileiro cujo horror (também metafísico) vem do mar e sua ameaça: a de nos tragar para sempre, como ocorre com seus personagens. Neste caso, o poder sedutor da maré (à espreita da morte), confunde com a metáfora da rede, o modesto instrumento usado para domar a imensidão inexorável do oceano. Estes cinemas silenciosos, de certa forma, são como janelas (sem moldura), não daquelas que nos transportam para outro mundo (para viver aventuras ficcionais), mas sim daquelas que comportam uma indiferenciação entre realidade e virtualidade, entre imagem e referente, entre sujeito e objeto. Se a associação entre cinema silencioso e poesia no título deste trabalho pareceu uma união de antípodas, é porque antes desconsideramos um terceiro elemento que funciona como enzima catalisadora de uma verdade que ocorre no meio destes processos: este elemento é o silêncio. 


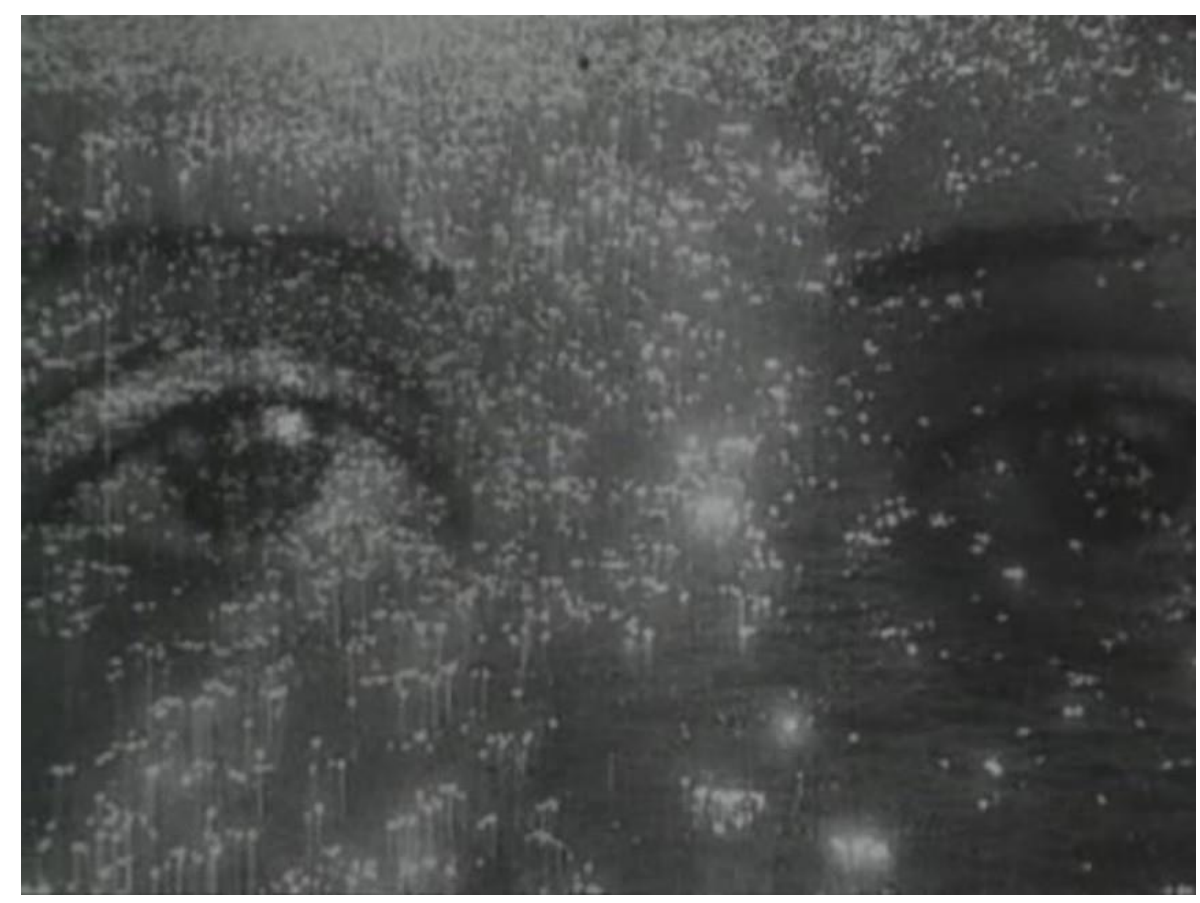

Figura 2

Se a poesia é o corolário de nossa reflexão, cinema e silêncio vão se tornar seus principais asseclas. Estes são os animais que queremos capturar com nossas redes. É o que justifica este trabalho ser uma poética. Em sua acepção de comum acordo, uma poética é um texto que procura definir a poesia e a literatura. É o que busca o literário na literatura; o poético na poesia. É um meta-método, portanto. Usa a palavra para procurar desbastar seu uso mais inalienável. A poética é fruto de uma razão instrumental, compartimentada, que procura aprisionar os termos do fenômeno da poesia e da literatura em camisas-de-força. Quanto mais se procura definir estes conceitos, mais eles perdem vitalidade, se espremem e se tornam paranoicos. Não à toa, a primeira poética foi escrita por Aristóteles, que alicerçou, quase em definitivo, a maneira como uma poética deve existir. Assim ele define, logo no início, a natureza do seu ofício:

Tratemos da natureza e das espécies de poesia, das características de cada uma, do modo como as fábulas se devem compor para dar perfeição ao poema; tratemos ainda da quantidade e da natureza de suas divisões e de tudo que pertença a esta matéria, começando, como a natureza pede, pelas coisas elementares (ARISTÓTELES, 2000, p. 37).

Natureza. Espécies. Características. Quantidade. Divisões. Coisas elementares. Aristóteles propõe, primeiramente, um método para a investigação dos fenômenos poéticos, literários e dramatúrgicos. Uma poética trata de um método. A rede 
aristotélica de observação da realidade foi uma das mais precisas em capturar, esquadrinhar e definir os animais retirados do mar. Com olho na divisibilidade e na possibilidade de catalogação infinita das coisas, ele estabeleceu um método de precisar o mundo, de aferir-lhe nomes, sentidos, ordem cósmica. Sua poética é, portanto, um sonho interminável e inatingível da humanidade, tão bem executado na ideia da biblioteca de Babel, de Borges: catálogos e mais catálogos de tudo o que for possível, e que cada palavra se torne um novo catálogo, e cada combinação entre as palavras, algo diferente daquilo que fora catalogado antes. Este sonho é premente e inatingível, mas guarda em si próprio a semente de nossa própria rede. Mais importante do que encontrar uma fórmula que classifique e justifique a existência de cada coisa individual que existe no mundo, o sonho de que isso um dia possa ser possível permanece como elemento de pregnância. Trata-se do sonho (poesia) do cientista. Nossa rede, de certa forma, é o contrário da de Aristóteles: se ele se foca no cientista, iremos nos focar no sonho. Nosso método não busca passar um pente fino em nosso objeto, mas sim avaliar as condições de nossa rede. De certa forma, o método que utilizamos aqui também é um metamétodo. Porém, ao invés de procurar usar a palavra para esgotar simbolicamente as possibilidades existentivas da poesia, vamos usar a poesia para verificar as possibilidades existentivas do observador. A poesia no procedimento é a única maneira de se falar tanto do procedimento, quanto da poesia. Nosso foco é a natureza do sonho do cientista. Nossa rede é a própria poesia.

Nossa poética, portanto, contém três elementos alienígenas a toda poética: em primeiro lugar, ela não recai sobre o texto literário, mas sim sobre sua antítese - a imagem do cinema silencioso. Em segundo lugar, mais longe ainda, nossa poética não investiga somente o mundo da palavra, aparentemente central a toda poesia, mas sim o do silêncio (expresso na imagem dos filmes e dos quadros), que configura outro tipo de visão sobre este tema. É uma poética silenciosa, e a investigação de um conjunto de temas tão carregados por aporias de definição requer um instrumental metodológico muito próximo do objeto, a ponto de se misturar com ele e compor, efetivamente, um pensamento que expanda seus horizontes de problematização. Se o objetivo da poética clássica, neste caso, é distinguir o que é o poético na poesia, buscando encalcar-lhe identidade, especificidade, nosso objetivo aqui é distinguir a poesia desta identidade. Perceber como seus ramos se espraiam por outras definições, tangem possibilidades não-experimentadas, produzem encontros improváveis. O contato com o cinema 
silencioso é uma associação fortuita, cheia de possibilidades. Se o nosso método pesca cinema, silêncio, imagem e poesia, que mundos são criados a partir deste microcosmo? A relação que vamos estabelecer entre estes temas se dá a partir de cinco princípios, todos dentro desta razão sensível, que estabelecemos como metodologia.

O primeiro princípio vem de Edgar Morin e se divide em duas noções: a do pensamento complexo e a da realidade hologramática. $\mathrm{O}$ primeiro procura mudar o paradigma de análise científica: da busca pela compreensão da completude (que se inicia em Aristóteles) sobre o mundo, procurando entender como cada elemento da realidade funciona, para a busca pelo entendimento da incompletude, ou seja, a compreensão de certa falibilidade do conhecimento em relação a este mundo. A procura é por compreender o motivo pelo qual as coisas são em si mesmo incompreensíveis:

\footnotetext{
O primeiro mal-entendido consiste em conceber a complexidade como receita, como resposta, em vez de considerá-la como desafio e como motivação para pensar. Acreditamos que a complexidade deve ser um substituto eficaz da significação mas que, como a simplificação, vai permitir programar e esclarecer.

Ou, ao contrário, concebemos a complexidade como o inimigo da ordem e da clareza e, nessas condições, a complexidade aparece como uma procura viciosa da obscuridade. Ora, repito, o problema da complexidade é, antes de tudo, o esforço para conceber um incontornável desafio que o real lança a nossa mente.

O segundo mal-entendido consiste em confundir a complexidade com a completude.

Acontece que o problema da complexidade não é o da completude, mas o da incompletude do conhecimento (MORIN, 2014, p. 176).
}

Morin considera a complexidade como a interface entre todas as relações possíveis entre as coisas do mundo, sendo naturalmente impossível depreender qualquer tipo de totalidade ou absoluto dele. A complexidade do real incita quem pensa o real a pensar na própria complexidade, e este é um ponto importante para Morin. Qualquer fenômeno humano possui desdobramentos biológicos, físicos, sociológicos, antropológicos, filosóficos, econômicos, tecnológicos, estéticos, etc. Como gerenciar tamanha dimensão de variáveis a respeito das possibilidades existentivas? Como transformar este princípio caótico em força que fortalece o pensamento, o conhecimento e a ciência? O princípio hologramático procura pensar uma estrutura metodológica que dê conta desta intensa descentralização da abordagem do pensamento sobre a realidade: 
informação do conjunto que ele representa. Bom, nós temos esse tipo de organização nos nossos organismos biológicos; cada uma de nossas células, até mesmo a mais modesta célula da epiderme, contém a informação genética do ser global. [...] Nesse sentido, podemos dizer que não só a parte está no todo, mas também que o todo está na parte (Ibid., p. 180).

Se o princípio da complexidade concebe uma realidade que se alterna como acêntrica (onde não podemos identificar um foco convergente para ela), policêntrica (onde o foco pode estar em vários locais ao mesmo tempo) e como cêntrica (onde, em determinadas circunstâncias, o foco se vetorializa em apenas uma direção), o princípio hologramático assume que todas estas noções de realidade podem estar contidas nos mesmos fenômenos, dotando-os de inúmeras (possivelmente infindáveis) perspectivas de abordagem. Quando Morin aplica este princípio para o pensamento, ele demole a possibilidade de que conceitos possam ser categorias fechadas, que possam encerrar qualquer coisa. A incerteza que gerou o conceito torna-se, portanto, uma variável importante em sua elaboração. Procuramos trabalhar aqui com estes princípios em duas direções: primeiro, que cada conceito se adapta a diferentes contextos diferentemente. Imagem, silêncio, medium, poesia e outros aparecerão em diversas situações em que precisarão se moldar à interface na qual estão sendo pensados, e muitas vezes o que será dito sobre eles em um momento ganhará outros contornos e conotações em momentos diferentes. Em segundo lugar, para que este fenômeno de multiplicação da valência dos conceitos (no sentido de fazê-los render em cada aplicação) transcorra bem, será necessário repeti-los exaustivamente. A reiteratividade barroca, nesse caso, é uma necessidade metodológica. Conceitos e contextos de análise inteiros serão revisados sob diferentes prismas e aplicações até o fim do texto.

O segundo princípio de nosso método vem do pensamento romântico de Friedrich Schlegel. Trata-se da dialética do fragmento. Diferentemente de seus pares como Schelling ou Novalis, que procuraram um pensamento mais sistemático, Schlegel escrevia em fragmentos, o que preconizou o pensamento moderno, ecoando fortemente, por exemplo, em Nietzsche e Walter Benjamin. Neste sentido, Schlegel parecia ser a antítese de Kant, o racionalista-mor, cujo objetivo era esgotar categorias puras da razão e esquadrinhar tudo que é possível ser pensado e entendido. Dono de um senso de humor e de um sarcasmo mordazes, Schlegel tratava seu pensamento com excelente inflexão metalinguística: ele tinha consciência de que o fragmento era método, e que ele era mais eficiente para abordar uma realidade evidentemente fragmentária. Assim ele 
fugia das tentativas de se construir fortalezas de conceitos encerrando a realidade que caracterizou boa parte do pensamento romântico. Na verdade, o pensamento de Schlegel representa a faceta mais radical do Romantismo, quando a própria vitalidade incessante das motivações dos românticos fez com que seus ideais se despedaçassem, deixando restar apenas a dialética do fragmento como pensamento possível. Porém, Schlegel tinha consciência de que o fragmento não era necessariamente um instrumento niilista de negação da realidade. É como afirma um de seus textos mais famosos: "Um fragmento tem de ser como uma pequena obra de arte, totalmente separado do mundo circundante e perfeito e acabado em si mesmo como um porco-espinho" (SCHLEGEL apud SUZUKI, 1997, p. 18).

A analogia do porco-espinho é precisa não apenas porque diz que cada excerto de pensamento está encerrado dentro de suas próprias contingências e lógicas, podendo ser hostil a contingências e lógicas vindas de outro locus; ela é precisa também porque antecipa o conceito da autopoiese, criado pelo epistemólogo Humberto Maturana, muito eficaz em avaliar o pensamento como algo sistêmico, ou seja, que funciona de uma forma dentro de um circuito interno, e de outras formas quando em contato com outros sistemas. Neste sentido, procuramos seguir o pensamento de Schlegel também em duas frentes: em primeiro lugar, aceitando que cada momento do texto é também uma espécie de fragmento, e que cada capítulo é um fragmento maior contendo diversos fragmentos menores que se comunicam muitas vezes por meio de certa hostilidade teórica. Desta forma, em segundo lugar, nossos fragmentos podem parecer perfeitamente integrados em sua autopoiese, mas podem também motivar conflito e imperfeição quando colocados em contato com outros fragmentos, produzindo um tipo de dialética que só se completa se continuarmos pensando em termos de complexidade. Assim, inúmeros materiais teóricos irrompem em momentos inesperados: elementos de artes diversas (pintura, teatro, música), ciências (física, química, astronomia, paleoantropologia) e media/medium (fotografia, histórias em quadrinhos, meios de comunicação do século XIX) aparecem para irrigar os sistemas compostos pelos temas gerais poesia, cinema, imagem e silêncio. Isso também justifica a imensa diversidade fragmentária do corpus fílmico, que não foi escolhido de acordo com sua importância ou mesmo por sua valência poética, mas sim porque os filmes ajudam especificamente a pensar com cada fragmento, dentro do contexto deles. Em muitos dos filmes analisamos nada mais que 
pequenos fragmentos, colocando ordem metonímica nesta relação: a parte no todo, e o todo na parte.

O terceiro princípio metodológico ao qual nos filiamos neste trabalho é aquele definido pelo historiador da arte Aby Warburg como iconologia dos intervalos, tal qual ele descreveu ao compor seu ambicioso projeto dos anos 1920, o Atlas Mnemosyne, grande livro feito somente com imagens cujo sentido historiográfico e estético era determinado pelas relações transversais entre estas imagens. Esta iconologia, conformada na ideia de "intervalo", previa uma leitura da arte que se baseasse sobretudo na não-linearidade das imagens e em suas relações disjuntas, eventuais, imprevisíveis. Em seu prefácio ao livro de Philippe Alain-Michaud sobre Warburg, Georges DidiHuberman traz à tona também o conceito de montagem de atrações, a famosa ideia de Sergei Eisenstein a respeito de como as imagens produzem uma dialética a partir da potência associativa que cada uma delas (especialmente no cinema) tem em atrair a potência da imagem seguinte. A sinergia provocada por estas atrações levanta todo tipo de relações simbólicas, semióticas, culturais, perceptivas e complexas. Em contraposição à atração existe ainda a ideia, também eisensteiniana, de choque entre as imagens, quando o atrito entre atrações opostas produz rupturas, fissuras, irregularidades. Atrações e choques, conjuntamente, portanto, fazem as imagens pensarem, e neste caso a estrutura própria do cinema em comunicar se transforma em método também para se elaborar uma epistemologia imagética para análises de arte, processos comunicacionais e ideias.

\footnotetext{
Uma terceira viagem nos indica em que a história da arte poderia transformar-se - em Hamburgo, onde o estudioso [Warburg] havia instalado seu famoso instituto - depois disso: num saber-movimento das imagens, um saber em extensões, em relações associativas, em montagens sempre renovadas, e não mais um saber em linhas retas, em corpos fechados, em tipologias estáveis.

[...] refiro-me, precisamente, ao caráter de "montagem de atrações" que seu pensamento usa em todos os níveis. A originalidade do ponto de vista proposto por Philippe Alain-Michaud - uma história da arte voltada para o cinema como maneira mais pertinente de compreender a temporalidade das imagens, seus movimentos, suas "sobrevivências", sua capacidade de animação - não é, portanto, desprovida de fundamentos epistemológicos e históricos (DIDI-HUBERMAN, 2013, pp. 20-21).
}

O método da montagem cinematográfica aplicado à história da arte por Michaud a partir de Warburg, portanto, nos serve não apenas porque não queremos pensar somente o cinema, e sim fazê-lo também pensar a partir de sua ordem estrutural, de sua 
maneira de comunicar. Como falamos extensivamente de imagens, é importante, neste caso, que estas se apregoem dos próprios fundamentos epistemológicos do texto e que possamos não apenas falar de cinema, mas também fazer cinema a partir desta iconologia e destas atrações. A montagem, portanto, será um conceito importante para fundamentar os arranjos entre os fragmentos construídos para o texto. Eles serão, assim, também imagens, que vão projetar sua potência sobre os outros fragmentos. É por isso que dedicamos também uma parte substancial deste trabalho ao pensamento sobre a arte e a pintura (nas figuras de Magritte e Monet), considerando que esta iconologia (conforme previa Warburg) não era exclusiva do método do cinema, mas extensiva a toda imagem e, em especial, a toda imagem silenciosa.

\begin{abstract}
Quando renunciamos a definir o dispositivo cinematográfico a partir de determinações materiais do filme, como a conjunção do suporte em celulóide flexível com a perfuração e as emulsões rápidas, para ver nele, de maneira mais original e mais ampla, o estabelecimento de uma relação conceitual entre a transparência, o movimento e a impressão, então vamos aflorar no campo do cinema categorias idênticas às que Warburg usou na história da arte. Na última década do século XIX, atuando em campos separados, o cineasta e o historiador da arte aplicaram processos idênticos, que revelavam uma orientação comum: à luz cruzada dos textos e dos filmes produziu-se na ordem dos discursos um deslocamento que nos levou a ver, no cinema, menos um espetáculo do que uma forma de pensar, e na história da arte, tal como praticada por Warburg, uma pesquisa menos voltada para o conhecimento do passado que para sua repetição no universo das representações (MICHAUD, 2013, p. 41).
\end{abstract}

O quarto princípio de nossa metodologia está em Michel Maffesoli e também se reparte em dois: em primeiro lugar, a ideia de deontologia. Ora, se podemos considerar a poesia um tipo de ontologia, ela determina o ser das coisas. Mas como abordar esta determinação se este ser da poesia é naturalmente esquivo, obscuro, deslocado? Quando para ele olhamos, já não está mais lá. Quando conseguimos capturá-lo, ele já se transmutou em alguma outra coisa. A ontologia a partir da poesia parte, portanto, não apenas da dispersão e da fragmentação, mas, de certa forma, da relação das coisas com seus negativos: sombras, desejos, irregularidades, impermanências, incertezas, sensações, afetos, imaginação, etc. É o que Maffesoli vai chamar de deontologia. Pensando no taoísmo chinês, a deontologia é uma ontologia a partir do yin, força de impermanência, obscuridade e destruição:

Como observa Carl Gustav Jung, "o racionalismo mantém com a superstição uma relação de complementariedade. Que a sombra aumenta proporcionalmente com a luz é uma regra psicológica; assim, quanto mais a consciência se mostrar racionalista, mais o universo quimérico do 
inconsciente ganhará em vitalidade". Pode-se interpretar de diversas maneiras tal observação, pode-se concordar quanto ao diagnóstico e lamentar as situações empíricas para as quais o mesmo remete; ainda assim, a atualidade nos dá inúmeros exemplos nesse sentido. Portanto, em vez de continuar pensando segundo um racionalismo puro e duro, em vez de ceder às sereias do irracionalismo, talvez seja melhor pôr em prática uma "deontologia" que saiba reconhecer em cada situação a ambivalência que a compõe: a sombra e a luz entremeadas, assim como o corpo e o espírito, interpenetram-se numa organicidade fecunda (MAFFESOLI, 1998, p. 19).

A deontologia propõe, portanto, um método adequado para se determinar o ser da poesia. Mesmo assim, não se trata de uma aplicabilidade mecânica que justifique incoerências lógicas e impertinências metodológicas. Não é a deontologia que busca a poesia como objeto, mas sim a poesia que, devido à sua natural impermanência enquanto ser e enquanto conhecimento (e, conforme veremos no corpo do texto, enquanto frequência), chega até a deontologia como forma de se autoprocessar. Neste, caso sujeito e objeto (e também observador e observado) estão extremamente próximos, deontologicamente imiscuindo-se um no outro. É o objeto, neste caso a poesia, que exige esta abordagem sobre si própria. Não há como elaborar um conhecimento potente sobre a poesia que não seja desta forma. Este tipo de abordagem vai contaminar, naturalmente, os outros objetos do texto (cinema silencioso, imagem, silêncio), que serão pensados essencialmente sob o prisma da ambiguidade e da impermanência. É daí que vem a segunda parte da proposição que extraímos de Maffesoli: o método erótico. Ao contrário do que prega a metodologia clássica e suas diretrizes de distanciar sujeito e objeto, a ideia de Maffesoli (baseada no raciovitalismo de Ortega y Gasset), seguindo o princípio de incerteza de Heisenberg, prega justamente o contrário: é a fusão entre observador e observado (um interferindo no outro) que produz um resultado verdadeiramente pulsante e fértil para propor novas categorias de pensar. A relação da ciência com o conhecimento, neste caso, ao invés de ser uma dialética (com o atrito proveniente do conflito entre os termos sendo determinante para uma síntese), torna-se uma erótica (a síntese provém da afinidade e do desejo de colaboração entre os termos):

Com efeito, é por intermédio das imagens que o microcosmo humano está correspondendo ao macrocosmo natural. Pode-se crer que assim será possível realizar uma nova harmonia que encontra seu fundamento na vida e, para além das diversas fragmentações, na potência do todo. É a isso que se pode chamar "raciovitalismo".

Isto é, aquilo que introduz um pensamento acariciante, que pouco se importa com a ilusão da verdade, que não propõe um sentido definitivo das coisas e das pessoas, mas que se empenha sempre em manter-se a caminho. No sentido estrito, trata-se de um "método" erótico, enamorado pela vida e que se empenha em mostrar sua fecundidade (Ibid., p. 113). 
A partir da revaloração de um pensamento (proposto por Maffesoli) vivificante e imbuído de nova energia capaz de encontrar diferentes sentidos para a verdade, chegamos ao nosso quinto e último princípio metodológico, desenvolvido a partir do pensamento da filósofa espanhola María Zambrano: trata-se da razão poética, que, de certa forma, confirma e aplica os princípios propostos por Maffesoli (ainda que tenha sido pensado muitos anos antes). Zambrano, em princípio, coloca a filosofia e a poesia como nascendo das mesmas inquietações. Porém, se a filosofia e a razão trilham o caminho da violência intelectual numa busca incessante por respostas, a poesia já não perfaz o caminho da busca. Ela já é contém a resposta em suas próprias contingências. Neste sentido, a filosofia seria a pergunta sem resposta. A poesia, por sua vez, seria a resposta sem pergunta. Zambrano primeiro reforça a oposição entre as duas, para depois desenvolver seu método:

E, precisamente, a partir desta maneira de enlaçar poesia e pensamento se faz mais difícil (impossível, na realidade), a reconciliação entre poesia e metafísica. Porque o poeta puro já não necessita dela. E, pelo outro lado, o filósofo moderno também crê realizar a essência do homem através de seu pensar metafísico. Dir-se-ia que poesia e pensamento vieram a ser duas formas de ação e por isso, mais do que nunca, se excluem, se ignoram $(\text { ZAMBRANO, 1996, p. 84) })^{2}$.

A transformação das ideias de Zambrano em um método para pensamento e poesia se dá, sim, através de uma reconciliação, mas não necessariamente de uma junção da metafísica com a poesia. Na verdade, é o sentido oculto da poesia que se estabelece como princípio. A manutenção dos mistérios das coisas e de áreas da existência que devem ser consideradas imperturbáveis traz às linhas da filósofa um tipo de razão oblíqua, em que somente a sublimação por meio de resoluções como a metáfora são capazes de dar conta da espessura da realidade. Assim, a razão poética é nosso último estágio metodológico porque ele já assume a dimensão (ou frequência) lírica da realidade, da percepção e do pensamento como uma forma capaz de unir opostos, encontrar pontes aparentemente invisíveis, deflagrar uma heurística para as contradições envolvendo conceitos tão ambíguos como imagem, silêncio e poesia. $\mathrm{O}$ conceito de Zambrano vai emergir, então, nos momentos mais difíceis de nossa argumentação, tanto no corpo da escrita, procurando resolvê-los no próprio desenrolar do significante, quanto conceitualmente, ajudando a conter tanto a polissemia quanto a

\footnotetext{
2 Tradução nossa.
} 
vacuidade do silêncio, assim como a potência e ao mesmo tempo o vazamento de significado da imagem.

A razão poética quer ser o âmbito onde o mistério possa aparecer como tal mistério. É dizer, dar constância de si sem chegar a ser enigma, conservando seu caráter sagrado. [...] Era preciso fazer ressurgir um universo simbólico que havia ficado petrificado no alvorecer da filosofia cristã e recuperar a circularidade da tradição órfica e platônica para se chegar ao que Zambrano pretendia: voltar a unir razão e vida, ser e existência, o centro de quietude e a ação cumpridora de um destino; lograr, no final das contas, a consciência da estância simultânea do homem em seus tempos múltiplos (MAILLARD, 1992, p. 12) . $^{3}$.

É dentro deste saber de retorno ao vitalismo e à simultaneidade de presenças dentro de um mesmo problema, vislumbrado por Zambrano, que finalizamos nossa proposta metodológica. Com a complexidade, abandonamos a ambição de totalidade, mas, com o método hologramático descobrimos que nosso objeto possui uma configuração policêntrica e pode ser abordado simultaneamente sob vários paradigmas diferentes. Com o fragmento, cada pequena parte do nosso objeto se torna um microcosmo fechado e sensível às alterações externas promovidas por outros sistemas, mas ainda assim retém sua autonomia fragmentária, autopoiética. Por meio da iconologia dos intervalos, iremos fazer nosso objeto ser pensado a partir de uma lógica imagética, com a ideia da montagem de atrações como propulsora de uma dialética própria às imagens. $\mathrm{O}$ cinema faz o texto pensar, e o texto faz o cinema pensar. A deontologia, método que propõe um pensamento a partir das fissuras entre os aspectos da realidade, será nosso instrumento para chegar ao ser da poesia (fazendo-a se tornar ontologia), e o método erótico aproxima nossa subjetividade do objeto a partir de um princípio afetivo, fazendo-nos pensar o mesmo objeto através de sua própria pulsão vivificante. Por fim, a razão poética permite realizar sínteses de pensamento sem que o objeto seja morto pela perda de seu mistério, sem que seja exaurido de sua essência. $\mathrm{O}$ grande trunfo deste método é a preservação do poético na análise da poesia. É como estudar os animais sem interferir em sua constituição física. É preservá-los em seu habitat, sem capturá-los ou dissecá-los. O gesto da razão poética, neste sentido, é o mesmo de libertar um animal de zoológico novamente na selva. É isso que pretendemos fazer com o cinema silencioso, a imagem, o silêncio e a poesia.

\footnotetext{
${ }^{3}$ Tradução nossa.
} 
Nosso corpus foi elaborado, portanto, para que possa dar conta da amplitude de tal metodologia. Ele obedece tanto à noção de fragmento, por ser pulverizado e disperso, quanto à de complexidade, pois procura entrecruzar cineastas, filmes, pintores e obras que, inseridos dentro de um universo próprio e bastante específico, possam projetar significação para os temas gerais do trabalho. A ideia, neste caso, é se aproveitar da inspiração em Warburg e sua iconologia dos intervalos para construir nossa própria memória (alinhada por afecções ligadas aos temas centrais do texto) impulsionada por relações transversais entre as imagens que constituem os filmes e obras artísticas analisadas. Assim, o corpus foi composto baseando-se em um princípio policêntrico. Em determinados momentos, a análise de um fragmento de um minuto e meio de um filme basta mais do que a imersão exaustiva em um filme de quatro horas de duração. Os filmes devem propulsionar o rendimento dos temas, e os temas devem liberar as relações escondidas por trás da aparente amenidade dos filmes. É por isso que, ao contrário do que havíamos imaginado no princípio da pesquisa, evitamos o uso de grandes filmes canônicos do cinema silencioso, mesmo os mais intimamente ligados a um contexto de poesia. Aurora (Sunrise, F.W. Murnau, 1927), O martírio de Joana D’Arc (La passion de Jeanne D'Arc, Carl T. Dreyer, 1928), Terra (Zemlya, Aleksandr Dovjenko, 1930), Um homem com uma câmera (Chelovek s kinoapparatom, Dziga Vertov, 1929), A roda (La Roue, Abel Gance, 1923), Os pescadores de Aran (Man ofAran, Robert Flaherty, 1934), Coração fiel (Coeur fidele, Jean Epstein, 1923), Página de loucura (Kurutta Ippēji, Teinosuke Kinugasa, 1926), Limite (Mário Peixoto, 1931), todos estes filmes (além de muitos outros) estão no cânone do cinema poético do período silencioso, mas são mencionados apenas en passant. Cada um deles certamente renderia um trabalho à parte, mas o principal critério para evitar estes filmes de grande peso histórico foi também evitar que a historiografia a respeito deles impedisse que o objetivo central do trabalho se desenvolvesse. Neste sentido, o corpus teórico é tão importante quanto corpus fílmico. Como dissemos no início deste texto, a poesia é o corolário de todo o trabalho. Os filmes selecionados não poderiam ser alvo de investigação extensiva devido ao volume de seu peso histórico e canônico. Seria mais adequado trabalhar, como já dissemos, com fragmentos e elementos pulverizados na trajetória do cinema silencioso. Mesmo os filmes com Chaplin, o cineasta mais conhecido presente no corpus, são todos curtas-metragens entre 1914-1917 e, logo, anteriores a todos os seus longas-metragens e filmes mais conhecidos. 
Assim, ao longo da pesquisa o corpus foi se erguendo junto com os temas centrais, que se tornaram foco do maior esforço teórico do trabalho. Silêncio, imagem e poesia, portanto, são tão importantes quanto cinema silencioso e pintura. Os mais de 25 filmes analisados, seja de maneira mais pontual ou pensados extensivamente junto à elaboração teórica, formam um todo de interinfluência com os temas. Uma poética deste cinema e seus desdobramentos (filmes falados, pintura, poesia literária, etc.) contém, ao mesmo tempo, todos estes filmes, mas não se aplica integralmente a nenhum deles. A poética silenciosa não é um guarda-chuva que abarque todos os filmes do período silencioso (entre as décadas de 1890 e 1930). Não basta ser um filme silencioso para ser um filme poético. Porém, conforme queremos argumentar, o silêncio inerente a estes filmes, motivado por uma "limitação" técnica (a ausência de falas sonoras), provoca uma mudança na modalidade de comunicação destes filmes. Isto se dá de inúmeras maneiras, e cada filme processa o silêncio de uma forma diferente. Cada uma destas formas gera uma alteração na frequência de percepção com que espectador recebe os filmes. Muitas destas frequências se enquadram naquilo que consideramos uma "frequência" poética, e é neste momento que o ser da poesia (portanto, seu estatuto ontológico) se manifesta, por meio da associação da imagem com o silêncio.

Apesar de ser policêntrica, a aplicação deste corpus não é aleatória. Os filmes foram escolhidos porque, sequencialmente, davam conta da narrativa teórica necessária para se pensar como a poesia aporta em media de imagens silenciosas como o próprio cinema silencioso e a pintura. Começamos com Chaplin, cuja motricidade de seu personagem anuncia esta poesia silenciosa, como espécie de nascimento. Partimos, portanto, do simples conceito da imagem em movimento em seus filmes rústicos, rodados em uma semana, sem qualquer intenção de grande feito artístico, para chegarmos, no último capítulo, à rarefação quase completa destes primeiros efeitos de um filme em grande parte abstrato. Retrato de um homem jovem (Portrait of a young man, de Henwar Rodakiewicz, 1931) cultiva uma intencionalidade completamente diferente, em grande parte olhando para o universo da pintura. Ambos são trabalhos com filmes silenciosos, e as diferenças entre eles são muito evidentes. Porém, de certa maneira, a transformação de Chaplin em Rodakiewicz compreende ao mesmo tempo um grande espectro representacional (da comédia farsesca à abstração) e um microcosmo bastante específico (a poesia dentro do cinema silencioso). Por mais que estas disparidades se reflitam por todo o corpus, a experiência destes filmes é ainda 
subsumida pelo silêncio e pela poesia. O que motiva isso é uma das intenções deste trabalho.

Há ainda, é claro, conforme anunciamos, a presença de corpos estranhos ao cinema silencioso dentro do material de análise selecionado. São os filmes falados (como Ivan, o terrível parte 1 - Ivan Grozniy, Sergei Eisenstein, 1944; e O boulevard do crime - Les enfants du paradis, Marcel Carné, 1945) e os pintores (como Edvard Munch, René Magritte e Claude Monet). Logicamente, se procuramos um método que inclua a complexidade tal qual descrita por Morin e pensarmos através de fissuras, elementos estranhos entrarão através delas. Os pontos de contato entre os campos adjacentes ao cinema silencioso naturalmente o invadem, pois, conforme já argumentamos, os sistemas se comunicam, produzem interferências operacionais.

No caso dos filmes falados, por um princípio ligado à própria deontologia, consideramos necessário pensar o silêncio e o cinema silencioso através de seus antípodas. Daí, para se compreender o silêncio, é necessário pensar o som (Ivan, o terrivel) e a fala ( $O$ boulevard do crime). Para se compreender o filme silencioso, mesmo que seja para a apreensão de uma transposição mediática, é necessário entender o medium que o substituiu (o cinema falado). A motivação que liga estes universos à constelação de fatores que os conectam aos temas principais do trabalho está bem detalhada no corpo do próprio texto. Já os pintores surgem em uma motivação ligada à iconologia dos intervalos. Como pensar de uma maneira cinematográfica sem se fazer cinema? Se elaboramos uma reflexão sobre a passagem da imagem silenciosa à imagem sonora, por que pensar que o elo de transposição desta cadeia de media não ocorreria também entre imagens técnicas (representadas pelo cinema - conforme previa Vilém Flusser) e imagens tradicionais (representadas aqui pela pintura). Se a poesia é o corolário destas relações, e elas estão plasmadas pelo silêncio, como elas se dão? É uma pergunta que a abordagem de um medium só (o cinema silencioso) não é suficiente. $\mathrm{O}$ pensar através das imagens comporta, portanto, todos os media imagéticos, e a pintura entra por esta fissura e se torna também, sob certo ponto de vista, cinema silencioso.

Por fim, cabem alguns esclarecimentos terminológicos sobre o vocabulário utilizado no texto. Optamos por usar, sempre que possível, os termos medium, media, mediático, medialidade e intermedialidade no lugar dos tradicionais mídia, mídias, 
meio, meios de comunicação, midialidade e intermidialidade. O motivo é, em primeiro lugar, porque boa parte da notação internacional a respeito do assunto unifica estes termos desta forma (basta conferir seu uso nas línguas inglesa, francesa, espanhola e alemã). Em segundo lugar (e não menos importante), é que os termos antigos suscitam muito maior ambiguidade do que a terminologia internacional. Mídia quer dizer, ao mesmo tempo, suporte, meio de comunicação, imprensa, etc. Ele se confunde com meio que, além de ser um sinônimo que concorre com mídia, ainda traz seu sentido original: caminho, forma de atravessar. Mantivemos o uso destes termos apenas quando se referem a expressões consolidadas na língua (por exemplo: "o meio é a mensagem”) e, no caso de meio, quando nos referimos ao seu sentido original. Meio de comunicação é ainda mais problemático, porque se refere a um recorte bastante específico, que são os media associados à tecnologia. Em nossa notação, portanto, medium é um conceito intensamente problematizado, que significa plataforma comunicacional por excelência ${ }^{4}$. Media é o plural de medium. Intermedialidade é o processo que se estabelece a partir da interação entre os media. São definições, por ora, meramente operacionais. Estes conceitos irão falar mais alto, e com maior complexidade, no decorrer do texto. Nossa contribuição terminológica é a ideia de frequência, que seria o medium quando aplicado fora da materialidade, ou seja, na pura percepção.

Este trabalho, pensado para ser um discurso hologramático, está dividido em quatro grandes capítulos que funcionam como "programas" a respeito de cinema silencioso, poesia, imagem e silêncio, com eventuais interferências do cinema falado e

\footnotetext{
${ }^{4}$ Ciro Marcondes Filho, ao organizar seu Dicionário da comunicação (2009), adotou (assim como adota em sua obra) a terminologia da notação internacional, e sua definição de media é precisa: "O termo mass media é, na verdade, equivocado, já que medium (e seu plural, media) é, para a física, o meio físico por onde passa o sinal comunicacional, não o próprio veículo que o transporta. No rádio, é o ar que repercute as ondas sonoras; no cinema, é a luz que permite, atravessando uma película cinematográfica, a projeção da imagem sobre uma tela; é a água que propaga o som emitido por algum sistema acústico. Quando se trata de jornais, revistas, rádio e televisão, mais certo seria, portanto, falar de veículos de comunicação e não de meios (MARCONDES FILHO, 2009, p. 242). Aqui, a definição de medium equivale a meio e a separa de "veículo". Como será perceptível na medida em que a leitura avançar, nossa definição procura ampliar a definição da física, podendo medium se referir tanto a qualquer plataforma comunicacional, seja ela a esteira para o sinal comunicacional, seu veículo ou até mesmo a categoria perceptiva por onde se desloca o pensamento. Neste sentido, vale mencionar a definição de Joachim Paech: "Dentre as inúmeras definições dos media, eu prefiro entendê-los como uma Forma - estética, ideológica, cultural - descrita pelo seu Medium" (PAECH apud MÜLLER, 2014, p. 196. Tradução nossa). Sobre o termo mídia, Marcondes Filho é enfático ao negar seu uso: "A forma brasileira mídia e suas variáveis [...] é uma construção linguística espúria, obtida a partir da pronúncia norte-americana do termo media e não se justifica essa incorporação ilegítima e empobrecedora, já que o termo medium é latino, como a própria língua portuguesa, e nos dota da forma linguisticamente mais correta do termo media. Além do mais, mídia é obrigatoriamente uma expressão no plural, cabendo, no máximo, a expressão "os mídia", devendo, contudo, a escrita manter a expressão os media" (MARCONDES FILHO, 2009, p. 249).
} 
da pintura. Cada um deles funciona como sistema autônomo, e eles possuem também sistemas menores encaixados um dentro do outro. $O$ espaço de interferência na operacionalidade programática deles faz com que, quando se tocam, eles se transformem a partir de um paradigma diferente de leitura dos mesmos temas. Lidos de maneira autônoma, porém, eles podem conter ideias que encerram um fechamento operacional. São, enfim, porcos-espinhos de Schlegel. Assim, é lícito pensar que existem quatro teses dentro desta tese, e não seria exagero dizer que são quatro teses diferentes, e que eventualmente entram em conflito resolvido somente nos espaços de abstração dos hiatos entre elas. Mesmo assim, o corpo geral do texto procura uma elaboração múltipla das relações entre estes conceitos, e a tese busca, no final das contas, sendo uma poética, fazer uma ciência poética (questionando diretamente a ironia de Schlegel na epígrafe). O poético aqui aparece não como exotismo, mas sim como base fundante da epistemologia de tudo o que for pensado a partir de agora. Nossa rede é a poesia, vale frisar novamente.

Dito isso, temos, no primeiro capítulo, "O terceiro vértice: cinema silencioso e poesia", uma entrada direta no coração da tese. Procuramos evitar alinhar conceitos, definições e abordagens para fazer o tema da poesia já entrar como foco e centro de análise, e agressivamente: através do conceito da violência. Para isso há uma explanação sobre o cinema de Chaplin relacionando violência e movimento como matrizes para o desenvolvimento da poesia no cinema silencioso. Esta argumentação é ampliada nos itens seguintes com a aparição da oposição entre palavra e imagem na análise da série Os vampiros (Les vampires, 1915-1916), de Louis Feuillade, finalizada com a ideia de que "a poesia redime o medium". Aqui aparece a primeira investida no conceito de imagem, e começamos a elaborar a ideia de que a poesia do cinema silencioso é oriunda não apenas do silêncio de seus filmes, mas também da imagem gerada, da montagem entre elas e do movimento (interno e externo) inerente a todo o processo. O item seguinte já anuncia metonimicamente os capítulos posteriores ao colocar o silêncio como problema para a constituição desta poesia muda. Dois atípicos filmes sonoros (Ivan, o terrível - parte 1 e Moana with sound) são problematizados como aporias da relação entre cinema silencioso e som, e isso abre as portas para o capítulo seguinte. 
"Mutações do silêncio" é um recomeço. Após a proposta de entrar violentamente com o tema principal em "O terceiro vértice: cinema silencioso e poesia", procuramos no capítulo seguinte pontuar, em primeiro lugar, questões terminológicas e técnicas sobre o cinema silencioso, para depois investir em sua etiologia (ou seja: sua origem, sua causa) e partir de duas problematizações: a da imagem-fantasma e a da descorporificação. Neste capítulo são também pensadas as manifestações sonoras do cinema silencioso (e sua participação no silêncio dos filmes) e a presença de intertítulos e letreiros, complexificando a questões a respeito de palavra e imagem trabalhadas em "O terceiro vértice: cinema silencioso e poesia". Estes temas serão muito intensificados nas duas grandes análises fílmicas seguintes: a de $O$ boulevard do crime, para pensar silêncio e fala; e a de $O$ gabinete das figuras de cera (Das wachsfigurenkabinett, Paul Leni, 1924), para pensar silêncio e escrita. O silêncio, portanto, é o tema deste capítulo.

O capítulo "Inventário de imagens silenciosas" retorna à imagem, retomando e ampliando o que foi discutido também em "O terceiro vértice: cinema silencioso e poesia". Para isso foi necessário revisar o clássico conceito de fotogenia e a problematização do objeto da imagem, que será também abordado no capítulo "Nefelibatas: autorretrato em silêncio". Isso tudo ganhará devida profundidade nas duas análises extensivas do capítulo: "imagem e objeto", com o filme A ponte (De brug, Joris Ivens, 1928), e "imagem e representação" na longa dissertação a respeito de Magritte e da série Fantômas. Aqui, a pintura emerge como elemento de cinema e se abre um novo caminho na tese, que é o escoamento da imagem do cinema silencioso para outros media. Este princípio será o tema do último capítulo.

"Nefelibatas: autorretrato em silêncio" é o maior capítulo da tese. Seu corpus se reduz a dois elementos principais: o filme Retrato de um homem jovem (Portrait of a young man, Henwar Rodakiewicz, 1931) e a série de painéis de Monet para o Museu da Orangerie, em Paris. Em primeiro lugar, há uma retomada, sob fôlego renovado, de tudo que havia sido pensado nos capítulos anteriores. A progressão de temas abordados nestas extensas análises parte daquilo que havíamos visto: a imagem, o silêncio, a poesia. Depois, outras relações se depreendem, dando à tese um acabamento e tons de desdobramentos últimos e mais avançados. O texto se encerra, portanto, nos temas da abstração, da alucinação, do Zen e da razão poética. 
É neste momento, investindo nos universos do Zen e da meditação, que olhamos definitivamente para os 'animais' colhidos em nossa rede teórica e metodológica. Tendo a poesia como corolário, e através da malha de análises, temas e conceitos, vimos florescer uma miríade de possíveis desdobramentos deste ato inicial que é elaborar uma poética. Mesmo que conscientemente trabalhando com problemas e objetos naturalmente indevassáveis e ambíguos, nosso sentido durante todo este percurso foi o de vislumbrar horizontes atrás de horizontes, como realidades encaixadas umas dentro das outras. Se um olho estava sempre na possibilidade de se descortinar um novo horizonte (e, portanto, um novo universo de abordagem), o outro estava na própria maneira de descobrir estes horizontes. Um estava, portanto, olhando para a virtualidade da imagem. O outro, na capacidade heurística da poesia. Como tantas obras poéticas de metáfora marítima, esta tese está interessada no que colhe a partir de suas investidas no mar das significações, mas está claro para nós, e assim também o ficará para o leitor, que o sentido de um trabalho é sempre a travessia. A maré está cheia. É hora de lançar a rede na vastidão inesgotável do oceano. 


\section{O TERCEIRO VÉRTICE: CINEMA SILENCIOSO E POESIA}

Il y a eu tant de mensonges, en ces temps où presque tout les hommes ont cru se battre pour la vérité, qu'on ose à peine affirmer l'évidence: un art est né pendent la guerra: N'est-ce pas l'évidence même?

Peu d'intellectuels en conviendront cependent. Mais le temps viendra où le cinéma, art tout neuf-on peut dire, si vouz le préferez, qu'il est une expression neuve de l'art et sans nombre - imposera toute sa force. - Louis Delluc ${ }^{5}$

\subsection{Primeiramente, a respeito de Chaplin}

Surpreendeu-me que eu estava testemunhando uma arte morta, um gênero totalmente defunto que jamais seria praticado novamente. E mesmo assim, com todas as mudanças que ocorreram desde então, o trabalho deles estava tão vivo e revigorante quanto na época em que fora mostrado pela primeira vez. Isso ocorreu porque eles tinham entendido a língua que estavam falando. Eles tinham inventado uma sintaxe para o olho, uma gramática de pura cinética e, exceto pelas fantasias, pelos carros e pelo mobiliário singular nos cenários, nada daquilo poderia envelhecer. Era o pensamento traduzido em ação, a vontade humana expressando-se através do corpo humano, e portanto isso era para sempre. A maioria das comédias silenciosas pouco se importavam em contar histórias. Elas eram como poemas, como a representação de sonhos, como alguma intrincada coreografia do espírito. - Paul Auster ${ }^{6}$

Por que começar com Charles Chaplin? Esta epígrafe retirada de um romance do escritor americano Paul Auster a respeito de um personagem que pesquisa a vida de um comediante de cinema silencioso (ao estilo de Chaplin) pode ser um bom gatilho para explicar esta opção. Quer estivesse falando de Chaplin, ou Buster Keaton, ou Harold Lloyd, ou Mack Sennet, ou Stan Laurel, ou Oliver Hardy, ou Roscoe Arbuckle, ou Mabel Normand, ou Harry Langdon ou qualquer das muitas dezenas de atores e atrizes que personificaram a comédia norte-americana durante o período silencioso do cinema

\footnotetext{
5 "Houve tantas mentiras nesta época onde quase todos os homens acreditaram lutar pela liberdade, que mal ousamos afirmar a evidência: uma arte nasceu durante a guerra. Não é óbvio? Poucos intelectuais, entretanto, concordarão. Mas o tempo chegará em que o cinema - arte toda nova - pode-se dizer, se vocês preferirem, que é uma expressão nova e sem nome da arte - vai impor toda a sua força" (tradução nossa). ${ }^{6} \mathrm{Em}$ The book of illusions, apud KOBEL, 2007, p. 55. Tradução nossa. No original: It stuck me that I was witnessing a dead art, a wholly defunct genre that would never be practiced again. And yet, for all the changes that had occurred since then, their work was as fresh and invigorating as it has been when it was first shown. That was because they had understood the language they were speaking. They had invented a syntax of the eye, a grammar of pure kinesis, and except for the costumes and the cars and the quaint furniture in the background, none of it could possibly grow old. It was thought translated into action, human will expressing itself through the human body, and therefore it was for all time. Most silent comedies hardly even bothered to tell stories. They were like poems, like the rendering of dreams, like some intricate choreography of the spirit.
} 
(especialmente entre as décadas de 1910 e 1920) -, quer estivesse falando de espécie de síntese do universo destes artistas todos, Auster guardou em seu texto uma importante preocupação: a de procurar definir a comédia silenciosa (e, por extensão, talvez todo o cinema silencioso) como um meio específico de produção de conhecimento. Ou seja: um tipo de epistemologia. O esforço do escritor, por meio do narrador-personagem, em explicar este tipo de cinema como linguagem, como algo cuja estrutura não se perde com a passagem do tempo, como um sistema autônomo de funcionamento, tudo isso contribui para iniciar e antecipar dados sobre a longa trajetória de reflexões sobre este cinema que se inicia agora, com Chaplin, e termina adiante, com Henwar Rodakiewicz. Este pequeno excerto extraído de um romance será para nós um Aleph, um primeiro limiar $^{7}$, que funciona como fragmento de sonho condensando informações em um fio que pode ser puxado e nos levar até a infância. Nossa Pedra de Rosetta, enfim.

Por que isso? Vejamos certas passagens cruciais do texto de Auster, colocadas em progressiva ordem estratégica: o trabalho deles estava tão vivo e revigorante quanto na época em que fora mostrado pela primeira vez. Esta é uma primeira e importante premissa: o cinema silencioso não é uma forma de arte e comunicação do passado, obsoleta ou irrecuperável. É, como a literatura de Homero, a poesia de Góngora, a pintura de Rubens ou o drama de Ibsen, algo que transcende a própria temporalidade. Em um século de transformações hipervelozes como o XX, o ciclo de nascimento, estabelecimento, consolidação e decaimento do cinema silencioso como forma cultural de expressão se fechou em poucas décadas, algo que formas de arte antigas levaram séculos para atingir. Porém, como ressalta o personagem de Auster, seu mecanismo de expressão pertence à realidade, à sensibilidade, à cognição, talvez antes que à cultura em si. Neste sentido, a forma maquinal do cinema silencioso talvez seja imortal, mas não de uma maneira laudatória e piegas, mas sim imortal tal qual a terceira lei da termodinâmica, ou a sintaxe de uma gramática gerativa, ou o teorema de Pitágoras. É imortal porque cristalizado, encravado em um sistema que subsiste a partir de suas

\footnotetext{
${ }^{7} \mathrm{O}$ Aleph (※) é a primeira letra do alfabeto hebraico. No pensamento esotérico da cabala, representa um ponto no espaço onde todos os pontos do universo são visíveis, em simultaneidade, simbolizando o infinito e a obliteração do tempo e do espaço. A literatura de Jorge Luís Borges, no conto O Aleph, popularizou o sentido místico/filosófico desta letra. A "travessia do primeiro limiar" corresponde ao quinto estágio da "jornada do herói” elaborada pelo antropólogo Joseph Campbell (1995), que encontra patamar comum às narrativas a partir de histórias mitológicas. $\mathrm{O}$ limiar representa o momento em que o herói deixa definitivamente o "mundo comum" e adentra de verdade no "chamado à aventura".
} 
próprias contingências, uma autopoiese. É neste sentido que o autor nos informa que aquele tipo de expressão jamais poderia envelhecer.

Seguindo por este caminho, na sequência, ele menciona: Isso ocorreu porque eles tinham entendido a língua que estavam falando. Eles tinham inventado uma sintaxe para o olho, uma gramática de pura cinética. Auster, de maneira literária e intuitiva, prevê uma gramática para este cinema, uma sintaxe do olho. Logicamente, ele não foi o primeiro a preconizar o cinema como língua ou linguagem. Vselovod Pudovkin (2003) e Sergei Eisenstein ${ }^{8}$ se debruçaram longamente sobre o assunto. Buscavam uma unidade mínima de significação que correspondesse ao fonema, à sílaba, algo que pudesse ser decomposto, estruturado, rearranjado no sentido de multiplicar a semântica. Eram formalistas. Já o teórico Christian Metz (2004) considerava que o cinema era um ótimo emulador de linguagem, um tipo de mecanismo amorfo e imitador que se apropriava das maneiras de funcionar de uma linguagem para produzir também significação. Desta forma, o cinema seria uma espécie de linguagem que poderia transformar suas regras de funcionamento a cada novo filme. Um tipo extraordinário de fenômeno comunicacional que se reinventa, enquanto língua, a cada vez que é acionado novamente. Além de Metz, também o cineasta (e teórico do cinema) Pier Paolo Pasolini (1982) considerava que o cinema era não apenas uma linguagem específica, mas a língua da própria realidade em si. Baseado em uma (eventualmente contestada ${ }^{9}$ ) semiótica livre e atrevida, Pasolini considera que o cinema captura signos que estão já presentes em uma espécie de língua "natural" da própria realidade, como se a imagem dos filmes fosse inscrição das imagens reais, que, por sua vez, já eram inscrição de algum código presente na fundação da natureza.

\footnotetext{
8 As unidades mínimas da linguagem do cinema para Eisenstein vinham da lógica de sua teoria da montagem: "A conclusão é que não há nenhuma incompatibilidade entre o método pelo qual o poeta escreve, o método pelo qual o ator forma sua criação dentro de si mesmo, o método pelo qual o mesmo ator interpreta seu papel dentro do enquadramento de um único plano, e o método pelo qual as suas ações e toda a interpretação, assim como as ações que o cercam, formando seu meio ambiente (ou todo o material de um filme), fulguram nas mãos do diretor através da mediação da exposição e da construção em montagem, do filme inteiro" (EISENSTEIN, 2002, p. 48).

9 O livro Empirismo eretico, lançado por Pasolini coletando ensaios seus sobre cinema de poesia, considerado à época por semioticistas como incoerente e contraditório, colecionou críticos de peso: "Christian Metz, Umberto Eco, Stephen Heath, Pio Badelli, Emilio Garroni, Gianfranco Bettitini e Antonio Costa representam a formidável coalisão de oponentes à primeira investida de Pasolini na teoria fílmica” (SITNEY, 2015, p. 16. Tradução nossa).
} 
A formulação de Auster pode não ter tão bem definida base semiótica, mas captura a essência do que efetivamente estas imagens reverberam: é pelo olho (imagem, espaço) que se constitui a apreensão do cinema. E é pela cinética (movimento) que a imagem exerce sua replicação do tempo (DELEUZE, 1996). Assim, talvez Auster queira exprimir literariamente a gramática de uma totalidade espaço-temporal. A maneira como estas coordenadas se tornam língua. Afinal, era o pensamento traduzido em ação, a vontade humana expressando-se através do corpo humano. Aqui, duas coisas: a possibilidade de que as estruturas do pensar possam ser traduzidas em movimento na tela do filme (sendo, portanto, medium); e que a vontade humana (ou seja, seu nietzschiano ímpeto vital) possa ser traduzida no gesto humano. São relações cruciais para o entendimento da experiência de se assistir a um filme silencioso. Cinema e linguagem. Imagem, tempo e movimento. Espectatorialidade e cognição. Medium, gesto e vida.

Este excerto possui ainda uma conclusão, corolário de todas as outras proposições, algo que encerra nosso pequeno círculo hermenêutico e nos traz de volta a Charles Chaplin: A maioria das comédias silenciosas pouco se importavam em contar histórias. Elas eram como poemas, como a representação de sonhos, como alguma intrincada coreografia do espírito. Neste momento, Auster se dá conta de que talvez a investigação a respeito destes filmes pelo viés da linguística e da semiótica simplesmente não contemplasse aquilo que eles naturalmente transmitem, comunicam e insuflam no espectador. A comédia silenciosa não residia necessariamente em uma emulação da língua, ou sequer nas operações da ficcionalidade, e tampouco no registro documental. Ela reside, enfim, oposta à ficção e ao documentário, em um terceiro vértice: a poesia cinematográfica. Que Auster, em seu curto arroubo dissertativo, tenha percorrido este extenso caminho em uma digressão ficcional, a isso cabe o ofício de um bom escritor. Nosso papel aqui é reconstruir esta trajetória, de uma arte morta à poesia imortal, em um percurso que vai da noção mais básica sobre o cinema silencioso (Chaplin) até a mais obscura e extrema (Rodakiewicz).

É por isso que começamos com Chaplin. À parte o status de mito do século XX que o ator e diretor adquiriu ao longo dos anos (que dispensa comentários), chama a atenção o quão precoce foi o fanatismo em torno dele. Chaplin chegou à Keystone, 
companhia de Mack Sennet, famosa por seus filmes seriados ${ }^{10}$ e amalucados, cheios de perseguições frenéticas e non-sense, em janeiro de 1914. Era sua primeira vez no cinema. Vindo de Londres e pertencendo à companhia de teatro de vaudeville britânica (music hall) de Fred Karno, Chaplin foi visto, praticamente ao acaso, por Sennet, apresentando um espetáculo chamado Uma noite num music hall inglês em um teatro em Nova York (CHAPLIN, 1989, p. 125). Isso foi durante uma das turnês norteamericanas da trupe de Karno. No início de 1914, chamado para ganhar 125 dólares por semana (bem mais atraente que os 75 dólares que ganhava com Karno), Chaplin largou tudo e foi até um subúrbio de Los Angeles para trabalhar na Keystone. Pouco mais de um ano depois, figurava entre os maiores astros do cinema de Hollywood.

A ascensão de Chaplin foi, sem exageros, implacável. Ainda em um período em que o cinema narrativo começava a ganhar solidez (tendo se desenvolvido e se transformado completamente a partir do cinema de atrações ${ }^{11}$, entre 1907 e 1915. Cf. BOWSER, 1990, pp. 255-272) e em que o star system hollywoodiano engatinhava e procurava estabelecer suas bases e regras, Chaplin e seu personagem, Carlitos (Charlie), chegaram para dar um rosto a uma forma de cinema que via acontecer uma transformação definitiva tanto em sua maneira de representar (em mudanças drásticas no apelo da linguagem) quanto em sua forma de se vender: o cinema narrativo, os planos próximos, o investimento em personagens fixos nos filmes seriados e na repetição dos atores. Tudo isso contribuiu para a formação de um sistema que colocava o ator no centro não apenas da arte cinematográfica, mas também de sua economia.

Chaplin emerge dentro do processo que, na trajetória do cinema silencioso americano, ficou conhecido como "virada narrativa", que a historiadora Eileen Bowser situa também como "era dos Nickeodeons ${ }^{12}$ ", ou seja, o momento em que o cinema

\footnotetext{
${ }^{10}$ Os serials (filmes seriados) eram muito comuns no cinema dos anos 1910. Tinham produção irregular e continuidade inconstante. Louis Feuillade foi quem teve maior êxito com este formato na França. Nos Estados Unidos, o formato consagrou atores e atrizes como William S. Hart, Pearl White e Mack Sennet. 11“Cinema de atrações" é um dos nomes pelos quais é conhecido o cinema anterior à "virada narrativa". Este cinema incluía as "vistas" tais quais as feitas por Lumière, cinema de "truques", ao estilo Méliès, e diversos tipos de "atrações", que incluíam coisas como coroações, execuções, registros de acidentes, exibições circenses e números diversos (COSTA, 2007, pp. 26-27).

${ }^{12} \mathrm{O}$ Nickelodeon era um tipo de cinema barato (seu ingresso custava um níquel, ou seja, 25 centavos de dólar), pequeno, caótico e voltado às classes operárias que se tornou febre nos Estados Unidos justamente entre 1907 e 1914, substituindo o período em que o cinema se instalava nos teatros de variedades e nas feiras no interior do país. Bowser (1990, p. 53) cita o período dos Nickelodeons como fundamental para o
} 
perde seu caráter de atração para sofisticar-se por meio do ato de contar histórias através de uma série de elementos narrativos de linguagem sistematizados em procedimentos a príncípio disjuntos e concorrentes, e que depois vão convergindo em códigos que vão modelar os diferentes tipos de narrativa clássica. David Wark Griffith, especialmente entre 1908 e 1914, quando estava a serviço da companhia Biograph ${ }^{13}$, foi um dos vetores desta transformação. Resumidamente, Griffith aprimorou a montagem alternada, complexificando-a em mais ações e em planos mais curtos, estabelecendo ritmos mais rápidos e elaborados, dinamizando as narrativas (crosscutting ${ }^{14}$ ); abordou inúmeros tipos de contraste, seja na montagem alternada ou analítica, direcionando com clareza as intenções do filme, o que fortaleceu o narrador cinematográfico; trouxe unidade à figura do diretor, tornando-o a figura central na produção cinematográfica; introduziu os ensaios profissionais; privilegiou o princípio da "economia", filmando apenas o necessário para que se compreendesse a história; e padronizou ângulos e tomadas para diversas situações, inaugurando um código comum ao cinema silencioso.

Mesmo assim, o tipo de narrativa desenvolvida por Griffith durante este período vai perdurar apenas alguns anos (a saber, de meados dos anos 1910 até meados dos anos 1920) até que seja substituído por uma narrativa transparente (Cf. XAVIER, 2005, pp. 17-26), em que a estrutura narrativa (ou o narrador propriamente dito ${ }^{15}$ ) se torne discreta

surgimento da "virada narrativa" e da mudança de paradigma para as estruturas de representação do cinema.

${ }^{13} \mathrm{~A}$ Biograph foi a mais popular dentre as Companhias que dominaram o mercado americano do nascimento do cinema até o estabelecimento dos novos estúdios em Hollywood em meados dos anos 1910. "Já que, nos primeiros dias do cinema, o domínio técnico era pré-requisito para o desenvolvimento artístico, é razoável assumir que a maioria dos filmes que valiam a pena tinham de vir das maiores e mais bem-estabelecidas companhias - o que necessariamente indicava que eram companhias que trabalhavam com a Motion Pictures Patents Company em algum momento, dentre elas: General Film Company, American Biograph, Essanay, Kalem, George Klein, Lubin, Méliès Company, Pathé, Selig e Vitagraph.” (EVERSON, 1998, pp. 30-31. Tradução nossa).

${ }^{14} \mathrm{Em}$ língua portuguesa o crosscutting geralmente é referenciado como montagem alternada ou montagem paralela. Como não nos ateremos a análises muito detalhadas neste sentido, utilizaremos aqui o termo mais corrente, montagem alternada. Eileen Bowser discute detalhadamente a diferença entre os conceitos, em inglês, de crosscutting (montagem alternada) e parallel editing (montagem paralela) em The transformation of cinema: "Na tentativa de analisar as formas emergentes de edição, David Bordwell, em The Classical Hollywood Cinema (1985), propôs a distinção entre o que ele chama montagem alternada [crosscuting] e montagem paralela [parallel editing]: ele define a montagem alternada como a "intercalação de duas ou mais diferentes séries de imagens. Se a simultaneidade temporal não é pertinente à série, a edição pode ser chamada de montagem paralela; se as séries precisam ser percebidas como temporalmente simultâneas, então nós temos a montagem alternada" (BOWSER, 1990, p.58).

${ }^{15}$ Conforme GAUDREAULT e JOST (2009, p. 75$)$ : “Assim, para se chegar a produzir uma narrativa fílmica pluripontual, seria necessário primeiramente fazer apelo a um mostrador, que seria essa instância responsável, no momento da filmagem, pelo 'encaixe' dessa multitude de 'micronarrativas' que são os planos. Interviria, em seguida, o narrador fílmico, que, apoderando-se dessas micronarrativas, inscreveria nelas, pelo intermédio da montagem, seu próprio percurso de leitura, consecutivo ao olhar que ele teria 
diante representação contida na história do filme, preocupada em mimetizar a vida em si. Este modelo transparente vai perdurar durante todo o período clássico do cinema norte-americano. Elucidando justamente o papel que a diegetização (que fundamenta a criação de uma estrutura narrativa para o cinema) e o discurso operam nos primeiros filmes de Griffith, o historiador do cinema Thomas Gunning ressalta a importância e a estilística do cineasta, diferenciando-o da já anacrônica incorporação geral dele como "pai da narrativa clássica":

\begin{abstract}
A importância histórica e teórica dos primeiros filmes de Griffith reside no fato de que eles nos permitem conhecer os dois elementos constitutivos do ato da narração: o "corte", que criou um certo tipo de discurso, e a "diegetização", que criou um certo tipo de continuidade que constitui, finalmente, uma história. Este movimento em direção à constituição de uma história será preservado e mesmo intensificado pelo cinema americano clássico que se seguirá, enquanto que os momentos de discurso, no estilo cinematográfico, serão, ao contrário, mais e mais atenuados e dissimulados (senão completamente eliminados). É por esta razão que Griffith é, ao mesmo tempo, o pai da "transparência" das narrativas posteriores e um total estranho em relação a estes filmes que se seguirão (GUNNING, 1984, p. 143) ${ }^{16}$.
\end{abstract}

Bowser, ao contrário do que pensa o senso comum da história do cinema ("Griffith inventou a narrativa clássica"), aproxima-o da montagem soviética (cuja estética ele notoriamente influenciou ${ }^{17}$ ), chegando a chamar o estilo de montagem griffthiano de "montagem ideológica" (BOWSER, 1990, p. 257), graças à forte orientação moral de seus curtas-metragens, o que determinou certo padrão temático nos melodramas da época, ao mesmo tempo em que ajudou a linearizar as narrativas cinematográficas. Moralizar o cinema a partir das demandas da audiência, com a sua crescente popularização nesta época, se tornou papel dos produtores, que queriam sua plateia plenamente satisfeita. Esta é uma das razões que Bowser cita como causa da virada narrativa: os filmes tinham que funcionar como uma parábola moral, e linearizar uma história era uma maneira fácil de fazer isso. Griffith foi importante neste processo. As outras razões incluíam: a necessidade de se padronizar os diversos métodos de se contar histórias presentes no cinema até 1907; a também necessidade de se racionalizar o cinema em produtos mais parecidos, para que se tornassem mais facilmente vendáveis; e a substituição, dentro do contingente de profissionais de cinema, de

inicialmente posto sobre essa narrativa primeira - os planos. Em um nível superior, a 'voz' dessas duas instâncias seria de fato modulada e regrada por esta instância fundamental que seria, então, o 'meganarrador fílmico', responsável pela 'meganarrativa' - o filme”.

${ }^{16}$ Tradução nossa.

${ }^{17}$ Basta conferir o artigo de Eisenstein "Dickens e Griffith” (2007). 
pessoas vindas do vaudeville, do circo e do teatro de variedades (que davam caráter burlesco e de atração aos filmes) por homens e mulheres do teatro, mais familiarizados com o ato de se contar histórias.

\begin{abstract}
Nos primeiros tempos, os filmes eram aceitos como um espetáculo, um número de mágica, um entretenimento divertido. A verossimilhança era uma das características dos filmes que mais entretinham. As primeiras audiências poderiam se maravilhar a respeito de quão "vívidas" as imagens do cinema eram quando documentaram o mundo ao redor delas. Quando os cineastas começaram a contar histórias mais complexas, porém, houve uma mudança de atitude. A realidade começou a ser demandada para o filme de ficção encenada. A tela não é a realidade, é claro, e todo espectador sabe disso muito bem. O que o filme de ficção veio representar foi um mundo de sonhos, fundado na ilusão do mundo real. Nenhum outro medium poderia fornecer tão concreta "evidência" da realidade. Deste ponto em diante, qualquer coisa que trouxesse o espectador para fora deste sonho estava sujeito à crítica no sentido de quebrar a ilusão da realidade (BOWSER, 1990, p. 55$)^{18}$
\end{abstract}

É dentro deste contexto, em 1914, que Chaplin vai fazer filmes na Keystone. Seu timing é ideal, pois a "virada narrativa" é um dos momentos-chave na história do cinema, algo que transformou completamente tanto a maneira com que os filmes são representados e percebidos, quanto a maneira com que são vendidos. Não à toa, Chaplin fundaria, em 1919, juntamente com Griffith (além dos astros Mary Pickford e Douglas Fairbanks), o estúdio United Artists, cuja principal diretriz era voltar a dar autoridade cinematográfica ao diretor. Porém, entre os dois (Griffith e Chaplin) havia diferenças evidentes. Em primeiro lugar, estilísticas: enquanto Griffith era virtuoso e cinético, abusando de movimentos de câmera e procedimentos arrojados de montagem, Chaplin optava por um cinema simples - ainda que a condução geral das histórias ocorresse no modelo griffthiano -, de câmera parada e pouca variação de angulação, privilegiando a mise-en-scène e a performance corporal dos atores. Em segundo lugar, o gênero: Griffith era um mestre nos melodramas, gênero que ele ajudou consolidar no cinema, e Chaplin, como se sabe, sobressaiu-se na comédia (ainda que, em sua carreira nos anos 1920, misturasse com frequência os dois gêneros, tornando-se uma marca registrada do Chaplin maduro). Por fim, e o que mais nos interessa aqui, é uma diferença ideológica entre os dois: Griffith, um homem conservador ${ }^{19}$, era filho de um coronel do exército

\footnotetext{
18 Tradução nossa.

19 É notório o racismo com que Griffith abordou os negros em seu clássico sobre a Guerra Civil Americana $O$ nascimento de uma nação (The birth of a nation, 1914). Everson (1998, p. 84. Tradução nossa) explica suas influências: "Se o filme parece ser anti-negro às vezes, isso pode ser entendido, pois
} 
confederado durante a Guerra Civil Americana, e fazia filmes que sustentavam uma moral cristã e tradicional, bem ao gosto das demandas do público da época. Já Chaplin, pelo contrário, tendo crescido nos subúrbios de uma Londres vitoriana violenta, encarnou em seu personagem (Carlitos ou "o Vagabundo") um sujeito contraditório, afeito a mesquinharias como roubar ou agredir, ao mesmo tempo em que poderia ser amável, gentil e completamente desapegado.

Chaplin passou por quatro estúdios (Keystone, Essaney, Mutual e First National) e participou de mais de 60 curtas-metragens até que realizasse seu primeiro longametragem, O garoto (The kid, 1921). Muito antes de grandes sucessos pelos quais é conhecido até hoje, como Em busca do ouro (The gold rush, 1925), Luzes da cidade (City lights, 1931) e Tempos modernos (Modern times, 1936), Chaplin já era uma celebridade que atraía milhões aos cinemas. Talvez tenha sido a primeira de proporções colossais. Ainda em 1915, quando estava na Keystone (portanto, seu primeiro ano no cinema), Chaplin já aparecia em histórias em quadrinhos, cartoons em revistas, e brindes com a cara dele eram oferecidos nos jornais (MALAND, 2004, p. 202). O crítico Charles J. McGuirk, da Motion Picture Magazine, foi o primeiro a chamá-lo de gênio, ainda em 1915. "Uma vez em cada século [...] um homem nasce com a capacidade de colorir e influenciar seu mundo. [...] Charles Chaplin está fazendo isso com pantomima e personalidade". (MCGUIRK apud MALAND, 2004, p. 203). Em sua autobiografia, Chaplin descreve com estupor as reações da plateia em seus primeiros filmes:

\footnotetext{
Por essa época é que o filme que Mack [Sennet] dirigira, $O$ estranho predicado de Mabel, foi exibido num cinema da cidade. Cheio de medo e de tremores, eu o vi com a plateia. Quando Ford Sterling apareceu, houve como sempre uma gargalhada geral e uma demonstração de caloroso entusiasmo, mas eu fui recebido com um frio silêncio. Todas as coisas engraçadas que eu fazia no saguão do hotel provocavam apenas sorrisos. Mas, à medida que o filme progredia, a plateia começava a dar mostras de interesse, depois a rir e, já quase no fim da película, eu arrancava uma ou duas gargalhadas. Nessa exibição, descobri que a plateia não era parcial para com os novatos (CHAPLIN, 1989, p, 145).
}

Chaplin angariou enorme popularidade com um ano de carreira. Os muitos anos vindouros seriam ainda melhores, elevando-o, enquanto presença midiática, a patamares poucas vezes pareados na história. Foi, efetivamente, o primeiro grande nome da guerra e sobre os negros também". 
reprodutibilidade técnica, seu rosto e o de seu personagem suplantaram a sua individualidade. Sua imagem e a de seu personagem tornaram-se estilemas para qualquer assunto relacionado ao cinema, em especial ao cinema silencioso. A partir de sua pantomima muda, impulsionado por um período-chave de consolidação do cinema enquanto entretenimento e arte, e lidando com sua imagem como um espelhamento representacional (a linguagem silenciosa) que remetia diretamente à novidade que representava o medium em que ele atuava, Chaplin tornou-se uma das figuras mais emblemáticas do século XX.

Mas o que fez de Chaplin, com sua linguagem simples, uma personificação do que pode representar o cinema silencioso? O que o difere de Griffith, que, a despeito de sua gigante popularidade na era muda e importância na trajetória formal do cinema, é praticamente desconhecido do público em geral, sendo seus filmes muito menos exibidos do que os de Chaplin? A resposta pode estar também em três vértices: a violência, o gesto e o movimento. Para pensarmos o primeiro item, é necessário voltarmos a seus curtas e pensarmos a trajetória de Chaplin ao mesmo tempo como um desenvolvimento programático (tendo seu estilo e personagem se transformado por questões mercadológicas e também artísticas através do tempo) e como um resíduo (ou reminiscência) que sempre esteve lá. E, de certa forma, a estética de Chaplin, se o levou a um equilíbrio delicado de afecções melodramáticas e humanísticas (como em Luzes da cidade ou $O$ grande ditador) com um tipo de humor refinado e elaborado com a colaboração de um contato cada vez mais íntimo com os procedimentos do cinema ( $O$ circo, Em busca do ouro), ela preservou também aquilo que originou todo este sólido equilíbrio na cabeça do cineasta, aquilo que primeira e ultimamente encantou as plateias do cinema silencioso: a violência de Carlitos.

O Carlitos dos curtas-metragens é conhecido por originar pequenas metonímias de suas grandes obras dos anos 1920. Seria o embrião do grande Chaplin. Isto, no entanto, não ocorreu exatamente assim. Se uma parte de Chaplin foi meticulosamente construída e planejada pela sua personalidade ambiciosa, a outra veio de condições não só do cinema que primeiro o acolheu (o slapstick americano de Mack Sennet), como de sua experiência pregressa ${ }^{20}$, tanto em sua história pessoal quanto sua formação no

${ }^{20}$ É como bem exemplifica esta citação do cineasta François Truffaut: "Quando Chaplin entrar na Keystone para rodar 'filmes de perseguição', correrá mais rápido e mais longe que seus colegas do music- 
music-hall inglês, com seu humor de certa forma degenerado, escatológico, violento. Chaplin encontrou nas corridas e perseguições amalucadas de Sennet ${ }^{21}$ uma maneira de fazer certa sinergia entre as comédias inglesa e americana da época. Cabe aqui a precisa descrição que o clássico historiador Georges Sadoul reservou a Sennet em sua História do cinema mundial:

O estilo de Mack Sennet é fluido, preciso, ágil, ele soube dosar a progressão
e utilizar a montagem com uma exatidão que aprendeu com Griffith. A
loucura e a liberdade são os distintivos de uma obra na qual as trucagens
tornavam possíveis as mais inverossímeis façanhas: motociclistas usavam os
fios do telégrafo como pista, os automóveis saltavam por cima dos bondes,
tipos atléticos brandiam os vencidos como se estes fossem fundas. Pular um
muro de pés juntos era brincadeira, como também cair de um sexto andar.
Esse gosto pelo inverossímil desapareceu hoje da comédia, mas subsiste nos
desenhos animados (SADOUL, s/d, pp. 108-109).

Sennet havia sido figurante em filmes de Griffith, e seu estilo, de perseguição amalucada, seguia não apenas os princípios que o diretor de Intolerância (Intolerance, 1916) vinha desenvolvendo em centenas de curtas-metragens desde 1908, como também a tradição da chamada "escola de Brighton" (Cf. SADOUL, s/d, pp. 39-44), grupo de cineastas britânicos que, durante a primeira década do novo século, desenvolveram alguns fundamentos do que se tornaria a linguagem do cinema, como a continuidade em contiguidade, os cortes analíticos, o close-up, etc. A influência de James Williamson, um dos pioneiros no chamado "filme de perseguição", é particularmente visível. Esta motricidade, característica deste tipo de filme, foi fundamental para instaurar no espectador um sentido de continuidade primeva, eletrizar o cinema com verdadeira cinética e impulsionar o olhar para fora do campo, buscando sempre a continuação da ação pregressa. No início, a simples perseguição em si bastava. E a violência era a combustão para que a correria e a algazarra irrompessem nestes filmes. Quase todos os filmes dos Keystone Kops eram baseados neste princípio. Chaplin, no início, se adaptava a esta fórmula. Como a Keystone, mesmo sendo um

hall, pois, embora não fosse o primeiro cineasta a descrever a fome, foi o único a conhecê-la, e isso é o que iriam perceber os espectadores do mundo inteiro quando os filmes começarem a circular a partir de 1914" (TRUFFAUT, 2000, p. 9).

${ }^{21}$ Hoje em dia Mack Sennet é mais lembrado por ter sido espécie de "tutor" de Chaplin no cinema, mas o estúdio Keystone já fazia bastante sucesso (Cf. MALAND, 2004) antes da chegada dele. Era famoso um serial da Keystone chamado Keystone Kops, em que sete ou oito policiais amalucados e completamente atrapalhados se envolviam em perseguições intermináveis. Eram filmes praticamente de dinâmica pura, burlescos e repetitivos. Este terreno de slapstick bruto e cru foi o que Chaplin encontrou, quando chegou ao cinema, para mesclar com sua pantomima sofisticada e privilegiada mise-en-scène (que aprendera no Music Hall inglês). Em alguns filmes da Keystone, como Dois heróis (The knockout, 1914), Chaplin chegou a contracenar com os Keystone Kops. 
jovem estúdio, já tinha seu time de "estrelas" nesta época, Chaplin teve de filmar várias vezes no modelo "dupla" antes que pudesse protagonizar e dirigir seus próprios filmes. Uma das duplas que realizou foi com Roscoe "Fatty" Arbuckle (conhecido no Brasil como Chico Boia), um obeso ator cômico que mais tarde faria par também com Buster Keaton (Cf. The garage, Roscoe Arbuckle e Buster Keaton, 1920). A dupla com Chaplin teria inspirado Laurel e Hardy a seguirem a fórmula para criar $O$ gordo e o magro, já nos anos 1920. Em Na farra (The rounders, Charles Chaplin, 1914), presenciamos uma pantomima crua, com poucos recursos realmente cinematográficos, em cinco cenários e duas locações simples em que, basicamente, dois bêbados (Chaplin e Arbuckle) tentam fugir de suas respectivas esposas para continuarem bebendo. A instauração do movimento (quando os personagens são jogados de um cenário a outro um truque comum dos estúdios da época presente também em outros filmes de Chaplin como Casa de penhores [The pawn shop, 1916]) e o ritmo frenético com que a trapalhadas ocorrem são gerados por elementos de violência: as mulheres batem nos homens, que fogem. O princípio é o mesmo em Carlitos e Mabel se casam (Mabel's married life, Charlie Chaplin, 1914), também da Keystone, quando Chaplin contracena com Mabel Normand, uma atriz cômica de sucesso que estava no estúdio antes dele. Normand, então com cerca de 20 anos, foi uma das primeiras mulheres a ter sucesso na direção em Hollywood. Ao contrário de Edna Purviance, com quem Chaplin contracenou em inúmeros filmes (e com que sem envolveu romanticamente), que fazia basicamente papéis dramáticos, Normand não apenas protagonizava os filmes que dirigia (como Carlitos e as salsichas [Mabel's busy day, 1914]), como também se especializou no humor. Em Carlitos e Mabel se casam, dois casais (incluindo um com Normand e Chaplin) flertam um com os cônjuges do outro de maneira deslavada e (para os padrões da época) quase imoral. Quadros "confusos" (sem decupagem - em que vários atores contracenam na mesma tomada, FIG.03) se misturam à mesma pantomima violenta de Na farra. A gag básica é: Carlitos bate em um boneco de treinamento de boxe, o boneco cai, retorna e atinge Normand. Esta mesma gag violenta é repetida em Dois heróis (The knockout, Mack Sennet, 1914), um filme de pugilismo em que Arbuckle bate no mesmo boneco do outro filme, que cai, retorna e bate nele de volta. Filmes de pugilismo, aliás, eram muito frequentes, sendo ideais como princípio para incentivar a motricidade que nunca para nestes filmes. Chaplin, por exemplo, já na Essaney, realizaria Campeão de boxe (The champion, Charles Chaplin, 1915), e Buster 
Keaton faria muito sucesso já nos anos 1920 com Boxe por amor (Battling butler, Buster Keaton, 1926).

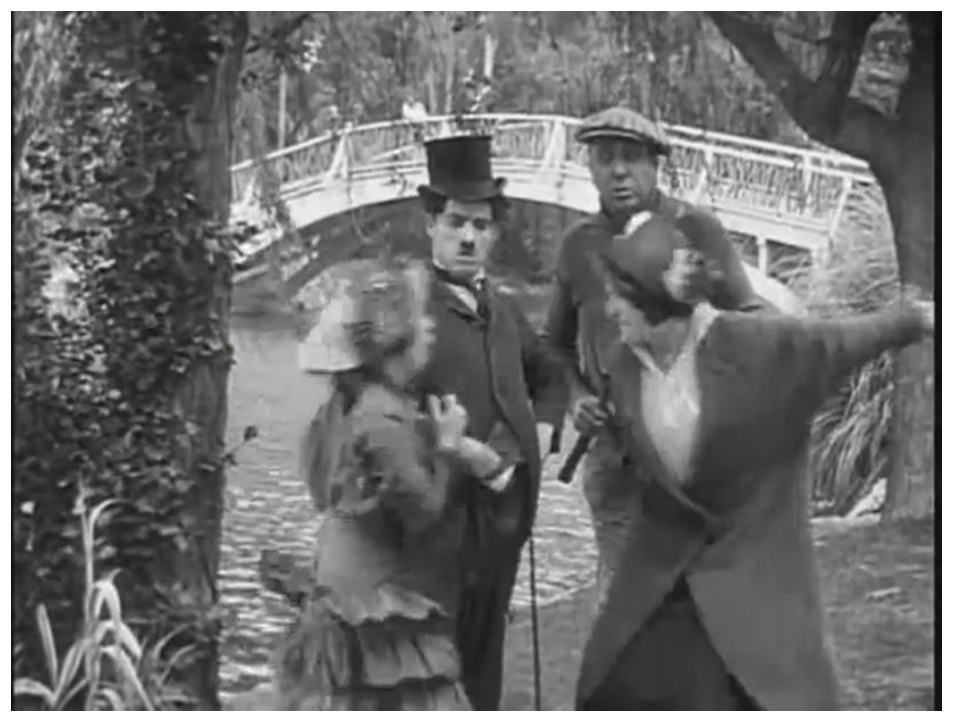

Figura 3

A violência destes filmes, logicamente de natureza bufa e diferente da violência exploitation $^{22}$ dos filmes contemporâneos, funcionava em princípio como alívio cômico (tornando os filmes muito politicamente incorretos, característica do primeiro cinema. Daí a necessidade de uma moralização, conforme vimos em Bowser) e, em segunda instância, como fator que desencadeia a perseguição. Em Dois heróis, por exemplo, Arbuckle, após perceber que havia perdido uma luta de boxe, saca duas pistolas e começa a atirar, enlouquecido, tentando atingir a plateia (FIG. 04). É o momento em que os Keystone Kops saem à sua caça e uma longa sequência de perseguição se inicia nos telhados dos subúrbios de Los Angeles. Quase todos os filmes da Keystone terminavam em brigas, às vezes envolvendo um número grande de personagens. Em Carlitos e as salsichas, Chaplin já se apresenta ao espectador agredindo gratuitamente e assediando mulheres. Quando Normand, a vendedora de salsichas, se vê vítima de valentões, Carlitos aparece para salvá-la, apenas para roubá-la em seguida. Este filme, assim como Dois heróis, termina com uma grotesca briga entre dezenas de personagens, com salsichas voando para toda parte. Como afirma o historiador Charles J. Maland, "A

\footnotetext{
22“"Explotation" é um termo usado para designar filmes, especialmente oriundos dos anos 1970, em que fatores apelativos (como a violência, o sexo, o conflito racial, as drogas, etc.) são explorados de maneira gratuita a fim de polemizar e chamar mais público. Em princípio criticada, a cultura do exploitation ganhou uma legião de seguidores a partir dos anos 1990.
} 
persona de Carlitos que emergiu dos filmes da Keystone era quase sempre malvada, crua e bruta" (MALAND, 2004, p. 199).

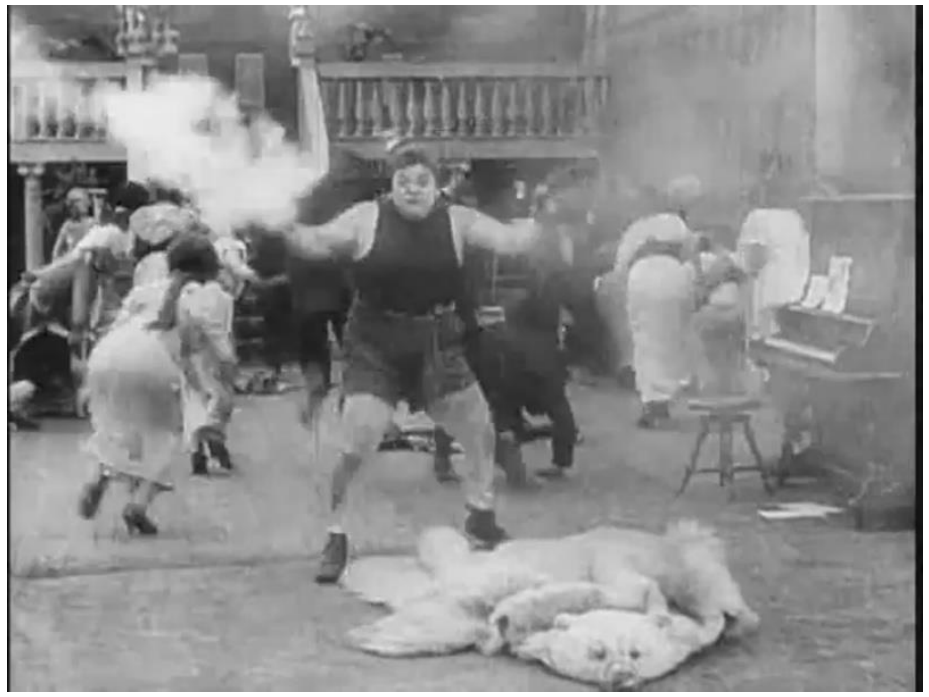

Figura 4

Mesmo fora da Keystone, como, por exemplo, nos mais vibrantes e "maduros" filmes da Mutual, a violência prevalece nos filmes de Chaplin. Em Rua da paz (Easy street, 1917), Carlitos se alista na polícia e deve controlar uma vizinhança completamente consumida por escroques, bandidos e vigaristas. Um bully gigantesco interpretado por Eric Campbell (ator amigo de Chaplin que reprisou este tipo de personagem - grande, violento e ameaçador - em diversos outros filmes, FIG.05) se torna o centro das atenções, desencadeando violência descontrolada até que, por obra do acaso, Carlitos consegue prendê-lo. Em outro momento, a seringa cheia de drogas de um junkie é acidentalmente injetada em Chaplin, que, atordoado, passa a ganhar espécie de superforça capaz de derrotar algozes muito mais fortes do que ele. Este filme, considerado uma das obras-primas da fase Mutual, parece encadear uma mecânica constante que inclui um jogo de forças de incitação à violência, pacificação e reposição da violência e fatalmente aparecendo como algo maquínico (a produção técnica da violência) conforme Chaplin instauraria, de maneira muito mais consciente, anos depois em Tempos modernos. 


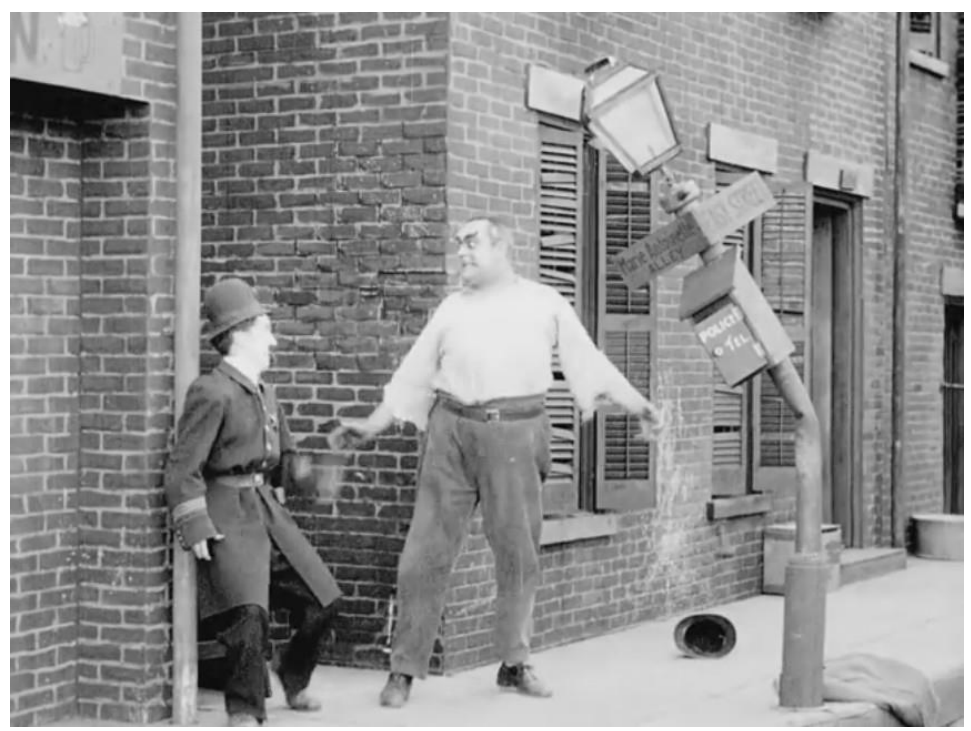

Figura 5

Esta questão da violência claramente trata de um nascimento. Carlitos nasce em meio à violência, e isso é privilegiado pela linguagem bufa, herdeira da commedia dell'arte, da pantomima elaborada no slapstick. Logicamente, estamos falando de linguagens mudas, e o gesto aberrante deste tipo de humor degenerado vai se tornar algo como um clichê, ou ao menos um estereótipo, de como o movimento no cinema silencioso seria visto como ridículo ou anacrônico para as plateias atuais. A questão é que, em primeiro lugar, a motricidade gerada pela necessidade de violência destes filmes vai gerar o fluxo autônomo das imagens do cinema silencioso. Muito em breve, a cinética destes filmes vai falar por si própria, e imagens-movimento se tornarão, conforme descreve Gilles Deleuze, em imagens-tempo, definitivamente. Esta passagem não ocorre naturalmente ou ao acaso. O nascimento destes dois elementos, neste contexto - a saber, a violência e a poesia - é simultâneo e simbiótico. Chaplin, conforme veremos, vai superar este nascimento violento e instituir graça e leveza aos seus filmes, mas, de certa forma, a indistinguibilidade de origem será marca indelével não apenas nele, mas em todo o cinema silencioso. Vários tipos de dicotomia reproduzem este decalque original: som e silêncio; fala e escrita; silêncio e fala; leveza e violência. A filósofa espanhola María Zambrano ${ }^{23}$ subsumiu estes decalques e dicotomias em uma aporia fundacional: a oposição entre filosofia e poesia.

\footnotetext{
${ }^{23}$ Vamos adentrar mais profundamente em suas ideias no capítulo 5.
} 
Para Zambrano, tanto a filosofia quanto a poesia nascem de um pasmar-se original diante da matéria da vida. A diferença é que, fundada na violência do conhecimento, a filosofia vai centrar-se em um "buscar" incessante, enquanto a poesia, que não "busca", mas "tem", nasce como uma epistemologia diferente, e proporá um amalgamento em tudo oposto com esta "matéria" que a realidade nos oferece em primeira instância.

E agora, admiração e violência, juntas, como forças contrárias que não se destroem, nos explicam este primeiro momento filosófico em que encontramos já uma dualidade e, talvez, o conflito originário da filosofia: o ser primeiramente pasmo e extasiado diante das coisas, e em seguida o violentar-se para libertar-se delas.

$[\ldots]$

E desde então o mundo se dividira, sulcado por dois caminhos. O caminho da filosofia, em que o filósofo, impulsionado pelo violento amor que buscava, abandonou a superfície do mundo, a generosa imediatez da vida, baseado sua ulterior possessão total em uma primeira renúncia. O ascetismo havia sido descoberto como instrumento deste gênero ambicioso de saber. A vida, as coisas, seriam exprimidas de uma maneira implacável, quase cruel. O pasmar primeiro será convertido em persistente interrogação; a inquisição do intelecto começou seu próprio martírio e também o da vida. (ZAMBRANO, 1996, pp. 16-17'24).

Esta violência original encontrada no nascimento da filosofia (a interrogação como violência que, tal qual um bandeirante, precisa desbastar florestas na base do facão para enfim encontrar sentido para o êxtase original diante da matéria da vida) - se considerarmos a filosofia secular como tributária de um logos racionalista - foi também pensada por Jacques Derrida em sua crítica desconstrutiva a Lévi-Strauss quando este coloca a relação entre oralidade (palavra falada) e escrita como submissão violenta (a segunda) e idílio original "extasiado" (a primeira). Vamos nos aprofundar mais nesta dicotomia entre escrita e silêncio quando formos falar sobre $O$ gabinete das figuras de cera no próximo capítulo, mas nos interessa agora o enfoque que Derrida coloca no desejo de Lévi-Strauss de que esta escala (primeiro a oralidade, depois a escritura enquanto violência) fosse verdadeira, como se uma ordem autoritária existisse entre oralidade e escritura (que Derrida considerava como simultânea ou até anterior à oralidade):

Em primeiro lugar, embora Derrida exponha convincentemente as inconsistências lógicas e as limitações conceituais do argumento de LéviStrauss, ele está sobretudo interessado no desejo de que uma distinção

${ }^{24}$ Tradução nossa. 
binária, entre preto e branco, deva existir entre fala e escritura, a primeira como meio de comunicação autêntica e próxima, e a segunda como alienação não natural e autêntica da voz (JOHNSON, 2001, p. 23).

Ainda que não estejamos falando de fala e escritura (por enquanto), mas sim de filosofia e poesia, podemos concluir que o método de pensar de Lévi-Strauss neste caso, hierárquico e estrutural, se opõe a Zambrano no sentido de que não considera os dois elementos analisados como gêmeos em princípio indistinguíveis que depois irão ser formulados como métodos distintos de se provar a experiência do mundo (conforme Derrida irá argumentar a respeito da muito maior ambiguidade existente entre fala e escritura). Conforme veremos em uma análise mais profunda da trajetória de Chaplin e sua relação com a poesia do cinema silencioso, é importante frisar que existem, simultaneamente, a filosofia e a poesia, e que, se ambas podem ser lidas como epistemologias distintas, que seguem caminhos diferentes, elas também podem ser pensadas como pertencendo a um mesmo fenômeno ambíguo. O fato de serem geradas a partir do mesmo estupor diante do mundo marca, nestas experiências epistemológicas, uma inseparabilidade do material residual de uma na outra, mesmo quando trilham trajetórias separadas.

Este é, ao que parece, o primeiro frente-a-frente do pensamento e da poesia em seu encontro originário, quando a Filosofia, soberba, se liberta do que foi sua qualidade matriz; quando a Filosofia resolver ser a razão que capta o ser, que, expresso em logos, nos mostra a verdade. A verdade... Como, tendo ela, a filosofia acabou não sendo o único caminho do homem na Terra, até este céu alto e imutável de onde resplandecem as ideias? O caminho sim se fez, mas há algo no homem que não é razão, nem ser, nem unidade, nem verdade - esta razão, este ser, esta unidade, esta verdade -. Mas isso não era fácil demonstrar, e nem se o queria, porque a poesia não nasceu na polêmica, e sua presença generosa jamais se afirmou polemicamente. Não surgiu contra nada (ZAMBRANO, 1996, p. 25) 25 .

Há uma bifurcação, portanto, nesta querela entre o pensamento e a poesia, que Chaplin, em princípio, quis sublimar de sua própria origem e, que, conforme temos argumentado a partir de um princípio de estabelecimento simbólico do cinema silencioso no mundo, ele mesmo representava. Para o senso comum, Chaplin já surgiu como um poeta das telas, como podemos ver no poema altamente laudatório que Carlos Drummond de Andrade lhe dedicou em 1945:

Para dizer-te como os brasileiros te amam e que nisso, como em tudo mais, nossa gente se parece com qualquer gente do mundo, inclusive os pequeno-judeus de bengalinha e

${ }^{25}$ Tradução nossa. 
chapéu-côco, sapatos compridos, olhos melancólicos, vagabundos que o mundo repeliu, mas zombam e vivem nos filmes, nas ruas tortas como tabuletas: Fábrica, Barbeiro, Polícia, e vencem a fome, iludem a brutalidade, prolongam o amor como um segredo dito no ouvido de um homem do povo caído na rua (ANDRADE, 2002, pp. 190-191).

Mesmo o próprio Chaplin renega, em sua autobiografia, seu nascimento no paradoxo e na violência. A ideia, um tanto quanto romântica, de que o personagem Carlitos veio de um pulo só, espontaneamente, referendando o suposto gênio natural de Chaplin, é marcada de maneira vívida neste texto, muito lido e muito influente:

Eu não tinha a menor ideia sobre a caracterização que iria usar. Mas não tinha gostado da que apresentara como repórter. Contudo, a caminho do guarda-roupa, pensei em usar umas calças bem largas, estilo balão, sapatos enormes, um casaquinho bem apertado e um chapéu coco pequenino, além de uma bengalinha. Queria que tudo estivesse em contradição: as calças fofas com o casaco justo, os sapatões com o chapeuzinho. Estava indeciso se devia parecer velho ou moço, mas lembrei-me de que Sennet esperava que eu fosse mais idoso e, por isso, adicionei ao tipo um pequeno bigode, que, pensei, aumentaria a idade sem prejudicar a mobilidade da minha expressão fisionômica.

Não tinha nenhuma ideia, igualmente, sobre a psicologia do personagem. Mas, no momento em que assim me vesti, as roupas e a caracterização me fizeram compreender a espécie de pessoa que ele era. Comecei a conhecê-lo $e$, no momento em que entrei no palco de filmagem, ele já havia nascido. Estava totalmente definido. Quando cheguei em frente de Mack, entrei no personagem, andando em passos rápidos, girando a bengalinha diante dele. Incidentes e ideias cômicas vinham em tropel à minha mente (CHAPLIN, 1989, pp. 141-142).

A origem violenta da poesia do cinema silencioso (convergida aqui na figura de Chaplin), portanto, é uma origem oculta, mas está associada a outros clichês associados a este cinema. Afinal, o reconhecimento de Chaplin como espécie de "poeta das telas" se dá, em primeiro lugar, por sua performance e carisma, sendo ele, como diz Drummond, "homem do povo caído na rua"? De certa maneira este raciocínio ratifica a noção, bastante comum, de que Chaplin teve de superar certa inconsistência original do cinema silencioso, como se tivesse de superar a si mesmo e, ao mesmo tempo, a inaptidão do medium, para fazer valer um tipo popular e celebratório de poesia. É por isso que a figura de Carlitos seria a de um homem desvalido, morador de rua muitas vezes, que enfrenta a fome e as mais diferentes adversidades, para seguir com resiliência e malandragem a sua trajetória errática. Sadoul foi um dos que ratificou esta visão: "Sua arte e poesia nascem não do cálculo longamente premeditado, mas da descoberta espontânea, da farsa e da prática constante" (SADOUL, s/d, pp. 110-111). Porém, sabe-se que a configuração da personalidade de Carlitos não foi tão instantânea 
e natural. Certos setores da sociedade, como críticos, burgueses e religiosos, começaram a se manifestar, ainda em 1915, contra o humor "vulgar" e cada vez mais popular que podia ser encontrado nos filmes de Chaplin. Em seus primeiros filmes na Keystone, Carlitos não era nem homogêneo (podendo ter personalidades e indumentárias distintas em cada filme) e nem flagrantemente "gentil", "poético" ou "homem do povo caído na rua". Maland realiza minuciosa reconstituição da trajetória dos filmes desta época e encontra Chaplin determinado a mudar a persona de seu alter-ego para poder angariar mais sucesso:

Como Chaplin respondeu a estas críticas? "O novo Charlie Chaplin", um artigo de 1916 na Motion Picture Magazine, sugere não apenas que Chaplin estava consciente destes desafios à sua popularidade mas também estava conscientemente começando a mudar e moldar sua imagem de estrela em resposta a eles. [...] No ensaio Chaplin se defendeu contra acusações de vulgaridade: "É por causa no meu treinamento e experiências com o musichall que... alguns fios de vulgaridade aparecem em minhas atuações." Ligando seu humor a uma tradição venerável, ele continuou, "Este estilo elisabetano de humor, esta forma crua de farsa e comédia slapstick... se deve inteiramente ao meu ambiente precoce, e estou agora tentando me livrar deste tipo de humor e me adaptar a uma forma mais fina e sutil de atuar". Este ensaio retrata Chaplin como aparentemente arrependido, ou ao menos tomando cuidado para não antagonizar um grupo que poderia limitar sua popularidade (MALAND, 2004, p. 204) ${ }^{26}$

Ainda que Chaplin fosse, sim, calculista e premeditasse seus passos em direção ao sucesso (o que fez com que ele transformasse a persona de Carlitos em poucos anos), é importante asseverar que a poesia no cinema silencioso, transfigurada de maneira tão clara e efetiva na comédia muda (Keaton, Lloyd e outros seguiram seus passos), pode estar enraizada nesta dicotomia original que é a violência fundando a mobilidade da mise-en-scène: a poesia silenciosa nasce e se desdobra, neste caso, da violência para o movimento, e o movimento, dotando a imagem de plasticidade ergonômica que encantava as primeiras plateias (e apenas por isso) é privilegiado pela ausência do som, medium concorrente que vai romper este equilíbrio anos depois. Daí tantos filmes importantes do cinema silencioso se balizarem na cinética muda para produzirem alumbramento. Em Eisenstein e no construtivismo soviético, é a velocidade da montagem que conduz a produção de beleza; em Abel Gance, é a velocidade do trem (em A roda - La roue, 1923) ou a destreza do campo de batalha (em Napoleão Napoleon, 1927) que produzirão este efeito; em Página de loucura (Kurutta Ippêji, Teinosuke Kinugasa, 1926, FIG.06), lendário filme de vanguarda japonês, é o

\footnotetext{
${ }^{26}$ Tradução nossa.
} 
movimento da dança dos loucos no sanatório, e ao mesmo tempo o movimento de sua insurreição, que trazem à tona seu aspecto grandioso; em boa parte dos filmes de vanguarda, como Entreato (Entr'Act, René Clair, 1924), Rien que les heures (Alberto Cavalcanti, 1926), La marche des machines (Eugene Deslaw, 1927), Montparnasse (Eugene Deslaw, 1929) ou Berlim, sinfonia da metrópole (Berlin: Die Sinfonie der Großstadt, Walter Ruttmann, 1927), a cinética da montagem e das máquinas convive com a cinética do olhar; em Couer Fidèle (Jean Epstein, 1923), é o giro do carrossel que imprime a cena mais poética do filme; nas produções que envolvem a poesia e forças da natureza, como Homem de Aran (Man of Aran, Robert Flaherty, 1934), Limite (Mário Peixoto, 1931) ou Aurora (Sunrise, F.W. Murnau, 1927), o movimento das águas é o elemento de coalizão entre todos os tropos poéticos; nos filmes tableau do Feuillade nos anos 1910 (como Os vampiros e Fantômas, conforme veremos), a elegância da mise-enscène (portanto, o movimento dos atores diante da câmera) é que os tornou imortais; Um cão andaluz (Um chien andalou, Luís Buñuel e Salvador Dalí, 1929) é impulsionado pelos movimentos do inconsciente ao mesmo tempo em que é embalado pelo ritmo rodopiante do tango. Os exemplos abundam, enfim.

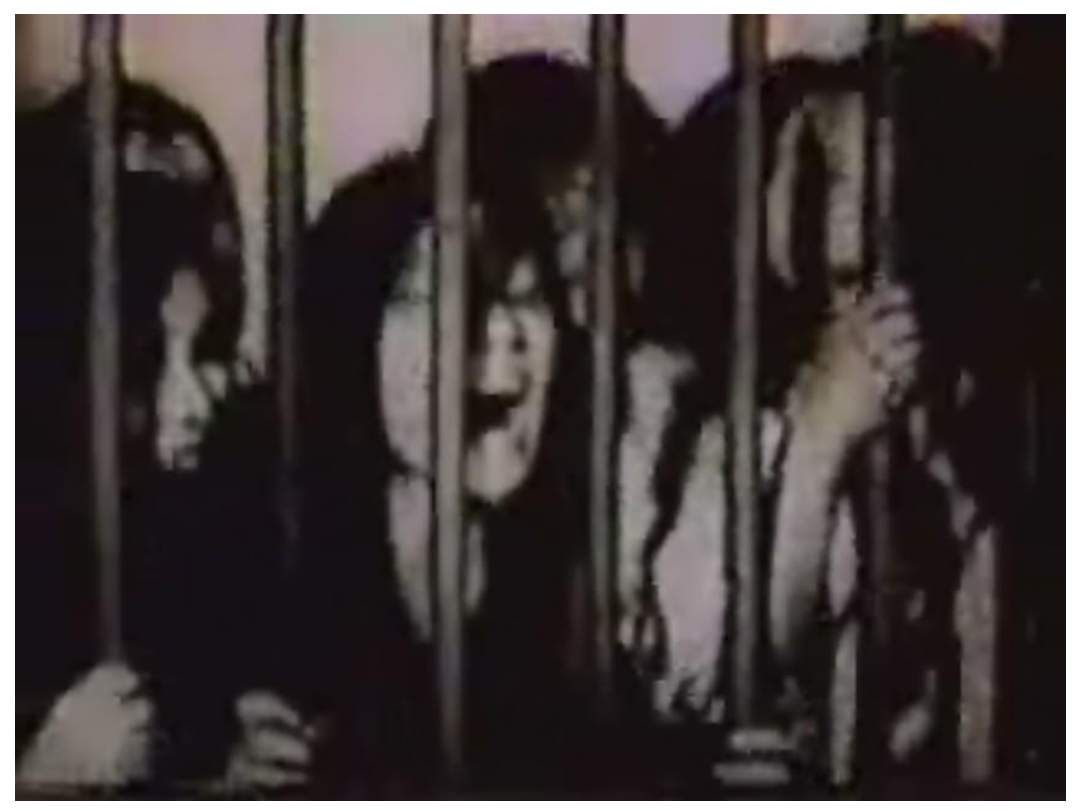

Figura 6

A poesia de Chaplin (aqui metonímia para todo o cinema silencioso) se funda, portanto, como qualquer poesia, no paradoxo. Por mais que seu personagem tenha se transformado e se acomodado a condições sociais e econômicas do cinema de sua época, é justamente nesta dupla progressividade (o fato de ele "nascer pronto" e ao 
mesmo tempo "se construir estética e socialmente") que esta poesia encontra um princípio que corrobore as ideias de Zambrano. O Chaplin maduro guarda a reminiscência de sua violência original. O Chaplin primevo já tinha, em si, o encanto que, mais elaborado adiante, o levaria ao estrelato absoluto. Poesia e filosofia, diria a filósofa, são potências gêmeas, que nascem do estupor, e são codependentes no caldo comum que as funda. Se a mesma cinética das imagens em movimento vai se bifurcar, como aponta Deleuze, em imagens-movimento (a narrativa cinematográfica) e imagenstempo (a emulação da passagem bergsoniana do tempo que nasce da busca pelo espaço cinematográfico), esta reminiscência inaugural também aponta caminhos distintos para o cinema. $\mathrm{O}$ vértice da ficção balizado pela fala apontará para o desbravamento do mundo (continuado na violência) iniciado na filosofia. $\mathrm{O}$ vértice documental terá sua própria maneira de representar. O terceiro vértice, o da poesia, vai procurar sublimar a violência inaugural e buscar unidade com o mundo por meio do fenômeno que o embala, que é o movimento.

Bergson procurava alertar a respeito da possibilidade de se confundir "movimento" com "espaço percorrido" (algo que ainda perdura no senso comum). No caso de Chaplin, não se trata disso. A mecânica que envolve o dinamismo disparado pela violência inaugural funciona como Máquinas de Goldberg ${ }^{27}$ imaginárias: Chaplin pisa em uma tábua, que arremessa um balde, que cai na cabeça de seu antagonista, que corre atrás dele e pisa no rabo de um cachorro, etc. O movimento, neste caso, aparece como algo que possui existência autônoma. Ele é mais importante que o seu objeto. Neste sentido, fica a meio caminho da definição de Deleuze: "o movimento será a passagem reguladora de uma forma a outra, uma ordem de poses ou instantes privilegiados" (DELEUZE, 1983, p. 9). Para ele, a passagem de uma forma a outra é necessariamente reguladora, ou seja, pressupõe uma mudança de estado em instantes privilegiados. Deleuze supõe que só há real movimento quando estas mudanças de estado ocorrem na matéria (no sentido bergsoniano), provocando um acontecimento. Portanto, não se trata somente de uma força-motriz. Não se trata de uma mecânica. $\mathrm{O}$ movimento em Chaplin pode começar desta forma (como uma mecânica), mas termina, para fins de constituir um cinema poético, no movimento deleuziano. E nada disso

\footnotetext{
${ }^{27}$ Uma Máquina de Goldberg é um dispositivo lúdico que cria uma engenharia hipercomplicada para resolver tarefas muito simples. O princípio de uma máquina dessas é admirar sua mecânica, e não os efeitos de sua atuação.
} 
poderia ocorrer, conforme veremos adiante, sem que sua imagem fosse silenciosa. É neste ínterim que se constitui a gramática de pura cinética, a intrincada coreografia do espírito de que falava Auster. Não à toa, o movimento de atores como Chaplin ou Buster Keaton é frequentemente associado à dança ou ao balé (o movimento poético - e silencioso, a despeito da música, conforme veremos - por excelência). Sadoul deixa isso claro: "Quase todos estes filmes têm a precisão e a graça de um balé, mas a sátira e a crítica social os tornam algo mais que brilhantes divertimentos" (SADOUL, s/d, p. 131). Já André Bazin, em texto clássico sobre Chaplin, coloca em termos mais complexos:

\begin{abstract}
A razão disso é que, de certa forma, a mecanização é o pecado fundamental de Carlitos, a tentação permanente. Sua liberdade a respeito das coisas e dos fatos só pode se projetar na duração sob forma mecânica, como uma força de inércia que se deflagra a partir de um acionamento inicial. A ação do homemda-sociedade, isto é, vocês e eu, é organizada pela previsão e controlada ao longo de seu desenvolvimento por uma referência constante à realidade que ela quer modificar. A ação adere por inteiro à evolução do acontecimento no qual se insere. A de Carlitos, ao contrário, é feita de uma sucessão de instantes: para cada um deles, um obstáculo. Mas vem a preguiça, e Carlitos reproduz nos instantes seguintes a solução que convinha em outro dado momento. O pecado capital de Carlitos - e ele, de resto, não hesita em nos fazer rir à sua custa - é a projeção, no tempo, de uma forma apropriada ao instante: a "repetição" (BAZIN, 2006, p. 20).
\end{abstract}

O texto de Bazin enfoca uma série de habilidade chaplinianas, como seu agarramento ao instante (trabalhando sempre o timing com rigor militar) e incapacidade de planejar os instantes imediatamente futuros; como sua capacidade de criar uma máscara para si, fazendo seu arquétipo incorporar outros, como se pudesse intepretar todos os personagens em um só; e, é claro, a capacidade que Chaplin tinha em interagir com os objetos, mudando sua valência simbólica, transformando-os em qualquer coisa útil para sua gag ou para seu instante poético, sendo isso (o deslocamento simbólico ou metáfora) uma base fundamental para qualquer poesia de qualquer forma. Tudo isso, sob o guarda-chuva da linguagem silenciosa (ou seja: sem palavras para interromper estes processos), faz com que o filme de Chaplin se pareça com uma experiência de completa mobilidade dentro da mente, uma experiência de bombardeio e estímulo sensorial, algo que desembocará na abstração.

Já em sua fase na Essaney (1915), Chaplin passaria a moldar Carlitos de maneira a deixar a atmosfera primal da violência ser transmutada na poesia que ratifica estas relações todas. Em $O$ vagabundo (The tramp, Charles Chaplin, 1915), um dos mais reverenciados curtas desta época, a inteligência do cineasta já havia aprisionado as 
condições específicas do novo medium que ele passara a experienciar e dominar. Aqui, Carlitos encontra a possibilidade de salvar Edna Purviance, uma moça rural, de assaltantes, "vagabundos" como ele próprio. Ele consegue salvá-la, mas ao contrário do que ocorre em Carlitos e as salsichas - em que ele procura passar a perna em Mabel Normand -, aqui vai se aproximar dela como ingênuo interesse romântico. Carlitos é então acolhido pela família de fazendeiros, passa a (tentar) trabalhar e no final impedem que os mesmos vagabundos retornem para roubar o pai de Purviance. Mesmo tendo sido um herói, ao ficar sabendo que sua amada ficara noiva de outro homem, ele decide deixar um tocante recado e ir embora. O último plano do filme é o de Carlitos caminhando sozinho em uma estrada poeirenta, com seu andar característico, algo cômico, algo melancólico, indefinido, que se encaixa perfeitamente no vértice poético do cinema. Neste filme, o movimento e a violência continuam a existir. Gags com fogo, ancinhos, escadas, sacos de farinha, etc., firmam terreno ainda no velho Chaplin. Porém, este filme é já a investida definitiva no melodrama, misturando gêneros, explorando a intercomunicabilidade entre cada um deles, criando uma alquimia que o fez ser comparado inúmeras vezes a Shakespeare (MALAND, 2004, p. 205) e Molière (SADOUL, s/d, 130-131).

Se tudo o que foi argumentado aqui até agora pôde ser inferido a partir de um excerto escrito por Paul Auster, também uma única cena de Chaplin pode cumprir este papel. Em Dois heróis, o filme da Keystone de pugilismo em que ele contracena com Roscoe Arbuckle, Chaplin não é mais que um mero coadjuvante. Aparece apenas em uma cena: quando Arbuckle vai entrar no ringue para confrontar um adversário maior e mais ameaçador que ele, Chaplin é o juiz. Sendo esta sem dúvida a melhor cena do filme (FIG.07), fica o registro de sua capacidade de transformar mera violência mecanizada de maneira bruta em um legítimo movimento deleuziano que faz instantes privilegiados (neste caso, cada fotograma do filme) operarem mudanças de estado nos acontecimentos envolvidos no processo. Chaplin sabia que seus movimentos e pantomima eram muito superiores aos dos atores e atrizes que contracenavam com ele na Keystone (CHAPLIN, 1998, p. 151). A cena da luta, com a presença de Chaplin conduzindo o balé mecânico ${ }^{28}$, produz um efeito (de reincidência do instante, conforme

\footnotetext{
${ }^{28}$ Neste sentido um filme de Chaplin é mais eficiente, enquanto mecânica, do que o filme cubista de Fernand Léger chamado justamente Balé mecânico (Ballet mécanique, Fernand Léger, 1924) que, não por acaso, começa com uma animação contendo o personagem de Chaplin. A mecânica que enlaça a poesia,
} 
apontado por Bazin) para cada pequeno movimento, cada tombo, cada soco dado no ar, com os três personagens se enlaçando como se fossem um fenômeno atmosférico, algo fortuitamente natural. Como se a violência do pensamento (que engendra a filosofia), através destes movimentos, operasse uma mudança de estado para estes instantes. Uma mudança para uma frequência poética.

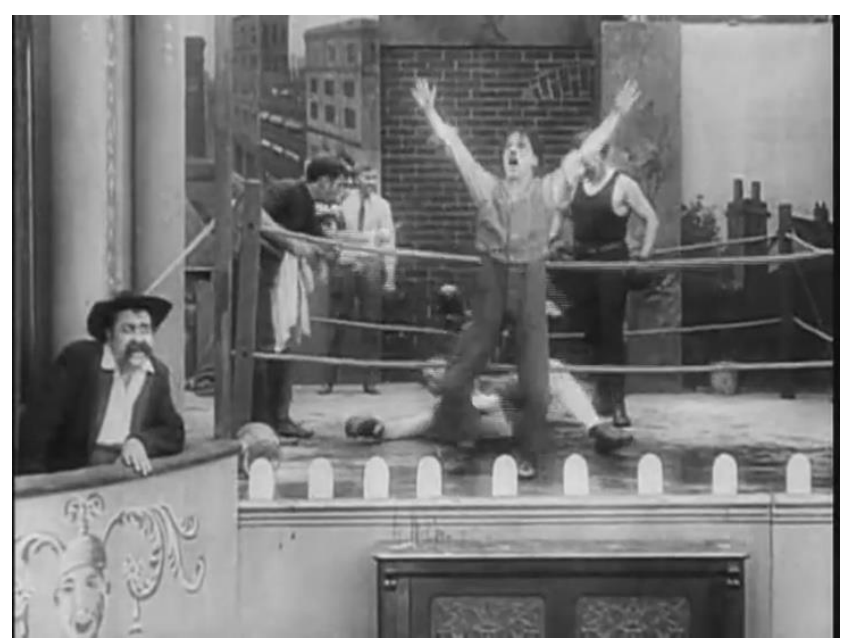

Figura 7

ao que parece, funciona melhor quando se origina de relações mais intimamente filosóficas do que quando são engendradas artificialmente e de maneira experimental. Parecer uma Máquina de Goldberg, neste caso, é melhor que ser uma Máquina de Goldberg. 


\subsection{Os vampiros: pequenas metonímias de imagem, movimento, presença e poesia}

Tudo o que pode ser pensado, pode ser pensado claramente. Tudo que pode ser dito, pode ser dito claramente. Mas nem tudo que pode ser pensado pode ser dito. - Wittgenstein

\subsubsection{Um vampiro escala um prédio e o cinema silencioso é inaugurado}

Como a mecânica da violência passa para o movimento, e depois à presença, e então à poesia? Chaplin pode ter realizado, em confluência com as condições econômicas de produção e com a estética cinematográfica de sua época, esta passagem trilhando um caminho próprio. Ao final de $O$ vagabundo, conforme descrevemos, há um plano de Carlitos caminhando por uma estrada de terra. Ele está de costas para a câmera, e caminha em direção ao fundo do campo. Este plano tem apenas 18 segundos $^{29}$ (FIG. 08 e 09) de duração e funciona como pequena metonímia deste processo de descoberta que o próprio medium (cinema silencioso) opera sobre si. Podemos perceber, aqui, o momento em que o movimento simbólico da violência se transforma no movimento simbólico do balé, e em que um estado de poesia é anunciado para este medium. Não que este processo seja algum tipo de teleologia que vai de um estado a outro. Não há condições de se pensar as interfaces e interpenetrações entre um estado e outro (sempre funcionando como sístole e diástole - a violência, a razão e o balé estarão sempre contidos na poesia) como narrativa, como processo histórico. Por isso, ao invés da imagem da narrativa, é melhor utilizar a imagem da metonímia, em que parte e todo funcionam como instâncias intermitentemente intercambiáveis. Carlitos caminha, portanto, neste plano, nos onze primeiros segundos, um caminhar tristonho, com a trouxa de roupas melancolicamente simbolizando seu estado de transitoriedade, sua itinerância ${ }^{30}$. Ele carrega também uma vara que funciona como espécie de bengala, que

\footnotetext{
${ }^{29}$ As cópias que vemos hoje projetam em 24 fotogramas por segundo. O padrão da época variava entre 16 e 18 fotogramas por segundo, o que poderia produzir variação na duração efetiva do plano. A velocidade com que o projecionista girava a manivela do projetor, na época, também poderia influir na variação da duração total dos planos no cinema silencioso.

${ }^{30}$ Chaplin retratou sua condição de imigrante muitas vezes simbolicamente em seus filmes. O movimento mecânico da violência também se converte, neste caso, no movimento geográfico, já que seu personagem, encarnando diversas personalidades e situações diferentes, nunca se fixa em qualquer lugar. $O$ personagem, neste caso, se mostra como uma instância iterativa, em que se move para todos os lados, mas sem sair do lugar. O ápice desta relação se encontra no famoso curta $O$ imigrante (The immigrant, 1917), que ele realizou para a Mutual justamente para denunciar as condições difíceis daqueles que migram para os Estados Unidos no começo do século XX.
} 
o auxilia a se apoiar, com a postura corporal frouxa e derrubada. Porém, a partir do décimo primeiro segundo no plano, seu gesto instantaneamente muda de postura: ele literalmente dá de ombros, balançando o corpo, com as pernas galgando passos acentuados, com os calcanhares se elevando do solo, e os movimentos dos braços passam a ser também vívidos e entusiasmados, com a trouxa e a bengala entrando como parte da dança.

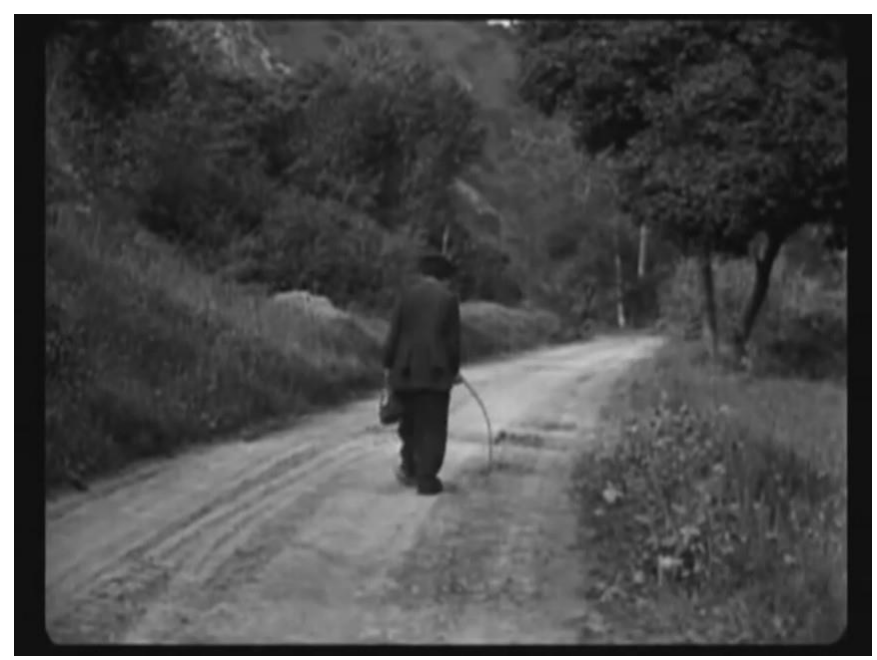

Figura 8

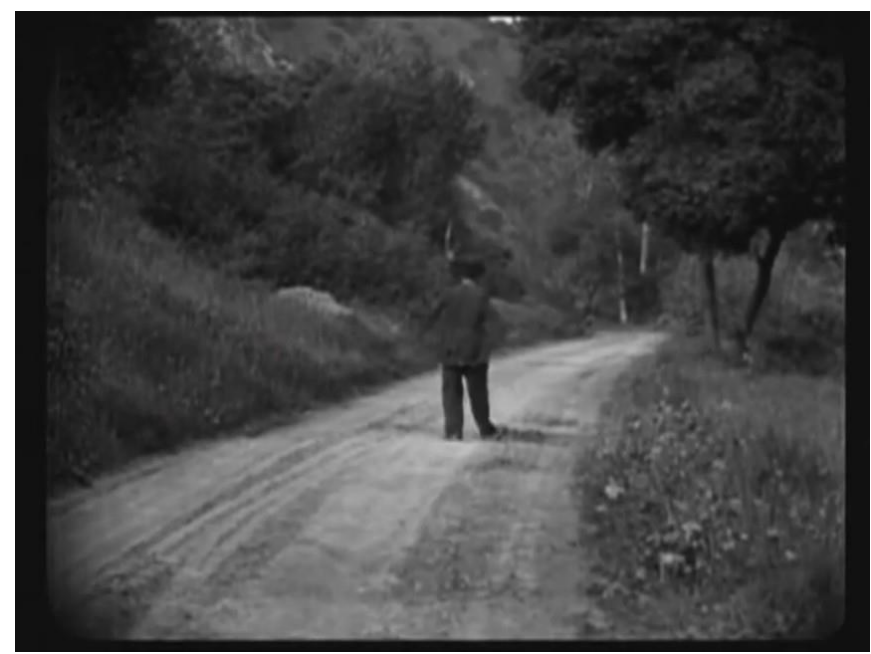

Figura 9

O teórico francês Phillipe-Alain Michaud, realizando intenso estudo sobre a relação do historiador e teórico da cultura alemão Aby Warburg com a imagem em movimento, localiza na dança e especialmente no gesto um aspecto importante na epistemologia que Warburg elabora para a arte. O teórico alemão considerava que o fundamento da arte não estava na estática (conforme apontava a tradição clássica da 
estética), mas sim no movimento. Michaud realiza uma investigação através da obra irregular de Warburg, que se inicia em trabalhos de campo etnográficos com povos indígenas do Novo México e Arizona nos Estados Unidos, depois passa a uma reflexão sobre a influência do classicismo e do Renascimento Florentino e, por fim, seu último projeto, à composição de um Atlas imagético (Mnemosyne) que procurasse reinventar a historiografia por meio da imagem (a relação e o movimento entre elas). O pensamento intermitente de Warburg, muito influente, que elabora uma história por meio de simultaneidades transversais entre imagens e gestos (diferentemente da linearidade logocêntrica da historiografia clássica), logo foi pensado como conjunto a um pensamento sobre a imagem em movimento e ao cinema. Em 1923, Warburg recapitula, em conferência, a experiência que havia tido com a etnografia e o papel fundamental da dança ameríndia na estruturação de seu pensamento:

[...] suas danças das máscaras não são um jogo, mas uma resposta, sob uma forma pagã primária, à grande e dolorosa questão do porquê das coisas: ao caráter incompreensível dos fenômenos naturais o índio opõe sua vontade de compreender, transformando-se pessoalmente, tornando-se, ele mesmo, essa causa das coisas. Num movimento instintivo, ele se constitui como causa do encadeamento inexplicado, o qual torna tão compreensível e tão visível quanto pode. A dança das máscaras é uma causalidade dançada. (WARBURG apud MICHAUD, 2013, p. 37).

A "dança" de Chaplin também é, de certa forma, uma causalidade dançada, e sua violência é também uma violência inaugural. Se a passagem (ou movimento iterativo) entre uma coisa e outra se dá por meio da intermitência - não seria difícil, para os padrões culturais de hoje, criar um meme hiper-repetitivo dos segundos de Carlitos andando na estrada poeirenta, ora tristonho, ora vigoroso e enfático -, tal qual as imagens que se vetorializam em várias direções no Atlas de Warburg, é complicado estabelecer um momento efetivamente inaugural para esta transformação da imagem muda. A violência do movimento, sofisticando-se e transformando-se na poesia do balé, para o cinema, seria esta metonímia iterativa que se replica, como vírus, em cada imagem do cinema silencioso e que só será interrompida com a irrupção de uma nova violência, que é da palavra e da fala. A associação com a dança ancestral dos pueblos indígenas feita por Warburg, produzindo logo um tipo de ligação animista da dança com as forças da natureza, leva à consciência de que este tipo de linguagem (Michaud enfatiza: "A linguagem dos gestos é o modo expressivo fundamental da humanidade" Cf. 2013, p. 305) nos conduz a um passado obnublado e temerário, antípoda e silencioso. Certo, o gesto para nós é uma instância fundacional, não apenas porque nos 
remete à pré-história ${ }^{31}$, mas também porque está na raiz tanto da violência no filme silencioso quanto no balé que ele perpetua, sendo cada instante que reitera esta relação metonímia capaz de remeter a toda ontologia deste cinema (que é uma ontologia poética).

Como, portanto, esta mecânica de gestos violentos se transforma na mecânica de gestos do balé? Michaud parece compartilhar desta visão a respeito de certa energia vital presente na violência citando um curioso filme rodado, ainda em 1894, por W. K. L. Dickson para o estúdio de Thomas Edison, exibido em seu aparelho de visualização de filmes individuais, o quinetoscópio. O filme, chamado tão simplesmente Registro de um espirro (Edison's kinetoscopic record of a sneeze, 1894) mostra, como era de praxe nestas primeiras manifestações da imagem em movimento, aquilo que seu título indica: um ator (Fred Ott) espirrando. Michaud identifica neste rosto contorcido a potência do cinema em si: "através da expulsão do sopro, do pneuma, Registro de um espirro exibe, no registro mítico-banal próprio do cinema nascente, a manifestação da energia vital numa convulsão extática" (MICHAUD, 2013, p. 57). Trata-se, portanto, da mesma violência que Hans Ulrich Gumbrecht vai encontrar na epifania produzida pela presença inerente à obra de arte: 'Eu propus definir 'poder' como o potencial de ocupar ou bloquear espaços com corpos, e 'violência' como a atualização do poder, ou seja, poder como performance ou evento" (GUMBRECHT, 2004, p. $114^{32}$ ).

O que ocorre, porém, quando este gesto de violência, transfigurado de forma iterativa no gesto da poesia, aparece em uma imagem técnica como a do cinema? Este ínterim, entre a metonímia que nos leva à pré-história e a nova violência que emerge (a palavra e fala, com o cinema sonoro), produziu, por meio de uma deficiência técnica ou ausência de um medium (a ausência de falas gravadas), um cinema de poesia. Mas de

\footnotetext{
${ }^{31}$ A pré-história é referenciada aqui não apenas como linearização que nos devolve aos nossos ancestrais (afinal, a relação não é propriamente esta, porque indígenas americanos do final do século XIX não são nossos ancestrais) mas sim na própria elaboração da História como algo que foi constituído pela trajetória das técnicas, conforme aponta Vilém Flusser: "Quem observar os movimentos de um fotógrafo munido de aparelho [...] estará observando um movimento de caça. O antiquíssimo gesto do caçador paleolítico que persegue a caça na tundra. Com a diferença que o fotógrafo não se movimenta em pradaria aberta, mas na floresta densa da cultura. Seu gesto é, pois, estruturado por essa taiga artificial, e toda fenomenologia do gesto fotográfico deve levar em consideração os obstáculos contra os quais o gesto se choca: reconstituir a condição de gesto" (FLUSSER, 2011, p. 49). Flusser sustenta que a imagem vem do gesto da mão que pinta, e que o texto, que surge para aplacar certa iconolatria, vem para traduzir as cenas compostas pelas imagens em processos que linearizam a consciência e fundam o processo histórico, sendo as imagens tradicionais, portanto, pré-históricas.

32 Tradução nossa.
} 
que ele se constitui? De que maneira a interposição do movimento e da montagem em uma imagem silenciosa transformaram estes tropos originários? Estas hiâncias querendo se transformar em algo, estas metonímias, enfim, geram um dispositivo técnico capaz de nos retirar de nossa frequência ordinária de percepção e nos sintonizar em outra, poética, capaz de nos fazer chegar a esta dança ancestral, a este animismo que retoma o fluxo das coisas e da consciência. O que ocorre aqui?

Para responder a estas questões é necessário recorrer a mais 105 segundos de filme silencioso. Os vampiros (Les vampires, Louis Feuillade, 1915-1916) é um serial produzido pela Gaumont, estúdio francês que herdou o primado da Pathé na década de 1910, e dirigido por Louis Feuillade, que modernizou o cinema francês nesta década a partir de seu seriado Fantômas ${ }^{33}$. O sucesso do primeiro seriado levou à irregular (a duração e as datas dos lançamentos dos episódios não eram programáticos) produção de Os vampiros, que pode ser visto, em sua fragmentação, como episódios independentes ou como um longo filme de 440 minutos, cheio de problemas de continuidade e reviravoltas mirabolantes na trama.

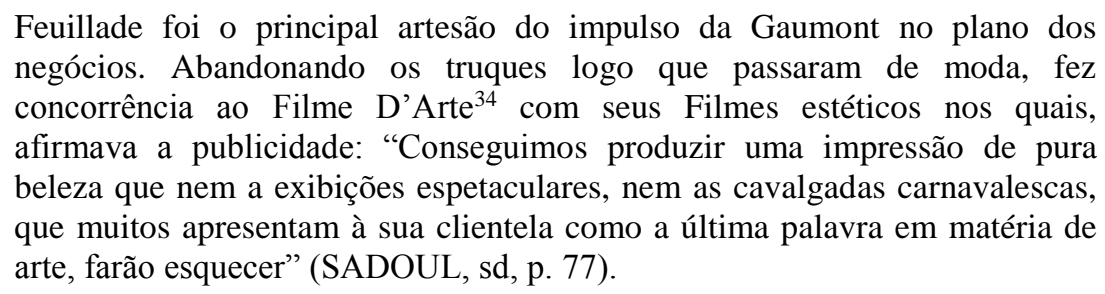

Como se pode ver, Os vampiros não foi exatamente concebido como uma produção de luxo, tendo os episódios sido filmados às pressas e sem muito rigor em sua estrutura narrativa. Por outro lado, a série trouxe várias inovações que ajudaram a modernizar certos aspectos do cinema na década de 1910. Se o estilo tableau de Feuillade ainda parecia, sendo herdeiro do Film D'Art, calcado no teatro, esta primeira impressão pode ser considerada errônea graças principalmente ao uso intenso da profundidade de campo e de uma mise-en-scène elaborada conjuntamente com os enquadramentos do espaço fílmico e com movimentos de câmera, dotando os episódios de elegância singular. Além disso, o uso do recurso da mise-en-abîme, de animações e

\footnotetext{
${ }^{33}$ Cf. capítulo 4.

${ }^{34} \mathrm{O}$ Film D'Art, ou Filme D'Arte foi um gênero francês do primeiro cinema inaugurado por $O$ assassinato do Duque de Guise (L'assassinat du duc de guise, Charles Le Bargy e André Calmettes, 1908), que primava pela trilha e roteiros originais. O Film D'Art tinha intenção de trazer certa respeitabilidade que ainda faltava ao cinema na década de 1900, procurando fazer isso com cenários pomposos e trama e mise-en-scène mimetizados do teatro.
} 
diversos tipos de trucagens técnicas fez de Os vampiros um precursor de thrillers elaborados em que a estrutura tanto dos truques técnicos quanto da montagem inspiravam e refletiam a natureza confusa de tramas policialescas. Ao contrário do contemporâneo Griffith, que baseou suas inovações na montagem one-to-one, portanto inovando no espaço entre as imagens, Feuillade foi um inovador na constituição do cinema dentro da imagem, aperfeiçoando os cenários, a disposição e movimentação dos atores e o posicionamento da câmera, instituindo elaborada abordagem do espaço fílmico dentro do campo.

A trama de Os vampiros, por sinal, nada tem de sobrenatural, ainda que encontre soluções mirabolantes (apetrechos, passagens secretas, poços com fundos falsos, entradas pela chaminé, carros com dispositivos, etc.) e por vezes tecnológicas para criar uma atmosfera fantástica. Os vampiros do título não são seres mágicos, mas sim uma gangue de profissionais do crime extremamente perversos que impõem seus métodos pérfidos a todo tipo de autoridade (polícia, governo, imprensa). A série completa é um jogo de gato e rato entre, basicamente, o repórter Philipe Guérande (Édouard Mathé, um dos atores franceses mais populares da época) e a vamp e sex-symbol precoce Irma Vep (a lendária Musidora), que é uma das peças-chave do grupo de bandidos. Os vampiros é uma série narrativa, muito contagiante, que em princípio pouco pode ser pensada em termos de cinema de poesia. Feuillade era um cineasta fortemente influenciado pelo aspecto mandatário de seu chefe Léon Gaumont (o dono e fundador do estúdio), e entendia o cinema como negócio. Mesmo assim, o dinamismo dos apetrechos e dispositivos utilizados por mocinhos e bandidos, assim como a mobilidade da trama em si (com reviravoltas, personagens que revivem e crimes chocantes, de bestial brutalidade) e trechos (conforme analisaremos) de perfeita sinuosidade nos levam a uma leitura de suas imagens como pertencentes à mesma lógica produzida no movimento chapliniano, porém ainda mais complexa. Nossa intenção aqui não é esgotar a série, mas sim recuperar pequenos pontos metonímicos na mesma medida com que fizemos com Chaplin, a fim de pensar a imagem do cinema silencioso como uma imagem intrinsecamente poética.

Logo no primeiro episódio, já somos carregados pela violência e pela barbárie. $A$ cabeça decepada (Les vampires - La tête coupée, Louis Feuillade, 1915) conta como Guérande inicia sua investigação para incriminar os vampiros e acaba se envolvendo em 
uma trama que inclui um inspetor de polícia que é encontrado com sua cabeça decepada e uma série de desenganos com identidades falsas e ameaças. A cabeça do inspetor acaba sendo encontrada em uma passagem secreta próxima ao quarto do castelo onde o repórter está hospedado. A trama em si, rocambolesca e ainda não muito naturalmente legível, pouco importa diante dos momentos em que os aspectos metonímicos gerados no cinema a partir do movimento em si proporcionam a elaboração da poesia silenciosa do filme. No final, após uma série de assassinatos e o surgimento de um bilhete ameaçador escrito pelo "Grande Vampiro" (o líder da gangue), ocorre uma cena completamente diferente e destoante do episódio, e esta presença ressignifica todo o resto (FIG. 10, 11 e 12).

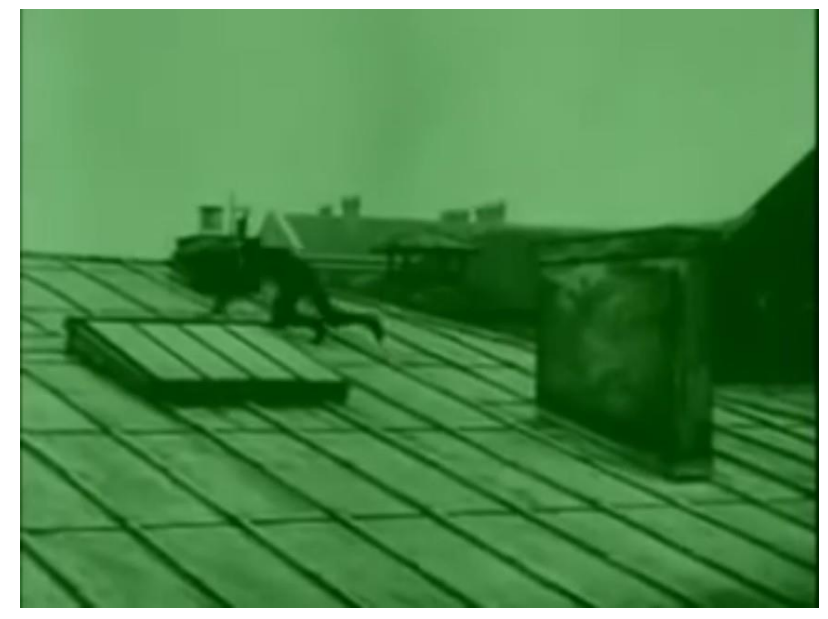

Figura 10

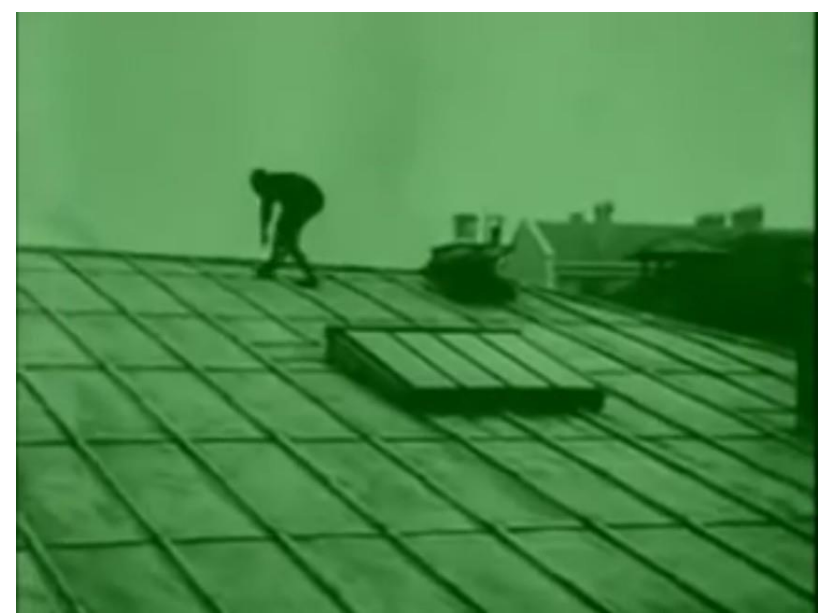

Figura 11 


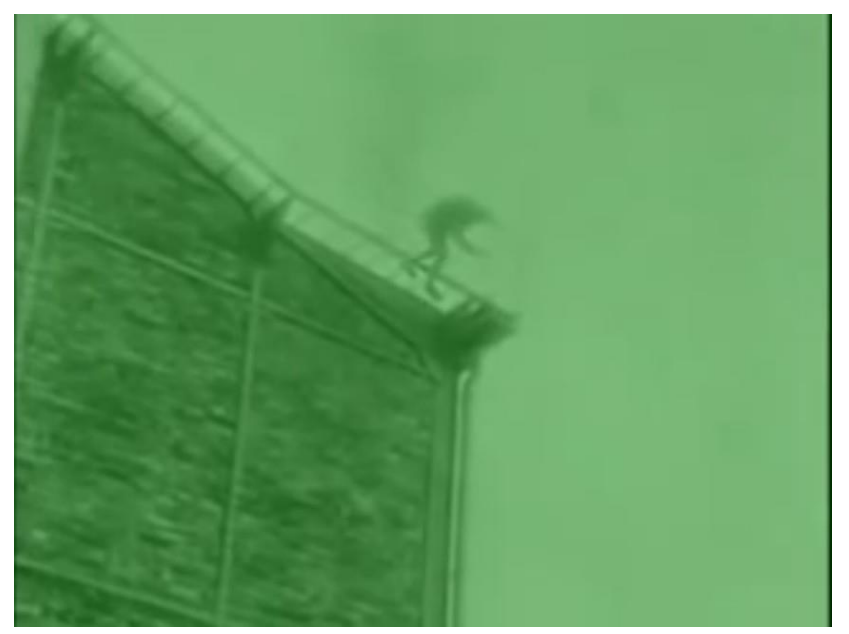

Figura 12

Após encontrarem a cabeça do Inspetor Durtal, Guérande e o Magistrado Thelès encontram assassinada, no castelo, a Srta. Simpson, que possuía interesse em comprar a propriedade do Dr. Nox (dono do castelo). Junto ao cadáver havia um bilhete: "Eu assassinei o verdadeiro Dr. Nox e assumi sua identidade. Nunca tente me encontrar. Eu sou - o Grande Vampiro". Guérande, o Magistrado e seus ajudantes percebem que haviam sido enganados, e que o Grande Vampiro, usando de astúcia e de seu domínio e conhecimento das passagens do castelo, escapara escalando a chaminé. O que se segue, na próxima cena (duas tomadas externas divididas em dois planos) é alienígena ao resto do filme, mas ao mesmo tempo funciona como princípio e carimbo para ressignificá-lo. Durante 105 segundos vemos uma figura encapuzada vestida de preto (O Grande Vampiro? Irma Vep? Outro vampiro? Não há como saber) escalar os tetos do que se supõe ser o castelo, ou uma grande casa, em um movimento felino e sinuoso, acompanhado de discreta correção da câmera para a esquerda. Os passos do vampiro (agachados, ou em pé) são lentos, precisos, calculados. A situação é real e o ator (desconhecido) precisa manter o equilíbrio entre o atuar e a demanda da prova física à qual está submetido. Tais quais as badernas dos Keystone Kops de Mack Sennet ou as acrobacias perigosas de Chaplin e Keaton, uma parte do que impressionava no cinema silencioso até a década de 1910 ainda residia no espetáculo, na atração: era impressionante ver o quanto os atores se arriscavam e se expunham a malabarismos difíceis para satisfazer o desejo de risco do público. O cinema ainda herdava a performance do circo, do vaudeville. 
O vampiro escala o telhado, com suas claraboias e lucarnas, como uma dança, por 43 segundos até que um corte ocorre e o vemos então descer uma parede da casa ou castelo, na mesma toada, pelos outros 62 segundos. Primeiro, o lento caminhar por uma escada horizontal. Depois, a delicada operação de descer por um cano paralelo à parede do castelo. A operação é difícil, lenta e real. Mas a sensação que transmite não é necessariamente de estupor ou assombro pelo risco. Somos imediatamente, neste caso, contaminados por aquela presença que parece bastar por si e, assim que o vampiro pula no chão, o episódio termina. A relação entre a violência e a poesia, neste caso, ocorre de uma forma diferente do que vemos em Chaplin, onde ela se manifesta de maneira matricial e fundacional. Em Os vampiros, o corte da violência para a poesia obedece à montagem cinematográfica. Ele afirma o próprio cinema, em seu ato de cortar, como um tipo de violência contra a realidade. Neste sentido, estamos ainda em Zambrano: a razão e a linguagem são violentas, geram a filosofia, "que busca”. A poesia, "que já tem", é erótica: ela nos envolve em torpor justamente no momento em que o movimento, antes pertencente ao primado da filosofia (o movimento em direção à violência) se verte em tempo, algo que reside no campo da pura sensibilidade, da pura presença.

Podemos detectar este nível de ambiguidade neste primeiro episódio de $O s$ vampiros, em que, ao contrário de em $O$ vagabundo (quando a mudança ocorre por meio do gesto), a transformação de um estado ao outro se dá de maneira mais clara, poder-se-ia dizer didática: em uma primeira instância, temos a cabeça decepada e a motricidade característica dos apetrechos e passagens secretas pelas quais passam os vampiros. O movimento é impulsionado pela violência originária do tema e sustentado pelos caminhos que este cinema abre através de seus túneis de mobilidade. Neste sentido este cinema se aproxima da imagem mais vulgar dos filmes de violência contemporâneos, completamente consumidos por esta motricidade ${ }^{35}$. Porém, ao contrário do que ocorre no cinema falado, quando a palavra lineariza e dá uma direção narrativa à violência originária, tornando a imensa maioria dos filmes falados razão discursiva (ou seja: filosofia nos termos de Zambrano), no cinema silencioso esta

\footnotetext{
${ }^{35}$ Neste sentido, não é por acaso que a maioria dos filmes contemporâneos que obedecem ao cronograma da Jornada do herói de Joseph Campbell (1995) (um percurso teleológico que transforma este movimento da violência em um ciclo paranoico e infindável) se sustentam em uma narrativa de violência (neste caso literal) e repetição sem que o elemento poético reminiscente a todo cinema se manifeste. A presença da fala acelera e facilita muito a ocorrência deste fenômeno.
} 
violência reminiscente ocorre também como intermitência e iteração. A chave é virada, de uma hora para outra, em A cabeça decepada, e a fuga do vampiro, que poderia ser contada como mais um objeto de ação, se transforma na presença da imagem moldada na matriz do tempo ${ }^{36}$. O cinema silencioso, sem nunca alcançar a segunda (e determinante) violência da fala, sobrevive na repetição incessante (iteração) e na alternância (e por vezes ocorrência simultânea) entre os tropos que a inauguram. Neste caso, ao contrário do que imagina Zambrano, a filosofia e a poesia não são necessariamente autoexcludentes, mas sobrevivem na intermitência. Como afirma o poeta argentino Aldo Pellegrini: “A poesia não é mais do que esta violenta necessidade de afirmar seu ser que impulsiona o homem" (PELLEGRINI apud JUARROZ, 2009, p. 25).

Gilles Deleuze, em seu famoso livro A imagem-movimento, discute detalhadamente o estatuto ontológico do movimento em relação às imagens e, afora sua imensa tabulação das imagens relacionado-as às afecções que elas determinam, algumas de suas colocações são úteis para pensarmos a posição do movimento no que tange ao nascimento da poesia cinematográfica silenciosa. Em primeiro lugar, o filósofo francês afirma (DELEUZE, 1983, p. 7) que o movimento pertence à imagem média enquanto dado imediato. Ao contrário de Bergson, a quem ele responde, que considerava imagem e movimento como o mesmo fenômeno, Deleuze insere todas as imagens do mundo (incluindo aí as imagens das coisas que vemos, sendo elas antes imagens do que coisas) em certo campo de imanência, um bloco de espaço-tempo de onde surge o agenciamento maquínico das imagens-movimento (Ibid. p. 71). A imagem, porém, residiria na consciência. O movimento, no próprio espaço. A permuta ocorreria da seguinte forma: a imagem age sobre a consciência, transmitindo o movimento que está no espaço. A permuta, por outro lado, se confirma: a consciência responde e restitui o movimento à imagem. O sistema de fabricação que Deleuze impõe para a realidade funciona, portanto, como um navio viking em que existem pessoas remando para os

\footnotetext{
${ }^{36}$ A famosa visão de Andrei Tarkovski sobre o cinema, ainda que um tanto impressionista, corrobora tanto a ideia de que a poesia é uma forma de ontologia quanto o fascínio pela propriedade que o cinema tem em capturar a presença temporal e moldá-la por meio do processo iterativo: "Pela primeira vez na história das artes, na história da cultura, o homem descobria um modo de registrar uma impressão do tempo. Surgia, simultaneamente, a possibilidade reproduzir na tela esse tempo, e de fazê-lo quantas vezes desejasse, de repeti-lo e retornar a ele. Conquistara-se uma matriz do tempo real (TARKOVSKI, 1998, p. 71).
} 
dois lados ao mesmo tempo. A despeito do paradoxo, o movimento ocorre e restitui a realidade do navio (ele anda), ou, neste caso, da imagem ou de seu plano de imanência.

Deleuze chega a dar uma definição precisa para a imagem: "o conjunto daquilo que aparece" (Ibid. p. 70). Logicamente, a visão do filósofo sobre a imagem implica em fenomenologia, e a indistinguibilidade entre realidade e imagem não tem serventia se pensarmos nas outras valências da imagem enquanto conceito. A imagem é polissêmica. Ela pode ser fotogenia ${ }^{37}$, quando nos impacta com o gigantismo de um rosto. Ela pode ser signo que se dá à leitura, à decodificação: está imersa em códigos culturais. Nesse caso, ela é texto. Ao mesmo tempo, seguindo a lógica warburguiana que já comentamos, a imagem pode ser catálogo: seu conjunto compõe um sistema dialético de significação, não necessariamente legível (desta vez não é texto), não linear, mas perceptível, sensível, que se submete mais aos augúrios de um tipo de quiromancia do que à leitura tradicional de uma narrativa. O cinema soviético dos anos 1920, por exemplo, se submetia a este tipo de relação entre imagem e montagem. Neste caso, a imagem é cinema.

Dentre tudo que a imagem pode ser, podemos filtrar duas valências que a carregam em direção à poesia: ela é (ou ao menos o tem como dado imediato) movimento (Deleuze) e ao mesmo tempo procura restituir presença (mesmo estando ausente). E em que consiste esta segunda valência? O poeta argentino Roberto Juarroz, em instigante conferência sobre a natureza da poesia ("Poesia e Realidade"), ensaia uma resposta que em muito se aproxima de nossa visão a respeito de uma das funções da imagem:

E o poema, que aparece assim como uma organização ou uma estrutura aberta, intencionalmente incompleta, já que deve completar-se no leitor ou no receptor ou no ouvinte, se nos impõe cabalmente como uma presença. E é o poema como presença o que vai mais além das afirmações e das explicações, para configurar essa vigência mais lógica e não discursiva que é a poesia.

E essa presença que é o poema, por añadidura, quebra também a solidão do homem, serve como companhia essencial e o ajuda a transcender o tenebroso jogo das perguntas e das respostas. Por tudo isso, a poesia é o maior realismo possível, ainda que incautos, ignorantes e soberbos a considerem uma abstração, uma evasão ou uma veleidade subsidiária da prepotência política ou ideológica (JUARROZ, 2009, p. 22).

\footnotetext{
${ }^{37}$ Cf. capítulo 4.
} 
A imagem em sua valência de poesia, portanto, se impõe como presença, em uma "vigência mais lógica e não discursiva". Juarroz concebe a presença poética como um companheiro, algo que está lá, sem necessariamente aferir sentido, mas cuja presença preenche. A presença da poesia é o "a poesia já tem" de Zambrano. Para ela, enquanto a filosofia tem como combustível a hiância do vazio interno e a busca (violência) por respostas, a poesia, ao invés desta ausência (na qual a psicanálise de Lacan, por exemplo, encontra sua fundação através do deslizamento da linguagem simbólica por cima dela), contém naturalmente a presença. Se a ausência busca a linguagem, portanto, e logo o sentido, a presença se abstém desta busca, é sempre saciada. Dois paradoxos emergem destas relações: primeiro, como pode o movimento (efêmero por natureza e perpetrador da violência no sentido em que estamos falando) conviver com a imagem enquanto presença? E, em segundo lugar, como pode a imagem técnica do cinema (logo, virtualidade; logo, ausência) incitar a presença, conforme percebemos a partir da análise deste trecho de Os vampiros. Afinal, trata-se da presença do vampiro em movimento no filme que basta. A ausência de qualquer atribuição de sentido a cenas como a do vampiro nos telhados é que encantou os cineastas e pintores surrealistas dos anos 1920 (Magritte incluso ${ }^{38}$ ), que passaram a procurar nesta presença silenciosa (sendo o silêncio um componente fundamental à presença) um tipo de escrita automática para o cinema.

Ora, para resolver estes dois paradoxos, cabe pensar primeiro que a poesia é transfiguração do paradoxo no corpo do mundo. Não apenas ela não é a resolução para o paradoxo (mantendo sempre sua qualidade paradoxal), como depende de que seu nascimento esteja vinculado ao paradoxo para existir. Daí a intermitência e a incapacidade de resolução, nestes filmes, entre a violência fundadora e a poesiapresença que sacia e acaricia. Quando a fala irrompe e quebra este circuito (este sistema ou frequência), a poesia deixa de existir enquanto enquadramento para a percepção do mundo e se normatiza enquanto vetor: a fala lineariza esta poesia originária do paradoxo, quebra o paradoxo e a insere no mundo do conceito. Ou seja, ela se torna gênero literário, forma de arte, tipo discursivo, etc. É por isso que a poesia é antes um tipo de ontologia que um tipo de estética. Quando recai no reino das palavras (caso da

\footnotetext{
${ }^{38}$ Cf. capítulo 4.
} 
poesia escrita), esta natureza ontológica se volta contra as próprias palavras, procurando exaurir os limites de sua violência.

Assim, para existir, a imagem poética do cinema silencioso precisa de seus três componentes paradoxais: o movimento, a presença e o silêncio. Se a montagem dos filmes, baseada na violência do corte, os empurra em direção à linearização narrativa, o movimento, a presença e o silêncio é que garantem a sobrevivência da intermitência, e a articulação entre estes componentes fecunda a poesia. Portanto, se o movimento é dado imediato da imagem, e a imagem remete presença, imagem, movimento e presença são diferentes dimensões de um único fenômeno, e o aproveitamento destas dimensões é que determina o rendimento poético da imagem em movimento.

Porém, como a imagem técnica restitui movimento se ela é, por definição, virtualidade? O filósofo tcheco-brasileiro Vilém Flusser tem uma outra definição para a imagem: "Imagens são superfícies que pretendem representar algo" (FLUSSER, 2011, p. 21). Ao invés da definição fenomenológica de Deleuze, portanto, Flusser elabora uma outra, concentrando-se em dois aspectos: em primeiro lugar, na qualidade representativa da imagem, que aparece na maioria das definições clássicas. Até aí, nada surpreendente. Porém, o termo superfície chama a atenção porque Flusser considerava que as imagens tradicionais eram superfícies cujo gesto deflagaria uma magicização desta representação calcada no rito ancestral e animista, tal qual Warburg previa para a dança (não à toa, estes dois elementos aparecem como fatores fundamentais para a composição de uma etiologia para o cinema silencioso). $\mathrm{O}$ olhar circular, que desliza pela superfície e repete incessantemente o rito gestual de composição da imagem tradicional (a mão que pinta) funciona como fetiche para a encenação que Flusser considera a alucinação da iconolatria ${ }^{39}$, somente substituída pela invenção da escrita por meio de símbolos discretos, responsável pela transformação da superfície em linha e, portanto, da magia em processo.

\footnotetext{
39 Já um outro pensador da imagem técnica como Friedrich Kittler (Cf. 1999, p. 52) vai localizar a alucinação no campo do simbólico representado pelo escrita. A qualidade altamente abstrativa do código simbólico teria mergulhado o século XIX no delírio coletivo da escrita (de estocagem, não computacional), quando o surgimento de novos meios de comunicação (o cinema incluso) teriam configurado uma nova consciência a partir das propriedades destes media. O cinema silencioso, de certa forma, surge como consequência disso.
} 
A imagem técnica, porém, conforme argumenta Flusser, inaugurada pela fotografia no século XIX, submete este processo textual a uma nova configuração, desta vez programática, em que o aparelho transforma processos (textos, números, cálculos) em superfície novamente, buscando um tipo de remagicização. Como ele mesmo afirma: "as imagens tradicionais imaginam o mundo; as imagens técnicas imaginam textos que concebem imagens que imaginam o mundo" (FLUSSER, 2011, pp. 29-30). Imagens técnicas, portanto, a despeito de seu aparente realismo, são também simbólicas (ainda que conotativas, ou seja, sujeitas à interpretação), e Flusser enfatiza esta ambiguidade. A diferença, porém, é que, supostamente, decifrar imagens tradicionais revela o mundo, enquanto decifrar imagens técnicas revela texto. $\mathrm{O}$ ato de subir $\mathrm{e}$ descer dos prédios perpetrado pelo vampiro nos 105 segundos que elegemos para ver nascer uma poética silenciosa está na verdade registrado no dispositivo da câmera, que por sua vez opera um programa pensado antes através de cálculos do que qualquer tipo de fenomenologia. A imagem silenciosa, neste caso, procura restituir a presença. $\mathrm{O}$ movimento do vampiro subindo e descendo encanta como os o girar de um cavalinho em um zootrópio. Temos uma presença, aqui, ausente (porque se trata de uma inscrição virtual na película), que perde a materialidade, mas captura a eternidade do movimento. A questão é que, para um pensador como Flusser, este movimento não está esculpido no tempo, como pensava Tarkovski, mas sim esculpido e previsto pelo mecanismo da câmera. $\mathrm{O}$ ato de esculpir o tempo que a câmera opera não difere tanto de uma moderna escultura realizada inteiramente por uma impressora $3 \mathrm{D}$, em que a natureza do programa computacional é responsável pelos mais "milagrosos" atos escultórios. Como previa Flusser, a relação com a materialidade passa da mão (o escultor) para a ponta dos dedos (os mesmos dedos que digitam textos no computador, operam botões em uma câmera ou programam uma impressora 3D).

A presença do vampiro caminhando pelo telhado, portanto, remete a dois níveis de virtualidade: a da imagem (técnica) e a do texto (que a programa). Resta a impressão do movimento, por si só uma presença (afinal, dado imediato da imagem, como previa Deleuze), e aí voltamos à violência (também movimento) e ao balé, que, associados ao silêncio destas imagens, funcionam como genitores deste tipo de poesia cinematográfica. A presença/ausência do vampiro, no entanto, perdura no sentido de que é neste paradoxo/ambiguidade que a imagem poética efetivamente emerge. Gumbrecht, também afeito a pensar as modalidades midiáticas como fatores sistêmicos 
que modulam a cognição a partir de variações no sentido, ressalta a necessidade de se deixar o próprio sentido de lado em prol de uma valorização da produção de presença:

A palavra "presença" não se refere [...] a uma relação temporal, mas sim a uma relação espacial com o mundo e seus objetos. Algo que está "presente" deve supostamente ser tangível às mãos humanas, o que implica que, reciprocamente, tem um impacto imediato em corpos humanos. "Produção", então, é usado de acordo com o sentido de sua raiz etimológica (i.e., do Latim, producere), que se refere ao ato de "trazer à tona" um objeto no espaço. [...] Portanto, a "produção de presença" aponta para todos os tipos de eventos e processos em que o impacto que os objetos "presentes" têm em corpos humanos está sendo iniciado ou intensificado (GUMBRECHT, 2004, p. XIII). ${ }^{40}$

Gumbrecht menciona a saturação do sentido (que acompanha o esgotamento da hermenêutica) em um mundo francamente cartesiano, porém inadvertidamente pontua que é ao mesmo tempo impossível se livrar do sentido quando ele pode ser encontrado em toda parte. Se a imagem técnica do cinema silencioso provoca uma remagicização do mundo através de um retorno ao código de superfície (que propicia o deslizar do olhar, operando a beleza que percebemos no vampiro escalando o prédio), estando aí a imagem servindo como replicadora da presença e buscando um patamar de eternidade, a adição do código da fala (no cinema sonoro) bloqueia esta presença ausente, instituindo novamente o sentido, linearizando a leitura destas imagens novamente. Gumbrecht entende que o sentido nunca desaparece completamente, e que a presença, efetivamente, ocorre como efeitos (naturalmente efêmeros) que concorrem com efeitos de sentido, gerando fenômenos como a epifania, locus onde reside qualquer estética.

[...] experimentar as coisas do mundo em sua coisidade anterior a qualquer conceito vai reativar o sentimento pelo corpóreo e pela dimensão espacial de nossa existência. [...] Eu acredito que nós estamos sempre - deliberadamente ou não - nos referindo a epifanias quando, em nossa situação cultural específica, usamos a palavra "estética". Estamos nos referindo, com esta palavra, a epifanias que, ao menos por momentos, nos fazem sonhar, nos fazer desejar e nos fazer talvez mesmo lembrar, com nossos corpos e ao mesmo tempo com nossas mentes, o quão bom seria viver sincronizado nas coisas do mundo (Ibid. p. 118).

O pensador alemão certamente identifica na epifania dos corpos, na existência daquilo que está ao alcance do toque (a presença efetiva), algo fundamental à experiência estética (o que foi problematizado por Benjamin em seu clássico ensaio sobre a reprodutibilidade técnica ${ }^{41}$ ) e, mesmo estando ausente do corpo, a imagem do

\footnotetext{
40 Tradução nossa.

${ }^{41}$ Cf. BENJAMIN, 1994.
} 
vampiro subindo e descendo o prédio procura replicar (como imagem replicativa que de fato é) certo efeito de presença. Está aí o trunfo, neste caso, da imagem técnica: ela não produz o movimento, mas o computa, em sua caixa preta. Ela não está efetivamente presente, mas produz seu efeito. Mais surpreendentemente ainda, ela procura replicar não apenas o efeito de presença dos objetos corpóreos, mas congelar (na base de dados de seu programa) sua efemeridade, para que possamos rever, em 2016, um ínterim capturado pela câmera em 1915.

A imagem técnica de Flusser, portanto, se localiza entre o puramente fenomênico plano de imanência deleuziano (onde qualquer objeto é imagem) e presença corpórea de Gumbrecht (onde nenhum objeto é imagem). Esta tensão, somada à ausência técnica (supressão de um medium) que é o silêncio do cinema silêncioso, é o insumo para a produção de um cinema de imagens poéticas.

\subsubsection{A interferência de um medium: palavra versus imagem}

A palavra interfere no aspecto comunicacional da imagem, isto é evidente, mas esta não é a única implicação que se pode inferir do encontro entre estes media. A contaminação de um medium no outro e os efeitos para os dados processados por cada um deles, tanto em relação ao caráter informacional quanto na própria cognição dos usuários destes media, são complexos e fundamentais para se compreender o que ocorre com o cinema na passagem do silêncio para o som. Aspectos importantes como a presença dos intertítulos e as diversas modalidades sonoras presentes no cinema silencioso serão abordados adiante. Neste momento, é fundamental considerar a incidência da palavra no corpo das imagens silenciosas e os efeitos desta interferência nos próprios dados que são processados nelas, a partir da ideia já discutida das imagens técnicas. Palavras aparecem nos filmes silenciosos desde seus primórdios, primeiramente dentro da diegese e, posteriormente, a partir da virada narrativa, com a presença de intertítulos, que vão servir para complexificar narrativas, falas, descrições e sentimentos. Eles vão cumprir papel fundamental para mudanças paradigmáticas na composição destes filmes, mas o que interessa neste momento é a presença da palavra inserida dentro da imagem, instância importante em que os dois media (palavra e imagem) existem enquanto medium misto. É o momento em que relações emergem: domínio de um sobre o outro, submissão, concorrência, anulação. Palavras são signos 
arbitrários, inteiramente conceituais, mas não deixam de ser imagens ou de produzir polissemia. Um hábito comum no cinema silencioso, conforme ocorre, por exemplo, em A roda (La roue, Abel Gance, 1923, FIG. 13), é a palavra ocorrer junto à primeira aparição de um personagem, apresentando-o para que o espectador fixe de imediato certas referências que precisam ser retidas para a compreensão do enredo do filme. Eventualmente, também os nomes dos atores que interpretam estes personagens aparecem grafados na tela junto a estas imagens.

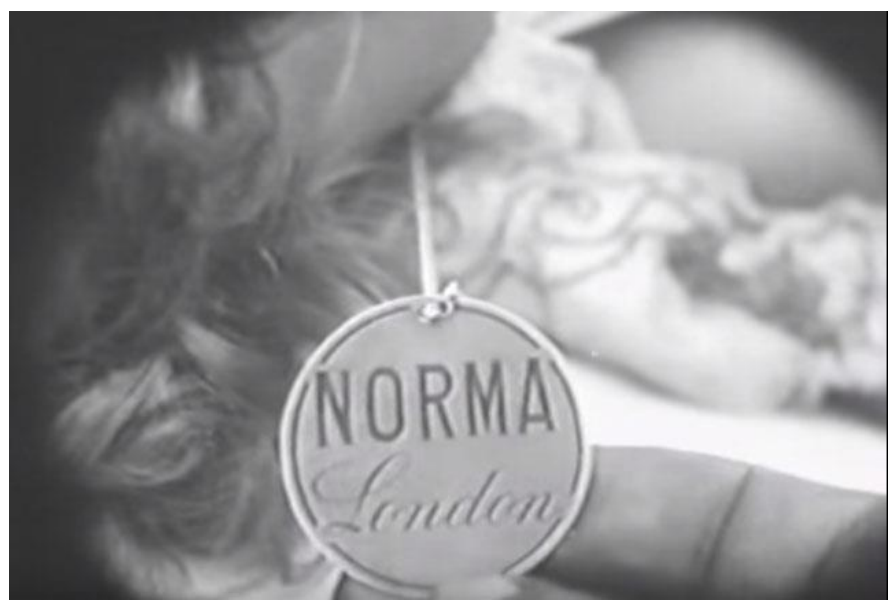

Figura 13

Em Os vampiros há a incidência de um evento muito interessante que serve como ponto de partida para um debate a respeito deste tipo de interferência. Tratam-se, mais uma vez, de poucos e valiosos segundos (desta vez, 100) que servirão de ponte metonímica para uma elaboração destas relações. No episódio 3 da série, $O$ criptograma vermelho (Les vampires - Le criptogramme rouge, Louis Feuillade, 1915), o personagem-repórter Philipe Guérande, na mira da gangue dos vampiros, se disfarça para realizar certas investigações de campo, e acaba aparecendo em um teatro de vaudeville em Paris chamado "O gato que uiva". A cena em questão é, na verdade, uma pequena sequência, dividida em uma tomada externa e um conjunto interno de planos, dentro do teatro. Ela começa com Guérande aparecendo na porta do teatro em questão, onde ele examina a placa-cartaz do evento anunciado naquela noite: trata-se de uma gravura com uma ilustração caricatural do rosto de uma mulher fortemente maquiada com a inscrição "Irma Vep" logo abaixo do desenho (FIG. 14). Como se sabe, Irma Vep é o nome da "vampira" interpretada por Musidora que se tornará a anti-heroína protagonista da série. A cena começa com um plano de conjunto, mas logo há um corte 
para um plano americano, aproximando o espectador de Guérande e do cartaz. O repórter aponta então para a inscrição no cartaz e a imagem muda novamente, através do corte: vemos um close na inscrição "Irma Vep" e então as palavras que compõem o nome da personagem, por meio de uma animação, se embaralham e o espectador, identificado com o insight do repórter, vê elas se recomporem na palavra "vampire" ("vampiro" em francês, FIG. 15, 16 e 17). Logo depois, também por meio de animação, as palavras se embaralham de novo e voltam a compor "Irma Vep". Guérande então entra no teatro e passamos a uma mudança de cena, agora interna. Vislumbramos, em plano geral, o interior do teatro com Irma Vep já em cena, sobre um palco simples com um cenário pintado ao fundo. Vemos também uma plateia eminentemente masculina, típica do vaudeville francês do final do século XIX e início do XX. Temos a impressão de se tratar de um local de "má visitação". Irma Vep atua com gestos efusivos e provocativos, incitando a plateia. Entra então o intertítulo com o simples dizer "Irma Vep", antológica entrada para a personagem. Depois disso passamos para um primeiro plano extremamente expressivo, de pura fotogenia ${ }^{42}$, que acabou se tornando uma das imagens mais conhecidas da série: a atriz veste um lenço e ostenta a maquiagem sombria anunciada no cartaz. O cenário ao fundo compõe a imagem como um quadro impressionista (contrastando com o expressionismo na maquiagem da atriz). O primeiro plano é frontal, e Musidora olha para a câmera. A atuação é eloquente, vívida (FIG. 18 e 19). Ela range os dentes, olha para a esquerda da tela, fecha os olhos, olha para a direita, balbucia coisas. Logo depois, o corte retoma o plano geral do teatro, com a câmera fixa, e Irma Vep continua atuando. Ela encerra a apresentação, agradece ao público e desce do palco, sob aplausos. A plateia se dispersa, encerrando a cena. Irma Vep é apresentada, portanto, primeiro em tipografia, na palavra-anagrama, e depois em imagem, com alguns segundos de marcante primeiro plano.

\footnotetext{
${ }^{42}$ Mais sobre a fotogenia no Capítulo 4.
} 


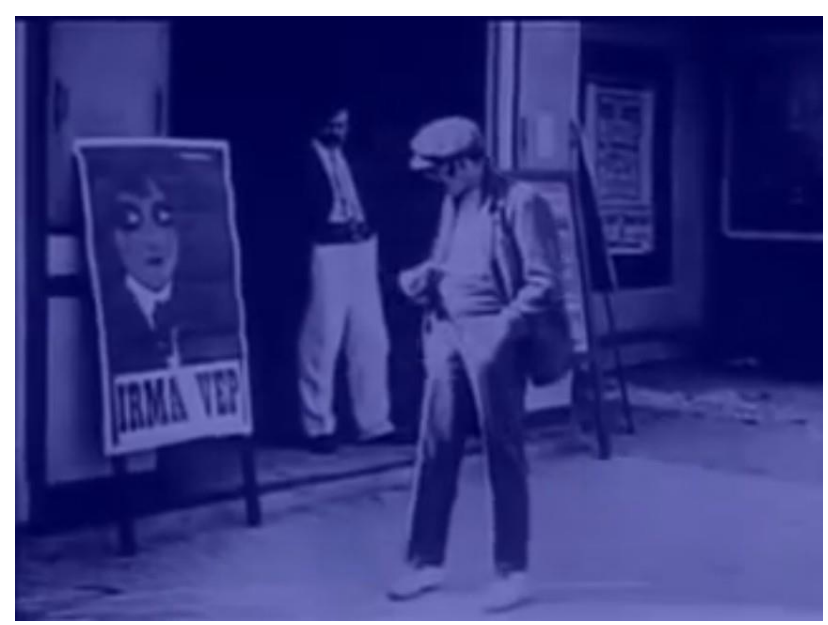

Figura 14

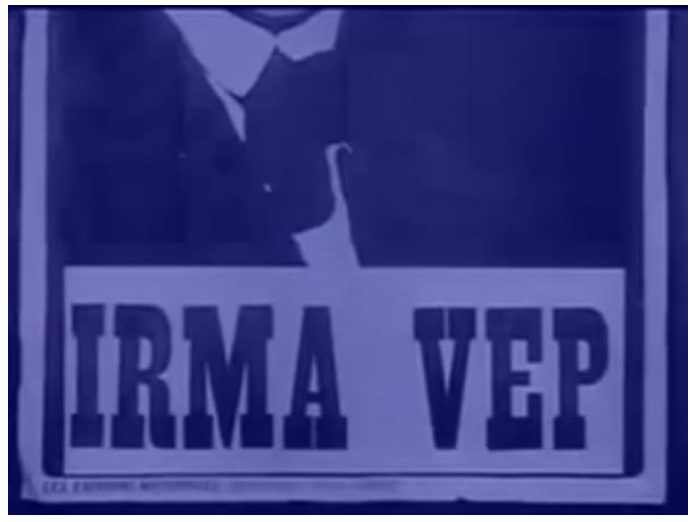

Figura 15

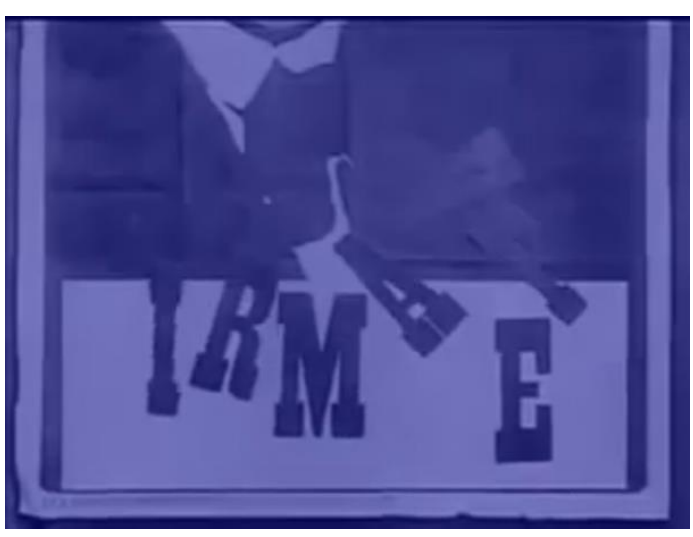

Figura 16 


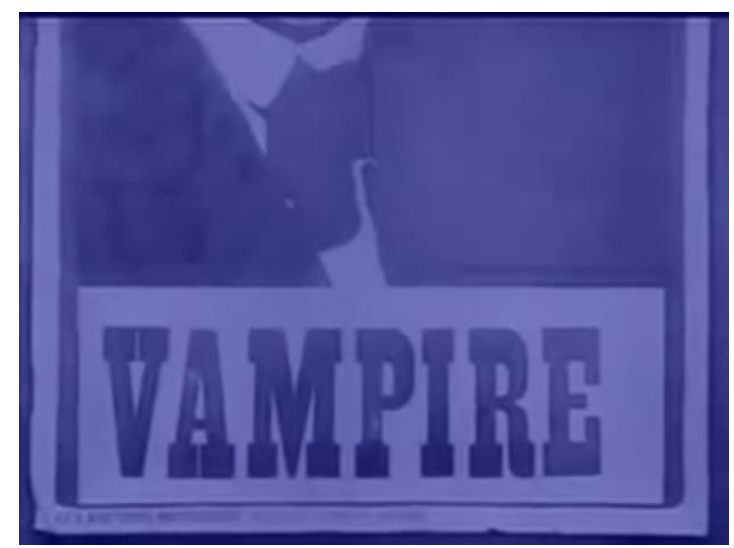

Figura 17

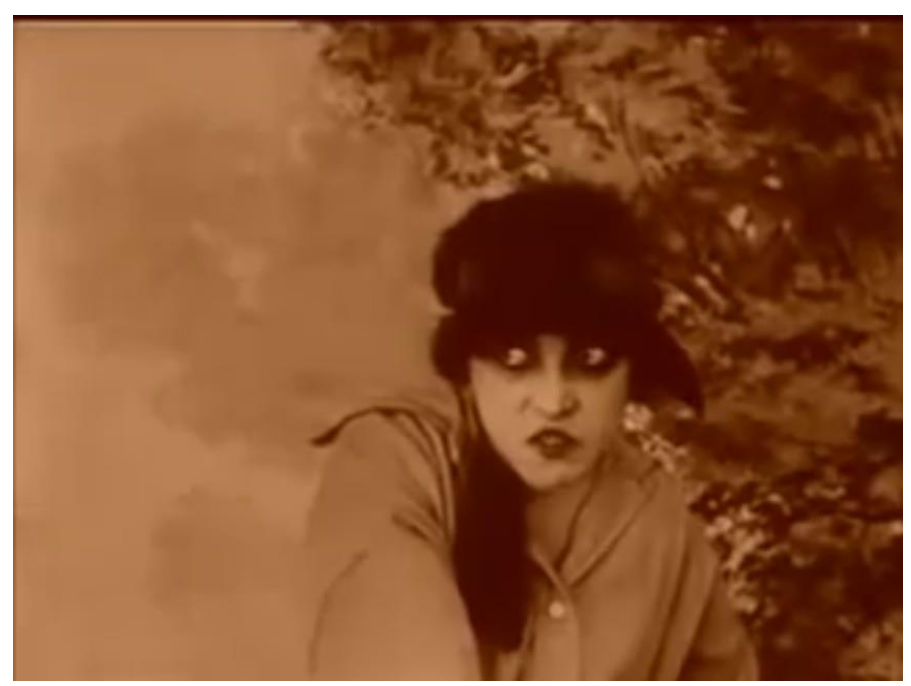

Figura 18

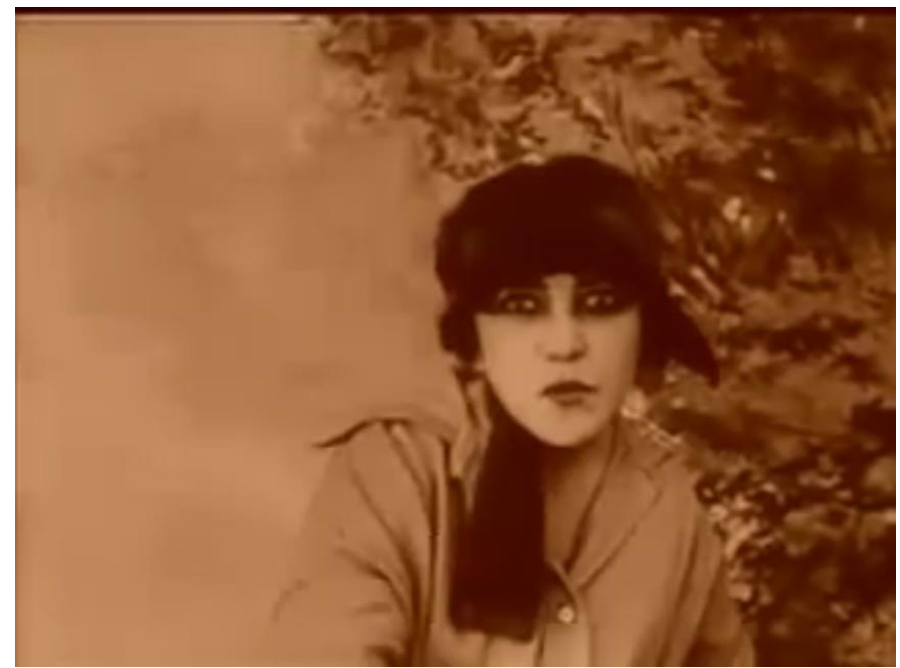

Figura 19

Esta pequena sequencia fixa no filme uma relação poderosa. A presença do teatro, da atuação e do imaginário do vaudeville enclausurados na imagem do cinema não ocorre à toa. $\mathrm{O}$ cinema silencioso nasceu do vaudeville. $\mathrm{O}$ chamado cinema de atrações, primeira manifestação e primeira cultura cinematográfica (que precede a 
virada narrativa e data aproximadamente entre 1895 e 1908), transformou as primeiras imagens fílmicas em mais um item no cardápio do vaudeville. Antes da era dos nickelodeons (que coincide com a virada narrativa), os filmes eram exibidos em teatros como estes, muitas vezes como entreatos de outras apresentações (de música, dança, teatro, etc.). Cafés, feiras e music-halls faziam parte da variedade de exibidores para este cinema. O público nem sempre era amistoso e era muito barulhento, interferindo nas apresentações e reagindo aos filmes (BARNIER, 2010, pp. 15-26). Esta sequência, portanto, é uma metassequência, e remete ao ambiente de fomentação da cultura cinematográfica no início do século. A presença da palavra na inscrição com o nome da personagem no cartaz e, ao mesmo tempo, a execução da cena dentro do teatro levam aos primeiros media processados pelo cinema em sua fase de formação: a literatura e a dramaturgia. A palavra e o gesto. Somos levados, portanto, a um ambiente de intermedialidade ${ }^{43}$.

No caso deste trecho do Os vampiros, a questão da presença, conforme temos discutido, é também importante. Nos planos gerais que mostram o teatro, é a presença dramatúrgica (ou seja: a presença física da atriz e seu corpo) que incita a epifania anunciada por Gumbrecht. Já nos primeiros planos com o expressivo rosto de Musidora, a presença ocorre no campo do cinema, em sua ambígua virtualidade de imagem técnica, tal qual analisamos a partir das ideias de Flusser.

Enquanto epifania, uma bela peça é sempre um evento: já que nunca podemos prever se ou quando ela vai emergir; se ela emerge, nós não sabemos como ela vai parecer (mesmo se, retrospectivamente, estamos aptos a descobrir similaridades com belas peças que vimos anteriormente); e ela se desfaz, quase literalmente, no momento em que emerge. Nenhuma fotografia poderia jamais capturar uma bela peça (GUMBRECHT, 2004, pp. 113$114)^{44}$.

\footnotetext{
43 Adalberto Müller (2014, pp. 195-196. Tradução nossa) explica que os estudos de intermedialidade surgem nos anos 1980 simultaneamente na Alemanha (com Jürgen Müller) e no Canadá (com André Gaudreault), partindo de noções como "interartes" e "intertextualidade". Ele afirma que a intermedialidade "deve ser entendida como uma prise de conscience (e também um parti pris) dialógico no mundo dos media, um jeito de efetivamente se "entender os media". A intensa afinidade do cinema com a intermedialidade é definida por Joachim Paech: "Meu entendimento da intermedialidade deriva da pluralidade do cinema. O cinema é sempre ‘isto' e 'aquilo': cinema e tecnologia, cinema e economia, cinema e arte, cinema e media. A intermedialidade do cinema é relevante em todas estas conexões, sempre que o cinema é definido como um medium: um medium de comunicação técnica, um medium da indústria da consciência, como medium da arte ou rede multimídia. Dentre as inúmeras definições dos media, eu prefiro entendê-los como uma Forma - estética, ideológica, cultural - descrita pelo seu Medium, e a intermedialidade como a figuração de suas conexões com a Forma de outros Media (PAECH apud MÜLLER, 2014, p. 196. Tradução nossa).

44 Tradução nossa.
} 
Conforme já discutimos, a imagem técnica do cinema procura capturar dois efeitos: um do movimento e outro da presença, sendo verdadeiro e falso ao mesmo tempo sobre ambos os casos. Teatro, com a presença, e o cinema, com a virtualidade potencializada pela fotogenia, estão indicando algo que falta, neste caso, à palavra: seu paradoxo inerente, sua força ambígua de mostração (teatro) e iconicidade (cinema). A poesia, quando invade o código escrito, leva aos limites seu caráter simbólico. Toda poesia que testa suas fronteiras vai se deparar com certa "ineficácia" da palavra. Este desarranjo produz a beleza de dizer o que não se diz, de significar aquilo a que não se pode atribuir sentido. Já quando a frequência poética da percepção repousa sobre um medium como o cinema, o "que já tem" anunciado por Zambrano se transfigura de maneira mais evidente: na replicação do efeito de presença, na potência paradoxal da virtualidade.

$\mathrm{O}$ atrito entre palavra e imagem é muito antigo. Um texto canônico como a Estética, de Leonardo Da Vinci, já se concentrava inteiramente nesta dicotomia. Contaminado por um racionalismo próprio ao Renascimento, Da Vinci se baseia no argumento da experiência para propor algumas premissas que norteiam seu argumento: a visão (que funcionaliza a pintura) seria um sentido superior à audição (que funcionaliza a poesia escrita), pois permite um contato imediato e sem interferências com a natureza (a "natureza" ocorrendo no sentido de "realidade"); sendo assim, aquilo que interfere neste processo (como a palavra e a língua) pertence a uma ordem inferior (Da Vinci, neste caso, é antiplatônico quase no patamar da iconolatria, considerando a imagem da pintura como um contato verdadeiro com a realidade); por fim, o renascentista florentino, com perspicácia, considera a poesia como uma instância anterior ao texto escrito (portanto, como ontologia), e afirma que o pintor é também um tipo de poeta.

\footnotetext{
A pintura possui um fim comunicável a todas as gerações do universo; este fim está subordinado à faculdade visual e não passa pelo ouvido para chegar ao sentido ordinário da mesma maneira com que ela passa pela vista. Portanto, a pintura não tem necessidade da interpretação de nenhuma língua, como a literatura; ela satisfaz imediatamente o espírito humano, como fazem as coisas produzidas pela natureza (DA VINCI, 1907, pp. 174-175). ${ }^{45}$
}

\footnotetext{
45 Tradução nossa.
} 
A visão de Da Vinci interessa por antecipar a ideia de que a poesia pode ser também um tipo de medium, ou melhor, uma frequência da sensibilidade (sendo a frequencia o medium quando respousa sobre a percepção) que se sintoniza em outros diferentes media para comunicar (ou transmitir sensorialmente) algo próprio à sua natureza. Um cinema sem som e sem palavras (especialmente sem palavras faladas - ou ouvidas) seria, neste caso, um cinema profundamente davinciano. Da Vinci curiosamente atribui à faculdade da imaginação uma relação com a palavra escrita e condena sua ineficácia diante do sentido da visão. A imagem, aqui, impera, e somente o visível transmite o efeito de presença que estamos procurando atribuir (mesmo dentro da virtualidade) ao cinema. Assim, ele realiza uma aproximação do simbólico (as palavras) ao imaginário, tradicionalmente cindidos na psicanálise lacaniana, por exemplo. A ideia de que o simbólico é a verdadeira alucinação, no entanto, aparece em Kittler e, por vezes, também em Flusser.

\begin{abstract}
A imaginação não enxerga de maneira tão excelente quanto o olho, que recebe o aspecto ou similitude dos objetos e que lhes transmite à sensibilidade, e da sensibilidade ao sentido ordinário comum, que julga; a imaginação não ultrapassa este mesmo sentido ordinário, senão quando ele se liberta à memória; e ele se fecha, se a coisa imaginada não é de grande excelência. Neste caso, a poesia se encontra na obra imaginativa do poeta, que inventa as mesmas coisas que o pintor, e através destas ficções quer igualar o artista. Ele chega muito longe disso, conforme demonstramos acima. Neste caso de ficção, eu afirmei que a proporção respectiva da pintura e da poesia era aquela do corpo e da sombra que o projeta. Ela é ainda mais acentuada, haja vista que a sombra deste corpo, ao menos para o olho, atende ao sentido ordinário, mas a imagem, noção deste corpo, não atende à mesma coisa, nascendo ela no olho tenebroso (o cérebro) (Ibidem, p. 180).
\end{abstract}

Por mais que Flusser considerasse a imaginação como parte da imagem (ao contrário de Da Vinci), a ideia de que escrita e imagem concorrem produz, na mentalidade do filósofo, algo mais que uma disputa pela primazia de um sentido sobre o outro. Flusser, efetivamente, considerava que o atrito entre os media gerava espécie de dialética histórica:

A luta da escrita contra a imagem, da consciência histórica contra a consciência mágica caracteriza a História toda e terá consequências imprevistas. A escrita se funda sobre a nova capacidade de codificar planos em retas e abstrair todas as dimensões, com exceção de uma: a da conceituação, que permite codificar textos e decifrá-los. Isto mostra que o pensamento conceitual é mais abstrato que o pensamento imaginativo, pois preserva apenas uma das dimensões do espaço-tempo (FLUSSER, 2011, p. 24). 
A consciência histórica, linear, desbarata o pensamento mágico, com sua reiterativa circularidade (como ocorre nos movimentos de Chaplin ou no escalar sinuoso do vampiro, por exemplo), segundo a lógica de Flusser. O que fica, para nós, além de certa fundação da História, é a ideia de que o pensamento em linha (vetorializado, teleológico) fundado pela palavra escrita ainda reside nela. A palavra ainda se organiza como origem da violência filosófica. Mas, para além deste debate, cabe perguntar o que ocorre quando palavra e imagem não ocorrem em concorrência, como vimos em Flusser e Da Vinci, mas sim em concomitância, como vimos no letreiro que anuncia Irma Vep/Vampiro, no filme de Feuillade.

O historiador da arte W.J.T. Mitchell eleva este debate a um outro patamar ao criar o conceito de imagem-texto (imagetext) para argumentar que, por princípio, todos os media são mistos, pois combinam "diferentes códigos, convenções discursivas, canais e modos cognitivos e sensórios" (MITCHELL, 2009, p. 118) ${ }^{46}$. Aqui, a materialidade do medium não determina necessariamente sua natureza. Conforme afirma Flusser, todas as imagens técnicas são textos. Mitchell vai radicalizar esta proposição ao afirmar que todas as imagens são textos. Afinal, todas as imagens guardam em si este componente discursivo e podem operar como textos na consciência de quem as olha. O texto, para ele, é uma categoria intrínseca ao mecanismo da percepção, um medium que se espraia sobre outros media, e nada poderia restar deste gênero difuso de contaminação a não ser o hibridismo. A imagem, por sua vez, reside em todo texto, seja através de descrições, metáforas, sugestões ou mesmo na natureza imagética das próprias palavras. Mitchell vai até a origem mesma das palavras, cuja inscrição se dá a partir das próprias imagens da realidade (conforme pensava Bergson), para dizer que há uma inseparabilidade entre esta origem e o uso das palavras enquanto imagens. As imagens, neste caso, estariam no DNA das palavras, e vice-versa. O conceito de imagem-texto guarda em si uma analogia com o de espaço-tempo einsteiniano, em que as dimensões do espaço e do tempo são várias (três espaciais e uma temporal) e uma só (espaço-tempo) simultaneamente. Como tempo e espaço são codependentes (a alteração de um influi nas dinâmicas do outro), é justo pensá-los como uma estrutura cujas dimensões são apenas faces percebidas a partir de perspectivas diferentes (no caso, a posição do observador em relação à dimensão observada).

\footnotetext{
${ }^{46}$ Tradução nossa.
} 
Mitchell considera texto e imagem como media, e sua visão sobre um medium é análoga à estrutura einsteiniana para o espaço-tempo: ele se espraia sobre seu objeto contaminando-o em diferentes dimensões. Imagem e texto são estruturas mentais antes de serem materialização de processos comunicacionais.

\begin{abstract}
De uma maneira similar, as representações visuais apropriadas a um discurso não precisam ser importadas: elas já são imanentes às próprias palavras, na construção da descrição, "visão" narrativa, objetos e lugares representados, metáforas, arranjos formais e distinções de funções textuais, mesmo na tipografia, papel ou (no caso da performance oral) na imediatez física da voz e do corpo do falante. Se é difícil manter o discurso fora da pintura, é igualmente difícil manter a visualidade fora da literatura, embora o impulso para fazer isso esteja esboçado no topos do poeta cego, a resposta da literatura à pintura como "poesia muda" (Ibid., p. 120).
\end{abstract}

A tentação em considerar o conceito de Mitchell como panaceia para todos os problemas envolvendo texto e imagem é considerável, mas, ao pensarmos uma composição como a formação das palavras "Irma Vep" e "vampire" na consciência do Guérande em Os vampiros, não podemos deixar de analisar a mecânica confusa que este evento incute na própria sensorialidade do filme, do personagem e do espectador. A ideia de que imagens são discursivas e que textos são imagéticos impede, de certa forma, que estabeleçamos procedimentos autopoiéticos como instrumento para verificar fenômenos da realidade, especialmente comunicacionais. Desta forma, a intrusão do texto em meio à imagem silenciosa também alimenta ambiguidade: a concorrência e a concomitância são concomitantes. A alternância e simultaneidade entre texto e imagem, para Mitchell, lembra a alternância entre efeitos de presença e efeitos de sentido em Gumbrecht, ou seja, ocorrem em concomitância e se imiscuem, mas se tornam categorias separadas quando levados a um plano conceitual.

Vejamos o que ocorre em $O$ criptograma vermelho: o anagrama Irma Vep/vampiro está, como qualquer anagrama, situado na instância do significante. O embaralhamento das letras, a surpresa com a nova forma das palavras, o rearranjo das disposições do código: tudo ocorre praticamente na materialidade da própria palavra. $\mathrm{O}$ sentido (que Irma Vep é uma "vampira"; que o "vampiro" é um ser degenerado e parasítico; e que este ser degenerado e parasítico é perigoso) emerge depois. E, para a mobilidade (no sentido do movimento que gera a poesia do cinema silencioso) do filme, o sentido vem também em segundo lugar. A palavra, neste caso, toma conta da imagem porque imprime nela o seu mecanismo, a sua programação (enquanto medium). Mesmo 
assim, portanto, quando não analisamos a cena do ponto de vista do sentido, a palavra, em seu uso instrumental, interfere na recepção (cognitiva, inclusive) do andamento do filme. Não à toa, Os vampiros é uma série em que o uso de tipografias, mensagens e códigos diferentes está em toda parte. Sendo este o estilo de Feuillade ${ }^{47}$, podemos imaginar que seus filmes induzem ao atrito entre palavra e imagem, e a sequência da cena com a sopa de letras de Irma Vep dá uma pista sobre como isto ocorre. Afinal, a palavra (no plano do cartaz), a presença (na cena do teatro) e o cinema com sua virtualidade que subsume as duas coisas no primeiro plano de Musidora (é imagem técnica, é texto) parecem construir pequena narrativa sobre como os filmes engolfam os outros media a partir de um escalonamento encaixado (à maneira do que descrevia $\operatorname{McLuhan}^{48}$ ). Porém, o que é surpreendente, estes media mantêm a sua integridade mesmo tendo se tornado "media mistos", tal qual afirma Mitchell. O próprio filme dá a pista sobre como a palavra escrita continua seu caminho, alienada do resto do filme, a partir de uma instância em seu movimento interno que não se mistura com o código da imagem no cinema. Em certo momento, Guérande tem acesso a um caderno vermelho (o do título) que está escrito em linguagem criptografada. Decifrando o código, ele descobre que neste caderno estão anotados todos os crimes cometidos pela gangue dos vampiros. Ora, a criptografia parte do significante (assim como o anagrama) para reelaborar a ordem dele próprio, mas de maneira velada. A presença da criptografia no filme ressalta a ideia de que a palavra, neste caso, não tem interesse em "colaborar" com a imagem, sendo o resultado deste desvelar (os crimes bárbaros) metáfora da violência implicada na invasão do filme com estes significantes vazios. A língua, no filme silencioso, surge como ameaça. Paira sobre Os vampiros a presença do filme sonoro, que é reconfigurado pela violência da palavra. O silêncio do filme silencioso, portanto, não está em oposição ao som, mas sim à fala.

A pesquisadora Ann Miller (2007, p. 100) se utiliza de um conceito de Barthes (ancoragem) para analisar a interinfluência entre texto e imagem nas histórias em quadrinhos. Por mais que este medium misto seja aparentado do cinema pela sua condição de utilizar imagens sequenciais para compor narrativas, as diferenças são

\footnotetext{
${ }^{47}$ Cf. análise de Fantômas no Capítulo 4.

${ }^{48}$ Aqui, McLuhan (1964, pp. 57-58) coloca esta questão em termos de "sistema", e avalia a passagem do cinema silencioso para o cinema falado: "Uma das causas mais comuns da ruptura em qualquer sistema é o cruzamento com outro sistema, como aconteceu com a imprensa e a prensa a vapor, ou com o rádio e o cinema (gerando o cinema falado)".
} 
também muito visíveis, sendo a principal delas a substituição da montagem (conforme ocorre nos filmes) pela configuração (que se dá no ambiente da página). Assim, no cinema, a articulação entre planos que obedecem a uma sequencia linear é substituída, nas histórias em quadrinhos, por uma disposição (layout) que configura os requadros dentro do limite variável do megarrequadro ${ }^{49}$, operando uma simultaneidade de ocorrência deles. Esta configuração implica, portanto, em uma mise-en-page (empaginação), ou seja, uma distribuição específica dos requadros na superfície da página, substituindo a mise-en-scène, que é a distribuição dos corpos sob o campo fílmico, gerando uma encenação. A despeito de diferenças estruturais como estas, no entanto, é comum que aproximem o cinema das histórias em quadrinhos. Nos estudos sobre este medium, a preocupação em relação à interinfluência entre imagem e texto é semelhante, e concerne a própria definição dos quadrinhos. O teórico Thierry Groensteen, que se preocupa em problematizar a definição do medium a partir de um instrumental semiótico, expõe o problema a partir de um texto de Roger Odin:

\begin{abstract}
Assim, dois critérios dogmáticos retidos na maioria das vezes em definições atuais dos quadrinhos precisam ser dispensados. A dificuldade encontrada aqui não é particular dos quadrinhos. Ela aparece em termos quase idênticos para a maioria, senão todas, das formas de arte moderna, como o cinema, e para formas cuja evolução através do curso de um século esmagou a definição tradicional (romance, pintura, música) em pedaços. Por exemplo, Roger Odin mostra claramente que é quase impossível expressar uma definição de cinema que também se aplique a filmes animados e a todas as formas de cinema experimental ou "expandido". A aporia que o semiólogo necessariamente desbloqueia é assim descrita (GROENSTEEN, 2009, p. 128):

Com que direito excluímos estas produções do cinema quando seus autores as apresentam explicitamente como "filmes"? O fato de que estas produções não se encaixam em nossa definição do "cinema", isso é uma justificativa suficiente para esta exclusão? Se não, devemos revisar nossa definição de cinema em uma maneira mais generalizante no sentido de integrar estes contra-exemplos? Se sim, aonde nós paramos esta generalização? Na ausência do filme? Na ausência da tela? Na ausência do projetor? Não chegaremos nós em um tipo de definição que não nos diz nada a respeito de seu objeto? (ODIN apud GROENSTEEN, 2009, p. 128) ${ }^{50}$.
\end{abstract}

Não à toa, o artigo de Groensteen se chama "A definição impossível", e a presença do texto, antes considerada como essencial à composição das histórias em quadrinhos enquanto medium, é problematizada como ocorre no cinema, com a diferença de que ausência da palavra aqui não é nem inaugural (os quadrinhos nascem

\footnotetext{
${ }^{49} \mathrm{Um}$ requadro (pannel), nas histórias em quadrinhos, é (sob controvérsia) a unidade mínima narrativa deste medium. É, por assim dizer, o quadrinho em si. Um megarrequadro é o requadro que comporta todos os requadros menores. É um quadro cuja extensão se confunde com a da página.

${ }^{50}$ Tradução nossa.
} 
com a palavra, ao contrário do cinema) e nem técnica (a supressão do texto, sempre intencional, opera no campo da linguagem, e não do medium ou da tecnologia, como ocorre na supressão do som no cinema silencioso). Neste sentido as imagens dos quadrinhos, por reprodutíveis que sejam (através da indústria dos impressos), não são técnicas porque guardam um original que as remete ao gesto da mão tal qual descrito por Flusser: magicizam o mundo com produção de cenas, remetem ainda mais à ancestralidade apontada por Warburg. O cinema, é claro, conforme vimos, alcança esta distensão por meio do movimento, que se opõe, neste caso, à imagem tradicional dos quadrinhos. Porém, ambos estão submetidos ao procedimento da ancoragem que a palavra submete à imagem. Miller argumenta que os efeitos disso são dois: ou a palavra ressalta a potência da imagem, ou aprisiona as propriedades dela naquelas da própria palavra, contaminando a imagem com discurso simbólico:

\footnotetext{
Em uma discussão sobre textos que ocorrem junto a imagens, Barthes faz uma referência específica às histórias em quadrinhos. Ele diz que o texto pode ou "ancorar" o sentido de uma imagem, já que as imagens tendem a ser polissêmicas (suscetíveis a mais de uma interpretação) ou "retransmiti-lo", trazendo sentidos adicionais, e é esta função de retransmissão que vai dominar nas histórias em quadrinhos (MILLER, 2007, p. 100).
}

No caso da cena que estamos analisando em Os vampiros, a ancoragem ocorre, certamente, mas de uma maneira que não é nenhuma das descritas por Barthes. Ela não vai necessariamente "marcar" a imagem com seu sentido ou sequer potencializar a polissemia dela (conforme ele atribui à função nos quadrinhos). A ancoragem é mais operacional e estrutural. O fato de as palavras "Irma Vep" e "vampire" constituírem anagrama remete a este jogo simbólico na superfície do significante. Na maioria dos filmes silenciosos, a ancoragem se dá no sentido de prender, vetorializar e linearizar a imagem na operação do texto, mas sempre impulsionando sentido. Em Aurora (Sunrise, F.W. Murnau, 1927), os letreiros estão postados de maneira que remetam aos caracteres da arte expressionista. As letras derretem ou se afogam (FIG. 20), induzindo o espectador a acompanhar o texto nas substituições que ocorrem em sua troca simbólica. Há uma permuta entre a iconicidade do texto simbólico e na simbologia das imagens. Em A greve (Stachka, Sergei Eisenstein, 1925, FIG. 21), os letreiros aumentam de acordo com a intensidade simbólica do enunciado, acompanhando tanto a possibilidade de uma mimetização do volume sonoro da fala quanto do poder persuasivo do conteúdo dela. Em Os vampiros isto também ocorre, conforme veremos, no sentido oculto do anagrama e da criptografia, mas a principal função da palavra-motora (afinal, ela se 
move por meio da animação) é justamente emular a motricidade da imagem, roubar-lhe a violência originária que deflagra, mais tarde, seu caráter poético. A função da palavra, aqui, é ancorar a imagem na paranoia de seu signo. O resultado no filme é intenso, surpreendente: não apenas temos o cinema como contraste na fotogenia de Musidora logo em seguida (como contraponto), como esta vilania da palavra se transmuta na vilania que é o tema do filme em si. Na maldade dos vampiros em si.

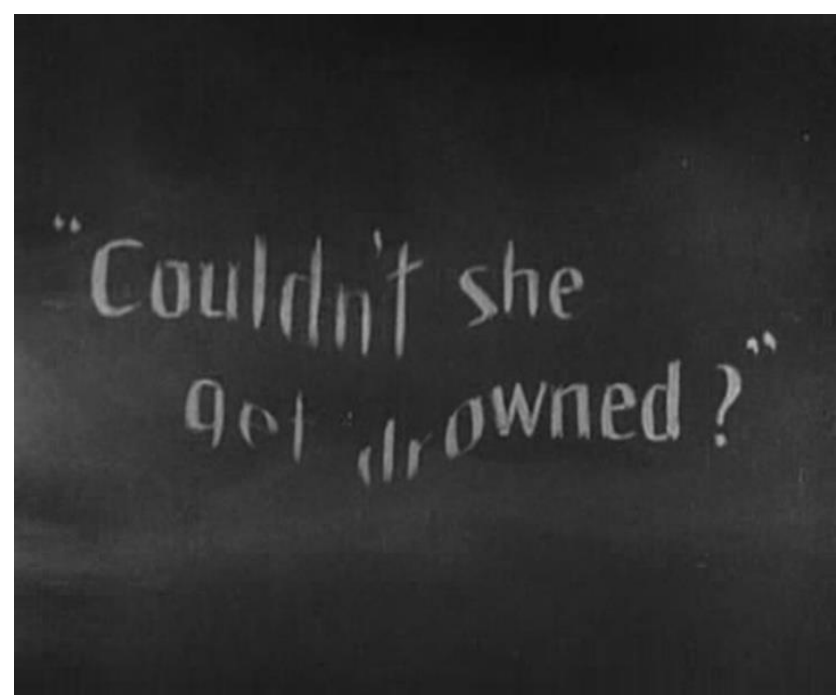

Figura 20

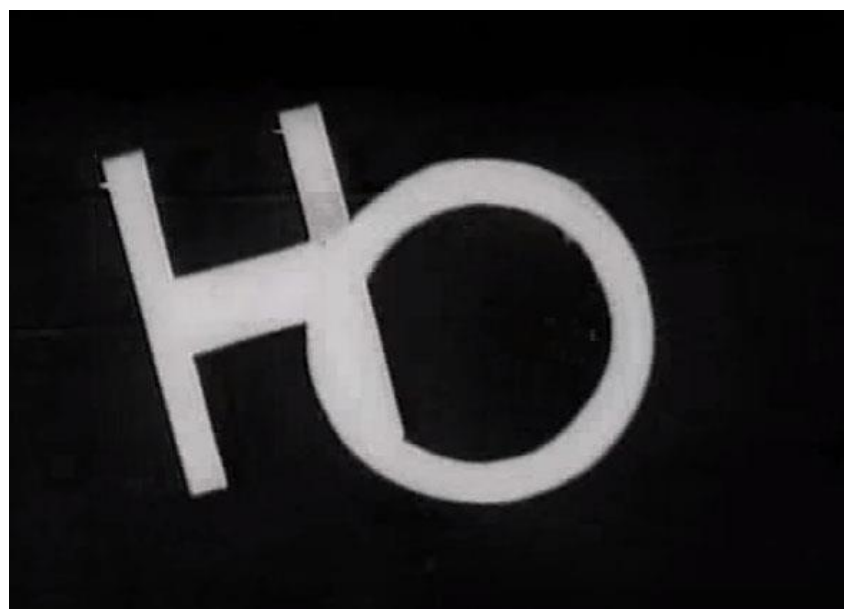

Figura 21

\subsubsection{A poesia redime o medium}

Por trás da arapuca simbólica armada pelo anagrama para ancorar (nos dois sentidos, e ao mesmo tempo em nenhum deles) a imagem na palavra, reside, portanto, a maldade inerente ao sentido do filme Os vampiros. A maldade da palavra transmuta-se 
em sentido, que emerge não da presença, neste caso, mas da alucinação do simbólico (como queria Kittler). Ao contrário de Chaplin, onde a maldade (violência) provinha da virtualidade da imagem e da virtualidade do movimento, aqui o perigo prova ser maior, e o desafio de se construir uma nova forma de comunicação (o cinema falado) aparece como na animação que transforma signos sem sentido ("Irma Vep") em um campo simbólico bem conhecido, que vai domar a consciência do filme e lhe introjetar toda uma nova proposta de medium. O anagrama acaba funcionando como um dispositivo que, ao ser acionado, arma uma singularidade que vai germinar no fim da poesia silenciosa.

Este fatalismo técnico de certa maneira ecoa na visão de Heidegger sobre a poesia, a língua e a própria técnica. O filósofo foi enfático ao denunciar a técnica como um processo altamente abstrativo que obnubla as chances de um ente (a sujeição que ainda não encontrou o ser) entrar em contato com seu ser-aí (dasein). Porém, a origem desta relação Heidegger joga para a língua, da qual ele trata com necessária ambiguidade. Em sua famosa conferência sobre Hölderlin, um dos principais textos em que o filósofo alemão trata da poesia, ele fundamenta sua visão sobre a língua partindo de dois princípios: primeiro, que a poesia está inextricavelmente ligada à palavra (posição que ele vai rever, anos depois, em outra conferência, A origem da obra de arte). "A poesia é a fundação do ser pela palavra" (HEIDEGGER, 2013, p. 51). Heidegger dá à língua a função de criar um mundo. Ela estabelece, por meio do princípio de criação inerente à sua própria estrutura, as condições de cultivo da terra, ou seja, um chão, um patamar, uma base sobre a qual o ser-aí pode ser conduzido. Portanto, desde 1936 (data da publicação de Explicações da poesia de Hölderlin), Heidegger anunciava uma relação profunda entre língua, poesia e ontologia. Isso corrobora nossa ideias, mas o segundo princípio de seu pensamento sobre a língua é que mais interessa neste momento. Ele afirma que à língua corresponde o perigo:

Em que medida, porém, a língua é o "mais perigoso dos bens"? Ela é o perigo supremo, pois constitui a possibilidade de um perigo. $\mathrm{O}$ perigo é a ameaça, mediante o ente, ao ser. Mas é bem graças à língua que o homem, de todo, se expõe a algo manifesto, que como ente assedia e inflama o homem em seu estar-aí, e como não ente o engana e decepciona. A língua cria pela primeira vez o lugar de ameaça ao ser e de erro, e assim a possibilidade de perda do ser, isto é, de perigo (Ibid., p. 47). 
A língua, portanto, é um não-ente que finge ser um, justamente porque possui a capacidade de "inflamar o ser" com esta espécie de ardil natural. Ela cria o mundo, a terra, mas ao mesmo tempo ventila a ilusão de que o ser possa ser pastoreado a partir deste patamar. A língua seria uma verdade que ao mesmo tempo corresponde ao erro. $\mathrm{O}$ resultado desta fórmula que envolve língua, mundo e terra não é verdade (responsabilidade que, na outra conferência, ele vai atribuir à arte), mas sim história:

\begin{abstract}
A língua não é um instrumento dentre muitos outros que o homem possui, mas antes garante, em geral e pela primeira vez, a possibilidade de erguer-se no meio da abertura do ente. Só onde há língua, há mundo, ou seja, o círculo em constante transformação da decisão e do trabalho, do ato e da responsabilidade, mas também da arbitrariedade e do ruído, da decadência e da confusão. Só há história onde o mundo governa. A língua é um bem em um sentido originário. Ela promete, isto é, garante que o homem possa ser histórico (Ibid., p. 48).
\end{abstract}

De certa forma, por meio da ontologia, Heidegger chega à mesma conclusão que Flusser faz através da teoria dos media, e Zambrano por meio da fenomenologia: a língua é responsável pela constituição da História. Flusser imagina esse processo sendo inaugurado através do pensamento em linha (a escrita). Zambrano o faz por meio da violência da racionalidade (a filosofia). Heidegger deposita a origem, curiosamente, no que estamos considerando como um medium infeccioso: a palavra. Porém, este caráter infeccioso da palavra (ou da língua) aponta, como vimos, para dois lados: a capacidade de criar (o mundo) e a disposição para destruir (o ser). É este o perigo que emerge do anagrama Irma Vep/Vampire. O vampiro, monstro contagioso, sanguessuga, infeccioso e viral, é como uma metáfora para o descontrole da palavra. O vampiro transforma tudo que morde em vampiro, e assim é o funcionamento do medium da palavra/língua. Isso não é um juízo, mas sim uma descrição da operacionalidade deste medium, sistema ou frequência autopoiética ${ }^{51}$ que, na contramão do que pensa Mitchell, busca sua sobrevivência como se fosse um código genético.

Este impulso à maldade acontece ainda no início da série (episódio 3), e vai disparar escalas cada vez mais grotescas de violência no restante dos episódios. Isso torna Os vampiros um filme ambíguo em sua natureza mediática. A poesia do movimento, a violência originária da motricidade, da dança ancestral, se funde à

\footnotetext{
51 Os conceitos de "frequência", "medium" e "sistema" podem eventualmente se entrecruzar e coincidir dependendo do contexto em que são utilizados. No nosso caso, cabe demarcar a frequência como medium no campo da percepção, o próprio medium como frequência no campo da técnica e posteriormente da tecnologia, e o sistema como atuando no campo das relações sociais e da comunicação.
} 
violência simbólica da palavra, ora concorrendo, ora ocorrendo em concomitância, produzindo sinergia. A maldade e a violência (de todos os tipos) são, neste caso, um trunfo para o desabrochar da poesia fílmica. A poesia redime o medium, seja ele a palavra ou a imagem. Como isto se dá, exatamente?

Para finalizar esta análise de Os vampiros, vale mencionar mais 2 minutos e 37 segundos do segundo episódio da série, $O$ anel que mata (Les vampires - La bague qui tue, 1915). O enredo desta outra pequena sequência é simples. O Grande Vampiro descobre que Philipe Guérande possui uma namorada, a atriz e dançarina Marfa Koutiloff (na famosa atuação de Stacia Napierkowska). Ele então se disfarça como Conde de Noirmoutier e dá de presente, à atriz, antes de ela entrar no palco, um anel envenenado. A cena propriamente dita começa após este intróito. Assim como na sequencia anterior com Musidora, aqui a ação também se dá nos palcos de um teatro. A diferença é que, ao invés de se passar em um vaudeville, a cena se dá em um local luxuoso e de "alta sociedade". Começamos, portanto, vendo uma imagem interessante do Grande Vampiro (FIG. 22), enquadrado em plano geral, assistindo à peça de um camarote. Koutiloff aparece ao fundo do campo, acompanhada de uma orquestra que, no fosso do teatro, dá acompanhamento sonoro à cena. Logo um corte analítico enquadra, em plano de conjunto, Koutiloff vestida de vampira e se posicionando na frente de um cenário gótico, além de uma outra mulher, de aparência inocente, que jaz dormindo em uma poltrona. A diferença desta cena para a de Musidora, além do modelo de palco (os grandes teatros seriam para onde o cinema migraria após a virada narrativa) é o fato de que, nesta cena, há efetivamente um vampiro (o ser sobrenatural) no palco. Koutiloff encena, com o anel envenenado no dedo, uma peça gótica. Seu figurino se tornou uma das imagens mais emblemáticas da série: a roupa colant toda preta, com asas e orelhas de morcego (FIG. 23). Ela abre as asas, e depois seduz a moça que está adormecida, com a típica sedução vampírica, em um plano de americano. A cena é carregada de erotismo e morte, e lembra a maneira com que Murnau faria seu Nosferatu (Nosferatu, eine Symphonie des Grauens, 1922) seduzir sua Mina (o filme era inspirado em Drácula) no final deste clássico do expressionismo (FIG. 24). A atriz que interpreta o vampiro, no palco, começa então a passar mal por causa do veneno incutido pelo anel, e Feuillade fecha ainda mais o plano (desta vez em um primeiro plano da vampira desfalecente), para então voltar a abri-lo, enquanto as pessoas a socorrem, até retornar ao plano inicial, geral, onde o Grande Vampiro, em seu camarote, sorri e vai embora. 


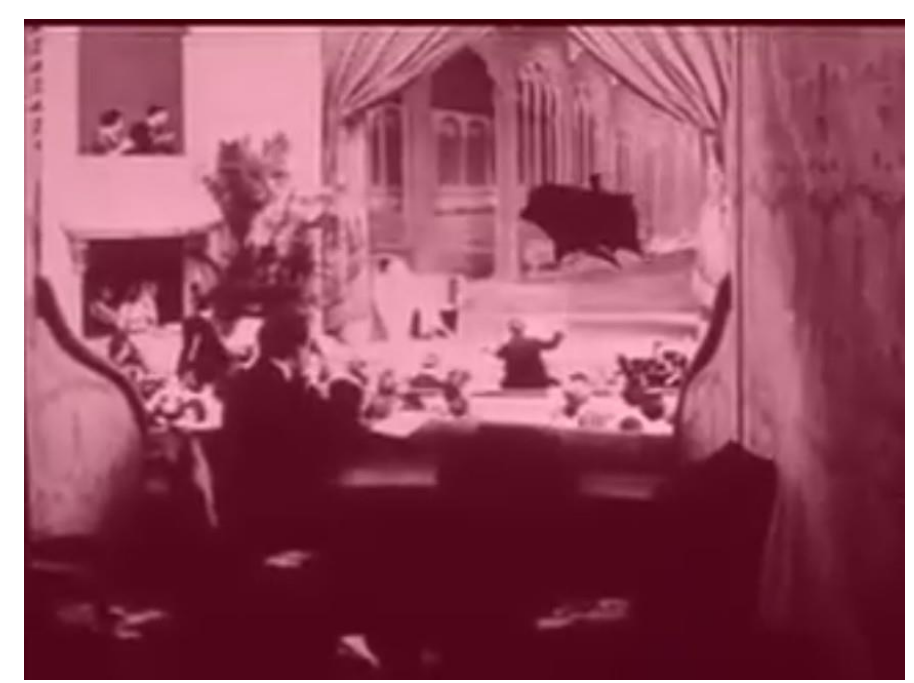

Figura 22

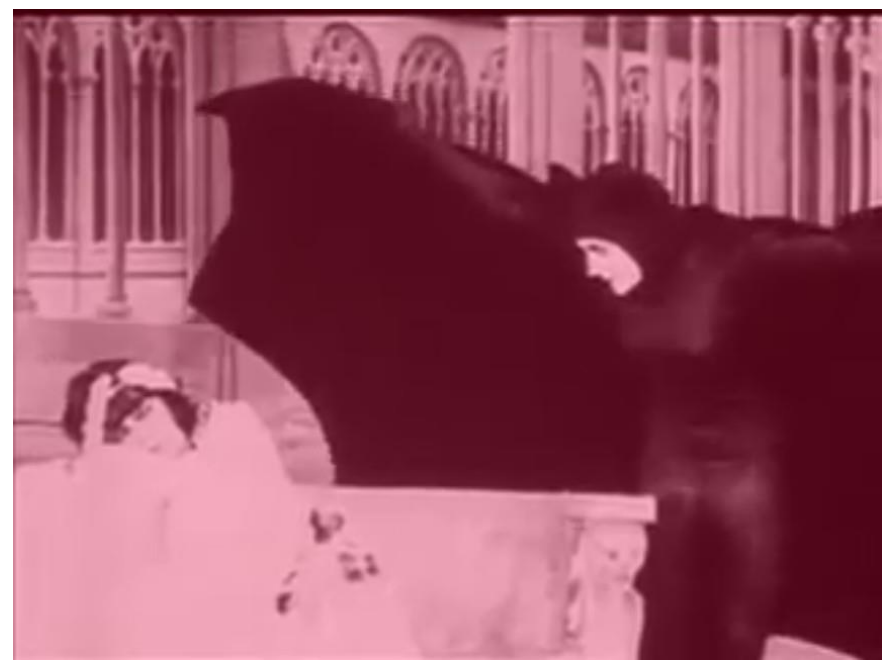

Figura 23

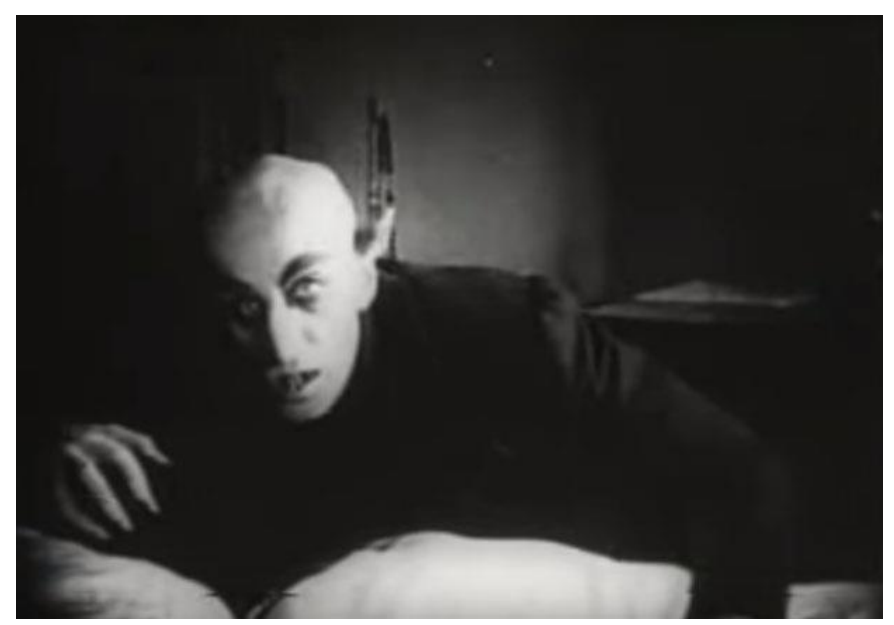

Figura 24 
A poesia no cinema silencioso emerge de vários fatores, às vezes combinados, às vezes de maneira independente, ancorados em violência inaugural . Na cena do vampiro escalando e descendo do castelo no primeiro episódio, ela vem do movimento. Na cena com Irma Vep, no terceiro, ela eclode da oposição (e por vezes confluência) entre a palavra no anagrama e a imagem de Musidora no teatro. Aqui, também diferentemente, ela vai surgir diretamente do olho do diretor, precisamente na montagem, que faz surgir uma poesia do espaço. Como podemos perceber pela descrição e pela visão da cena, a relação em abismo ${ }^{52}$ (que coloca um medium inserido dentro do outro. Neste caso, o teatro dentro do cinema) se dá na forma de zoom espacial, in e out: começamos no plano geral, passamos ao plano de conjunto, depois ao americano, depois ao primeiro plano, e depois vamos regredindo, progressivamente, do primeiro plano ao plano geral novamente ${ }^{53}$. De certa maneira, este movimento operado pela montagem representa um assombramento terrível que ocorre dentro do espaço. Afinal, trata-se de uma instância que vai se aproximando cada vez mais da personagem (que dança sensualmente ao redor de sua vítima), inocula nela um terrível destino, assassina-a e vai embora pelo mesmo caminho. A instância narrativa do filme, portanto, funciona aqui como uma espécie de fantasma que transmite a peste, a maldade. Se, na cena com Musidora, o responsável por esta maldade era a presença da palavra escrita, aqui a violência da maldade se dá por meio da própria construção fílmica (a montagem e o aproveitamento do espaço através da abordagem do campo), sendo a relação entre os media (teatro, literatura, cinema) a fricção que gera a poesia silenciosa.

Como, portanto, a poesia subverte o atrito entre os media e os redime? A resposta se dá no fato de que a poesia não é exatamente um medium (apesar funcionar como tal em inúmeras situações), mas sim uma frequência da percepção ${ }^{54}$. A poesia subsume os media nos quais atua, os engolfa no sentido de que em cada manifestação em uma esteira comunicacional diferente, ela se reconfigura, aproveitando as aporias geradas entre estes contatos metonímicos. Os próprios poetas possuem um entendimento profundo destas relações. Octávio Paz, especialmente, em sua prosa

\footnotetext{
${ }^{52} \mathrm{Cf}$. estudo mais atento sobre este tema no capítulo 4.

$53 \mathrm{O}$ plano geral mostra imagens em angulações abertas em que as pessoas aparecem inteiras e com considerável espaço entre as fronteiras de cima e de baixo do quadro e os personagens. O plano de conjunto reduz este espaço, mas os personagens ainda aparecem inteiros na tela. O plano americano já corta o personagem no joelho ou na barriga. O primeiro plano vai cortá-lo no ombro. O close-up vai exibir um rosto ou um detalhe (MARTIN, 2005, pp. 51-55).

${ }^{54}$ Nas palavras de Gumbrecht (2004, p. 107. Tradução nossa), a percepção é, no sentido fenomenológico, "uma relação humana com o mundo mediada pelos sentidos".
} 
poética, dominava com precisão estas ideias. Para ele a multitude de formas poéticas não atrapalha a definição (impossível?) da poesia: “[...] a pluralidade dos poemas não nega, senão afirma, a unidade da poesia" (PAZ, 2003, p. $23^{55}$ ). Todo o argumento de seu livro $O$ arco e a lira se baseia na ideia de que a poesia é maior do que o poema, de que a frequência é maior do que o medium:

\begin{abstract}
Um soneto não é um poema, senão uma forma literária, exceto quando este mecanismo retórico - estrofes, metrificação e rimas - tenha sido tocado pela poesia. Há máquinas de rimar, porém não de poetizar. Por outro lado, há poesia sem poemas; paisagens, pessoas e feitos podem ser poéticos: são poesia sem ser poemas. Pois bem, quando a poesia se dá como uma condensação do acaso ou é uma cristalização de poderes e circunstâncias alheios à vontade criadora do poeta, nos deparamos com o poético (Ibid., p. $14)$.
\end{abstract}

Instância fractal, replicativa e ao mesmo tempo autopoiética, a poesia se instala no campo da metonímia. "A poesia não é a soma de todos os poemas. Por si mesma, cada criação poética é uma unidade autossuficiente. A parte é o todo. Cada poema é único, irredutível e irrepetível" (Ibid., p. 15). Ora, esta verdade também se aplica à poética silenciosa. Cada filme silencioso processa sua matriz poética contando uma origem diferente para si mesma, conforme vimos nos três excertos de Os vampiros que analisamos. Não à toa, pensadores tão distintos como Heidegger e o poeta Roberto Juarroz chegaram, em suas conferências, a conclusões semelhantes sobre a relação entre poesia e realidade. Em última instância, medium, frequência, presença, fala, palavra e silêncio compõem lados para este polígono de mil faces que é a realidade. Heidegger creditava aos poetas, reafirmando sua matriz pré-socrática, um augúrio especial para ver, em simultaneidade (tal qual o espaço-tempo einsteniano), estas mil faces. E a realidade aparece, finalmente, com aspecto de sonho: "A poesia desperta aparência de ineficácia e do sonho em contraste com a realidade palpável e sonora na qual acreditamos estar em casa. E, contudo, o real é bem antes o contrário; é o que o poeta diz e aceita ser" (HEIDEGGER, 2013, p. 56). Se, para Heidegger, a língua é íntima da poesia e cria o mundo, Juarroz vai inseminar esta ideia no encantamento com a própria realidade:

Não há escapatória: a poesia abre a escala do real (espaço, tempo, espírito, ser, não ser) e muda a vida, a linguagem, a visão ou a experiência de mundo, a possibilidade de cada um, sua disponibilidade de criação. E neste processo que não admite atenuantes, ao romper também o uso normal, encallecido e às

55 Tradução nossa. 
vezes encanallado das palavras, ao assumir a transgressão redentora e inevitável da linguagem, para ir mais longe na expressão do real e do humano, ao buscar essa "profundidade de forma" que pretendia Hebbel e que é inseparável da profundidade de sentido, a poesia cria mais realidade, agrega realidade à realidade, é realidade (JUARROZ, 2009, p. 21).

A poesia trata e trabalha, portanto, com o excesso da realidade. Ela em si própria é este excesso, este plasma amorfo que transforma a dicção do mundo e se apregoa das formas de comunicar, perceber e sentir. Em uma forma como o cinema, quando ela também o contamina, ela se esvai da possibilidade de se ler o mundo por meio de imagens captadas diretamente dele (o documentário) em um registro frio ou ensaístico. Ao mesmo tempo, também se esvai da farsa linear que constitui a ficção. É um terceiro vértice no tripé que compõe as grandes formas gerais do cinema. Porém, a despeito de termos falado de tantos elementos (faces do poliedro infinito que é a realidade) que possibilitam a entrada no cinema silencioso, resta comentar o item principal, que efetivamente dispara a poesia em cada imagem muda. Este elemento é o silêncio. 


\subsection{Grito e Som}

The art of our time is noisy with appeals for silence. - Susan Sontag ${ }^{56}$

\subsubsection{Skrik}

Por que ainda nos surpreende e impacta a aura fantasmagórica de um quadro como O grito (Skrik, 1893), de Edvard Munch? Logicamente a aferição a um estado profundo de angústia, clara conotação de qualquer uma das quatro versões pintadas da tela, é a resposta mais imediata. Um grito, em si, é uma ação que denota uma alteração substancial nos estados de humor. Pode estar acompanhado da euforia, da surpresa, do medo, da dor, do júbilo, do sofrimento. Pensado de imediato, o grito é uma ponte comunicacional crua, feita de ar e voz, que alerta ou surpreende; que convoca, que suplica, ou que tem um fim em si mesmo. São muitas as possibilidades de atribuição de sentido a um gesto ou ação como o grito, e não nos cabe aqui procurar exauri-las. Chama a atenção, porém, que em todas estas atribuições, a passagem comunicacional que representa o grito é feita através da transmissão sonora. Só se pode gritar produzindo um som alto e aleatório que é propagado pelas ondas de ar, que vibram num deslizar potente pelo mundo. $\mathrm{O}$ grito é um objeto sonoro ${ }^{57}$, um acontecimento que perfura o mundo e some. Tudo isso parece bastante evidente, a não ser, como podemos ver no caso de Munch, quando ele vem em silêncio. O próprio Munch escreve, em seu diário, sobre a relação entre a angústia e a potência do grito, levando-o em direção ao inexorável:

Caminhava com dois amigos e, quando o sol se punha, o céu tornou-se, de repente, todo vermelho de sangue. Parei, esgotado até a morte, enconstado em um muro. O fjord de um negro-azulado e a cidade estavam inundados de sangue e atingidos por línguas de fogo. Meus amigos seguiam caminho enquanto eu tremia ainda de angústia, e sentia que a natureza estava atravessada por um longo grito infinito (MUNCH apud NOVAES, 2014, p. 26).

\footnotetext{
56 “A arte do nosso tempo é ruidosa, com apelos para o silêncio" (tradução nossa).

57 "Percebidos fora da toda visualização e sua fonte efetiva, numerosos sons se revelam opacos ou ambíguos, suscetíveis de despertar a imagem de muitas fontes possíveis. O fato de se escutar ou não um disparo de arma de fogo depende sobretudo do contexto situacional no qual a ocorrência se insere. Os fenômenos acústicos são, então, primeiramente, percebidos como objetos sonoros" (CAMPAN, 1999, pp. 34-35. Tradução nossa).
} 
Assim como as ondas de tinta expressionista que circundam o personagem andrógino da tela do pintor norueguês são uma tentativa de criar um procedimento sinestésico ${ }^{58}$ que busque representar a viagem do som pelo espaço ao redor, fazendo do corpo representado e do espaço presumido caixas de reverberação (interna e externa) da relação angustiosa do ser com o mundo, o cinema silencioso possui inúmeros exemplos de como estes mesmos parâmetros para um processo de reverter um efeito da natureza sensitiva do mundo em outro podem ser eficazes como processo comunicacional, como arte, como potência criadora. Em outras palavras, o cinema produziu este mesmo grito mudo, e este processo é fundamental para se compreender a relação complexa e profunda entre as imagens e os sons do cinema, sejam eles sons presumidos pelo silêncio da tela muda, sejam eles as gravações sonoras que, através das décadas, foram se sofisticando e criando os parâmetros para uma linguagem audiovisual.

Em Limite (1931), o clássico crepuscular de Mário Peixoto, o "Homem número 1" grita (FIG. 25), nos hipercloses enquadrados por Edgar Brazil, ao fugir de desespero após um encontro sinistro no cemitério. São imagens potentes, que reverberam até o corpo do espectador, eletrizadas pela música de Prokofiev. Em Terra (Zemlya, 1930), o belo libelo político de Aleksandr Dovjenko, Vasyl, o herói da coletivização das terras, grita (FIG. 26) de euforia com a chegada dos primeiros tratores nos rincões de uma fazenda na Ucrânia. A angulação e a vibração imagética da cena são muito semelhantes às de Limite, assim como ocorre em O homem de Aran (Man of Aran, 1934), o etnodocumentário "ficcional" já sonorizado, mas ainda eivado de linguagem silenciosa (ainda usa intertítulos, e as falas em língua irlandesa não possuem legendas) que Robert Flaherty realizou sobre a dura vida dos habitantes das áridas ilhas de Aran na Irlanda. Aqui, mãe e filho gritam (FIG. 27), com o som abafado pelo barulho estrondoso das ondas do mar, procurando os pescadores perdidos no oceano. Em todos estes casos, a virulência do som atravessa a imagem muda sem chegar a existir. São modelos a respeito de como a relação entre som e silêncio no cinema é paradoxal e axial para uma compreensão de seu processamento cognitivo e perceptivo, ou seja, para o próprio entendimento do cinema. Isso pode se dar através de um vococentrismo ou verbocentrismo no cinema falado, produzindo uma competição, mais do que uma

58 "Se então fazemos a experiência da fabricação de uma sonoridade em pintura, é necessário adotar uma outra hipótese que vai permitir dar conta de fazer ouvir o olho e de fazer ver o ouvido. É necessário supor uma "comunicação existencial" dos sentidos: cada órgão dos sentidos, ou cada domínio do sensível fará eco aos outros" (BURNET, 2002, p. 31. Tradução nossa). 
complementaridade, entre as bandas visual e sonora do filme (CHION, 2005, p, 9; CAMPAN, 1999, pp. 39-40); através de uma linearização ou racionalização do cinema produzidos pelo som (eminentemente temporal) em relação à espacialidade "selvagem" das imagens (CHION, 2005, p. 19); pela percepção de que o som é eco de si mesmo e, portanto, uma fantasmagoria (CASTANT, 2007, pp. 156-157); ou pela relação propriamente mediática entre as tecnologias de reprodução sonora e de imagens, afinal, “o som abre uma porta técnica na instância da imagem" (CHION apud CASTANT, 2007, p. 183). Voltaremos a estas ideias pontualmente adiante, mas, por enquanto, como síntese, podemos utilizar o pensamento de Francis Bacon, que não apenas havia, à maneira de Munch, pintado o grito, como também havia pintado o cinema silencioso, através de um tela que revivia uma cena de $O$ encouraçado Potemkin (Bronenosets Potyomkin, 1925) de Eisenstein:

Bacon compreendeu que este grito do cinema silencioso grita mais forte do que se estivesse associado a uma banda sonora. Nas imagens mudas, tudo está pronto para que o grito saia (rosto, boca, mãos, tensão do corpo), mas ele não sai como se estivesse retido no interior, esperando ser expulso. $\mathrm{O}$ grito silencioso é mais barulhento que o gritar realista da banda sonora porque cada um pode escutar seu próprio grito (BURNET, 2002, p. 30).

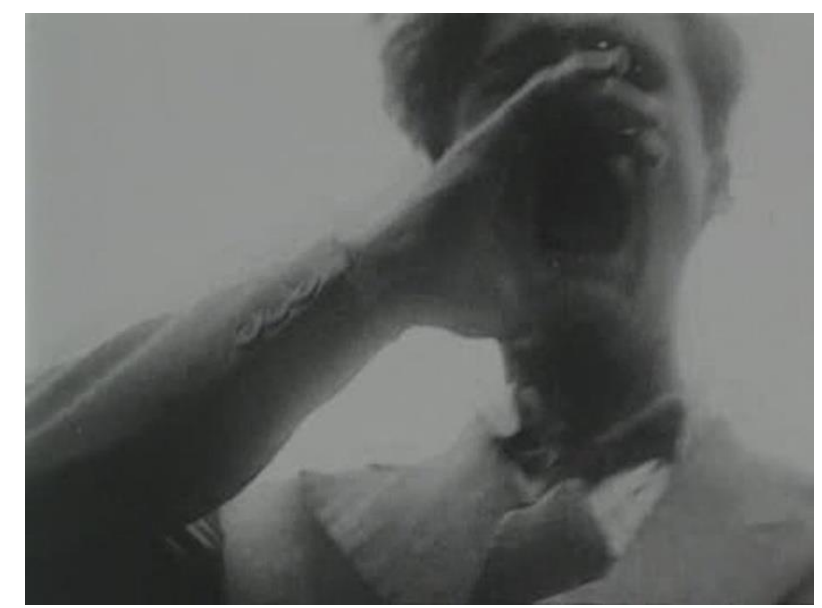

Figura 25

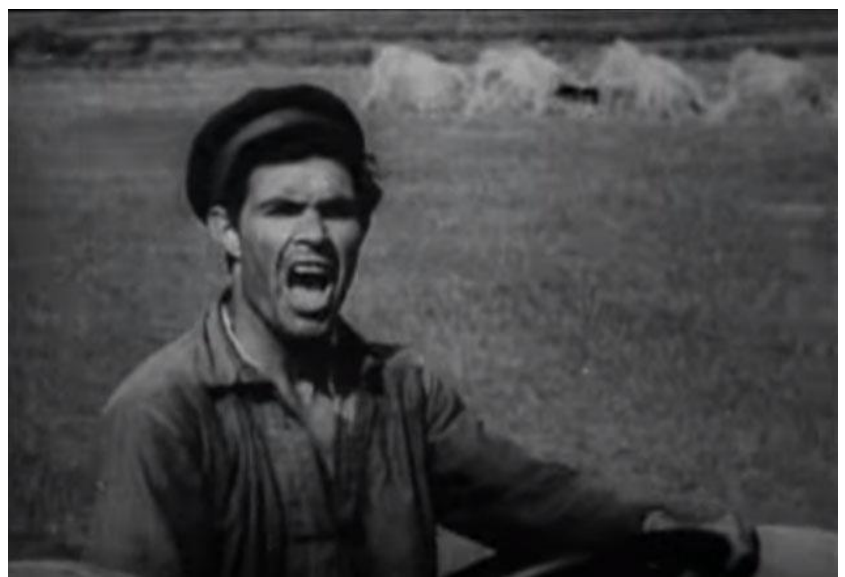

Figura 26 


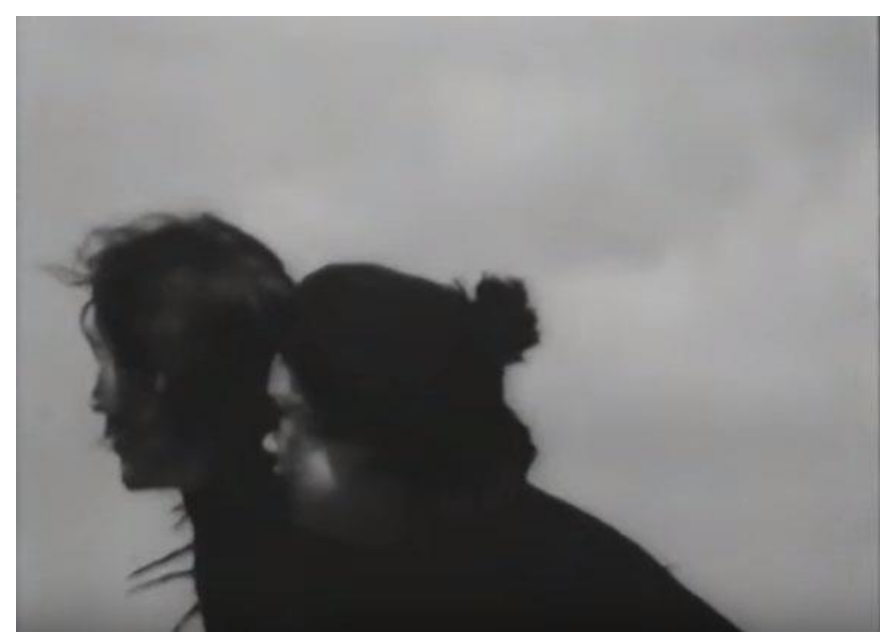

Figura 27

O grito, portanto, não apenas está no cerne de uma proposição que busca analisar o (des)entendimento entre som, imagem e silêncio no cinema, como está presente na própria origem do medium, quando, no cinema que antecipa a primeira guerra mundial (o chamado primeiro cinema ${ }^{59}$ ), não apenas várias tecnologias de gravação e reprodução sonora buscavam se fixar como pioneiras na criação de um cinema efetivamente sonoro (derrubando os mitos de que este cinema fosse realmente silencioso), como diversos outros tipos de manifestação sonora transformavam os espaços onde estes filmes eram veiculados (feiras, circos, cassinos, bares, jóqueis, teatros de vaudevilles, etc.) em verdadeiras balbúrdias. Conforme nos apresenta o historiador Martin Barnier, após extensa pesquisa sobre a aparição do som no primeiro cinema:

Cinema? Gritos, aplausos, barulhos de copos, de garrafas, de pratos, o grunhido de feras, máquinas a vapor, orquestrações, fonógrafos, canções sincronizadas, vozes humanas e às vezes mesmo um pianista. Esta lista não exaustiva dá uma ideia dos "acompanhamentos sonoros" possíveis nas projeções de filmes na França entre 1896 e 1914 (BARNIER, 2010, p. 15 $5^{60}$ ).

Como se pode ver, a experiência sonora esteve presente no cinema desde o princípio, mas, paradoxalmente, a ideia de que som e imagem são complementares ou naturalmente extensivos um ao outro (a chamada "ilusão audiovisual" ${ }^{61}$ ) também pode

\footnotetext{
${ }^{59}$ François Jost elabora preciosa reflexão a respeito da capacidade de pensar do primeiro cinema: "Se o primeiro cinema está aquém do pensamento, isso não quer dizer que ele faz mostrar um pensamento degradante ou inferior, mas sim que ele pertence à esfera da mão mais do que à do olho"(JOST, 2014, p. 17). Isto certamente desperta ideias sobre sinestesia e cinema silencioso.

${ }^{60}$ Tradução nossa.

${ }^{61}$ Um termo correlato seria "homogeneidade audiovisual", que Laurent Jullier associa à "opinião ingênua" de que o som no cinema pode ser tão complexo quanto a forma com o qual ele ocorre na "vida real" (JULLIER, 1995, p. 57).
} 
ser pensada a partir desta caótica experiência dos primórdios do medium. Afinal, o grito exteriorizado por esta plateia antiga, fazendo do ambiente fílmico uma algazarra altamente participativa e nada silenciosa, contrasta com o ambiente já "maduro", visto nos filmes dos anos 1930 citados, próximo da institucionalização do comportamento do público dentro do cinema e também da utilização de uma tecnologia de reprodução sonora que unificasse todos os procedimentos de sincronização (BARNIER, 2002, p. 209). No primeiro cinema, o grito vem do público, eufórico, tomado pela experiência realista e socializante, eminentemente coletiva, daquelas celebrações em torno da imagem em movimento. Nos anos 1930, o grito vem de dentro da tela, mas não é materializado como banda sonora. A imagem é muda, mesmo que acompanhada de som. O grito pode ser percebido, mas não ouvido, e a experiência, antes exteriorizada e febril, se torna um grito interno de angústia, que de alguma forma metaforiza este mesmo decalque entre a produção de som e a produção de imagens no cinema. De um lado, portanto, temos um som histérico (o grito da plateia) que se manifesta na projeção sobre uma imagem muda. De outro, temos uma imagem muda que projeta o grito a partir de si própria, produzindo a ilusão de uma imagem sonora na cabeça do próprio espectador. Chama a atenção o artifício e até a precariedade do cinema em buscar a complementaridade entre estes dois meios de organização da experiência, como se um fosse intercambiável ou traduzível um no outro. A arte audiovisual é incrivelmente complexa em suas formas de apresentar as relações entre estes meios, mas, de alguma maneira, não é possível deixar de pensar que esta "falha trágica" inicial, demonstrada nestes dois modelos de grito cinematográfico, se perpetua por toda a continuidade da história do cinema.

O problema está, fundamentalmente, na ideia de sincronia. Este foi o Santo Graal de todo o chamado "período silencioso" do cinema: buscar uma tecnologia que fosse capaz de restituir temporalmente um aspecto sonoro e um visual para a então nova arte. Várias foram apresentadas. Somente a partir de meados dos anos 1930 isso efetivamente ocorreu. Este problema pode ser estendido a vários níveis de entendimento profundo a respeito da relação entre som e imagem no cinema. Michel Chion aponta que o primeiro fator para se deflagrar a ilusão audiovisual é justamente o "valor agregado" do som em relação à imagem, ou seja, a ideia de que o som se "destaca" naturalmente da imagem, como se estivesse contido nela. Isso é especialmente perceptível no cinema falado porque o som é naturalmente temporizado (um objeto 
temporal), que começa e acaba, assim como a imagem sequencial do cinema. A voz humana no cinema sonoro atua como um fator de vetorização racional (dando uma direção à imagem) a partir de sua natureza temporal. É o que Chion chama de vococentrismo ou verbocentrismo (CHION, 2005, pp. 7-12). Som e imagem, no entanto, não se depreendem um do outro naturalmente, e, provavelmente, estão mais próximos de se apresentarem como instâncias em conflito. Conforme veremos, um filme que não apresenta a vetorização das palavras tem maior possibilidade de mergulhar na espacialidade pura das imagens, fazendo emergir uma matriz poética.

Friedrich Kittler vai colocar o problema da sincronização de maneira ainda mais curiosa e radical. Para o pensador alemão, o fim do primado da palavra (e especialmente da "sensual" letra cursiva) - que era capaz de produzir a "alucinação" de estocar informação sem reter seu sentido, vertendo tudo no código simbólico - vai se dar justamente num sincronismo de tecnologias do fim do século XIX, a saber, a máquina de escrever, o gramofone e o cinema. Para Kittler, cada uma destas tecnologias liberta o sentido para um dos estados do inconsciente trifásico que encontramos em Lacan: a máquina de escrever estaria associada ao "simbólico" (por representar o mundo em símbolos discretos); o "imaginário" estaria associado ao cinema, arte da fantasmagoria por excelência; e, curiosamente, o inatingível "real" lacaniano estaria associado ao fonógrafo, justamente pela capacidade que o som tem em fazer irromper uma "cura pela fala". Cindidos, portanto, dentro de um inconsciente que separa o "imaginário" do "real", som e imagem situam-se em polos opostos da inteligibilidade dos fenômenos comunicacionais. A própria leitura visual é mais lenta do que a sonora. Em uma mensagem audiovisual, o olho é mais hábil espacialmente, e o ouvido temporalmente (CHION, 2005, pp. 13-14). Este decalque faz com que processemos a informação visual e a informação sonora em partes diferentes do cérebro, constituindo uma computação dos dados da realidade que nem sempre se opera na forma de uma sinergia. Quando adicionamos mais um modelo informacional (a língua verbal), conforme ocorre na vasta maioria do cinema falado, a coordenação precisa ocorrer entre som, imagem e língua, produzindo uma recepção cognitiva bastante diferente da de um filme silencioso desprovido de qualquer sonoridade. Para Chion (Ibidem: 19-20), o tempo no cinema sonoro é uma cronografia, enquanto no cinema silencioso ele seria elástico, ou seja, aproveita a plasticidade atemporal da imagem crua, separada do som e da palavra. Logicamente, a montagem de qualquer filme complexifica estas relações por inserir a 
imagem no tempo. Kittler a atribui à produção de fragmentos esparsos associados ao imaginário lacaniano, não necessariamente vinculando-a a uma temporalidade clara, enquanto o fonógrafo registra ondas físicas, o que o aproxima de uma experiência do real:

\begin{abstract}
Desde o arranjo experimental de Muybridge, todas as sequencias fílmicas têm sido scans, excertos, seleções. E toda estética cinemática se desenvolveu a partir da tomada de 24-quadros-por-segundo, que foi mais tarde tornada padrão. Truques de edição, montagem, câmera lenta e time lapse apenas traduzem a tecnologia nos desejos da audiência. Como fantasmas dos nossos olhos iludidos, os cortes reproduzem as continuidades e regularidades do movimento. $\mathrm{O}$ fonógrafo e o longa-metragem correspondem, um para ou outro, como o fazem o real e o imaginário (KITTLER, 1999, p.119).
\end{abstract}

E é na instância do corte, naturalmente, que podemos pensar um terceiro e último tipo de sincronia ao qual se filia os processos relacionando som e imagem no cinema silencioso: a montagem vertical eisensteiniana. Em seu famoso ensaio "A sincronização dos sentidos", o cineasta russo busca fazer uma diferença entre seu conceito de montagem polifônica, que captura um detalhamento completo da superfície da imagem e sua potência de representação de um tema geral a partir da justaposição dos planos, da montagem vertical, que inclui todo um universo novo - a banda sonora dentro das possibilidades de entrecruzamentos destas relações. A afirmação dele é categórica: "Não há diferença fundamental quanto às abordagens dos problemas de montagem puramente visual e da montagem que liga diferentes esferas de sentidos particularmente a imagem visual à imagem sonora - no processo de criação de uma imagem única, unificadora, sonoro-visual” (EISENSTEIN, 2002, p. 54). Ele acreditava, portanto, que uma "sincronização física dos sentidos" era possível e que elementos mínimos de som e imagem (como gestos e entonação) provinham dos mesmos sentimentos, tornando factível esta sincronização interna e "oculta", cujo objetivo final seria produzir uma "atração ${ }^{62 "}$ entre todos os elementos do filme, e que esta reproduzisse um "tema" em uma série total de aspectos. A ambição de Eisenstein ia de coordenar elementos plásticos e tonais dentro de um patamar de montagem a sincronizar posteriormente cores e formas de maneira métrica, rítmica, melódica e tonal (Ibidem, p. $60)$.

62 "Para explicar a atração, o cineasta russo recorreu à ideia (partindo dos experimentos de Pavlov) de que cada elemento do filme só ganha significado em contraste e relação com um outro, produzindo em cada mente receptora uma série de estímulos derivados do entendimento desses efeitos atrativos" (MARCONDES, 2009, p. 18). 
Apesar de a teoria da montagem polifônica funcionar muito bem para o cinema silencioso, ou seja, Eisenstein dominava muito bem as aglutinações e efeitos dialéticos do diálogo puro entre imagens, a montagem vertical simplesmente não funciona (tanto que não foi desenvolvida por outros autores) porque elementos sonoros e visuais não são intercambiáveis em termos de corte e edição. $\mathrm{O}$ sonoro é alienígena à imagem e possui universo próprio. Relacionar tom e cor, ainda que haja o desejo de se pensar em termos sinestésicos, simplesmente não encontra verificação experimental. Isto se dá porque o nível de decomposição que podemos realizar na banda sonora fílmica é absolutamente distinto do que podemos fazer com imagens. Não podemos segmentar o som em planos. Suas várias faixas de atuação são simultâneas, ondulatórias, imprecisas. Não há superfície no som, como na imagem, e não há definição de seus limites de ocorrência.

\footnotetext{
A banda sonora de um filme constitui para a escuta um fluxo sem cortes? Nós até a distinguimos em unidades: mas estas - frases, barulhos, temas musicais, células sonoras - são exatamente do mesmo tipo que na experiência comum, e são identificadas em função de critérios específicos aos diferentes tipos de sons escutados. Se se trata, por exemplo, de um diálogo, vamos decompor o fluxo vocal em palavras. Unidades linguísticas, portanto. Se se tratam de barulhos, realizaremos uma decupagem perceptiva em eventos sonoros, mais fácil quando se trata de sons isolados [...]. Em resumo, operamos normalmente, com unidades que não são especificamente cinematográficas, e que dependem na verdade do tipo de som e do nível de escuta escolhido (CHION, 2005, p. 41).
}

A escolha pela teoria clássica de Eisenstein para finalizar esta problematização inicial a respeito das contradições perceptivas e cognitivas que envolvem som e imagem no cinema silencioso (e além) não vem à toa. Procurar entender o que acontece com a experiência fílmica quando a ela se acrescentam um código de linguagem (a palavra) ou um medium (a banda sonora) significa buscar a natureza própria não apenas das imagens, do movimento, do som ou da língua, mas também o papel que o próprio silêncio representa para este paradoxalmente chamado "cinema silencioso". É com isto em mente que procuraremos, agora, analisar pontualmente cenas de dois filmes que de alguma maneira problematizam estas questões, a começar pelo próprio uso da fala e da música que Eisenstein realizou em seu Ivan, o terrível (Ivan Grozniy, Parte 1, 1944; Parte 2, 1958), aparentemente contradizendo suas próprias teorias. Em seguida passamos para a versão sonora do clássico polinésio de Robert Flaherty Moana (1926), relançado com som em 1980, altamente sugestivo no sentido de construir suporte para se pensar os limites da atuação sonora em um filme. 


\subsubsection{Ivan, o terrível e uma ubiquidade sonora e espacial}

Ivan, o terrível, em suas duas partes, é talvez o filme mais controverso do cineasta russo não apenas por seu retrato simpático à figura de Stalin (especialmente na primeira parte. A segunda desagradou o líder soviético e trouxe consequências para a vida do cineasta), mas também pelas ideias até hoje não muito bem compreendidas a respeito de como Eisenstein colocaria em prática o que vinha desenvolvendo desde sua "Declaração sobre o futuro do cinema sonoro" (com Pudovkin e Alexandrov) até os trabalhos contemporâneos ao filme, hoje reunidos em $O$ sentido do filme. Se em Aleksander Nevksy (1938) ele tirou proveito da tentativa de realizar a montagem vertical por meio de uma sincronização entre tom e pigmentação das imagens (EISENSTEIN, 2002, p.52), visando uma série total de aspectos, em Ivan, o terrível, sua ambição se estende especialmente ao campo da fala, e as triangulações entre música, fala, palavra, imagem, montagem, etc., são claramente perceptíveis desde a primeira cena.

O filme conta a trajetória do primeiro czar a unificar a Rússia, de maneira gloriosa na primeira parte, e sombria, na segunda. Não cabe aqui procurar exaurir hermeneuticamente as possibilidades deste longo filme, e sim pensar em como Eisenstein trabalhou som, silêncio e imagem de maneira que tanto o cinema silencioso quanto o então novo cinema falado emergissem. O resultado é ambíguo, controverso. Se em 1944 o cinema americano já trazia incrível sofisticação espacial e sonora em um filme como Cidadão Kane e em toda a cultura do noir, no filme estatal de Eisenstein a impressão que temos é a de um cinema silencioso estranhamente tocado pela presença alienígena do som, que busca surgir como produção autônoma de sentido, mas articulada ao pensamento por imagens e à montagem de atrações já preconizada pelo cineasta em filmes anteriores. Música, falas e ruídos coabitam o espaço fílmico como se não estivessem presentes nele, como se pairassem em outra dimensão, soprando correlações e percepções exógenas a uma organicidade do filme.

Nossa análise se restringirá à primeira cena da primeira parte, a própria coroação do czar. A trilha sonora do filme, intermitente e aparecendo em momentos precisamente calculados, é de Serguei Prokofiev (assim como o fora em Aleksander Nevsky). Nesta cena - que se passa em uma catedral e que é lembrada pela suntuosidade dos figurinos e 
da direção de arte, assim como pela aplicação meyerholdiana de um teatro construtivista na direção de atores - as vozes são dubladas e o som é monofônico ${ }^{63}$. Portanto, é compreensível que a banda sonora do filme denote extrema artificialidade. Isso não era um problema para Eisenstein, para quem o cinema era essencialmente um artifício, e cujos filmes traziam grande carga de exagero, deformações visuais e certa carga expressionista. A ideia de que o som fosse tratado também de maneira calculada e construtivista parece extensiva ao pensamento do cineasta. O som precisaria ser traduzido no contexto das ideias e temas gerais que precisam ser articulados pelas atrações do filme. Daí, da cena da coroação se depreender uma decupagem circular, em que rostos tanto dos apoiadores do czar (interpretado por Nikolai Cherkasov) quanto os de seus inimigos são perfilados como em um museu de caricaturas temerosas e grosseiras, com olhares terríveis e expressões histéricas (FIG. 28). Como se criando seu próprio museu de retratos de um Renascimento alemão (lembrando Dührer ou Cranach), o cineasta vai montando este pequeno desfile de horrores enquanto o czar, que demora a aparecer, vai sendo anunciado pelo sacerdote.

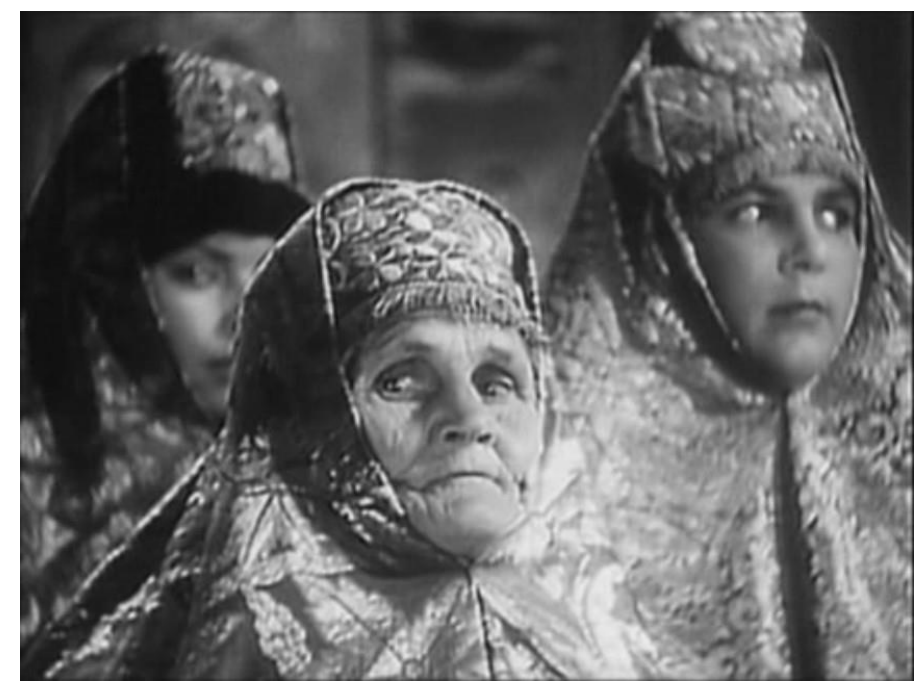

Figura 28

Este desfile circular de retratos parece limpidamente separado da banda sonora, que inclui a trilha de Prokofiev, o som da missa para receber o novo czar, momentos calculados de silêncio e as vozes dos próprios personagens. Estas não parecem criar efeitos de distanciamento em relação ao espaço. Sussurros são ouvidos como se falados

\footnotetext{
${ }^{63}$ Para o cinema monofônico, há apenas uma pista de som. Para o cinema multipistas, há várias pistas de som capazes de fornecer informações sonoras diferentes em um mesmo instante (JULLIER, 1995, p. 196).
} 
em voz alta. Personagens distantes no espaço se escutam normalmente, e a voz do sacerdote offscreen, produz um efeito de voz over, funcionando como uma narração propriamente dita. A montagem sonora é fria, etérea e parece pouco orgânica especialmente em relação ao conjunto de imagens trazidas por Eisenstein com a intenção de anular a dimensão espacial da cena, como se tudo fosse simplesmente ubíquo e a simbologia dos fatos narrados fosse muito mais importante do que os fatos em si. Na verdade, o som em Ivan, o terrível funciona como se ele fosse intencionalmente acusmático, ou seja, do qual ninguém tem ideia da procedência, mesmo que saibamos que estes sons são replicativos, ou seja, que remetem a uma fonte clara de origem (a boca dos personagens). Se Chion (2005) situa o som acusmático como sons cuja fonte não pode ser identificada, e que vem de um tempo e espaço diferentes da diegese, Véronique Campan expande o conceito para uma definição mais ampla e técnica, que nos ajuda neste momento:

Todo som fílmico pode, na verdade, ser considerado acusmático na medida em que a causa original de onde ele provém, assim como sua causa tecnológica (o alto-falante) estão ambos ocultados, e relegados a um fora-dequadro definitivo. Cada ocorrência acústica registrada, desligada de seu ponto de emissão inicial, está disponível para toda nova ancoragem que o texto fílmico será capaz de induzir (CAMPAN, 1999, p. $26^{64}$ ).

Ora, se todos os sons em Ivan, o terrível, incluindo suas falas, se comportam como acusmáticos, Eisenstein está chamando a atenção para a aleatoriedade da montagem sonora em si, e não a uma sincronização profunda, como ele propõe em $A$ sincronização dos sentidos. O processo de desacusmatização ocorre apenas quando a imagem do czar é finalmente mostrada e o ator Nikolai Cherkasov passa a falar (FIG. 29). Neste momento, a voz trovejante soa como um encaixe articulado do som na imagem, e tudo parece adquirir um fatalismo auspicioso, como se naquele momento voz e imagens estivessem efetivamente coordenados em uma mesma frequência de representação. Curiosamente, Chion visualiza estes fenômenos de corporificação (miseen-corps) como a morte da aura do ser acusmático. Porém, o que vemos no filme é justamente o contraste sólido construído pela montagem sonora e relacionando a voz de Ivan, os comentários dos convidados presentes (geralmente questionando, em burburinho, seus planos de reunificação da Rússia), e pontuados momentos de silêncio, em que nem a voz e nem a música irrompem. A ciranda de perfis pensados como retratos renascentistas ganha então também uma roda sonora girando ao seu redor, como

\footnotetext{
64 Tradução nossa.
} 
planetas que se orbitam, mas não se tocam. A beleza desta estranha composição entre silêncio e som reside, portanto, na articulação não-usual, negando a ilusão audiovisual, e ao mesmo tempo na existência do filme mudo que resiste, como um rio subterrâneo, abaixo da camada sonora do filme. É como se Eisenstein quisesse construir um filme silencioso a partir da ideia de que todo filme nunca deixa de ser silencioso. Cada filme sonoro são dois filmes, um contemplado pela visão e outro contemplado pela audiovisão ${ }^{65}$. Um filme visível é sempre um filme silencioso, e isso acaba ratificando a noção de Robert Bresson de que "o cinema sonoro inventou o silêncio" (apud CASTANT, 2007, p. 160).

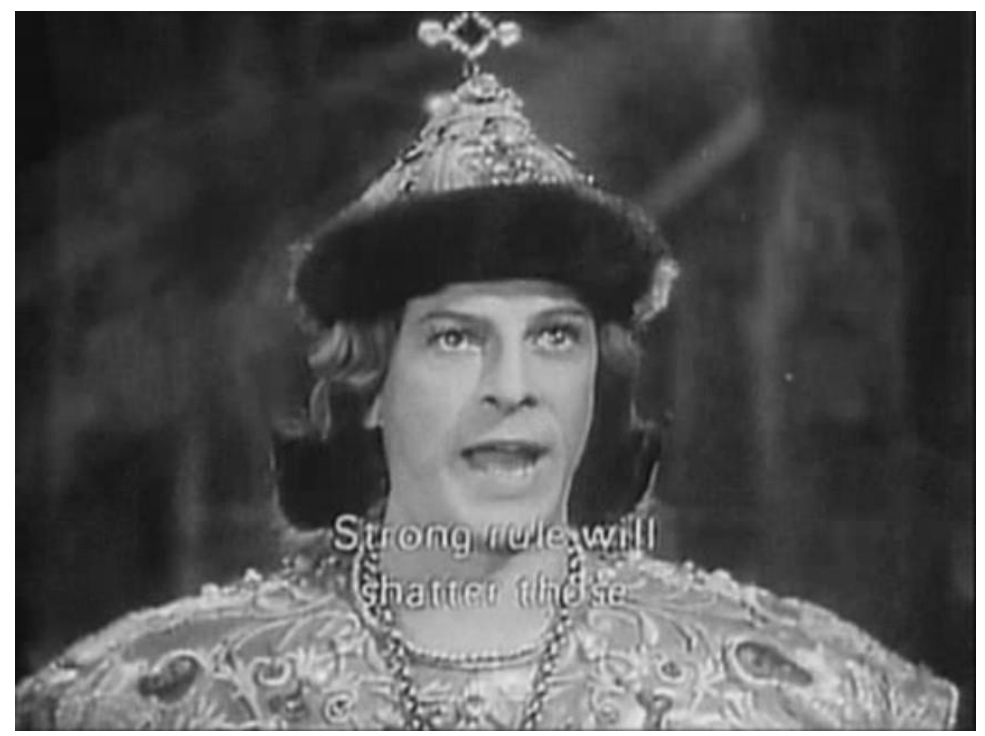

Figura 29

\subsubsection{Moana with sound... e com silêncio}

O som acusmático, pensado de maneira generalista conforme coloca Campan, também é um tema interessante a ser abordado no que diz a respeito a Moana with sound, a versão que Monica Flaherty (filha de Robert) lançou em 1980 para o filme originalmente silencioso de seu pai. A cópia original deste lançamento havia desaparecido, mas uma nova versão restaurada a partir de vários negativos originais em 35mm foi relançada tanto no "New York Film Festival" de 2014 quanto no "Festival International du film restauré (Toute la mémoire du monde)" de 2015, em Paris. Ainda que raro, tornou-se possível assistir novamente a Moana with sound e pensar a relação

\footnotetext{
65“Audiovisão" é o termo que Michel Chion (2005) dá a todo o complexo fenômeno de percepção
} auditiva que ocorre na espectatorialidade fílmica. 
entre som e imagem a partir deste filme reconstruído e, a partir de agora, também reconstituído.

Quando seus pais, Robert e Frances Hubbard Flaherty, viajaram às ilhas Samoa, no sul do Pacífico, entre 1923 e 1925, para filmar o modo de vida dos polinésios, a pedido da Paramount, tal qual havia sido feito com Nanook, o esquimó (Nanook of the North, 1921), levaram seus filhos, e isso incluiu a jovem Monica, então com três anos de idade. A ideia de Monica $^{66}$, ao revisitar o filme e sonorizá-lo, era restaurar a integridade do ambiente sonoro da ilha Savai'i e de seus habitantes, tal qual era o sonho de seu pai. Como resultado, no lugar das tradicionais gravações musicais que acompanham as sessões dos filmes silenciosos (o Moana original não tinha trilha sonora), ouvimos, em Moana with sound, sons ambientes registrados anos depois na própria ilha, que inclui barulhos da natureza e gritos de animais, além do som dos cânticos dos polinésios e das falas redubladas na língua samoana. A versão sonora, evidentemente, apresenta um novo filme. $\mathrm{O}$ que, no entanto, esta sonorização $a$ posteriori pode nos dizer sobre a própria indistinguibilidade entre filme silencioso e filme falado fundada a partir desta subversão da obra original?

Em primeiro lugar, podemos salientar que Moana guarda em si a estilística e a estética particulares a Flaherty. Ou seja, o filme, que procura elaborar uma relação de afeto entre dois protagonistas e trazer à tona os costumes das culturas polinésias, é quase todo encenado, com hábitos já extintos trazidos à tona de novo para procurar "recuperar" uma certa humanidade ancestral e impulsionar maior interesse na ficção que deveria se comportar de maneira documental (CLEMENTE, 1963, pp. 37-46). É característica do cinema de Flaherty, portanto, se servir da realidade para imaginar seu próprio mundo e ideias a respeito dos temas tratados, estando um filme como este nem no vértice da ficção e nem no documental. Ele se desloca, na verdade, para o eixo da poesia, em que a valência lírica das imagens não tem preocupação com um índice de verificabilidade na realidade. Pensando assim, a natureza acusmática da versão sonora não apenas não se incomoda por soar falsa, como está de acordo com a estética radical e despreocupada de Flaherty.

\footnotetext{
${ }^{66}$ Tal qual relatada pelo restaurador Bruce Posner na sessão do "Festival International du film restauré (Toute la mémoire du monde)", em 01/02/15.
} 
Na verdade, o interesse em Moana with sound, mesmo que ele possa ser considerado um filme sonoro e falado, está justamente na manutenção de seu estatuto como filme silencioso pelos seguintes fatores:

1 - Uma preocupação em assumir certa verossimilhança sonora, ou seja, fazer com que estes sons acusmáticos, dos quais pouco se sabe de onde vieram, pareçam estar inseridos naturalmente na paisagem do filme. O que é interessante, neste caso, é a forte contradição que tal produção provoca, já que, ao assistirmos Moana with sound, sabemos que aquelas vozes, gravadas décadas depois, não pertencem àquelas pessoas, e nem aqueles sons de animais e da natureza pertencem àquele ambiente. Neste sentido, Moana with sound escancara seu artifício da mesma maneira que Flaherty escancara suas cenas ensaiadas, seus procedimentos planejados e meticulosos envolvendo as contradições que estão presentes na produção de ficção e cinema em geral.

2 - A voz humana no filme também aparece como elemento de paradoxo, já que os personagens falam o tempo inteiro (ao contrário da versão silenciosa, que tem de se sustentar com algumas poucas cartelas de intertítulos), mas não podem propriamente ser compreendidos, porque muito poucas pessoas no mundo falam a língua samoana. Assim como ocorre com o gaélico em $O$ homem de Aran, a língua em Moana with sound é deixada propositadamente sem legendas, para que ninguém a compreenda e ela se torne também uma espécie de artifício para a construção de um ambiente sonoro. Neste sentido, se opusermos o silêncio não ao som, mas sim à fala e à palavra, Moana with sound continua sendo um filme silencioso. O processo de vetorização do tempo real proposto por Chion em relação à fala (ou seja: fazer perceptível a passagem do passado ao futuro ou futuro ao passado através da temporalização do discurso verbal) não ocorre. Moana with sound mantém sua atemporalidade, sua qualidade intrínseca de imagem elástica, que eterniza aquelas encenações/documentações a partir de uma frequência poética que não obedece a ordens e teleologias fílmicas ou narrativas.

3 - Moana with sound não deixa de parecer estranho ou exógeno a si mesmo a partir do momento em que uma banda sonora nova é arbitrariamente colocada para "concorrer" com suas imagens de quase cem anos de idade. Isso o torna um dos exemplos mais interessantes da discrepância paradoxal entre som e imagem, quando um dos canais de comunicação passa a deslizar sobre o outro de maneira com que quase se 
toquem e quase construam uma sinergia tal qual sonhava Eisenstein. Campan descreve esta relação com precisão:

\begin{abstract}
Os sons, na verdade, ocupam o espaço sem incorporá-lo, e lembram à nossa atenção o que lhe escapa ordinariamente: o local intermediário no qual eles se propagam, o espaço interior de uma transmissão ou da ressonância de uma voz. Coisas dos quais eles são a emanação, das quais eles retêm apenas a mutabilidade, o devir, manifestando a emergência ou a evanescência mais do que a aparência. O dispositivo fílmico contribui então a colocar em concorrência, e mais do que em complementaridade, dois modos diferentes de organização da experiência (CAMPAN, 1999, p. 39).
\end{abstract}

No final das contas, o som em Moana with sound privilegia o silêncio original do filme ao trazer à tona uma espécie de ruído de fundo - seja nos cânticos, seja nas falas que não compreendemos, seja nos sons da natureza - que funciona como barulho branco: a célula de caos deslocado que todo som carrega, livre e desautomatizado, contribui para unificar a experiência do filme com suas imagens arquetípicas, ancestrais. Basta olharmos para a cena (FIG. 30) em que um menino habitante da ilha empenha-se em fazer fogo a partir de dois pedaços de madeira para que possa queimar a casa de um caranguejo ladrão de cocos e expulsar esta "ameaça" do coqueiro de seu tio. A cena, montada de maneira picotada, bem ao gosto de Flaherty, possui algo de cômico, e ao mesmo tempo algo de essencial: a operação para fazer emergir o fogo é a operação do cinema, a de construir artificialmente a luz, a de transformar o mundo em linguagem, a de expressar o eterno por meio da engenhosidade humana. Os sons do vento e do mar, nesse caso, mesclam-se neste artifício claramente construído e falsificado, e ao mesmo tempo legítimo, precioso, inigualável. A imagem do menino fabricando o fogo se torna uma imagem revelatória, arquissemelhante (conforme veremos em Rancière), enquanto o som, em sua indefinição de barulho branco, se torna uma escuta reduzida (Chion, 2005 , p. 28), ou seja, que se projeta sobre as qualidades próprias do som independente da causa e do sentido. A imagem arquissemelhante e o barulho branco da escuta reduzida nos transportam, neste caso, para a atemporalidade do estado poético da mente. 


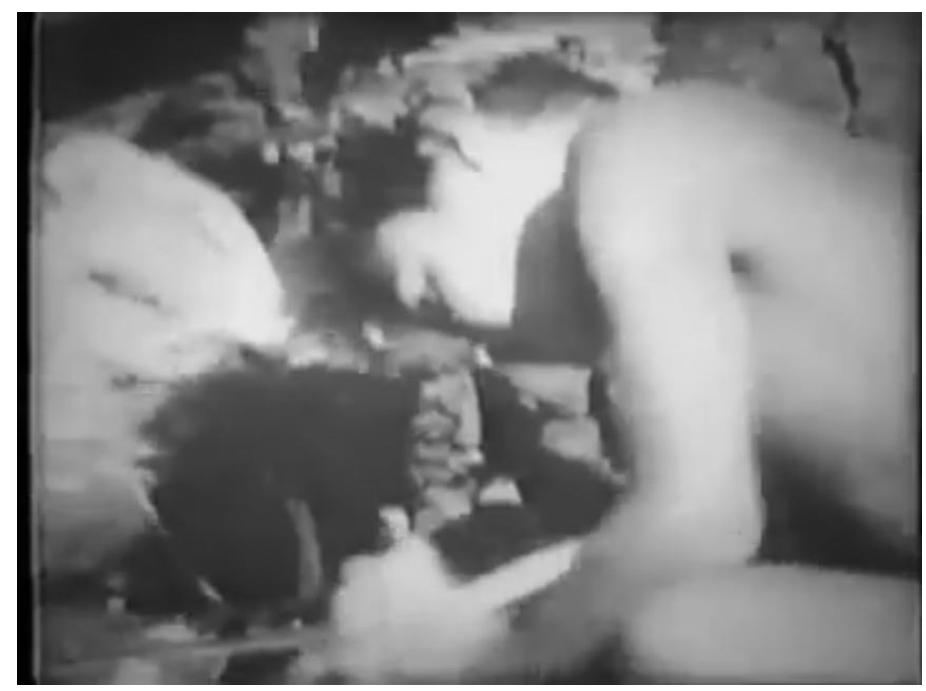

Figura 30

Campan (1999, p. 34) pensa os fenômenos acústicos a partir da mitologia da ninfa Eco, que, quando replica os dizeres de Narciso, pouco a pouco os modifica, deixando a natureza do som ambígua, preservando-se a si mesma, mas ao mesmo tempo em constante mutação. Esta metáfora fica clara quando pensamos no som reproduzido pelo cinema e seus vários canais de replicação de sua transitoriedade: o som é registrado, e no registro ele seleciona o que o equipamento de gravação é capaz de preservar. Depois ele é reprocessado na edição do filme, quando, por meio dos autofalantes, é novamente transformado, e chega aos ouvidos do espectador, quando mais uma vez passa pelo filtro da recepção cognitiva. A fantasmagoria do som, neste caso, é carregar os esporos do mundo original onde ele esteve presente, mas estes esporos também sofrem mutações, e o que percebemos, nestas retransmissões constantes dos objetos sonoros, é apenas o rastro destes fenômenos, sua pálida forma transmutada. Em Moana with sound esta fantasmagoria se torna mais evidente justamente porque este rastro da capacidade comunicativa do som é luminoso, direto. $\mathrm{O}$ mutismo em Moana with sound não está apenas nas imagens silenciosas eternizadas por Flaherty, ou sequer na língua incompreensível, que se torna o murmúrio do barulho branco, que é falada pelos personagens do filme. O mutismo está neste duplo fantasma que o filme revela, com suas imagens e sons espectrais, furtivos, que não se alojam em nenhuma representação definitiva.

Este rastro fantasmagórico, fruto de ecos disléxicos e deslocados de sons que nunca foram, somado à imagem espectral naturalmente fugidia do cinema mudo, 
transforma Moana with sound em um filme duplamente silencioso. De certa forma ele internaliza a dupla valência dos gritos que anunciamos no início deste texto: o grito externo da plateia, presente nos barulhos dos animais, nos cânticos e na natureza selvagem retratada como espectadora de si mesma; e o grito interno, do cinema maduro dos anos 1930, presente na natureza existencial, na simples vivência dos fenômenos, que o filme de Flaherty propõe.

No final do filme acompanhamos o doloroso processo para se tatuar o jovem Moana, algo que pertence ao seu rito de passagem (FIG. 31). Flaherty situou esta sequência - meticulosamente montada em etapas elementares para a composição da tatuagem no corpo do personagem (CLEMENTE, 1963, p 41) -, no final do filme justamente para produzir esta branda catarse - a acumulação da experiência estética de um povo. Se não vemos em Moana o risco à vida e a fúria da natureza como acompanhamos em Nanoon, o esquimó ou em $O$ homem de Aran, aqui temos a vantagem não apenas de entender uma natureza do mundo frugal e idílica, mas também a oportunidade de compreender o mundo pela chave da imagem e do silêncio. Afinal, se o som em Moana é barulho branco e se mescla à fantasmagoria muda e difusa de sua própria ancestralidade, a imagem das tatuagens, abstrata, também comunica o silêncio. O grito de dor de Moana, no final, seja na imagem silenciosa que se desloca de sua sonorização artificial, seja no próprio barulho branco do grito fantasmagórico ecoado na banda sonora, é um grito primordial. Talvez não um grito de angústia existencial, tal qual vemos em Munch, mas um grito que exprime o próprio silêncio primordial.

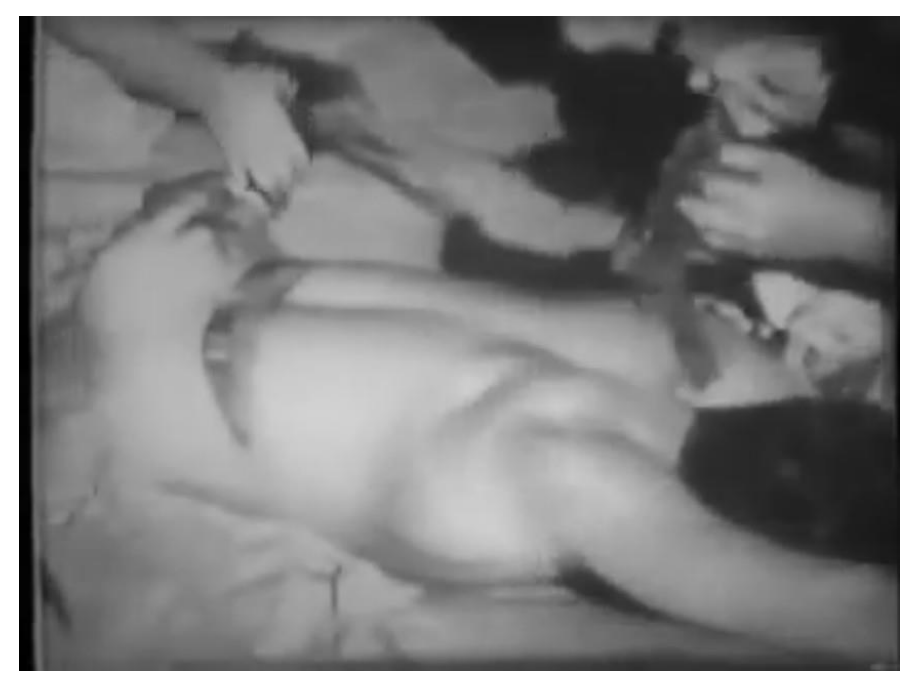

Figura 31 
O som recriado para Moana, portanto, produz um efeito distinto daquilo que haviam preconizado Robert e Monica Flaherty: ao invés de adicionar ao realismo do som material do filme, a banda sonora fantasmagórica adiciona ao seu silêncio. Ao invés de adicionar ao grito de dor literal de um homem sendo dolorosamente tatuado, adiciona ao grito metafísico do silêncio forte, da expressão pura dos desenhos tatuados na pele, e da própria imagem transcendental do cinema silencioso em si. As funções disjuntas de imagem e som, arquissemelhantes ou fantasmagóricos, flutuam no filme sem produzir uma síntese, ainda sem alcançar a sincronia sonhada por Eisenstein, mas ainda assim ratificando a ideia de que meios de expressão intraduzíveis podem produzir, juntos, a potência originária que compõe o mundo. E esta potência é feita de imagem e som. 


\section{MUTAÇÕES DO SILÊNCIO}

Deve ser imenso o silêncio em que tais ruídos e movimentos têm lugar.- Rilke

\subsection{Duas dicotomias}

Diremos nós que a virtude das plantas e das pedras não está nelas, pois os homens a desconhecem? Certamente não: nós reconheceremos que as plantas têm em si mesmas sua nobreza, sem a ajuda da língua e das letras humanas. - Leonardo Da Vinci

\subsubsection{Um problema de terminologia}

Pensar o cinema silencioso é também pensar, por meio de um encadeamento de temas correlatos que se alimentam um ao outro, os temas mais gerais do som e da fala. E pensar o som e a fala nos leva, seja por meio de uma intencionalidade, seja por meio de uma relação de simples sobreposição ou perspectiva, a colocar em relevo o tema do silêncio como um todo. E pensar o tema do silêncio leva também, de maneira adjunta, a pensar o seu contrário, ou, olhando de outra forma, a enfatizar o seu corolário: a linguagem. O jogo prossegue: a linguagem se encaminha a pensar a produção de sentido (ou a ausência dele, ou a presença, conforme vimos em Gumbrecht), que nos leva a buscar um entendimento maior das formas de expressão, ou, melhor dizendo, das formas estéticas. Dentre as formas estéticas há o cinema, e dentro do cinema há o cinema silencioso. No meio desta cadeia simples de termos entre o silêncio e o cinema silencioso reside, naturalmente, um universo de coisas. Há, por exemplo, este cinema como fenômeno cultural, tecnicamente localizado no final do século XIX e primeiras décadas do século XX, cujas marcas de cotidianidade vão desaparecendo cada vez mais na medida em que este fenômeno se torna mais antigo. $\mathrm{O}$ que entendemos por "cinema silencioso" hoje é radicalmente diferente do que era entendido em sua própria época. Há também este cinema como fenômeno histórico, cujas ligações com as trajetórias políticas e econômicas das nações não devem ser desprezadas, pois o fazem emergir como fenômeno também de complexidade ${ }^{67}$. Além disso, há este cinema como

67 “Acontece que o problema da complexidade não é o da completude, mas o da incompletude do conhecimento. Num sentido, o pensamento complexo tenta dar conta daquilo que os tipos de pensamento mutilante se desfaz, excluindo o que eu chamo de simplificadores e por isso ele luta, não contra a 
fenômeno comuncacional, medium, o que nos permite compreender sua natureza enquanto modulador de consciências, individuais e coletivas, e as interfaces destes processos. Evidentemente, o cinema silencioso é também um fenômeno estético, cujas leis e especificidades enquanto arte precisam também ser trabalhadas para chegarmos, finalmente, à ideia de pensá-lo como meio que produz uma resposta cognitiva, ou seja, atua sobre a mente, sobre a percepção, interpretação e decodificação do mundo, utilizando-se dos recursos que lhe são inerentes.

Como se pode ver, o escopo de abordagens a respeito do fenômeno do cinema silencioso como um todo é naturalmente muito grande, sendo cada um destes tópicos (histórico, tecnológico, mediático, político, econômico, estético, etc.) um campo determinado de investigação científica. Não nos cabe aqui resumir o avanço de cada um deles, mas sim considerar que, como novo ponto de partida, em algum grau, elementos de todos eles poderão compor esta proposta de se pensar o cinema silencioso como uma poética. Será necessário nos voltarmos também ao cinema falado e à suas propriedades, afinal, que tipo de mediação se interpõe entre estes dois modelos de expressão cinematográfica?

Para começar a se pensar a questão, é necessário partir da própria terminologia, e, neste âmbito, duas dicotomias se estabelecem como paradoxos/entraves a um entendimento esclarecedor sobre estes cinemas. Em primeiro lugar, o alojamento do silêncio no cinema silencioso. Tradicionalmente, no jargão em português, há duas formas de se nomear as várias, e diversas entre si, formas de cinema que se desenvolveram entre as décadas de 1890, 1900, 1910, 1920 e 1930. Esporadicamente, em décadas posteriores. Eventualmente, ainda hoje. A mais popular, atualmente, talvez vista como pejorativa, é a do cinema mudo. Ela corresponde à maneira francesa: cinema mиеt. Hoje em dia é mais comum utilizar-se, porém, ao menos em textos críticos, a forma do inglês: cinema silencioso (silent cinema). Eis a dicotomia. Poderíamos pensála em termos de mudança de tradição epistemológica nos estudos brasileiros sobre cinema: se, até os anos 1990, pesava na produção acadêmica a tradição de historiadores

incompletude, mas contra a mutilação. Por exemplo, se tentarmos pensar no fato de que somos seres ao mesmo tempo físicos, biológicos, sociais, culturais, psíquicos e espirituais, é evidente que a completude é aquilo que tenta conceber a articulação, a identidade e a diferença de todos esses aspectos, enquanto o pensamento simplificante separa esses diferentes aspectos, ou unifica-os por uma redução mutilante" (MORIN, 2014, p. 176). 
e da grande teoria, de matriz francesa (de Sadoul e Mitry a Bazin), a partir dos anos 2000 a virada para os estudos anglófonos, fortemente influenciada por arquivistas e historiadores como Eileen Bowser, Charles Musser, Tom Gunning, etc. (COSTA, 2010, pp. 23-24), impulsionou uma nova divisão de trabalhos a respeito deste tipo de cinema. Campos diversos, diferentes dos já tradicionais (expressionismo alemão, avant-garde francesa, montagem soviética, narrativa griffthiana, etc.), surgiram como novas possibilidades de se abordar estes cinemas: o desenvolvimento da narrativa, o cinema de atrações, os modelos de exibição, os primeiro gêneros, as "vistas", a economia em torno das primeiras companhias, as tecnologias de coloração dos filmes, as modalidades sonoras destes cinemas, entre outros. Tudo isso para justificar uma simples mudança de paradigma lexical: ao invés de "mudo" (muet), "silencioso" (silent).

Em relação à semântica desta terminologia, argumentar que "mudo" seria um termo pejorativo porque não "fala" (induzindo-nos a pensar que o cinema "mudo", sim, fala) seria diminuir, evidentemente, a completa capacidade de expressão dos próprios mudos. Pior ainda seria auferir algum tipo de poder comunicacional superior ao termo "silencioso" em relação ao "mudo". Dizer que o silêncio comunica da mesma forma que a "fala" seria subestimar seu próprio poder de expressão. Seria subjugá-lo de maneira hierárquica à sua antítese. Se o poder comunicacional do silêncio é grande, não é porque ele "fala" (da maneira como, por exemplo, um papagaio "fala"), mas sim porque ele nos coloca em um estado inflexivo. Uma primeira hipótese sobre isso, se pensarmos em termos heideggerianos, seria a de que o estado a que nos submetemos quando buscamos o silêncio permite-nos desdobrar onticamente sobre nosso próprio ser. O silêncio, como a meditação ${ }^{68}$, prepara o ser para investigar a si próprio, prepara o Dasein ${ }^{69}$. Esta seria uma conotação útil para se começar a investigar a natureza do silêncio enquanto uma ausência que se ocupa do ser. Em última instância, esta vigilância do ser confundiria o silêncio com o próprio ser:

Heidegger, por exemplo, quando se pergunta a propósito da origem da obra de arte, sobre o estatuto da "Coisa" (das Ding), desenvolve uma intricada reflexão para mostrar que a existência da coisa - tais como o jarro, a árvore, a ponte - consiste no distanciar-se da simples coisa. A essência não estaria,

\footnotetext{
${ }^{68}$ Vamos nos aprofundar nestas questões no capítulo 5.

${ }^{69} \mathrm{O}$ Dasein é "um sujeito inicialmente desprovido de um mundo, ou que não está seguro de seu mundo e que, no fundo, precisa assegurar-se de um mundo" (HEIDEGGER apud RÉE, 2000, p.41). Neste sentido, compreender o próprio silêncio interno seria uma atitude hermenêutica, de autointerpretação, capaz fornecer uma pista de uma prova de mundo.
} 
assim, na objetividade com que ela é representada, e sim no vazio, em algo que se subtrai à visão imediata (SODRÉ, 2008, p.11).

Este estado de "simples existência" heideggeriano, tão raro, que paradoxalmente se dá pela negação da coisa (e afirmação de seu vazio ou silêncio) curiosamente encontra eco em tantos trabalhos de artistas de matriz poética. Basta lembrar da Ponte de Joris Ivens (corroborando a argumentação de Muniz Sodré) ${ }^{70}$, no Caixote de Francis Ponge e na Maçã de Magritte ${ }^{71}$ (FIG. 32). Nestes casos, o objeto, a coisa, ou a imagem da coisa, tudo se submete a um regime de silêncio, um silêncio prenhe de potência ôntica, uma cama estendida para conforto (ou o tormento) do encontro com o Ser, ou a afirmação da perseguição do Ser.

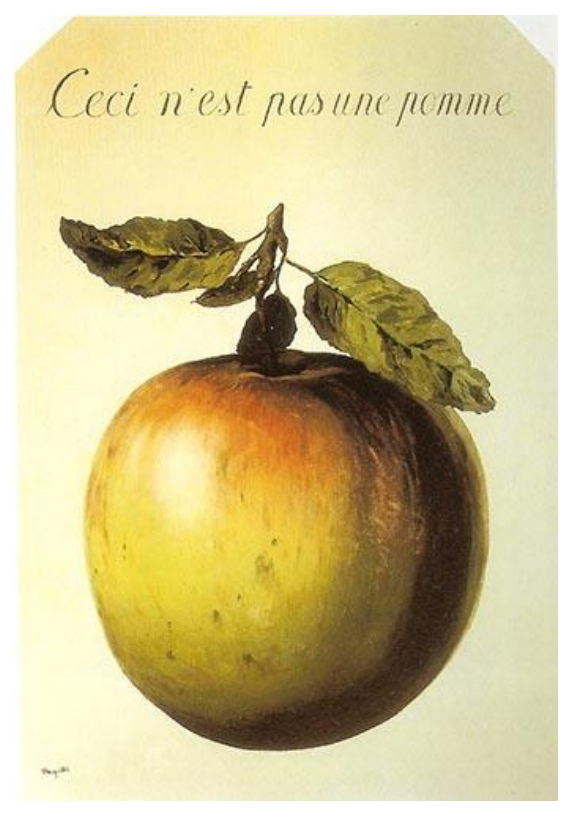

Figura 32

\subsubsection{O silêncio ao redor}

É necessário fazer-se entender que a qualidade ontológica do silêncio, sua dimensão mais propriamente transcendental, é apenas um dos possíveis silêncios dentro de um mundo de infinita representação, dentro do qual repousam muitas diferentes versões do silêncio. Qual é, portanto, o "silêncio" do cinema silencioso? Segundo Kevin Brownlow, historiador britânico deste cinema, "a própria palavra silencioso sugere que

\footnotetext{
${ }^{70}$ Veremos mais sobre isso adiante.

${ }^{71}$ Ao dizer "isso não é uma maçã”, Magritte certamente rompe com o silêncio da tela, mas, ao mesmo tempo, chama a atenção ao silêncio da imagem em si. Se isto não é uma maçã, e sim a imagem de uma maçã, o que ela diz sobre a maçã, enquanto imagem, em seu silêncio? No capítulo quatro, discutiremos isso mais detalhadamente.
} 
algo está faltando" (BROWNLOW, 2007, p. 10) ${ }^{72}$. Este tipo de complexo de inferioridade se propaga intensamente no senso comum, onde o cinema silencioso é visto, mais ou menos, como tipo imperfeito de cinema, escada para a completude subjetiva e de perspectiva racional do cinema falado. Esta perspectiva nos remete imediatamente a McLuhan, para quem os meios de comunicação (os media) atuam como extensões de nós mesmos, mas nós só os percebemos como amputações. Ou seja: sentimos seus efeitos, mas não os atribuímos à qualidade de sensibilidade expandida. Curiosamente, dentro de uma lógica de senso comum, isso parece se aplicar da mesma forma a este cinema. O espectador "leigo" consegue acompanhar tecnicamente um filme silencioso, especialmente se for de matriz narrativa: consegue compreendê-lo, fazer uma leitura dele, inseri-lo dentro de uma tradição, localizá-lo em um espaço representacional do mundo. De alguma forma, a leitura "leiga" de um filme silencioso qualquer (vamos dizer, por exemplo, Chaplin) é completa e integrada: são sistemas que se comunicam, o riso acontence, a mecânica e a dinâmica composicional do filme são inteiramente absorvidas. Porém, ele sente, em analogia à sua própria condição existencial, a sensação de amputação. Seja no pastoreio do ser (o jarro vazio de Heidegger), o véu de Nietzsche (a aparência como verdade) ou o Real de Lacan (inalcançável), a configuração da ausência como ontologia é transferida para a tecnologia. Para este espectador contemporâneo, o cinema silencioso é como um corpo amputado, e o cinema falado oferece uma redenção metafísica: um centro, uma essência, um corpo completo, uma imagem reluzente refletida no espelho. Por isso, nesse caso, é preciso assumir o que o historiador do cinema silencioso Rick Altman chama de crisis historiography (historiografia de crise), buscando negar modelos de representação que sejam baseados na continuidade do medium ou em sua leitura contemporânea:

Muitos historiadores descrevem e julgam novos modos de representação retroativamente. Ou o valor de um meio particular é acessado de acordo com suas contribuições a meios desenvolvidos subsequentemente, ou sua habilidade de aferir sentido é analisada com base em padrões da atualidade (ALTMAN, 2004, p. 17) (3) $^{2}$

É preciso, portanto, pensar o cinema silencioso dentro de suas próprias contingências, e dentro das contingências de seu público. Altman defende que, para se realizar uma historiografia da presença do som no cinema silencioso, é preciso

\footnotetext{
${ }^{72}$ Tradução nossa. Grifo do autor.

${ }^{73}$ Tradução nossa.
} 
considerar um grande número de variáveis concernindo estes cinemas (o plural é relevante): em que época se localizam os filmes (se nos anos 1890, se na era dos nickelodeons, se no auge das orquestras, se nos anos 1920, etc.); para que público se destinavam; em que locais eram exibidos; em que países circulavam. Enfim, é preciso pensar em que condições de produção estes filmes faziam valer sua significação. Em que condições de silêncio. Pensando assim, ressaltam-se as seguintes informações ${ }^{74}$ :

- O cinema silencioso praticamente nunca foi assistido "em silêncio". O acompanhamento musical era absolutamente comum a praticamente todas as épocas e culturas cinematográficas até a chegada do som sincronizado pela tecnologia Movietone (em 1927). Até 1908 (JOST, 2001), porém, ainda há controvérsia sobre a utilização de música nos filmes do primeiro cinema.

- A natureza e organização deste material musical variavam muito em relação à época, local e condição econômica destes cinemas. Em todo o período, na Inglaterra, na França e nos Estados Unidos, era comum que houvesse ao menos um piano, um violino ou um violão (e às vezes uma bateria), e a música era geralmente derivada dos vaudevilles do final do século XIX. Na era dos nickelodeons (aproximadamente entre 1908 e 1915), vigorava o hábito de que cada pequena sala de cinema tivesse sua banda, sendo o ritmo preferido o ragtime, uma forma de música militar que prenunciou o jazz. Nesta época existiam também pianos automáticos e órgãos adaptados aos sons emulados para os filmes ${ }^{75}$. Na época dos grandes cinema theaters era comum que orquestras inteiras tocassem no fosso das salas. "Durante a Era de Ouro, a reputação de uma sala de cinema dependia de sua orquestra. As pessoas às vezes declaravam que elas iam ao cinema 'apenas pela música'” (BROWNLOW, 1996, p.338) ${ }^{76}$.

\footnotetext{
${ }^{74}$ As informações listadas a seguir foram compiladas e estão descritas com maior detalhamento em ALTMAN (2001 e 2004), BROWNLOW (1996) e KOBEL (2008).

75 François Jost fala inclusive sobre a chegada dos dispositivos sonoros portáteis que ambientavam mecanicamente as salas de cinema, algo ignorado por muitos historiadores: "Se a imitação no modelo teatral dependia da habilidade de um homem e, consequentemente, fazia variar de um performador de som a outro, a 'peça de mobília portátil para sons de bastidores' marcou uma ruptura na história do cinema. Primeiro, ela tornou possível replicar sons idênticos [...]. A influência da performance se tornava cada vez mais distante, assim como o então forte componente autográfico do cinema. Como os intertítulos, que garantiram uma absoluta iterabilidade da narrativa verbal (em oposição ao comentarista), o dispositivo portátil, avaliável para locação e portanto transportável, garantia a continuidade do show independentemente do performador ou do local" (JOST, 2001, p. 49. Tradução nossa).

76 Tradução nossa.
} 
- As trilhas para os filmes, nos anos 1920, recaíam sob duas categorias: ou eram compiladas de clássicos (Schubert ou Weber, por exemplo), ou trilhas totalmente originais. Antes disso, a improvisação dava o tom: os músicos de cinema tinham cadernos inteiros com indicações de melodias para todo tipo de cenas, as chamadas cue sheets. A interação da música com o filme, porém, dependia da intencionalidade dos músicos. Muitas vezes eles tocavam o mesmo tipo de música para todos os filmes.

- Os críticos de cinema, entretanto, viam o filme totalmente silencioso, o que nos faz pensar a respeito de diferentes recepções estéticas entre crítica e público, assim como na maleabilidade de representações do cinema silencioso que o tornavam uma arte não tão técnica assim e mais performática do que se imagina, aproximando-o dos números de vaudeville, do teatro e dos próprios concertos musicais. Esta parte móvel da experiência do cinema silencioso, entretanto, está perdida para nós enquanto performance, restando a sua forma como medium discursivo (conceito de Flusser.Cf. MÜLLER, 2012, p. 44), ou seja, da memória de um emissor à memória de um receptor.

- Outra informação pouco conhecida é a de que, durante o período silencioso, mesmo os sets cinematográficos possuíam acompanhamento musical. Boa parte das produtoras, estúdios e diretores de cinema do período solicitavam a presença de músicos tocando durante as filmagens. Isso ajudava a fazer os atores encontrarem o tom certo na atuação, a imaginar como as cenas se configurariam quando acompanhadas do som no cinema, e davam caráter lúdico ao trabalho no set.

- Após a chegada da tecnologia do som sincronizado, entre 1928 e 1930, aproximadamente 10.000 músicos, a maioria deles músicos de cinema, perderam seus empregos nos Estados Unidos.

A partir destas informações é fácil inferir que estes cinemas não eram, absolutamente, "silenciosos" do ponto de vista estritamente sonoro. Se a imagem de alguns destes cinemas (como discutiremos adiante) produziu o efeito de silenciamento, em outros filmes "mudos" o ato comunicacional era claro, intencional, vívido, explícito, "tagarela". Em quase todos eles, porém, a presença física do som se dava através da música, o que nos leva a pensar o silêncio por dois prismas: o primeiro deles, material, leva em consideração a possibilidade de existência do silêncio quando o ar veicula a 
propagação do som de maneira organizada, baseada em ritmo, harmonia e melodia (música). Neste caso, estaria o silêncio oposto aos caos entrópico (som desordenado), estabelecendo ele uma relação diferente com o som organizado? Vale lembrar a célebre declaração de John Cage: "Não existe tal coisa como o silêncio. Algo está sempre acontecendo e emitindo um som" (apud SONTAG, 2002, p. 16). Se considerarmos isso tecnicamente correto (especialmente do ponto de vista material), resta ao silêncio existir como conceito. Mais do que a definição a respeito da ausência de uma propagação sonora através de um meio físico, o silêncio poderia ser uma abstração que elucida um estado da percepção: algo inerente ao mundo interior, ou a uma permuta com o Outro. Um problema da alteridade. Seria este um segundo prisma - o silêncio e sua relação com o sensível, com o ser, com a comunicação, com a linguagem. O silêncio como acontecimento $^{77}$.

Esta perspectiva se torna atraente especialmente se não considerarmos o silêncio como oposto ao som, mas sim como oposto à palavra e à fala ${ }^{78}$. Desta forma, o silêncio se configura como um conceito que se opõe ao mundo conceitual. Sendo oposta à palavra, a música (instrumental, evidentemente) pode se tornar também uma forma de silêncio, tornando a pulsão do cinema silencioso mais forte a partir de sua conjugação com a sua atmosfera. Este silêncio prenhe do mundo das imagens acompanhadas exclusivamente de música vai se tornar desafiador em relação aos silêncios que ocorrem entre as falas no cinema falado. Cada qual, portanto, desenvolve um tipo de sonoridade e também um tipo de silêncio. É sempre bom não esquecermos que Hegel considerava a música como manifestação emotiva superior, meio para a manifestação do Espírito (KOVADLOFF, 2003, p. 82). É nessa esteira, em oposição ao universo da palavra e do conhecimento logocêntrico, que o filósofo Santiago Kovadloff situa o silêncio musical. "Sim, a música nos restitui ao silêncio que nos constitui" (Idem, p. 80). A premissa pode não ser tão clara, mas deve estar atrelada à ideia de que, quando ouvimos música, nosso sistema de percepção mental, operacionalizado através dos processos da linguagem, da recepção de imagens e das sensações, entra em um tipo de oclusão e faz

\footnotetext{
77،JJean-François Lyotard diz que o acontecimento está sempre num 'lugar vazio'. Ele não se dá no 'corpo próprio', de Merleau-Ponty, mas no espaço vazio aberto pelo desejo. O acontecimento, em Lyotard, seria uma 'doação', vem como algo que me é entregue, não algo que eu reconheça ou compreenda" (MARCONDES FILHO, 2009, p. 15).

78 "Se eu estive em condições anteriormente de levar adiante a ideia de que a música era a continuação do silêncio por outros meios, devo isso ao fato de que, para as pessoas que codificaram o film d'art, o silêncio estava em oposição paradigmática apenas à fala" (JOST, 2001, p. 51. Tradução nossa).
} 
emergir um sistema diferente, musical, que, ao menos em sua forma ideal, substitui inteiramente o primeiro sistema, calando-o momentaneamente e fazendo-o hibernar em silêncio. Por outro lado, esta inversão de sistemas de percepção faz com que a música seja capaz de comunicar algo incomunicável pela linguagem, já que a música tem essa capacidade de comunicar os sentimentos em si, replicando-os em nosso receptáculo perceptivo, limando a barreira processual e sígnica da linguagem. O resultado pode ser entendido como silêncio, já que prescinde da tecnicidade da língua, mas não como vazio, porque os estados emocionais provocados pela música são carregados de completude. O sistema musical silencia uma parte de nós, mas ilumina e acorda outra, uma parte condizente com o indizível.

\begin{abstract}
Minha intenção inicial é reconhecer na música um sinônimo de silêncio; ao silêncio extremo como som musical. Porque se o silêncio não é necessariamente ausência de som, e sim presença de um sentido que excede nossa compreensão, então a música pode ser expressão de silêncio. $\mathrm{O}$ que significa ouvir o silêncio senão escutar o que não chega a ser dito? (Ibid. p. 75)
\end{abstract}

Será possível, portanto, que a música torne o cinema silencioso ainda mais silencioso? Que a experiência da imagem crua e silenciosa destes filmes some-se ao silêncio "primordial" (como diz Kovadloff) expresso por este caráter atravessador da música, tornando a experiência destes filmes a soma de dois silêncios? Considerando a música como organização estética do som, por outro lado, não podemos deixar de considerar que a percepção deste silêncio está se dando através de seu reverso material, e que, se considerarmos a afirmação de John Cage, se o silêncio material não existe, toda organização do mundo se dá pela via sonora, incluindo sua produção de silêncios. E diferentes tipos de silêncio emergem, no mundo consumido pelo som: em primeiro lugar, o silêncio musical, sobre o qual já falamos; em segundo, o silêncio dos intervalos entre os sons, pausas sonoras, uma presença invisível em cada diálogo, em cada interação $^{79}$; por último, o silêncio produzido pela soma de todos os sons, o caos, a cacofonia.

\title{
2.1.3 Ser um fantasma: a etiologia do filme silencioso
}

\footnotetext{
79،'Desta intuição deriva a bela metáfora que descreve o silêncio como um terceiro interlocutor do diálogo: quando dois homens conversam, existe sempre um terceiro presente: o silêncio que a tudo escuta" (FELINTO, 2008, p.57, parafraseando Picard).
} 
Ora, se existe um meio que seja capaz de reproduzir estes três níveis de silêncio e que não seja a própria realidade, este meio é o cinema... sonoro. Daí a necessidade de se entender o silêncio que vaga em meio ao som. De se entender o cinema silencioso a partir do cinema sonoro. De se pensar em como o cinema sonoro comporta o cinema silencioso e, mais difícil ainda, se o cinema silencioso também comporta, por meio de uma antecipação mediática, um cinema sonoro. Daí a necessidade de passarmos para a segunda dicotomia e, antes de analisarmos os filmes silenciosos propriamente ditos, olharmos o universo silencioso que está guardado em determinados cinemas sonoros. Neste caso, cabe principiar distinguindo o cinema falado do cinema sonoro em si.

Em uma época (a saber, final dos anos 1920 e começo dos anos 1930) em que havia uma concomitância de ocorrências entre o cinema silencioso e o cinema falado, uma nova terminologia teve de surgir para que se demarcassem alguns territórios sobre o que o cinema se tornaria. $\mathrm{O}$ cinema falado rapidamente passou a ser conhecido como talkie, um termo popular que possui certa conotação afetiva (daí o diminutivo) e ao mesmo tempo pejorativa (o talkie possui uma aura de descartabilidade, de produto de massa). Talvez seja esta oposição mais acentuada com o ato de fala, somada à clara e comprovada presença de muitos elementos sonoros nas sessões do cinema silencioso, que levaram Kobel a afirmar que "um termo melhor para os filmes silenciosos - mesmo que soe de alguma forma estranho - seria filmes-não-dialogados, porque estes chamados filmes silenciosos sempre tinham algum tipo de acompanhamento musical" (KOBEL, 2008, p.259) ${ }^{80}$.

A presença do diálogo ${ }^{81}$, portanto, é fundamental para demarcar a mudança de paradigma e para que o talkie se afirme não apenas como um tipo de filme que contenha som gravado, mas como um filme "falante", ou seja, que tenha muitas falas, que seja conduzido por este elemento, que faça dele sua força motriz. Don Juan, filme da Warner lançado em 1926 e estrelado por John Barrymore, foi uma das primeiras experiências com a Vitaphone, tecnologia que sincronizava o som a partir de um disco (depois substituída pela Movietone, com o som gravado no próprio filme, cujo princípio ainda é usado hoje no cinema analógico). Neste filme, em tudo parecido com os filmes

\footnotetext{
80 Tradução nossa.

${ }^{81}$ Tecnicamente, “diálogos sonoros”, para deixar a definição de Kobel ainda mais precisa, já que a maioria dos filmes silenciosos a partir da era dos nickelodeons possuíam sim diálogos, por meio dos intertítulos.
} 
silenciosos da era de ouro, a trilha sonora não era executada por uma orquestra, mas sim gravada. Era um filme sonoro (um dos primeiros), mas não era um filme falado (talkie). Da mesma forma, Aurora, de Murnau, também foi lançado com o som gravado, e em sua trilha se incluíam algumas inovações: sons de buzinas, latidos de cachorros, sons de passos, barulhos das ruas. No entanto, não havia diálogos sonoros (FISCHER, 1998, pp. 28-32). O conceito de cinema sonoro, porém, vai além de uma mera formalidade técnica. O filme sonoro não é um "mero" talkie. É um filme que se permite desierarquizar $^{82}$ os elementos do cinema, destronando a imagem como seu significante de maior valor. O som, distante do universo datado dos talkies dos anos 1930, acabou progressivamente sendo elaborado como uma dimensão significante inteira e conceitual para o cinema. Isso pode ser verificado primeiro a partir de cineastas que antes eram contrários ou no mínimo levantavam suspeições diante do advento do som, como Chaplin ou o próprio Eisenstein ${ }^{83}$, para chegar a inovações que estes mesmos cineastas incutiram no aproveitamento desta tecnologia (como, por exemplo, em $O$ grande ditador e Ivan, o terrível). Em segundo lugar, há os nomes que efetivamente trabalharam o som para longe da mera representação (ou seja: a fala e a trilha de acompanhamento $^{84}$ ), fosse por um prisma autoral, como no caso de Orson Welles, ou em parcerias conceituais, como Hitchcock e Bernard Hermann fizeram nos anos 1950/60. A recente valorização da profissão do designer de som, antes considerado apenas um técnico, consolida a releitura histórica desta dimensão sonora do filme (ALTMAN, 2004, p.6).

Porém, para além deste truísmo (“o som é importante para o cinema”), é preciso reconsiderar uma certa axiologia a respeito deste tema para que ele possa, efetivamente, reverberar como uma utilidade no momento de se pensar o conceito de "silêncio" para o cinema silencioso. Afinal de contas, tendo como parti pris o cinema silencioso, a

\footnotetext{
${ }^{82}$ Este aproveitamento do som segue o sistema de composição fílmica proposto por Eisenstein: "[...] Eisenstein desejou criar para o cinema um sistema em que todos os elementos seriam iguais e comensuráveis: iluminação, composição, interpretação, história, mesmo legendas devem ser interrelacionadas, a fim de que o filme possa escapar do realismo cru de apenas contar uma história acompanhada por elementos de apoio. [...] Para Eisenstein, ver um filme é como ser sacudido por uma cadeia contínua de choques vindos de cada um dos vários elementos do espetáculo cinematográfico, não apenas do enredo" (ANDREW, 1989, p. 50).

${ }^{83} \mathrm{Ou}$ Pudovkin, que chegou a escrever um "manifesto assincronista" visando uma utilização contrapontual da trilha sonora no cinema sonoro (Cf. GALLEZ, 1970, pp. 42-5).

${ }^{84}$ Spottiswoode, pensando ainda no cinema da década de 30, e, portanto, na aurora do cinema sonoro, definiu cinco funções para a trilha de um filme: imitação, comentário, evocação, contraste e uso dinâmico (Cf. GALLEZ, 1970, p. 40).
} 
pergunta "por que o som é importante para o cinema" ganha um novo verniz. Para além do senso genérico de que o som e a fala adicionam à "verdade" mimética do filme (tornando-o mais naturalista), em que efetivamente estes elementos e estas tecnologias transformam o medium cinema? Em primeiro lugar, talvez seja interessante desbaratar as razões, dadas como certas, de que o advento do som, em relação ao cinema silencioso, era uma espécie de "destino inevitável" deste meio, como se a trajetória tecnológica dele fosse uma forma teleológica. Altman lista estas razões: o som serviria para abafar sons desagradáveis da sala de projeção; para evitar o "esquisito" efeito de se ter imagens que se movem sem o acompanhamento do som; e o som serviria para completar a totalidade audiovisual "natural" do mundo (ALTMAN, 2004, p.9). Se Altman traz estes elementos à tona com ironia, não é este o caso de um teórico do som mais clássico e supracitado como Hans Eisler:

\begin{abstract}
A música foi desenvolvida [no cinema silencioso] como um tipo de antídoto contra a imagem. Esta necessidade foi desenvolvida para afastar do espectador o sentimento desagradável envolvido no ato de se ver efígies de vida, de atuações, e mesmo de pessoas falando, que eram ao mesmo tempo silenciosas. O fato de que elas vivem e não-vivem ao mesmo tempo é o que constitui seu caráter fantasmagórico, e a música foi introduzida não para suprimi-los com a vida que lhes falta - mas para exorcizar o medo ou ajudar o espectador a absorver o choque (EISLER apud GORBMAN, 1980, p. $186)^{85}$.
\end{abstract}

Esta ideia, criticada por Altman e corroborada por Eisler, de que a imagem silenciosa precisaria da música, e mais tarde da fala, para poder expurgar um certo incômodo que mistura uma ojeriza sensitiva com uma incompatibilidade existencial (a percepção da amputação) pode ser verdadeira para plateias atuais, mas é possível que não o fosse em plateias contemporâneas à época. A noção de que a chegada da fala e do som fosse evidentemente necessária e uma extensão natural do andamento tecnológico para o cinema talvez fizesse sentido para técnicos obcecados como Edison e Dickson ${ }^{86}$, ou então para os estúdios, que percebiam a necessidade constante de renovação tecnológica para que o negócio do cinema se mantivesse suficientemente lucrativo (KOBEL, 2008, p.264). Porém, em termos de crisis historiography proposta por Altman, talvez seja sensato entender que ler a recepção do cinema silencioso desta

\footnotetext{
85 Tradução nossa.

86 W.K.L. Dickson, inventor e cinegrafista, foi o braço-direito de Thomas Edison em muitas das suas invenções, tendo sido importante para as inovações do famoso cientista americano em sua investida tanto no fonógrafo quanto no cinema: "Em Nova York, entre 1889 e 1894, William Kennedy Laurie Dickson elaborou na Edison Manufacturing Company um procedimento técnico que permitia gravar e reproduzir a circulação de elementos móveis" (MICHAUD, 2013, pp. 40-41).
} 
forma seja pensá-lo por meio do sonoro, ou seja, pensar uma tecnologia a partir dos efeitos de sua continuidade.

O problema em definições como esta talvez seja a utilização de termos como "espectros" e "fantasmas" a partir de um ponto de vista francamente deletério, como se, no momento em que a imagem é percebida segundo uma epistemologia da experiência fantasmagórica, ela resultasse sempre em algo incompleto, desvanecido, a ponto de se esboroar como experiência totalizante ou mesmo legítima. É o que ocorre quando entramos em contato com fotografias de família do século XIX (cujo apelo horripilante e fantasmagórico é explorado em filmes como Os outros - The others, Alejandro Amenábar, 2001) ou fotografias "espíritas"87, comuns nesta mesma época, em que supostos fantasmas são registrados exclusivamente pelo filtro da câmara escura. Isso torna interessante notar a sempre inovada "capacidade" da tecnologia em desenvolver apetrechos capazes de desvelar um mundo invisível, para além de sua mera capacidade técnica de mimetizar, colocando-se também como criadora de outros mundos, como produtora instantânea, ao mesmo tempo, de realidades alternativas e de ficção. Foi assim com a fotografia espírita, com a fotografia em raios- $x$, com aparelhos de gravação de som e atualmente com as câmeras digitais de vídeo, fenômeno percebido em filmes de found footage como A bruxa de Blair (The blairwitch project, Eduardo Sánchez e Daniel Myrick, 1999) ou Atividade paranormal (Paranormal activity, Oren Peli, 2009). Nestes casos, a utilização de tecnologias de produção automática de "fantasmas" (como a fotografia ou o cinema), ao falarem explicitamente da captação ou captura deles ${ }^{88}$,necessariamente duplicam a percepção a respeito do efeito fantasmagórico delas próprias: se um filme registra explicitamente um fantasma, está evidenciando seu próprio processo de constituição de uma realidade ficcional, posto que, independente de estar falando sobre fantasmas ou não, um filme ou uma foto já criam fantasmas de qualquer forma. Que este registro, na representação ficcional, seja um fantasma em si,

\footnotetext{
${ }^{87}$ Gunning, em interessante artigo sobre a popularidade do fonógrafo no século XIX, encontra relação parecida: "Então o recente fenômeno do espiritualismo, nos quais espíritos dos mortos falavam através de mediums em transe, explica por que para muitos ocultistas o fonógrafo parecia prova o suficiente de uma nova revelação científica na qual os mundos material e espiritual seriam revelados como um só" (GUNNING, 2001, p. 22. Tradução nossa).

${ }^{88}$ Não esquecer que mesmo em um filme infantil como Os caça-fantasmas (Ghostbusters, Ivan Reitman, 1984), a captura ou aprisionamento dos seres sobrenaturais se dá através de tecnologias avançadas, como raios com feixes de prótons e armadilhas energético-mecânicas, como se este tipo de entidade e as tecnologias se sincronizassem dentro de um mesmo patamar comunicacional.
} 
apenas torna a relação mais óbvia e evidente. Ou seja: é o cinema comunicando sua própria comunicabilidade ${ }^{89}$.

Ao associar o fantasma a uma teoria da imagem, Erick Felinto nos ajuda a pensar a imagem do cinema silencioso como propriamente fantasmática. Esta relação estabelece um patamar mais racional para este suposto incômodo ou terror existencial infligido pelas imagens deste cinema, especialmente se pensarmos a partir de um ponto de vista atual. Afinal, qualquer imagem do cinema silencioso vai trazer à tona figuras de pessoas que já morreram, às vezes há dezenas de anos (algumas imagens dos primeiros filmes contêm pessoas que morreram há mais de cem anos), exatamente como as fotografias do século XIX. Porém, a adição do movimento e da narrativa a estas imagens torna-as ainda mais perturbadoras, porque replicam os gestos vivos destas pessoas, e estes gestos estão geralmente inseridos em um código de representação que instila sentimentos e afetos no espectador. O gesto em si, como vimos em Agamben, é comunicador de sua natureza, comunica a fantasmagoria. A ambiguidade destes efeitos é letal: se a representação no cinema silencioso procura, tecnologicamente (tal qual o Dr. Frankenstein), inseminar a vida em estruturas mortas, o resultado não pode deixar de ser admirável. Alegres, pulsantes e energizadas com o movimento, estas imagens reinscreveram os imaginários do final do século XIX e começo do século XX, encantando milhões de pessoas e se tornando um dos maiores fenômenos da história da cultura de massa. Porém, como pudemos aferir, sempre sob o signo da morte. A imagem técnica é sempre um instante passado, é sempre um signo de finitude. O primeiro recado de uma imagem fotográfica é sempre sua própria temporalidade determinada: ela já passou. Isso foi ${ }^{90}$. A imagem do cinema silencioso, portanto, para nós que somos espectadores longínquos, é ambígua porque pulsa em vida e pulsa em

\footnotetext{
${ }^{89}$ Agamben considera que "o cinema reconduz as imagens para a pátria do gesto", e o gesto, por sua vez, funciona como pura medialidade: "Do mesmo modo, compreendendo-se por palavra o meio da comunicação, mostrar uma palavra não significa dispor de um plano mais elevado (uma metalinguagem, esta mesma incomunicável no interior do primeiro nível), a partir do qual se faz dela objeto da comunicação, mas expô-la sem nenhuma transcendência na sua própria medialidade, no seu próprio ser meio. O gesto é, neste sentido, comunicação de uma comunicabilidade. Este não tem propriamente nada a dizer, porque aquilo que mostra é o ser-na-linguagem do homem como pura medialidade" (AGAMBEN, 2007, p.13).

90“"A pintura pode simular a realidade sem tê-la visto. O discurso combina signos que certamente têm referentes, mas esses referentes podem ser e na maior parte das vezes são 'quimeras'. Ao contrário dessas imitações, na Fotografia jamais posso negar que a coisa esteve lá" (BARTHES, 1984, p. 115).
} 
morte, projeção de nossa própria psique (basta pensar em Freud). É um fantasma, coisa que não está nem viva e nem morta:

O fantasma que não fala é o fantasma por excelência. Ao recusar a facilidade do som e do discurso oral, esse espectro torna-se ainda mais aterrador. Ele simplesmente está lá, e não sabemos o que quer com sua presença insistente. Convoca-nos a desvendar sua mensagem sem palavras, sob pena de atormentar-nos eternamente com sua visão (FELINTO, 2008, p. 24).

Não é à toa que tantas manifestações históricas do cinema silencioso se voltaram para a ideia do fantasmático e do monstruoso (expressionismo alemão), da morte (melodrama escandinavo), da loucura (neossensorialismo japonês) ou da tragédia (melodrama americano). Isso nos faz pensar que, ao contrário do que pensam teóricos clássicos da sonoridade no cinema, como Eisler ou Mitry, a ausência da falas gravadas não provoca exatamente um desconforto por conta de uma incompletude ou amputação midiática, mas sim graças a uma etiologia própria destas imagens silenciosas, que aderem a este aspecto fantasmático e passam a fornecer experiências que se instalam dentro desta etiologia. A experiência volúvel e ambígua da imagem-fantasma, que remete ao mesmo tempo ao poder vivificador da tecnologia e à lembrança intermitente da finitude e da morte, é totalizante à sua própria maneira. Ela se fecha em suas contingências dramáticas. Isso é muito diferente da experiência do cinema sonoro, que busca sua representação por meio de uma transfiguração do próprio corpo do espectador.

\subsubsection{Cinema silencioso: um fenômeno de descorporificação}

Passando, portanto, do silêncio ao som, é também a noção do fantasmático que emerge para se pensar uma combinação de estruturas do cinema falado. Neste caso é necessário invocar o ensaio já clássico de Mary Ann Doane ${ }^{91}$. Aqui, diferentemente do que pensa Morin (para quem a simbiose cinematográfica é uma permuta de projeção e identificação relacionada ao imaginário e à mente), o cinema representa uma própria inscrição do corpo do espectador em um medium. Doane ressalta que esta mediação física que o cinema proporciona ao espectador, de seu corpo consigo mesmo, é também um tipo de inscrição fantasmática. Se o cinema silencioso se apropria da própria fantasmagoria do medium (as imagens terríveis) para justificar uma etiologia de morte e

${ }^{91}$ DOANE, Mary-Ann. A voz no cinema: a articulação de corpo e espaço. In: XAVIER, Ismail (Org.) A experiência do cinema. Rio de Janeiro: Edições Graal, 1983. 
de finitude, provocando automaticamente o espectador, o cinema falado cria um corpo fantasmático, virtual e inscrito na percepção do espectador, que permite que a decrepitude e o desfalecimento representados no regime mediático anterior (o cinema silencioso) se transforme em um corpo completo, não mais amputado, mas dotado de uma ilusão configuracional reconfortante e de encaixe exato.

O acréscimo do som no cinema introduz a possibilidade de representar um corpo mais cheio (e organicamente unificado) e de confirmar o status da fala como um direito de propriedade individual. O número potencial e as espécies de articulações entre som e imagem são reduzidos pela própria expressão associada ao novo e heterogêneo medium - o "cinema falado" (DOANE, 1983, p.458).

O som, e mais particularmente a voz (daí a importância tão grande em se diferenciar cinema sonoro de cinema falado), é item essencial nesta propriedade que o cinema tem em reconfigurar a especularidade representacional de um sujeito para consigo mesmo. Evidentemente, Doane está se baseando em Lacan para a construção desta instância simbólica, este projeto de corporeidade, esta fantasia de funcionalidade. Daí o cinema clássico e suas diretrizes rigorosas, sua preocupação com um mimetismo "transparente" (XAVIER, 2005, pp. 41-45), sua estrutura decidida, "alegre" e "falante". Não à toa, é possível pensar o início do cinema clássico somente a partir da inserção da fala, rompendo com uma continuidade direta entre Griffith e a narrativa dos anos 1930/40, como se é quase natural conceber. Afinal, uma composição básica em termos de montagem, continuidade, visibilidade e ação neste cinema deriva das experiências de Griffith. Mesmo assim, há sentido em se pensar que há, diferentes entre si, uma "narrativa griffithiana" e uma "narrativa clássica", e que ambas são separadas pelo abismo da fala.

Thomas Gunning, em interessante reflexão sobre a tecnologia do final do século XIX e sua influência na noção de corpo a partir dos indivíduos, argumenta também que estes aparelhos (como o fonógrafo e o quinetoscópio) seguindo um princípio positivista de compartimentação dos conhecimentos das ciências, contribuíram para criar-se a noção de que a ciência mutila o corpo. Separar a voz e as imagens de sua origem atestata uma intensa fragmentação do corpo e da consciência que emergia naquela época. Gunning aproveita para pensar a ideia de Bazin que, idealista, considerava o cinema uma forma de reunificar o corpo e a consciência em um todo. O que ocorre com o cinema silencioso, no entanto, é mais complexo. 


\begin{abstract}
"Eu quis fazer pelo olho o que o fonógrafo faz pelo ouvido. Por meio desta intenção primordial e sua tardia repetição, eu acredito que Edison quis dizer duas coisas. Primeiro, que o fonógrafo era o instrumento original de uma nova forma de reprodução, uma que estendia e transformava nossa concepção dos sentidos humanos pelo ato de gravá-los tais quais eles ocorriam em tempo real [...]. Em segundo lugar, em implicitamente, isso indicava que o fonógrafo tinha, com efeito, separado os sentidos humanos, divorciando o olho do ouvido, e que a intenção original de Edison em persistir com os filmes era trazê-los de volta, unidos. Em outras palavras, a relação entre o fonógrafo e os filmes mostra tanto o processo de separação dos sentidos que Crary julga essencial para investigações sobre a percepção do século XIX e também a ansiedade a respeito desta separação, um desejo de curar a violação. Em outras palavras, o cinema total de Bazin é a resposta para um senso do desespero e divisão anterior" (GUNNING, 2001, p. 16).
\end{abstract}

O cinema silencioso, exprimindo-se através de sua suposta "amputação", não representa exatamente um corpo incompleto (estaríamos, aqui, concordando com Eisler e o espectador que sente falta de alguma coisa neste cinema), mas uma outra instância, a da descorporificação. Ora, se a imagem do cinema silencioso leva à ruptura, à finitude e à morte, conforme pensamos antes, evidentemente ela está na contramão da completude corporificada pela presença da voz no cinema falado. Neste sentido, não apenas o cinema falado não seria uma extensão do cinema silencioso, não apenas o cinema silencioso não se conduziria naturalmente ao cinema falado, como, acima de tudo, $o$ cinema silencioso seria o oposto do cinema falado. A relação entre as duas formas mediáticas seria de absoluta ruptura.Mais valiosa ainda é a lembrança de que, através desta experiência descontínua e esquizofrenizante que a tela muda proporciona, o cinema silencioso estaria escalado na fronteira da vanguarda moderna, plasmando a ruptura com o sujeito unificado (juntamente com as artes modernistas) e dando definitivamente um fim ao positivismo do século XIX, tornando-se uma experiência estética precursora de um descentramento filosófico como o de Derrida, da pulverização da metafísica (Nietzsche) e da ruptura com estruturas aglutinadoras de sentido, conforme vamos acompanhar na trajetória das artes do século $\mathrm{XX}$, especialmente a partir do cubismo. Não à toa, um demolidor do sentido como Duchamp arriscou-se no cinema (silencioso), e tantas estéticas destes cinemas, do formalismo soviético ao primeiro documentário etnográfico, se assemelham mais a poéticas do que a instâncias mais estritamente produtoras de sentido.

Doane amplifica o debate a respeito de uma reconfiguração cognitiva/perceptiva por meio da inserção das vozes no cinema com uma interessante reflexão a respeito das 
vozes offlover ${ }^{92}$ na narrativa no cinema falado. Se a voz off amplifica a diegese, tornando o espaço da representação mais factível e dimensionado ao espectador, a voz overtem a propriedade de regular a significação das imagens, por meio de um autoritarismo centralizador que só pode ser auferido a essa composição de um corpo vertical que a voz sinaliza nas imagens do filme. Porém, para além desta configuração de autoridade, a voz over se destaca do resto da composição orgânica do filme (em relação ao espectador) porque não pertence (necessariamente) ao mundo da diegese. É comum que, nos documentários de matriz clássica, se alcunhem esse procedimento de "voz de Deus", o que não deixa de carregar certa ironia. Enquanto a voz off informa o espectador de que ele pode, sim acreditar em um espaço representacional unificado, já que o som extrapola a dimensão das imagens e indica outros espaços onde a ação do filme ocorre, a voz over, por seu caráter dissociativo (a voz geralmente não pertence a ninguém que interfira na diegese - é um narrador verbal), perigosamente denunciaria a artificialidade do filme, estando, neste ponto, mais perto do humano e mais longe de uma integralidade divinal. Doane, porém, argumenta que a voz over, não pertencendo ao "corpo" presumido do espectador (e sim de um narrador "de fora do filme"), acrescente à individualidade do próprio filme, fortalecendo-o enquanto discurso, expandido as possibilidade sensoriais deste corpo do espectador: "Precisamente por não ser localizável, por não ser escrava de um corpo, é que esta voz é capaz de interpretar a imagem, produzindo a verdade dela" (Idem, pp. 466-7).

No cinema silencioso a voz over, evidentemente, não existe tecnicamente. Mas não é difícil pensar como sua precursora as cartelas de intertítulos, tão significativas e problematizadoras de qualquer noção de "mutismo" para o cinema silencioso. Popularizados a partir de 1907 (BOWSER, 1990) para substituir a já obsoleta figura do "comentarista" (um narrador físico que ficava dentro das salas de cinema, na era dos nickelodeons, para explicar a fábula da narração juntamente à exibição do filme) e consolidar a maturidade na narrativa fílmica, os intertítulos pavimentam o caminho a uma clara discursividade fílmica, inaugurando o "cinema falado" antes mesmo da

\footnotetext{
${ }^{92}$ Para elucidar a diferença de significação entre os dois termos, reproduzo aqui a nota de Ismail Xavier ao próprio texto de Doane publicada em XAVIER, 1983, p. 459: (1) voz-off, usada especificamente para a voz de uma personagem de ficção que fala sem ser vista mas está presente no espaço da cena. (2) vozover, usada para aquela situação onde existe uma descontinuidade entre o espaço da imagem e o espaço de onde emana a voz, como acontece, por exemplo, na narração de muitos documentários (a voz autoral que fala do estúdio) ou mesmo em filmes de ficção quando a imagem corresponde a um flashback, ou outra situação, onde a voz de quem fala vem de um espaço que não corresponde ao da cena imediatamente vista.
} 
implementação da fala em si. Outro evento que substituiu o comentarista foi a chegada da música composta para o filme, por volta 1908. "Em termos mais semiológicos, podese dizer que duas missões que eram do comentarista agora recaíram sobre a música pontuar movimentos e gestos e constituir unidades sintagmáticas e distingui-las umas das outras" (JOST, 2001, p. 54) ${ }^{93}$. Poderíamos, portanto, pensar a transposição do intertítulo para a fala como uma mera substituição mediática, em que uma tecnologia obsoleta dá lugar a um meio mais "quente" (na terminologia de McLuhan), ou seja, com muito melhor definição e que exige muito menos interpretação por parte dos interlocutores deste meio. Isso, de fato, parece correto, mas há mais detalhes a se considerar. E para pensar isto vale a pena examinar, com a "voz over" em mente, os intertítulos do início de um clássico documentário do cinema silencioso.

\subsubsection{Nanook e uma dialética de ambiguidade}

Os primeiros intertítulos de Nanook, o esquimó (Nanook of the North,Robert Flaherty, 1922) trazem os seguintes dizeres, que ficam na tela por quase 10 segundos: "As misteriosas Barren Lands - desoladas, áridas, varridas por ventos - espaços ilimitados no topo do mundo"94 (FIG. 33). Logo depois, somos submetidos a um plano muito simples, mas substantivo: ele persiste por (até longos) 30 segundos, e mostra uma paisagem em algum lugar do Oceano Ártico (conforme saberemos depois), onde calotas de gelo flutuam em água ondulante, e onde podemos ver um pedaço de terra escuro ao fundo da imagem (possivelmente, as tais "Barren Lands"), como ponto de fuga (FIG. 34). Existe um outro corte do filme em que vemos ainda um segundo plano que dispensa a ilha, mas igualmente mostra calotas flutuantes, e com um diferencial: podese ver um pedaço do barco de Flaherty no canto inferior direito, denotando presença humana. Para fins de análise, no entanto, interessa-nos apenas o primeiro plano, que é o único na versão mais popular do filme.

\footnotetext{
93 Tradução nossa.

${ }^{94}$ No original: "The mysterious Barren Lands - desolate, boulder-strewn, wind-swept - illimitable spaces which top the world".
} 


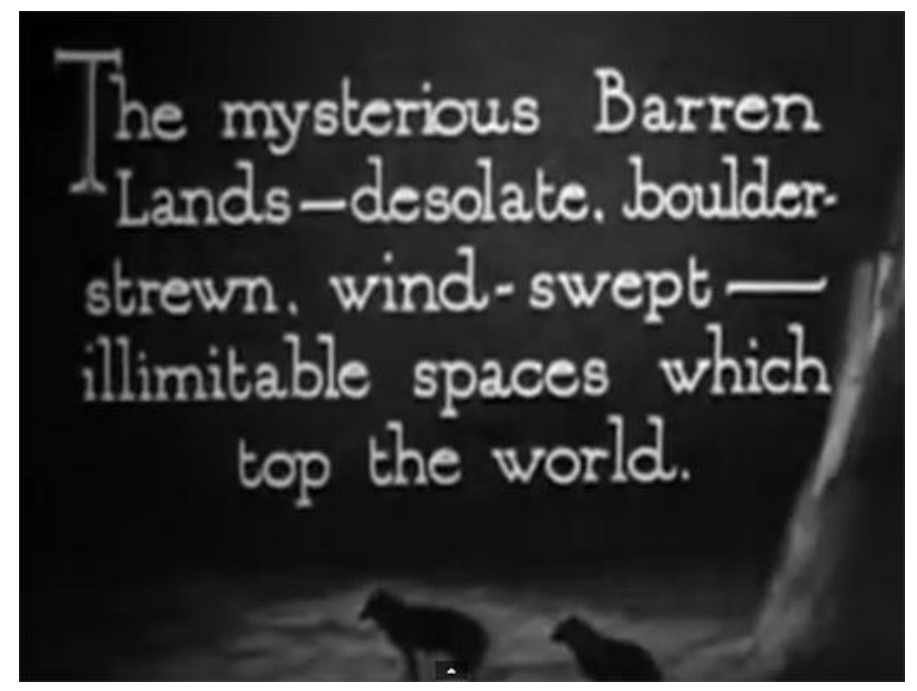

Figura 33

A leitura das imagens para este curto início de filme (total: 40 segundos) é, logicamente, muito diferente daquilo que os intertítulos referenciam. Como legítima "voz de Deus", as palavras neles usam de adjetivações duvidosas e tendenciosas ("desoladas", "áridas") para demarcar um sentido de leitura, assim como figuras de linguagem ("topo do mundo") para representar uma hierarquia de significação para a proposição de uma hermenêutica. Neste sentido, os intertítulos funcionam como a voz over de Doane: fortalecem o filme enquanto discurso e interpretam a imagem. As imagens, entretanto, não poderiam ser mais mudas. Tudo o que vemos, sem os intertítulos, é a água em fluxo e o pedaço de continente em sombras, num travelling que parece puxar nosso olhar para dentro do mistério desta paisagem gelada. Se também nos utilizamos de figuras de linguagem para demarcar estas imagens, isto se dá porque nossa impotência de traduzi-las é a mesma de Flaherty ou de qualquer um que procure verter imagens em palavras: são sistemas que efetivamente não se comunicam. No final das contas, parece que desejamos que aquelas palavras escritas na tela desapareçam rapidamente (e seus 10 segundos parecem longos), e, quanto às imagens, queremos que elas durem para sempre, porque são intermitentes, como um farol, e eternas, já que, a despeito de sua (lamentável) temporalidade, ela parecem ser feitas para que se as olhem para sempre. 


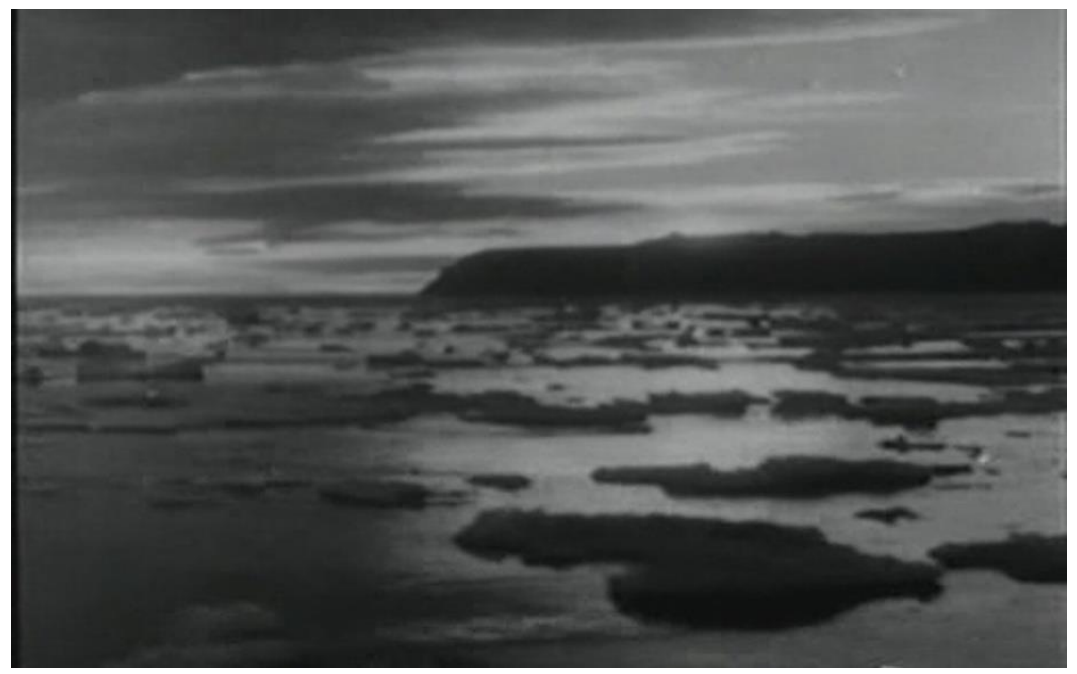

Figura 34

Esta primeira imagem de Nanook, assim como seus intertítulos correspondentes, que permitem um salto mais poético e meditativo sobre suas qualidades intrínsecas, pertencem a um tipo de registro, tanto escritural quanto imagético, diferente do que será exibido no resto do filme. Como é sabido, Nanook é um documento etnográfico a respeito de uma das culturas esquimós (Itivimuits, segundo letreiro posterior do próprio filme), rodado a partir da experiência de um só personagem (o próprio caçador Nanook) e sua família. Nanook é considerado um dos primeiros registros mais maduros, com esta proposta, dentro da história do cinema, e boa parte de seus atos foram ensaiados com o personagem. Da mesma forma, alguns costumes encenados já não pertenciam mais à cultura do caçador. Dito isso, é necessário pensar uma análise na fronteira do discurso que nos permita compreender em que modalidade se enquadram os intertítulos para os filmes silenciosos.

Tecnicamente, estes primeiros intertítulos de Nanook diferem do restante por serem essencialmente descritivos. Vale recordar os três modos do discurso, dentro do registro escritural, que nos permitem entender que função um texto está obedecendo quando em ato: o primeiro deles é justamente o modo narrativo, que duplica a realidade por meio de uma temporalidade, fazendo os fatos sucederem-se uns aos outros. $\mathrm{O}$ segundo é o modo descritivo, em que a temporalidade é anulada para que, neste instante de congelamento, possa-se detalhar a forma das coisas que estão inseridas na diegese de uma narração. O terceiro modo seria o dissertativo, mais complexo de todos, em que, ao invés da passagem de uma temporalidade ou do congelamento desta para a inserção de uma descrição, temos o discurso integrado a um plano mais abstrato, de elaboração de 
ideias, fora do campo da representação. Este modo raramente é representado em intertítulos no cinema silencioso, ainda que, evidentemente, os modos se misturem em cada trecho literário, aparecendo muito pouco em suas formas puras, isolados uns dos outros. Dentro de um registro escritural, porém, percebemos que estas primeiras palavras em Nanook perpetuam - com certo efeito dramático, evidentemente claramente o efeito da descrição. Fala-se destas "terras áridas", e logo em seguida as vemos. Isso difere muito do que ocorre no restante do filme, em que a função dos intertítulos será primordialmente narrativa, ou seja, vai sequenciar temporalmente os acontecimentos diegéticos (neste caso, mesmo que se trate de um documentário, o sentido de ficcionalização é muito evidente), ou eventualmente dissertativa, pontuando alguns comentários observacionais a respeito daquilo que se está vendo no filme. Neste ponto, vale lembrar os efeitos de linguagem enumerados por Gaudreault e Jost a respeito dos intertítulos (“cartelas") do cinema silencioso:

Efeitos de linguagem: a palavra traz algumas informações que a imagem muda não pode fornecer:

a) Dirige o espectador entre os diferentes significados possíveis de uma ação representada visualmente. É a sua função de fixação.

b) Dá um sentido ideológico, permitindo um julgamento a respeito daquilo que a imagem não pode apresentar de modo assertativo; desse modo dá instruções ao espectador para interpretar aquilo que vê.

c) Ela nomeia aquilo que a imagem só pode mostrar: os lugares, os tempos, os personagens.

d) Acrescenta à narração a possibilidade do discurso direto por meio da transmissão de réplicas do personagem (GAUDREAULT; JOST, 2009, p. 92).

Como se pode notar, a primeira cartela de intertítulos de Nanook cumpre bem com as três primeiras funções detalhadas aqui: representa a imagem, dirigindo o espectador a uma leitura descritiva (procurando invalidar outros sentidos de percepção da imagem. O de uma metáfora existencial, por exemplo); ao mesmo tempo em que dirige o espectador a uma leitura descritiva, adjetiva estas imagens, tornando-as "misteriosas" e "desoladas", coisas que não podem ser obviamente inferidas a partir das imagens em si, isoladas em sua neutralidade natural; e "nomeia" estas terras ("Barren Lands"), atribuindo uma função geográfica aos intertítulos. Evidentemente, a quarta função não se aplica, já que não se trata de um diálogo.

O que percebemos, portanto, é que os intertítulos constroem, anteriormente à apresentação das imagens em si, um discurso completo a respeito delas, esquadrinhando-as dentro de vários limites. Este discurso busca uma anterioridade da palavra em relação ao potencial expressivo da imagem, subjugando-a a um discurso 
verbal, procurando situá-la em algum dos modos axiológicos deste discurso. Ao contrário do que parece, portanto, não é o letreiro que auxilia e acompanha a imagem, mas sim a imagem que ilustra o conteúdo literário do filme, tornando-o, essencialmente, um filme falado. Esta relação se dá graças a algo que inexiste na voz over do cinema sonoro: o estabelecimento de uma ordem sequencial entre a palavra e a imagem, gerando necessariamente uma hierarquia de representação entre as duas formas de expressão. Isso poderia nos levar à fácil conclusão de que a voz over e a fala em geral, a partir do cinema falado, sublimaram este decalque entre palavra e imagem no cinema silencioso, corrigindo esta hierarquia e "ajustando" de maneira mais homogênea o discurso fílmico, tornando seu "corpo" (conforme Doane) mais visível e completo, fazendo-nos reconhecer a nós mesmos, nele, de maneira mais confortável.

Se isso for verdade, os intertítulos do cinema silencioso, com sua ordenação polêmica, mais uma vez o reafirmam como estrutura desigual, fragmentária, que resiste a uma totalidade. Basta lembrar que, ao mesmo tempo em que a palavra dos intertítulos vai ferroar estas imagens com um grande punhado de demarcações semânticas, estas imagens vão, de alguma maneira (certamente sublime) procurar se desvincular deste cerco de significações precisas, de uma maneira estranha, incômoda, hipnótica, fantasmática. Assim, da mesma maneira que as imagens iniciais de Nanook são forçadas a se autorrepresentarem como as tais "Barren Lands", e como "desoladas", "misteriosas" e "varridas por terríveis ventos", elas também nos puxam para um outro lugar, distante de localizações geográficas ou de supostas atribuições a respeito de sua natureza tal qual vista pelo discurso do filme. Este lugar é o universo da imagem em si, da origem de seu registro, de um discurso da imagem para a imagem, algo sobre o qual podemos lançar um olhar, estimular nossa percepção, mas, efetivamente, pouco podemos dizer. Este tipo de pureza só pode ser encontrada na imagem crua, sem a demarcação da palavra, que, como vimos, concorre com ela. Daí a ideia de que, ao mesmo tempo em que muitos dos filmes silenciosos carregados de intertítulos são também falados graças a uma racionalização feita pelo discurso literário presente nestas cartelas, estes filmes jamais deixam de ser essencialmente silêncio porque as imagens, que ocorrem com as palavras de forma intermitente, estão, em última instância, sempre sozinhas. Ou seja: o mesmo motivo que torna o filme silencioso discursivo (uma ordem estabelecida entre palavra e imagem) é o que o torna também signo do silêncio (pois as imagens, mesmo que antecedidas por palavras, estão sempre isoladas). Trata-se de uma 
ambiguidade própria a este cinema, impossível de ser representada para o cinema falado, onde ambos os meios expressivos ocorrem concomitantemente.

Doane tinham uma percepção útil sobre o porquê de a voz over ser tão condicionante no cinema falado, e os intertítulos funcionarem como um agente descentralizador dentro de espectro de corporeidade que compõe a experiência do filme silencioso e do filme falado. Diz ela: "O estranho efeito do cinema mudo na era do som está em parte ligado à separação, por meio de intertítulos, entre a fala de um ator e a imagem do corpo dele ou dela" (DOANE, 2003, p. 457). A autora, porém, não se detém muito sobre o cinema silencioso, tornando-se difícil entender se ela considera este decalque um problema próprio a uma tecnologia obsoleta, ou se considera esta configuração entre fala e silêncio uma etiologia própria a este cinema, o que proporcionaria um tipo de experiência com a percepção e com a cognição, em geral, bastante diferente da do cinema falado. Gaudreault e Jost, da mesma forma, evitam interpretar em termos de percepção (afinal, trabalham no âmbito da narratologia) a ordem sequencial entre intertítulos e imagens, mas colocam explicitamente o ato de “interromper a progressão da narrativa visual” (GAUDREAULT; JOST, 2009, p.94) como um dos efeitos narrativos da cartela, indicando que talvez considerem esta ordenação própria ao cinema silencioso não como uma forma ineficaz de voz over, mas sim como uma estrutura dialética capaz de produzir significação de maneira diferente do cinema falado.

As relações entre estes dois modelos de cinema, conforme pudemos averiguar até aqui, não são simples e atravessam uma miríade de conceitos que talvez precisem ser investigados, um a um, até que se possa ter uma visão mais clara deles. Além das duas dicotomias propostas (o mutismo e o silêncio; o som e a fala), termos como voz, narrativa, imagem e música emergem como ideias que circundam as primeiras no sentido de problematizá-las e extrair delas noções que o senso comum não comporta. A despeito das dificuldades inerentes a este processo, fica claro que um estudo sobre a natureza do cinema silencioso não pode ser empreendido sem que se conheça a natureza do som e da fala; sem que se compreenda em que instância surge, no cinema, o fenômeno da fala, em que momento o som passa a significar, e em que circunstâncias, a despeito de estar rodeado de sons e falas de todos os tipos, o silêncio permanece, seja no cinema silencioso ou no cinema falado. É por isso que cabe, agora, antes de voltar ao 
cinema silencioso propriamente dito, pensar ainda mais intensamente o próprio cinema falado, por meio de um filme absolutamente falante, e até verborrágico, mas que guarda, em intervalos sensíveis, espaços de silêncio.

\section{2 $O$ boulevard do crime: 0 silêncio demarca a fala}

Se a palavra que você vai pronunciar não é mais bela do que o silêncio, não a pronuncie. - Preceito Sufi

Há um par de cenas no clássico de Marcel Carné O boulevard do crime (Les enfants du paradis, 1945) que nos ajuda a compreender em que medida a fala (e o filme falado como um todo) necessita de instâncias de silêncio para produzir uma dialética contrapontual, como se o filme falado buscasse retornar às suas origens no silencioso por uma série diversa de razões: em primeiro lugar, isso ocorreria por uma questão de adaptação mediática, ou seja, o falado busca o silencioso porque “o 'conteúdo' de qualquer meio ou veículo é sempre um outro meio ou veículo" (MCLUHAN, 1964, p. 22). O cinema falado como conceito depende do cinema silencioso como um de seus próprios termos, e seria impossível, especialmente tão pouco tempo depois da emergência desta modalidade de cinema, que um não contivesse o outro dentro de si, ou ao menos que não transformasse sua estrutura comunicacional em uma outra forma de arte, como aponta McLuhan. Em segundo lugar, conforme pretendemos demonstrar, a própria relação da fala com o silêncio parece emergir de uma situação parecida: o silêncio existe como relevo gestáltico ${ }^{95} \mathrm{da}$ fala, e vice-versa. Se, em última instância (de maneira mais essencial), o filme falado trata da fala e o filme silencioso trata do silêncio, é natural que, em decorrência disso, o filme falado trate do silêncio e o filme silencioso trate da fala. Fala e silêncio funcionam, neste caso, como palíndromo, instância intermediária entre subjetividade e alteridade.

Por fim, há uma razão cultural e histórica para que este processo de problematização da fala e do silêncio se dê em um filme no auge do clássico como $O$ boulevard do crime: filmada durante a segunda guerra mundial e em uma Paris ainda ocupada, esta foi uma produção que enfrentou as agruras de um processo que incluía, ao

\footnotetext{
95“'Inicialmente, no texto de 1949, Lacan utiliza a palavra Gestalt para designar a propriedade unitária dada pela forma total do corpo que surge a partir de uma exterioridade, em um relevo de estatura que a fixa e em uma simetria que a inverte" (MASAGÃO, 2013, p. 8).
} 
mesmo tempo, a overdose da fala e uma política de silenciamento. Ainda que não seja a intenção principal deste estudo, podemos pensar em vários fatos envolvendo este período que trazem à tona a amplificação hipermidiática da fala, como os discursos de Hitler, exaltados em $O$ triunfo da vontade (Triumph des willens, Leni Riefenstahl, 1935) e parodiados/corrigidos em $O$ grande ditador (The great dictator, Charles Chaplin, 1940) ou o silenciamento da imagem, como no caso da censura aos filmes do período construtivista soviético no governo stalinista e na própria ausência de qualquer imagem filmada dos campos de extermínio no holocausto nazista, algo problematizado na série de filmes Shoah, de Claude Lanzmann (1985). O próprio projeto de extermínio protagonizado pelos nazistas não deixa de ser, obviamente, um aproveitamento macabro do silêncio, acobertado pelo excesso de fala e discursos de suas diretrizes ideológicas. Some-se a isso o fato de os anos 1930/1940 terem dado à luz filmes com sentidos francamente narrativos, aproveitando-se logicamente da linearidade da recém-surgida fala no cinema, fazendo da era de ouro de Hollywood, por exemplo, esteira para o auge da recriação mitológica da nação americana (o western), da musicalidade expressa por meio de uma narratividade (o musical, com função muito diferente para a música do que acontecia no cinema silencioso) e de um amplo reaproveitamento da dramaturgia estética (verborrágica) do século XIX, caso do melodrama. Daí a se compreender que $O$ boulevard do crime, dirigido por um esteta como Carné e escrito por um poeta como Jacques Prévert, de alguma forma problematizasse o local da fala e do silêncio no mundo contemporâneo ao que viviam. Filmado na República de Vichy, a França ocupada, a produção do filme estava envolvida neste processo: o produtor André Paulvé, que trabalhara em outros filmes com Carné, teve de se afastar após começar a ser investigado pelos nazistas; o ator Robert Le Vigan acabou preso por ser um colaborador deles; o compositor Joseph Kosma e o diretor de arte Alex Trauner tiveram de trabalhar às escondidas, por serem judeus, e isso foi mencionado nos créditos do filme (CARNÉ, 1979, pp. 215-42). A relação entre silêncio e fala, portanto, ganhou intensas conotações políticas antes que o filme pudesse estrear, e não é à toa que estes temas vão emergir no corpo do filme, tanto em forma quanto em conteúdo.

Mas como isso se dá? As duas cenas mencionadas ocorrem logo no início da história. Vale lembrar que o filme trata de uma longa (190 minutos) história de amor, afeita a um certo romantismo trágico ("realismo poético") envolvendo três personagens principais na Paris pré-haussmaniana (o filme se passa entre 1830-1840): o lendário e 
sorumbático mímico Baptiste Debureau (Jean-Louis Barrault), o famoso e galanteador ator Frédérick Lamaitre (Pierre Brasseur - ambos personagens reais) e a enigmática e esquiva Garance (Arletti), atriz de vaudeville afeita a jogos sociais. Além do trio principal, há a presença de Pierre-François Lacenaire (Marcel Herrand), personagem também famoso, um criminoso requintado, adepto do dandismo, afeito a delírios existencialistas, autor de peças de teatro. O universo do teatro oitocentista, aliás, é o pano de fundo para o desenvolvimento da trama. O longa (no original, "As crianças do paraíso") é dividido em duas partes, sendo a primeira "O boulevard do crime" (de onde a tradução brasileira tirou o título do filme), e a segunda "O homem branco". Os trechos que mencionaremos aqui são da primeira parte do filme, onde se concentram as referências mais interessantes de uma relação entre linguagem falada e linguagem silenciosa.

$\mathrm{Na}$ primeira cena do filme somos introduzidos à balbúrdia do "Boulevard do Crime" (apelido de uma rua famosa - o Boulevard du Temple - da Paris da primeira metade do século XIX, onde se instalava o grande Funambules, teatro popular a partir do qual se desenrolam as tramas principais), e o primeiro som que escutamos, após os créditos, é a cacofonia provocada pela fala: são tantos transeuntes, atores circenses, vendedores e trambiqueiros que é difícil se concentrar em qualquer coisa, seja pelo excesso de movimento dentro das imagens, pontuadas por correções em panorâmica e cortes muito discretos, seja pela malha indiscernível de sons de centenas de pessoas falando, fanfarras tocando, cornetas buzinando, animais grunhindo. Esta primeira cena (FIG. 35) é marcada, curiosamente, tanto pela fala (o excesso indiscernível) quanto pelo silêncio (já que indiscernível, a cacofonia se rende ao silêncio) e, já numa primeira instância, a ambiguidade do filme se instaura. Passeamos por esta paisagem de maneira casual até nos encontrarmos com a primeira imagem de Garance, dentro de uma tenda (FIG. 36). Do lado de fora, em meio ao caos verbal, podemos distinguir um apresentador, ao lado de uma lona que ostenta a pintura de uma mulher nua. Ele grita para que as pessoas entrem na tenda afim de se "conhecer a verdade". O ofício de Garance não é exatamente especificado. Ela é mostrada como espécie de vidente, capaz de "transformar sonhos em realidade". Dentro da tenda, vemo-la mergulhada, do tórax para baixo, em uma espécie de tanque ou poço, ostentando uma guirlanda na cabeça e segurando um espelho, com o olhar teso e fixo nele. Interessa-nos, neste momento, que Garance faça sua entrada no filme em silêncio, no meio do mais absoluto caos 
cacofônico provocado pela fala. O boulevard do crime, portanto, nasce em meio a um plural de falas, mas resguarda sua sutileza maior a um olhar silencioso. A postura tesa de Garance, somada ao apelo apolíneo da beleza clássica de Arletti, produzem um efeito de estranhamento com a cena, uma primeira imersão em um estado fora da verossimilhança. Como se, por breves instantes, em meio à balbúrdia, houvesse o transe.

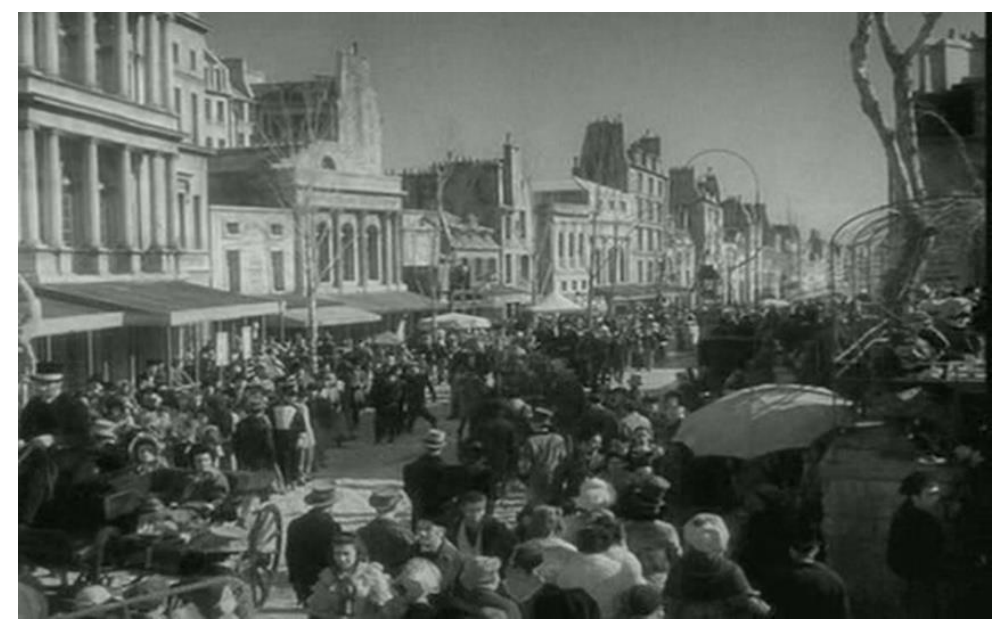

Figura 35

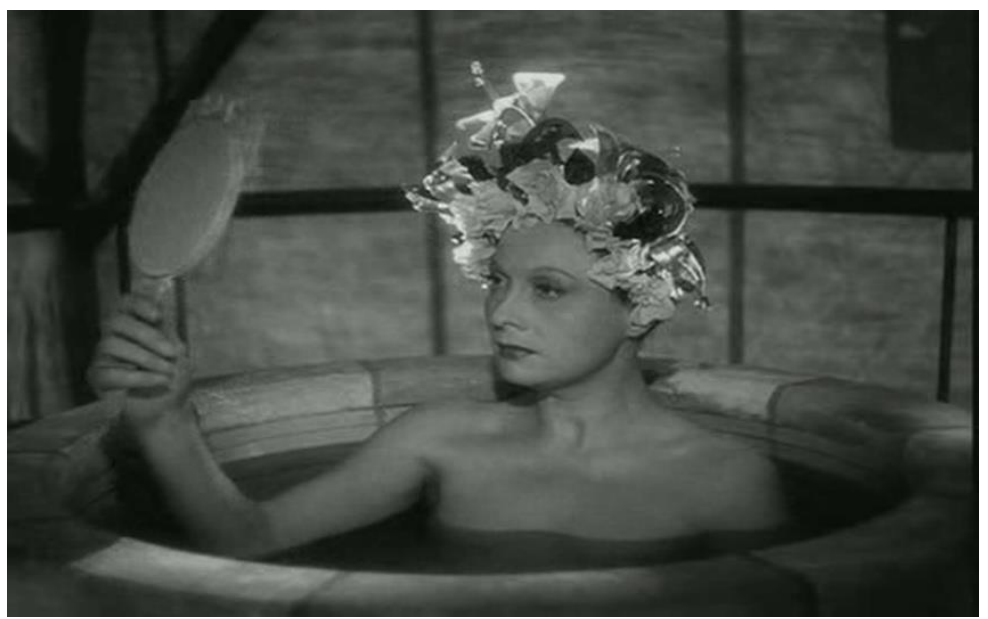

Figura 36

Após uma breve troca de galanteios entre Garance e Lamaitre (que nos é apresentado como um galanteador sem pudores, um tanto excessivo ${ }^{96}$ ), adentramos no

\footnotetext{
${ }^{96}$ Lamaitre é notoriamente o personagem mais "afetado" do filme, e sua ansiedade por passar, profissionalmente, da pantomima silenciosa ao teatro falado denuncia a tensão e a ambiguidade com que o filme trata a questão do cinema silencioso e do cinema falado. Como se efetivamente representasse a chegada do som (em oposição ao "silencioso" Baptiste), Lamaitre chega a pronunciar, em determinado momento: "estou morrendo de silêncio, como outros morrem de fome e de sede".
} 
escritório do Escrivão Público, também no Boulevard do Crime, onde somos apresentados ao personagem Lacenaire. Nossa primeira impressão dele diz respeito à sua habilidade com as palavras: a atividade de escrivão, como se evidencia logo a seguir, não passa de um disfarce. Ele utiliza este álibi para exercer outros ofícios. O primeiro deles: escrever pelos/para os outros. Logo no início da cena o acompanhamos a ditar uma carta com um pedido de perdão à esposa de um pobre-diabo. Depois, descobrimos sua segunda atividade, mais proeminente: a de liderar um pequeno e organizado grupo de ladrões. Mesmo assim, ele é elogiado por um de seus "empregados" a respeito da beleza de sua instrução, de sua polidez, da elegância de suas palavras. É a entrada de Garance em cena, porém, que desencadeia o verdadeiro potencial verborrágico do personagem. Com Lacenaire, é impossível duvidar de que estamos assistindo a um filme em que a fala seja um de seus elementos essenciais. Da balbúrdia da primeira cena (mais legitimamente uterina, já que não distinguimos os sons, mas nos sentimos confortáveis neles) até o discurso organizado da segunda, percebemos tratar-se este filme, de alguma forma, da organização de uma lógica, do nascimento de uma fala, da estruturação de um discurso. Após sermos apresentados à estranha relação de Garance com Lacenaire (Amantes? Amigos? Parceiros do crime?), somos também introduzidos ao quase-monólogo do ladrão (FIG. 37) - polido, enfático, literário, apenas pontualmente interceptado pelas silenciosas observações de Garance:

- Não sou cruel, sou lógico. Depois de muito tempo, declarei guerra à sociedade.

- E você matou muita gente nesse período, Pierre-François?

- Não, meu anjo. Veja, não há sinal de sangue. Somente algumas manchas de tinta. Mas estou planejando uma coisa extraordinária. Não sorria, Garance. Eu não sou um homem como os outros. Meu coração não bate como o deles. Absolutamente! Você já foi humilhada, Garance?

- Não, nunca.

- Eu também não. Mas tentaram, e foi o suficiente para um homem como eu. Quando eu era pequeno, era mais são e mais inteligente que os outros. Nunca fui perdoado por isso. Eles queriam que eu fosse como eles. Que falasse como eles. "Levante a cabeça, Pierre-François. Olhe para mim! Abaixe a cabeça!" Eles abarrotaram minha cabeça com livros. Velhos livros! Tanta poeira na cabeça de uma criança! É uma bela juventude, não? Não me admira que minha mãe preferisse meu estúpido irmão. No confessionário, uma vez me disseram: "você é muito orgulhoso, Pierre-François. Precisa entrar em contato consigo mesmo". Então, eu entrei em contato comigo mesmo. E não pude mais sair deste lugar. Fui deixado só comigo mesmo para evitar companhia duvidosa. Que coisa inconsequente! Mas que destino prodigioso! Não amar ninguém. Ser só. Não ser amado por ninguém. Ser livre. É verdade que eu não amo ninguém. Nem mesmo você, Garance. Mas você é a única mulher por quem eu não sinto desprezo.

- Eu também não te amo, Pierre-François.

- Muito oportuno! 
- Mas então por que você vem me ver todos os dias? Será porque eu não demando o que os outros homens demandam?

- Não...

- Mas você não é uma coquette. Então, por quê?

- Porque eu me sinto entediada.

- Eu te entretenho, talvez...!

- Sim, você fala o tempo todo. É como uma peça de teatro.

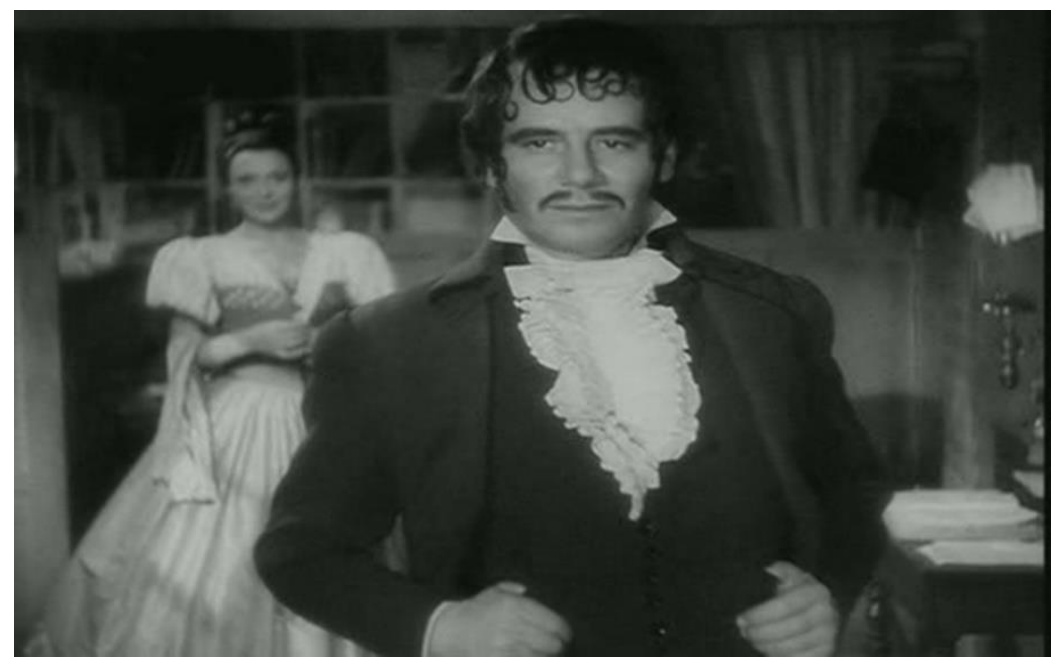

Figura 37

O fato de Garance debochar do falatório de Lacenaire não ocorre por acaso. O teatro francês da época pré-haussmaniana ainda era francamente derivado do neoclassicismo do século XVIII (ROUBINE, 2003), de verniz declamatório e gestual enfático, valorizando o texto. Na verdade, todo o Boulevard do crime parece remeter a um padrão de atuação neoclássico, sendo possivelmente um dos filmes mais falados da história do cinema francês (daí nosso interesse nele), exceto pelo discreto contraponto estabelecido pelo personagem Baptiste e seu alento pelo discurso silencioso, oposto à tagarelagem de Lacenaire e Lamaitre. Este último, por sinal, encarna a figura do "homem de teatro", ávido pela fala, que repudia a mímica, por considerá-la um gênero menor de representação.Evidentemente, o que se anuncia desde o início do filme é um jogo de representação que procura pensar concomitantemente o cinema e o teatro, fazendo ao mesmo tempo uma homenagem aos dias de glória do último, mas atualizado pela franca "superioridade" mediática do segundo. Esta comparação do teatro com o cinema, mesmo do ponto de vista da teoria dos media, obviamente, não é nova. Desde o primeiro cinema que a experiência teatral era uma referência forte para a atividade cinematográfica. Não apenas os filmes eram apresentados (mas não só) em teatros, mas 
o posicionamento da câmera (ângulo do "cavalheiro da plateia" "97) e a utilização dos estúdios (com seus cenários falsos) buscavam uma mimetização da experiência teatral. Pode-se dizer que, naquela época, ter o teatro como conteúdo principal do cinema, independente do tema do filme, era muito evidente ${ }^{98}$. Pensar no teatro, quando se ia ao cinema, era uma inevitabilidade, e, mais que isso, um anseio tanto por parte dos homens de cinema quanto por parte dos espectadores. Como um medium novo e desconhecedor de suas próprias possibilidades, este cinema se contentava em lutar por um lugar como espetáculo de vaudeville. Ainda que este cinema de atrações (COSTA, 2010, pp.26-7) fosse uma forma de expressão que cumprisse uma função social completa e estivesse confortavelmente associado a um imaginário do final do século XIX, a relação do medium cinema com o teatro só se tornaria completa, efetivamente, quando o cinema não procurasse mais mimetizá-lo, mas sim processá-lo através de uma dialética dos media. Aí sim, efetivamente, o cinema estaria falando sobre o teatro, e não procurando macaquear seus trejeitos. McLuhan foi um dos primeiros a pensar isso. Para ele, a ideia de que o conteúdo de um medium será sempre outro medium não é apenas uma frase de efeito, mas o estabelecimento de uma hierarquia de sentido: em primeiro lugar, antes de qualquer coisa, devemos pensar a respeito de para onde se dirige um medum: para qual outro medium? Qual o primeiro conteúdo de um medium? Outro medium. E por que isso é importante? Porque a história dos media é a história do conhecimento.

Nossa resposta aos meios e veículos de comunicação - ou seja, o que conta é o modo como são usados - tem muito da postura alvar do idiota tecnológico. O "conteúdo" de um meio é como "bola" de carne que o assaltante leva consigo para distrair o cão de guarda da mente. $\mathrm{O}$ efeito de um meio se torna mais forte e intenso justamente porque o seu "conteúdo" é um outro meio. O conteúdo de um filme é um romance, uma peça de teatro ou uma ópera (MCLUHAN, 1964, p. 33).

McLuhan considera que os meios "elétricos" instauram um tipo de conhecimento, "compartimentado" (ou seja, que prima pela simultaneidade), que vai se opor à tradição do conhecimento "narrativo" (letrado, escrito, logocêntrico). Estas ideias

\footnotetext{
${ }^{97}$ Flávia Cesarino Costa (2010, p.29) explica a natureza deste plano: "Em geral, a câmera ficava estática, de modo a mostrar o corpo inteiro de todo um conjunto de pessoas, realizando panorâmicas apenas para reenquadrar certas ações mais movimentadas. Quando dentro de estúdios, a câmera se localizava no que seria o lugar de um espectador de teatro, daí a crítica de muitos historiadores de que os primeiros filmes eram demasiadamente teatrais".

${ }^{98}$ Bordwell (2010) defende que uma parte do que se considera ainda "primeiro cinema", ou "préclássico", como, por exemplo, o "tableau cinema" de Louis Feuillade nos anos 1910 (como veremos adiante), possui diferenças substanciais em relação à encenação teatral no que tange aos enquadramentos cinematográficos e à mise-en-scène fílmica.
} 
terão consequência no pensamento de Flusser, conforme veremos, e nos permitem fazer uma leitura da relação entre cinema e teatro de $O$ boulevard do crime que descomplique seu paradoxo. Se o filme faz uma paródia do teatro ao mesmo tempo em que o homenageia, isso não deve ser entendido como uma contradição, mas como um tipo de síntese mediática: sendo um pensamento configuracional, capaz de relacionar uma miríade de coisas simultaneamente, o cinema tem esse poder de apresentar (tal qual um quadro cubista) as inúmeras hipóteses do fenômeno "teatro $x$ cinema" sem necessariamente resolvê-las. E é próprio e justo do fenômeno da configuração que ele não as resolva. $\mathrm{O}$ fenômeno, em última instância, é a própria configuração, e este dado é mais importante do que a valoração ou não do medium anterior pelo medium mais atual. $O$ boulevard do crime nem homenageia e nem tampouco ridiculariza o teatro. Ele apenas o configura enquanto fenômeno, e enquanto cinema.

Porém, o caminho para uma compreensão sobre como este filme lida com sua experiência mediática fica ainda mais interessante a partir da terceira - e famosa - cena do filme. Aqui, a antes autoevidente e tradicional relação do teatro com o cinema é deixada para trás para percebermos que este cinema também discursa sobre um outro medium, seu quase em tudo oposto (como vimos) e imediatamente anterior decalque: o cinema silencioso. Em praça pública, somos apresentados, de maneira deletéria e vexatória (por seu próprio pai Anselme Debureau) (FIG. 38), ao mímico Baptiste, figura quieta, imóvel, tristonha, toda vestida de branco, maquiada como um clown blanc (FIG. 39, o chamado "palhaço triste", na tradição de Joseph Grimaldi ${ }^{99}$ ). Neste momento, não é exótico associar o silêncio deste personagem a um discurso discreto, em oposição ao falatório exuberante e espalhafatoso do teatro neoclássico. Esta oposição - a do teatro do século XVIII à pantomima muda - é também uma das relações sub-reptícias do filme, que prefigura, afinal de contas, uma relação entre o filme falado e o filme silencioso.

\footnotetext{
${ }^{99}$ Para uma bastante detalhada (e lírica) explanação a respeito da origem e cultura do clown blanc, vale conferir o documentário Os palhaços (I clowns, Federico Fellini, 1970).
} 


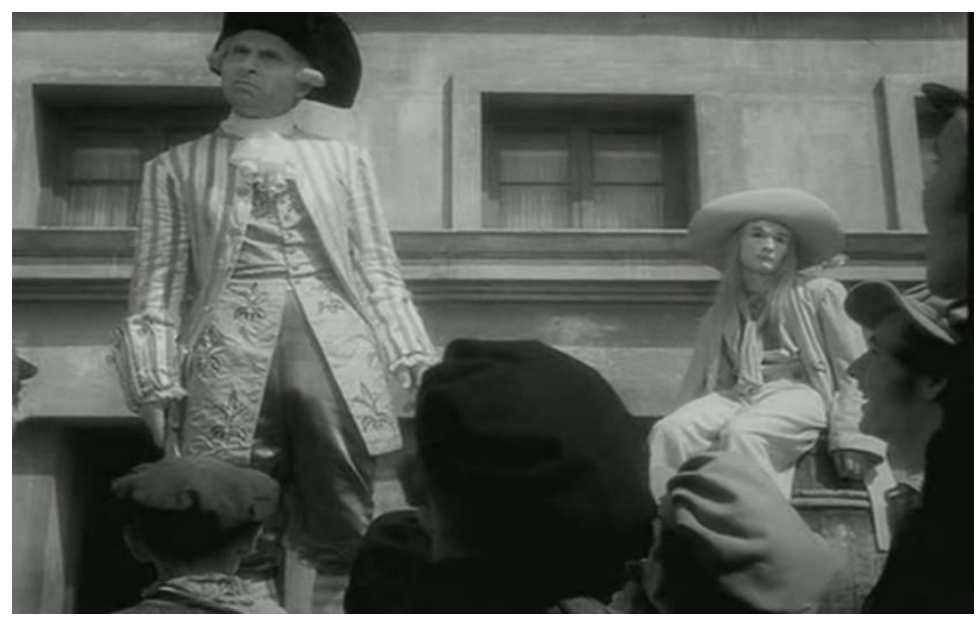

Figura 38

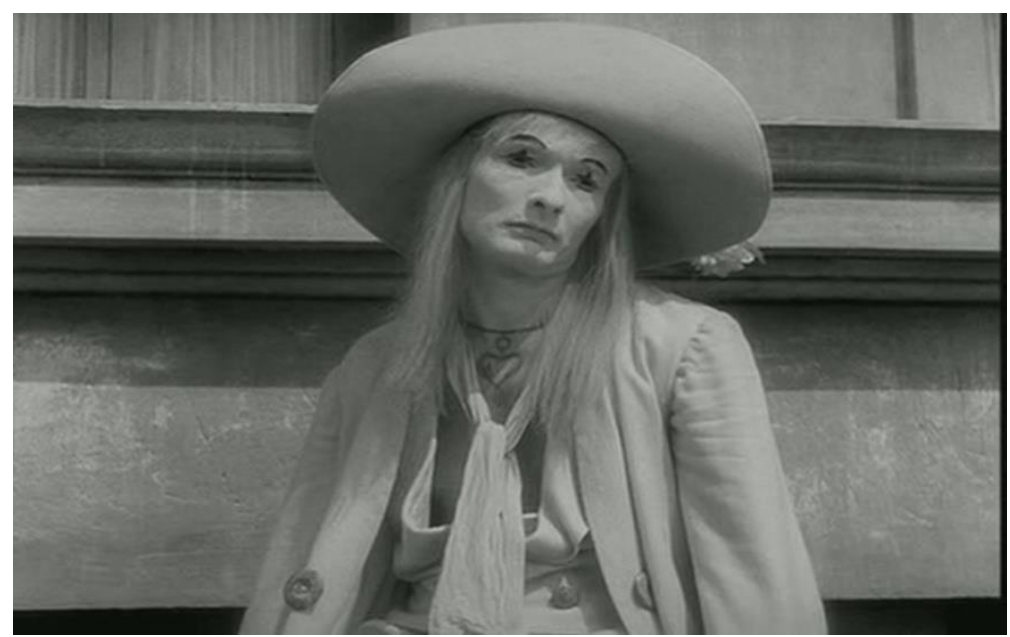

Figura 39

"Este aqui não sabe fazer nada", diz o pai de Baptiste, enquanto a câmera vai posicionando o espectador dentro da cena: uma hora vemos o palco, em outra Anselme, aos poucos vamos nos aproximando de Baptiste, e também enxergamos quem os vê, num interessante jogo de espectatorialidade. Carné posiciona sua câmera no meio da plateia, para nos sentirmos como que também dentro deste jogo, até que o plano se abre para vermos, posicionados à frente do palco, Garance, Lacenaire e um gordo senhor burguês, de aspecto bonachão e escarninho, que aprova as chacotas que o pai aplica teatralmente ao filho. Tudo parece em seu devido lugar até que um discreto passo adiante dado pelo ladrão Lacenaire muda o tom da cena (FIG. 40). O espectador percebe que algo de errado está acontecendo justamente através do olhar de Baptiste, em close, representado em contracampo (FIG. 41). Logo, o senhor burguês, notando a ausência de seu relógio e percebendo-se roubado, passa a gritar e a acusar Garance, enquanto Lacenaire sai de cena discretamente. Toda a mise-en-scène cinematográfica é elaborada 
de maneira que ninguém, na diegese, perceba nada do que está acontecendo, e que o espectador perceba tudo, ainda que nós não tenhamos condições de ver o ato de Lacenaire, encoberto pelas roupas dos personagens. No entanto, Baptiste vê por nós, e nós vemos o roubo através da expressão de seu olhar. Neste momento, em meio à balbúrdia da cena, inflamada e ruidosa, o olhar silencioso de Baptiste denuncia o discurso secreto do filme, como se dissesse: “olhe para além do que está tão evidente. O excesso de vidência pode cegar o olhar".

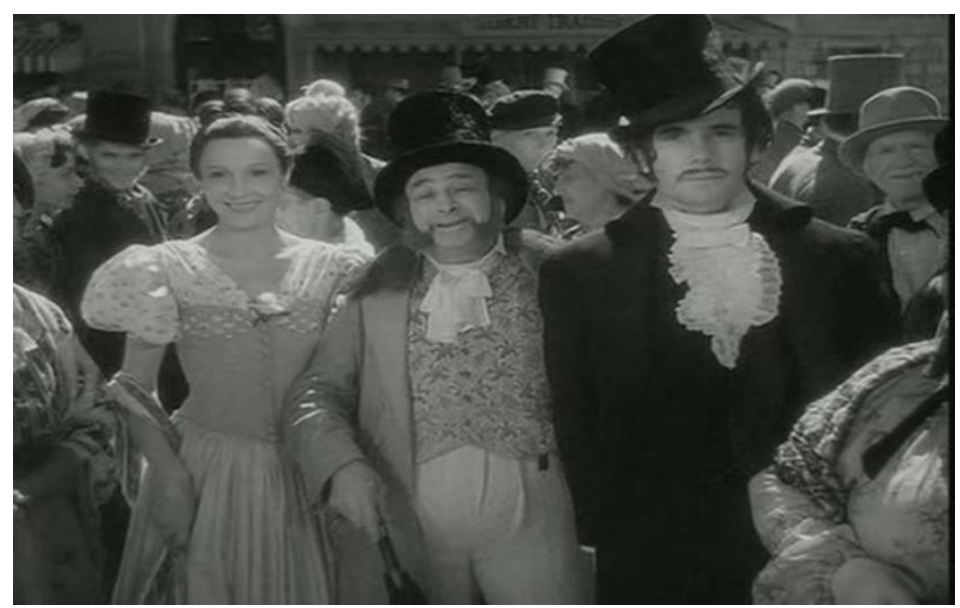

Figura 40

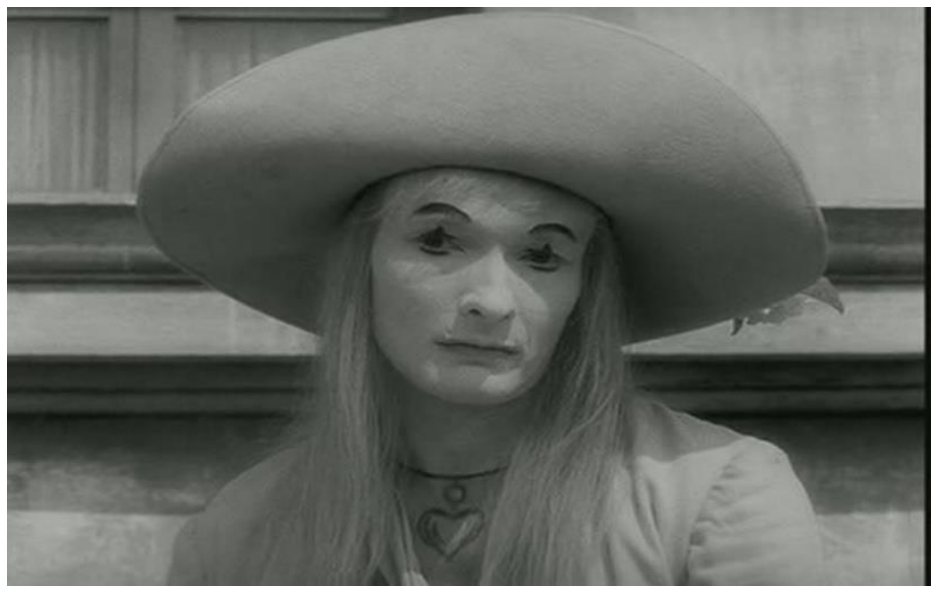

Figura 41

A cena, é lógico, não para por aí. Diante dos gritos e acusações do burguês, um policial aparece e pergunta ao povo se alguém havia visto o que aconteceu. É aí que o som (mesmo tecnicamente) é interrompido para que, do meio do silêncio, irrompa a voz de Baptiste: "Quem aqui foi testemunha"? "Eu", diz Baptiste. "Sou testemunha". "E o que você viu"? "Tudo". A fala lacônica de Baptiste, reduzindo a informação à sua essência mais crua, pode ser considerada uma introdução ao seu silêncio. Neste caso, a 
fala serve ao silêncio. Ela pontua o silêncio e prepara o território para a sua chegada. Baptiste passa então a representar, numa pantomima ao mesmo tempo despojada e rigorosa, cômica e lírica, um passo-a-passo a respeito da cena do roubo (FIG. 42 a 45). Carné, percebendo a importância simbólica da cena para a compreensão do filme, insere nela uma trilha extradiegética, mais uma vez ratificando a relação do silêncio com a música, e ao mesmo tempo transferindo o imaginário do espectador para o cinema silencioso. A cena muda de Baptiste fazendo a mímica sob fundo musical transporta o filme para um imaginário antigo, estabelece sinapses comunicacionais, aciona a memória do espectador ${ }^{100}$. Baptiste vai fazer a mímica de cada um dos personagens envolvidos ${ }^{101}$ - Garance, o burguês e Lacenaire - e denunciar o crime. Após a cena, a música se dissipa, assim como o estado onírico que havia se instaurado, e um discurso de autoridade, proferido pelo policial, restabelece a ordem. A "explicação" de Baptiste através da mímica parecia plausível, o caso é resolvido e a multidão se dispersa. É aqui, evidentemente, em uma representação de matriz naturalista, mas que em alguns momentos "escapa" à verossimilhança (que policial daria crédito a uma mímica enquanto testemunha?), que reside o tal "realismo poético" de Carné. Tudo nos leva a crer, então, que um filme como $O$ boulevard do crime seja uma representação realista, com pontos de escapada, para efeito de alívio lírico. Porém, a elevação do discurso silencioso no filme, neste e em outros momentos, pode produzir justamente o efeito contrário: o silêncio se evidencia ainda mais no meio da balbúrdia, da cacofonia e da verborragia. O contraste é nítido, e não passa incólume: Garance, ao final da cena, entrega uma rosa e manda um beijo a Baptiste. Se ela confessava, francamente, não amar a fala (Lacenaire, na cena anterior), ela, gestualmente, demonstra amar o silêncio (Baptiste).

\footnotetext{
${ }^{100} \mathrm{O}$ mesmo efeito ocorre, por exemplo, na cena de hipnose/adivinhação em Fellini 8 1/2 (Federico Fellini, 1963): quando a médium Maya começa o show de leitura das mentes das pessoas presentes na festa, inicia-se um processo performático que inclui a música extradiegética. De maneira semelhante à mímica em $O$ boulevard do crime, o evento paranormal parece disparar uma temporalidade performática, à parte da verossimilhança do filme, como se fosse um filme por si só.

${ }^{101}$ Por mais que seja interessante aproximar o gesto da pantomima do cinema silencioso, Jost, partindo de Brisson, frisa sua oposição, estabelecendo para o gestual do cinema algo mais ambicioso: "O fato de que esta arte [o cinema silencioso] 'na qual as palavras estão ausentes' possa estar além da linguagem encontraria confirmação no fato de que Brisson a opôs à pantomima, com 'sua linguagem, sua própria gramática, seus signos imutáveis cujo sentido nunca muda', enquanto 'o cinema se abstém de recorrer ao seu alfabeto; sua ambição é a vida"” (JOST, 2001, pp. 51-52).
} 

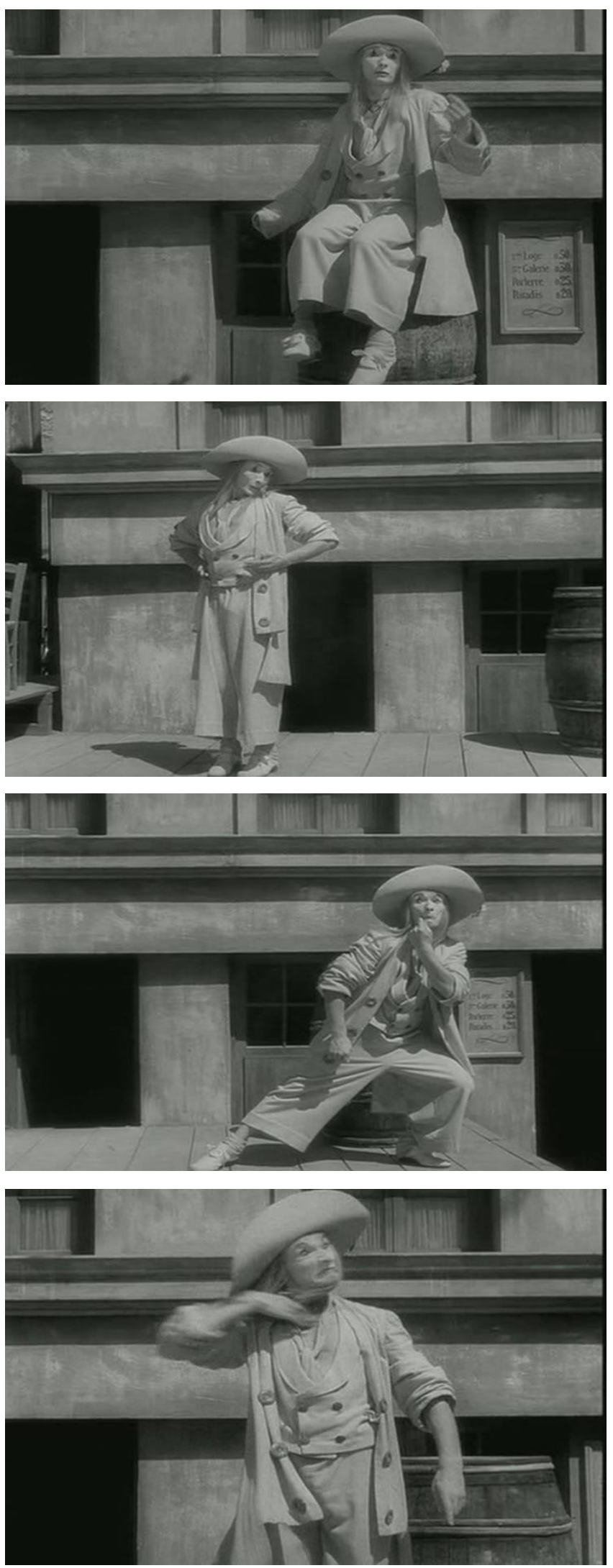

Figuras 42 a 45

E é o gesto que transfigura o poder da mímica. Para aprofundar esta relação entre gesto e fala, torna-se instrutivo buscar na paleoantropologia uma localização mais 
precisa a respeito de quando estas duas atividades, fundamentais a seu próprio modo para a integralidade do homem como espécie, surgiram e que papel desempenharem no seu desenvolvimento cognitivo e cultural. Em relação à fala, há a ideia (TATTERSAL, 2005, pp. 68-75; e WONG, 2005, pp. 76-83) de que houve uma grande revolução no comportamento humano entre o Paleolítico Médio e o Paleolítico Superior, entre 60 e 50 mil anos atrás. Este seria o momento em que, por meio de alguma transformação evolutiva bastante radical, os seres humanos teriam adquirido sua mente moderna, ou seja, que fossem capazes de produzir o pensamento simbólico, o que tornaria possível a arte, a ciência e a tecnologia, algo registrado apenas pontualmente nas centenas de milhares de anos anteriores da jornada da espécie humana. No entanto, em termos evolutivos, é pouco provável que uma modificação genética capaz de desenvolver tal habilidade ou processo provocasse uma substituição tão rápida na população. Seria mais fácil pensar, como argumenta o paleoantropólogo Ian Tattersal, que o corpo (e o cérebro) humano já tivesse desenvolvido a forma desta habilidade há mais tempo, mas que ela fosse utilizada para alguma outra coisa, um processo conhecido com exaptação.

\begin{abstract}
Tem-se discutido, por exemplo, que em algum momento há cerca de 60 mil e 50 mil anos, um evento de especiação ocorreu na linhagem humana dando surgimento a uma entidade nova e simbolicamente expressiva. Por inferência, essa espécie nova possuiria modificações neurais que permitiram padrões de comportamento modernos. Seria ótimo acreditar nisso, porque simplificaria a história. O problema, entretanto, é que a escala do tempo não parece permitir isso. Para que esta explicação funcione, uma nova espécie humana, fisicamente idêntica, mas intelectualmente superior à que já existia, teria de ter aparecido por todo o Velho Mundo em um curto período de tempo, eliminando totalmente a espécie predecessora. E não há nenhuma indicação, em registros que se admitem imperfeitos, de que algo desse tipo tenha ocorrido (TATTERSAL, 2005, pp.71-72).
\end{abstract}

A opção restante para a compreensão deste fenômeno seria justamente a exaptação: a habilidade já existia, mas era utilizada para outra coisa. Entretanto, no momento em que ela foi descoberta como canal para a produção simbólica, ela se disseminou na velocidade com que os eventos culturais se disseminam, explicando, possivelmente, a rapidez com que essa nova habilidade se propagou entre a espécie humana em tão curto período de tempo. Não há consenso sobre o que seja esta habilidade fantástica adquirida pela humanidade, mas há forte inclinação para se acreditar que ela seja a linguagem, e, consequentemente, a fala.

Se há um único aspecto da função mental humana que se liga de forma mais íntima aos processos simbólicos do que outras, esse é certamente o nosso uso 
da linguagem. A linguagem é de fato a função mental simbólica suprema, e é virtualmente impossível conceber o pensamento na sua ausência (Idem, p.73).

O mais curioso de tudo isso é que se sabe que a humanidade assumiu sua anatomia moderna (com um cérebro idêntico ao nosso) há cerca de 190 mil anos, ou seja, dezenas de milhares de anos antes de assumir a mente moderna. Ao mesmo tempo, o aparelho fonológico humano, capaz de produzir a fala tal qual a conhecemos hoje, já estava pronto nos humanos há quase 1 milhão de anos atrás (Ibid. p. 75). Se ele servia para algum processo respiratório (já que, atualmente, também auxilia nisso) ou para processar modelos mais rudimentares de fala, é difícil saber, mas não custa dizer que a humanidade, já com sua anatomia moderna, passou cerca de 150 mil anos se comunicando por outros meios que não a fala. Com certeza os gestos, o olfato, outros tipos de sons e até o paladar devem ter feito parte destes sistemas hoje esquecidos de comunicação. Entretanto, se, conforme sugerimos anteriormente, o silêncio não deve ser oposto ao som, mas sim à palavra e à fala, podemos pensar que, de alguma forma, o alvorecer comunicacional humano - ainda numa era pré-simbólica, e, portanto, incapaz de planejar (inferir o passado e o futuro, por exemplo) ou de aferir realidade fora da experiência imediata (incapaz de transformar coisas em símbolos abstratos e, portanto, transmiti-las)- se deu na instância do silêncio. Um silêncio fora do logos racional, baseado em uma experiência radicalmente animal, tão inefável quanto os poucos traços que estes humanos deixaram para trás. O silêncio adquiriria, aqui, um aspecto fundacional, dentro do qual passamos a maior da parte da nossa existência enquanto espécie, e não é à toa que boa parte de nossa herança mitológica comunique algo sobre o silêncio e a fala como instauradores do universo, da vida e da cultura (basta olhar, por exemplo, ao Gênesis ou ao mito de Babel) ${ }^{102}$.

Para se pensar o surgimento desta linguagem, entretanto, outros fatores devem ser debatidos. O neurofisiologista teórico William H. Calvin descreve a capacidade de planejar como fundamental para o desenvolvimento da inteligência em geral. Ele associa a rapidez do pensamento à nossa capacidade de criar narrativas:

As capacidades humanas de planejamento podem vir do nosso talento de construir narrativas. Podemos tomar emprestadas as estruturas mentais da

102“Depois da Torre de Babel, veio a confusão de línguas, o burburinho incessante de uma multiplicidade de códigos onde o sentido nunca repousa. Para outros, após Babel só existe o silêncio, como impossibilidade de qualquer discurso autêntico" (FELINTO, 2008, p. 55). 
sintaxe para avaliar combinações de ações possíveis. Em certo grau, fazemos isso conversando em silêncio conosco, criando narrativas do que poderia acontecer aplicando regras sintáticas de combinação para considerar um cenário improvável, possível ou provável (CALVIN, 2005, p. 88).

Curiosamente, Calvin especula que estas habilidades de construção sintática e, logo, de planejamento e desenvolvimento da inteligência, podem ter sido adquiridas não de algum tipo de mutação genética que nos faria recair no problema apontado por Tattersal, mas sim de um processo de exaptação desenvolvido a partir de funções motoras do corpo. Calvin argumenta que movimentos balísticos ("ações extremamente rápidas dos membros, as quais, uma vez iniciadas, não podem ser modificadas”, Idem, p. 88), tais quais bater um prego em um martelo ou arremessar coisas com precisão, que exigem intenso planejamento antes de serem executados, já que a ação não pode ser interrompida, teriam ajudado a formular a linguagem. No já mencionado curto período do desenvolvimento da linguagem humana, situado entre algumas eras do gelo que demandavam rápida adaptação às mudanças drásticas do ambiente, as capacidades de forjar ferramentas e caçar com precisão podem ter sido definitivas para a sobrevivência da espécie.

\begin{abstract}
Se os movimentos da boca dependem da mesma faculdade que guia os movimentos balísticos de mão, melhorias na destreza podem ajudar na linguagem, e vice-versa. A capacidade de fazer arremessos acurados, que teria ajudado os hominídeos a sobreviver aos episódios de resfriamento nos trópicos, também abriu a possibilidade de comer carne regularmente e de sobreviver ao inverno em zona temperada. $\mathrm{O}$ dom da fala seria um benefício acidental (Idem, p. 89).
\end{abstract}

Em outras palavras, e voltando ao nosso tema principal, se, por um lado, a fala e a cognição modernas emergiram de 150 mil anos de um silêncio selvagem, por outro, elas também podem ter emergido do gesto ${ }^{103}$, representado tanto nos movimentos balísticos quanto no ato de mastigar. Desta maneira, aplicando uma certa psicanálise à espécie como um todo, cada gesto nosso se voltaria na direção deste silêncio selvagem. Cada palavra buscaria um sentido em direção a um inconsciente irracional. Cada projeto de ordem seria um movimento em direção ao caos. Baudrillard vê um movimento semelhante ao pensar que nos encaminhamos no sentido de retornar a um éden anterior à divisão sexual, quando a divisão binária, nos seres unicelulares, representava a

\footnotetext{
${ }^{103}$ Não à toa, Vilém Flusser também ancora o gesto fundador da nossa primeira sociedade imagética na pré-história, pensando nas cavernas de Lascaux, cujas pinturas, no entanto, datam de apenas 15 mil anos. Mesmo as antiquíssimas pinturas das cavernas de Chauvet, mais recentemente descobertas, datam de 30 mil anos. O gesto flusseriano que dá origem ao pensamento de superfície é mais recente, portanto, que o gesto evolutivo apontado por Calvin, sendo consequência deste. "A consciência cognitiva não pode conceber desenvolvimento linear, apenas o eterno retorno. $\mathrm{O}$ gesto produtor de imagens tradicionais é o gesto pré-histórico, magia a serviço do mito" (FLUSSER, 2008, p. 24).
} 
simples replicação da informação genética, sem transformações ou mutações, o que seria signo de uma imortalidade estéril. Ele vê nas tecnologias modernas, que replicam a informação humana desta maneira, um sinal deste encaminhamento (BAUDRILLARD, 2000, pp. 9-35).

O gesto de Baptiste aponta para este retorno, da fala ao silêncio, e o cinema falado aponta para o cinema silencioso. E o gesto é um conceito caro a Giorgio Agamben. Para o filósofo italiano, o século XX desaprendeu a praticar seu gestual. Esta conclusão ele tira a partir de estudos sobre a síndrome de Tourette, um quadro clínico comum no final do século XIX, em que o doente passa a perder controle de seus movimentos, executando um gestual aleatório ou repetitivo, constantemente. O desaparecimento deste modelo de Tourette no início do século XX é para Agamben não um sinal de que esta doença tenha encontrado cura definitiva, mas sim o de que a atribuição de "doença" para este fenômeno tenha sido largada para trás e que toda a sociedade ocidental tenha se adequado ao gestual patológico de Tourette, perdendo a naturalidade gestual original:

\footnotetext{
A dança de Isadora e Diaghilev, o romance de Proust, a grande poesia de Pascoli a Rilke e, enfim, no modo mais exemplar, o cinema mudo, traçam o círculo mágico no qual a humanidade procurou pela última vez evocar aquilo que lhe estava escapando das mãos para sempre (AGAMBEN, 2007, p.11).
}

Para Agamben, portanto, a fantasmagoria principal do cinema mudo residiria em sua tentativa de cristalizar o gesto, já perdido ou desaparecido fora de suas instâncias mediáticas. Não surpreende, então, que ele posicione o gesto, e não a imagem, como elemento central do cinema, já que "em toda imagem está sempre em ação uma espécie de ligatio, um poder paralisante que é preciso desencantar, e é como se de toda história da arte se elevasse um mudo chamado para a liberação da imagem no gesto" (Idem, p. 12). O retorno ou cristalização do gesto no início do século $X X$, a partir de imagens técnicas como as do cinema silencioso, sinaliza um ato desesperado de recompor este universo primitivo onde o gesto dá origem à linguagem na pré-história, conferindo vitória inalienável da linguagem, no final das contas, mas demarcando o espaço da nostalgia e de uma certa melancolia diante deste passado perdido que nos delimitou enquanto humanos modernos. 
Fincada no gesto e no silêncio, a fala não passa, a despeito de todo seu cabedal simbólico, de redundância. Todo o resto de Boulevard do crime serve para confirmar esta expectativa em mensagens subliminares, quase arquetípicas, liberadas nestas primeiras cenas. Isso acontece especialmente na cena do encontro de Baptiste com um cego na rua. Mais adiante, saberemos que este homem não é cego, mas sim um farsante que analisa a qualidade do ouro roubado para a gangue de Lacenaire. Este jogo de ilusões, porém, produz um efeito curioso sobre como são tratados os atos de ver e falar em $O$ boulevard do crime.

Baptiste caminha errante nas ruas noturnas de Paris, fruindo este ato secreto do flanar desacompanhado, até que um homem cego, balançando uma latinha com moedas e acompanhado de um papagaio no ombro e uma gaiola aberta do outro lado, lhe pede esmola. Tentando escapar do constrangimento de ter de lidar com o mendigo sentado na rua, Baptiste, um mestre da pantomima e, portanto, do caminhar silencioso, procura dar passos lentos para atravessar despercebido (FIG. 46). A estratégia, entretanto, não funciona, e o cego lhe chama a atenção e pergunta por que o mímico procura evitá-lo. Baptiste rende-se ao discurso do homem e passa a conversar com ele. Quando questionado a respeito do que faz ali naquela hora da noite, Baptiste responde: "estou aqui para ver". "Ver o quê"? "Tudo". Como se pode perceber, ele dá a mesma resposta que quando questionado na cena do roubo do relógio. Baptiste pode ver tudo. Seu interesse é observar tudo. Neste sentido, o personagem funciona como uma imagem, cuja dupla interface é justamente ser olhado (é o mímico) e retribuir esse olhar novamente ("ver tudo" - a imagem que nos olha), ratificando que este discurso, imagético, ocorre por uma via de comunicação instantânea, em que a relação entre sujeito e objeto (e logo toda a relação de alteridade), se dá em uma permuta sem hierarquia, criando uma fenomenologia. Aqui é que podemos perceber já uma relação próxima e decisiva entre os conceito de imagem e silêncio, que será melhor abordada adiante. 


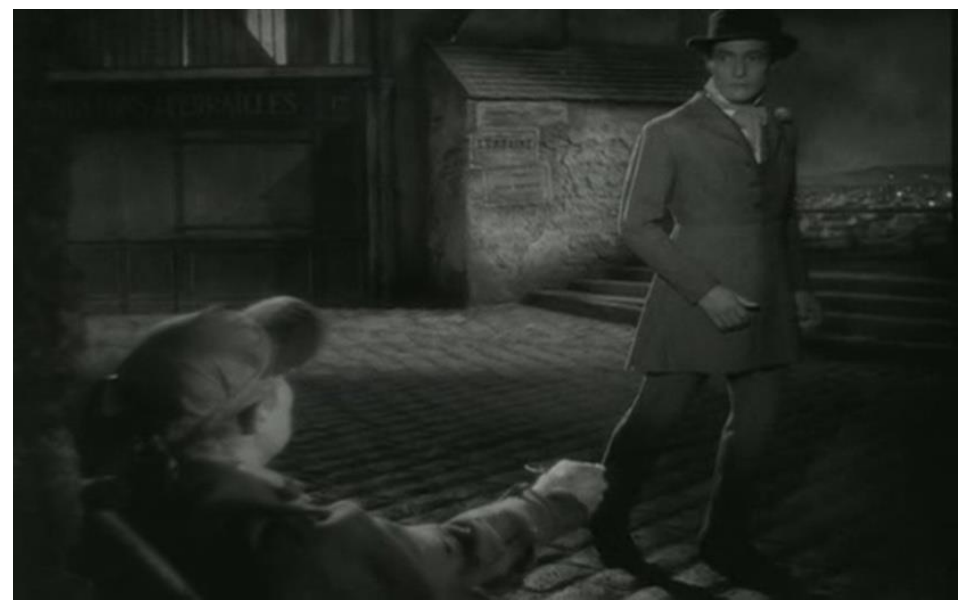

Figura 46

Esta cena ainda produz mais charadas a serem pensadas pelo espectador a respeito da relação entre visão e fala. Quando descobre que Baptiste é um mímico do teatro Funambules, o cego prontamente afirma que adora a pantomima e que um amigo lhe descreve tudo o que acontece. Este evento é particularmente curioso e produz uma sensação paradoxal, afinal, a pantomima é um tipo de representação que explicitamente, diretamente, confessadamente, rejeita a fala. Todo o sentido representacional da pantomima reside no fato de ela negar a fala para produzir uma outra natureza discursiva. Se alguém descreve a pantomima, vai naturalmente verter o gesto em discurso verbal, vai verter o gesto em narrativa. O que era, portanto, oriundo do universo da imagem, do movimento, da dança, vai novamente ser canalizado para uma articulação em linha, pontual e logocêntrica. O encanto primitivo do gesto, que, como vimos, é a origem de nossa consciência simbólica, acaba recaindo em uma espiral de tradução e traição desta origem, engendrado uma neurose do signo ${ }^{104}$, que não se afirma como mera substituição e nem como acontecimento no mundo. O irônico de tudo, nesta cena, é que o meio cinema francamente chama atenção para si: estamos mergulhados em uma escala de narrativas, afinal, o cego conta que o amigo conta a pantomima, que é representada. No entanto, estamos, enquanto espectadores, vendo o cego contar que o amigo conta a pantomima, que atribui seu poder de representação à visão. A cena, no final das contas, sai da visão e retorna à visão, de onde nunca havia saído, já que todo o

\footnotetext{
104“'O signo 'saudável', para Barthes, é aquele que chama a atenção para a sua própria arbitrariedade aquele que não tenta fazer-se passar por 'natural', mas que, no momento mesmo de transmitir um significado, comunica também alguma coisa de sua própria condição relativa e artificial. Em sua obra inicial, o impulso que está por trás dessa convicção é político: o signo que se pretende natural, que se oferece como a única maneira concebível de ver o mundo, é por isso mesmo autoritário e ideológico" (EAGLETON, 2001, p. 186).
} 
discurso verbal nela está encerrado dentro do quadro visual do filme. A fala, aqui, portanto, é problematizada como significação do paradoxo, um cão que corre atrás do próprio rabo. Acreditar que formas não-verbais de comunicação, como o gesto, a imagem e o próprio silêncio não incorrem em uma neurotização da representação é alinhar-se a uma antimetafísica nietzschiana, onde certo logos definitivamente não predomina. "Nietzsche acredita que a linguagem se origine de um elemento prélinguístico que a comanda e é de essência estética" (MARCONDES FILHO, 2004, p. 332). Para Nietzsche (o que é fundamental), é a arte que origina a linguagem, e não o contrário. Expressões como a da música e a da dança ${ }^{105}$, por exemplo, fincadas neste elemento pré-linguístico capaz de gerar a expressão humana, estão em ligação extensiva à vontade de poder em sua forma pura, cuja degenerescência é representada pela linguagem. Daí a antipatia tão grande de Nietzsche pelo logocentrismo e pelo idealismo platônico, cuja essência reside no mundo do simbólico.

\begin{abstract}
A música é analogia dionisíaca, noturna, em oposição à linguagem, que é analogia apolínea, formal, luminosa. Contrário à forma pré-linguística da música, a língua significa uma degradação, uma queda de nível em nível, obedecendo a uma pseudo-imitação, sem que haja nenhuma continuidade da emoção ao som, do som ao signo. A poesia, assim, tentaria recuperar, reconstituir a "música afetiva", mas isto seria em vão, pois a linguagem articulada é [...] entropia, perda de força, que só permite a reconstrução fictícia da universalidade e dos sentidos abstratos (Idem).
\end{abstract}

O mais curioso nesta assertiva sobre Nietzsche é a inserção da poesia como uma tentativa mais ou menos vã de se recuperar esta "música afetiva" dos sentidos, que está também na imagem e no gesto, como uma forma de redenção da palavra, mas que resulta em fracasso. Um fracasso assumido (MARCONDES, 2008, p. 29). É como se o sonhar da linguagem fosse representado no retorno à sua mudez original, e as figuras de linguagem da poesia fossem instrumento para pavimentar o caminho em direção a este éden. Não à toa, Lacan estrutura a linguagem como baseada em duas figuras (a metáfora e a metonímia) que ilustram representações de substituição e proporção em relação às coisas do mundo. Se a linguagem é automaticamente representação, ela é, em sua base estruturante, fincada em processos semelhantes aos da arte ${ }^{106}$. A linguagem, portanto,

\footnotetext{
${ }^{105}$ Neste caso não é demais citar Zaratustra: "Eu acreditaria somente num Deus que soubesse dançar" (NIETZSCHE, 1977, p. 58).

${ }^{106}$ Pensando desta forma, torna-se menos difícil afeiçoar-se pelo gesto radical de Paul De Man, conforme nos explica Eagleton: "Toda linguagem, como ele [De Man] acertadamente percebe, é inevitavelmente metafórica, operando por tropos e figuras; é um engano acreditar que qualquer linguagem é literalmente literal. A filosofia, o direito, a teoria política, funcionam por metáfora tal qual os poemas, e portanto são tão ficcionais quanto os poemas" (EAGLETON, 2001, p. 200).
} 
sempre conduz à poesia, que, por sua vez, conduz a um mundo pré-simbólico, que se plasma nas instâncias do gesto, e, por fim, do silêncio. Como veremos adiante, a poesia não se limita a este papel de atravessador, afinal, "a poesia não se limita ao livro; diferentes mídias criam diferentes tipos de poesia; e a poesia deve ser entendida como fenômeno de intermedialidade" (MÜLLER, 2012, pp. 19-21).

A continuidade desta cena do cego arremata tudo isto que vem sido pensado até aqui: ele sugere a Baptiste que ambos se dirijam até uma taverna próxima, para beberem e se divertirem. Chegando lá e sentando-se à mesa no animado ambiente, o cego recebe um colega e retira um monóculo para examinar um punhado de peças de ouro, revelando-se como um não-cego, afinal. Diante da surpresa do mímico, ele diz: "Não pode acreditar nos seus próprios olhos"? Baptiste, percebendo que "aquele que tudo vê e observa" também pode cair diante do ilusionamento da imagem, resolve replicar em um outro código, que ele domina: o silêncio (e se cala). Diante do fracasso da palavra e da ilusão da imagem (ambos representados nesse curioso personagem do cego), o silêncio. “O que você me diz”?, pergunta-lhe o cego, agora vidente. "Nada? Você é um sábio". Sendo esta a última fala da cena, a parábola se resolve, e o entrecruzamento entre todos estes sistemas de expressão encontra seu ponto ótimo.

Em $O$ boulevard do crime, a palavra encontra seu caminho como contraponto ao silêncio ao ser usada também como ênfase no nome dos personagens. Este aspecto é particularmente intenso na famosa cena da apresentação no Funambules, uma pantomima praticamente completa em mise-en-abyme ${ }^{107}$, de onde podemos vislumbrar não apenas a representação no palco em si, mas a reação do público, a orquestra tocando no fosso, os comentários nos bastidores e a apreciação de personagens-chave, atravessando vários pontos importantes de leitura do filme. Aqui, presenciamos uma experiência de imersão que procura tornar o fenômeno do teatro francês préhaussmaniano em uma miniatura completa da significação do filme, abordando desde a relação da encenação com seu público, visando pensar a espectatorialidade; a relação com o cinema silencioso, transformando a pantomima, durante 10 minutos, em um retorno à tela muda; à configuração melodramática da trama do filme, encaixotando o

\footnotetext{
${ }^{107} \mathrm{~A}$ mise-em-abyme é uma estrutura de linguagem ficcional, muito comum na literatura e no cinema, em que uma forma de representação é incluída dentro da outra. Uma carta dentro de um romance, por exemplo. Ou uma peça de teatro dentro de um filme. Ou uma pintura sendo pintada dentro de um quadro, como ocorre em As meninas, de Velázquez.
} 
drama principal dentro da microtrama da pantomima, o que eleva o sentido do filme a um segundo grau de representação; e, por fim, trazendo, mais uma vez, à tona a fricção fundamental que norteia a relação entre palavra, silêncio e imagem, desta vez com uma mensagem ainda mais enfática.

A cena é muito longa para ser transcrita aqui. Apenas vamos remarcar que, na encenação da pantomima está configurado o rascunho da trama amorosa do filme: Baptiste ama Garance, mas é rejeitado por ela. Garance, por sua vez, foge com o galhofeiro Lamaitre, inspirando a tentação do suicídio em Baptiste. Claramente, a farsa reinscreve o ambiente da commedia dell'arte, com Baptiste fazendo o Pierrot, Garance, a Columbina, e Lamaitre, o Arlequim. A cena é interrompida, entretanto, pela presença de Nathalie, a filha do dono da companhia, apaixonada, mas rejeitada, por Baptiste. Enquanto o Pierrot de Baptiste prepara uma corda para se enforcar, a personagem de Nathalie entra em cena, trajada como camponesa, para estender roupas em um varal. Ela gentilmente pede a corda a Baptiste, que a cede, criando o alívio cômico para a cena dramática (FIG. 47). A cena (cinematográfica, desta vez) é cortada, entretanto, para um grande primeiro plano do rosto de Baptiste (FIG. 48), e um plano-ponto-de-vista, em seguida, mostra os bastidores do palco, onde Garance e Lamaitre trocam cortesias com segundas intenções (FIG. 49). No meio do palco, Baptiste é então acossado por terrível melancolia, que é percebida por Nathalie que, por sua vez, interrompe o espaço sagrado da pantomima, viola o pacto de silêncio da peça e, saindo da personagem, entoa um nome: "Baptiste!" (FIG. 50) O que se segue é um grande rebuliço no teatro, como se o rompimento da cadeia de silêncio da cena provocasse uma cadeia ruidosa em igual grau, e todos os ambientes, que antes eram silenciosos (ou que flutuavam junto com a música da orquestra), passam a falar: desde a plateia até os bastidores, um sistema de representação do mundo é substituído por outro, levando-nos a perceber o quão tênue é o equilíbrio entre a expressão do silêncio e a expressão da palavra, ainda que uma guarde, em sua própria natureza, a versão negativa da outra. Silêncio e palavra entram, em instâncias como esta, em um jogo eterno de conversão um no outro, cada um recriando códigos para desbaratar o outro, ao mesmo tempo ratificando uma relação de autodestruição e de recriação a partir das cinzas do outro. $\mathrm{O}$ desenlace deste jogo, nesta cena do filme, nos leva a duas ponderações: 

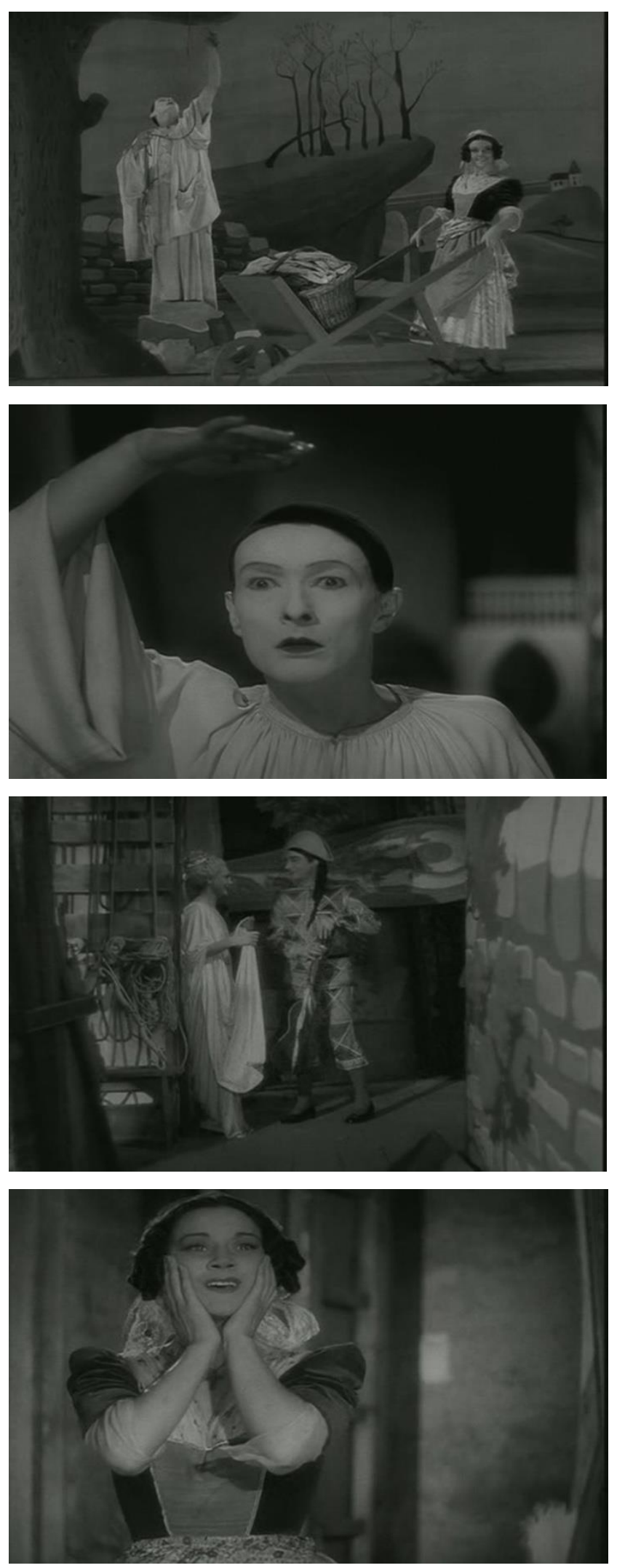

Figuras 47 a 50 
Em primeiro lugar, com a demolição de todo o quadro silencioso da cena a partir de uma única palavra ${ }^{108}$, cabe pensar na teoria dos sistemas da Niklas Luhmann, em que os patamares comunicacionais humanos são determinados por sistemas radicalmente defensivos, com pouca ou nenhuma interface entre $\mathrm{si}^{109}$. Estes sistemas são regidos por um processo chamado fechamento operacional, que determina a autorregulação dos mesmos visando sempre uma autorreprodução de suas estruturas. São sistemas assim, autopoiéticos, que se manifestam nas estruturas sociais, éticas, culturais, psicológicas, políticas, econômicas, etc., da vida humana. Evidentemente, os processos comunicacionais também estão implicados nesta escala complexa de sistemas, e podemos procurar pensar media como sistemas também autopoiéticos. O que chama a atenção no processo desencadeado por esta cena de $O$ boulevard do crime, entretanto, é a qualidade de anulação de um sistema por outro. "Pelo seu método [de Luhmann], a racionalidade dos sistemas é defensiva, atua no sentido de captar os sinais externos e neutralizá-los" (MARCONDES FILHO, 2004, p.424). Luhmann estabelece que a interface entre estes sistemas não é impossível, mas funciona segundo um acoplamento estrutural que entra em funcionamento no momento em que um sistema entra em contato com o outro. A "invasão" de um elemento de um sistema dentro do corpo do outro (como, por exemplo, uma fala gravada dentro de um filme silencioso) provoca o que o sociólogo chama de "irritação", que só pode ser "acoplada" pelo sistema após ser processada por ele: “As irritações remetem às estruturas e só são aceitas se tiverem que ver com as expectativas do sistema: é a partir destas que configura-se uma perturbação e faz com que a autopoiese reaja, identificando-a ou recusando-a” (Idem, p. 428).

\footnotetext{
${ }^{108}$ Uma situação muito parecida ocorre no final do filme $O$ artista (The artist, Michel Hazanavicius, 2011): após o filme transcorrer inteiro em silêncio, acompanhado apenas pela música e por breves intervenções sonoras, na última cena, o ator que é o personagem principal do filme busca se redimir fazendo musicais. Durante a filmagem de um deles, após elaborada cena de dança, o diretor do filme grita "Corta!", rompendo com a cadeia de silêncio do filme e instalando um sistema novo sobre o anterior. O filme segue falado: o diretor pergunta se o ator poderia refazer a cena mais uma vez e ele responde, revelando sua dicção fanha pela primeira vez no filme: "com prazer". Estes últimos momentos reconfiguram inteiramente a significação prévia do filme, apenas com a inserção de poucas palavras sonoras que invadem a paisagem silenciosa.

${ }^{109}$ Edgar Morin faz a leitura do problema dos sistemas a partir de uma concomitância entre autonomia e dependência: "O conceito de autonomia só pode ser concebido a partir de uma teoria de sistemas ao mesmo tempo aberta e fechada; um sistema que funciona precisa de uma energia nova para sobreviver e, portanto, deve captar essa energia no meio ambiente. Consequentemente, a autonomia se fundamenta na dependência do meio ambiente e o conceito de autonomia passa a ser um conceito complementar ao de dependência, embora lhe seja, também, antagônico. Aliás, um sistema autônomo aberto deve ser ao mesmo tempo fechado, para preservar sua individualidade e sua originalidade. Ainda aqui, temos um problema conceitual da complexidade. No universo das coisas simples, é preciso "que a porta esteja aberta ou fechada", mas, no universo complexo, é preciso que um sistema autônomo esteja aberto e fechado, a um só tempo" (MORIN, 2014, p. 184).
} 
Ainda que $O$ boulevard do crime não seja um filme silencioso (muito pelo contrário), pode-se perceber que ele sintetiza questões relacionadas a estes conflitos sistêmicos, a partir dos meios de expressão que ele operacionaliza: a commedia dell'arte e o teatro oitocentista; a pantomima e a oratória; o cinema o teatro; o cinema falado e o cinema silencioso; o silêncio e a fala. A ruptura completa com o sistema engendrado na encenação no Funambules a partir do chamado do nome de Baptiste de alguma maneira demonstra que a relação entre o silencioso e o falado se situa na superfície da "irritação" de Luhmann: o silêncio expele a palavra, mas a palavra volta, sempre, a investir em direção ao silêncio, reiniciando um ciclo infindável. Como podemos perceber pelo próprio $O$ boulevard do crime, a inserção do filme silencioso no filme falado não é tão problemática quanto o seu contrário. Filmes como Persona (1966), de Bergman, $O$ espelho (Zerkalo, 1975), de Tarkovsky, Casa Vazia (Bin-Jip, 2004) de Kim Ki-Duk, ou Tabu (2012), de Miguel Gomes, promovem um perfeito acoplamento estrutural na funcionalidade do cinema sonoro, integrando o cinema silencioso, gerando obras que são híbridas, mas completas, ressignificadas em suas contingências sistêmicas. O que parece curioso é perceber que o mesmo não ocorre na inserção pontual da fala no cinema silencioso, um sistema que repele constantemente o seu oposto, o que talvez tenha determinado um fim praticamente absoluto da estética muda com a chegada do cinema falado.

Esta deflagração de um curto-circuito entre os sistemas silencioso e falado a partir da pronunciação de um nome (como quando Nathalie clama por Baptiste, interrompendo a pantomima) é ratificada outras vezes durante $O$ boulevard do crime: em determinado momento, é Garance que fala o nome da Baptiste durante um sonho, e, em outro, a personagem reflete sobre o ato de se autonomear. "Eu nunca chamo a mim mesma. Mas os outros me chamam Garance. Minha mãe me chama Claire”. O ato de nomear, posto aqui em uma instância de reflexividade, pode ser pensando como a função inaugural da fala. Ou melhor, do registro escrito, que cristaliza a fala, consigna a palavra, confia-a a um sulco, a uma gravura, a um relevo, como diria Derrida (2002, p. 26). Garance pertence a uma linhagem de personagens femininas de filmes franceses que têm o poder de deliberar a respeito da própria liberdade, como se simbolicamente pudessem gravar o próprio nome, ou optar por não se chamarem de coisa alguma, como se o passado e as marcas identitárias fossem marcas que se dissolvem, rastros 
propriamente derridianos, a não-origem que se torna a "origem da origem". Assim também o são a Catherine de Jules e Jim (Jules et Jim, 1962), de Truffaut, cuja volatilidade dos atos torna-se uma maneira de reescrever um passado móvel, desapegada da narrativa da memória, afeita a uma experiência descentralizada e esparsa; ou Séverine Serizy, a Belle de jour (1967) de Buñuel, situada na encruzilhada máxima da paradoxal condição feminina no meio do século XX, indecidível entre a frigidez e a prostituição. $\mathrm{O}$ coração destas atitudes femininas que buscam apagar uma linha que traceje qualquer tipo legível de historiografia para si própria está simbolizado neste gesto impuro de Garance, o de escolher o próprio nome, de fazer estremecer um sistema ancestral de representação com a instauração da fala, com a grafia da própria subjetividade, atribuída por si mesma ou aos outros: "Nomear, dar os nomes que eventualmente será proibido pronunciar, esta é a violência originária da linguagem que consiste em inscrever uma diferença, em classificar, em suspender o vocativo absoluto" (DERRIDA apud JOHNSON, 2001, p. 30).

Para Derrida, o ato de nomear instaura esta violência justamente porque funciona como uma demarcação primária da escritura, implementando a História, deixando marcas que "inventam" a origem das coisas ${ }^{110}$. A fala, inclusive, é pensada como espécie também de éden, porque não deixa estes rastros (ou eles se apagam instantaneamente), sobrando à demarcação arbitrária da escritura (originada no ato de nomear) a função de ser paradoxalmente a origem de todo tipo de subjetividade e ao mesmo tempo a destruição desta origem. Em O boulevard do crime, a constante pontuação, até mesmo por atos falhos, do nome dos personagens em instâncias de franca substituição sistêmica leva a narrativa do filme a dosar o dimensionamento de instâncias como a fala, a escrita e o silêncio até o limite de suas possíveis convivências, tornando complexo identificar um patamar subliminar unificado para a formação do discurso do filme.

\footnotetext{
110 Maffesoli pode complementar refletindo sobre a força autoritária e ao mesmo tempo sagrada do nomear: "Isso também se encontra em outros tipos de civilização em que o fato de dizer é um ato sagrado que não pode ser efetuado impunemente. A aura que envolvia o juramento, em numerosas sociedades primitivas ou tradicionais, é certamente uma manifestação desse caráter sagrado. Dá-se o mesmo, na tradição judaico-cristã, com a importância do "verbo" e de sua função criadora. Eis o que registra Raymond Abellio, em fórmula penetrante: 'Ao nomear, se conhece. Ao nomear, se possui'. Na Antiga China, os sábios diziam: a ciência das justas designações é a ciência suprema” (MAFFESOLI, 1998, p. 127).
} 
Evidentemente, há outros filmes falados que problematizam este trio conceitual (a fala, a escrita, o silêncio), acrescidos, como veremos adiante, ainda da instigação a respeito da imagem, fazendo da representação fílmica quase sempre uma metarreflexão, levando estas estruturas mediáticas a se implodirem em desígnios de si próprias, em revoluteios do próprio ato de comunicar. São assim os filmes de Leos Carax, que assumem o silêncio como violência. Poderíamos pensar também no mutismo de filmes de explícita agressividade contemporânea, como ocorre em Old boy (Park Chan-Wook, 2003) ou na linguagem abusiva, puro exploitation, de Ichi, o assassino (Koroshiya 1, Takashi Miike, 2001), em tudo excessiva, exceto pelo mutismo de seu personagem principal. Em outras vias, filmes como Mogari no mori (Naomi Kawase, 2007) ou Mal dos trópicos (Sud pralad, Apichatpong Weerasethakul, 2004) levam a percepção do silêncio a um tipo de impenetrabilidade só vivenciável dentro da natureza, transformando a incapacidade de se pensar o silêncio em sua própria essência estética. Há também os casos em que o debate sobre cinema silencioso e cinema falado é explícito, quase vulgar, como ocorre em clássicos como Crepúsculo dos deuses(Sunset Blvd., Billy Wilder, 1950), Cantando na chuva (Singin' in the rain, Stanley Donen, 1952), ou no próprio $O$ artista. Fica registrado, entretanto, que, mais próximo ao fenômeno que acompanhamos em $O$ boulevard do crime estão os filmes dos Irmãos Marx, que, de alguma forma, representam o "ápice" da fala no cinema. Se estes filmes, que são responsáveis por uma mudança de paradigma no humor americano, transferindo o humor físico de Chaplin e Keaton para o humor verbal de Groucho, transformam a fala em obra de arte (abrindo espaço para uma tradição que vai de Woody Allen a Jerry Seinfeld), é perceptível que esta mesma fala só ganhe relevo quando confrontada com certa irracionalidade do mutismo, representada pelo personagem de Harpo Marx ${ }^{111}$. Personagem de pura impulsividade irracional, que visivelmente considera a fala uma tolice, Harpo, em contraste com a verborragia impositiva de Groucho, está ali justamente para representar um ponto de fuga, um referencial que permita que a fala alcance seu apogeu. Da mesma forma que vimos em $O$ boulevard do crime, fala e silêncio nos filmes dos irmãos Marx denotam ao mesmo tempo complementariedade e paradoxo, o que merecia análise mais aprofundada. No entanto, cabe agora pensar a relação contrária: a inserção do mundo da palavra no universo do cinema silencioso a

\footnotetext{
${ }^{111}$ Há uma interessante análise psicanalítica dos Irmãos Marx realizada por Slavoj Zizek em seu filme $O$ guia dos pervertidos para o cinema (The pervert's guide to cinema, Sophie Finnes e Slavoj Zizek, 2006). Lá, o filósofo associa cada um dos irmãos como correspondendo a uma categoria freudiana da mente (Id, Ego e Superego). Harpo Marx, é claro, representa o Id.
} 
partir da configuração de um quadro de escrita e produção de imagens em $O$ gabinete das figuras de cera (Das wachsfigurenkabinett, Paul Leni, 1924).

\title{
3.3 O gabinete das figuras de cera: escrevendo imagens a partir do silêncio
}

\author{
A ausência da palavra \\ é um longo signo menos \\ que se desprende de sua cifra. \\ - Roberto Juarroz
}

Narrativas-moldura são aquelas em que textos são intercalados dentro de outros através de procedimentos de narração e subnarração. Uma voz narrante delega a narração a outra voz narrante, geralmente dentro da própria diegese, tornando a narrativa um processo iterativo em que o espectador deve elaborar uma leitura em profundidade destas instâncias de delegação para que as escalas formais de conteúdo sejam compreendidas. O caso mais famoso de narrativa-moldura é o de As mil e uma noites, em que um narrador onisciente, em primeira instância, vai narrar a história de Sheherazade, que, por sua vez, precisa, por efeito da própria trama em si, narrar outras tantas ("mil e uma") histórias, cuja narração é delegada à voz da própria personagem. Dentro das narrações proferidas por Sheherazade há ainda momentos em que personagens narrados por ela passam a contar também suas histórias, seja através de simples diálogos (que sempre são narrações delegadas) ou através de verdadeiras narrativas encaixadas. Neste caso percebemos, portanto, pelo menos três graus de narração intercalados um dentro do outro, e, no caso da literatura, todos devidamente verbalizados, um substituindo a narração do outro, sempre no código da língua.

Como se pode perceber, há um flerte com a narrativa-moldura em $O$ boulevard do crime, já que presenciamos, no decorrer do filme, várias formas de mise-en-abyme, em que uma representação ocorre dentro de outra. Porém, ainda que consideremos a soma de todos os dispositivos representacionais fílmicos como um meganarrador ou grande imagista (uma instância que é a soma de todos os atributos narrativos do som, da imagem e da montagem em um filme), a representação teatral em $O$ boulevard do crime ainda não é tecnicamente delegada, porque o teatro tecnicamente não narra, mas sim mostra. Gaudreault e Jost distinguem especificamente os fenômenos de mostrar e 
narrar como dois modelos diferentes de representação. A mostração, neste caso, que pertence também ao cinema (ainda que subjugada a uma narração operada por instâncias fílmicas) seria autonarrada (ou mostrada por um mostrador que age no nível do fotograma, e não do plano), prescindiria de uma instância organizadora, seria a pura representação, mimese imediata.

Em um filme silencioso como $O$ gabinete das figuras cera, entretanto, a miseen-abîme ocorre dentro de um processo de delegação narrativa, e não apenas na instância do teatro filmado. Isso pode ocorrer, é claro, em filmes falados (não é uma especificidade do cinema silencioso), sendo o caso mais famoso o de Cidadão Kane. Porém, nos interessa chamar a atenção para este aspecto de $O$ gabinete das figuras de cera porque ele é determinante para estabelecer uma relação entre a palavra e o silêncio do próprio filme. Assim, ele age de maneira complementar à análise pontual que realizamos de algumas cenas de $O$ boulevard do crime pensando na inserção do silêncio em um mundo consumido quase completamente pela fala. Antes, porém, cabe contextualizar a época e condições de produção do filme, assim como do filme que o inspirou, $O$ gabinete do Dr. Caligari.

O gabinete das figuras de cera foi produzido em 1924, o auge da indústria alemã de cinema silencioso, que a esta altura consolidava uma produtividade que abrangia tanto o mercado interno (com filmes de gênero, mais afeitos ao gosto da população) quanto o externo (com famosas superproduções como Metropolis, Os nibelungos e Fausto, que intencionavam competir com Hollywood), e alçava à mais alta popularidade seu próprio star system, especialmente a partir das duas maiores produtoras, UFA e Emelka. O filme foi lançado pela pequena Neptune, mas distribuído pela gigante UFA, conhecida por misturar os conceitos de filme de arte com os de filme popular, buscando ao mesmo tempo representatividade e requinte, e também largas bilheterias. Este conceito de filme de arte (autorenfilm, "filme de autor") acabou sendo historicamente associado ao do expressionismo alemão, que, em suas formas iniciais, não durou até depois de 1922, dando lugar a outros gêneros, como o blockbuster de fantasia ou o kammerspiel, um tipo de cinema operário voltado para as classes trabalhadoras, que se tornaram, nos anos 1920, a principal audiência na Alemanha. É mais abrangente relacionar o cinema que vai de O estudante de Praga (1914) até Berlin, sinfonia da metrópole (1927) como cinema de Weimar (ELSAESSER, 2000), referindo- 
se à República que se sucedeu ao período Guilhermino, na Alemanha, e antecedeu a ascensão do regime nazista. O termo expressionismo, no entanto, aqui é importante porque $O$ gabinete das figuras de cera pode ser pensado como um dos principais filmes de Weimar que fizeram referência explícita (neste caso, ao mesmo tempo uma homenagem e uma paródia) a este modelo de cinema.

Não nos cabe aqui fazer extensa problematização do que significa o expressionismo no cinema alemão, e nem o que esta estética, que, após o filme $O$ gabinete do Dr. Caligari, acabou virando estilema de publicidade no país, significou no âmbito da afirmação ou negação de um estado totalitário alemão ${ }^{112}$. Importa, em nosso caso, pensar que uma das características deste cinema, além da distorção moral e a degenerescência (a loucura, o assassinato, o suicídio), e da distorção visual (deformação dos cenários, efeitos fotográficos radicais, montagem oblíquia), havia também uma distorção narrativa, que era estranhada pelas plateias americanas, por exemplo, justamente por não criar referências sólidas em termos de caracterização e motivação dos personagens. No cinema de Weimar, histórias de assassinato, dominação, subjugação e controle frequentemente ocorriam sem motivação aparente, e blocos narrativos inteiros se passavam sem que hipóteses de antecipação da trama fossem criadas. Ou seja, sem que o espectador pudesse criar um elo de previsibilidade entre ele próprio e o filme. Assim são, por exemplo, os atos brutais e aparentemente impensados em $O$ gabinete do Dr. Caligari, transmutados uns nos outros como se as imagens derivassem de si próprias, sem o efeito lógico das narrativas. Estes efeitos de mesmerização e controle, que ocorrem em casos clássicos como Nosferatu e Dr. Mabuse, são atribuídos, nos filmes, ao psiquismo e à tecnologia (gerando infinitas interpretações envolvendo teorias dos media, psicanálise, cultura de massas, etc.).Porém, este descontrole sobre as ações dos personagens e suas consequências está, muitas vezes, embutido na própria maneira que o filme assume para narrar, como é o caso das narrativas-moldura, presentes tanto em $O$ estudante de Praga, quanto em $O$ gabinete do Dr. Caligari, quanto em A morte cansada e, é claro, em Os gabinetes das figuras de cera.

\footnotetext{
${ }^{112}$ Para amplo debate a respeito destas e outras leituras do cinema de Weimar, Cf. EISNER (2002), KRACAUER (1988), e extensa revisão em ELSAESSER (2000) e GARNCARZ (2004).
} 
Mas ainda em $O$ gabinete do Dr. Caligari, conforme extensa análise de Elsaesser (2000, pp. 61-105), a narrativa-moldura, cuja real natureza só nos é informada no final do filme, serve mais para confundir e adicionar elementos sinistros de dupla interpretação ao espectador do que propriamente "enquadrá-la" em algum formato mais claro. Neste filme, no início, vemos o jovem Francis contar a incrível aventura que viveu ao ajudar a capturar o maléfico Dr. Caligari e seu assistente-sonâmbulo, o assassino Cesare. Vemos a história inteira emergir, em flashback, da memória de Francis (daí a "moldura"), para, no final, voltarmos à narrativa inicial e descobrirmos que Francis se encontra em um hospício, e a que a fisionomia que ele associava a Caligari pertencia, na verdade, a seu médico. O gabinete das figuras de cera é uma clara paródia a Caligari, já que, além do próprio "gabinete" no nome, temos também a presença de uma narrativa-moldura que serve a vários propósitos, sendo um deles o de misturar a ficção dentro de uma outra ficção, chamando a atenção para o ato de contar história ("narrar") em si. Este filme foi também inspirado no sucesso A morte cansada (Der müde Tod, Fritz Lang, 1921) que, também enquadrado numa moldura, contava a história de uma moça que vai atrás da própria figura da Morte para tentar trazer seu marido de volta à vida. A Morte então lhe lança o desafio de salvar três pessoas que estão perecendo em diferentes épocas e lugares, para, como resultado, lhe premiar com a ressurreição do marido. Sendo a trama da moça e da Morte a moldura, o filme passa a transmitir as narrativas dos três desafios da personagem, retornando, é claro, à própria moldura no final do filme.

A moldura em $O$ gabinete das figuras de cera, semelhante à de $A$ morte cansada (porque vai gerar três outras histórias dentro dela) se dá a partir de um ato literário, e isso particularmente nos interessa. No início do filme, estamos em um circo (caligarescamente representado, na primeira imagem, por meio de sobreimpressões. FIG. 20), e acompanhamos a chegada de um escritor a uma tenda de figuras de cera, atendendo a um anúncio que chamava por alguém com talento capaz de escrever um trabalho publicitário para o estabelecimento. O escritor (William Dieterle), nunca nomeado, chega à tenda, local de aspecto sufocante e sinistro, e conhece ao mesmo tempo o dono, figura descabelada e também caligaresca, e sua bela filha, com quem há um rápido flerte (FIG. 51). Lá, o dono mostra-lhe algumas de suas figuras de cera e oferece-lhe a oportunidade de escrever contos assustadores a respeito delas. As figuras representadas são personagens históricos: Harun Al-Rashid (Emmil Jannings, FIG. 52), 
famoso Califa de Bagdá na Idade Média (não por acaso, presente n'As mil e uma noites); o tirano czar da Rússia Ivan, o terrível (Conrad Veidt, FIG. 53); e o psicopata vitoriano Jack, o estripador (Werner Krauss, FIG. 54). O escritor vai, então, produzir uma história para cada uma daquelas estátuas/imagens (FIG. 55), e à narração fílmica caberá transvisualizá-las. Vamos, então, primeiro à Bagdá da Idade Média conferir como Harun Al-Rashid perdeu um braço, e depois à Rússia de Ivan para presenciar suas atrocidades. O final, no entanto, guarda uma pequena surpresa, conforme veremos adiante.
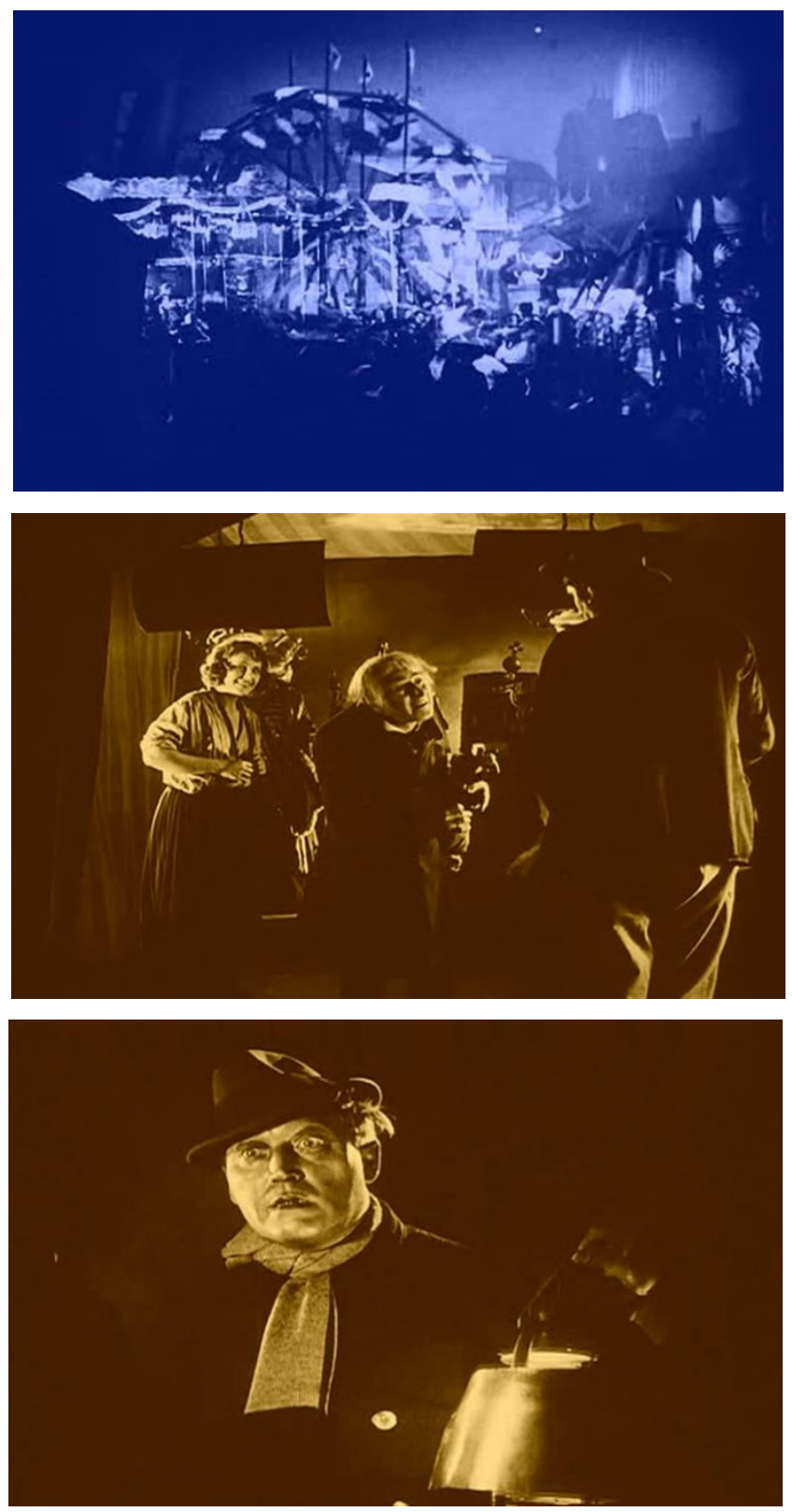

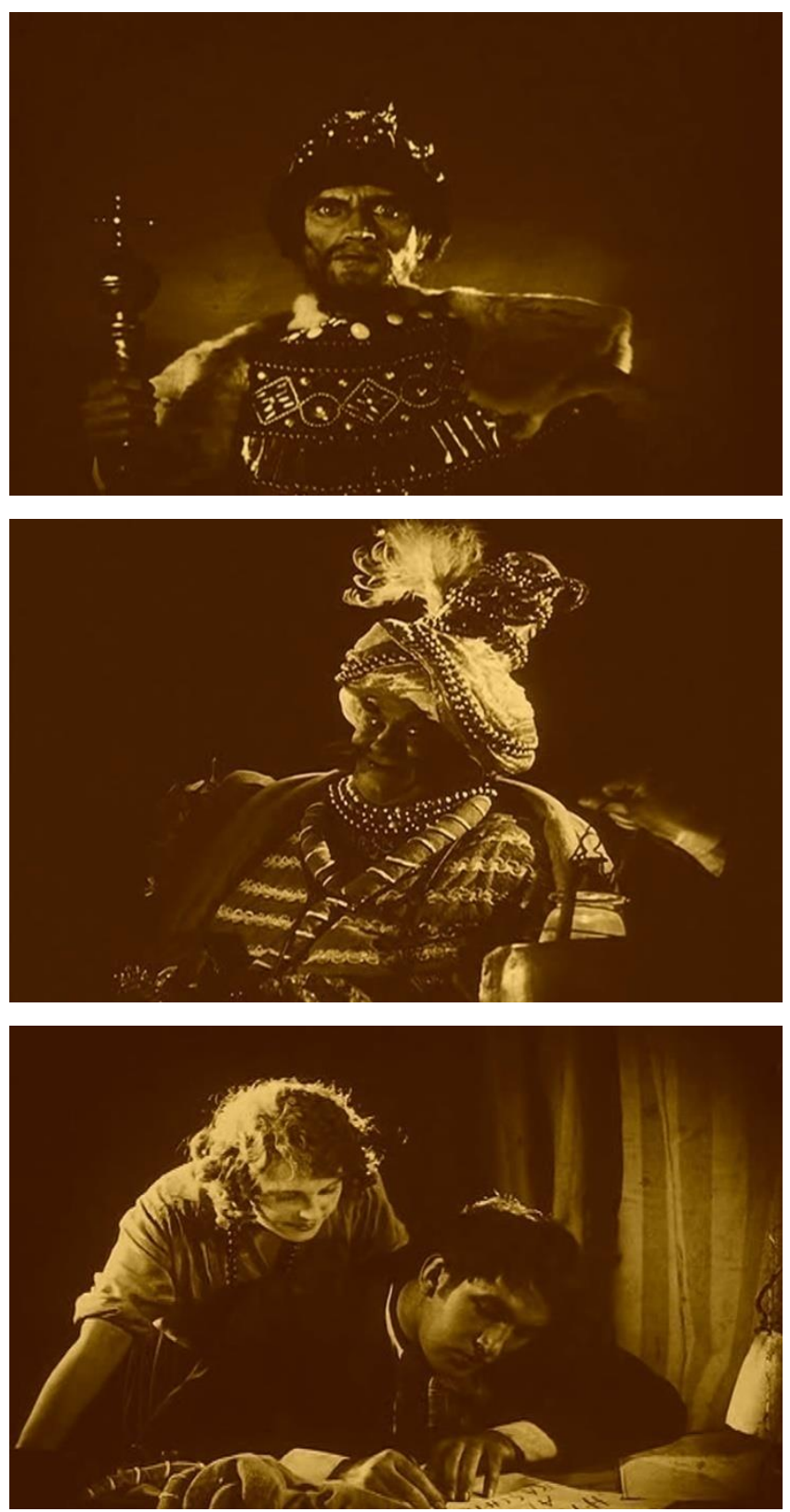

Figuras 51 a 55

Como se pode ver, não apenas $O$ gabinete das figuras de cera parodia $D r$. Caligari como utiliza seus mesmos atores (a saber, Veidt e Krauss, verdadeiras celebridades na época ${ }^{113}$ ) e emplaca estrutura narrativa semelhante. O que chama a atenção neste caso, porém, é a presença do escritor e da imagem das figuras históricas, entrelaçadas por este gesto narrativo da moldura, criando estranha estrutura de

\footnotetext{
${ }^{113}$ As estrelas alemãs eram geralmente reconhecidas como distintas, oriundas da dramaturgia teatral, e dispostas com uma aura de respeitabilidade, discrição e decência. "Mesmo que o star system dos anos 1920 servisse para a mesma coisa nos EUA e na Alemanha, ou seja, para levar espectadores ao cinema, os dois sistemas alcançavam seus objetivos com diferentes maneiras. As estrelas alemãs tinham, culturalmente, diferentes meios de vida, atitudes e modismos. O sucesso deles era baseado em tradições culturais familiares às audiências alemãs, e eles representavam atitudes e interesses que eram muito específicas à Alemanha" (GARNCARZ, 2004, p.392, tradução nossa).
} 
visualização da literariedade proposta pelo filme, arriscando uma substituição do discurso escrito (que, em sua própria natureza, já é a substituição do discurso falado) por um discurso visual/cinematográfico que não apenas é silencioso, mas também alucinado, deformativo, grotesco, delirante, à moda expressionista (com um "toque exótico" de orientalismo), como se, pela mera substituição da escrita pela imagem, a voz originária da fala se tornasse turva, desalinhada, fora de uma racionalidade explícita.

O que chama a atenção neste filme, em relação aos outros que se aproveitaram da moldura, é que, neste caso, a moldura não apenas serve para correlacionar temas e "derramar" as palavras criadas pelo escritor em imagens cinematográficas que de alguma forma replicam o mote da própria moldura, mas também para criar uma outra "moldura", desta vez intermedial, que enquadre a escrita (no caso, a literatura, mais especificamente o conto pulp de crime à maneira de Edgar Allan Poe) dentro do cinema. Mais uma vez pensando em McLuhan, esta seria uma estranha maneira de o cinema processar desta vez a escrita dentro de si, produzindo, em primeira instância, uma reflexão sobre os media, mas não apenas isto. Como ocorre em Cidadão Kane, filme francamente influenciado por uma estética expressionista (GAUDREAULT e JOST, 2009, pp. 71-73), um registro escritural, representado pela pena do próprio escritor dentro da tenda, é substituído por uma narrativa cinematográfica, ou seja, aquilo que está sendo escrito pelo escritor, ao invés de ser vertido em um outro código escrito (como n'As mil e uma noites), e portanto substituído, passa a ser traduzido e transvisualizado em código cinematográfico. Isso inclui omitir uma série de elementos que estão detalhadas no código original, a escrita (incluindo seu detalhamento linguístico), e incorporar outros que não estavam no texto original (incluindo detalhamentos visuais não descritos no texto e especificidades da linguagem cinematográfica, como enquadramentos, cortes, movimentos de câmera, etc.). Em suma, a passagem de um registro a outro tem de lidar com as aporias de uma tradução intermedial. Isso implica em pensar um pouco a natureza das instâncias comunicacionais envolvidas no processar discursivo deste filme: a fala, a escrita, o silêncio, a imagem e o próprio dispositivo do cinema.

Como vimos anteriormente em relação ao processo de nomeação, Derrida, em sua Gramatologia, ao procurar desconstruir a teoria da escritura de Lévi-Strauss -para 
quem a função primeira da comunicação escrita é "escravizar e subordinar", em oposição à "naturalidade" da fala, discurso fluido e conectado diretamente à humanidade em si - vai tratar a escritura como um tipo de violência que antecede a própria invenção da escrita (daí a necessidade de se alterar o vocábulo). O próprio processo de nomear as coisas já pertence, em uma instância originária (“arquiescritura"), à criação da diferença ${ }^{114}$, ou seja, de separar o mundo em si mesmo, de instaurar o ato de postular. Está aí o nascimento das leis, da moral, dos códigos culturais. O que Lévi-Strauss enxerga como uma violência contra um certo estado natural, idílico e "verdadeiro" que é a fala, Derrida enxerga, por sua vez, como a própria naturalidade inevitável, antecipando a escritura mesmo ao ato da própria fala, correlacionando necessariamente violência, escritura e diferença. A violência, neste caso, é o ato inaugural que encobre a origem "essencial" buscada por Lévi-Strauss. Como esta origem apaga os próprios traços, resta a ela mesma servir como origem profanada, que sabe que não é origem, ao mesmo tempo funcionando como sua prótese e negando sua própria existência. Membro-fantasma, a inscrição derridiana perpetua um beco sem saída na relação entre imagem e palavra, admitindo uma anterioridade à escrita, mas ao mesmo tempo assumindo que desta anterioridade só se pode perceber o rastro, naturalmente impossível de ser visto.

\begin{abstract}
A escritura, no sentido cotidiano, comum da palavra, dependente como ela é da inscrição de uma superfície, a violenta incisão e separação de um meio (mesmo a projeção de caracteres sobre uma tela de computador não é um processo passivo), funciona, portanto, como um modelo dessa inscrição mais fundamentalmente violenta que Derrida chamou mais acima de “arquiescritura". É evidente que a fala - a voz - não pode servir como um modelo para tal processo: de acordo com o sistema tradicional (logo e fonocêntrico) de representação que opõe fala e escritura, a fala é transmitida pelo meio transparente e não passível de impressão do ar, ela não deixa traços; ela é a mediação ideal e imediata da alma, enquanto a escritura habita o reino externo e corpóreo da matéria. Simplificando, poder-se-ia dizer que violência é (arqui-)escritura é diferença (JOHNSON, 2001, p. 33).
\end{abstract}

Se confiarmos em Derrida e considerarmos a escritura como violência fundacional que opera a proeza de apagar os próprios rastros e a origem de sua anterioridade, estamos certamente adentrando em um terreno de silêncio ${ }^{115}$. O rastro

\footnotetext{
${ }^{114}$ Neste sentido, voltamos a Heidegger: "Mas entendemos agora a poesia como o nomear fundante dos deuses e da essência das coisas. 'Habitar poeticamente' significa: permanecer na presença dos deuses e ser atingido pela proximidade essencial das coisas. 'Poético' é o estar-aí, conforme instituído (fundado) não o é em função de serviços prestados, mas por doação" (HEIDEGGER, 2013, p. 53).

115 “O sentido deve esperar ser dito ou escrito para se habitar a si próprio e tornar-se naquilo que a diferir de si é: o sentido" (DERRIDA, 2002, p. 24).
} 
derridiano leva a uma formulação de silêncio que é absolutamente inextricável, inatingível, inefável. Se a escritura é uma violação, a única categoria que pode ser pensada em termos de algo a ser violado é o silêncio. E a inserção do tema da escritura em $O$ gabinete das figuras de cera, a partir da fagocitação intermedial promovida pelas dimensões da mise-en-abyme, leva a algumas considerações sobre as possibilidades de silêncio do filme, e em especial uma utilização irônica da mesma escritura, plasmada em um jogo de bonecas russas narrativo que transforma o caráter simbólico da palavra ("sulco", "gravura", "relevo") em um derramado caldeirão sígnico e alucinatório, incluindo cenários devassados pela deformidade, imagens que ganham vida, pensamentos que se transformam em narrativas e sonhos que se vivificam e assombram os vivos.

O silêncio, em $O$ gabinete das figuras de cera, portanto, segundo uma lógica derridiana, não é um retorno a um estado idílico (sendo ele mesmo o local de Éden, substituindo a fala em Lévi-Strauss) em que tudo funciona em paz, ausente do domínio da escrita e do som. O silêncio (de onde emerge o traço derridiano) é um espaço de conflito, justamente por estar, a cada momento, a um passo de inaugurar novamente a arquiescritura que nomeia e põe ordem no mundo. Um filme silencioso, graças a seu retorno teimoso a esta instância, está o tempo inteiro insistindo em andar para trás, em buscar o incomunicável, em trilhar novamente este traço que se apaga. É um medium, portanto, oposto ao cinema sonoro, que busca andar para frente e comunicar-se de uma maneira racionalmente logocêntrica. $O$ gabinete das figuras de cera tem o mérito de problematizar as vicissitudes desta oposição mediática no seio de seus próprios temas e de sua narrativa. De um lado temos o escritor procurando racionalizar aquelas imagens de cera e colocá-las dentro de uma proposição evolutiva e lógica. Do outro, temos todas as instâncias do filme (sua montagem, suas atuações, sua direção de arte) procurando validar o silêncio e seu traço irrecuperável. Verdadeiro caos originário. E é neste conflito que reside a potência do filme.

Sem ainda nos determos muito em uma teoria da imagem, podemos perceber que a relação entre um imaginário da escrita (na figura do escritor) e o ato de plasmá-la em uma narrativa cinematográfica é francamente calcada na ironia, ou no mínimo em uma espécie de revanchismo perverso das linguagens mudas (como a imagem pura, a música e a montagem, todas presentes no filme) em relação à literariedade que deflagra a diegese. Em primeiro lugar, há a quebra, típica da narrativa expressionista, associada ao 
processo de escrita. O próprio escritor parece preso a uma instância de atemporalidade, inverossímil a uma narrativa mais causal: ele "fica" o tempo todo na tenda enquanto escreve, como se não houvesse uma mudança de temporalidade necessária, obviamente, à escrita de histórias e à continuidade narrativa de qualquer filme. Tempo e espaço, nas histórias visualizadas a partir da moldura, parecem constantemente obliterados, como se fizessem parte efetivamente de um sonho, onde elementos simbólicos, oriundos do inconsciente, condensados e deslocados são mais importantes do que qualquer tipo de sequenciação causal.

\begin{abstract}
O código simbólico bloqueia a maestria discursiva da parte do espectador, em contraste com a ilusão de controle narrativo que a audiência frui no cinema clássico hollywoodiano, por exemplo, frequentemente sabendo mais do que os personagens. Comparado com este modelo clássico de se contar histórias, cuja condescendência com o desejo do espectador de 'ver e saber' faz o filme parecer invisível, o cinema de Weimar muitas vezes coloca em relevo a questão a respeito de quem autoriza ou controla o ato de narrar. A profusão de narrativas-moldura, flashbacks, construções em mise-en-abyme e o entrelaçamentos de vozes narrativas é um índice das diferenças que estabeleceram o cinema silencioso alemão como historicamente específico (ELSAESSER, 2000, pp. 81-2) ${ }^{116}$.
\end{abstract}

Como se pode notar pela própria natureza ambígua da relação entre fala, silêncio e escrita (especialmente a partir de Derrida), a transformação de um discurso escrito e verbal em um discurso de imagens e silêncio em $O$ gabinete das figuras de cera não ocorre exatamente como uma inversão da relação entre fala/silêncio que observamos em O boulevard do crime. Aqui, não há fala verdadeira, e muito pouca escrita. Não há um texto fonte, como no caso de uma adaptação. Tudo se passa, verdadeiramente, dentro de uma fantasia de escrita. Imagens que sonham ser escrita. Silêncio que sonha ser vozes. Tudo que percebemos no filme está plasmado em imagens que conotam escrita (imagens do escritor, imagens do escritor escrevendo e até imagens da própria escrita do escritor. Vale sempre lembrar que a escrita é também constituída de imagens, e em um filme silencioso a aparição da escrita nos letreiros adquire sentido estético). Estas imagens, dinamicamente, geram outras imagens de maneira quase espontânea, justamente propaladas pelas relações escrita/imagem e fala/silêncio que são ativadas a partir dos elementos essenciais que compõem a estrutura e o enredo do filme. Em $O$ boulevard do crime, existe uma integração entre fala e silêncio justamente porque, no filme falado, há espaço para uma concomitância entre os dois. O estrago que observamos pontualmente na relação entre os sistemas que pensamos a partir de

\footnotetext{
116 Tradução nossa.
} 
Luhmann se dá justamente quando, de maneira enganosa, o filme silencioso se infiltra em $O$ boulevard do crime e é bruscamente interrompido pela intervenção inesperada da fala. Porém, em um filme silencioso como $O$ gabinete das figuras de cera a fala não existe tecnicamente, e estes dois sistemas de alguma forma se orbitam, mas jamais se tocam. Daí tudo que se refira à fala se situe apenas nas aporias dos letreiros, já demonstradas quando pensamos Nanook, e tudo que se refira à escrita não passe de um sonho da imagem representada pelo próprio escritor.

Da mesma forma que, em um nível quase biológico, conforme apontamos antes, a fala busca retornar ao silêncio pré-linguístico que norteou nossos ancestrais, e, consequentemente, seja por uma transposição deste princípio ou por inter-relação mediática, o cinema falado busca retornar ao cinema silencioso, um filme silencioso como $O$ gabinete das figuras de cera busca estar na ambiência silenciosa que é o rastro derridiano. Se a escritura instaura o humano e todo o resto inalcançável é silêncio, o filme silencioso, mimetizando estruturas, equivalendo forças de representação, distorcendo e contorcendo as suas próprias possibilidades, também procura retornar a este rastro que se apaga, procura estar nele, ainda que não possa representá-lo. Daí, finalmente, a natural apregoação que se constrói entre silêncio e imagem, gerando a fortaleza silenciosa do cinema silencioso, configuração essa que vilipendia e expurga a inserção da palavra (oposta à imagem) e a fala (oposta ao silêncio), consumando sua linguagem através do processo perceptivo da poesia.

Esta quase intuitiva associação da imagem (desvinculada da palavra) com o silêncio que catalisa os processos estéticos e de recepção cognitiva do cinema silencioso está demonstrada, em $O$ gabinete das figuras de cera, de maneira bastante engenhosa, na própria vivificação das figuras de cera em si. Afinal de contas, não podemos nos esquecer que as estátuas de cera de Harun Al-Rashid, Ivan, o terrível, e Jack, o estripador são, para o filme, imagens destes personagens. Cada uma destas imagens estáticas, processadas na mente do escritor, se tornam imagens vivas (tableaux vivants; moving pictures), que silenciosamente vão penetrar os cenários quase feéricos, produtos de um imaginário prontamente onírico e deformativo (próprio ao expressionismo) que serão criados também pela imagem do escritor. Neste caso, imagens emergem de imagens, transformando o panorama expressionista do filme em algo desconectado da realidade. Isso se dá não apenas no sentido de que ele é um produto da ficção (que é 
intelectiva), mas sim de que a ausência do mundo sonoro obriga todos os aspectos visuais do filme a dialogarem entre si a partir de um panorama que também emerge do pictórico. Assim, as atuações exageradas e grotescas são extensões dos cenários geométricos, como se todo o código visual do filme seguisse um caminho livre, longe da realidade aprisionadora e reguladora do mundo sonoro (CHION, 2005, 7-12). É como atestam, falando sobre a estética expressionista, Bordwell e Thompson:

[...] O Expressionismo Alemão depende pesadamente da mise-en-scène. Formas são distorcidas e exageradas de maneira não-realista para propósitos expressivos. Os atores muitas vezes usam pesadas maquiagens e se movem em padrões sinuosos, frenéticos ou lentos. Mais importante, todos os elementos da mise-en-scène interagem graficamente para criar uma composição totalizante; os personagens não existem simplesmente no cenário, mas, ao invés disso, formam um elemento visual que se mescla com aquele cenário" (BORDWELL; THOMPSON, 1986, p.354) ${ }^{117}$.

Logicamente, as imagens de cera em muito contribuem para incentivar o caráter deformativo, tanto psicológico quanto visual, que o filme procurar imprimir a partir deste fluxo desgovernado de imagens. De certa forma, a estátua de cera serve tanto para alienar o espectador diante das atrocidades cometidas pelas figuras retratadas nos três episódios, quanto para justificá-las. Harun Al-Rashid ordena decapitações. Ivan, o terrível possui câmaras de tortura. Jack, o estripador procura assassinar o próprio escritor. São histórias de violência, tragédia, ciúmes e loucura. Tais temas degenerados são processados pelas figuras de cera tanto no aspecto simbólico (os crimes são praticados, na mente do espectador, por meras imagens de imagens, figuras não-vivas) quanto histórico. É importante o papel exercido pelos museus de cera no imaginário dos anos 1920. Siegfried Kracauer, em sua longa avaliação dos filmes de Weimar por meio do tema da tirania, também coloca à figura de cera um papel central na significação de O gabinete das figuras de cera:

A auréola de irrealidade com que Leni cercou os três episódios foi a mais apropriada, porque estes episódios têm como figura central as figuras de cera. Tais figuras em geral reproduzem reis, assassinos ou heróis que pertencem ao passado - imita-os para permitir que os contemporâneos sintam os arrepios de terror ou medo que eles causaram em sua época. Sua aparência cerosa numa barraca de parque de diversões caracteriza Harun e Ivan como fantasmas que são remotos tanto no tempo quanto com relação ao mundo real (KRACAUER, 1988, 104).

117 Tradução nossa. 
É importante lembrar que os museus de cera representaram, para as metrópoles do século XIX, um tipo de evento social que ao mesmo tempo era responsável por congregar a população dentro de interesses comuns, sendo um dos primeiros eventos de entretenimento de massas, e também por trazer representações realistas, fidedignas, de cenas históricas ou mesmo do cotidiano, a partir da captura do instante, sendo, desta forma, irmãos da fotografia em seu incentivo pela captura da realidade. Cenas armadas com complexidade narrativa eram ostentadas nestes museus, que estimulavam um certo tom jornalístico às suas representações e originaram uma primeira cultura das celebridades no século XIX. As figuras de cera do filme, portanto, não representavam o anacronismo e exotismo que podem parecer ao espectador moderno, mas sim procuravam estabelecer uma sinergia com mais um dos media que geraram e foram consumidos (fagocitados, poder-se-ia dizer) pela representação cinematográfica, conforme analisamos em relação ao teatro e à literatura. Em ensaio sobre o famoso Musée Grévin - que dispunha cenas extremamente realistas de acontecimentos cotidianos, misturando certo tom ficcional da narrativa com aspectos mais cinéticos da pintura acadêmica francesa, assim como atribuindo credibilidade jornalística às montagens - a historiadora Vanessa Schwartz fala sobre a inserção do museu de cera no imaginário do século XIX, o que certamente dá uma dimensão extra ao excesso de imaginário produzido em $O$ gabinete das figuras de cera:

\footnotetext{
Como um panteão diversificado, o museu imitava a forma do jornal: os quadros na maioria das vezes ficavam lado a lado sem relação particular um com o outro, como faziam as colunas de jornal preenchidas com histórias aparentemente desconexas. A justaposição de líderes políticos, atores e artistas confirmava uma ordem social moderna dominada pela celebridade e baseada na popularidade. Com o que parecia uma "ousada extravagância", celebridades preenchiam este "panteão parisiense". Que a cantora de caféconcerto Yvette Guilbert e o presidente da república pudessem estar lado a lado indicava que o museu de cera também fazia eco à base de legitimidade da Terceira República francesa, na qual políticos - como atores e artistas ascendiam e caíam aparentemente em virtude da preferência da multidão. $\mathrm{O}$ museu de cera materializou essa nova ordem social baseada nos caprichos da massa (SCHWARTZ, 2001, pp. 346-7).
}

Não podemos esquecer também que os três personagens de cera do filme são, claramente, a imagem de seus atores, Jannings, Veidt e Krauss, celebridades imediatamente reconhecidas pelo público da época. Neste sentido, o filme pode ser pensado, em sua configuração mais popularesca e mediática, como um tipo de museu de cera vivo, em que se vê, ao mesmo tempo e de forma indistinguível, Harun Al-Rashid e Emil Jannings, como se os imaginários histórico, social e mediático fossem interfaces 
comunicantes um do outro. Trata-se de um aspecto múltiplo, simultâneo e indiscernível da imagem também irrepresentável exclusivamente por meio da escrita ou da fala. Em toda e qualquer direção, portanto, a farsa do escritor em $O$ gabinete das figuras de cera aponta para o que ele não é: a imagem técnica do filme, que procura falsear a fala e a escrita; a imaginação do próprio escritor, responsável pelos desvios delirantes tanto na verossimilhança quanto na constituição das ambientações e cenários da história; e a imagem consumível do star system do cinema silencioso alemão, também transmissível imediatamente, sem o auxílio dos códigos que o filme procura parodiar. ${ }^{118}$

Não é à toa que partimos do escritor, da palavra e da fala para chegarmos, neste caso bastante evidentemente, ao silêncio e especialmente à imagem. Basta lembrar que o próprio filme se resolve desta maneira. Após vermos, transvisualizadas em filme, as histórias do Califa e do Czar russo, supomos que veremos completa, também em uma mise-en-abyme, no final, a história do serial killer britânico. Porém, não é o que acontece. Em apenas cinco minutos, a farsa do escritor é definitivamente denunciada pela narrativa do filme, que resolve assumir um código próprio, independente do fluxo de metamorfoses imagéticas que se operava quando havia uma hierarquia entre a imagem da escrita e a imagem do cinema. Assim, o escritor, já exausto após passar a noite escrevendo, cai no sono depois de iniciar o conto sobre Jack, o estripador. O que se segue são os cinco minutos mais intensos, do ponto de vista estético, do filme. Quase toda formatada em sobreimpressões (fotogramas diferentes que são recortados e sobrepostos uns nos outros, causando a sensação de estarmos vendo múltiplas imagens ao mesmo tempo - comuns no cinema silencioso), a cena age como se disparasse um inconsciente imagético sobre a tela, e a realidade já não se distingue do sonho do escritor (FIG. 56). O que antes era linearidade, narrativa, empostação e farsa, se transforma em um fluxo irrestrito de imagens de Jack perseguindo o próprio escritor e a sua protegida. Não apenas perdemos a noção a respeito de tempo e espaço, como os próprios cenários do filme acentuam sua deformação. Desta vez sem o filtro cognitivo da palavra, o filme parece dizer que, enfim, é sobre aquilo que ele trata. Ele se reclina sobre a imagem pura, sem referente, turva, multiplicada, verdadeiro pesadelo da palavra. Já não sai do escritor o afã do discurso escrito, mas sim uma produção oriunda

\footnotetext{
${ }^{118}$ Apenas para não deixar de mencionar uma possível contradição, os nomes dos atores apareciam escritos nos letreiros na primeira vez em que a imagem deles era mostrada, como era de praxe no cinema silencioso, mas isso não invalida o fato de os atores serem reconhecidos por sua imensa popularidade, especialmente por suas imagens.
} 
diretamente de sua mente inconsciente. Mais uma vez, então, o sonho aparece como meio para a imagem selvagem, e o recado final do filme dificilmente pode ser interpretado de outra forma: pensando ser atingido por Jack, o escritor enfia a caneta em seu próprio peito, não morrendo apenas pelo fato de ter sido salvo a tempo pela mocinha (FIG. 57). Este gesto, o da ineficácia da escrita no filme silencioso, foi também percebido por Elsaessar, que nos serve aqui de introdução à relação entre imagem, palavra e silêncio:

Que o escritor, no momento em que adormece, parece se 'estocar' com a caneta, isso apenas adiciona mais 'tinta' e ligação à cadeia de ansiedades de castração, mas com um comentário sarcástico-sádico sobre o conflito central do Kino-Debatte, nomeadamente a batalha de retaguarda entre o establishment literário - os escritores - para reter seu capital cultural, enquanto alguns dos seus colegas menos ambiciosos estão preparados para "se venderem" para o cinema, aqui, mais uma vez, assim como em Dr. Caligari, representado como um parque de diversões (ELSAESSER, 2000, p.86).

O final de $O$ gabinete das figuras de cera, enfim, nos permite traçar uma ligação entre a estética expressionista, o traço derridiano e uma teoria do cinema silencioso. $\mathrm{O}$ expressionismo (literal ou paródico) do filme, em sua ligação profunda com a transmutação natural das imagens, é o ambiente perfeito para a veiculação de um conflito mais profundo. É como afirmou Kracauer, muito a propósito, sobre o filme:

Mas o que na história-moldura nada mais era do que um lugar cheio de divertimentos, agora é um deserto campo de caça para fantasmas. Quadros expressionistas, engenhosos efeitos de luz e muitos outros recursos disponíveis em 1924 foram usados para criar esta fantasmagoria lúgubre, que substancia a noção de caos de maneira ainda mais forte do que o cenário de Caligari (Kracauer, 1988, p. 105).

A transformação do espaço em fantasmagoria serve como ponte para pensarmos a imagem e o silêncio como ligados ao traço (que se apaga) originário da arquiescritura derridiana, colocando-os como epicentro de um debate (transmediático, inclusive) que inclui também a escrita, o som e a fala. Neste sentido, o cinema silencioso, com todas as suas idiossincrasias, funciona como corpo mediático que permite um diálogo aberto, a respeito destes temas, que atravessa a filosofia e a teoria dos media. 

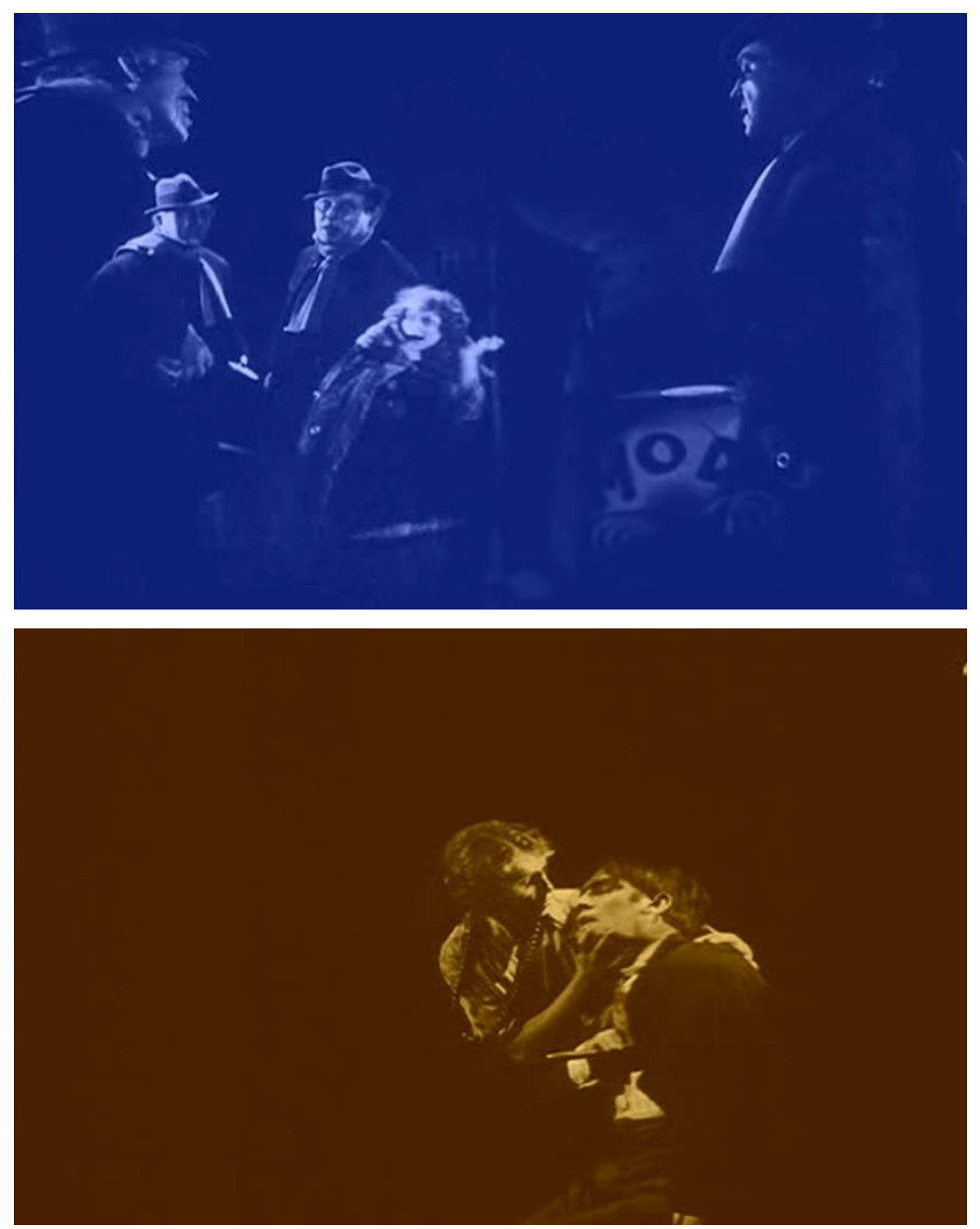

Figuras 56 e 57 


\section{INVENTÁRIO DE IMAGENS SILENCIOSAS}

Nem a vista é o Sol, nem é o olho, onde a vista se forma. - Platão

\subsection{Imagem e objeto}

Não é nem um homem, nem uma maçã, nem uma árvore, que Cézanne quer representar; ele serve-se de tudo isso para criar uma coisa pintada que proporciona um som bem interior e se chama imagem. Kandinsky

\subsubsection{Revisão da fotogenia}

O primeiro plano é um enquadramento muito caro à recepção do cinema silencioso. Alguns dos filmes mais célebres desta era fizeram um aproveitamento fortemente rentável deste recurso para a criação de uma espécie de mitologia a respeito da tela silenciosa. A imagem do rosto humano dimensionada tantas vezes e amplificada para o estupor do espectador dentro do cinema de alguma maneira elevou uma forma ainda calcada em um planejamento visual derivado do teatro (o "plano do cavalheiro da plateia”, conforme discutimos no capítulo anterior) - em que a percepção do mundo ficcional deveria se dar a partir de um declarado distanciamento entre o filme e sua plateia- a uma outra forma, a da "arte". Nesta nova forma, não apenas era possível reconhecer visualmente as expressões dos atores, adicionando verossimilhança emocional à relação entre os enredos dos filmes e suas imagens, como era também possível atravessar o mero mapa de significantes destes rostos agigantados e atravessálos, olhar nos olhos dos personagens, reconhecer sua humanidade. Há, portanto, um desdobramento tríplice na chegada do primeiro plano ao cinema silencioso, o que a torna um dos fatores determinantes na passagem de um primeiro cinema baseado no truque e a atração (ou seja: na experiência de ludibriar, maravilhar, encantar o espectador) para um cinema narrativo e autônomo, baseado na representação.

O primeiro deles é a constituição de uma linguagem mais complexa, dramaticamente, para os filmes, já que, com a inserção do primeiro plano, o leque de possibilidades de decupagem fílmica se amplia, permitindo que o filme, no que tange ao 
detalhamento visual, se complexifique no nível da minúcia. Isso adiciona, evidentemente, à dramaticidade e expande as possibilidades emotivas dos filmes, já que podemos "ver" as emoções dos personagens expressas em seus rostos. Em segundo lugar, a criação do primeiro plano foi útil para as indústrias do cinema, já que permitiam a ascensão de um star system (COSTA, 2010, pp. 37-40). Por fim, o que consideramos mais importante, o primeiro plano dá acesso a esta interpenetração fenomenológica por trás da imagem do cinema, deixando-nos perceber o valor humano que cada imagem exala. $\mathrm{O}$ historiador Jacques Polet ainda adiciona mais uma função importante para o primeiro plano, que seria, em primeira instância, a de "esvaziar" os planos, tornando-os mais "topológicos" (no sentido de percebermos uma geografia do rosto) e ao mesmo tempo centralizando e "educando" o olhar do espectador:

\begin{abstract}
A reflexão que eu proponho aqui depende desta dupla metodologia, uma envolvendo o objeto, a outra lidando com a posição escolhida em relação a ele. É notório que o acompanhamento sonoro foi usado para reforçar o efeito de realidade intimamemente ligado à recepção das primeiras imagens em movimento. Mais do que isso, sabemos que modos de representação antigos induziram os espectadores a centralizem seus olhares, ao mesmo tempo que este olhar estava sendo vastamente solicitado pelas múltiplas ações ocorrendo simultaneamente no quadro (POLET, 2001, p. 193).
\end{abstract}

Este tipo de transformação pode ser percebido desde as primeiras tentativas de se construir um cinema mais complexo, ainda no primeiro cinema, como é o famoso caso de $O$ grande assalto de trem (The great train robbery, Edwin S. Porter, 1903), em que Porter, o cinegrafista e montador do filme, encontrou dificuldade em inserir um grande primeiro plano que mostrava um dos bandidos atirando em direção à tela (FIG. 58). O restante do filme inteiro é enquadrado no já citado "plano do cavalheiro da plateia", bastante distante, que hoje se aproximaria de um plano de conjunto ou um plano geral, com largos espaços entre a cabeça e os pés dos personagens. Esse primeiro plano do bandido atirando, à época, não tinha muita serventia, porque Porter usava muito pouco a decupagem fílmica e os espectadores de 1902 ainda não tinham condições de compreender a inserção de uma "cabeça gigante" no corpo da diegese. O cinegrafista alojou, então, o primeiro plano como abertura do filme, em alguns cortes, e como plano final, em outros, para criar um efeito mais espetaculoso. A intuição de Porter, no entanto, era certeira: de alguma forma aquela imagem deveria fazer parte do filme, porque sub-repticiamente secretava uma poderosa mensagem, que já era, como veremos adiante, a mensagem da fotogenia. 


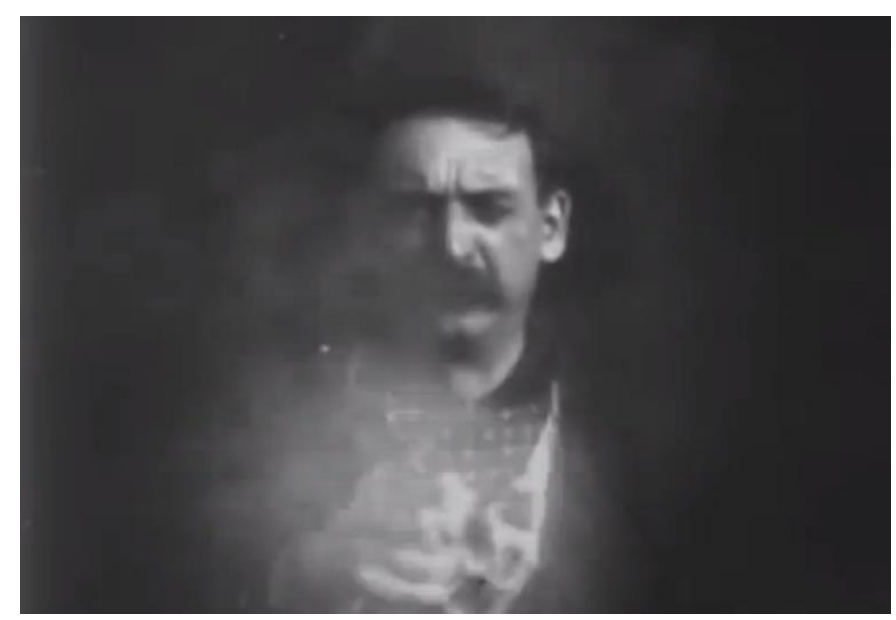

Figura 58

Outro caso interessante vindo de um pioneiro é o do curto filme The big swallow (1901), realizado pelo cinegrafista britânico James Willamson. Aqui, como em um close-up às avessas, um simpático personagem de chapéu, enquadrado inicialmente em um plano americano, vai se aproximando da câmera até que sua cabeça preencha completamente o campo, deflagrando o primeiro plano quase que acidentalmente. Depois, como se não bastasse a ousadia, o personagem passa a se aproximar ainda mais da câmera, até que o campo abarque apenas seu nariz e sua boca (FIG. 59), e logo depois apenas a sua boca, que se abre e "engole" o próprio cinegrafista, que aparece (à maneira de Vertov em Um homem com um câmera) sob um fundo preto, através de um corte discreto e "invisível". O personagem que "engole" o cinegrafista passa então a se afastar, depois de outro corte discreto, fingindo mastigar aquele que produzia sua imagem, retornando ao plano americano inicial. A engenhosidade deste filme pioneiro não se dá apenas no universo da técnica (os cortes “invisíveis"), mas também na abordagem surrealista e especialmente no insight metalinguístico, já que, ironicamente, o cinegrafista "engolido", que filmava antes, precisa também ser filmado, gerando uma cadeia em abismo infinita que lembra, como veremos, as ideias do pintor belga René Magritte, que se iniciariam não muitos anos depois. Neste caso, a ideia de se fazer um filme que fosse transversal, completamente não-narrativo - que deflagrasse uma reflexão sobre a própria técnica cinematográfica em si e também sobre os paradoxos da produção de imagens - está associada ao caráter ao mesmo tempo absurdo e hiperrealista do primeiro plano. 


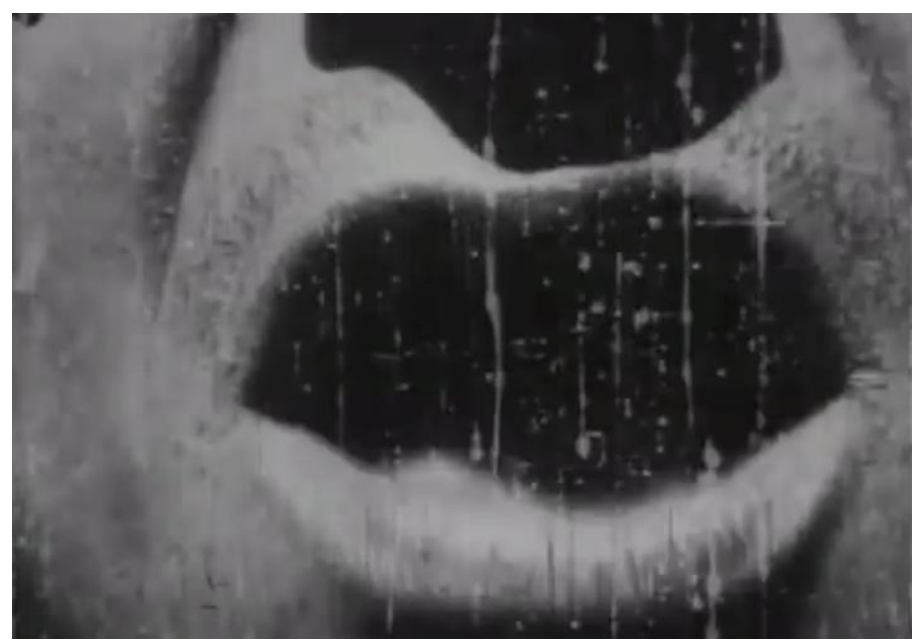

Figura 59

Estes dois exemplos quase prosaicos, oriundos dos primórdios do cinema, são apenas um início caso quiséssemos avançar em uma trajetória do uso do primeiro plano no desenvolvimento do cinema silencioso. Certamente foi esse uso (mas não só) que elevou o clássico de Carl Dreyer O martírio de Joana D’Arc (La passion de Jeanne $\left.D^{\prime} A r c, 1928\right)$ a ser tão representativo para a história do cinema. Filmado quase que inteiramente em primeiros planos, com rostos tesos, severos, em intenso sofrimento ou intensa contemplação, todos sem maquiagem, este filme demarca algumas fronteiras entre a representabilidade mimética e um sentido ulterior capaz de ser produzido pelas imagens. O mesmo ocorre em outros filmes da era mais crepuscular do cinema silencioso, como é o caso de Terra (Zemlya, Aleksandr Dovjenko, 1930), que inspira relação direta entre o rosto e as coisas, ou o de A linha geral (Staroye i novoye, Sergei Eisenstein, 1929), com sua intensa sequência sobrepondo os rostos dos camponeses e as engrenagens de uma máquina leiteira. Outros casos importantes incluem o primeiro plano da moça com o olho sendo retalhado em $O$ cão andaluz (Un chien andalou, Luís Buñuel e Salvador Dalí, 1929) ou mesmo o do olhar melancólico-suicida da atriz Taciana Rei no brasileiro Limite ${ }^{119}$ (Mário Peixoto, 1931).

Esta propriedade, digamos, "transcendental" do primeiro plano, especialmente no cinema silencioso, encontrou como corolário o conceito de fotogenia, instituído pelo teórico e cineasta Louis Delluc ainda em 1919, e posteriormente amplificado pelo também teórico e cineasta Jean Epstein. Delluc é um nome importante para várias

\footnotetext{
${ }^{119}$ Uma análise mais completa a respeito da poética de Limite pode ser encontrada em nossa dissertação de mestrado Limite, o poema em filme (MARCONDES, 2008).
} 
frentes do cinema francês. Cineasta de imagens enigmáticas, contemplativas e com pouco uso da palavra (sua precoce carreira foi interrompida pela morte aos 34 anos), ele se destacou enormemente também no plano da crítica, sendo considerado, por excelência, o fundador da tradição crítica francesa:

\begin{abstract}
Assim se demarca, de maneira adiantada, a concepção intelectualista, estetizante e dogmática do cinema que é sempre associada ao seu nome - não a partir de uma análise fundamentada em seus escritos, mas sob a base de uma ideia dada, que nutriu toda a cinefilia que se seguiu. Se, precisamente, entendemos por cinefilia uma disposição do espírito que traz um reconhecimento ao cinema, como também à literatura, à pintura ou à música, uma capacidade de descrever e penetrar a complexidade e o escopo das relações humanas, de dar forma, pelo meio do filme, às interrogações dos criadores sobre o homem e sobre o mundo e, por fim, de criar ele mesmo seu universo - então Louis Delluc, se ele não, por acaso, "inventou” a própria crítica do cinema, ele foi efetivamente seu pioneiro e profeta (LHERMINIER, 2008, p. 71).
\end{abstract}

Para Delluc, a fotogenia cinematográfica vai especialmente diferir daquela do senso comum ${ }^{120}$ (o simples fato de os atores e atrizes serem "bonitos", "simpáticos", "atraentes", "fotogênicos"), produzindo efeito de estranhamento e maravilhamento por meio da linguagem cinematográfica (enquadramentos, iluminação, cortes, etc.), capaz de ressaltar e amplificar a beleza natural das coisas:

\begin{abstract}
Mas, se continuarmos a querer o "bonitinho", obteremos o "feio". Pudemos perceber isso a partir dos objetos. A beleza da linha de um sofá ou de uma estátua é desenvolvida pela foto, e não criada a partir do nada. Da mesma maneira, os seres e os animais. Um tigre e um cavalo serão muito bonitos sob a luz de uma tela de cinema porque são naturalmente bonitos, e assim se apresenta sua beleza, por assim dizer. Um indivíduo, belo ou feio, expressivo, manterá sua expressão, que a foto vai intensificar se assim o permitirmos (DELLUC, 1953, p. 36) ${ }^{121}$.
\end{abstract}

É Epstein, porém, quem vai deslocar a fotogenia para o âmbito do primeiro plano. Diferentemente de Delluc, para quem a fotogenia residiria no formato escolhido pelo cineasta para revelar a "verdade" do cinema, propiciando, portanto, a criação de filmes inteiramente "fotogênicos", Epstein vai olhar para este conceito como um mero

\footnotetext{
${ }^{120}$ Delluc não criou o termo "fotogenia". Ele já existia na tradição da fotografia desde o século XIX (Cf. LHERMINIER, 2008, pp. 49-50). Porém, é consenso que o crítico e cineasta francês dotou o termo de complexidade e lhe aferiu uma conotação que perdura até hoje. Mesmo assim, como podemos ler no texto laudatório de Léon Moussinac quando da morte de Delluc, a mito de que ele inventou o termo já existia quando ele era vivo : "É que, para além do maravilhamento, Delluc descobriu no cinema uma forma de expressão nova, enfim à escala do sentimento e da razões modernas, de acordo com a vertigem mecânica, a rapidez e a complexidade da vida atual. A esta forma de expressão, ele dá um nome definitivo: fotogenia" (MOUSSINAC apud LHERMINIER, 2008, p. 13. Tradução nossa).

121 Tradução nossa.
} 
lampejo, um instante arrebatador e muito raro, verdadeiro Santo Graal da estética cinematográfica. Somente os mais talentosos artistas conseguiriam produzi-lo:

O primeiro plano é a alma do cinema. Ele pode ser curto, pois a fotogenia é um valor da ordem do segundo. Se ele for longo, não experimentarei um prazer contínuo. Paroxismos intermitentes me emocionam como picadas. Até hoje nunca vi fotogenia pura durante um minuto inteiro. É preciso, pois, admitir que ela é uma faísca e uma exceção que se dá como um abalo. Isto impõe uma decupagem mil vezes mais minuciosa do que a dos melhores filmes, mesmo os americanos. Uma dissecação. O rosto que se prepara para o riso é mais bonito que o próprio riso (EPSTEIN, 1983, p. 278) ${ }^{122}$.

Delluc e Epstein são pioneiros na teoria do cinema, e o conceito de fotogenia, mesmo ainda sendo bastante utilizado, já não possui a mesma pregnância ou sentido do período silencioso, quando foi desenvolvido. Porém, ele ainda pode ser repensado especialmente se não aceitarmos as condições impostas por Epstein (restringindo-o ao átimo de duração e ao primeiro plano), pelas quais o conceito ficou conhecido, e sim retornarmos à formulação mais genérica trazida por Delluc. Nossa ideia é que, sim, a fotogenia persiste, e ainda é fundamental para se compreender a natureza semântica e epistemológica da tela silenciosa, mas é preciso que o fascínio que atribuímos ao primeiro plano "fotogênico" seja transferido aos objetos como um todo, em uma relação de sujeição a partir do silêncio dos filmes. E, em segundo lugar, que a "fotogenia" seja substituída, é claro, por algo mais complexo e rico conceitualmente: a ideia da imagem silenciosa.

A natureza desta imagem se engaja, naturalmente, nos outros conceitos que temos trabalhado para se pensar, ao mesmo tempo, uma epistemologia (ou seja: como ele constrói níveis de conhecimento) e uma etiologia (suas causas enquanto fenômeno) do cinema silencioso, conforme já começamos a desenvolver no capítulo anterior. Para isso, é necessário que segmentemos a experiência do filme silencioso em três níveis elementares que norteiam sua estruturação: o primeiro é a participação do silêncio, enquanto elemento fundante, em sua maneira de comunicar; o segundo, como veremos neste capítulo, é a participação de suas imagens (silenciosas, móveis e isoladas das palavras) enquanto matéria-prima para sua formatação como conhecimento estético; e, por fim, a maneira específica, a natureza própria de seu ato de comunicar, a poesia.

${ }^{122}$ Grifo nosso. 
A imagem especificamente silenciosa é, como se pode ver, um dos pilares para a compreensão a respeito de como o cinema silencioso produz significação, e como essa significação é recebida de maneira diferente (seja como fenômeno estético ou cognitivo) pela percepção do espectador. A ideia de frisar o especificamente silencioso nesta imagem é importante porque, se olharmos para o óbvio, praticamente todas as imagens, historicamente falando, dos bisões de Lascaux, passando pela Mona Lisa, até a fotografia de Daguèrre, são, efetivamente, silenciosas ${ }^{123}$. A imagem falante ou sonora (conforme problematizamos no capítulo anterior) é um fenômeno da modernidade, uma imagem técnica ${ }^{124}$. A imagem do cinema silencioso, no entanto, apesar de seu mutismo que a filia à tradição de uma teoria secular da imagem, é também imagem técnica: sua produção se dá por meio de um aparelho (o cinematógrafo, ou a câmera) que processa reações químicas capazes de revelar, ponto a ponto através da inscrição da luz na película, efígies ou imagens capturadas diretamente da realidade. Flusser diferiria esta imagem à da pintura. Nesta, usamos nossas mãos para produzir volumes que configuram cenas (imagens) bidimensionais (superfícies). Se, ao escrevemos o texto, estamos produzindo linhas (unidimensionais, e processuais), através da conceituação, no caso da imagem técnica partimos de pontos (dados) para procurar emular o mesmo efeito das cenas da imagem não-técnica, mas há uma diferença:

\begin{abstract}
As imagens tradicionais são superfícies abstraídas de volumes, enquanto as imagens técnicas são superfícies construídas com pontos. De maneira que, ao recorrermos a tais imagens, não estamos retornando da unidimensionalidade para a bidimensionalidade, mas nos precipitando da unidimensionalidade para o abismo de zero-dimensionalidade. Não se trata de volta do processo para a cena, mas sim da queda do processo rumo ao vácuo dos quanta. A superficialidade que se pretende elogiar é a das superfícies que se condensam sobre semelhante abismo (FLUSSER, 2008, p. 16) ${ }^{125}$.
\end{abstract}

A substituição do gesto de usar o braço e pintar pelo gesto de apertar teclas e disparar uma programação é, portanto, fundamental para uma substituição de paradigma. Da escrita para a imagem técnica. Da unidimensionalidade para a zerodimensionalidade. A imagem do cinema silencioso, no entanto, assim como a da fotografia, a despeito de sua natureza técnica, ainda se posiciona em um estado

\footnotetext{
${ }^{123}$ Rancière (2003, p. 15. Tradução nossa) vai problematizar o regime das imagens com a ideia provocativa de que "[...] a imagem não é uma exclusividade do visível. Há o visível que não chega a formar a imagem, e há imagens que residem em palavras".

124 "As imagens técnicas são tentativas de juntar os elementos pontuais em nosso torno e em nossa consciência de modo a formarem superfícies e destarte taparem os intervalos. Tentativas de transferir os fótons, elétrons e bits de informação para uma imagem" (FLUSSER, 2008, p. 28).

125 Grifo do autor.
} 
intermediário, ela se situa claramente em um período de transição. Sem a fala, destituída da escrita (mesmo com a presença dos intertítulos, como vimos no caso de Nanook), esta imagem parece guardar ainda a nostalgia de uma primeira fase comunicacional tal qual descrita por Flusser, quando supostamente vivíamos assolados pela "loucura alucinatória das imagens" (MÜLLER, 2012, p. 42). De alguma forma, a imagem do cinema silencioso ainda busca a "magia" da imagem não-técnica, mas, ao mesmo tempo, sua natureza programática a transforma ainda em uma outra coisa, que nos situa em um campo problemático a respeito dos efeitos que este cinema produz. Afinal, a fotogenia, o primeiro plano e a suposta transcendentalidade destas imagens efetivamente se justifica de alguma forma que não apenas um devaneio impressionista? E quanto à vasta maioria do cinema silencioso, com suas imagens ordinárias, meramente voltadas ao entretenimento, carregadas de intertítulos e narrativas lineares? Este cinema também compartilha desta nostalgia "mágica", "alucinatória", ligada à imagem anterior à escrita?

Para se explorar este problema, é necessário seccionar a imagem do cinema silencioso em suas atribuições básicas, ou seja, o que a faz funcionar desta maneira. Em primeiro lugar, temos o silêncio inerente a esta imagens, o que as distancia de uma distração conceitual provocada pelo som e pela fala. Como com os diferentes (já analisados) tipos de distração musical disponíveis no ambiente do cinema silencioso, ou com a presença dos intertítulos, que certamente invocam tipos diversos de discurso que concorrem com o próprio discurso das imagens, é difícil negar a prevalência da imagem muda como principal significante deste cinema. E, ao contrário do cinema falado, onde encontramos um código completo, conceitual e concorrente que ocorre simultaneamente ao processo de significação das imagens, no cinema silencioso há o privilégio de se ver praticamente apenas a imagem, especialmente considerando que o intertítulo - quando o há - aparece sempre antes ou depois da imagem, tecnicamente isolando-a, deixando-a se exibir, deixando-a aparecer com algum grau de pureza.

A imagem do cinema silencioso, portanto, estaria mais próxima de uma expressão solitária da imagem em si. Ela é técnica, constituída a partir de pontos, e sua significação é limitada pela própria programação da câmera, mas, ao mesmo tempo, a imagem deste cinema poderia ser pensada como carregada de ambiguidade, pois se situa entre as imagens técnica e tradicional. Pode-se dizer que, separada do aparato 
cinematográfico, das escalas de montagem, da produção diegética, dos textos, da música, e até mesmo das relações simbólicas, a imagem silenciosa sobrevive ${ }^{126}$. Ressalta-se, nela, algo que poderíamos aproximar da fotogenia, e que Jacques Rancière vai chamar de trop visible (visível demais), ou seja, uma propriedade primária das imagens que se desenvolvem especialmente a partir do Séc. XIX, quando paulatinamente deixam de representar ideias ou conceitos para buscar uma presença que se localiza mais no campo do insondável. Este aspecto se ressalta não apenas na fotografia, onde a programação mecânica da máquina faz aderir ao produto final sempre alguma coisa não-humana, que foge ao controle, mas também na pintura impressionista, obcecada com efeitos do tempo e da luz sobre as imagens, voltando sua atenção ao visível, como também, é claro, no primeiro cinema perpetrado por Lumière, o verdadeiro libertador das imagens, ainda cruas e solitárias, descodificadas, que demandam que se as leiam da forma com que se as deseje (AUMONT, 2004, pp. 2546).

No novo regime, o regime estético das artes, que se constitui no século XIX, a imagem não é mais a expressão codificada de um pensamento ou de um sentimento. Ela não é mais um duplo ou uma tradução, mas uma maneira pela qual as próprias coisas falam e se calam. Ela vem, de alguma maneira, se alojar no coração das coisas como se fosse sua fala muda (RANCIÈRE, 2003, p. 21$)^{127}$.

Esta nova imagem a que Rancière se refere, localizada entre a invenção da fotografia e o advento da cultura de massas, e que proporciona uma paradoxal "fala muda" para as coisas representadas, tem como seu último representante a imagem do cinema silencioso, especialmente se partirmos do princípio de que a imagem somada à fala devolve o furor conceitual (a produção de um "pensamento" ou "sentimento") a estas mesmas imagens. Neste sentido, a imagem do cinema silencioso seria a última, já na beira de uma substituição paradigmática pela irrefreável imagem técnica, a ainda se apresentar como uma "pergunta infinita" (Jean-Luc Nancy) ou como uma "presença bruta e sensível" (Rancière).

\footnotetext{
${ }^{126}$ A noção de sobrevivência poderia ser pensada, aqui, a partir da formulação de Didi-Huberman (2011, pp. 13-4), para quem este tipo de imagem intermitente, plasmada na metáfora do vaga-lume, sobrevive em relação aos grandes espetáculos (no sentido de Débord) imagéticos da grande indústria: “Assim, a vida dos vaga-lumes parecerá estranha e inquietante, como se fosse feita da matéria sobrevivente luminescente, mas pálida e fraca, muitas vezes esverdeada - dos fantasmas".

127 Tradução nossa.
} 
Isso nos leva a uma segunda atribuição básica desta imagem, que é o fato de ela arbitrariamente aparecer sem a palavra. A imagem silenciosa não apenas rejeita a fala e problematiza a palavra, como é hostil a estes sistemas comunicacionais que lhe são heterodoxos, e mesmo análises de base mais semiótica do que sistêmica vão colocar palavra e imagem como formas de linguagem intraduzíveis, conforme podemos ver neste trecho de um verbete "Imagem" (escrito pelo teórico funcionalista da comunicação Elihu Katz) de um dicionário publicado ainda em 1971:

Não há unidades elementares na imagem, pois a imagem significa relacionalmente. Sua significação é dada como tematização dependente da cadeia do significante mas não pode ser articulada teoricamente como o é a linguagem falada. A tradução da imagem visual "fato" na palavra "fato" implica no empobrecimento imagético (KATZ, 1971, p. 165).

As relações estabelecidas pela incompatibilidade de códigos ou de camadas expressivas levantadas por imagem e palavra são profundas e nem sempre tão evidentes. O fato de o acréscimo de fala (mais especificamente do que a palavra) ao cinema ter trazido ao espectador a percepção de uma totalidade corporal (conforme vimos em Doane), quando estes sistemas parecem incompatíveis, parece levantar um pequeno paradoxo. Mas, como vimos, a percepção do silêncio dentro do cinema falado é diferente da percepção da fala no cinema silencioso. Como ainda aprofundaremos esta questão adiante, vale trazer um terceiro e último atributo evidente da imagem do cinema silencioso, que é a sua mobilidade (como, aliás, ocorre em qualquer cinema). $\mathrm{O}$ fato de serem imagens móveis provoca uma inflexão do olhar do espectador, não mais passivo diante da prefiguração estacionada da imagem da pintura ou da fotografia ${ }^{128}$. No senso comum, isto pode parecer um truísmo, afinal, o que encanta nas imagens do cinema é o fato de que elas mimetizam não o aspecto visual, material, do mundo, mas sim a sua temporalidade. Ao ver replicadas as instâncias da temporalidade que governam a vida real, o espectador se identifica com a representação do cinema, já que ela se insere em uma mesma perspectiva fenomenológica ${ }^{129}$. Porém, para além disso, o que o espectador não percebe é que, além da mimese material, e além da mimese temporal, existe a mobilização do olhar, ou seja, a imagem móvel o ativa por dentro. Aumont identifica esta propriedade nas pinturas que procuram escapar do campo representacional, como

\footnotetext{
${ }^{128}$ Logicamente, a noção de movimento pode ser prefigurada tanto para a fotografia quanto para a pintura. Basta pensar nas telas de Delacroix ou Franz Marc. O movimento próprio ao cinema, no entanto, possui natureza muito diferente, conforme desenvolveu Deleuze (1983) a partir de Bergson.

${ }^{129}$ Mais uma vez, conferir Deleuze (2005) e o conceito de imagem-tempo.
} 
no paisagismo do século XIX, e na fotografia, dada como centrífuga (conforme BAZIN, 2003). Ele aplica esta "reeducação do olhar" a partir de Gombrich:

\begin{abstract}
Mas, nesse esforço para apreender, a um só tempo, o momento que foge $e$ compreendê-lo como momento fugidio e qualquer - para se livrar do "instante pregnante" -, o que se constrói é o ver: uma confiança nova dada à visão como instrumento de conhecimento, e porque não de ciência. Aprender olhando, aprender a olhar: é o tema, também gombrichiano, da "descoberta do visual por meio da arte", da similitude entre ver e compreender. O tema do conhecimento pelas aparências, que é o tema do século XIX, e o do cinema (AUMONT, 2004, p. 51).
\end{abstract}

A partir destas três atribuições básicas da imagem no cinema silencioso (o silêncio inerente a estas imagens; a recusa da palavra; e a mobilidade), é possível procurar um funcionamento para ela, buscar a sua maneira de produzir sentido, e pensar em como esta maneira difere do que ocorre no cinema falado. Porém, criar uma oposição entre uma imagem "insondável", que seja a "fala muda das coisas" e que seja uma "pergunta infinita"; e uma imagem "legível", que transcodifique relações e ideias e que se aloje confortavelmente no papel de significante pode ser não apenas redutor, mas inútil. Não apenas Rancière, mas também Dietmar Kamper ${ }^{130}$ e Jacques Aumont ${ }^{131}$ percebem que esta disputa tradicional na maneira como vemos uma possível epistemologia para a imagem (a oposição entre o dizível e o visível) não é adequada para a compreensão de suas dimensões ambíguas e profundas. A imagem, efetivamente, não pode ser encerrada em uma realidade única. Ela gera a expectativa, no mínimo, de uma dicotomia, sobre a qual Rancière se detém intensamente. Além de relações móveis entre o dizível e o visível, a imagem comporta um "discurso que oculta uma história" que existe concomitantemente à sua "presença bruta e sensível" (RANCIÈRE, 2003, p.19). Isso provoca um desacordo entre o que nos afeta (a presença bruta da imagem) e o que nosso pensamento pode dominar (a elaboração do discurso, a hermenêutica). No caso do cinema falado, ainda que possamos pontuar tanto exceções que constituem filmes inteiros (como o caso de Tarkovsky) ou inserções pontuais dentro de inúmeros filmes, fica claro que a inserção de um código ou sistema discursivo como o da fala vai influenciar em uma tomada de posição por parte de suas imagens: quase que com um

\footnotetext{
130“A imagem assume, de acordo com seu significado, três funções: a de presença mágica, a de representação hábil e a de simulação técnica" (KAMPER, 2012, pp. 20-21). Veremos, adiante, os desdobramentos desta assertiva.

131“Uma imagem [...] é, a um só tempo, gato por lebre, ótica e imaginário. Ela é feita para que nos percamos nela - sabendo, ou mais raramente, sem o saber -, e a produção de imagens em nossa cultura "oculocentrista" não é senão o casamento do objetivo com o subjetivo, a indistinção de ambos. Fazer uma imagem é, portanto, sempre apresentar o equivalente de um certo campo - campo visual e campo fantasmático, e os dois a um só tempo, indivisivelmente" (AUMONT, 2004, p. 114).
} 
dever ético em relação aos códigos que o coligam, essas imagens vão escolher o modelo discursivo das imagens para representar.

Ora, a questão é mais complicada em relação ao cinema silencioso. Mesmo que a imagem do cinema falado ressoe também como "insondável" (o argumento de Rancière é justamente que estas atribuições são inerentes, ambas, a qualquer imagem), fica claro que a imagem silenciosa, isolada de seu código rival, se inclina a privilegiar, como expressão, a "presença bruta e sensível", reverberante e "fotogênica" que qualquer imagem exala a partir do momento em que é produzida como uma efígie de mundo, que remete à ausência de seu referente ${ }^{132}$. Isso resolveria nosso problema: 0 cinema silencioso, por ser um sistema "amputado" da fala, dirige-se naturalmente à imagem, que, sem a concorrência de um código explicitamente conceitual, vai se voltar às suas propriedades que não se situam no terreno do dizível, produzindo uma linguagem poética. Por isso, as cinematografias de Murnau, Flaherty, Vertov, Kinugasa, entre tantos outros, estariam isoladas, enquanto arte, do resto da história do cinema, porque, tecnicamente, estes cineastas estariam produzindo suas obras dentro de um medium de natureza muito diferente, que privilegia este estado propriamente poético das imagens.

Porém, concomitantemente, todos estes cineastas, seus filmes e as imagens de seus filmes estão também inseridos na imagem discursiva, provocando a profusão de leituras opostas, contrastantes ou até mesmo gritantemente discordantes, a respeito de seus meios de expressão. É inegável pensar que Murnau, a despeito de seu cuidado valioso com o pulsar de suas imagens, inseria seus filmes em contextos francamente narrativos, "discursivos". Murnau, inclusive, mesmo com toda arte envolvida, considerava que seus filmes eram blockbusters, realizados com muitos efeitos especiais na tentativa de atrair o mercado estrangeiro para o cinema alemão (GARNCARZ, 2004, pp. 389-398). Até mesmo filmes silenciosos muito radicais, de fragilíssima compleição narrativa, como Limite, podem ser interpretados a partir de sua diegese (HERTZ, 2001). E mesmo um filme francamente antinarrativo, como Um cão andaluz, que procura explicitamente ironizar ou parodiar os módulos narrativos de um filme convencional, precisa se reportar (seja como via negativa ou não), à produção discursiva, para produzir

${ }^{132} \mathrm{~A}$ percepção da realidade na mente, segundo Peirce, se configura em termos de signos. "[...] esta relação, como se pode ver, é tripla [...]: um signo se refere a um objeto, e este signo produz na mente de quem o percebe um outro signo, já diferente do primeiro, chamado interpretante" (MARCONDES, 2009, p. 283). 
sua expressão. O que dizer, então, de filmes silenciosos como Robin Hood (Allan Dwan, 1922), com Douglas Fairbanks, e toda produção hollywoodiana e suas histórias mirabolantes, com Greta Garbo, Mae West, Mary Pickford, Lon Chaney, entre tantos outros? O que dizer dos épicos de Cecil B. de Mille? E das inúmeras adaptações literárias? E de Griffith? Rancière, de alguma forma, se antecipa a esta reflexão (mesmo que não fale especificamente do cinema silencioso), e assume que este tipo de conversibilidade entre as propriedades das imagens é inevitável e fatídico:

\begin{abstract}
Mas o semiólogo que lia a mensagem cifrada das imagens e o teórico do punctum [conforme Barthes] que dispensa a frase, se apoiam sobre um mesmo princípio: um princípio de equivalência reversível entre o mutismo das imagens e sua fala. O primeiro mostra que a imagem é, efetivamente, o veículo de um discurso mudo do qual ele se empenha em traduzir em frases. O segundo nos diz que a imagem nos fala no momento em que ela se cala, onde ela não nos transmite mais nenhuma mensagem. Tanto um quanto $o$ outro concebem a imagem como uma fala que se cala. Um fará seu silêncio falar, e o outro fará deste silêncio a anulação de toda fala (RANCIÈRE, 2003, p. 19) ${ }^{133}$.
\end{abstract}

\title{
4.1.2 A ponte: objeto indecidível
}

Neste momento absolutamente indecidível (para pegar emprestado o termo de Derrida) a respeito do que a imagem silenciosa pode produzir, cabe pensar um exemplo bastante conveniente. O filme A ponte (De brug, Joris Ivens, 1928), realizado pelo holandês Joris Ivens já no final da era silenciosa, concentra em suas premissas estéticas os dois princípios de expressão que estamos confrontando (ou fazendo-os coabitar um no outro) desde o início deste capítulo. A ponte foi filmado a partir de ideias mais abstracionistas que Ivens admirava, por inspiração da famosa geração de cineastas experimentais alemães do final da década de 1920, como Eggeling e Richter (pioneiros na animação abstrata) e Ruttman (diretor do célebre Berlin, sinfonia da metrópole, filmado um ano antes e inspiração para o filme holandês). Fazendo parte da Filmliga (liga de cinema de Amsterdã), Ivens entusiasticamente filmou A ponte como um filme de cunho experimental, em que vai desenvolver e problematizar as fronteiras entre o documentário, a narrativa e a poética a ponto de se destacar mundialmente pelo olhar dinâmico direcionado aos objetos e às coisas, ficando ainda mais famoso em seu curtametragem seguinte, Chuva (Regen, 1929).

133 Tradução nossa. 
A ponte dura apenas 14 minutos, mas concentra em sua disposição elegante de imagens e montagem uma grande miríade de abordagens possíveis, graças à beleza enigmática com que o diretor constrói, em filme, seu objeto-tema. Ivens subiu, durante várias semanas seguidas, na ponte Hefbrug em Roterdã - uma grande ponte de ferro, então recém-inaugurada, com capacidade de elevação para a passagem de navios pelo rio abaixo dela, e trens, por cima, quando não está levitada - para captar em filme uma fértil diversidade de ângulos e imagens possíveis e depois reconstruí-la, conceitualmente, por meio da linguagem cinematográfica. Uma sinopse, portanto, é breve no que tange a um discurso narrativo para o filme: Ivens filma a si próprio observando, por diversos ângulos diferentes, a passagem de um trem sobre a ponte. Tanto o trem quanto a ponte são mostrados a partir de ângulos muito abertos, em planos gerais, até à minúcia mais recôndita (engrenagens, parafusos), gerando uma profusão de planos distintos, com um grande aproveitamento da dilatação temporal própria ao cinema. Depois, vemos a ponte espetacularmente ativar seu dispositivo de elevação, soerguendo-se sobre o rio, para acompanharmos a passagem de um navio por baixo dela. Logo após esse momento, a ponte novamente se rebaixa até seu nível normal, enquanto, em cross-cutting, acompanhamos outro trem se dirigir a ela, velozmente, para atravessá-la no final e encerrar o filme.

Vários sinais, incluindo as influências de Ivens, nos indicam que a intenção do cineasta ao filmar a ponte tinha um cunho futurista/construtivista, querendo elevar a filmagem de uma estrutura carregada de maquinário moderno e complexo, cheia de premissas progressivas, a uma espécie de visão pura da velocidade, da tecnologia, da capacidade humana de erguer monumentos, funcionalizá-los, potencializando a velocidade com que a sociedade se desloca e se constrói. Do alto da ponte, Ivens contrapõe a visão da cidade às pessoas diminutas, funcionando como insetos operários e ressaltando a fragilidade humana diante de suas realizações (FIG. 60). Esta visão construtivista da relação homem/máquina não era exatamente uma novidade no cinema silencioso. Ela havia sido trabalhada em 1924 por Léger (Ballet Mécanique), e seria constantemente reaproveitada por Vertov. Ao mesmo tempo, ao evidenciar o caráter maquinal do filme, Ivens, naturalmente, quase por via negativa, chama a atenção para o que diferencia nós, humanos, dos objetos como as pontes, os trens e os navios, acionando um princípio de ontologia. Antes de entrar neste mérito, porém, cabe compreender por que $A$ ponte funciona estruturalmente como uma micronarração, não 
contando a "história" de um trem, uma ponte e um navio, mas sequenciando o detalhamento operacional a respeito de como se pode construir, a partir da decupagem fílmica, e em especial da montagem analítica, a trajetória de um mecanismo. Isso pode ser percebido logo em suas primeiras imagens, e, digamos, em sua primeira "cena" (é difícil pensar neste termo considerando que não se trata de um filme ficcional): após um primeiro contato com um desenho da ponte (FIG. 61) para, logo depois, visualizarmos a "verdadeira" ponte (FIG. 62 - lembremos que a ponte do filme é também uma imagem), logo notamos que vamos adentrar no "mundo" deste objeto (a ponte) quando Ivens se aproxima novamente dela através de um corte seco, analítico. Logo depois, vemos quatro planos alternados que mostram o próprio cineasta empunhando a câmera (FIG. 63 - em primeiro plano e depois em close-up), deflagrando possíveis conotações: "isso é um olhar"; “isso é olhar humano”, “isso é um olhar humano, porém cinematográfico"; "de que maneira o olhar cinematográfico modifica o olhar humano, e, por extensão, a coisa cinematografada"?
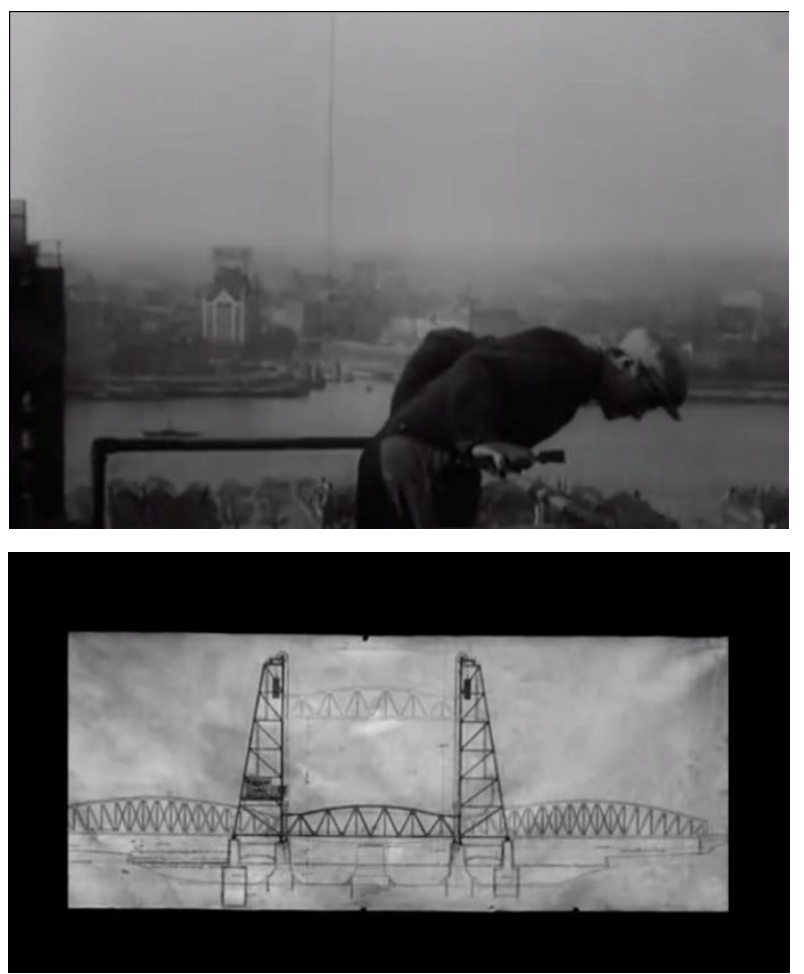

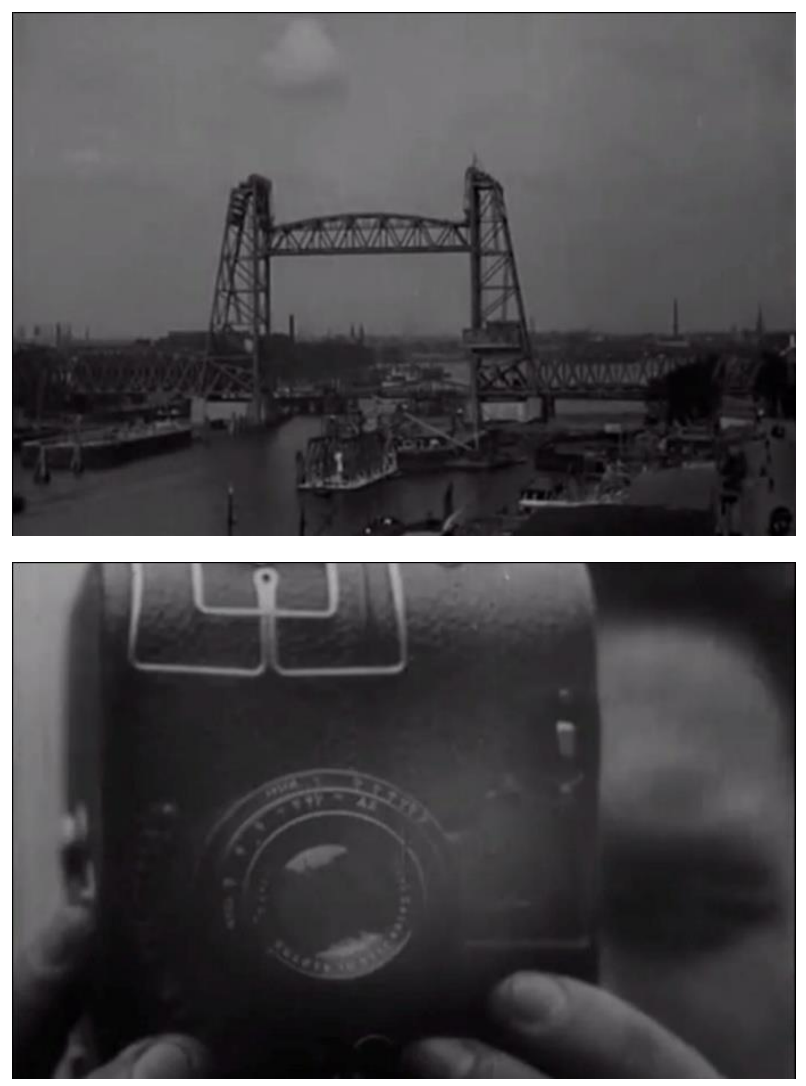

Figuras 60 a 63

O que se segue, nesta primeira sequência, é uma profusão de planos que se aproximam do abstrato, com a câmera alojada na frente do primeiro trem, ou em suas janelas, "observando" aspectos da própria ponte ou dos arredores. Ao mesmo tempo, como por uma lógica inversa, da própria ponte observa-se o trem, e, a partir de ângulos ainda mais dinâmicos, observa-se a ponte ao longe, ou a cidade, ou o rio. Esquadrinhase o ambiente, e aquela realidade, tanto sua paisagem quanto seus objetos, é retalhada. Percebe-se, pela presença do cineasta e da câmera no próprio filme, assim como com a naturalidade com que são amalgamados os cortes (o retalhamento desta realidade), que A ponte pode ser lido, facilmente, como um jogo de espelhos reflexivo sobre a própria operacionalidade do cinema, e este jogo é o que condiciona sua narratividade, seu "discurso que oculta uma história”. Isso fica mais claro se apenas nos voltarmos brevemente para um desdobramento semântico dos signos que compõem o quadro geral do filme. Ponte, trem e navio são, inegavelmente, em sua mais pura essência funcional, meios de passagem, meios de transporte. Antes de qualquer coisa, meios (media), como o próprio cinema. Novamente, McLuhan: 
Pois a "mensagem" de qualquer meio ou tecnologia é a mudança de escala, cadência ou padrão que esse meio ou tecnologia introduz nas coisas humanas. A estrada de ferro não introduziu movimento, transporte, roda ou caminhos na sociedade humana, mas acelerou e ampliou a escala das funções humanas anteriores, criando tipos de cidades, de trabalho e de lazer totalmente novos (MCLUHAN, 1964, p.22) ${ }^{134}$.

Esta realidade mcluhaniana traduz bem a fetichização que Ivens propõe para sua visão compartimentada das máquinas e dos objetos. A narração que se estabelece no filme é a do funcionamento da engrenagem, a articulação parafusada da ponte, dos freios do trem. Poucos filmes traduzem uma visão tão límpida (ainda que poética) do próprio processo da medialidade, metaforizado. Isto fica particularmente visível na cena de elevação da ponte (FIG. 64), situada exatamente no meio do filme, em que todo o procedimento mecânico (incluindo aí a força humana) arregimentado para conquistar o notável efeito se torna detalhado e minucioso. Cada grão de engenharia, cada etapa do planejamento, é elucidado por meio da dialética da montagem, bem à maneira soviética. Diante de tamanha minúcia e, ao mesmo tempo, com tamanho efeito de estranhamento, já não podemos acreditar que este filme trate pura e simplesmente de uma ponte. A colossal elevação nos faz crer que estamos diante de categorias abstratas, como ideias platônicas, não de uma elevação da ponte, mas a noção em si da elevação. É neste momento que percebemos que essa abstração narrativa (a "história da elevação", ou a "história da mecânica", ou ainda a "história da medialidade") coloca A ponte em uma fronteira bastante difícil de definir em termos de representação, afinal, o que se narra aqui é a microrrepresentação de um mundo abstrato e invisível. A sequenciação fílmica coloca em causa a potência das coisas e do mundo em si, incluindo suas relações e situações de causa e efeito. A ponte parte, portanto, de uma fagulha narrativa para logo adentrar em situações metafóricas e metonímicas, dimensionando-se cada vez mais em direção a situações de percepção sutil e volúvel. Quando, em meio à nossa distração, percebemos efetivamente o que estamos vendo, notamos que estamos no campo da poesia, e não mais no da narrativa.

${ }^{134}$ Grifos nossos. 


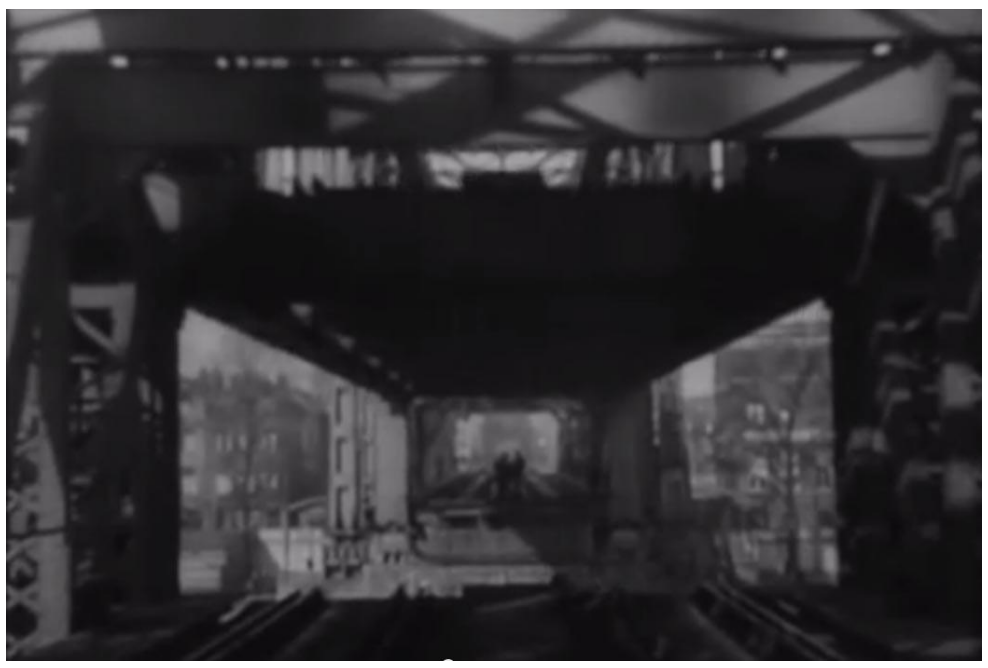

Figura 64

E é este segundo sentido, para além de um simples comentário sobre a modernidade, que nos interessa. O cineasta deixa claro que não está simplesmente replicando a tendência futurista quando apresenta o filme, em sua primeira imagem, como um desenho, um rascunho da própria ponte, que, em um belo raccord, se transforma na imagem da própria ponte a partir de um corte simples. Já de partida, portanto, Ivens nos comunica que está falando sobre as efígies das coisas, sobre a passagem do referente ao signo, sobre as imagens, propriamente ditas, e seus objetos. Neste sentido, a velha noção da fotogenia se atualiza para uma dimensão não mais propriamente palpável. Não se trata apenas de um deslumbramento quase "místico" provocado pela amplificação de um rosto (como se pudéssemos atravessá-lo e chegar na "alma" do personagem). A fagulha que a ideia da fotogenia despertou nos primeiros teóricos do cinema talvez esteja mais associada ao universo poroso da localização imprecisa da imagem dentro do processo da representação. O próprio Rancière não reconhecia uma natureza apenas dupla (quanto mais simples) da imagem. Não apenas qualquer imagem aporta consigo sua dimensão "legível” e sua dimensão "sensível", como também uma terceira valência, chamada "arquissemelhança" (archiressemblance, Cf. RANCIÈRE, 2003, pp. 16-17), que suplanta a alternância entre os universos da analogia (visível) e o da dessemelhança (dizível) para produzir uma espécie de síntese toda nova a respeito da imagem em si, uma espécie de interpretação que expressa o locus originário de onde a imagem provém, para além de sua dicotomia básica. Talvez seja efetivamente isso, uma espécie de arquissemelhança, que a ponte de Joris Ivens comunique em última instância. Não se trata, necessariamente, de um comentário sobre a modernidade, ou sequer um comentário sobre a medialidade. 
Também não se trata do objeto em si, a ponte, já que ele não pode ser resgatado pela imagem, seja em filme, seja no olho da mente ${ }^{135}$. A tessitura poética do filme só pode ser captada, efetivamente, dentro da própria natureza paradoxal da imagem e sua relação escorregadia com seu objeto, levando-nos a uma proposição mais propriamente bergsoniana (FIG. 65). Para isso, vale recordar a própria e intrigante definição que o filósofo dá à imagem em si:

A matéria, para nós, é um conjunto de "imagens". E por “imagem" entendemos uma certa existência que é mais do que aquilo que o idealista chama uma representação, porém menos do que aquilo que o realista chama uma coisa - uma existência situada a meio caminho entre a "coisa" e a "representação" (BERGSON, 2010, pp. 1-2).

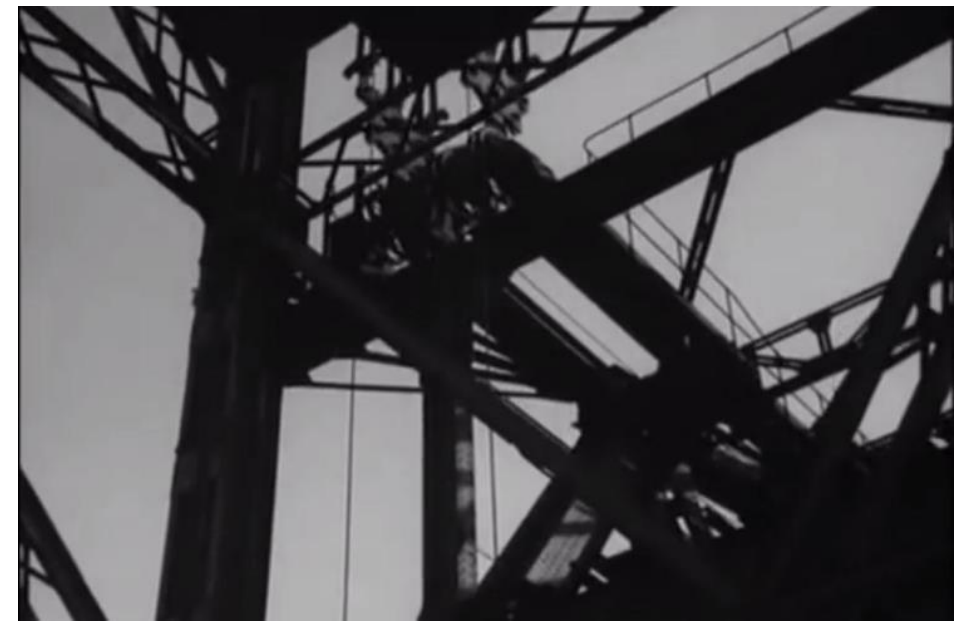

Figura 65

Bergson claramente situa a imagem em um “entrelugar”. Não se trata da imagem idealista, platônica ${ }^{136}$, desacreditada porque inferior dentro de uma "escala de verdade". A ponte de Joris Ivens, portanto, não é apenas a sombra de uma ponte, um pálido reflexo. Ao mesmo tempo, ela continua ausente, não é também o extremo que Bergson associa a um certo realismo que confunde a imagem com a própria coisa, associação esta que certamente limaria qualquer capacidade que a imagem tem em se exprimir, já que não pode se distinguir da realidade. Para o filósofo, este entrelugar é o locus da matéria, espécie de plasma de imagens, que é e não é a sua "coisa" ao mesmo tempo, conceito que gerou o "campo de imanência" deleuziano. Bergson afirma que estamos

\footnotetext{
${ }^{135}$ Richard Allen e Murray Smith, comentando a teoria do cinema a partir de Derrida, o explicam: "A presença de um objeto no olho da mente é assegurada apenas pela presença de algo - o significante material - que, por definição, está ausente" (ALLEN; SMITH, 2005, pp. 86-7).

${ }^{136}$ Vale lembrar a própria definição de Platão, francamente representacional, para a imagem: "Denomino imagens primeiramente às sombras, depois aos reflexos que se veem nas águas, ou na superfície dos corpos opacos, polidos e brilhantes, e a todas as representações semelhantes" (PLATÃO, 1999, p. 222).
} 
submersos neste mundo de imagens que ao mesmo tempo nos conecta (através da imagem seminal do próprio corpo) e nos afasta da realidade. O processo de recortar estas imagens, de segmentá-las para além de seu fluxo imanente, ou seja, criar a realidade a partir do ato de separá-la de suas imagens (especialmente por meio da memória) é que seria o ato fundacional de nossa experiência com o mundo. "Para transformar sua existência pura e simples em representação, bastaria suprimir de uma só vez o que a segue, o que a precede, e também o que a preenche, não conservando mais do que sua crosta exterior, sua película superficial” (Idem, p. 33).

Criar a representação (uma das valências da imagem, que seria a própria imagem platônica), portanto, para Bergson, significa extrair esta película superficial da matéria, ou seja, descolar a imagem de seu locus originário. Reencontrar este locus, colocar a imagem de volta em contato com a matéria é que seria encontrar a arquissemelhança de que fala Rancière. Em cada imagem representacional, e especialmente em cada imagem silenciosa, destituída de uma malha de códigos que a levam para lugares cada vez mais abstratos, é que vive ainda sua arquissemelhança. Em uma leitura francamente transcendental, agora, radicalmente diferente da leitura construtivista ou da leitura estruturalista, a ponte de Joris Ivens busca sua arquissemelhança, sua função enquanto matéria bergsoniana, não apenas por repousar as imagens aos olhos do espectador, mas também por reoperacionalizar nosso processo de aquisição da consciência. Se, para instaurarmos nossa experiência com o mundo, precisamos operar uma estrutura de corte e montagem em relação à matéria e às imagens, o cinema, voltando-se para um objeto e retalhando-o para sublimar sua capacidade representacional, está também chamando a atenção para este processo humano de reconhecimento da realidade. É assim, neste difícil e abstrato jogo de recorte e duplicação do mundo a partir da realidade, que $A$ ponte constrói seu discurso poético:

Toda imagem é interior a certas imagens e exterior a outras; mas do conjunto das imagens não é possível dizer que ele nos seja interior ou que nos seja exterior, já que interioridade e a exterioridade não são mais que relações entre imagens. Perguntar se o universo existe apenas em nosso pensamento ou fora dele é, portanto, enunciar o problema em termos insolúveis, supondo-se que sejam inteligíveis; [...] Para solucionar o debate, é preciso encontrar primeiro um terreno comum onde se trava a luta, e visto que, tanto para uns como para outros, só apreendemos as coisas sob forma de imagens, é em função de imagens, e somente de imagens, que devemos colocar o problema. Ora, nenhuma doutrina filosófica contesta que as mesmas imagens possam entrar ao mesmo tempo em dois sistemas distintos, um que pertence à ciência, e onde cada imagem, estando relacionada apenas a ela mesma, guarda um valor 
absoluto, o outro que é o mundo da consciência, e onde todas as imagens regulam-se por uma imagem central, nosso corpo, cujas variações elas acompanham (Ibid. p. 21).

A noção bergsoniana de que uma imagem é exterior e outra interior, regulada pelo nosso corpo, ecoa nas diversas visões que qualificam o conceito de imagem como eminentemente plural, duplo, triplo, polissígnico, jamais podendo ser referido como uma coisa só. Estas oposições entre ver e dizer, ser e representar, ciência e consciência são modelos difíceis, paradoxais, de leitura das imagens. Se, como vimos em Rancière, cada um destes polos igualmente concebe a imagem como uma fala que se cala, é inevitável que pensemos que a imagem muda do cinema silencioso vai se voltar, necessariamente, à sua própria natureza epistemológica, ao contrário da imagem do cinema falado, que vai mergulhar cada vez mais fundo na instância da representação platônica. É por isso que, neste momento, cabe a nós nos afastarmos um pouco da imagem cinematográfica para nos aproximarmos da pintura modernista, mais especificamente a de René Magritte, para encontrarmos um modelo de imagem que, à sua maneira, também comporta a etiologia do cinema silencioso, demonstrando que o conhecimento trazido por este cinema não é exclusivo dele, mas sim pertence à imagem que o comporta.

\subsection{O cinema silencioso de Magritte}

Une image peut parfois mettre son spectateur en accusation grave - Magritte ${ }^{137}$

\subsubsection{Imagem, abismo e ficção}

René Magritte ficou famoso não apenas pelo vasto e intrigante corpus de sua obra em pintura, mas também por escrever a respeito do que pintava. Sua preocupação ao verter sua obra em palavras não toca apenas uma investigação a respeito da natureza do sentido, mas era também uma prática (ou melhor: uma práxis) que não somente complementava sua pintura, mas também a subvertia, realizando uma inversão de procedimentos. "Eu faço uso da pintura para tornar os pensamentos visíveis" (MAGRITTE apud PAQUET, 1992, p. 45), dizia ele, possivelmente querendo indicar que suas telas são transfigurações de mecanismos do pensamento, reprocessando suas

137““Uma imagem pode, às vezes, colocar seu espectador em acusação grave” (Tradução nossa). 
partes operacionais a partir de um código imagético. Da mesma maneira, Magritte fazia intenso uso da palavra em sua maneira de se expressar, fosse escrevendo irônicos ensaios e manifestos (muitas vezes parodiando o estilo mandatário de André Breton), fosse fazendo aproveitamento plástico dela, pintando as letras nos próprios quadros, fosse atribuindo títulos enigmáticos (que desafiam a interpretação) a eles. Além disso, o que é mais surpreendente, Magritte eventualmente escrevia pequenas descrições (poéticas?) dos quadros, em uma tentativa conscientemente vã de processar uma linguagem através da outra (imagem pela palavra e vice-versa). Em seu momento mais radical, ele chegou a escrever descrições pitorescas para quadros que nunca pintou, como se aquele conjunto de palavras fosse um gerador de imagens invisíveis, sempre metamorfoseáveis. Talvez esteja aí a imagem ideal para Magritte: aquela que nunca chega a ser pintada, porque inscrita no código compulsório da escrita.

Magritte possui uma relação com a linguagem do cinema silencioso. Como pintor que viveu o auge das vanguardas heroicas nos anos 1920, ele compartilhou do entusiasmo que outros artistas, como Duchamp e Man Ray, nutriram pela forma de arte que nascia, chegando a pintar algumas telas que a referenciavam. Mas o interesse em relacionar o cinema silencioso com a arte de Magritte vai além da sua própria devoção por ele. Para começarmos a pensar esta questão, temos de observar justamente a maneira com que o pintor olhava para seus próprios quadros, e que tipo de expressão buscava ao problematizar tanto uma configuração do corpo humano quanto a localização das palavras em sua obra.

\footnotetext{
Meus quadros foram concebidos para serem signos materiais da liberdade do pensamento. É por esta razão que eles são imagens sensíveis que não desmerecem o Sentido. Poder responder à questão "qual é o 'sentido' destas imagens?" corresponderia a levar o Sentido, o Impossível, a um pensamento possível. Estar tentando a responder esta questão seria reconhecê-la como tendo um "sentido" válido (MAGRITTE, 1994, p. 122) ${ }^{138}$.
}

O sentido (que o pintor gostava de grafar com "s" maiúsculo), portanto, para Magritte, repousa no campo do impossível. Não que ele o negue (o sentido), mas era-lhe mais atraente que o pensamento aparecesse como sua prioridade representacional, ou seja, é possível pintá-lo (o pensamento), justamente porque ele está coligado ao campo do possível, enquanto o sentido pertence a algures. Magritte estava interessado, à maneira de Wittgenstein ou Richard Rorty, no que era possível fazer com o possível. O

\footnotetext{
138 Tradução nossa.
} 
pensamento, por ser uma operação, é calculável, transmissível, traduzível. Daí uma primeira aproximação da expressão de Magritte com o cinema: ambos são meios (em todos os sentidos), e não finalidades. A pintura em Magritte funciona como uma máquina de produzir permutas entre o dizível e o visível, reexaminando as possibilidades de organização destes mecanismos intolerantes: a palavra e a imagem. Sua pintura poderia até realmente rebelar-se contra a produção de sentido da arte mimética, naturalista e acadêmica que o precedeu, mas ao mesmo tempo não era uma demolição, plasmada no irracional, do sentido conforme defendido pelos dadaístas. Magritte estava, justamente, interessado em efeitos de recepção estética causados pela sobreposição e superimposição de relações como a imagem e seu reverso, a imagem e a palavra, a imagem da imagem. Vale, neste caso, citar a famosa reflexão de Foucault, intencionalmente confusa, a respeito da tela Os dois mistérios (Les deux mystères), de 1966 (FIG. 66). Ela trazia pintado o já famoso quadro A traição das imagens (La trahison des images, de 1928, com o cachimbo e sua famosa legenda: "isso não é um cachimbo") sobre um cavalete, que, por sua vez, se afixava em um chão de tábuas de madeira. Fora dele, diante de uma parede cinza, paira um outro cachimbo, grande e imperioso, como que "flutuando" no ar. É de se ressaltar a intensidade com que Foucault mergulha nos possíveis mistérios destes "dois mistérios":

\footnotetext{
Mas isto é ainda apenas a menor das incertezas. Eis outras: há dois cachimbos. Não seria necessário dizer, em vez disso: dois desenhos de um mesmo cachimbo? Ou ainda um cachimbo e seu desenho, ou ainda dois desenhos representando cada um deles um cachimbo, ou ainda dois desenhos dos quais um representa um cachimbo mas o outro não, ou ainda dois desenhos que, nem um nem outro são ou representam cachimbos, ou ainda um desenho representando não um cachimbo, mas um outro desenho que, ele, representa um cachimbo, de tal forma que sou obrigado a perguntar: a que se refere a frase escrita no quadro? Ao desenho, debaixo do qual ela se encontra imediatamente colocada? "Vejam esses traços agrupados sobre o quadronegro; por mais que possam se assemelhar, sem a menor discrepância, a menor infidelidade, àquilo que está mostrado lá em cima, não se enganem com isso: é lá em cima que se encontra o cachimbo, não neste grafismo elementar." Mas talvez a frase se refira precisamente a esse cachimbo desmedido, flutuante, ideal - simples sonho ou ideia de um cachimbo. Será necessário então ler: "Não busquem no alto um cachimbo verdadeiro; é o sonho do cachimbo; mas o desenho que está lá sobre o quadro, bem firme e rigorosamente traçado, é este desenho que deve ser tomado por uma verdade manifesta" (FOUCAULT, 1988, p.13).
} 


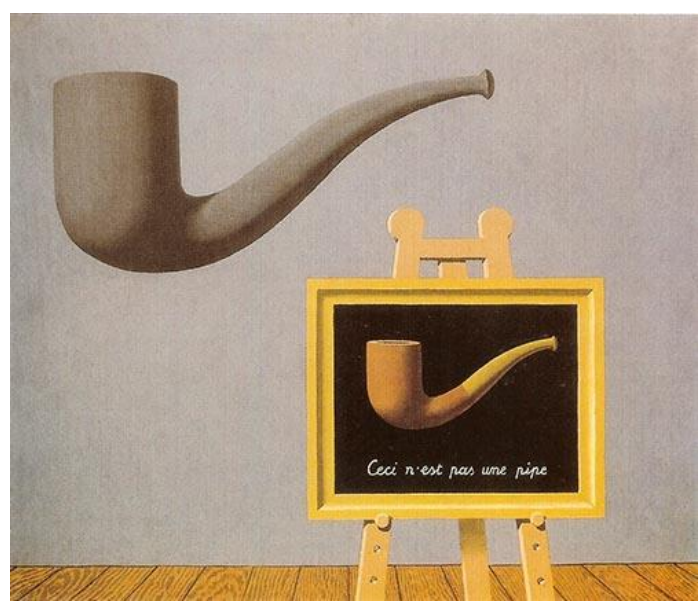

Figura 66

Magritte discute, como se argumentasse por comparações lógicas, envolvendo proporção, tamanho, posição, relação, inscrição, etc., o estatuto da imagem nesta tela. Foucault vai argumentar, depois, que o "enquadramento" da tela original era sua prisão, seu vínculo a um mundo terreno, feito de materialidade (a moldura, o cavalete, a tinta, o giz), e que sua mensagem era a de que existe, "lá fora", um outro cachimbo, mais etéreo, ideal, "simples sonho ou ideia de um cachimbo". Como em O boulevard do crime, $O$ gabinete das figuras de cera ou A ponte, a relação entre cachimbos em Dois mistérios se estabelece emmise-en-abyme: um cachimbo olha para o outro, um deles sendo um quadro material, famoso e localizável na realidade, e o outro sendo uma imagem fantasmática deste cachimbo, procurando libertar-se de suas atribuições históricas e "terrenas". O que acontece, porém, e percebemos rapidamente a ironia, é que o segundo cachimbo também é uma imagem, que também se transforma em uma inscrição histórica e material, e também se converte em uma ficção, ainda que uma ficção da ficção, que já era, digamos, a "lição" de A traição das imagens. A realidade inteira, para Magritte, está sempre em abismo, e a imagem, conforme também vimos em Bergson, está sempre arrolada na própria realidade, não sendo "representação" ao mesmo tempo em que não é “coisa”. Em Magritte, a imagem é a imagem de sua própria medialidade, em uma relação não muito diferente daquela que analisamos em $A$ ponte.

Vejamos, porém, mais, e que tipo de relações estas características da obra e do pensamento de Magritte guardam com o cinema silencioso. No quadro Reprodução proibida (Reproduction interdite), de 1937 (FIG. 67), ele pinta um homem, bem vestido com um sobretudo, olhando-se no espelho. A imagem que o espelho reflete, no entanto, não é o seu rosto, mas suas costas. O ponto de vista do personagem é o mesmo do 
nosso, com a diferença de que o nosso está duplicado: vemos suas costas, e o vemos vendo suas costas. O truque, ou talvez fosse melhor dizer a engenharia da realidade, operada por Magritte nesse caso não difere da de Dois mistérios: da mesma maneira vemos uma imagem duplicada, sendo que uma delas está enquadrada (o espelho; a moldura) e a outra assume a "responsabilidade" de corresponder de alguma forma a um mundo "ulterior" que não representa uma mera cópia (o homem "original"; o cachimbo “etéreo"). Porém, em ambos os casos, o objeto que se pretende "representante da realidade" é também uma imagem, a imagem do próprio quadro em si. Ou seja: se olharmos para a imagem, a imagem nega a nós mesmos. A ideia de Magritte, para qualquer um capaz de abstrair um pouco mais esta relação, é a de que aquele que olha o quadro real (ou seja: nós mesmos) é também uma imagem que se pretende realidade, replicando indefinidamente esta cadeia mediática, revelando que a realidade efetivamente se costura na mediação e por fim concordando com Bergson, para quem nós mesmos somos uma imagem mediada pela imagem do nosso corpo. Para o filósofo, até mesmo nosso cérebro, antes de ser o produtor fisiológico das imagens, é uma imagem criada por outras imagens (2010, p. 39).

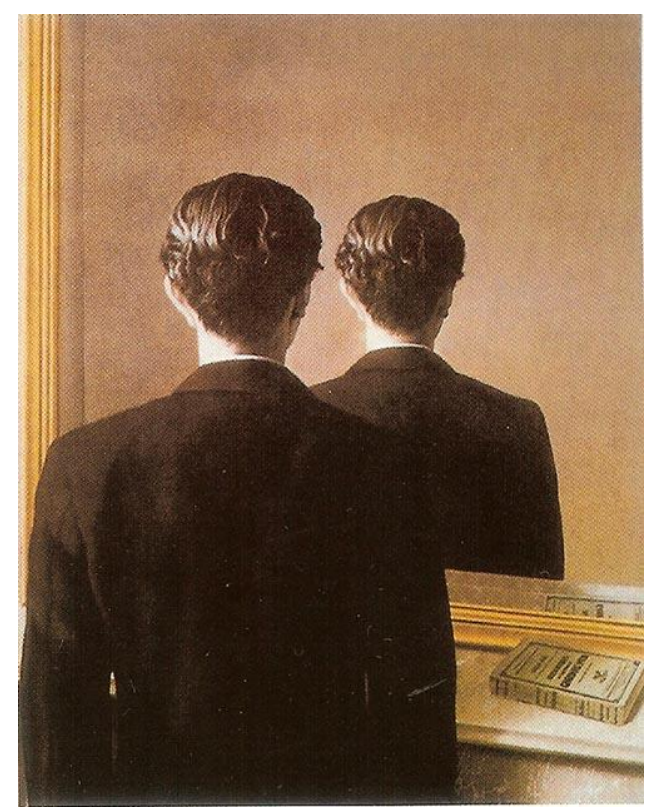

Figura 67

Ainda que Reprodução proibida tenha sido pintado antes de os Seminários de Lacan serem realizados, não deixa de ser curiosa a atitude antipsicanalítica da tela, tanto em um sentido freudiano (como se dissesse que, quanto mais olhamos para dentro de nós, mais distantes estamos de nós mesmos), quanto negando a possibilidade de o 
espelho representar algum tipo de unificação psíquica em torno de um ego ou de uma Lei, instaurando não uma ilusão de totalidade para o nosso comportamento psicológico, mas sim um tipo de disfunção fragmentária, ou seja, um tipo de descorporificação, como vimos em Doane em relação ao cinema silencioso. Negar a psicanálise (PAQUET, 1992, p. 25), remando contra a maré do surrealismo "doutrinário" de Breton ou Dalí (adeptos do freudismo), é sinal de que Magritte estivesse pensando, talvez de maneira niilista, em uma ausência fundamental não apenas no que tange a um centro emulsionador de pulsões psíquicas (como pensaria Lacan), mas também em uma ausência de qualquer unidade na própria superfície. Seria impossível diferenciar a imagem da realidade, e uma imagem de outra imagem. Neste sentido, talvez fosse mais sensato aproximá-lo a Nietzsche, para quem, de maneira completamente contrária a Platão, a imagem é verdade, e, por trás da imagem, não há nada.

\begin{abstract}
Ao revelar-se, um objeto esconde-se simultaneamente, funcionando portanto como cortina para outro. Magritte estava sempre profundamente consciente desta tentativa de manter o equilíbrio entre a revelação e a ocultação. As coisas têm um lado irreverente, um reverso, que é ainda mais curioso e fascinante do que sua forma evidente, a fachada que apresentam, o rosto; e foi este reverso, este lado negro, que Magritte captou tão sutilmente e tornou visível, desafiando toda a lógica (Idem, p. 29).
\end{abstract}

O fato de Magritte colocar, dentro destes quadros, outros quadros (o espelho, a moldura), é muito significativo. Como em $O$ boulevard do crime, como em $O$ gabinete das figuras de cera, como em A ponte e como em (como veremos) Fantômas, há um meio dentro do outro, há um medium processando outro, há uma fagocitação de uma forma pela outra. Pensando, ao mesmo tempo, a noção de quadro para o cinema e para a pintura, Jacques Aumont vai dar a este termo três funções básicas, e claras (2004, pp. 112-13): o quadro-objeto, que representa a própria moldura ou aspecto material que é exterior ao quadro (no caso do cinema, a própria escuridão representaria o quadroobjeto); o quadro-limite, que representa o limite visual da imagem dentro do quadro (o que, em cinema, chamamos campo $^{139}$ ); e o quadro-janela, que representa uma função um pouco mais abstrata: a de atribuir uma "vista" ou "visão" à imagem enquadrada, podendo encadear sentidos, projetando o olhar, incitando o imaginário.

\footnotetext{
139“'A imagem de filme é percebida, a um só tempo, como uma superfície plana (real) e como um fragmento de espaço em três dimensões (imaginário) (Arnheim, 1932). O campo é a porção de espaço tridimensional que é percebida a cada instante na imagem fílmica" (AUMONT; MARIE, 2003, p. 43).
} 
Magritte é especialmente hábil em problematizar estas três concepções de quadro de uma só vez. Basta olhar para um de suas telas mais famosas, jocosamente entitulada A condição humana (La condition humaine - ele gostava de atribuir nomes literários às suas obras - FIG. 68), de 1935. Aqui, vemos uma parede bege com um portal abobadado dando vazão à visão de uma praia e do mar. Dentro deste quarto há também um cavalete e uma tela, cujo conteúdo é justamente... a visão de uma praia e do mar, continuamente alinhados com seu duplo na "realidade exterior", reproduzindo o efeito fractal já analisado nos dois quadros anteriores. A questão aqui é que, estendendo o quadro na paisagem "real" situada de fora do quarto, Magritte desmonta a perspectiva Renascentista ao alinhar os pontos de fuga, tanto do mar exterior, na "realidade", quanto do interior da pequena tela, dentro de uma mesma dimensão. Aqui, portanto, o quadroobjeto (o exterior da tela no cavelete) não defere interferência em relação ao seu exterior, eliminando também a função do quadro-limite, cuja fronteira se estende até o que está de fora do quarto. Isso propicia uma interpretação toda nova para o quadrojanela, mostrando que a "visão" de uma instância enquadrada e outra "real" são absolutamente intercambiáveis e perpassáveis uma pela outra, especialmente considerando que a "realidade exterior" também se encontra enquadrada pelo próprio portal, que, por sua vez, encontra-se enquadrado pelo limite da própria tela $A$ condição humana. Por mais que Magritte não gostasse que se interpretassem seus quadros a partir dos títulos (a função do nome de um quadro, para ele, era de amplificar a disjunção, e não de complementaridade ${ }^{140}$ ), é difícil não arriscar que a tal condição humana seja justamente a que está sugerida no esquete representado na tela: nosso próprio filtro é mais uma tela enquadrando uma "realidade" que não passa de uma imagem enquadrada por outra imagem ${ }^{141}$. Ora, a ideia de que o sentido pode ser empurrado de um lado para o outro é próprio da linguagem do silêncio. No final das contas, Magritte põe perguntas paradoxais, no limite do indecifrável, levando o pensamento à sua fronteira com o "impossível".

\footnotetext{
140" Os títulos são escolhidos de tal maneira que impedem de situar meus quadros numa região familiar que o automatismo do pensamento não deixaria de suscitar a fim de se subtrair à inquietação" (MAGRITTE apud FOUCAULT, 1974, p. 47).

${ }^{141}$ Neste sentido, vale lembrar uma curiosa declaração do diretor Wim Wenders no documentário Janela da alma (Walter Carvalho, João Jardim, 2001). Para ele, usar óculos lhe trazia uma vantagem como cineasta, pois ele já via o mundo "enquadrado". A mesma relação pode, facilmente, ser estendida ao nosso olhar virgem, e é muito possível que fosse a isso que Magritte se referia ao pintar A condição humana.
} 


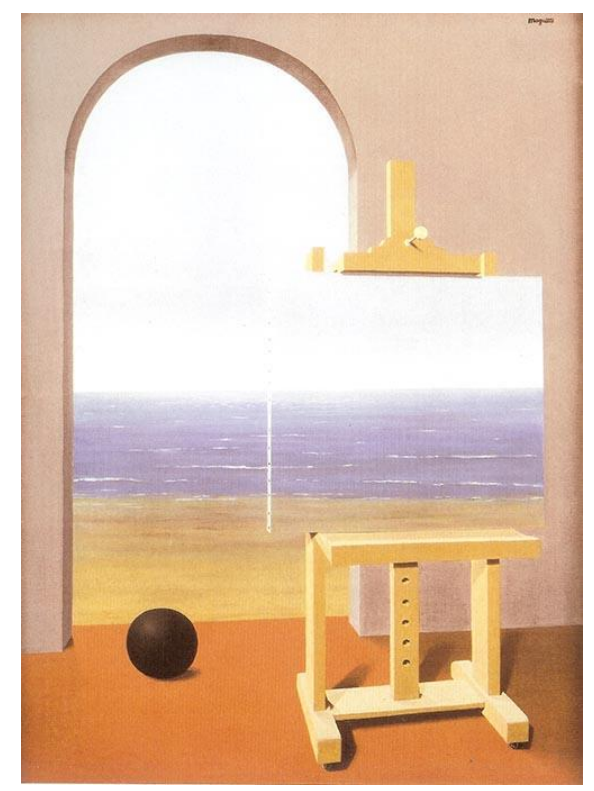

Figura 68

O abuso da estrutura em abismo aproxima o gesto de Magritte daquilo que percebemos até aqui a respeito do cinema silencioso. Conforme já refletimos sobre as possibilidades duais, tríplices ou polivalentes das imagens, enquanto a imagem do cinema falado invoca uma percepção representacional e platônica, fundamentalmente centrífuga (conforme lhe atribuía Bazin), a imagem silenciosa possui a tendência (centrípeta) em se voltar às suas próprias contingências epistemológicas enquanto imagem, e, nesse sentido, o gesto de Magritte é idêntico ao do cinema silencioso. Ao mesmo tempo, Magritte apelava para a imagem como fenômeno de descorporificação (enquanto duplicação da percepção no medium), algo que também atribuímos à amputação-extensão sentida, mas não racionalizada, pelo espectador do cinema silencioso. Por fim, conforme veremos, Magritte estabelecia, entre a palavra e a imagem, uma cisão radical, tantas vezes ironizada tanto em suas telas quanto em seus textos, algo também já problematizado em relação ao cinema silencioso.

A opção do pintor belga por acenar o mesmo gesto do cinema silencioso não pode, ser é claro, uma coincidência. Nascido no interior da Bélgica, país dividido em duas culturas que são conhecidas por não se tolerarem (os Flamengos, no norte, e os Valões, no sul - daí talvez a obsessão do pintor em desencaixes e incompatibilidades), Magritte divide sua carreira passando por três cidades: o início na pequena Charleroi, onde começou como pintor derivado do cubismo; a ascensão e imersão no surrealismo na pacata Bruxelas; e o salto cosmopolita em Paris, onde conheceu e se juntou ao grupo 
histórico dos surrealistas, de quem se desvinculou justamente para voltar a Bruxelas e pintar vivendo em idiossincrático solipsismo. Este comportamento pacato, recluso e individualista de Magritte se enquadra no aspecto misantropo do estereótipo do fã de cinema, o cinéfilo, criatura obcecada por seu próprio refúgio, enclausurado em sua própria janela. É sabido que Magritte era entusiasta do cinema silencioso (HUGHES, 2009, p. 7; PAQUET, 1992, p. 29), e chegou a dedicar vários quadros ao tema, como $O$ regresso da chama (Le Retour de flame, 1943), em que representa o anti-herói Fantômas, célebre personagem de seriados da década de 1910 dirigidos pelo lendário Louis Feuillade; ou O cinema azul (Le cinéma bleu, 1925), ainda na fase cubista, em que representava graficamente o tema de sua paixão; e, é claro, a célebre tela Homenagem a Mack Sennet (Hommage a Mack Sennet, 1937), em que ele pinta um robe de dormir, com seios, dentro de um armário, imagem de erotismo perturbador. $\mathrm{O}$ sentido da tal "homenagem" ao famoso comediante canadense-americano, mestre da pantomima da década de 1910 e que influenciou profundamente Chaplin, é bastante obscuro.

É em Fantômas, porém, que podemos encontrar um elo mais forte entre a arte de Magritte e o cinema silencioso. Filmado como uma franquia de cinco episódios de aproximadamente 60 minutos cada, Fantômas é visto hoje como um precursor das séries de TV, já que os filmes previam continuidade entre si e deixavam pistas que só seriam resolvidas nos episódios sucessores. Conforme vimos no Capítulo 2, Louis Feuillade, hoje considerado um dos principais estetas do cinema da década de 1910, realizou outras séries de filmes famosas, como Os vampiros e Tih Minh (1919). Fantômas é a primeira série de filmes realizada pelo diretor, e seu primeiro episódio data de 1913. Toda a série é baseada em um conjunto de livros pulp publicados a partir de 1911 pelos escritores Marcel Allain e Pierre Souvestre. Como se sabe, Magritte era fanático por literatura policial, especialmente Poe (PAQUET, 1992, pp. 39-41), e Fantômas arrastou milhões aos cinemas entre 1913 e 1914, no mundo inteiro, graças às tramas policialescas vividas pelo anti-herói pérfido que rapidamente tornou-se muito mais carismático do que seus antagonistas, o detetive Juve e o jornalista Jérôme Fandor. De fato, o personagem Fantômas é um criminoso que em tudo antecipa o panorama de anti-heróis controladores, mentes brilhantes e malignas, que operam impérios do crime, e que iriam se alastrar pelos anos 1910 e 1920, como ocorre em As aranhas, Dr. Mabuse, O gabinete do Dr. Caligari, etc. O primeiro Fantômas, é claro, tendo sido 
lançado pela Gaumont (na época, um das maiores companhias cinematográficas do mundo e, de certa forma, no auge do cinema silencioso francês) em 1913, carece de certa estrutura narrativa com a qual o espectador contemporâneo está acostumado. Há pouca decupagem analítica, ausência de campo/contracampo, pouca angulação fechada e ausência da montagem alternada. Todas estas ausências fazem com que Fantômas se sobressaia pela mise-en-scène fílmica (diferente da teatral, conforme argumenta Bordwell), com interessante aproveitamento dos cenários e da (ainda primitiva) profundidade de campo, além, é claro, dos enredos elaborados a partir de uma linearidade bastante racional. Esta estilística, própria dos anos 1910, especialmente no cinema francês (nos Estados Unidos, nesta época, Griffith já trabalhava com os três níveis básicos de montagem: alternada, analítica e em contiguidade), ficou conhecida como cinema tableau, e tem Feuillade como seu maior representante.

Para além de uma estética especialmente arrojada, Fantômas é uma série que trabalha dois fatores que são de interesse para se conhecer a obra de Magritte e sua aproximação com o cinema silencioso: em primeiro lugar, a ordenação da trama ${ }^{142}$, sempre elaborada segundo um encadeamento de causas e efeitos, muitas vezes mirabolantes (FIG. 69 - e que Fritz Lang imitaria flagrantemente na série do Dr. Mabuse), que de alguma forma remetem ao pensamento tornado visível a que se refere constantemente Magritte. Se os quadros do pintor belga não são imagens punctum $^{143}$, ou seja, que arrebatam, de uma vez, por uma propriedade especialmente fotogênica (o que talvez os distanciassem do que falamos até aqui sobre o cinema silencioso), e nem perpetuam uma noção de movimento particularmente espetaculosa (são basicamente estruturas congeladas no tempo, o que também os difere do cinema), é no encadeamento de pequenas tramas metafísicas, pequenos jogos de encaixe e desencaixe estabelecidos entre os elementos do quadro, que Magritte e Fantômas podem estabelecer um solo comum. Telas como $O$ assassino ameaçado (L'assassin menacé, 1926, FIG. 70), em que o pintor parece querer relacionar passado, presente e futuro de um assassinato em

\footnotetext{
${ }^{142}$ Neste caso vale lembrar o termo propriamente narratológico, conforme denominação de Bordwell (2005, p. 278): "Syuzhet: Termo do formalismo russo que designa a apresentação sistêmica dos eventos da fábula no texto". Os arranjos do syuzhet em Fantômas, portanto, é que são importantes para se pensar as tramas sugeridas nos quadros de Magritte.

143“"A esse segundo elemento que vem contrariar o studium chamarei então punctum; pois punctum é também picada, pequeno buraco, pequena mancha, pequeno corte - e também lance de dados. O punctum de uma foto é esse acaso que, nela, me punge (mas também me mortifica, me fere)" (BARTHES, 1984, p. 46).
} 
uma mesma imagem, criando uma narrativa a partir de figuras estáticas, parecem confirmar estas ideias. Aqui, cada elemento do quadro antecipa-se a outro, como se a cena representada, por mais que não contenha movimento, fosse um cálculo de probabilidade quântica em que, a cada peça modificada no panorama da cena, muda-se a configuração geral de seus desdobramentos, tanto anteriores quanto posteriores. Dispositivos como este indicam que Magritte admirava a capacidade que o cinema tem em estabelecer programas narrativos, sequências e confirmações de hipóteses, algo que ele levaria para um plano ainda mais profundo em sua obra madura, criando verdadeiras “arapucas" metafísicas a partir das relações entre objeto e realidade.
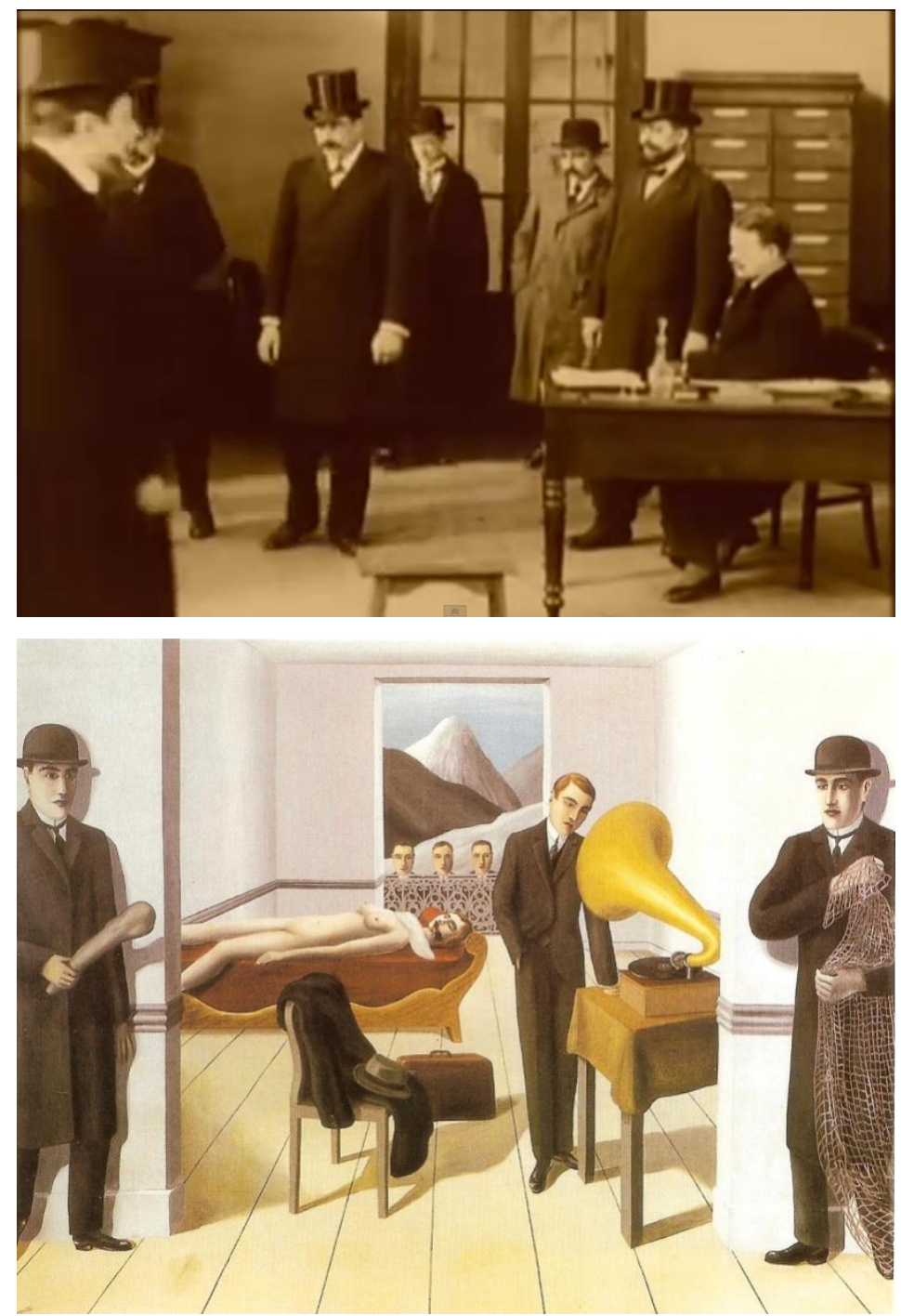

Figuras 69 e 70

Em segundo lugar, Fantômas e seu caráter absurdo, misturando planos mirabolantes, escapadas inacreditáveis, personagens maníacos e comportamentos 
exóticos, certamente tinha a capacidade de impressionar e talvez iluminar as ideias de artistas e poetas como, além de Magritte, Apollinaire, Robert Desnos e Alain Resnais. Este último chegou a afirmar (BORDWELL, 2010) que, além das tradicionais vias abertas por Lumière (realismo) e Méliès (fantasia) para pavimentar a estrada do cinema, houve também a terceira via aberta por Feuillade, que justamente combinava a sobriedade do primeiro com os excessos do segundo, criando uma cinematografia de realismo assombrado. Um pequeno olhar para o primeiro episódio de Fantômas (que originalmente é autoentitulado, mas, depois, passou a ser conhecido também por um subtítulo: À l'ombre de la guillotine- "À sombra da guilhotina") pode nos revelar alguns procedimentos que se assemelham à maneira com que Magritte produzia sua expressão.

O enredo do filme é simples, ainda que tenha seus desdobramentos difíceis: o vilão Fantômas (René Navarre), após praticar um roubo espetacular, passa a se disfarçar como um certo cavalheiro chamado Major Gurn, com a ajuda da ambígua Lady Beltham (René Carl). Porém, após ser investigado pelo astucioso Comissário Juve (Edmond Bréon), Gurn, ou melhor, Fantômas, é preso. A história se torna célebre e passa a ser encenada no teatro pelo grande ator Valgrand (Volbert), que, coincidentemente, é muito parecido com Fantômas. Condenado à guilhotina, o vilão arquiteta seu plano: através de subornos e sequestros, Lady Beltham consegue libertar Fantômas e colocar Valgrand, entorpecido, para morrer em seu lugar. No final das contas, Juve consegue salvar o ator de teatro, mas perde a pista de Fantômas. O final do filme é emblemático: Juve, obcecado com sua "presa", tem uma visão de Fantômas e corre para agarrá-lo, mas abraça uma ilusão, que desaparece no ar.

A presença de um mestre dos disfarces e de várias atitudes falsárias que invocam mudanças repentinas na trama, assim como a de personagens que são confundidos com outros, ilusões que parecem reais, etc., já seriam motivos suficientes para se considerar que Fantômas possui algo de magritteano. Alguns elementos pontuais, entretanto, chamam ainda mais a atenção. O filme abre já com algo inusitado: um primeiro plano do ator René Navarre, ou seja, o próprio Fantômas, bem vestido e de cara limpa, com o olhar percorrendo a tela de maneira suspeita. Esta imagem é seguida de uma fusão para Navarre agora ostentando longa barba e bigodes. O truque se repete mais duas vezes, com outros disfarces (FIG. 71). Assim como em $O$ grande assalto de trem, quando o 
primeiro plano não tinha serventia, em Fantômas a utilização desta angulação também se restringe a apresentar o personagem, sinistro, a partir destas primeiras fusões. Ao contrário do filme de Porter (em que o primeiro plano parece completamente deslocado), entretanto, aqui as imagens da abertura traduzem a essência do personagem e seu mecanismo: a metamorfose, o truque, a transmutação, o engodo, a ilusão, a imagem $^{144}$. Talvez não seja exagero comparar esta deformação do retrato (essencialmente renascentista) com as formas ridículas (ou, no mínimo, auspiciosas), que Magritte cria para este mesmo gênero de pintura em telas como A grande guerra (La grande guerre, 1964), em que substitui o rosto da mulher retratada por um buquê de flores, ou O princípio do prazer (Le principe du plaisir, 1937), em que o rosto dá lugar a uma lâmpada luminescente. Esta anulação da subjetividade, seja apagando o rosto, seja transformando-o em mil coisas diferentes (e, portanto, em coisa alguma), tem a ver com a substituição de uma motivação psicológica, essencial, interior das obras por uma mais intencionalmente superficial, que se organiza no plano das operações do mundo, na afirmação da imagem, tanto interior quanto exterior, como ausente de um referente no mundo material. Isso se casa com um certo "Manifesto do amentalista", flagrantemente irônico, escrito pelo próprio Magritte pra afirmar a impossibilidade de que algo seja pensado fora dos limites do que é criado na mente. Eis as principais "diretrizes" do manifesto:

1) TUDO SE PASSA NO NOSSO UNIVERSO MENTAL [...]

2) NÃO NOS É POSSÍVEL TER QUALQUER COISA QUE SEJA, EXCETO TER O UNIVERSO MENTAL [...]

3) A NOÇÃO DA EXISTÊNCIA DO A-MENTAL É A ÚNICA QUE PODEMOS TER A RESPEITO DO ASSUNTO DO A-MENTAL (MAGRITTE, 1994, pp. 75-6) $)^{145}$.

\footnotetext{
${ }^{144}$ Este mesmo recurso (a fusão de rostos que se transmutam) voltaria a ser extensivamente utilizado por Eisenstein em filmes como A greve (Stachka, 1925), onde o rosto dos personagens se funde à imagem de animais, provocando um efeito simples de montagem de atrações kuleshoviana. Já em um filme como Limite a fusão do rosto com mãos e olhos tem a função de representar o todo simbólico da obra. No primeiro caso, a fusão é metáfora. No segundo, metonímia. Em ambos os casos, poesia.

145 Tradução nossa.
} 


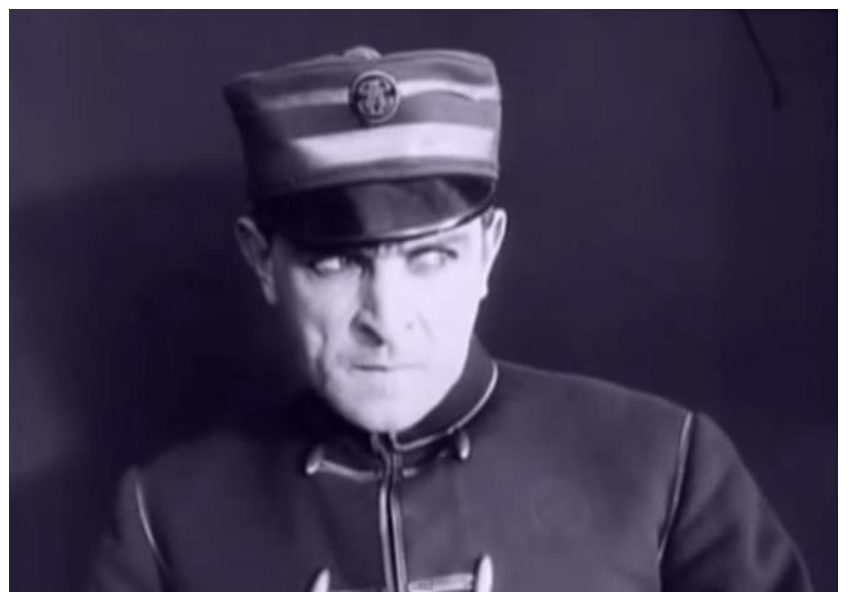

Figura 71

De Münsterberg (2004) a Arnheim (1960), passando por Merleau-Ponty (2003) ou Morin (2003), é possível elencar uma grande quantidade de teóricos que associaram, de uma forma ou de outra, as atribuições do cinema a nosso universo "mental"; que pensassem que, de alguma forma, o cinema ou replica as funções da mente, ou se modula conforma suas contingências, ou estabelece uma permuta perceptiva entre ela e os filmes. Esta permuta, essencial para se pensar o cinema silencioso justamente porque prevê um material mental desorganizado e despedaçado, entra no debate complexo a respeito da ficção, da capacidade, absolutamente antirracionalista, de se perceber que este universo mental não pode penetrar em certa "verdade" do mundo, que não pode unificá-lo em um parâmetro sólido, estruturado. A mente, que, como afirma Magritte, não pode dizer nada a respeito do que é a-mental, precisa criar e recriar constantemente seus próprios parâmetros, elaborando constantemente sua capacidade ficcional, literalmente reconcebendo e reconfigurando o mundo, como forma de lidar com uma "realidade" inacessível. A mente, neste sentido, feita de imagens, não pode ser senão imagem de si própria, e certamente não a imagem representacional, platônica, que finge ser o que não é, mas uma imagem volátil, gasosa, capaz de se condensar, de se diluir, de se solidificar. Não é à toa que pintores surrealistas como Dalí e De Chirico trataram de criar um imaginário cheio de formas opacas que se diluem, que derretem, que assumem a forma de plasma. Magritte certamente acompanha seus colegas neste quesito, mas, sempre cínico, retira o componente épico destas obras, tornando-as prosaicas, modulações do cotidiano mental.

Com sua técnica seca e prosaica, Magritte pintava objetos tão ordinários que eles poderiam ter saído diretamente de um manual de imagens: uma maçã, um pente, um chapéu coco, uma gaiola de pássaros, uma rua cheia de casas de subúrbio, um homem de negócios vestindo um sobretudo escuro, um nu 
fleumático. Seu repertório de imagens, em seus detalhes, não continha, na verdade, mais objetos do que os que um funcionário público belga médio veria no fim de um dia ordinário do ano de 1935 (HUGHES, 2009, p. 7) ${ }^{146}$.

Não é de se surpreender, portanto, que Magritte se interessasse por algo, como o cinema dos anos 1910, considerado espúrio e vulgar, ridículo entretenimento de massas. O primeiro filme de Fantômas também não deixa de apresentar sua própria relação com este patamar de ficcionalidade imbuído no pensamento e na obra de Magritte. Um primeiro sinal é a presença, uma vez mais, de uma instância mise-en-abyme, conforme já detectamos em tantos trabalhos analisados até aqui e que aparece como uma espécie de corolário de toda a obra do pintor belga. No meio do filme acompanhamos o célebre ator Valgrand interpretar o próprio Fantômas, o que, como sabemos, resultará em sua própria desgraça. Feuillade filma a cena de uma perspectiva bastante longínqua, o que deixa evidente o contraste entre a cena dramática (do teatro) e a cena cinematográfica. Bordwell aponta estas sutilezas (BORDWELL, 2010), chamando atenção à tênue percepção do diretor a respeito do jogo de ilusões que se estabelece entre a ficção e a realidade na trama detetivesca de Fantômas. Se não chega a ser um William Wilson ou um mito grego, o filme tem outras maneiras de se fazer perceber algo que aponta para uma indissolução entre imagem e verdade, entre ficção e realidade. Estamos falando, é claro, da cena final, quando Juve literalmente vê o vilão, corre atrás dele e, no momento em que consegue agarrá-lo, percebe que estava agarrando o nada (FIG. 72).

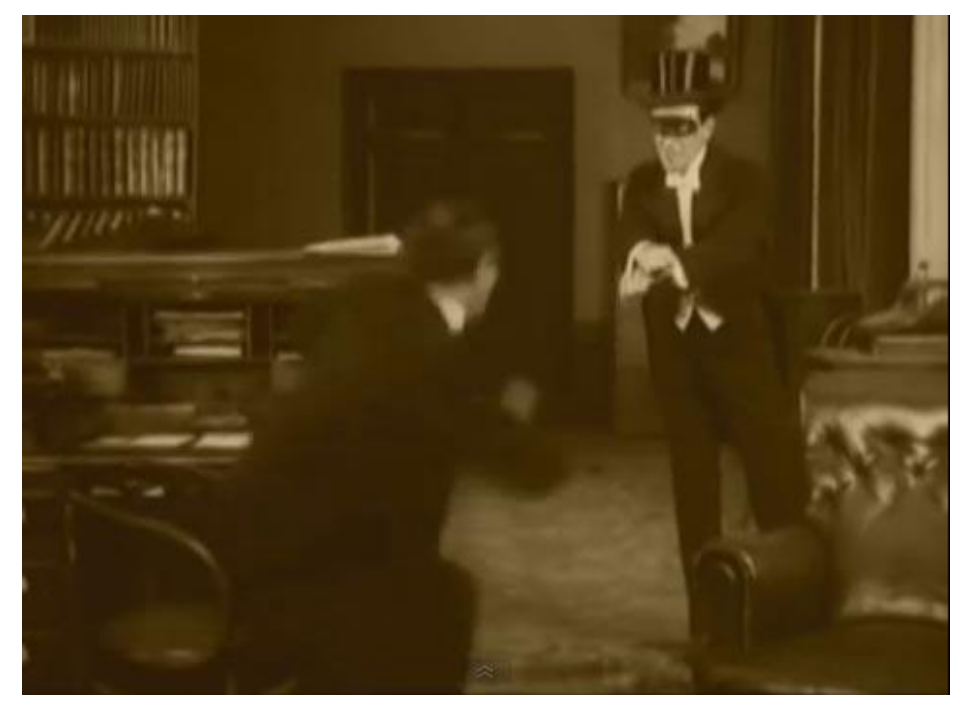

Figura 72

146 Tradução nossa. 
Dietmar Kamper problematiza esta relação entre imagem e ficção. Para o pensador alemão, o principal problema envolvendo esta fronteira fluida entre verdade, imagem e ficção consiste em uma ambiguidade (como, aliás, é de praxe em qualquer problema relativo ao conceito de imagem): enquanto a imagem continua sendo signo imprescindível à nossa condição de existência (afinal, somos feitos delas), ao mesmo tempo o fluxo irrefreável de imagens e ilusões destrói qualquer possibilidade de representação. Ou seja: sem a representação, não temos capacidade de nos ancorarmos em qualquer coisa, de aferir verdade, de aferir sentido. Tanto Magritte quanto o cinema silencioso se encontram no epicentro desta encruzilhada. O cinema silencioso, ao mesmo tempo em que pode ser última imagem tradicional, é também aquela que aponta para o nascimento definitivo da imagem técnica. O número incalculável de filmes realizados durante os aproximadamente 40 anos desta forma de expressão (60 milhões de americanos iam ao cinema por semana nos anos 1920) demonstra que, além de ser epistemologicamente um duplo desfigurado de nossa unidade mental e corporal, este cinema foi também o que promulgou a libertação definitiva das imagens técnicas, tornando-se o primeiro grande fenômeno da cultura de massas do século XX. Magritte, por sua vez, compartilhando um gesto que se assemelha ao deste cinema ${ }^{147}$, promove sua ficção caótica baseada em estruturas micronarrativas que emulam dispositivos mágicos, fractais, autorreferentes, buscando certo autismo representacional ao mesmo tempo em que reafirma a condição mesma dos objetos enquanto potências ônticas. "Os homens não vivem hoje no mundo. Eles não vivem nem mesmo na língua. Eles vivem em suas imagens, nas imagens que fazem do mundo, deles mesmos e dos outros. Eles vivem mais mal do que bem nesta imanência imaginária" (KAMPER, 2012, p. 21) ${ }^{148}$.

Uma das telas em que Magritte melhor procura sistematizar este mecanismo que se estabelece entre imagem, objeto e ficção é Perspicácia (La Clairvoyance, de 1936 (FIG. 73). Aqui, vemos o pintor realizando um autorretrato. Ele pinta a si mesmo, pintando. E pinta a si mesmo pintando e olhando para um ovo sobre uma mesa. Porém, o que se vê na tela que Magritte pinta dentro deste quadro é a imagem de um pássaro. Fica claro o dispositivo do interpretante: o que vemos do objeto não é aquilo que o objeto é, porque aquilo que o objeto é sequer existe. Uma imagem, processada por um

\footnotetext{
${ }^{147} \mathrm{E}$ que se constrói em um mesmo locus mediático, a poesia, conforme veremos no próximo capítulo: daí a importância de se analisar dois fenômenos - Magritte e o cinema silencioso - que se formulam dentro de um mesmo patamar de percepção, na mesma época.

${ }^{148}$ Grifos do autor.
} 
meio (o olho do pintor) é, naturalmente, um outra imagem, aferida a partir da potência ôntica da imagem anterior. Porém, mais uma vez irônico, Magritte certamente estabelece que sua própria imagem é também um ovo que se transforma em pássaro quando processado por outra imagem, que é o próprio meio. Quando pinta a si mesmo pintando uma imagem que é volúvel, o artista afirma que ele próprio é também uma imagem volúvel, pintada (vamos pensar à maneira dos surrealistas) por sabe-se lá o quê (alhures). É notável que Magritte aplique tanto esforço de racionalidade (o tal mental) para depois afirmar-se contra a produção de sentido. O fato é que Magritte não nega o sentido, mas, como vimos, enquadra-o no campo do impossível. Porém, mesmo sabendo que não alcançará o sentido, ele investe enorme energia no ato de buscar o sentido (o pensamento), criando seus sistemas autopoiéticos e fractais, que dizem respeito apenas a eles mesmos, algo compartilhado também por um artista como Escher. Sem dúvida, por mais que Magritte instaurasse todo tipo de interrogação em seus jogos de pensamento, ele não oferecia qualquer resposta, ao contrário de Kamper, para quem a dispersão total em um mundo imagético alucinado era francamente deletéria. "As imagens são, sob essa perspectiva, substitutos do que falta, do que está ausente, sem, no entanto, jamais atingir a dignidade daquilo que substituem" (Idem, p. 25).

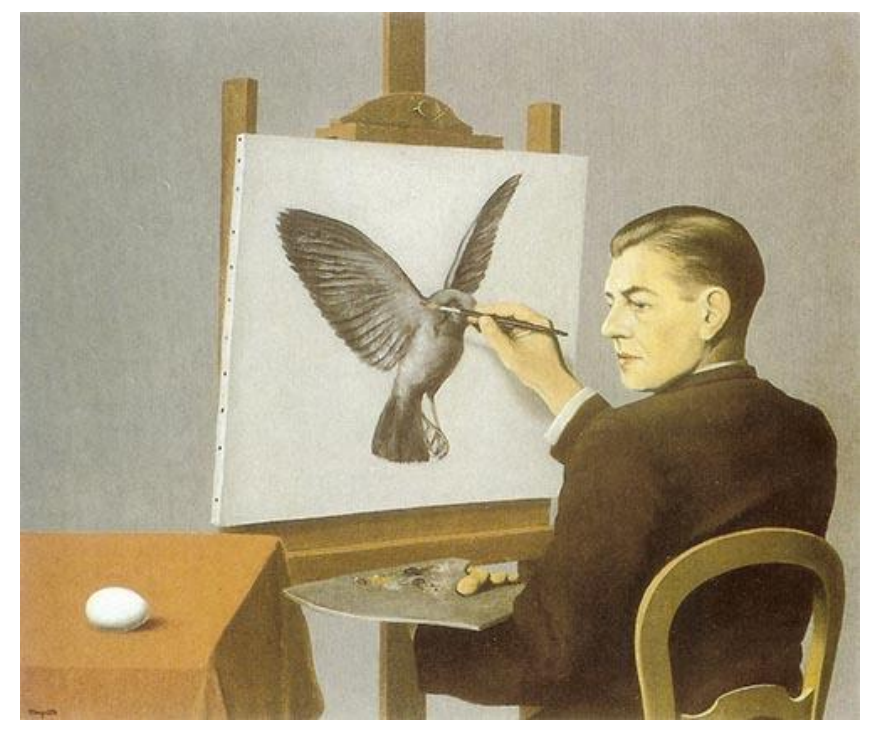

Figura 73

\subsubsection{Imagem, corpo e palavra}

Além do que já foi explanado até aqui, os motivos que mais fortemente relacionam a obra de Magritte ao cinema silencioso como um tipo de operação 
epistemológica própria à época de ambos são dois: primeiro, a necessidade que o pintor tinha em problematizar objeto e corpo, na maioria das vezes destituindo-o de sua falsa unidade, retalhando-o conforme a operação psíquica que detectamos no cinema silencioso a partir de Doane. Em segundo lugar, Magritte potencializa a fricção entre palavra e imagem, separando-as em universos antagônicos (usando principalmente de ironia, mas também de outras figuras de linguagem), e justapondo-as para evidenciar sua disjunção, conforme observamos, a partir de Derrida, no cinema silencioso ao analisarmos $O$ gabinete das figuras de cera. Mas como isso se dá? Como amplificar a leitura que podemos fazer do objeto e do corpo a partir de Magritte, para além do já discutido na sessão anterior?

O quadro Ligações perigosas (Les liaisons dangereuses, 1926 - FIG. 74), um dos mais enigmáticos do pintor belga, traz pistas a respeito de como Magritte procurava problematizar não apenas o corpo humano (e, em consequência, sua duplicação psíquica na representação da arte pictórica), mas também o ato de se observar, o ato de olhar. Com o título inspirado no famoso romance epistolar de Pierre Choderlos de Laclos, que é um inventário de confissões e manipulações amorosas (e eróticas) na corte francesa do Séc. XVIII, o quadro suscita o tema do desejo, mas não apenas. Vemos uma mulher nua segurando um grande espelho, que lhe cobre parte do rosto, o tórax, o abdômen e toda a sua cintura. $\mathrm{O}$ espelho, um objeto que serve como suposta autorrevelação, aqui ocorre como instrumento de censura. Espera-se, em condições naturalistas, que o espelho revele alguma coisa, no entanto. Espera-se que ele revele o espectador (ou seja: nós mesmos), mas o que ele revela, na tela, é uma imagem revertida da própria mulher que segura o espelho, mostrando, de costas, o que estava sendo ocultado por ele. A imagem é intrigante. À maneira de Foucault, poderíamos pensar em vários destinos para uma leitura desta tela. O espectador vê o que deseja ver, e, portanto, vê no espelho o que a mulher deseja esconder? A tela poderia indicar que uma imagem guarda sempre seu reverso, ou seja, que, quando nos olhamos no espelho, a imagem negativa de nossa superfície é o que efetivamente emerge, para além do reflexo que esperamos ver? $\mathrm{O}$ desejo pode ser também um tipo de imagem, refletido em todas as vezes que olhamos para nós mesmos? Ao olharmo-nos no espelho, reconstruímos nosso corpo de acordo com a perspectiva de nosso desejo? 


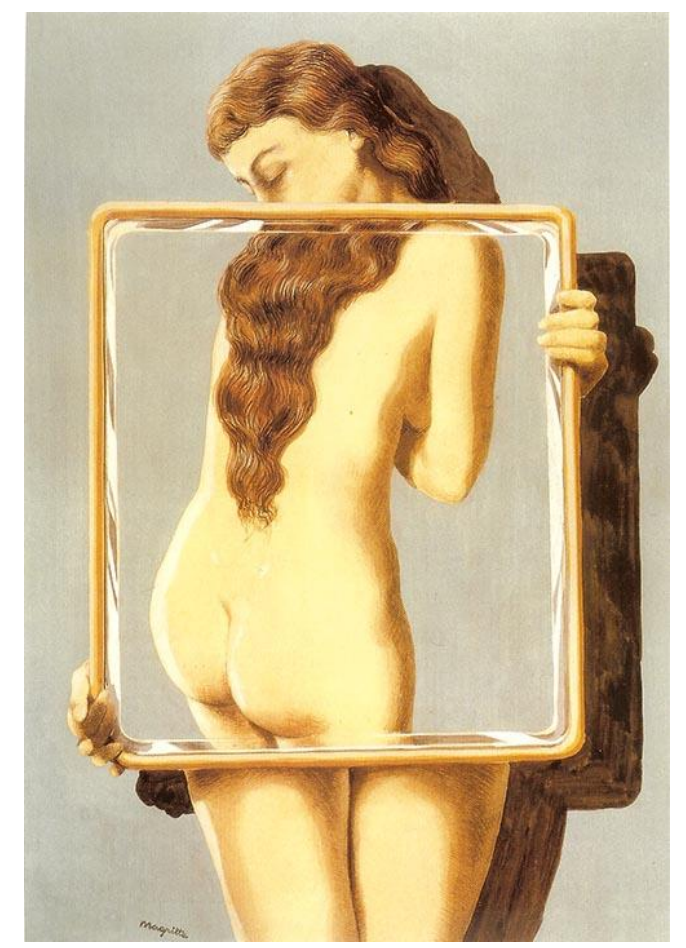

Figura 74

O jogo poderia prosseguir, abundantemente. Sendo um dos quadros mais complexos de Magritte no que tange às relações entre imagens e seus duplos (para além da mera mise-en-abyme e das relações fractais analisadas anteriormente), Ligações perigosas poderia facilmente ser pensado do ponto de vista psicanalítico (o desejo, o espelho...), mas nos interessa mais, de acordo com nosso contexto, pensá-lo de um ponto de vista comunicacional. Esta imagem parece querer dizer algo, assim como Perspicácia, a respeito do observador que é observado, e da natureza da observação em si. Se, em Perspicácia, o pintor se autorretrata observando um objeto e pintando outro, indicando um fluxo volátil da imagem em si através dos filtros mediáticos, em Ligações perigosas a posição observacional é ainda mais complexa. Observamos a imagem refletida no espelho, mas que não nos reflete, e sim reflete a o reverso da imagem que a mulher segurando o espelho quer esconder. Como em Perspicácia, há um ato de observar a observação, mas neste caso, observamos o espelho, objeto que, por definição, devolve de volta para nós a observação enviada. Porém, a observação que vem do espelho não é o que enviamos. É um ponto cego daquilo que queríamos observar, atrás do espelho. Afinal, o que o espelho reflete não é a nudez frontal da mulher, mas sim suas costas. O conflito paradoxal não é facilmente respondível, e nem possui tal intenção (é Magritte), mas ele nos é útil a partir do momento em que parece 
substituir as categorias de sujeito/objeto ${ }^{149}$ pelas de observador/observado, ou "observador que observa a observação", tal qual aponta Luhmann para o ato comunicacional. Ciro Marcondes Filho, ao explanar sobre o pensamento sistêmico do pensador alemão, explicita estas ideias:

\begin{abstract}
Em vez da dualidade sujeito/objeto (ontológica, criando ilusão da realidade), de um mesmo objeto estar sendo observado por vários sujeitos, importa agora observar e observar o observar. Daí as operações comunicativas baterem-se mutuamente e não existir, em princípio, nenhum sujeito "por trás" delas. Esse é o sentido que Luhmann dá à comunicação: a capacidade de sistemas observarem e de se observar a sua observação. É nessa dupla operação que os sistemas vivem e sobrevivem (MARCONDES FILHO, 2004, pp. 432-3).
\end{abstract}

Para o sociólogo alemão, conforme já explanamos, a racionalidade dos sistemas é defensiva, no sentido de que ela seleciona acontecimentos externos (reduzindo, portanto, a complexidade externa, simplificando-a) para aumentar sua própria complexidade, e os objetos podem também ser sujeitos, ou seja, observações que observam o próprio observador. Isso, efetivamente, se enquadra no efeito-espelho proposto por Magritte em Ligações perigosas: o objeto-espelho nos observa de volta, não com o detalhe que esperamos ser observado por nós, mas com sua própria observação, seja na sugestão erótica (um reversão do objeto que não intenta ser observado, a mulher) deste quadro ou no reverso de nós mesmos visto em Reprodução proibida.

Uma sugestão importante a respeito deste fenômeno de complexidade é a de que o corpo, quando observado, segundo Magritte, observa de volta, devolvendo-nos, na imagem, algo fragmentário, que não supúnhamos estar contido em nossa observação inicial. Daí vermos, ao mesmo tempo, a frente coberta da mulher, e, quando olhamos, supostamente, para nós mesmos, vermos suas costas desnudas. E este fenômeno é idêntico ao que ocorre na descorporificação trabalhada ao se pensar o cinema silencioso. Olhamos algo que devolve um olhar, sem nos apercebemos. Somos observados por aquilo que observamos. A diferença, porém, é que o olhar unitário que lançamos ao cinema silencioso, buscando um projeção de nós mesmos ou uma identificação com o objeto (conforme MORIN, 2003), nos é devolvido como um corpo cindido, como uma subjetividade esfacelada. É este o espelho.

\footnotetext{
${ }^{149}$ Neste sentido, vale aceitar a provocação de Kovadloff (2003, p. 10): “O silêncio não tem objeto, tem, porém, sujeito".
} 
Mesmo que reconhecesse que o silêncio é apenas o silêncio técnico, factual ("Deveríamos falar de um silêncio transcendental? De forma alguma. Não estamos falando de algo que transcenda os elos da experiência.", LUHMANN, 1994, p. 35) ${ }^{150}$, Luhmann não deixou de considerar, conforme sugerimos antes, que a relação entre a fala e o silêncio fosse sistêmica. Sua ideia é a de que, sobre o que desconhecemos ou que não podemos comunicar, bem à maneira do primeiro Wittgenstein, podemos afirmar, ao menos, do incomunicável, que ele é incomunicável (Idem, p. 26). O silêncio e suas várias formas (ele sugere desde o silêncio arbitrário da ordem "cale-se!", até o silêncio de Auschwitz), efetivamente, se enquadra neste nível de comunicação por via negativa, endossando, reafirmando, negando, problematizando o dito:

\footnotetext{
O que não é dito no sistema pode ainda ser comunicado por outros sistemas, em outras ocasiões, com diferentes palavras, conceitos e metáforas. Isso não se aplica à sociedade. Seu ambiente se mantém silencioso. E mesmo esta caracterização de "silêncio" é ainda uma caracterização de comunicação, e uma com referência à comunicação; porque, em realidade, o "silêncio" não é uma operação fora da sociedade, mas apenas uma contraimagem que a sociedade projeta em seu ambiente, ou é o espelho no qual a sociedade vem ver que o que não está dito, não está dito (Idem, p. 33) ${ }^{151}$.
}

Ora, em certo momento, parece que Luhmann está falando sobre o quadro de Magritte, mas ele se refere ao silêncio. Esta relação, que afirma ser o silêncio uma "contraimagem que a sociedade projeta em seu ambiente", e onde a sociedade vem verificar a existência do não-dito, se completa justamente se pensarmos o cinema silencioso como corolário operante deste sistema, e a partir da visão corpórea fragmentada, totalmente "silenciada" no discurso restaurador e unificador do cinema falado. Magritte vai abordar isso em inúmeras telas. Em $O$ exercícios do acrobata (Les idées de l'acrobat, 1928), os corpos de várias mulheres são "derretidos" e mesclados a objetos do mundo cotidiano (um rifle, uma trompa). Em Intervalo (Entr'acte, 1927-28), vemos a indecifrável imagem de pernas unidas por um quadril, mas sem o resto do corpo, em atroz surrealismo. O caso mais famoso talvez seja o de Eterna evidência (L'evidence eternelle, 1930), em que Magritte pinta vários quadros diferentes, cada um com um pedaço do corpo de mulher, realizando a operação de fragmentação para além do quadro-objeto de Aumont, indicando que talvez toda sua obra seja ativada por este princípio. A associação que Luhmann faz do silêncio com o incomunicável também ecoa nas pretensões bufas de Magritte com seu "Manifesto do amentalista". Afinal, ela

\footnotetext{
150 Tradução nossa.

151 Tradução nossa; grifos do autor.
} 
se parece muito com a diretriz mais enfática do texto do pintor: "A NOÇÃO DA EXISTÊNCIA DO A-MENTAL É A ÚNICA QUE PODEMOS TER A RESPEITO DO ASSUNTO DO A-MENTAL". Já a preocupação do pintor com o fim de uma autoimagem centralizada do corpo, assim como a devolução de um patamar comunicacional a partir do objeto observado ecoa justamente na filosofia de imagens de Bergson, que já discutimos, mas que pode retornar, neste momento, a fim de cauterizar estas ideias:

\begin{abstract}
Eis as imagens exteriores, meu corpo, e finalmente as modificações causadas por meu corpo às imagens que o cercam. Percebo bem de que maneira as imagens exteriores influem sobre a imagem que chamo meu corpo: elas the transmitem movimento. Meu corpo é portanto, no conjunto do mundo material, uma imagem que atua como as outras imagens, recebendo e devolvendo movimento, com a única diferença, talvez, de que meu corpo parece escolher, em uma certa medida, a maneira de devolver o que recebe (BERGSON, 2010, p. 14).
\end{abstract}

O corpo, portanto, para Bergson, é a imagem central que modula a extração das outras imagens do universo da matéria ${ }^{152}$, e ele se situa na fronteira deste incomunicável anunciado por Luhmann, e, portanto, na fronteira em que se encontra o silêncio. Daí a obsessão de Magritte com todos estes temas, e a representação deles coligados em Ligações perigosas. O fato de Bergson mencionar também o movimento devolvido pelo objeto observado (o corpo) nos leva, naturalmente, de volta ao cinema silencioso, e, mais especificamente, de volta ao primeiro filme de Fantômas, para tratar do segundo motivo que relaciona a obra de Magritte a este cinema: a fricção entre a palavra e a imagem. A referência principal, neste caso, é a da apresentação dos "cartões de visitas" de Fantômas como rastro inescapável de que ele esteve lá, na cena do crime, e com a indicação de que a polícia seguramente não vai capturá-lo. Este evento ocorre algumas vezes no filme, sempre se incidindo como um close da mão de alguém (geralmente o Comissário Juve) segurando o cartão que contém a inscrição "Fantômas". A parte mais interessante, no filme, em que isso acontece é quando Juve descobre um cartão em branco logo após encontrar o cadáver de Lord Beltham. O Comissário precisa lamber o cartão para que, agora com o objeto enquadrado em close, dele apareça, como em um blow-up fotográfico, a assinatura de Fantômas (FIG. 75, 76 e 77). O efeito desta visão,

\footnotetext{
${ }^{152} \mathrm{O}$ pensamento de Bergson de alguma forma leva à concepção propriamente dialética da imagem artística para Eisenstein, para quem há um processo de desconstrução e reconstrução por parte do espectador: "Não é suficiente apenas ver - algo tem de acontecer com a representação, algo mais tem de ser feito com ela, antes que deixe de ser percebida como apenas uma simples figura geométrica e se torne perceptível como a imagem [...] particular na qual o acontecimento está ocorrendo" (EISENSTEIN, 2002, p. 19).
} 
um truque de sobreimpressão à Méliès, é admirável porque - assim como a atitude autorreflexiva de Garance em $O$ boulevard do crime - demarca a nomeação dentro do corpo do filme, neste caso por escrito. Isso nos remete novamente a Derrida: o ato de escrever instaura a diferença, dá o salto inicial para nossa própria inserção no mundo. $\mathrm{O}$ fato de o nome surgir ou emergir desta forma, a partir do nada, curiosamente ecoa na ideia derridiana de que a escritura é que é o ato fundacional da nossa capacidade perceptiva e cognitiva. $O$ personagem de Fantômas demarca, portanto, tanto literalmente quanto simbolicamente, seu posicionamento diferencial, sua ruptura radical com toda a sistemática do status quo que está contra ele. $\mathrm{O}$ ato parece realmente mágico ${ }^{153}$, como se remetesse ao clichê da "magia do cinema", o que de certa forma faz sentido considerando-se que o efeito de projeção e identificação que o cinema desperta (MORIN, 1956, pp. 91-120) tem raiz no antropomorfismo da projeção total que encontramos no pensamento mágico das sociedades selvagens. Quando uma sociedade concebe a ideia da possessão total, os recursos que o indivíduo xamânico utiliza para realizar tal feito se assemelham a um tipo de participação afetiva que Morin encontra, de uma forma bem mais branda, na ligação do espectador de cinema com o filme. Ainda que Magritte não pense em uma mágica exatamente nestes conformes para seus quadros (sendo seu ideário aquele que busca o limite das relações racionais), não é de se surpreender que estas imagens de "mãos gigantes segurando cartões de onde surgem mensagens invisíveis" - ainda mais em um filme em que o close-up ocorre apenas em funções muito específicas - se pareçam com imagens propriamente surrealistas. Conforme observamos analisando $O$ grande assalto de trem ou The big swallow, retalhar o corpo por meio de decupagem era ainda um tabu, mais ou menos, entre 1900 e 1913, e o efeito da "mão gigante" em Fantômas deve ter sido bastante impressionante, propriamente fotogênico. Vale lembrar que a mão cortada é motivo de muita especulação e controvérsia em Um cão andaluz, que é o manifesto cinematográfico surrealista por excelência, e que Magritte colocou a "mão" como parte do corpo em evidência (em close-up) em vários de seus quadros, como Xeque-mate (Échec et mat,

\footnotetext{
${ }^{153}$ Não à toa, Kamper nos lembra que a palavra imagem deriva etimologicamente da latina imago, que vai gerar também o vocábulo magia. E que a presença mágica é a primeira função que nossos antepassados aferiram à imagem, que seria substituída pela representação hábil (no sentido platônico), e depois pela simulação técnica (no sentido de Flusser - Cf. KAMPER, 2012, p. 19). Já Flusser vai encadear as transformações técnicas das sociedades a partir da escala que coloca em primeiro lugar o gesto com a mão, que produz volumes (as primeiras pinturas); depois o gesto com o olho, que vislumbra a superfície e produz a representação; depois o gesto com o dedo, que produz a escrita; e por fim o gesto com as pontas dos dedos, que teclam os botões que ativam os dispositivos das imagens técnicas. Cada um destes tipos de ordem do gesto produz sociedades distintas (FLUSSER, 2008, p. 19).
} 
1926) e As cicatrizes da memória (Les cicatrices de la mémoire, 1927). O caso mais extremo ocorre em O museu de uma noite (Le Musée d'une nuit, 1927), em que o pintor aloja quatro objetos em uma caixa dividida em quatro compartimentos. Em um deles, repousa uma mão solitária, “decepada” de seu corpo, em posição inerte.
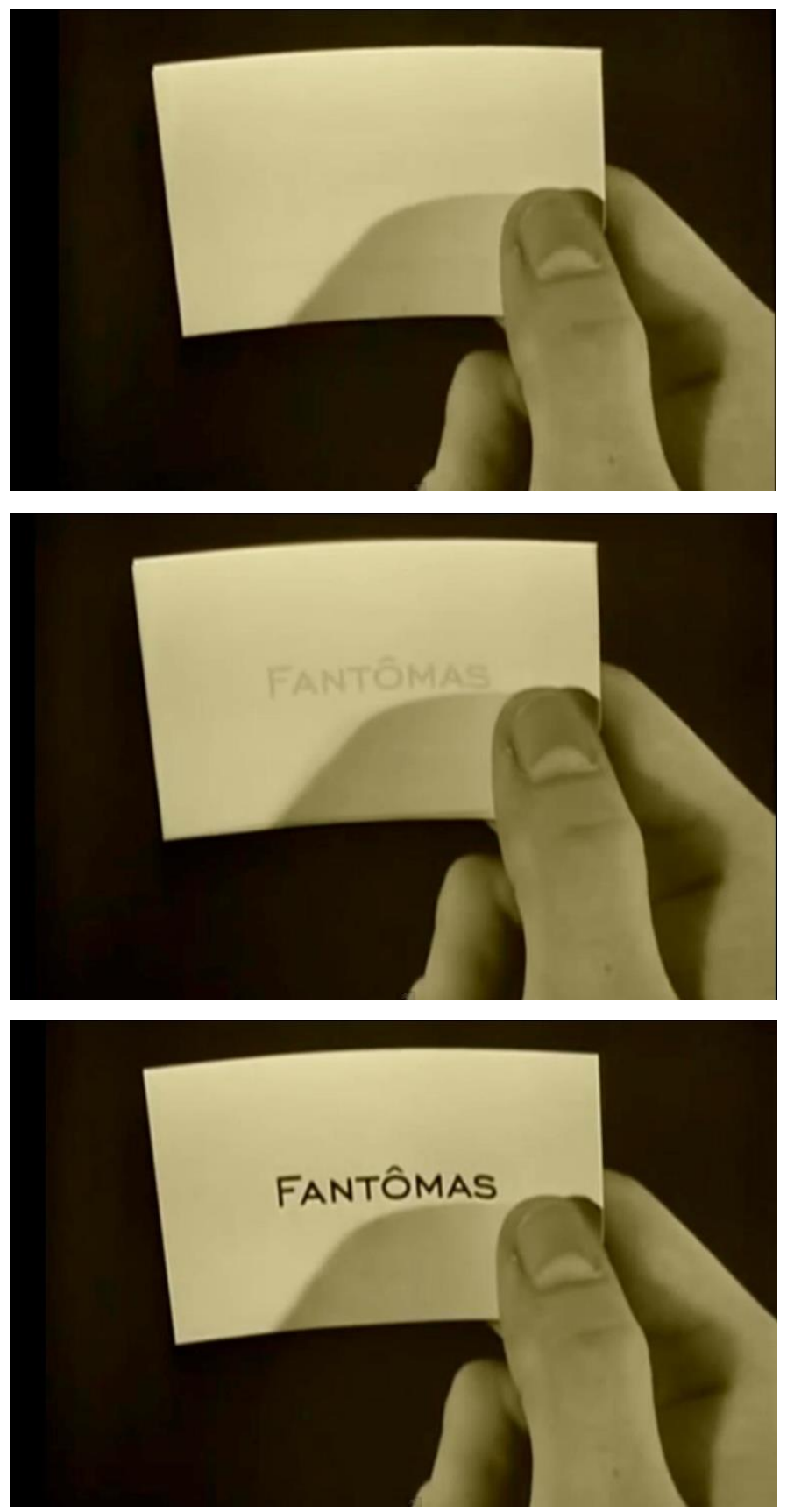

Figuras 75,76 e 77

Para além de uma associação simples da "mão" em Fantômas com a "mão" nas pinturas de Magritte, importa o fato de que este plano do filme introduza a relação, mais complexa, que o pintor via entre imagem e palavra, e, mais importante, a inserção, 
quase paradoxal, da imagem na palavra, buscando um efeito profundo de estranhamento, um deslocar-se da condição inteira da imagem, um tipo de fragmentação que toma conta da tela e passa a tornar-se, ela própria, a causa daquela imagem como um todo. Se, no cinema falado, a inserção, não apenas da palavra, mas da voz vai encontrar o caminho para uma totalização harmônica e sincronizada destes dois modos de representação (um “corpo saudável”), em uma imagem muda, como ocorre no cinema silencioso e nos quadros de Magritte, este efeito não apenas sabota a ambição do corpo saudável, mas transforma esta aparente moléstia da palavra e da imagem em sua própria maneira de produzir expressão, sua origem quase genética, sua etiologia.

São inúmeros (muitas dezenas) os quadros em que Magritte faz uso da palavra dentro da representação pictórica. O mais famoso deles continua sendo A traição das imagens, que ainda pode ser considerado o registro definitivo sobre o tema, sua máxima síntese expressiva. Outros dois quadros interessantes, analisados por Foucault, são $A$ arte da conversa IV ( $L$ 'art de la conversation $I V, 1950)$, em que ruínas ancestrais formam a palavra "rêve" (sonho) enquanto pessoas diminutas conversam em frente ao monumento; e A aparição (L'Apparition, 1928), em que um homem (como sempre, de sobretudo e chapéu) de costas está rodeado por manchas amorfas (como plasmas), nas quais estão inscritas as palavras "fuzil", "poltrona", "cavalo", "horizonte" e "nuvem". Magritte dispunha de uma ampla gama de recursos para inserir palavras em suas telas. Isso poderia ocorrer na forma de anúncios, de palavras inscritas em produtos, na moldura de quadros, em túmulos, ou simplesmente em frases e sentenças pintadas quase aleatoriamente junto às imagens. Eventualmente, as palavras aparecem absolutamente fora de qualquer contexto, como uma agressão que não deixa de lembrar uma possessão demoníaca, em que podemos atribuir inclusive sentido político. É o caso, por exemplo, de Planta com palavra (Plante avec mot, 1929), em que, de um simples vaso de flores sai um balão, como se fosse um galho a mais, com a palavra "canon" ("pistola"). Neste caso, o domínio do estado natural ("natureza morta", inclusive) da pintura pela palavra é francamente irônico, debochado, quase um insulto. Porém, Magritte dispunha de escalas de abstração para distribuir palavras em seus quadros. Foucault, por exemplo, pensou $A$ aparição como ainda remetendo a um mundo figurativo, já que o balão "plasmático" ("porta-palavras") onde está escrita a palavra "céu" fica no alto do quadro. O "cavalo" fica no chão, etc. A tela mantém seu centro de gravidade. A ideia radical, no entanto, de que por trás daquelas imagens (“cavalo", “fuzil”, "horizonte”, etc.) não resta nada além 
destes resíduos na formas de conceitos (palavras), é que impressiona Foucault, como se Magritte pensasse de forma exatamente reversa de Platão: a imagem é vazia ${ }^{154}$, sim, mas quando ela é reduzida a um conceito, torna-se uma sombra ainda menos significativa. Desta forma, o pintor estaria invertendo a pirâmide idealista platônica ${ }^{155}$, reduzindo a "ideia" ao mais baixo escalão ontológico.

\begin{abstract}
Esses “porta-palavras" são mais espessos, mais substanciais que os próprios objetos, são coisas mal e mal formuladas (um vago triângulo para o horizonte, um retângulo para o cavalo, uma verticalidade para o fuzil), sem figura nem identidade, esse gênero de coisas que não se pode nomear e que justamente "se chamam" a si próprias, trazem um nome preciso e familiar (FOUCAULT, 1988, p. 52).
\end{abstract}

Em várias outras pinturas de Magritte estes "porta-palavras", entretanto, vão saindo de suas disposições mais representacionais, como no caso exemplificado por Foucault, ou mesmo da ironia mais sardônica, como em Planta com palavra, para recair em uma relação mais pura entre, simplesmente, imagem e conceito. É o caso de $O$ espelho vivo (Le miroir vivant, 1928 - FIG 78), em que as "bolhas de plasma" agora não se ancoram em nenhum referencial mimético ou naturalista. Toda a pintura trata simplesmente de quatro balões interligados por pequenas pontes igualmente feitas de "material viscoso e opaco" contendo, em cada um deles, os dizeres "personagem morrendo de rir", "horizonte", "guarda-roupa" e "pio de pássaro". Em primeiro lugar, poderíamos pensar que Magritte estava detalhando o simples sketch de um quadro futuro, onde pintaria, figurativamente os dizeres mencionados nos balões. É o mesmo procedimento que podemos pensar, por exemplo, para os "nomes de quadros nunca pintados" que o pintor escreve em forma de versos curtos. Porém, quadros como $O$ espelho vivo e A aparição não são sketches, são a própria forma final das pinturas. Isso nos leva a refletir que Magritte estivesse necessariamente discutindo sobre os procedimentos de composição intelectual de suas telas, como se cada etapa fosse uma tela em si, como se cada procedimento pensado já fosse, por si só, um fenômeno fechado. Mesmo assim, fica mais visível a oposição entre conceito e imagem quando Magritte não está trabalhando com bolhas vazias, mas sim com objetos e palavras, todos

\footnotetext{
154“Magritte deixa reinar o velho espaço da representação, mas em superfície somente, pois não é mais do que uma pedra lisa, que traz figuras e palavras: embaixo, não há nada” (FOUCAULT, 1973, p.54).

155“Aplica agora a estas quatro seções estas quatro operações da alma: a inteligência à seção mais elevada, o conhecimento discursivo à segunda, a fé à terceira, a imaginação à última; e dispõe-nas por ordem de clareza, partindo do princípio de que, quanto mais seus objetos participam da verdade, mais eles são claros" (PLATÃO, 1999, p. 224).
} 
imiscuídos em uma miscelânea de representação. O quadro mais famoso dentro desta perspectiva é A interpretação dos sonhos (La clef des songes, 1930 - FIG. 79) - de título extraído, assim como $O$ princípio do prazer, da obra de Freud. A sugestão nesta tela é a de que há condensação e deslocamento, tal qual no sonho, na relação entre palavra e imagem -, em que, desta vez, ele divide a tela em seis pequenos quadros separados por uma sarjeta, e, em cada um deles, coloca um objeto e sua respectiva descrição. Como se sabe, a descrição e a imagem são completamente heterogêneas. Magritte quis colocar associações especialmente distantes nesta tela, para que a radicalidade da diferença entre o que se apreende pela palavra e pela imagem fosse amplamente ressaltada. Um ovo é acompanhado da palavra "acácia". Um sapato, por "a Lua”. Um chapéu, por “a neve”. Uma vela, por “o teto". Um copo, por “a tempestade". Um martelo, por "o deserto".

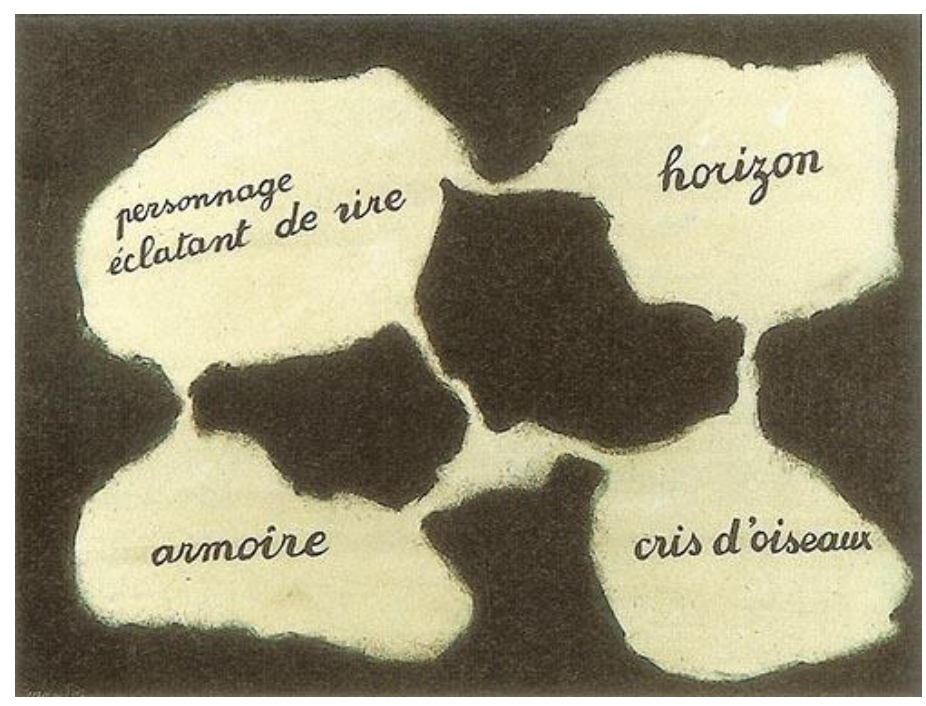

Figura 78 


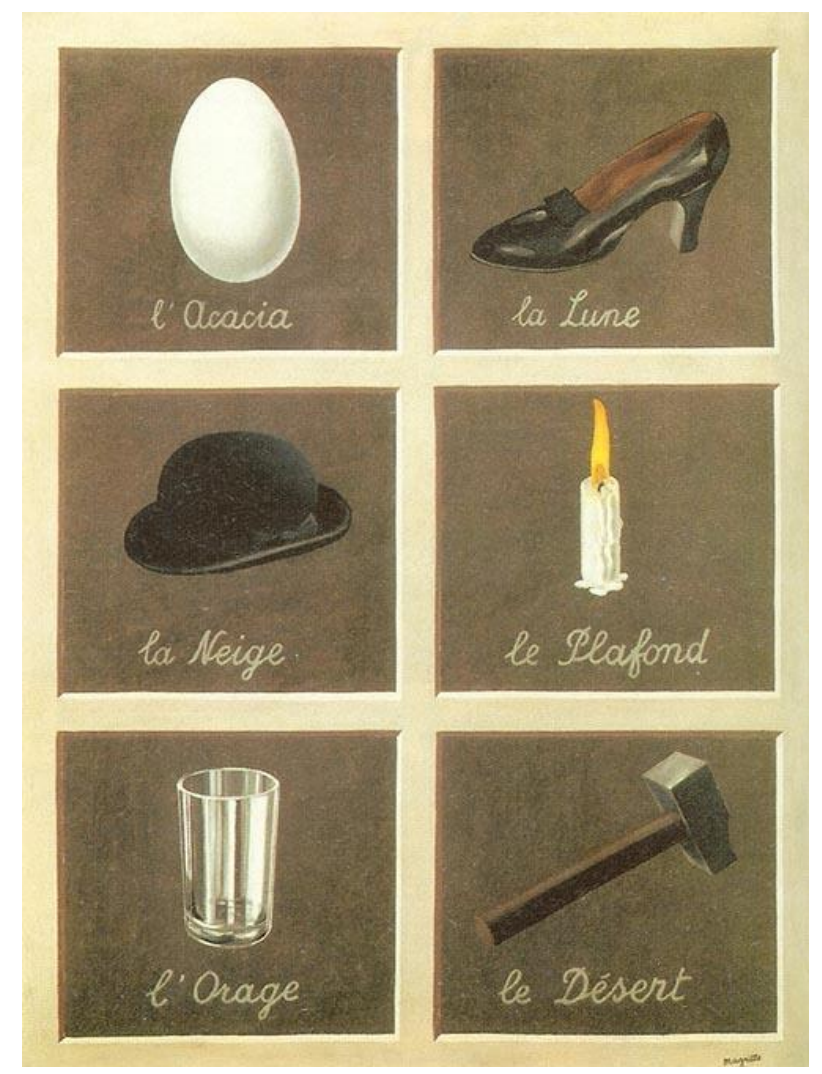

Figura 79

A discrepância é absurda, abusiva. Fossem imagens, as árvores de acácia, a visão da Lua, um campo de neve, a visão da tempestade, etc., todos seriam paisagens deslumbrantes, clichês do naturalismo na pintura. À exceção do teto, ironia dentro da ironia, todos estes temas trazem à tona uma pintura metafísica, à maneira dos românticos, ápice do paisagismo. Magritte enfileira estes conceitos para, no entanto, ridicularizá-los, tirando-lhes toda a sua potência ao associá-los a objetos prosaicos, até meio ridículos, como a vela ou o copo. A palavra, em Magritte, está sempre alojada em um lugar que não é seu. O mundo conceitual, ideal, simbólico, da palavra, é reduzido ao reflexo mais pálido da realidade. É o que pensa Günther Anders ao afirmar que “imagens, metáforas, e histórias representam a tentativa de apanhar as coisas sem precisar, com isso, confiar em conceitos discursivos e, por outro lado, ampliar a capacidade de imaginação para reduzir a discrepância entre as diferentes capacidades humanas [...]" (HILDEBRANDT apud MARCONDES FILHO, 2004, p. 378). Neste sentido, torna-se cada vez mais difícil pensar a imagem como uma possibilidade conceitual, e, considerando a proposta de Deleuze de definir a filosofia como pura e simples criação de conceitos, em que instância entra o pensamento imagético? Com que mecanismos a imagem busca filosofar, se não é capaz de produzir conceitos? A resposta 
de Magritte é o mecanismo do cinema silencioso: a imagem de Magritte é uma antilinguagem, que produz anticonceitos, baseados em uma devastação dos procedimentos lógicos, justamente quando pretende reapresentá-los. O paradoxo de Magritte é o de, ao buscar tornar o pensamento visível, construir o mais radical dos antipensamentos.

\begin{abstract}
Magritte não está preocupado em construir através de imagens e palavras um aparelho destinado a captar a realidade e refreá-la como se fosse um vício através da aliança de dois sistemas complementares. Antes, faz uso da distância interior até às palavras e da distância exterior até às imagens para fazer com que surja um mistério, um sonho perceptivo e acordado, essa diferença intocada e misteriosa, o pensamento original (PAQUET, 1992, p.69).
\end{abstract}

Magritte considerava o próprio princípio da poesia esta separação tão incisiva entre a palavra e a imagem ${ }^{156}$, e não é à toa que Anders colocava a metáfora, figurasíntese do pensamento poético, no mesmo patamar das imagens, ou seja, algo que investe contra o conceito. É Flusser quem vai demarcar ainda mais radicalmente, com verniz mais propriamente "técnico", esta cisão entre o mundo da superfície (a imagem e em primeiro lugar a imagem não-técnica, que produz volumes) e o da linha (a substituição da planície da superfície pelo sequenciamento sintático ponto a ponto, que produz o pensamento em linha). Sabemos bem que todos os caracteres (as letras) de todos os alfabetos se originaram de imagens, e não é difícil pensar que o pensamento sistemático e simbólico seja uma reprogramação, dentro de suas contingências, do que se procurava absorver na era do pensamento em superfície. Em suma, a palavra busca retornar ao ambiente livre e não-conceitual de seu idílico passado em superfície. Ao escancarar esta ambivalência, Magritte efetivamente repete o gesto do cinema falado em direção ao cinema silencioso: se a palavra quer voltar a ser imagem, o cinema falado quer voltar a ser cinema silencioso. Os modelos, as estruturas destas duas maneiras de se pensar o mundo e as coisas, são similares.

\footnotetext{
As imagens podem substituir-se pela circunstância a ser por elas representada, podem tornar-se opacas e vedar o acesso ao mundo palpável. $\mathrm{O}$ homem pode agir em função das imagens ("magia"). Dezenas de milênios se passaram até que tivéssemos aprendido a tornar transparentes as imagens, a "explicá-las", a arrancar com os dedos os elementos da superfície das
}

\footnotetext{
156“'Os títulos dos quadros não constituem explicações; nem os quadros ilustram os títulos. A relação entre quadro e título é poética: esta relação serve apenas para registrar certas características dos objetos tal como são habitualmente ignorados pela nossa consciência, mas das quais temos às vezes um pressentimento quando confrontados com acontecimentos extraordinários sobre os quais a nossa razão não conseguiu ainda lançar luz” (MAGRITTE apud PAQUET, 1992, p. 23).
} 
imagens e alinhá-los a fim de contá-los; até que tivéssemos aprendido a enfiar os elementos sobre as linhas, a tornar as cenas "contáveis" (nos dois sentidos do termo), a desenrolar e desenvolver as cenas em processos, vale dizer, a escrever textos e a "conceber o imaginado". Consequentemente, a conceituação é o terceiro gesto abstraidor (abstrai a largura da superfície); graças a ele o homem transforma a si próprio em homem histórico, em ator que concebe o imaginado (FLUSSER, 2008, pp. 17-8).

Diante de uma afirmação como a de Flusser, de que o gesto conceitual inaugura a história, Magritte se refreia, não exatamente contrariado, utilizando o conceito de maneira desencaixada, rompendo com a linha, para produzir um tipo de anti-história. Talvez seu gesto mais radical seja justamente seu trabalho com as palavras, que se divide em duas instâncias: na primeira, ainda apoiado nos quadros, o pintor escreve um pequeno texto, talvez um pequeno poema, que sirva de "espelho" conceitual para a obra pintada. Por exemplo, para o famoso quadro As flores do mal (Les fleurs du mal, 1946), ele escreveu as seguintes palavras: "A estátua de carne de uma jovem mulher nua tem às mãos um rosa de carne. A outra mão se apoia sobre uma pedra. As cortinas se abrem sobre o mar e um céu de verão" (MAGRITTE, 1994, p.65). A descrição, como se pode ver, é muito parecida com o próprio quadro, com pequenas modulações, sutilezas que poderíamos considerar como "poéticas". O fato de Magritte chamar a estátua parda, quase dourada, cobre, inspirada em sua mulher Georgette, que está pintada neste quadro, de estátua de carne, traz algo a mais à visão inicial que temos, como se o próprio nos revelasse um segredo, construindo uma obra sobre a outra, buscando uma relação que nem estrague a visão pura da imagem original, e nem a aprimore demais, evitando a necessidade de coligar a palavra à imagem. Aqui, dentro de tal estoicismo, Magritte vai separando cada vez mais as instâncias das imagens e das palavras. Há uma série de desenhos ilustrados (As imagens e as palavras, Les mots et les images, 1929 FIG. 80), quase como um livro infantil, em que Magritte estende esta percepção, como se didaticamente explicasse tanto seu discurso de imagens quanto seu discurso de palavras, e ao mesmo tempo suas relações exógenas: "Um objeto não atende tanto assim ao seu nome de maneira que não se possa encontrar um outro que melhor lhe convenha", escreve ele, desenhando logo abaixo uma folha seguida da palavra "pistola". Ou, ainda, "Em um quadro, as palavras são da mesma substância que as imagens", desenhando, logo abaixo, palavras que se misturam a desenhos. Este pequeno manual “em quadrinhos" de Magritte curiosamente, à parte a sua despretensão (ele nunca chegou a pintá-lo), pode ser, no final das contas, seu libelo a respeito de como se relacionam palavras e imagens, e quais seriam suas intenções ao criar estruturas como 
“porta-palavras", ou criar séries em que relaciona diferentes significados para imagens e suas descrições. Magritte, como o poeta Manoel de Barros, está preocupado em reinscrever a palavra por meio de seu desalojamento "histórico", "conceitual" (no sentido de Flusser), e fazê-la florescer novamente a partir de sua origem, que é a própria imagem. Ao devolver a imagem à palavra, a palavra, de maneira um tanto claudicante e esquizofrênica, passa a se reportar ao mundo "mágico" do pensamento em superfície novamente, e talvez seja este mesmo o procedimento da poesia, quando ela se manifesta em palavras. Tanto que, quando Magritte realmente abandona a imagem e passa a escrever sobre quadros que nunca pintou, ele realmente sai destes sketches ou de seu pequeno livro didático para se arvorar no mundo onde a palavra busca se desgarrar de seus conceitos. Destituídas das imagens, essas "visagens" escritas por Magritte não se tornam mais ridículas como em $O$ espelho vivo ou $A$ interpretação dos sonhos. Sem uma imagem que coloque a palavra "em acusação grave", a palavra é libertada para viver seu sonho de ser poesia. Para o quadro nunca pintado A utopia, a paisagem é: "A rosa está só, em uma ilha". Para A garota do grande segredo, ele escreve: "Perto do mar, a grande rosa com pernas de mulher está estendida sobre a areia ardente".

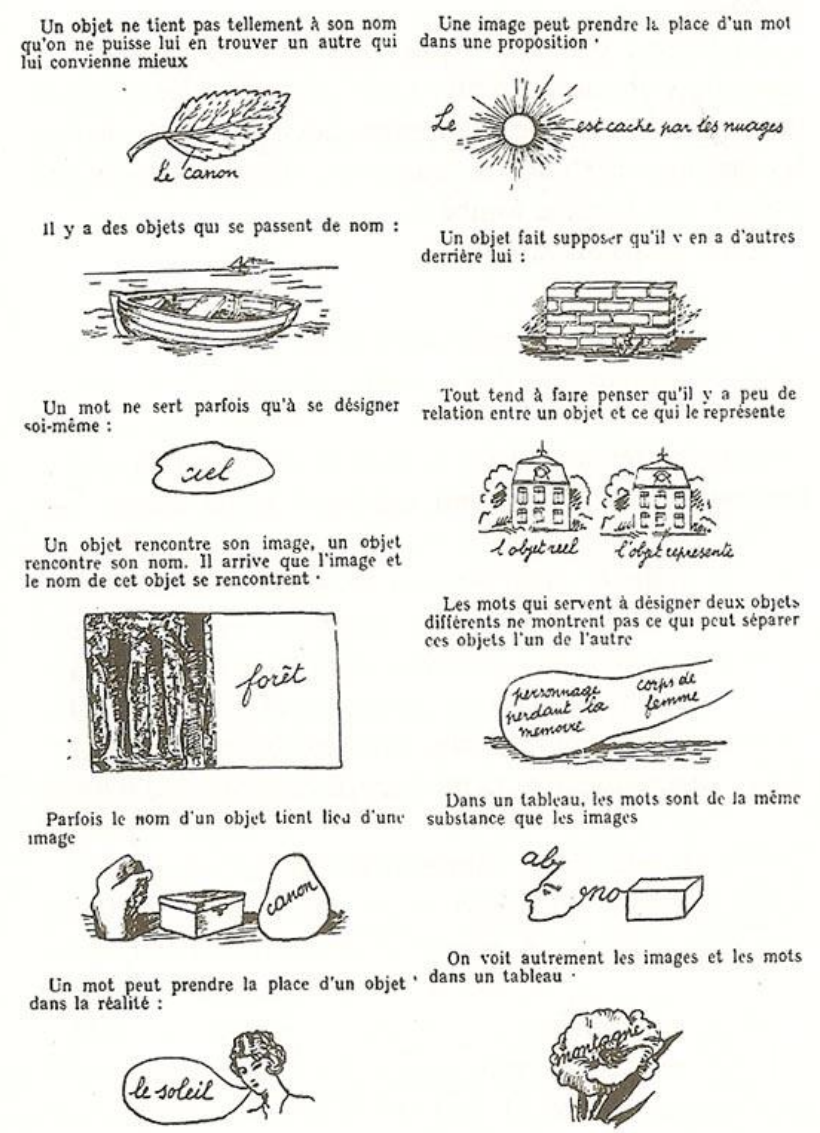

Figura 80 
A beleza efetiva da poesia, a partir desta escala de destituição de um compromisso entre palavra e imagem a partir de Magritte, efetiva-se no silêncio de todo o processo. Ao dizer que as imagens são volúveis e se processam em filtros infinitos de metamorfoses de si mesmas, o pintor talvez queira dizer que suas imagens evadem-se do significado (é bom lembrar-se sempre de que o "sentido está no campo do impossível") e que estão, efetivamente, em silêncio. Ao primeiro expor a palavra ao ridículo conceitual, impossibilitando a história e a filosofia, e depois, gradativamente, colocá-la em uma evidência onde a fricção com a palavra não seja tão destrutiva, ele também vai aproximando a palavra poética daquilo que Kovadloff chamada de "silêncio da significação excedida", ou seja, de irredutível complexidade, de abismal potência de sentido, uma epifania da palavra, onde tudo, no final das contas, se cala. É diante desta modalidade de poesia, aquela que, associada a um silenciamento, produz uma expressão inefável, epifânica, é que pretendemos pensar, no próximo capítulo, a produção de um pensamento poético veiculado pelas contingências do cinema silencioso a partir de filmes e assuntos tão díspares como a obra de Monet e o filme Retrato de um homem jovem, de Henwar Rodakiewicz. Por ora, cabe-nos encerrar a discussão com o silêncio epifânico tal qual observado por Kovadloff:

Já não é, conforme podemos ver, o silêncio do que foi forçado a se recolher na falsa irrelevância, o silêncio do que, emudecido e encoberto, se supõe que não inquieta. Estamos pelo contrário, diante do silêncio altivo daquilo que, sem recusar-nos seu contato, resiste a deixar-se limitar pelos recursos da nossa lógica usual. Estamos, em suma, diante do extraordinário - palpável e simultaneamente inalcançável; tangível e, no entanto, informe. É graças, portanto, à sua intensa função reveladora que proponho chamar esta modalidade do silêncio de silêncio da epifania. E muito perto desta noção de epifania, creio eu, encontra-se Octavio Paz quando em seu Teatro de signos considera que "se a linguagem é a forma mais perfeita de comunicação, a perfeição da linguagem não pode ser outra a não ser a erótica, e inclui a morte e o silêncio: o fracasso da linguagem... O fracasso? O silêncio não é o fracasso, e sim o acabamento, a culminação da linguagem" (KOVADLOFF, 2003, p. 25). 


\section{NEFELIBATAS: AUTORRETRATO EM SILÊNCIO}

I wandered lonely as a cloud that floats on high o'er vales and hills

When all at once I saw a crowd

A host, of golden daffodils;

Beside the lake, beneath the trees,

Fluttering and dancing in the breeze.

- William Wordsworth

\subsection{Autorretratos}

Étonnate peinture, sans dessin et sans bords, cantique sans paroles, tableau où le peintre n'a plus d'autre sujet que lui-même... - Louis Gillet ${ }^{157}$

\subsubsection{A cinética de Claude Monet}

O pintor Claude Monet (1840-1926) era um entusiasta da então jovem técnica da fotografia. Não apenas ficaram célebres os inúmeros retratos que ele protagonizou no final de sua vida em sua casa e jardim na cidade de Giverny, como também ficaram famosas as fotos do pintor produzidas pelo mais prestigiado fotógrafo francês da época, Félix Nadar (FIG. 81). Estes retratos, fotografias de estúdio tiradas em cerca de 1899, seguem o padrão do "novo Renascimento" técnico-industrial trazido à tona pelo surgimento e proliferação dos inúmeros meios de comunicação inventados no século XIX: o enquadramento é leonardino, o fundo opaco, o retratado está sério, sisudo, com a luz difusa. Mais do que retratos dos artistas e celebridades de sua época, Nadar procurava exprimir, em suas fotos, o verdadeiro zeitgeist racional e positivista derivado do iluminismo, das revoluções e da ciência. As pessoas não podem sorrir e devem exprimir uma seriedade à altura de sua importância, respeitando um patamar de dignidade e solenidade. Tratava-se de uma época, afinal, de afirmação da ciência e do progresso, e a esta altura Monet já possuía grande renome, tendo passado por um início difícil na pintura, depois pela controvérsia ${ }^{158}$ das exposições impressionistas (não tendo

\footnotetext{
157 "Pintura surpreendente, sem desenho e sem bordas, canto sem falas, quadro onde o pintor não tem mais nenhum outro assunto a não ser ele mesmo" (tradução nossa).

${ }^{158} \mathrm{~A}$ primeira exposição impressionista foi organizada em 1874 por artistas que se rebelavam contra a política e os preceitos artísticos do Salon de pintura em Paris, então o mais prestigiado evento artístico da
} 
sequer participado das últimas), e, por fim, por sua mudança, em 1883, para a cidade de Giverny, na Normandia, onde aluga e posteriormente compra uma casa com um vasto terreno em que realiza progressivas mudanças e reformas, construindo um elaborado jardim com um lago (bassin) em que instala a famosa ponte japonesa e também no qual cultiva os nenúfares (nymphéas), inspirações para centenas das pinturas na parte final de sua carreira (FIG. 82).

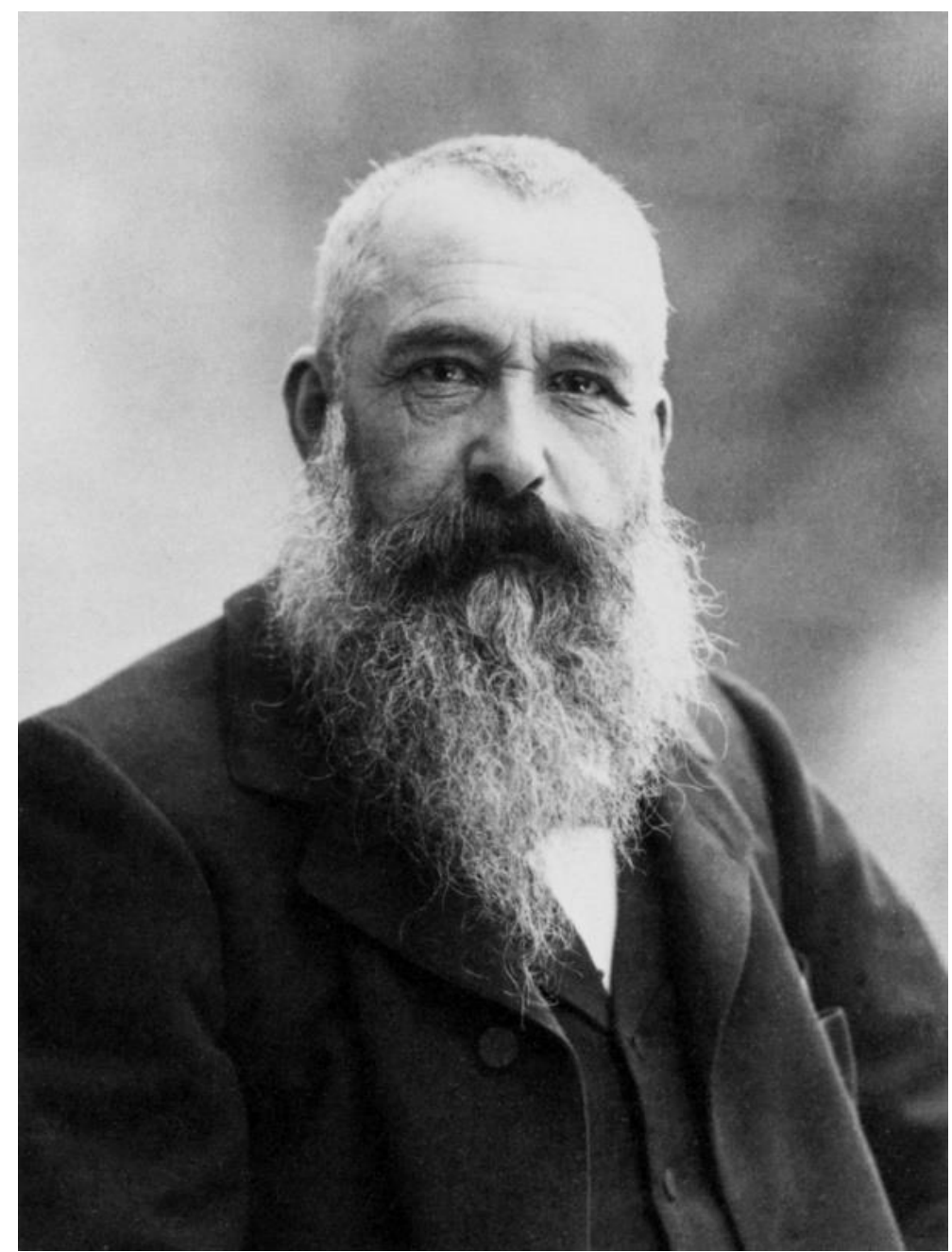

Figura 81

cidade. "A empresa não foi um sucesso. Embora 8000 a 10000 pessoas visitassem por dia o Salon, a exposição [dos impressionistas] só chama a atenção de 175 visitantes no primeiro dia e de 54 no último dia, dos quais alguns só aparecem para se divertir.” (HEINRICH, 2000, pp. 31-2). As exposições impressionistas ocorreram nos anos de 1974, 1876, 1877, 1879, 1880, 1881, 1882 e 1886. Monet abdica da participação da exposição a partir de 1879 . 


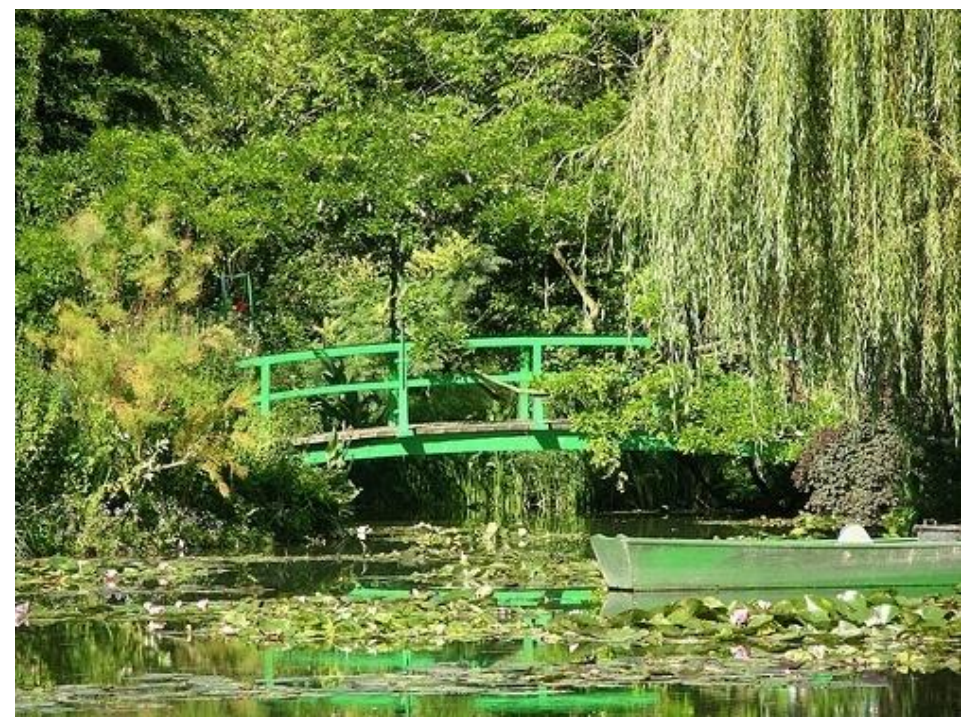

Figura 82

Além do jardim, Monet construiu, dentro dos mais de quarenta anos (1883-1926) em que viveu em Giverny, três ateliês de pintura e uma câmara escura na qual pudesse trabalhar a fotografia. É curioso pensar que, se Nadar cultivava uma visão positivista da arte e da técnica fotográficas, o mesmo não poderia ser necessariamente atribuído a Monet. A partir da virada do século, mesmo já envelhecido, quase cego e não sendo mais um signo de inovação dentro do mundo da arte impressionista (suas séries, e em especial a série dos nenúfares, foram duramente criticadas), Monet permanecia conectado a formas de expressão que o ajudassem a construir uma visão cada vez mais aprofundada de sua própria capacidade de realizar uma leitura do mundo através da arte: a fotografia, o cinema e até mesmo a jardinagem, que se tornou corolário de seu modus operandi reiterativo nas últimas décadas de sua vida (HOOG, 2006, p. 13). A associação entre o Impressionismo e a arte moderna não apenas não é nova como também é possível pensar este movimento como precursor de formas de arte especificamente baseadas em tecnologias então novas, como o cinema e o rádio, ambos trabalhados na chave da efemeridade que havia norteado as transformações comunicacionais e tecnológicas oriundas da Revolução Industrial: do trem ao telefone, do telégrafo aos cartazes nas ruas, uma multitude de expressões e novas formas de tecnologia pareciam responder à simples ideia impressionista de que o que está ali em um instante, não está mais no instante seguinte. Uma arte da impermanência sugeriria uma imagem em movimento. 
Como exemplificado pela flânerie, a atenção moderna foi concebida não somente como visual e móvel, mas também fugaz e efêmera. A atenção moderna era visão em movimento. As formas modernas de experiência dependiam não apenas do movimento, mas dessa junção de movimento e visão: imagens em movimento. Um precursor óbvio dessas imagens foi a estrada de ferro, que eliminou as barreiras tradicionais de espaço e distância à medida que forjou uma intimidade física com tempo, espaço e movimento (CHARNEY e SCHWARTZ, 2004, p. 22).

Conforme propõem Charney e Schwartz em O cinema e a invenção da vida moderna, o tipo de atenção e recepção cognitiva progressivamente construídos com as novas experiências possibilitadas pelas inovações do século XIX anteciparam o que viria a ser a experiência do cinema para o século XX. A diferença é que, estratificada em diversos aparatos, objetos e propostas culturais (cartões postais, catálogos de venda, carros, parques de diversão, etc.) a experiência de uma cinética no século XIX foi reunida, basicamente, em um único "maravilhoso" aparelho que fosse capaz de congregar todos estes atributos em uma atividade unificada e coletiva: o cinema. $\mathrm{O}$ interesse de Monet pela fotografia, aliado à cinética própria da estética impressionista, de certa forma, passa por este mesmo fenômeno, e pode ser pensado como um indicativo de uma relação mais estreita entre o pintor e a forma de arte que emergia.

Monet foi retratado inúmeras vezes em sua casa em Giverny (FIG. 83), fosse posando para retratos, fosse com colegas que o visitavam, fosse em fotos de natureza menos ortodoxa. Uma delas, de 1905 (FIG. 84), em especial, é um tanto reveladora. Espécie de autorretrato, é uma foto do lago de Giverny que mostra os nenúfares (tal qual as pinturas), com um detalhe: a sombra da cabeça de Monet, vestido com o chapéu de Sol que tanto lhe caracterizava, aparece na borda de baixo da foto, como se fosse um tipo de aparição fantasma. $\mathrm{O}$ fato de Monet privilegiar o lago com as plantas aquáticas em seu próprio "autorretrato" fotográfico diz muito a respeito de sua relação com sua casa em Giverny, com os elementos da natureza, com as plantas aquáticas, com a água em si e com o lugar que ele chamou de lar por mais de quarenta anos. A série com mais de 200 telas de nenúfares e outras plantas e flores que Monet cultivava em seu jardim não foi exatamente uma novidade em sua carreira. Ao menos desde 1880 (HEINRICH, 2000, p. 55), o pintor realizou seus estudos de luz ao pintar as mesmas imagens (muitas vezes com mesmo objeto e enquadramento) dezenas de vezes, sob a incidência de uma iluminação cujas manifestações podiam distar apenas poucos minutos umas das outras, algo que foi considerado um experimento de natureza meticulosa e fotográfica. 
Nos seus estudos de luz em Argentueil e em Vétheuil, Monet tinha querido dar à sua vista a objetividade de um aparelho que registra as impressões quase fotográficas, adjetivo que também foi aplicado às séries dos anos 90 . Todavia, a subjetividade afetiva do pintor joga aí o seu papel. Os efeitos da cor são mais inventados por analogia com o real do que fielmente representados. A um uso imaginativo da cor responde uma utilização muito livre dos meios pictóricos. Mesmo que se trate de uma experiência visual subjetiva, vivida de forma fugaz num momento do dia que está na base de cada quadro, a obra acabada vai mais longe. O tema perde aí, por sua vez, os pormenores e a sua individualidade material. Desembaraçadas de toda a ressonância anedótica, as telas tornam-se intemporais, e portanto, monumentais (HEINRICH, 2000, p.57).

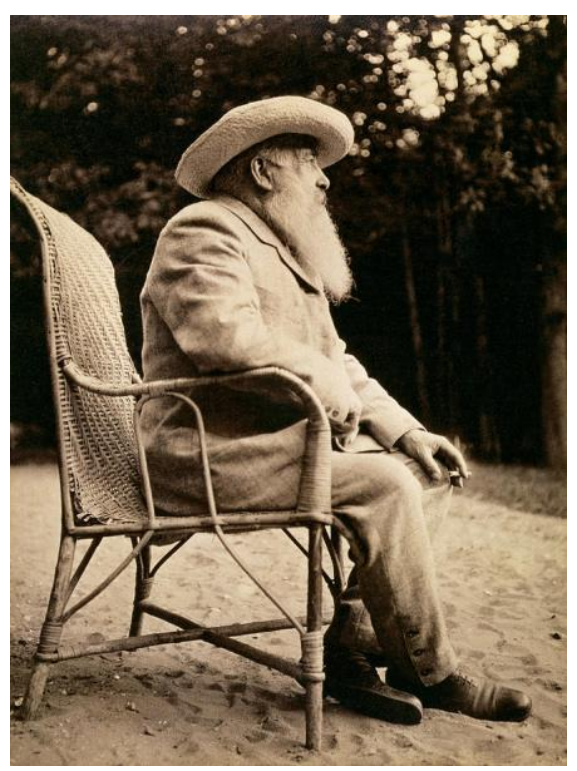

Figura 83

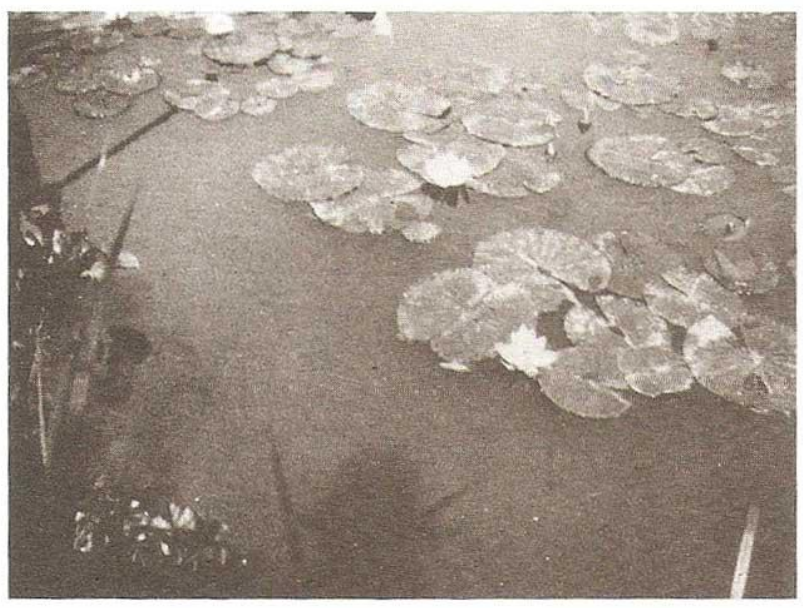

Claude Monet, Autoportrait à la surface du bassin aux nymphéas, Giverny, vers 1905

Figura 84

São célebres, portanto, as séries que Monet realizou sobre as Medas de Feno (1880-1), os Álamos (1891), as Catedrais de Rouen (1894) e as Manhãs sobre o Sena 
(1896-7). Ainda que sua obra tenha sido tachada, em chave pejorativa, como "decorativa" (suas pinturas não eram históricas, narrativas ou paisagens, Cf. HOOG, 2006, p. 48), é evidente que os estudos de luz realizados por Monet nas séries não eram pura afetação de um pintor cujas ideias haviam envelhecido. Reiterativamente, e obsessivamente, ele buscava entender a própria época, que replicava imagens extraídas da luz da própria realidade para recompô-las em movimento a partir de dispositivos ópticos que, tal como enunciou Flusser, operariam uma mudança de paradigma a respeito de como nos relacionaríamos com estas mesmas imagens. Diante da fotografia, e, posteriormente, do cinema, era necessário não "libertar a arte do jugo do realismo figurativista", como diz o clichê sobre o Impressionismo e os modernismos, mas praticamente o contrário: era necessário entender como uma forma de arte antiga como a pintura poderia se readequar e se atualizar a partir dos novos paradigmas de produção de imagens. Se, nos anos 1870, Monet capitaneou o movimento impressionista com uma atitude rebelde, quiçá amadora, de pintar ao ar livre e produzir um naturalismo muito distante daquilo que pregava o academicismo da época, na virada do século o desafio do velho pintor era outro: era necessário mudar de medium, de frequência, reverter a pintura em efemeridade pura, em um olhar cientificista e microscópico, que, se não era austero e formal como no caso de Nadar, buscava uma ciência à frente: a partícula, o átomo, a relatividade ${ }^{159}$.

Séries como a da Catedral de Rouen anunciam um aspecto cinemático, mas não compunham um tipo de montagem linear, criando movimento sequencial e narrativo, tal qual os trípticos góticos ou as telas sequenciais de William Hogarth no século XVIII ${ }^{160}$. O momento narrativo de Monet havia sido em sua série de telas retratando a Estação Saint-Lazare em Paris nos anos 1870 (FIG. 85, 86 e 87). Naquele caso, Monet estava preocupado em capturar justamente este tipo de sequencialidade que encantaria o mundo com a chegada do cinema a partir de Lumière: os movimentos dos trens são

\footnotetext{
${ }^{159}$ Einstein publica, ainda em 1905, a "Relatividade Restrita", em que estabelece o conceito de espaçotempo (integrados em quatro dimensões) e o da velocidade da luz. Em 1915, Einstein publica "Teoria Geral da Relatividade", ampliando estes conceitos e estabelecendo um espaço-tempo curvo. A Relatividade, portanto, por mais que muito recente e posterior às principais séries de Monet (exceto pelos últimos nenúfares) fez parte dos eventos que inovaram sua época ainda em vida.

${ }^{160} \mathrm{O}$ teórico dos quadrinhos Scott McCloud explica as inovações trazidas por Hogarth: "A sofisticação da história com imagens atingiu seu apogeu nas mãos de William Hogart. Esta é uma minúscula peça (cerca de um vigésimo) da história com imagens de seis ilustrações de Hogarth, 'O progresso de uma prostituta', publicada em 1731. Apesar de ter poucos quadros, essas figuras contam uma história rica em detalhes e motivada por fortes preocupações sociais. As histórias de Hogarth foram mostradas pela primeira vez como uma série de pinturas, e, mais tarde, vendidas como portfólio de gravuras. As pinturas e gravuras eram para ser vistas lado a lado... em sequência." (MCCLOUD, 2005, pp. 16-17).
} 
claros, e uma passagem do tempo é explícita entre as telas. O historiador americano Steven Z. Levine realizou uma objetiva análise destas telas, aproximando Monet e Lumière não por meio do mimetismo ou o naturalismo normalmente associados ao cinema ${ }^{161}$, mas por uma série de outras características:

Se a fidelidade à aparência fotográfica não é o critério com o qual podemos comparar Lumière e Monet, eu sugiro, no lugar disso, que o que eles, ou melhor, que o que a manipulação que fazem de seus meios tinham em comum era o fato de serem compreendidos fenomenologicamente, como traços de um gradativo processo de estar-no-mundo, com o propósito de enquadrar, produzir e projetar uma vista. Os primeiros filmes de Lumière, é claro, eram chamados simplesmente de vistas, exatamente como muitas das pinturas de Monet. E, assim como Lumière, Monet buscava vistas apropriadas no curso de extensas viagens que o levaram a lugares como Londres, Veneza e a Noruega (LEVINE, 1978, 442). ${ }^{162}$

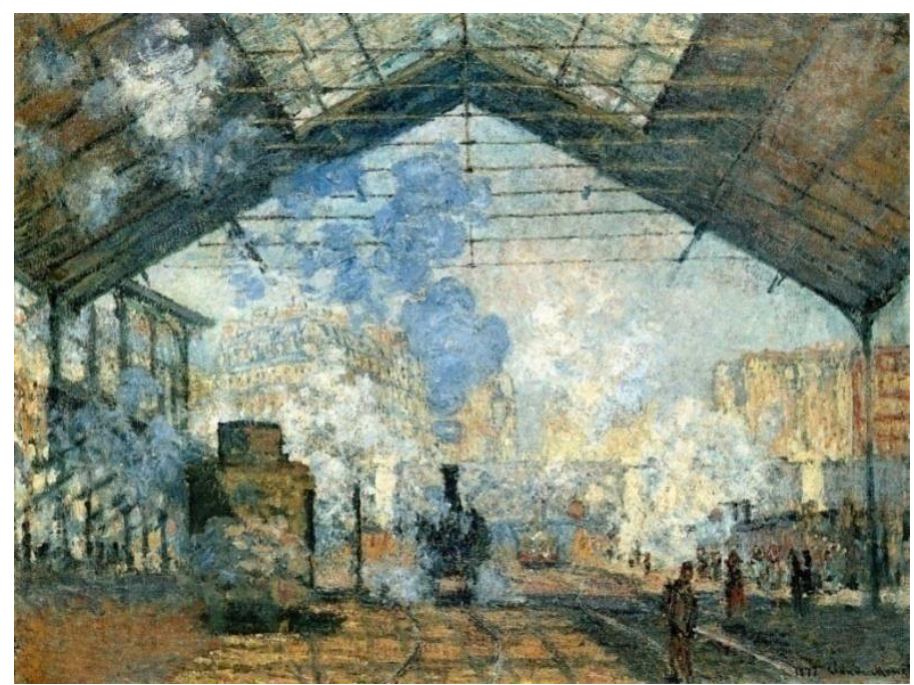

Figura 85

\footnotetext{
${ }^{161}$ Ficou famosa a declaração de Jean-Luc Godard, 1966, a propósito de uma retrospectiva Lumière: "O que interessava a Méliès era o ordinário no extraordinário, e a Lumière o extraordinário no ordinário. Louis Lumière, via impressionistas, era, portanto, bem descendente de Flaubert, e também de Stendhal, cujo espelho ele levou ao longo dos caminhos." (GODARD apud AUMONT, 2004, p. 27).

162 Tradução nossa; grifo nosso.
} 


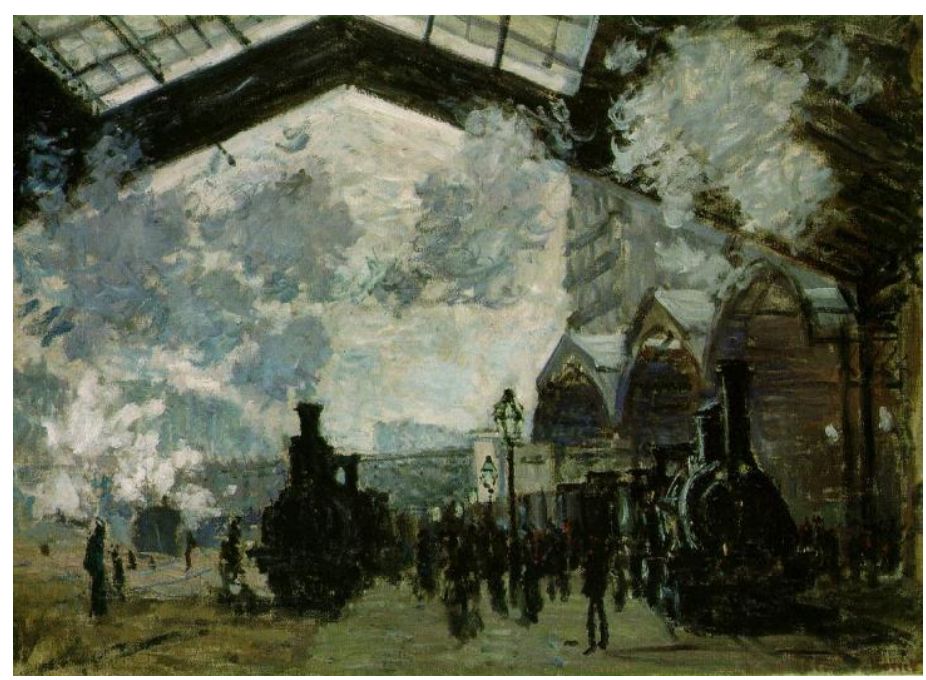

Figura 86

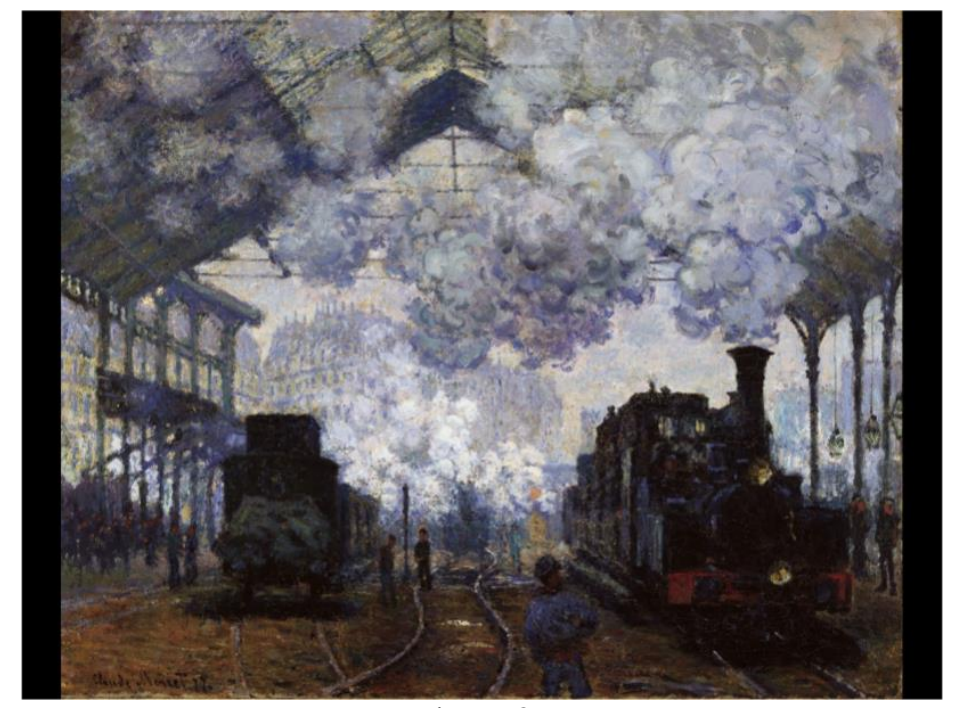

Figura 87

Este processo de estar-no-mundo a partir da criação de uma vista ecoava nas futuras filmagens de Lumière nas séries de trens e estações dos anos 1870. Também havia se transformado substancialmente em 1894-5, época da produção das séries das Catedrais de Rouen (FIG. 88 e 89) (e também das primeiras projeções Lumière). Este conjunto de numerosas pinturas, transformadas à revelia tanto da mudança sutil de luz, quando da sofisticada subjetividade do pintor, diz menos sobre o movimento das mudanças de planos e da articulada montagem do cinema, do que sobre a associação mais elementar que pode ser deduzida desta forma de arte: a união de um fotograma a outro. A série, composta de mais de trinta telas, mostra pouquíssima variação angular (três, na verdade, porque Monet precisou mudar de habitação duas vezes nos dois anos em que trabalhou nas catedrais. Cf. HEINRICH, 2000, p. 56.), mas ao mesmo tempo exibe uma sutileza na variação do temperamento das cores através das horas do dia que 
às vezes ficavam na cabeça do pintor apenas por alguns minutos (Ibidem). Não seria sem cabimento conceber que Monet estava pensando não como um filme tal qual passaríamos a ver em todo o Século $\mathrm{XX}$, mas sim como a própria composição minuciosa da fita cinematográfica, com seus milhares de fotogramas infimamente parecidos, diferenciando-se uns dos outros por microdetalhes que só poderiam ser percebidos após exaustiva exibição sequencial na projeção. Monet, obviamente, não estava a par da revolução que o cinema causaria, mas o fato de que sua célebre série das Catedrais de Rouen tenha saído no ano da primeira exibição Lumière diz muito a respeito de sua mentalidade científica e de sua procura em expressar uma arte que fizesse sentido dentro das novas categorias de comunicação e pensamento que emergiam no final do século. A mudança e o movimento, em Monet, portanto, segundo Levine, se aproximam do cinema por duas vias, e é importante mencioná-las:

Seja em filme ou em pintura, é através da elaboração seriada de tais enquadramentos que um registro dual de movimento e mudança pode ser inscrito: mudança como o deslocamento espacial do olhar do espectador, como nos cortes plano-a-plano; e a mudança como o desvelamento temporal do mundo fenomênico, como no par de pinturas que descrevemos aqui ou no plano-sequência do cinema (LEVINE, 1978, p. 444) ${ }^{163}$.

163 Tradução nossa. 

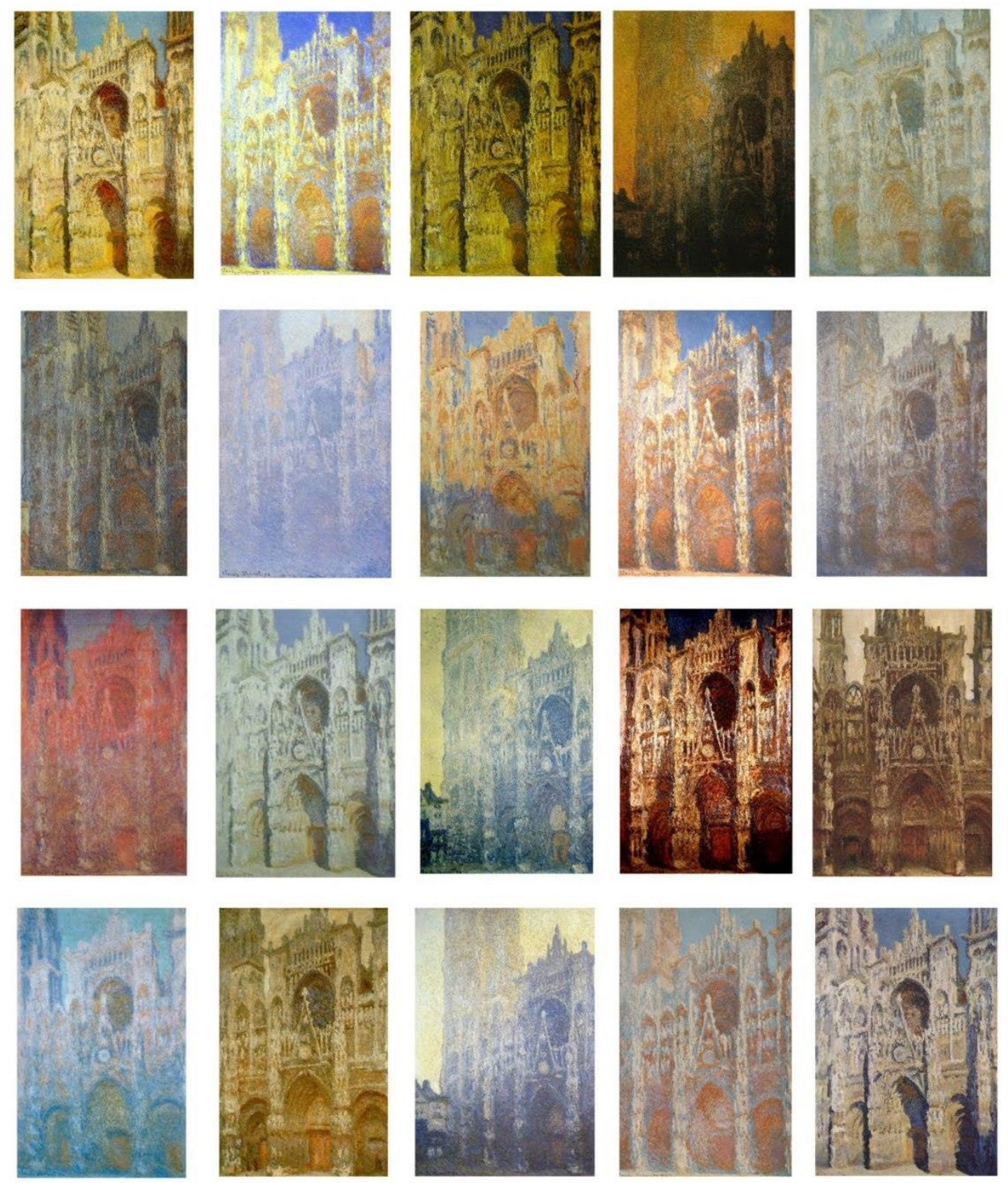

Figura 88 


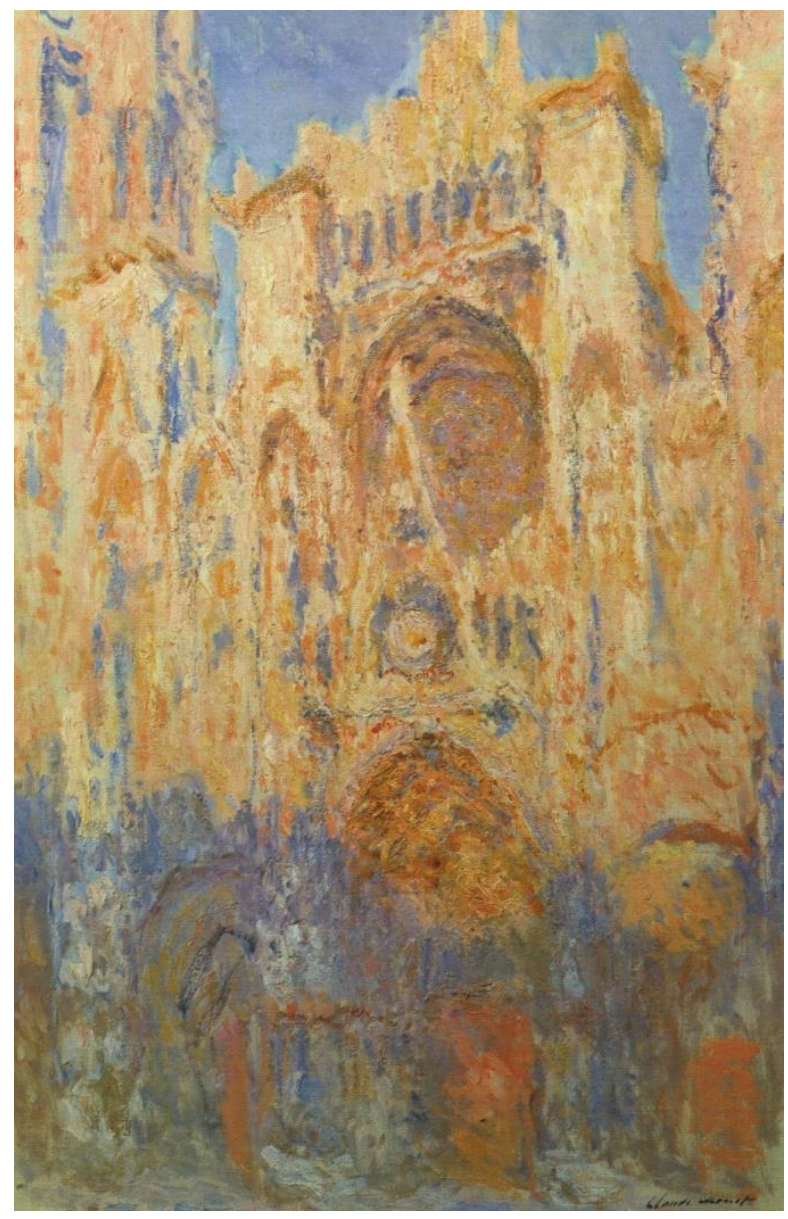

Figura 89

A ausência deste deslocamento espacial do olhar do espectador na série das Catedrais de Rouen, e, portanto, ausência de montagem, não implica necessariamente em uma ausência de cinética nestas telas estáticas. Ao trabalhar uma cinética da luz incidindo-se sobre a catedral e suas ínfimas variações, Monet estava não apenas antecipando o plano-sequência, conforme sugere Levine, mas trabalhando uma estética cinematográfica que ultrapassa a simples compleição narrativa, de sequencialidade bruta e quase obtusa, baseada no corte entre planos, que passou a definir o cinema a partir mais ou menos de 1907 com a virada narrativa. Com uma intuição muito arrojada a respeito do que poderia ser representado a partir da serialização de imagens, Monet antecipou um cinema de intensa e persistente duração temporal como se se baseasse na montagem operada no nível do fotograma, algo que, por exemplo, um cineasta e videoartista experimental como Stan Brakhage faria a partir dos anos 1960. Monet estava, de fato, buscando uma poética dentro da cinética da pintura de observação quase positivista que desenvolveu a partir dos anos 1880. Este procedimento apenas se intensificaria com sua mudança para Giverny e seu propósito em realizar a maior e mais ambiciosa série de todas: as telas dos nenúfares. 


\subsection{2 - A série de painéis decorativos do museu da Orangerie.}

A foto mencionada acima enquanto possível "autorretrato" de Monet não aparece aqui por acaso. Monet viveu em sua casa em Giverny desde 1883 e cultivou, a partir de inúmeras reformas do jardim e ampliações do terreno, um sem-número de espécies vegetais e flores, o que se tornou um ofício tão elaborado e dispendioso quanto pintar. Glicínias, lírios, tubérculos, bambus e diversos tipos de árvores fizeram a fama da morada do pintor, que hoje é um local de intensa visitação turística. Mas são os nenúfares, presentes como protagonistas da foto e tema de mais de 200 telas de Monet (exemplo na FIG. 90), que acabaram se tornando o mais célebre adereço desta fase da vida do pintor, e palco de suas mais intensas experimentações. Ele os pinta a partir de meados de 1890, e, desde então, juntamente com o lago do terreno, seus salgueiros, a ponte japonesa e as nuvens no céu, as plantas aquáticas passam a ocupar um lugar muito grande no imaginário de e sobre Monet. Após a sequência de séries que elevaram a capacidade de intuição óptica do pintor a patamares que talvez só fossem alcançados por outros media (como o cinema e a fotografia), talvez fosse natural que a extensão de seu trabalho se desse no âmbito de um certo enclausuramento temático, misturando ao dia-a-dia monocromático de sua vida regrada e pacata (o acordar e o levantar cedo pontuados pelas elaboradas refeições que entrecruzavam as muitas horas de trabalho diante das telas) uma rarefação cada vez mais intensificada de sua pintura. Isso talvez transformasse a cinética do fotograma proposta na série das Catedrais de Rouen em um movimento interno inerente a toda a realidade que saísse até mesmo da atividade do cinema e o levasse a uma espécie de fenomenologia que tangesse a pura representação do movimento. Estamos falando, como é possível perceber, de três aspectos que correlacionam esta nova fase de Monet: 1) a sua não intenção inicial em pintar os nenúfares; 2) a natural dissolução do objeto em sua pintura; 3) em decorrência desta dissolução, a também natural tendência à abstração. 


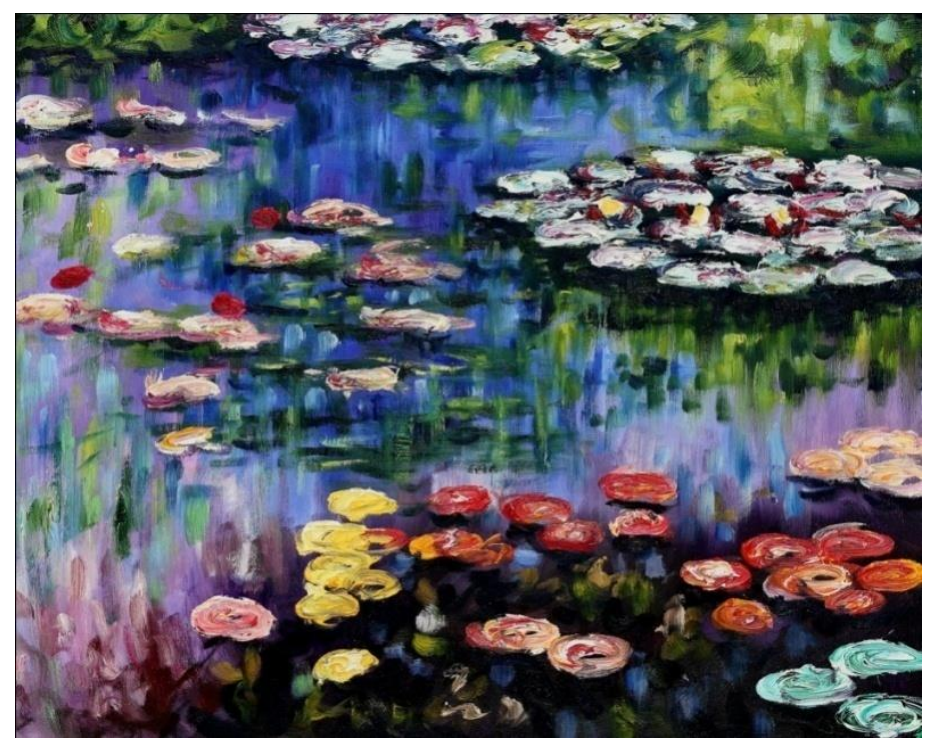

Figura 90

A primeira assertiva diz respeito à autorrepresentação que Monet acabou se impondo no processo de pintar esta enorme série. Dizia ele: "Eu precisei de tempo para entender meus nenúfares. Eu os havia plantado por prazer; eu os cultivava sem considerar pintá-los... Uma paisagem não se impregna em nós de um dia para o outro..." (MONET apud PIGUET, 2010, p. 17) ${ }^{164}$. A obsessão do pintor em representar o visível (seja lá como ele se nos apresente) levou-o, possivelmente, a um adensamento da realidade perceptível a partir do universo que podia ver no limitado espaço de convivência de sua casa e de seu jardim. Fazendo isso, Monet acabou finalmente, por transformar o jardim em universo, em retrato panteísta de sua subjetividade quase cósmica. "Imagens concentradas de uma paisagem que é ela mesma concentrada do universo. As paisagens aquáticas são, da mesma forma, modelos reduzidos de uma totalidade reenviada ao essencial." (GEORGEL apud PIGUET, 2010, p. 24) ${ }^{165}$. Conforme veremos adiante, os efeitos decorrentes disso são muitos, e similares ao que analisaremos a respeito do filme Retrato de um homem jovem (Portrait of a young man, Henwar Rodakiewicz, 1931), que parece incorrer nos mesmos efeitos de aproveitamento de uma frequência ou modulação poética da percepção, como faz Monet, mas dentro das especificidades de um outro medium, o cinema.

Isso nos leva ao segundo aspecto relevante à produção de telas de nenúfares em Monet: limitando seu objeto ao que poderia ser considerado, em primeira instância, um

\footnotetext{
164 Tradução nossa.

165 Tradução nossa.
} 
item vulgar de decoração ou mero e insistente exercício (a representação de uma planta), o pintor alcança aquilo que sugeria a própria intenção de subjetividade proposta em sua fusão com o ambiente que o circunda, ou seja, a extinção do próprio objeto e da própria representação. "Eu sentia, de maneira confusa, que o objeto faltava ao quadro [...]. Mas, inconscientemente, 'o objeto' empregado na obra, enquanto elemento indispensável do quadro, perdia para mim a sua importância." (MONET apud PIGUET, 2010, p. 12) ${ }^{166}$. É importante frisar aqui as transformações no estilo de Monet em relação à sua produção de pinturas seriadas e os modelos de produção cinematográfica que apareceriam ao longo do século XX. Primeiro, com a série das estações e trens dos anos 1870, ele aborda a montagem em planos, a passagem sequencial do tempo, conforme o modelo dos cinemas narrativo e clássico ${ }^{167}$; em segundo lugar, as séries dos anos 1880, como a da Catedral de Rouen, em que o modelo do fotograma é utilizado ao invés do plano, produzindo uma cinética inerente à qualidade pictorial das imagens entre instantes ínfimos, o que resulta em uma estética que ao mesmo tempo se assemelha às trucagens do cinema de atrações e ao cinema experimental de Stan Brakhage, Ken Jacobs ou Norman McLaren. Por fim, iniciando com as séries de nenúfares realizadas a partir dos anos 1890 e se estendendo até os monumentais Painéis Decorativos produzidos para o Museu da Orangérie em Paris entre os anos 1914 e 1926, a fase final da carreira de Monet remete a possibilidades relacionadas ao cinema tão díspares quanto os Panoramas do século XIX e o cinema experimental dos anos 1920 e 1930. Cineastas americanos como Dwinel Grant e Douglass Crockwell, seguindo os passos de pioneiros como Oskar Fischinger e Mary Ellen Bute ${ }^{168}$, inspiraram-se principalmente em Kandinsky e Mondrian para realizar um cinema de animação puramente abstrata (STARR, 2001, pp. 80-1), também baseado no fotograma porque

\footnotetext{
166 Tradução nossa.

${ }^{167} \mathrm{O}$ cinema clássico americano utiliza, com maior ou menor grau, uma série de recursos narrativos inspirados no que Griffith havia desenvolvido: montagem em continuidade, "centralização" figurativa no plano, convenções de espaço e tempo, montagem paralela, unidade cênica. A força da narrativa clássica se concentra principalmente nas ideias de que se deve filmar apenas o que é importante para a história, dispensando detalhes desnecessários, e também filmá-la em sua melhor visibilidade, tanto em termos de iluminação quanto de angulação (XAVIER, 2005, pp. 27-41).

${ }^{168}$ Fischinger, alemão, chegou em Hollywood em 1936. Tendo participado, junto a Fritz Lang, da onda expressionista, foi um pioneiro da animação abstrata. Em 1938 realiza, junto ao estúdio MGM, o curtametragem An optical poem, único filme abstrato a ser lançado por um grande estúdio em Hollywood (STARR, 2001, pp. 78-79). Em 1940, ajuda Walt Disney no primeiro segmento de Fantasia (1940). Já Bute, pintora e cineasta, foi a primeira mulher a trabalhar com a abstração no cinema, tendo ficado famosa por seu primeiro filme, Rhythm in light (1934), que usava técnica de animação stop-motion, semelhante ao estilo de Fischinger.
} 
elaborado na técnica stop-motion ${ }^{169}$. Seus filmes, como o peculiar Themis (Composition $\left.N^{o} 1\right)$ (1940, FIG. 91), de Grant, buscavam um tipo de expressão pura das formas e cores em movimento, trazendo à tona uma vibração originária do mundo, remetendo a forças elementares, proposições fundadoras, estruturas ocultas no mecanismo de todas as coisas. Não à toa, eram também pintores (Grant, um pintor abstrato; e Crockwell um pintor de murais mais afiliado ao que se convencionaria posteriormente chamar de arte pop). Logicamente, os Painéis Decorativos da Orangerie têm uma afinidade ainda maior com filmes de compleição abstrata ligados ao tema da natureza e não das formas geométricas à Kandinsky (o chamado abstracionismo geométrico). Dentre estes casos destacamos não apenas Retrato de um homem jovem, sobre o qual discorreremos longamente à frente, mas também a obra de Ralph Steiner (especialmente H2O, de 1929), que busca a rarefação do objeto através de uma progressiva deformação visual abstrata de imagens da água até que suas imagens se tornem irreconhecíveis, dentro do material profílmico ${ }^{170}$, se comparadas ao material originalmente filmado (FIG. 92). Todos estes filmes, é importante frisar, foram realizados de maneira que fossem exibidos sem som, ou seja, ressaltando o silêncio das obras, fato que, conforme veremos, é extremamente relevante para sua comunicação de natureza poética. A relação dos pintores e cineastas americanos (de cunho experimental, fora de Hollywood) com a abstração é longa, e, se tem, em uma ponta da história, o action painting e o expressionismo abstrato de Jackson Pollock ou Mark Rothko, na outra temos exatamente Monet, que, com os Painéis da Orangerie, não apenas sinalizou o caminho até estes movimentos (além de sugerir o surgimento da instalação) como abrigou, no fim dos anos 1880 em Giverny, uma colônia de pintores americanos interessados em seus ensinamentos que ficou conhecida como "givernistas", dentre eles Theodore Butler (HEINRICH, 2000, p. 76).

\footnotetext{
${ }^{169}$ Stop-motion, como o próprio nome diz, é uma técnica de animação que utiliza a interrupção e posterior acionamento da filmagem para articular, no nível do fotograma, a produção de um desenho em movimento.

${ }^{170}$ Chama-se profílmico tudo aquilo que é capturado pelo campo cinematográfico. Tudo aquilo que aparece na tela (AUMONT; MARIE, 2007, p. 242).
} 


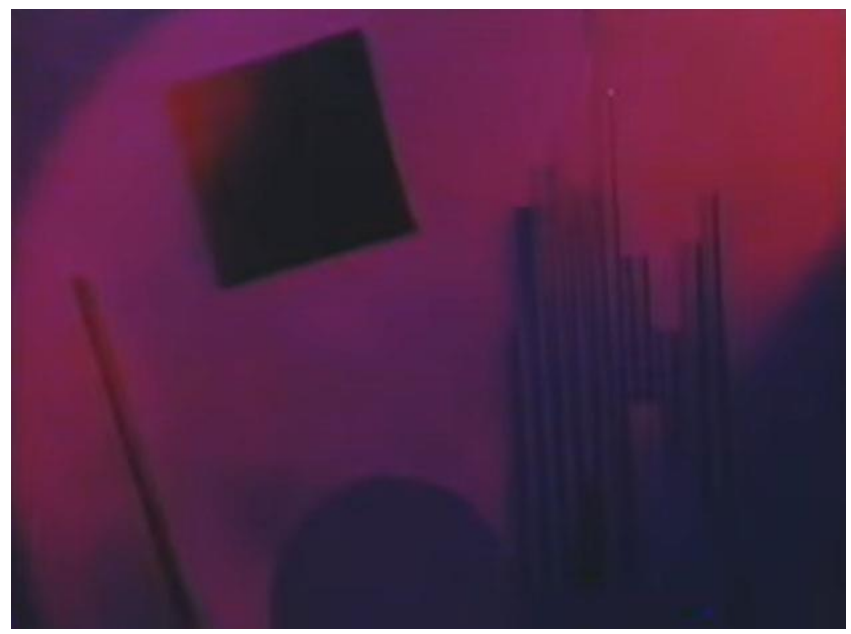

Figura 91

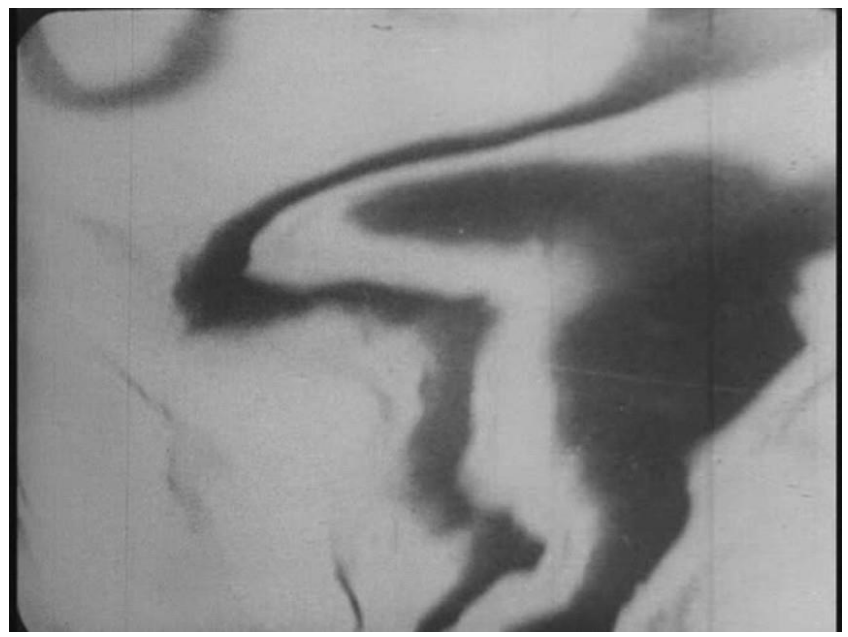

Figura 92

Todo este percurso existe para que possamos traçar o caminho de Monet em direção à abstração (o terceiro aspecto de nosso diagnóstico das fases finais do pintor) e pensar aspectos de sua estética como relacionados não apenas ao cinema como um todo (a tecnologia, as técnicas de filmagem e montagem, a fotografia, os tipos de representação, etc.), mas também a um cinema específico (a vanguarda abstrata americana dos anos 1920 e 1930), que, como veremos, a partir de um reprocessamento mediático (pintura-cinema), destila uma poética oriunda do silêncio. Os Painéis da Orangerie são o desdobramento final das séries de nenúfares de Monet, e é comum que se os considere como uma espécie de testamento, expressão final de sua vida e obra, versão mais radical para os seus autorretratos. (HOOG, 2006, p. 4). Desde o início de sua carreira, a pintura de Monet sempre se situou no limite do visível, e diante desta particularidade se fundou toda a estética do Impressionismo, considerando a opção de 
pintores como Renoir, Sisley ou Pissarro pela composição de paisagens pintadas ao ar livre, com tintas de pigmentos vívidos que deixavam as cores saturadas e vibrantes, notoriamente um escândalo para a crítica e para a academia francesa da época, mais concentrada na linha do que na cor. Em maior ou menor grau, mas de certa forma presente em todos eles, o aspecto incompleto e vibratório das paisagens (Monet), naturezas-mortas (Cézanne) e cenas do cotidiano (Renoir) era capaz não apenas de suplantar a representação desejada pelos acadêmicos, mas de provocar uma visão interior que adviesse do visível. Como se a vibração molecular das pinceladas finas e minuciosas dos impressionistas colocasse automaticamente nosso mundo nos campos da óptica e da probabilidade, campos estes capazes de questionar nossos sentidos, de duvidar de uma empiria e de colocar a arte definitivamente em contato com a então emergente ciência moderna ${ }^{171}$. A respeito de Cézanne, o pintor abstracionista russo Wassily Kandinsky compreendeu com clareza de espírito o fator revelatório da pintura impressionista:

\begin{abstract}
De uma xícara de chá, ele fez um ser dotado de alma ou, mais exatamente, distinguiu um ser nesta xícara. Elevou a "natureza morta" ao nível de objeto exteriormente "morto" e interiormente vivo. Tratou os objetos como tratou o homem, pois tinha o dom de descobrir a vida interior em tudo. Captura-os e entrega-os à cor. Recebem dela a vida - uma vida interior - e uma nota essencialmente pictórica. Impõe-lhes uma forma redutível a fórmulas abstratas, frequentemente matemáticas, das quais emana uma radiante harmonia. Não é nem um homem, nem uma maçã, nem uma árvore, que Cézanne quer representar; ele serve-se de tudo isso para criar uma coisa pintada que proporciona um som interior e se chama imagem (KANDINSKY, 1996, p. 53).
\end{abstract}

A visão de Kandinsky sobre Cézanne, que atribui "vida” (e, logo, uma visão) interior às coisas pintadas pela pincelada impressionista, será ampliada por Heidegger em sua leitura de Van Gogh, um herdeiro direto desta estética. O filósofo alemão vai além (NUNES, 2007, pp. 92-97) e atribui a um simples objeto pintado (as botas de Van Gogh) a função de fio de Ariadne ${ }^{172}$ em direção a um contínuo desvelar da verdade em

\footnotetext{
171 "Acontece que Bohr marcou, na minha opinião, um acontecimento de importância epistemológica capital quando, não por cansaço, mas por consciência dos limites da lógica, interrompeu o grande torneio entre a concepção corpuscular e a concepção ondulatória da partícula, declarando que era preciso aceitar a contradição entre as duas noções que se tornaram complementares, já que, racionalmente, a experiências levavam a essa contradição" (MORIN, 2014, p. 186).

172“"Filha de Minos e Pasifae. Ao ver Teseu recém-chegado a Creta para tentar matar o Minotauro, Ariadne apaixonou-se por ele; querendo ajudá-lo, deu-lhe um novelo de linha que lhe permitiu entrar no Labirinto, morada do monstro, sem se perder, desenrolando o novelo à proporção que avançava, para saber por onde iria sair. Graças a esse expediente Teseu cumpriu a missão, e Ariadne fugiu com ele para livrar-se da cólera paterna." (KURY, 1999, p. 44). A menção ao fio de Ariadne aqui é, evidentemente, uma metáfora.
} 
si, que vai caindo como camadas de uma cebola diante dos vários níveis de complexidade que vão sendo desmontados. Não à toa, Kandinsky tornou-se elo fundamental entre a pintura impressionista (especialmente a última fase de Monet), a deflagração do abstracionismo na pintura e, por fim, a própria vanguarda abstracionista no cinema. Voltaremos ainda tanto a Kandinsky quanto a Heidegger, mas ressaltemos agora a necessidade de se frisar a importância da relação que os impressionistas estabeleciam entre o visível, a realidade da verificação científica e a realidade interior.

Foi Georges Clemenceau, duas vezes primeiro ministro da França, entusiasta das artes e amigo pessoal de Monet, quem lhe sugeriu, em 1914, que pintasse uma série especial de nenúfares e a entregasse de presente ao Estado Francês. Monet sentiu-se estimulado e o entusiasmo lhe fez planejar algo ambicioso: pintaria painéis muito grandes, com tamanhos variáveis entre $2 \mathrm{~m}$ x $6 \mathrm{~m}$ e $2 \mathrm{~m}$ x $17 \mathrm{~m}$, sem molduras, perspectiva, pontos de fuga, profundidade ou volume. Toda expressão pictórica residiria em elementares duas dimensões, na mais residual superfície. Nestas novas composições, a água do lago, os nenúfares, os salgueiros, as folhas, o sol, as nuvens e todo tipo de reflexo vão se confundir em uma massa quase amorfa, de constante e interminável transformação, onde os elementos se fundem uns nos outros, resultando em um desnorteante tipo de cinética moldada no calor e na frieza das cores. "Um todo sem fim, uma onda sem horizonte e sem costa" (MONET apud PIGUET, 2010, p. 21), como afirmou o próprio pintor.

Devido às dificuldades em se empreender qualquer coisa em meio à Primeira Guerra Mundial, o projeto levou mais de uma década para ser concluído. Monet chegou a pintar dezoito painéis, que depois foram reduzidos a doze, para finalmente chegarem à configuração final de apenas oito, cada um deles formado por painéis menores. A intenção inicial era hospedar as pinturas no Hotel Biron em Paris, mesmo lugar onde se localiza o Museu Rodin. Porém, o local foi rejeitado pelo Ministério de Obras Públicas da França e Clemenceau conseguiu renegociar sua instalação no museu da Orangerie, localizado no Jardim das Tuileries, no coração da cidade e à beira do Sena. As oito composições foram instaladas, em dois grupos de quatro painéis, em dois salões ovais. Cada um dos painéis foi nomeado com a posição cardeal da parede em que foi instalado. Portanto, em cada sala temos uma parede norte, uma parede sul, uma parede leste e uma parede oeste. Além disso, o hall de entrada é mais uma sala oval, porém com as paredes 
vazias, em branco, ressaltando o aspecto meditativo e o silêncio das obras (FIG. 93 e 94).

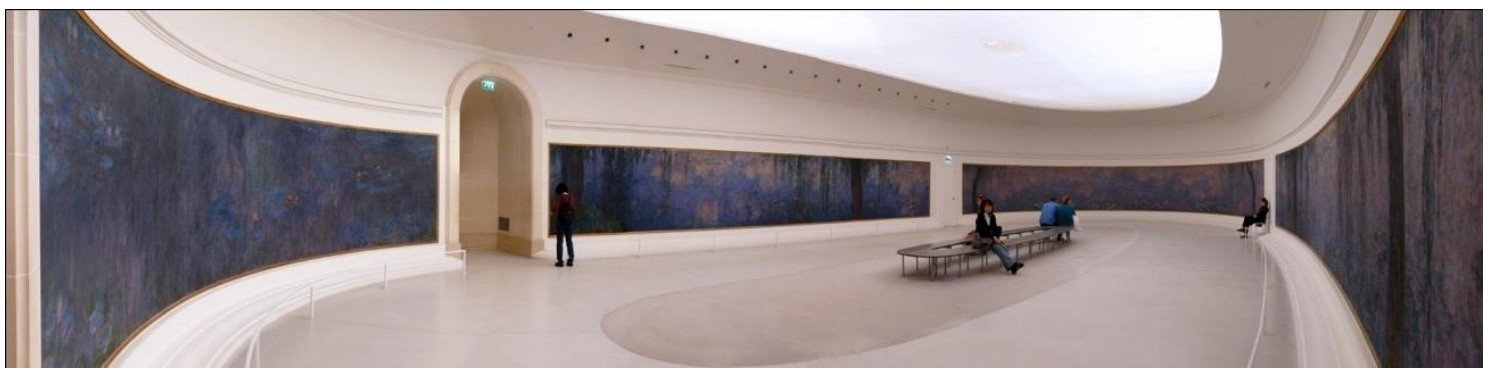

Figura 93

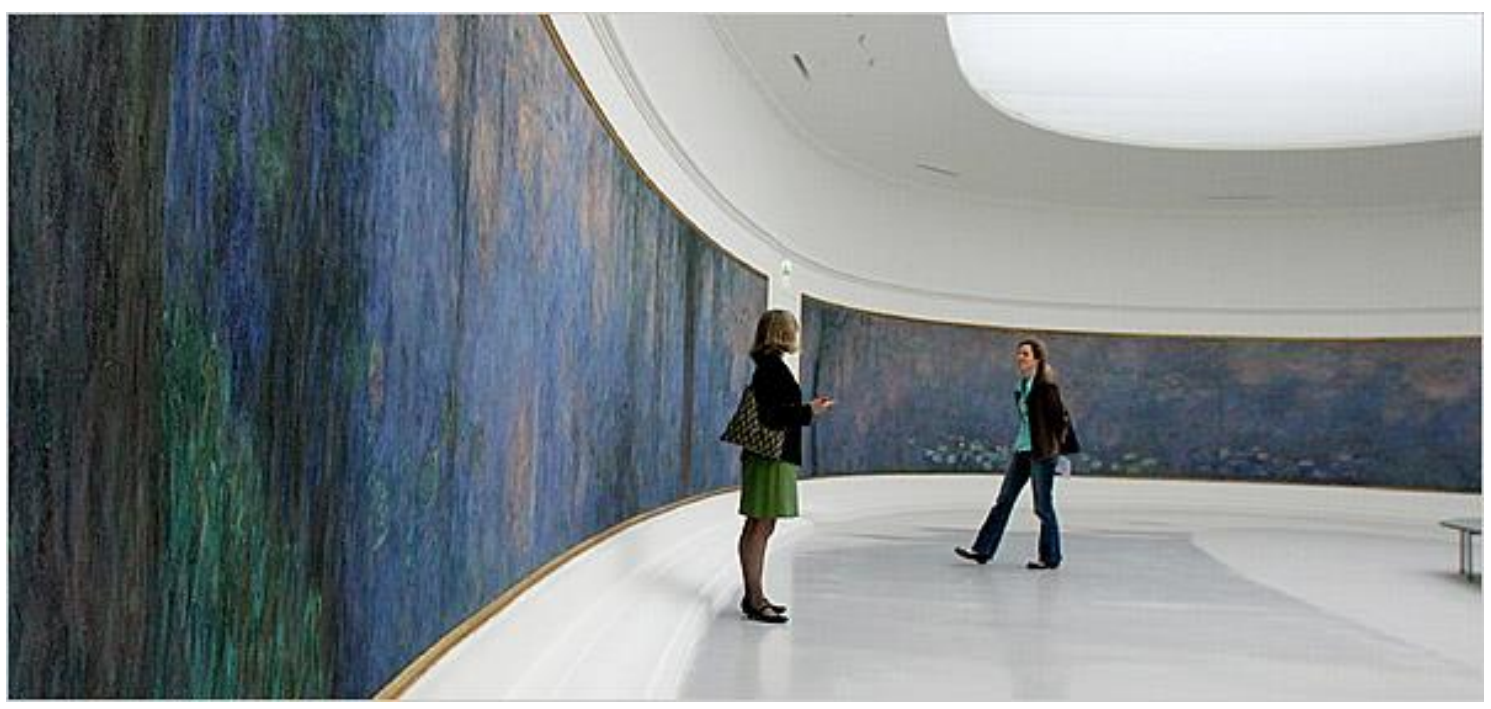

Figura 94

O Museu da Orangerie é hoje um dos mais visitados de Paris (cerca de 800 mil visitantes por ano ${ }^{173}$ ). A proposta original de Monet e Clemenceau - uma instalação imersiva onde somos circundados pela vastidão sem fronteiras das obras e pelo silêncio inerente à estética de suas composições - se perdeu hoje em dia diante das hordas de turistas barulhentos com suas máquinas fotográficas e celulares, sua pouca disposição para sentar diante dos painéis e pouco interesse em viver a experiência contemplativa que eles propiciam. A própria ideia de um salão do Museu da Orangerie entulhado de pessoas diariamente vai contra a imagem de isolamento e mergulho em um cosmos abstrato que Monet provavelmente preconizou para as salas. O silêncio das obras e sua qualidade abstrativa, conforme veremos, são componentes fundamentais, dos pontos de vista estético, cognitivo e perceptivo, para estabelecermos uma devida comparação com

${ }^{173}$ Verificado no relatório de atividades do próprio museu, no site oficial. Em: http://www.museeorangerie.fr/fr/article/letablissement-public-du-musee-dorsay-et-du-musee-de-lorangerie. Último acesso: $13 / 12 / 2015$. 
os cinemas silenciosos e as adaptações que uma transferência entre os media (pinturacinema silencioso) provocam nas poéticas oriundas destas relações.

\begin{abstract}
Os Nenúfares da Orangerie obrigam ao exercício de um movimento ininterrupto, um tipo de deambulação - talvez até de navegação - tanto mental quanto física, porque eles são o local de uma operação alquímica em ação perpétua. Na superfície de seus painéis, Claude Monet erigiu a pintura da mesma maneira com que preenchemos um recipiente até que o continente substitua o conteúdo, ocupando-o dialeticamente para mais nada deixar supor daquilo que o suporta. Fazendo isso, existe em Claude Monet uma propensão irresistível em abraçar o espaço - acima, abaixo, adiante, atrás, em todos os sentidos - de tal maneira que o corpo que vê faça parte integrante do conjunto, que mergulhe nele, que se afogue nele, que se confunda com ele, que constitua nele, enfim, um tipo de osmose (PIGUET, 2010, pp. 38-9) ${ }^{174}$.
\end{abstract}

Esta descrição do historiador da arte Phillipe Piguet remete imediatamente às intenções de participação do público, recurso a uma instância fora-do-campo ${ }^{175} \mathrm{e}$ tridimensionalidade propostas pelas instalações artísticas que surgem a partir dos anos 1950. Porém o fato de que, no decorrer das décadas no século XX, as instalações foram incorporando tecnologias modernas, especialmente audiovisuais (Nam June Paik e Bill Viola, com o vídeo e projeções digitais, para ficar em dois exemplos), levou a um natural distanciamento destas formas de extensão do cinema ${ }^{176}$ em relação à série de nenúfares da Orangerie, que poderíamos chamar de pré-cinema. Seria mais fácil, no entanto, pensar estes painéis como formas de expressão que se servem dos media do passado e do futuro, elaborando uma forma toda específica de se comunicarem. Se tangenciam o primeiro cinema, se são o desenvolvimento da pintura impressionista, se antecipam o cinema abstrato dos anos 20 e 30, se influenciam o expressionismo abstrato ou se servem de modelo para a arte da instalação (silenciosa ou audiovisual), isso ocorre porque o projeto de Monet - situado em uma época de conflitos e entrechoques nos media novos, na cultura que se transforma e nas possibilidades comunicacionais que se amalgamam - acabou se tornando um ponto de convergência intermedial ${ }^{177}$. Pintura, cinema e, conforme veremos, o próprio medium da poesia programam o envio e reenvio de suas potências comunicacionais e perceptivas de uma instância a outra, alojando os painéis nesta espécie de entrelugar.

\footnotetext{
${ }^{174}$ Tradução nossa.

175“ "O campo definido por um plano do filme é delimitado pelo quadro, mas acontece, frequentemente, elementos não vistos (situados fora do quadro) estejam, imaginariamente, ligados ao campo, por um vínculo sonoro, narrativo e até mesmo visual." (AUMONT; MARIE, 2003, p. 132).

${ }^{176}$ Para uma conceituação do cinema expandido, Cf. Pré-cinemas e pós-cinemas in: MACHADO, 1997.

177،Jürgen Müller [...] analisa a incidência de uma mídia sobre a outra, e de várias mídias entre si, por meio do conceito de intermedialidade (Intermedialität), para descrever os processos equivalentes à intertextualidade no caso das mídias" (MÜLLER, 2012, pp. 23-24).
} 
O caso da influência dos "Panoramas" nos painéis da Orangerie é particularmente curioso. Esta antiga forma de representação e reprodução da realidade (datada do final do século XVIII, com florescimento no início do século XIX e posterior redescoberta e modernização no final do século XIX. (SCHWARTZ, 2004, p. 352), muito popular na França no período em que Monet esteve em Giverny, assumia basicamente dois modelos: o primeiro, mais antigo e conhecido, são as grandes pinturas circulares, em grandes ou pequenos salões, que no início representavam exclusivamente paisagens (ou vistas das grandes cidades) e que, no final do século XIX, evoluíram para cenas e eventos cotidianos tais quais os retratados nos jornais e outras atrações de massa como os museus de cera. O segundo, desenvolvido no final do século XIX, era o Panorama móvel, que utilizava um sistema de substituição das pinturas, criando um efeito de montagem pré-cinematográfico, para emular a sensação de deslocamento em paisagens diversas, algo não muito diferente das vistas dos Lumière. A historiadora Vanessa Schwartz (2004, p. 355-6) descreve uma atração desse tipo na Exposição Universal de 1889, em Paris, onde um navio em tamanho real foi reconstituído para receber as milhares de pessoas que iam assistir, a bombordo e a estibordo da embarcação, as várias telas móveis que exibiam passeios por paisagens marítimas. Ela argumenta que o sentido dos Panoramas, por mais que antecipassem de alguma forma a ilusão e a montagem das imagens cinematográficas, estava mais próximo da obsessão pela fidelidade realista-positivista da época. Experimentar sensações muito próximas do real era algo que se podia encontrar não apenas nos Panoramas, mas também nos necrotérios, nos museus de cera e nos teatros de vaudeville das cidades.

\footnotetext{
Embora a pintura [dos panoramas] não retratasse um momento real, ela descrevia um momento possível na vida parisiense que a maioria dos leitores da imprensa diária poderia ter imaginado com base na familiaridade com o local e com as pessoas que o habitavam. Em outras palavras, a pintura era similar à vida porque materializava visualmente um mundo que formava uma narrativa popular familiar: o mundo real que se encontrava representado na imprensa parisiense. Como o museu de cera, o sucesso do panorama estava no olho e na mente do espectador; o realismo não era meramente uma evocação tecnológica (Ibidem, p. 355).
}

Obviamente, os painéis da Orangerie não se encaixam neste contexto. Eles não eram realistas e nem tampouco procuravam uma experiência do real modelada no positivismo tais quais os Panoramas ou as já mencionadas fotografias de Nadar. Seu realismo se enquadra mais dentro da frieza da meditação ou no borbulhar febril do 
mundo subatômico ${ }^{178}$. Porém, de certa forma, este descompasso entre os Panoramas e os painéis revela ainda mais a capacidade de Monet, neste trabalho, de ser um ponto de convergência entre certas possibilidades mediáticas e expressivas dos séculos XIX e XX. Certamente as duas salas ovais da Orangerie, com suas quatro paredes preenchidas por enormes painéis de Monet, emulam a experiência do panorama no sentido de que somos preenchidos por certa paisagem. O próprio Monet começou como um jovem radical pintor de paisagens, e todo o século XIX, especialmente na Inglaterra que ele tanto amava, havia sido dominado por pintores paisagistas e românticos, como Constable ou Turner, que atribuíam sentido metafórico, de plena transfiguração do mundo exterior no mundo interior, à paisagem. Certamente todo o Impressionismo nasce desta origem romântica. Mas, de que tipo de paisagem falamos, a respeito dos painéis da Orangerie, se suas imagens diluídas estão à beira da abstração total? Turvando completamente a imagem, Monet nos coloca na paisagem antípoda cuja experiência se assemelha a ouvir a cacofonia do som da chuva, a observar o caos organizado das ondas do mar $^{179}$, ou a ver e ouvir estática em uma televisão quebrada. $\mathrm{O}$ silêncio da obra e anulação da figuração pode remeter ao apagamento de qualquer imagem da mente para viabilizar o ato da meditação zen, ou pode representar a soma unívoca de todos os sons, quando o barulho total também equivale ao silenciamento ${ }^{180}$. De uma forma ou de outra, o panorama criado por Monet cria uma espécie de paisagem artificial que nos faz passear não pelo mundo da realidade factível, mas por uma jornada interior em direção a uma nova frequência de percepção:

\footnotetext{
178 "O que diremos [...] sobre a desordem? É macroconceito que envolve realidades muito diferentes, sempre comportando a aleatoriedade. Pode-se dizer também que a desordem invadiu o universo; é certo que a desordem não substituiu totalmente a ordem no universo, mas já não existe nenhum setor em que não haja desordem. Ela está na energia (calor), no tecido subatômico do universo, em sua origem acidental" (MORIN, 2014, p. 200).

179 Ítalo Calvino, no conto "Palomar na praia", descreve com perfeição este caos organizado das ondas do mar: "Em suma, não se pode observar uma onda sem levar em conta os aspectos complexos que concorrem para formá-la e aqueles também complexos a que essa dá ensejo. Tais aspectos variam continuamente, decorrendo daí que cada onda é diferente de outra onda; mas da mesma maneira é verdade que cada onda é igual a outra onda, mesmo quando não imediatamente contígua ou sucessiva; enfim, são formas e sequências que se repetem, ainda que distribuídas de modo irregular no espaço e no tempo" (CALVINO, 1994, p. 8).

180 Joachim-Ernst Berendt cita a teoria da harmonia para justificar como sons dissonantes tendem a encontrar harmonia. Neste caso, a harmonia suprema (o silêncio) viria da cacofonia: "Qualquer um que esteja ao menos levemente familiarizado com teoria da harmonia sabe que cada dissonância tende a ser tornar harmonia. Se é verdade que as relações harmônicas na música refletem as harmônicas e matemáticas relações no sistema planetário da mesma que no cosmos, no microcosmo, na biosfera, e em todos os outros campos sobre os quais nós falamos, então esta regra também deve ser válida fora da música: todas as dissonâncias gravitam em direção a se tornarem harmonias" (BERENDT, 1991, p. 122).
} 
Com os Nenúfares, Monet iria desenvolver sua obra de uma maneira ainda mais audaciosa, totalmente inovadora. Em relação ao tempo, de um lado, se atrelando a um motivo que deveria vir como uma assinatura; não a marca de um estilo, mas o selo incontestável de uma identidade. Em relação ao espaço, por outro lado, empurrando a pintura até seu entrincheiramento mais extremo e oferecendo um alcance de 360 graus - um pouco à maneira dos "panoramas" do século XIX que ainda faziam muito sucesso, mas com uma intenção completamente diferente. Se Claude Monet enunciou o motivo dos nenúfares durante 27 anos, ele, sobretudo, inventou um lugar para eles. Um lugar próprio, fabricado em toda a sua inteireza. Um lugar totalmente artificial (PIGUET, 2010, pp. 15-6).

Se existe uma aproximação que pode ser feita entre os painéis da Orangerie e certo cinema silencioso, portanto, isso se dá não pela antecipação do dispositivo cinematográfico feito pelo panorama móvel, ou sequer pela tentativa de reprodução de cenas reais pelo panorama tradicional, mas sim pela amplificação do próprio silêncio inerente a estas obras em relação ao silêncio inerente ao cinema silencioso. A relação entre a aproximação com a abstração proposta por Monet, este silêncio e uma ideia de poesia que subjaz a todas estas instâncias é o que possibilita a análise da transposição de um conteúdo no outro, a partir de diferentes media, que iremos propor.

Mas em que consistem, efetivamente, estes painéis? Observando as pinturas, percebemos que, mesmo que elas tanjam a abstração e coloquem Monet como possivelmente tentando alcançar o fator de decomposição da figuração ${ }^{181}$, ele não estava na mesma sintonia que Kandinsky ou Malevich, detentores de uma expressão pictorial calculada, geométrica, elementar. A questão é que, por mais que, em um exercício puro para desenovelar a mente, possamos perceber as imagens dos painéis como desprovidas de qualquer traço de figuração, é ainda possível compreender que elas são de alguma forma importadas da realidade (neste sentido são mais obras abstraídas do que abstratas). Como dizia Clemenceau: "Monet não pode pintar outra coisa senão aquilo que ele vê." (CLEMENCEAU apud HOOG, 2006, p. 76) ${ }^{182}$. Isso é essencial para demarcarmos a ausência de um lugar específico para os painéis tanto na obra de Monet quanto na arte e no ambiente cultural de sua época. Os painéis podem ser quase abstratos, mas são baseados naquilo que o pintor via. Eles se inclinam para a cultura de Panoramas, mas não têm qualquer similaridade com a atualização da realidade factual e jornalística que eles propunham. Eles compunham um cenário totalmente novo para o

\footnotetext{
${ }^{181}$ HOOG (2006, p. 17) afirma que Monet conhecia o fauvismo, os balés russos de Serge de Diaghilev, os começos da abstração, Matisse, o cubismo e até mesmo Picasso. "Isso aí não me diz nada", disse ele, após ver reproduções do último em revistas. (Ibidem. Tradução nossa).

182 Tradução nossa.
} 
Impressionismo, mas não eram o fauvismo de Matisse, ou o cubismo de Picasso e Braque, ou abstracionismo já mencionado. Eles tangenciam o cinema, mas não qualquer cinema. Do primeiro cinema, de truques e sem montagem ${ }^{183}$, ao contrário das outras séries, eles se distanciam. Do cinema narrativo já vigente na época, eles se conformam apenas com o silêncio dos próprios filmes. Do cinema de vanguarda dadaísta e da animação abstrata, eles se aproximam, assim como do conceito do cinemascope nos anos 1950. Além disso, eles preconizam a instalação, a action painting, a land art e outras manifestações mais contemporâneas, mas tampouco podem ser consideradas qualquer uma dessas coisas. Dada a sua localização na história da arte, da cultura e dos media, a série da Orangerie pode ser considerada como algo único, e sua relação com a ideia de poesia é enormemente responsável por isso, conforme veremos.

Cabe, portanto, um olhar mais acurado. O painel da parede sul da sala 1 ( $2 \mathrm{~m} \mathrm{x}$ 12,75 m, FIG. 95), intitulado simplesmente Manhã (Matin), é um dos mais largos da série e o resultado da montagem realizada com quatro painéis menores que compõem a obra total. Diante de uma pintura tão grande, nossa percepção do que está pintado depende, evidentemente, da distância a que nos situamos dela. Neste caso, já que os painéis estão instalados na altura do nosso olhar, vale posicionar-se a dois metros do painel para obter uma visão adequada e perceber os aspectos de figuração nele. De fato, este é um dos painéis mais figurativos da série. Monet não abusa de contrastes e varia em tons leves de azul e verde para pintar os nenúfares em uma manhã translúcida, onde podemos identificar claramente plantas, folhas, flores, água e vegetação. Branco, amarelo e tons róseos também são salpicados nas imagens das flores, e a composição vai ganhando um corpo maior de abstração na medida em que nos aproximamos das pinceladas (como é de praxe em pinturas impressionistas), em estocadas mais vigorosas e selvagens. Da mesma forma, um distanciamento maior do painel provoca também uma acentuação na qualidade abstrativa, quando os nenúfares se transformam em estranhas manchas brancas, como se fossem fungos no painel, e a vegetação verdejante se transforma em manchas escuras nas bordas, fazendo a composição adquirir um aspecto mais sinistro, como se fosse algo produzido por alguém como Sam Francis ou

\footnotetext{
${ }^{183} \mathrm{Um}$ historiador e narratólogo como André Gaudreault vai afirmar que a montagem existe em todo tipo de cinema. Ela apenas é uma articulação de fotograma em fotograma no nível do Mostrador fílmico (onde se situa quase todo o primeiro cinema), e uma articulação de plano em plano no nível do Narrador fílmico. (GAUDREAULT; JOST, 2009, p. 75).
} 
pelo tachismo ${ }^{184}$ francês. Como se poder ver, neste caso a composição pictórica de Monet só se aproxima do que seria conhecido como abstracionismo sensível a partir de uma relatividade espectatorial.

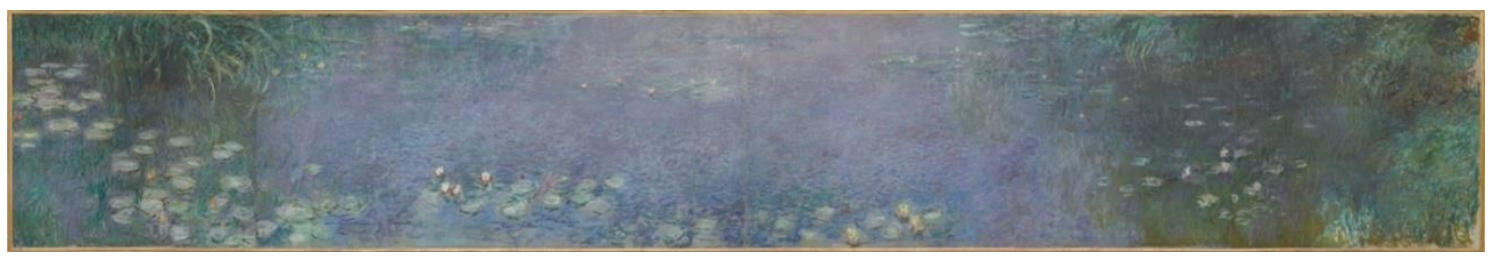

Figura 95

Já o painel da parede norte da sala 1 (mesma altura e largura; formado por três painéis menores, FIG. 96), As nuvens (Les nuages), mostra o reflexo das nuvens no lago do jardim com uma vasta extensão de manchas brancas dominando a porção central dele. Pelas bordas, assim como em Manhã, há o que parece ser o também o reflexo da vegetação no lago. Ao contrário do primeiro painel, porém, neste caso é difícil diferenciar o que está na superfície do lago, o que está em seu reflexo e o que está fora dele. Monet opta, aqui, por um tensionamento das formas e cores muito mais complicado de se deslindar do que no painel anterior (não que haja qualquer tipo de ordem narrativa entre eles), e os conceitos de superfície, profundidade, interior, exterior, dentro e fora se confundem completamente. Neste caso, a distância já não é um fator preponderante para se afirmar a qualidade abstrativa da pintura. Se há figuração, esta é a das próprias nuvens, e, a favor de Monet, podemos constatar que as nuvens já são, em si, abstratas na e por natureza. A imagem da nuvem, conforme veremos, será um dos fios que conduziremos para associar poesia, zen, abstração e silêncio a partir deste painel e do filme Retrato de um homem jovem. Curiosamente, na massa branca de tinta que compõe a porção direita das nuvens no painel, podemos distinguir talvez uma figura barbuda, com olhos, nariz e boca, que sugere uma representação de Monet, espécie de autorretrato. Isso não seria novidade em sua obra e, se aproveitarmos a ideia de que o pintor praticava, em suas telas, uma forma metafórica de nefelomancia (a arte de adivinhar através da leitura das nuvens), ou de que em suas nuvens habitavam alguns nefelibatas (habitantes das nuvens - conforme veremos adiante), a sugestão de que os

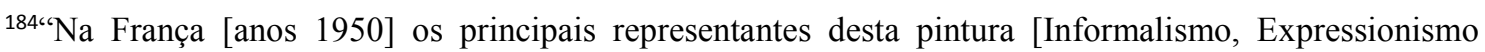
abstrato], liberada das velhas regras de composição, são Jean Fautrier, os emigrados da Alemanha como Wols e Hans Hartung, assim como Georges Mathieu. Na França, como sinônimo de Informel, emprega-se o termo Tachisme, derivado de tache (mancha). Sobretudo para as obras de Wols se emprega também o conceito de 'abstração lírica'” (ESCHENBURG, ESSERS et al, 2005, pp. 621-22. Tradução nossa).
} 
painéis da Orangerie são não apenas um tipo de testamento, mas também de autorretrato, ganha contornos politeístas, como se Monet quisesse efetivamente revelar um tipo de cosmos oculto na névoa de sua abstração.

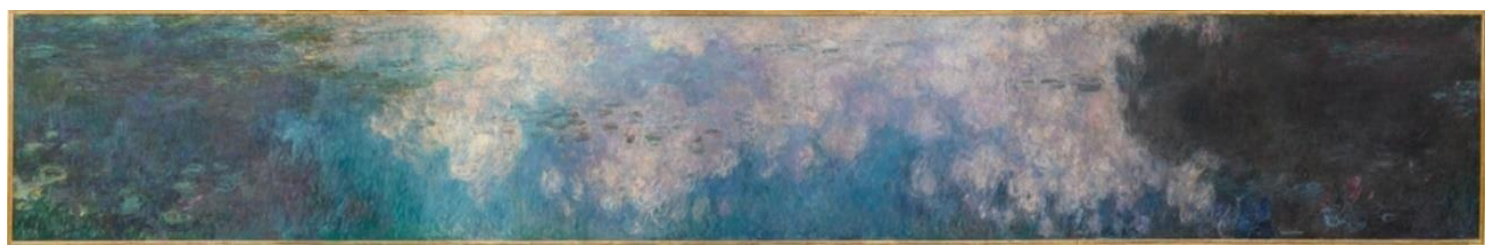

Figura 96

O painel da parede oeste da sala 1 ( $2 \mathrm{~m}$ x $5,99 \mathrm{~m}$, composto por um único painel, FIG. 97), O Sol se pondo (Soleil couchant), de alguma forma confirma esta ideia. Mesmo sendo o menos largo dos oito painéis da Orangerie, ele é certamente um dos que mais chama a atenção, graças à presença mais maciça de cores quentes na pintura (os incandescentes amarelo e vermelho do reflexo do Sol na água). Mas não é apenas esta visão borbulhante de um mundo que se dissolve em ebulição que impressiona neste painel, mas sim também as tonalidades de púrpura, violeta e roxo, acima da grande chama à esquerda da pintura, e as labaredas em forma de pincelada que consomem os já quase indefectíveis nenúfares que bóiam naquilo que um dia poderia ter sido um plácido lago em um jardim. Se já tornamos comum aqui comparar esta obra de Monet a um tipo de inferno subatômico modalizado pelas leis da probabilidade em que tudo se move eternamente, sendo a cinética a própria natureza última da realidade, em um princípio de incerteza infinito, nesse caso vale também observar a possibilidade de este painel remeter a um inferno de proporções astronômicas e colossais: uma estrela em supernova, as espirais de uma nebulosa (FIG. 98), o horizonte de eventos de um buraco negro, um sistema solar primitivo em formação. É como já havia observado, dentro das limitações da ciência de sua época, Clemenceau:

[...] a pintura nos desvenda, como se à luz de um ultra-microscópio, profundezas elementares que, sem ele, nós não teríamos conhecido. Não estamos nós muito perto de uma interpretação representativa dos movimentos brownianos? Isso dada toda a distância entre a ciência e a arte, que fique claro. Mas, ao mesmo tempo, toda a unidade dos fenômenos cósmicos, dentre os quais o pintor, no lugar da visão direta, nos oferece uma interpretação coroada por contagiantes emoção e beleza, onde o conhecimento puro não chega a não ser depois de um longo tateamento em direção à observação" (CLEMENCEU apud HOOG, 2006, pp. 102-3) ${ }^{185}$.

185 Grifo do autor; tradução nossa. 


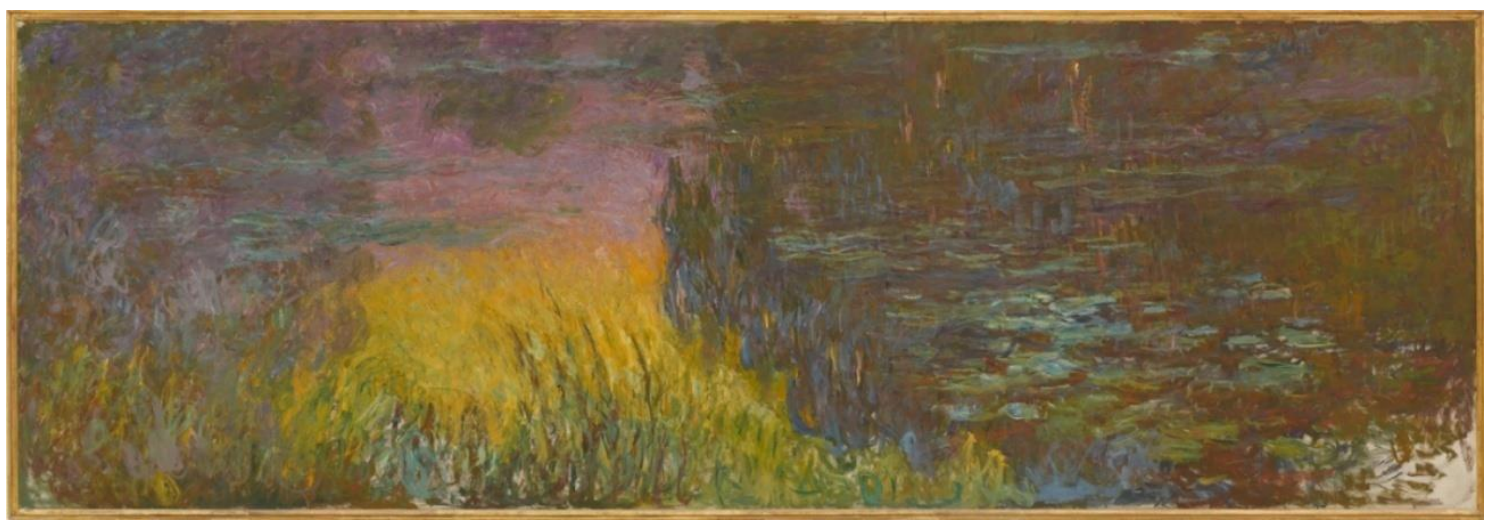

Figura 97

Se Clemenceau menciona os movimentos brownianos, fazendo referência ao movimento aleatório de partículas em colisão (verdadeiro enxame ocorrendo na entropia de um mundo em escala atômica, FIG. 99), é porque também via a percepção de Monet como ligada a uma fabricação elementar da realidade, uma colisão entre fundamentos heraclitianos ${ }^{186}$ que fazem surgir imagens como estes painéis, que não estão distantes nem das imagens deste caldeirão microscópico, nem das fotografias retroativas da formação do universo (outro lugar e época de inimaginável calor, FIG. 100), tiradas por telescópios espaciais como Hubble e Planck. Monet estava aquém deste tipo de conhecimento e destas (posteriores) descobertas, mas sua visão de mundo, de certa forma holística, panteísta, mas ao mesmo tempo ateia e positivista, lhe proporcionaram a possibilidade de conceber tais mundos ao observar o microcosmo que representava seu lago e jardim. Em certas instâncias, Monet tinha o olhar de um cineasta. Em outros, o de um físico. Em todo caso, foi o contato com as vicissitudes de sua época de transição que o permitiram se tornar também espécie de profeta da modernidade pósindustrial através da dinâmica de suas últimas pinturas.

\footnotetext{
${ }^{186}$ Para citar um aforismo do próprio Heráclito: "Todas as coisas são trocadas em fogo e o fogo se troca em todas as coisas, como as mercadorias se trocam por ouro e o ouro é trocado por mercadorias." (HERÁCLITO apud SOUZA, 2000, p. 25).
} 


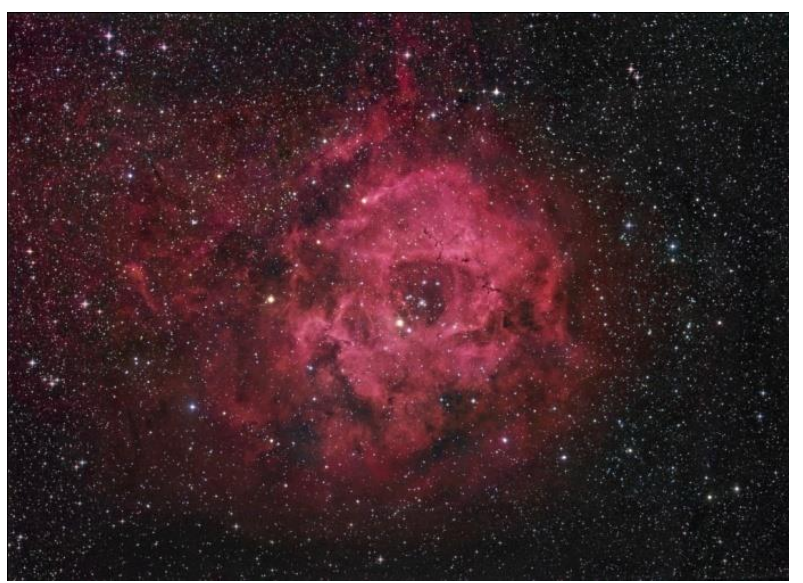

Figura 98

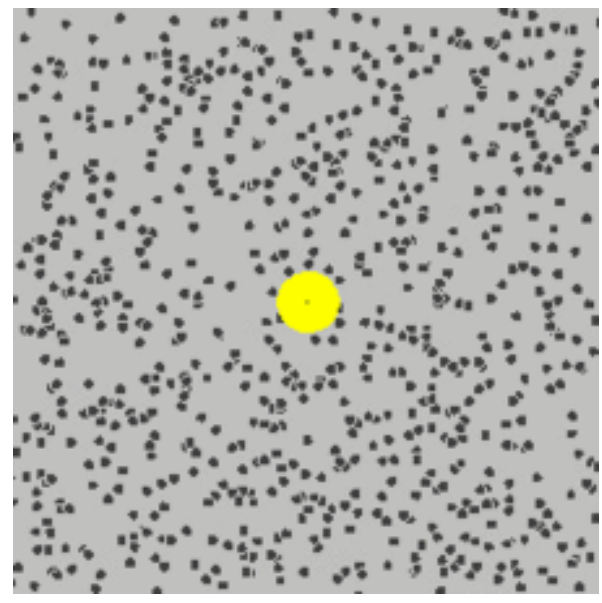

Figura 99

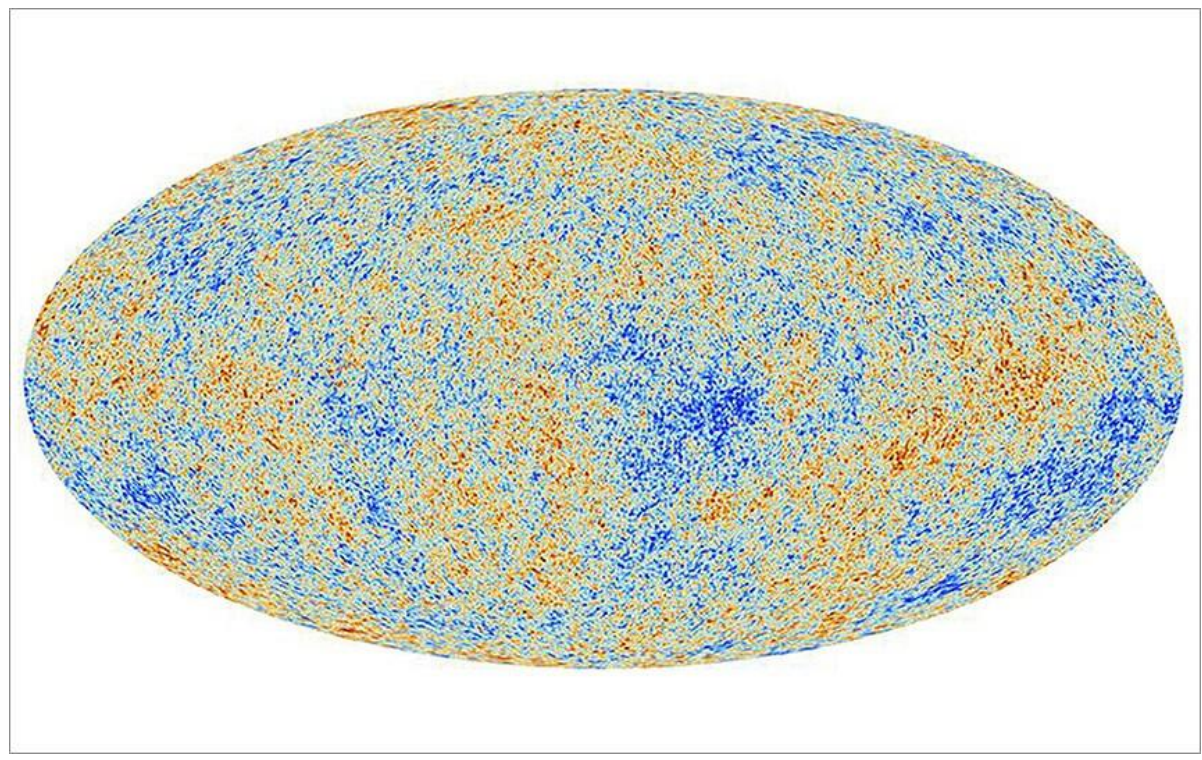

Figura 100 
O painel da parede leste da sala $1(2 \mathrm{~m} \times 8,5 \mathrm{~m}$, composto por dois painéis menores, FIG. 101), intitulado Reflexos verdes (Reflets verts), tem o poder de amalgamar os mundos aquático e vegetal de maneira mais intensa do que nos outros painéis, já que a abundância de tonalidades verdes e o equilíbrio interno desta pintura a transformam em um dos mais plácidos modelos para a abordagem de silêncio zen que pode ser depreendida do trabalho final de Monet. Novamente, torna-se indiferenciado, aqui, o que é reflexo e o que é objeto imediato, e os borrões representando os nenúfares se confundem indiscernivelmente com o resto das "coisas verdes" que aparecem no painel. Imagem, representação e as coisas em si operam segundo um jogo mediado pelos reflexos, que funcionam como corpo que valida a percepção. Portanto, recuperamos aqui todo o jogo ilusório envolvendo a ideia de que a matéria é uma imagem a meio caminho entre a coisa e a representação, conforme vimos em Bergson no capítulo 4. O reflexo em si, solvente da matéria em memória, aparece na tela com o elemento água, o emolidor pré-socrático (desta vez, em Tales de Mileto ${ }^{187}$ ) que realiza a transformação e metamorfose de umas coisas nas outras.

\begin{abstract}
Monet, ao final de sua longa vida, após ter estudado tudo o que os diferentes motivos da natureza podiam responder à questão da luz em relação aos conjuntos das cores, terminou por se dirigir ao elemento ele mesmo o mais doce, o mais penetrável, a água que, a cada momento, é transparência, irrigação e espelho. Graças à água, ele se tornou o pintor direto daquilo que não vemos. (CLAUDEL apud HOOG, 2006, p. 96) ${ }^{188}$.
\end{abstract}

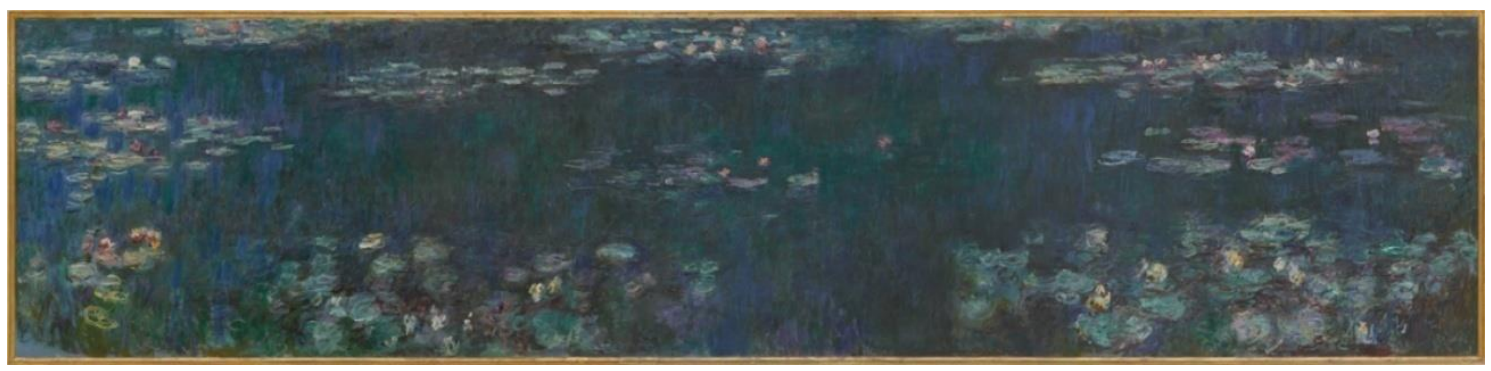

Figura 101

O poeta Paul Claudel foi um dos primeiros a ter contato com os painéis da Orangerie (ele os viu antes da abertura oficial), e sua sensibilidade foi capaz de captar, neste elemento da água, a natureza translúcida da pintura de Monet. Se a água

\footnotetext{
187“"Para a história da filosofia, a importância de Tales advém sobretudo de ter afirmado que a água era a origem de todas as coisas. A água seria a physis, que, no vocabulário da época, abrangia tanto a acepção de 'fonte originária' quanto a de 'processo de surgimento e de desenvolvimento', correspondendo perfeitamente a 'gênese'. Segundo a interpretação que dará Aristóteles séculos mais tarde, teria tido início com Tales a explicação do universo através da "causa material" (SOUZA, 2000, p. 15).

188 Grifo do autor; tradução nossa.
} 
representa aquilo que não vemos, e se Monet se propôs a pintar este meio, este campo de ação da realidade por onde tudo passa, se deforma e se refrata, ele não apenas estava preocupado com a medialidade da água em si (e da própria pintura, o medium de seu próprio trabalho), mas também com o tipo de comunicabilidade responsável por dizer algo sobre isto mesmo que não podemos ver. Ora, se olharmos para a história do pensamento sobre a poesia, seja na síntese romântica de Schelling ${ }^{189}$, no desvelar da verdade em Heidegger ${ }^{190}$ ou na lírica do paradoxo em Octávio Paz ${ }^{191}$, em toda esta trajetória reside principalmente a ideia de que o campo poético é o campo onde se faz necessário dizer o indizível. Quer dizer: mergulhar na ambiguidade mais profunda das coisas. Sublimar os contrastes. Dar conta de uma realidade inexorável. Isso, evidentemente, se parece com pintar aquilo que não vemos, e dois conceitos (que serão retomados adiante) podem nos ajudar a entender esta série de painéis de Monet. Ao falar sobre o poeta francês René Char, Gustavo de Castro e Florence Dravet introduzem a importância do Aberto e da Transparência para a compreensão do papel comunicacional da poesia:

Em sua poesia, dois elementos se nos apresentam como forças fundamentais para a compreensão de sua obra, forças que são também fundamentalmente esclarecedoras para nossa reflexão sobre a comunicação. Faremos delas chaves-conceitos e veremos como se manifestam na linguagem poética. São elas o Aberto e a Transparência. A primeira noção é antiga, uma herança que provém de longe e, embora presente em toda a obra de Char (muitas vezes sob o termo Espaço), não caracteriza propriamente a originalidade de sua linguagem. Consiste em uma base conceitual, filosófica e cosmológica para assentar suas buscas, um contexto para a criação e para a vida. Com efeito, na sua concepção de mundo, o fogo heraclitiano não é o organizador, e o cosmo não é o primeiro; o que vem antes é o campo de possibilidades mais largo, não necessário nem governado, que ele mesmo nomeia Espaço. Já a segunda noção nos parece caracterizar genuinamente sua poética e provavelmente seja o passo adiante que o poeta deu com relação a seus predecessores. Com a

\footnotetext{
${ }^{189}$ O tradutor e crítico de arte Márcio Suzuki explica a origem paradoxal, dentro do artista, do impulso estético para a filosofia de Schelling: "Toda produção estética', diz o Sistema de Idealismo Transcendental [...], baseia-se numa oposição entre uma atividade livre, consciente, e uma atividade impulsiva, inconsciente. Que seja assim, é o que se pode com a razão presumir ouvindo os próprios artistas, quando afirmam que são 'impelidos involuntariamente à produção de suas obras". O 'impulso artístico' provém do 'sentimento de uma contradição interna"” (SUZUKI, 2010, p. 11).

190 “A origem da obra de arte e do artista é a arte. A origem é a proveniência da essência, onde advém o ser de um ente. $\mathrm{O}$ que é a arte? Procuramos a sua essência na obra real. A realidade da obra determina-se a partir do que na obra está em obra, a partir do acontecer [...] da verdade. Pensamos este acontecimento como o travar do combate entre mundo e terra. No movimento congregado deste combate, advém o repouso. Aqui se fundamenta o repousar-em-si [...] da obra” (HEIDEGGER, 1977, p. 46).

${ }^{191} \mathrm{Paz}$ inclusive se refere a certo "estado poético" que em muito se assemelha àquilo que temos chamado de "frequência poética da percepção": "Há apenas uma nota comum a todos os poemas, sem a qual nunca seriam poesia: a participação. Cada vez que o leitor revive o poema, ele ascende a um estado que podemos chamar poético. A experiência pode se adaptar a esta ou aquela forma, mas é sempre ir um mais além de si, um romper dos muros temporais, para ser outro" (PAZ, 2003, p. 25. Tradução nossa).
} 
Transparência, Char opera, em termos de linguagem, que podemos chamar, junto com Heidegger, de "uma clareira no Aberto" (CASTRO e DRAVET, 2014, p.45).

Portanto, o Aberto, enquanto conceito que vai de Heráclito a Heidegger e representa toda a dimensão da realidade em sua inconcebível inteireza, funcionando sob a máquina de irrefreável transmutação que é o devir, seria o campo pantanoso e insondável ao qual se sujeita a hermenêutica da realidade em si. É a própria floresta de Monet e seu amálgama traiçoeiro de plantas, flores, cores, água e reflexos. Jogo de espelhos que sempre leva a um local e a um espaço inidentificáveis. Uma estrutura fractal em que, quanto mais perto dela chegamos, abrimos mais portas para novos universos em que o primeiro processo precisa ser repetido. É este o momento em que a própria hermenêutica falha, e é necessário um instrumento de Transparência para que se possa atravessá-lo. A poesia (que é a água, e que é a própria sensibilidade artística de Monet) é não apenas o vetor da Transparência - ou seja, aquilo que é capaz de produzir uma redução fenomenológica em relação ao Aberto - como é, ao mesmo tempo, o próprio medium pelo qual a comunicação em si vai fluir em direção a este conhecimento oculto. Neste caso, a poesia é capaz de, em várias instâncias, resolver este impasse filosófico por meio de sua racionalidade propriamente poética, fazendo-se compreender através da sintonia em sua própria e exclusiva frequência poética da percepção, conforme veremos adiante. Esta frequência é transparente, invisível, fluida, translúcida, capaz de penetrar de maneira indistinta na mata cerrada do Aberto. Abrir uma clareira.

Heidegger pontua uma diferença clara entre as simples Belas-Artes (que produzem o Belo, e são reservadas ao campo da estética) e a obra de arte capaz de produzir a verdade. Esta obra nos diz o que é o instrumento, o que está em obra na obra. E isso é o acontecimento da verdade. O pôr-se-em obra, por meio do instrumento, revela a verdade. A essência da obra seria justamente o pôr-em-obra da verdade do ente. Sendo assim, a arte deve evocar uma miríade de efeitos e desdobramentos nos fenômenos que compartilha para não ser apenas um mero ser-objeto (Belas Artes), mas sim um ser-coisa (fincado na produção por meio do instrumento; verdadeiro desvelamento do ente). Aqueles que se mantém nesta abertura do ente abrem um mundo, ou seja, a obra é a obra de construção de um mundo. "A obra mantém aberto o aberto do mundo" (HEIDEGGER, 1977, p. 35). Para dar suporte a este mundo a obra ainda estabelece a terra, outro conceito caro a Heidegger. Se o mundo está ligado à abertura do ente (e logo à sua possibilidade de encontrar o ser-aí), a terra, como chão, dá 
suporte a este mundo. "A terra é, por essência, o que se fecha em si [...]. Pro-duzir a terra significa: trazê-la ao aberto com o que em si se fecha” (Idem, p. 37). A produção de terra pelo mundo trazendo-a ao aberto, no entanto, não se dá pacificamente. É a violência e o conflito desta gênese (entre terra e mundo) que permitem que o ente ${ }^{192}$ processe sua desocultação na verdade:

\begin{abstract}
Na obra, a verdade está em obra, portanto, não é apenas algo de verdadeiro. O quadro, que mostra os sapatos do camponês, o poema que canta a fonte romana, no sentido rigoroso do termo, informam não só o que é que este ente isolado é enquanto tal, mas deixam acontecer desocultação como tal em relação ao ente na totalidade. Quanto mais simples e essencial o calçado, quanto mais sóbria e puramente a fonte se erguem na sua essência, tanto mais imediata e manifestamente todo o ente se torna mais ente conjutamente com eles. Detsa forma, o ser que se oculta clareia-se. O clareado desta natureza na obra é o belo. A beleza é um modo como a verdade enquanto desocultação advém. (Idem, p. 45).
\end{abstract}

A beleza (o que, em nosso caso, estamos associando à poesia), portanto é a forma (ou frequência) com que a verdade se desoculta através da arte, abrindo a clareira no Aberto. É a Transparência. E este painel tem a virtude de consagrar as duas coisas: é o Aberto (água turva) e a Transparência (água translúcida). Mesmo próximo da abstração, o painel tem o potencial para disparar e encadear uma sequência hermenêutica heideggeriana, permitindo ir da superfície da água como medium até o desvelamento da verdade do ente na relação entre terra, mundo e aberto.

A segunda sala do Museu da Orangerie é marcada pela presença de painéis extensos (especialmente o gigantesco Os dois salgueiros, de $17 \mathrm{~m}$ de comprimento) e pela pintura mais amena com a presença dos salgueiros, que compõem a paisagem de três deles. Estes três painéis, A manhã com salgueiros (Le matin aux saules - na parede norte, $2 \mathrm{~m} \times 12,75 \mathrm{~m}$, com três painéis menores fazendo a composição total, FIG. 102), A manhã clara com salgueiros (Le matin clair aux saules - na parede sul, 2m x 12,75m, com três painéis menores fazendo a composição total, FIG. 103), e Os dois salgueiros (Les deux saules - na parede leste, $2 \mathrm{~m} \times 17 \mathrm{~m}$, com quatro painéis menores fazendo a composição total, FIG. 104) de certa forma repetem a limpidez e a beleza frugal de Manhã, da sala um, trazendo uma série de componentes repetidos: a luz clara, que privilegia os reflexos das nuvens, folhas e cipós das árvores, além da presença dos nenúfares, que se misturam às manchas que podem ser o branco das nuvens ou a própria

\footnotetext{
${ }^{192}$ Heidegger define o ente: “As coisas são, os homens, os dons e a oferta são, o animal e a planta são, o
} apetrecho e a obra são. O ente está no ser” (HEIDEGGER, 1977, p. 42). 
espuma da água. A diferença se dá praticamente em uma pequena variação na tonalidade das cores em relação à luz: em A manhã com salgueiros e $A$ manhã clara com salgueiros, o azul emerge mais marinho, a vegetação mais densa, e as figuras aparecem com maior delineamento; pode-se dizer que são os painéis menos abstratos da série. Os salgueiros são pintados mais de perto, e é possível perceber certo detalhamento na casca dos troncos. Na enorme extensão de Os dois salgueiros, estamos submergindo na placidez de um azul muito claro e manso, com novamente os motivos das nuvens e sua rarefação trazendo um aspecto de sonho transitório ao painel, com os troncos dos dois salgueiros, mais distantes do que nos outros dois painéis, servindo de limite para as dependências da pintura, posicionando-se, cada um deles, em um dos extremos.

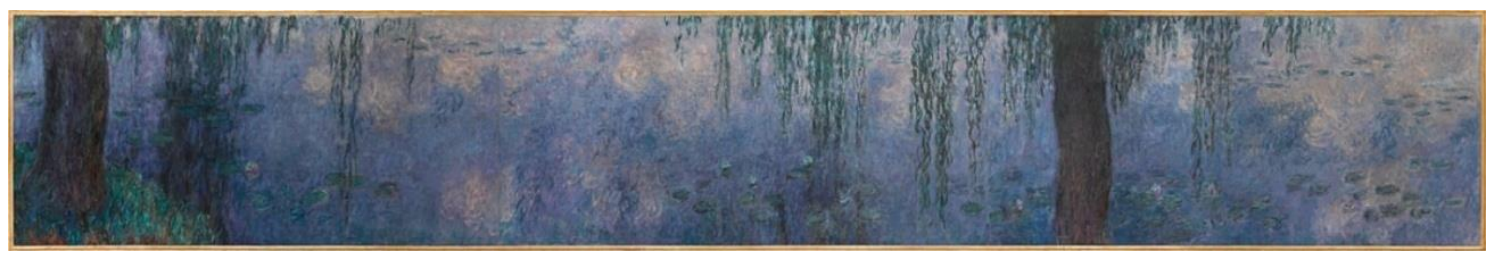

Figura 102

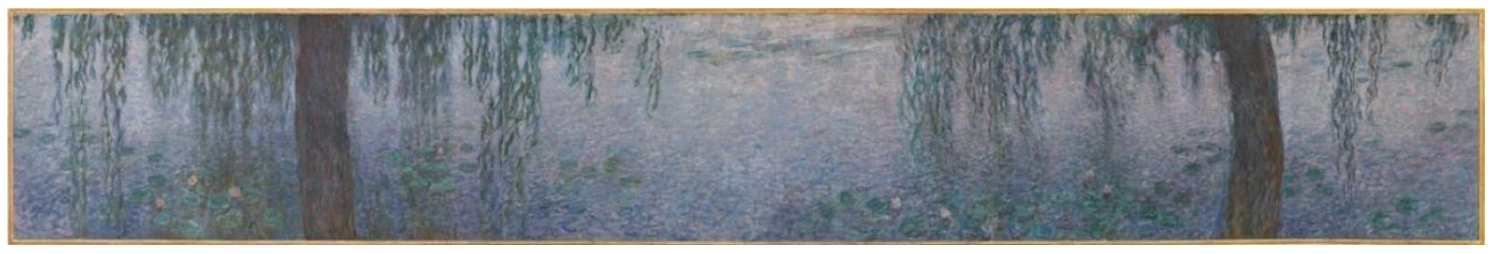

Figura 103

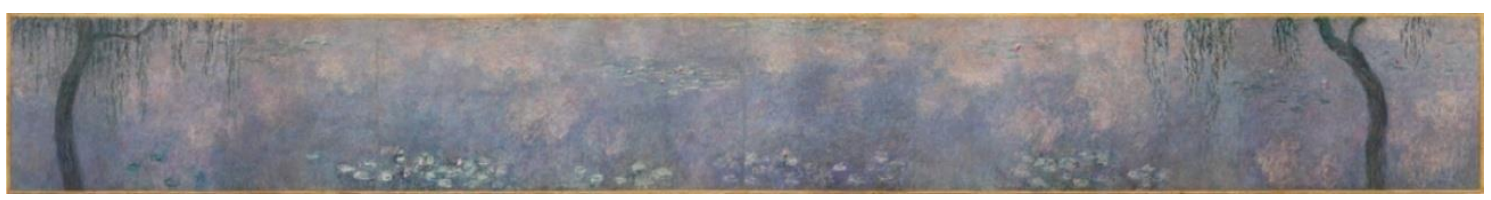

Figura 104

Os nomes simples, quase lacônicos, destes três painéis-irmãos na sala 2 revelam as intenções de Monet em produzir algo eminentemente meditativo, como se cultivasse estas pinturas como havia cultivado seu jardim ao longo de décadas. O próprio nome da série toda, Painéis decorativos, estranho à primeira vista (justamente pela modéstia na denominação), se enquadra ao projeto desligado de qualquer objeto dotado de sentido que representa a obra. Curiosamente, os painéis da Orangerie foram oferecidos, em 1926, logo após a morte do pintor, ao Estado Francês como forma de celebração pelo fim da Primeira Guerra Mundial e pela chegada dos tempos de paz. Fora isso, porém, os 
painéis são tão esvaziados de uma condição ideologizante que podemos, não sem qualquer fundamento, aproximá-los de uma poética propriamente zen. Pouco se sabe até mesmo sobre como Monet nomeou os painéis, ou se foi realmente ele que fez isso. Que nenhum destes painéis tenha nome, ou que se reduzam à nomenclatura o mais minimalista possível, tudo isso remete ao esvaziamento da mente proposto pela meditação zen. Monet não apenas estava a par de vários aspectos da cultura japonesa como colecionava estampas do século XIX $\left(u k y i o-e^{193}\right)$, notadamente do grande mestre deste prolífico gênero, Katsushika Hokusai, cuja vastíssima obra foi construída em parâmetros que influenciariam a arte moderna, começando pelos impressionistas. As estampas de Hokusai não possuíam ponto de fuga ou tridimensionalidade, tornando o espaço delas muito distantes do padrão albertiano ${ }^{194}$ que caracterizou a pintura ocidental até o século XIX. Por mais que, durante todo o século XIX, aquilo que ficou conhecido como orientalismo ou até japonismo (HOOG, 2006, p. 74) tenha se tornado (especialmente dentro do Romantismo, como por exemplo em Delacroix) um tanto vulgar e até kitsch, o aproveitamento que Monet faz desta cultura tanto em seu jardim (daí a famosa ponte japonesa) quanto em suas pinturas não pode ser atribuído a um simples decalque de uma cultura estrangeira.

\begin{abstract}
Desde muitas das obras anteriores aos Nenúfares, Claude Monet teve a ocasião de mostrar um desinteresse, ou um tipo de impertinência, com respeito aos princípios da perspectiva tradicional. Os Álamos, ou alguns dos Barcos dos anos 1885-1888, especialmente aquele do museu de Arte ocidental de Tóquio, mostram uma quase-ausência de perspectiva, em planos que remontam, com pouco ou nenhum céu, a um cenário que cobre tudo. Havendo ou não lembrança da estampa japonesa, os códigos tradicionais de representação são ignorados aqui, mais ao acaso do que simplesmente abolidos (HOOG, 2006, p. 69) $)^{195}$.
\end{abstract}

Por fim, o oitavo painel das "Grandes Decorações" da Orangerie, Reflexos de árvores (Reflets d'arbres - na parede oeste da sala dois, $2 \mathrm{~m}$ x 8,5m, formado por dois painéis menores, FIG. 105), escuro, esfumaçado, quase totalmente abstrato, é uma composição que valoriza os matizes pantanosos de verde e azul para permitir uma imersão toda lúgubre desta vez em uma espécie de inferno gelado. É o mundo que

\footnotetext{
${ }^{193}$ Surgidas no século XVII e muito populares no século XIX, as estampas Ukiyo-e eram impressões com blocos xilográficos com até 15 cores e tinham como temas coisas como desenhos de atores kabuki, lutas de sumô, gueixas, mudanças de estação, etc. (GRAVETT, 2006, p. 54).

194“ $\mathrm{O}$ espaço albertiano, definido pelo arquiteto italiano do século XV Leon Battista Alberti, consiste em considerar a pintura como ponto de convergência da pirâmide visual formada pelos raios ópticos. Esta concepção governará a prática da pintura até o século XIX” (HOOG, 2006, p. 56. Tradução nossa). 195 Tradução nossa.
} 
termina no gelo, sem a presença do Sol, em uma vegetação oculta, fria, que perde para sempre sua incandescência. Se, em $O$ Sol se pondo, a violenta imagem de calor nos remete a supernovas, rastros de luminescência espacial, e até ao Big Bang, em Reflexos de árvores a metáfora cósmica seria a da "morte térmica" do universo. Quando o hidrogênio de todas as estrelas for consumido (em trilhões de anos), e as estrelas maiores forem progressivamente dando lugar a estrelas menores, até sobrarem apenas anãs vermelhas, que são as menores estrelas do universo, o universo estará à beira de seu colapso frio. Quando a última delas esgotar, finalmente, sua carga total de hidrogênio, o universo ficará para sempre totalmente escuro. Ainda que não seja possível afirmar categoricamente que este será o fim do universo (dependendo do parâmetro de densidade ômega, o fim do universo poderia ocorrer com uma fusão de toda a sua energia em um ponto mínimo através de uma contração, uma "morte quente", também conhecida como "Big Crunch"196), a metáfora cósmica existe, neste caso, para pensarmos não que Monet, obviamente, estivesse com a cosmologia em mente ao pintar os Nenúfares (todas estas teorias e projeções foram pensadas décadas depois de sua morte), mas sim que em sua intuição estivessem contidos elementos de transformação, mobilidade, cinética, ou até o infinito, o contemplativo e o sagrado. É por isso que, agora, partiremos para o estudo e análise do filme Retrato de um homem jovem para investigar não apenas sua ligação temática com as pinturas de Monet, mas também a maneira com que o aspecto contemplativo das obras de ambos os artistas é transferido de um medium (a pintura) para outro (o cinema), composto de imagens técnicas. O que este conteúdo é capaz de dizer à luz de diferentes meios de comunicação? Para isso, temas já inicialmente elaborados aqui, como a abstração, o silêncio, a poesia e o zen serão retomados mais extensivamente.

\footnotetext{
${ }^{196}$ Conforme explicação do geneticista Richard Dawkins: "Dependendo dos valores de números como as seis constantes de Martin Ree, nosso universo pode estar destinado a expandir indefinidamente, ou ele pode estabilizar em um equilíbrio, ou a expansão pode reverter a si própria e passar a uma contração, culminando no chamado 'big crunch'. Alguns modelos do big crunch colocam então o universo retomando a expansão, e assim indefinidamente com, digamos, um ciclo de 20 bilhões de anos" (DAWKINS, 2007, p. 174. Tradução nossa).
} 


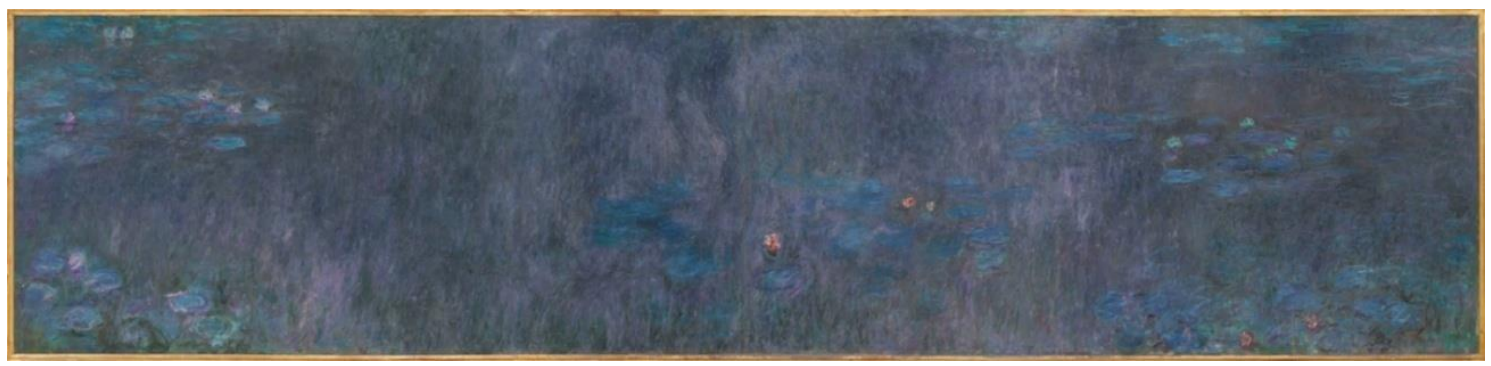

Figura 105

\subsection{3 - Estrada para Retrato de um homem jovem}

Quando se pensa em vanguarda americana no cinema, são lembrados geralmente nomes como Stan Brakhage, Kenneth Anger, Bruce Baillie, e, mais frequentemente, Maya Deren. Todos estes diretores firmaram suas carreiras no pós-guerra, especialmente se considerarmos os primeiros filmes de Deren como espécie de marco inicial. O legado desta pioneira, diretora de clássicos da avant-garde como Meshes of the afternoon (1943, com Alexander Hammid) e At land (1944), foi grande o bastante para que, de maneira um tanto obtusa, considere-se (POSNER, 2001, p. 39) que todas as linhagens de cinema experimental nos Estados Unidos descendam dela, incluindo as escolas de Nova York e São Francisco que floresceram imediatamente após seus primeiros filmes ganharem notoriedade. Uma pesquisa mais cuidadosa na trajetória do primeiro cinema americano e do cinema fora de Hollywood até os anos 1940 revela não apenas que isso não é verdade, mas também todo um vasto universo de cineastas, cinegrafistas, produtores, documentaristas e outros que trabalharam em filmes que hoje podem ser considerados à frente (como experimentais ou de vanguarda ${ }^{197}$ ), seja no quesito da produção, da tecnologia, da temática ou da linguagem (muitas vezes combinando estes fatores).

Pensando ainda no primeiro cinema, é notável assinalar desde o início a presença de técnicos e cinegrafistas como William Kennedy Dickson e Edwin S. Porter, que trabalhavam para Thomas Edison, ou Billy Bitzer, que trabalhava para D.W. Griffith.

\footnotetext{
${ }^{197}$ Peter Bürguer vai associar o conceito "vanguarda" ao aparecimento do conceito isolado "arte" (ligado à institucionalização da comercialização da mesma) no século XIX: "Para Bürguer, o desenvolvimento da avant-garde não tem nada a ver com uma consciência crítica sobre a linguagem; ele não é a continuação de tendências já presentes no Esteticismo. Ao invés disso, para ele o ponto de virada do Esteticismo para a avant-garde é determinado na medida em que a arte compreendeu o modo na qual ela funcionava na sociedade burguesa; a compreensão de seu próprio status social. A histórica vanguarda dos anos 1920 foi o primeiro movimento na história da arte que se voltou contra a instituição "arte" e o modo em que funciona a autonomia" (SCHULTE-SASSE, 1994, p. 14. Tradução nossa).
} 
Tendo sido os homens responsáveis por literalmente milhares de filmagens, estes técnicos e cineastas inovaram nas filmagens das Serpentine dances, realizadas por Dickson e Edison ainda para o quinetoscópio ${ }^{198}$, nas famosas filmagens de Paris na Exposição Mundial de 1900 (também pela equipe de Edison), ou nos progressivas narrativas invertidas que Bitzer realizou junto a Griffith em centenas de curtasmetragens entre 1908 e 1913. Movimentos de câmera, estabelecimento do plano como unidade de linguagem, angulações inusitadas e abordagens nada usuais de temas polêmicos, tudo isso fazia parte do contingente de inovações trazidas por estes pioneiros. Fora isso, outros tipos de vanguarda floresceram no cinema americano fora de Hollywood entre os anos 1920 e 1930: a escola de Nova York, que propiciou a ascensão de um jovem e entusiasmado Orson Welles, além da presença do excepcional documentarista, especialista em travelogues ${ }^{199}$, Rudy Burckhardt. Há, é claro, a escola de animação experimental em stop motion, capitaneada pelo trio Oskar Fischinger, Mary Ellen Bute e o canadense Norman McLaren, mas também os já mencionados pintores Dwinel Grant e Douglass Crockwell. Já a escola da Provincial Americana, formada especialmente por documentaristas etnográficos, tais quais Robert Flaherty, Paul Strand, e, é claro, Henwar Rodakiewicz, foi responsável por realizar leituras ricamente elaboradas - fosse da cidade ou do campo, da natureza ou da cultura humana, nos Estados Unidos ou em alhures - na forma de filmes que não se definiam enquanto ficção ou documentário, residindo naturalmente no terceiro vértice da poesia. Sobre estes filmes, logicamente, por conta da presença de Rodakiewicz, vamos nos deter mais longamente à frente.

\begin{abstract}
Os primeiros filmes americanos feitos entre 1893 até aproximadamente 1913 foram experimentais em seu método de produção, fazendo uso de recémdescobertas técnicas e estilos, e, desta forma, influenciando diretamente o cinema americano adiante, experimental ou mainstream. Consequentemente, o cinema experimental cresceu de mãos dadas com a supremacia do filme holywoodiano como uma instituição socioeconômica. A indústria proporcionava ao americano médio a exposição a filmes e técnicas, acesso a equipamentos e estoques de filmes, e o potencial para encontrar emprego em Hollywood e em negócios auxiliares. A profissão de cineasta floresceu sob estas condições oportunistas. Entre 1925 e 1929, pode-se não apenas clamar por uma "era de ouro" dos longas-metragens silenciosos em Hollywood, mas também por um período igualmente vibrante de atividade em filmes de
\end{abstract}

\footnotetext{
${ }^{198} \mathrm{O}$ quinetoscópio, ou cinetoscópio, é um projetor de visualização interna inventado por Dickson em 1891. Ele foi popular nos Estados Unidos até a supremacia do cinematógrafo dos Lumière, que se inicia em 1895. Para uma descrição mais completa do universo do quinetoscópio, Cf. MUSSER, 2004.

${ }^{199} \mathrm{O}$ travelogue é um tipo de filme de viagens oriundo do primeiro cinema. Posteriormente, alguns documentários sobre lugares, filmes institucionais e sinfonias das cidades passaram a ser conhecidos também, em alguns casos, como travelogues.
} 
vanguarda através do país, com filmes significativos de Watson e Webber, Vorkapich, Florey, Steiner e Flaherty liderando o caminho. Este momento atingiu seu auge no começo dos anos 1930, quando profissionais da indústria, amadores, e outros entusiastas do cinema produziram um impressionante conjunto de filmes experimentais, longas e curtas. Nos anos 30, cineastas trabalharam na recém-florescida tradição do filme experimental como polemistas que avançavam em novas abordagens e retórica. Filmes como $A$ Bronx morning (Jay Leyda, 1930), Portrait of a young man (Henwar Rodakiewicz, 1925-1931), Poem 8 (Emlen Etting, 1933), e o não concluído Qué Viva México (Sergei Eisenstein, 1930-32), todos obras-primas de construção cinemática, exploraram novas direções para um fazer cinematográfico criativo, mas não inspiraram, imediatamente, nenhuma exploração mais avançada (POSNER, 2001, p. 40) ${ }^{200}$.

Além destes pequenos grupos e "escolas" de cinema experimental, outros nomes se destacaram no cenário do cinema americano de vanguarda anterior à Segunda Guerra Mundial: Ralph Steiner (de H2O, mencionado anteriormente), o músico Aaron Copeland, Robert Florey e Slavko Vorkapich. Estes últimos, um jornalista francês morando nos Estados Unidos (Florey) e um expatriado artista comercial iugoslavo (Vorkapich) foram responsáveis, junto com o cinegrafista Gregg Toland, por aquele que o historiador americano David E. James chamou de "o protótipo do filme da vanguarda americano" (JAMES, 2001, pp. 44-52). Trata-se de The life and death of $9413-A$ Hollywood extra (1928), um curta-metragem de quase 14 minutos filmado na cozinha de Vorkapich com o módico custo de 97 dólares. A despeito da modéstia na produção e sua mensagem anti-hollywoodiana, o filme pode ser considerado como um "calling card" (algo como um "cartão de visitas") que ajudou a alavancar a carreira dos três profissionais envolvidos. The life and death of 9413 - A Hollywood extra é fortemente calcado na linguagem de expressionismo caligarista que havia chegado com certo atraso nos Estados Unidos ( $O$ gabinete do Dr. Caligari havia sido lançado nove anos antes), com cenários construídos em angulações oblíquas, fortes contrastes de luz, abuso do uso de sobreimpressões e letreiros deformados, dotando o filme de uma qualidade alucinatória, que potencializa a ideia do sonho hollywoodiano como uma refração muito distinta da realidade (FIG. 106). Isso ocorre justamente porque o filme conta a história, dentro destes parâmetros dadaístas-surrealistas, de um aspirante a ator (numerado como 9413, marca que é posta em sua testa) que chega em Hollywood buscando o sonho de se tornar uma estrela e acaba desprezado e humilhado, para finalmente morrer na pobreza. Simbolismo (marcas nas testas das personagens, uso de máscaras, forte esquematismo nas atuações e na mise-en-scène em geral), certa deformação expressionista e uso de recursos simples, mas efetivos (fusões, sobreimpressões, divisão das telas) para a

${ }^{200}$ Tradução nossa; grifos do autor. 
vanguarda da época, tornam The life and death of 9413 - A Hollywood extra um dos filmes mais interessantes que foram realizados, fora de Hollywood, nos anos 1920. Sua intenção de questionar a "fábrica de sonhos" da indústria americana expunha, corretamente, todas as ambiguidades do cinema independente (e amador) a respeito de se depender de Hollywood (em recursos, tecnologias, know-how, equipes, oportunidades, etc.) e ao mesmo tempo estar à margem do que era verdadeiramente oferecido por esta indústria. Todo o cinema experimental, independente ou amador da época tinha de lidar com este paradoxo. O próprio Henwar Rodakiewicz (na Paramount e na MGM), assim como Flaherty (na Paramount e na Fox), trabalharam para a indústria em momentos-chave de suas carreiras, e este tipo de permuta, por mais que os deixasse à margem dos aspectos gloriosos de Hollywood, os desenvolvia técnica e estilisticamente a ponto de poderem seguir suas carreiras como cineastas independentes. Em The life and death of 9413 - A Hollywood extra, Florey e Vorkapich apenas evidenciam este contraste no seio do próprio tema do filme, conforme aponta David E. James:

Em suma, então, a crítica de A Hollywood extra da exploração dos trabalhadores na indústria do cinema intersecciona e se entrelaça em críticas similares a Hollywood que operam em muitos níveis culturais, em uma variedade de formas cinemáticas. Os paralelos para os dispositivos formais do filme, motivos da trama, efeitos especiais, e mais ainda em filmes da primeira e da avançada indústria proíbem a absoluta segregação da experimentação ou de propriedades estilísticas em um ou outro de esferas mutuamente exclusivas. Todas as pessoas que independentemente e domesticamente fizeram A Hollywood extra seguiram para carreiras profissionais através tanto do centro quanto da periferia da indústria e das instituições que a orbitam. Estas interconexões e a porosidade em geral das ligações formais e práticas conectam as várias práticas do cinema e sugerem que a vanguarda deve ser entendida não como um completo outro, mas como uma série de movimentos e impulsos intersticiais em relação à hegemonia do modo dominante de produção de filmes. The life and death of $9413-A$ Hollywood extra é, portanto, o protótipo de uma tradição do filme de vanguarda americano (JAMES, 2001, 47-8) ${ }^{201}$.

${ }^{201}$ Tradução nossa. 


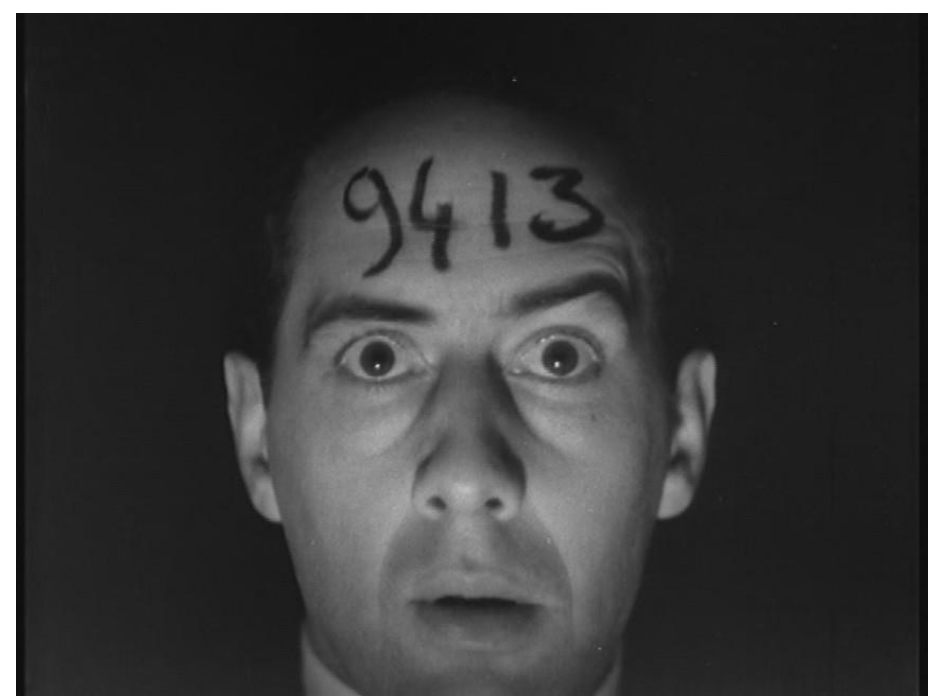

Figura 106

Se o filme de Florey e Vorkapich, partindo de estéticas já superaproveitadas no cinema europeu, evidenciava os contrastes nas relações entre o cinema independente e o cinema industrial americano nos anos 1920, nos anos 1930 encontraremos, na figura do artista plástico, colecionador e cineasta Joseph Cornell, uma outra vertente do cinema silencioso de vanguarda, que nos aproxima cada vez mais de Rodakiewicz. Excêntrico, Cornell foi pioneiro em dois aspectos da cinematografia de vanguarda: primeiro, ao adotar um procedimento semelhante ao sample ${ }^{202}$ da cultura musical contemporânea, quando, ao pegar o filme East of Borneo (George Melford, 1931) - uma fita de aventuras banal e esquecível estrelando a atriz Rose Hobart, produto exemplar da descartabilidade da Hollywood da era de ouro -, ele inseriu uma série de modificações no material original, incluindo inversões e repetições, além de inserts de outros filmes, produzindo uma obra inteiramente diferente. De fato, Cornell renomeou o filme como Rose Hobart (1936) e carregou-o com uma poética impressionista de desdobramentos líricos, procurando estabelecer o cinema como eterna reinvenção de suas próprias propriedades (FIG. 107). Todo material fílmico, no caso, é um material encontrado, todo cinema é invenção, mas ao mesmo tempo não existe originalidade. Estes aspectos levaram o historiador e teórico americano P. Adams Sitney a incluir Cornell no seleto grupo de cineastas-poetas do seu livro The cinema of poetry. Aqui, ele descreve o procedimento utilizado em Rose Hobart:

\footnotetext{
${ }^{202}$ Muito utilizado na cultura do hip-hop e da música eletrônica, o sample é a montagem de uma peça musical original a partir de material previamente elaborado por outros artistas através de recursos como o mash-up, que mistura este material encontrado com criações originais ou de artistas diferentes.
} 
Em primeiro lugar, ele projetou o filme sem som. Ao retirar os diálogos do filme e sua música ambiente, ele transformou sua banalidade em mistério onírico. Ele não apenas mostrou isso sem a fala, como ele também o projetou na velocidade do cinema silencioso. Com a chegada do som no final dos anos 1920 , os projetores foram programados em uma velocidade uniforme e mecânica de maneira que pudessem reproduzir o som sem o tom vacilante experimentado quando alguma coisa toca e muda a velocidade de um disco em uma vitrola (SITNEY, 2015, p. 120) ${ }^{203}$.

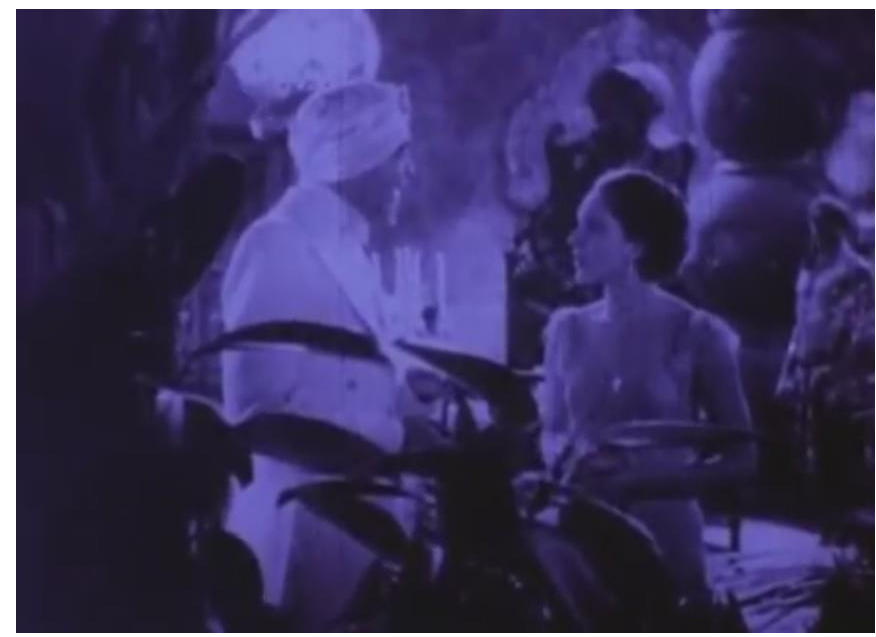

Figura 107

O fato de que Cornell modifica os padrões tanto da velocidade de projeção quanto do som do filme (na verdade, eliminando-o) torna-o um dos primeiros cineastas a fazer do cinema um tipo de conhecimento poético cuja poesia é extraída do próprio material mediático em si (aproveitando-se da materialidade do próprio medium). Aí está a outra inovação trazida por este nome singular da vanguarda americana do entreguerras: a compreensão da natureza do medium, a utilização do material encontrado. Cornell, neste caso, fazia filmes sem filmar nada. Sua "trilogia das crianças", montada dois anos após Rose Hobart, vai levar este princípio a um paroxismo do cinema dadaísta, em que a montagem de imagens praticamente aleatória funciona por afinidades exclusivamente poéticas. Cornell era um colecionador de filmes amadores e caseiros, e dispunha de um vasto material de base para realizar suas montagens. No primeiro filme, Children's party (1938), ele vai usar imagens encontradas e amadoras de festas infantis e circos, vídeos científicos e outras curiosidades para fundar uma espécie de cosmologia própria a partir de recursos como o congelamento de fotogramas, animações, inversão da posição dos planos, intervenção na duração das imagens e nos letreiros e outros "truques" (FIG. 108). Estas imagens, deslocadas de qualquer contexto e justapostas a partir de um princípio não-

203 Tradução nossa. 
eisensteiniano de atrações - não há "tema" dominante aqui ${ }^{204}$, apenas a frágil aleatoriedade da morfologia das coisas e das imagens quando são reunidas sob o princípio do absurdo -, acabam liberando uma espécie de incognoscível fascinante, hipnótico, que emana diretamente desta ausência de referências, como se os signos da realidade tivessem sido completamente embaralhados e rearranjados, transformando-se em valises para outras potências e afetos ${ }^{205}$. O segundo filme, Cotillion (1938), segue a mesma tendência (usando muitas vezes as mesmas imagens e planos), com a preferência de congelar os fotogramas de bebês e crianças brincando após eles aparecerem em movimento, levantando imediatamente um debate sobre a fotografia e o cinema, sobre a imagem estática e a imagem em movimento (FIG. 109). Já o terceiro, The midnight party (1938), aproveita muitas das mesmas imagens, mas, de duração menor (4 minutos), e reserva-se a um apanhado mais abstrato e aleatório do material encontrado.

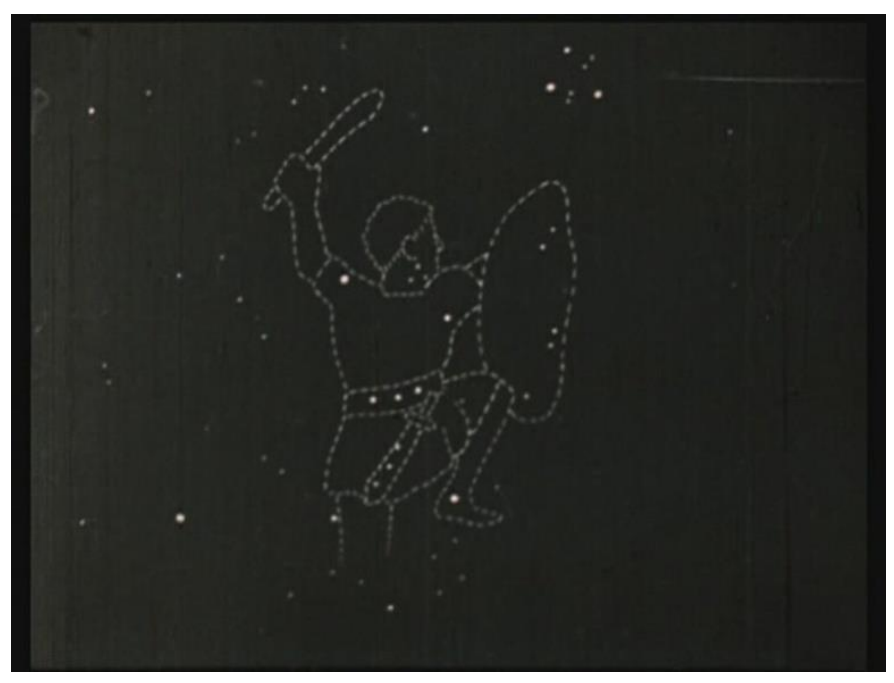

Figura 108

\footnotetext{
204“Ao analisar os códigos subsidiários, Eisenstein voltou à sua analogia musical, sugerindo que cada plano é feito de uma série de tons e sobretons ao lado de seu dominante. O dominante é o que mais plenamente chama a atenção do espectador, enquanto os tons e sobretons são 'estímulos secundários' agindo na periferia tanto da imagem quanto da consciência do espectador” (ANDREW, 2002, p. 58).

${ }^{205}$ Isso lembra os Im-signos, conceito elaborado por Pasolini, que são as propriedades comunicacionais presentes naturalmente no próprio corpo da realidade, dos quais o cinema retira sua construção e significação (SITNEY, 2015, pp. 20-21).
} 


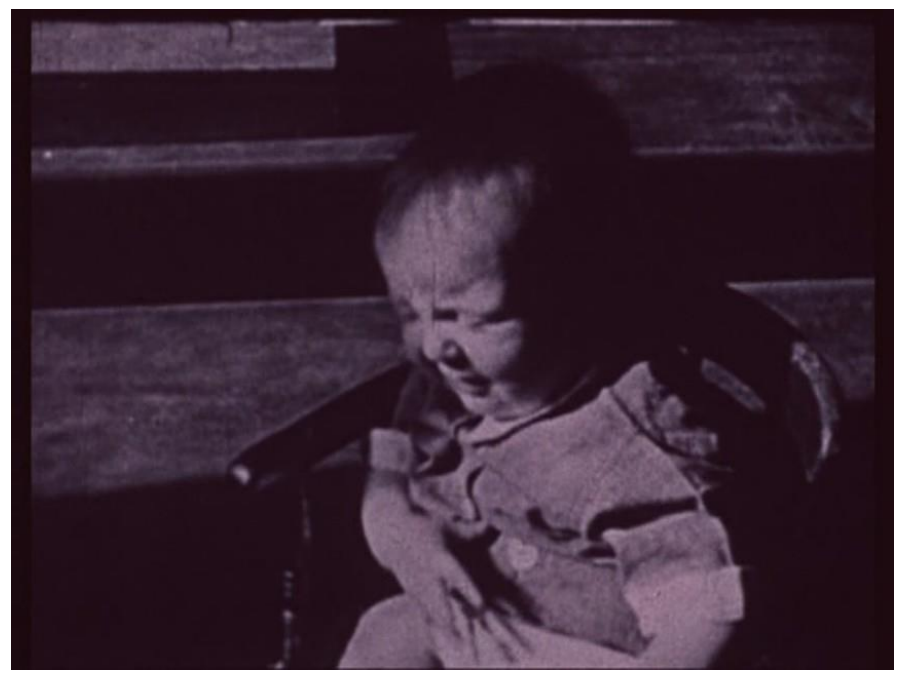

Figura 109

Ora, o fato de Cornell silenciar suas imagens em uma era em que os talkies já dominavam $100 \%$ do mercado americano de filmes justifica não só uma ação política no sentido de perpetrar um silenciamento do mundo, como opta pelo silêncio como ferramenta para ressaltar as imagens e fazê-las falarem a partir de um total desarranjo das expectativas em relação a elas. De certa forma, a ausência do som retira das imagens a sua relação com a representação. Elas se tornam, como diz Rancière, imagens visíveis demais (trop visibles), cuja visibilidade em si ultrapassa qualquer significação e codificação sígnica. A verdade da imagem, neste caso, é extraída de sua própria e pura visibilidade. Olhar para estas imagens cega, em sua poética silenciosa, da maneira como cega olhar para o Sol. São imagens tão visíveis que se torna impossível vê-las para além de sua cintilante superfície: "De um lado, existe o visível demais, o visível que não está agarrado à dependência da fala, que se impõe por si próprio. Do outro, há o inteligível demais. Os oráculos falam demais" (RANCIÈRE, 2003, p. 128) ${ }^{206}$.

Se Rancière opõe, neste caso, o visível à fala, colocando-os em extremos, isso é um assunto do qual trataremos mais adiante. O que importa, aqui, a respeito de Joseph Cornell, é compreender que o recurso que ele utiliza para destacar suas imagens de um referencial de racionalidade é o mesmo que Rodakiewicz vai utilizar em Retrato de um homem jovem (eliminando qualquer tipo de banda sonora), no intuito de valorizar o silêncio e, por sua vez, as imagens. Além de Florey, Vorkapich e Cornell, outro cineasta desta primeira vanguarda americana precisa ser mencionado para que possamos completar nossa estrada em direção a Rodakiewicz. Trata-se, mais uma vez, de Robert

206 Tradução nossa. 
Flaherty. Pioneiro desde o já mencionado Nanook, o esquimó (de 1922), Flaherty é uma figura central para o desenvolvimento tanto do cinema independente americano, quanto de sua permuta com os estúdios (da maneira com que demonstramos a respeito de Florey e Vorkapich), quanto da fundação tanto de um cinema documental quanto do terceiro vértice (poético, conforme elaboramos no capítulo 2). Por enquanto, o que nos interessa aqui é não apenas a relação de Flaherty com Rodakiewicz, mas a interinfluência entre os cinemas dos dois que, além de realizadores, eram excepcionais diretores de fotografia. $\mathrm{O}$ historiador e restaurador Bruce Posner especula a respeito da possibilidade de ambos terem trabalhado juntos no adorável filme amador $A$ day in Santa Fe (1931), dirigido pelo poeta Lynn Riggs e pelo diretor de fotografia James Hughes. O filme, espécie de libelo poético à maneira dos travelogues e das sinfonias das cidades, mas com uma abordagem idílica sobre a ainda bastante rural vida na capital do Novo México (FIG. 110), segundo relatos (POSNER, 2005, p. 14.) do próprio diretor (Riggs), foi fortemente influenciado por Retrato de um homem jovem, de Rodakiewicz.

Dentro do ambiente social de Santa Fé, Flaherty se movia com destreza. Ele encontrou noites de bebedeira e ótima prosa com os poeta Witte Bynner e Spud Johnson, e com o cineasta Rodakiewicz. Em alguns anos, os três ajudariam Lynn Riggs com seus planos de realização de filmes. Podemos especular se Riggs e Flaherty travaram contato pessoal substancial, já que o filme amador de Riggs, A day in Santa Fe (1931) opera em território similar ao de um filme de Flaherty. Rodakiewicz compartilhou muita coisa com Flaherty. Ambos os homens possuíam ótimo olho fotográfico e amavam filmar (POSNER, 2005, p. 13) ${ }^{207}$.

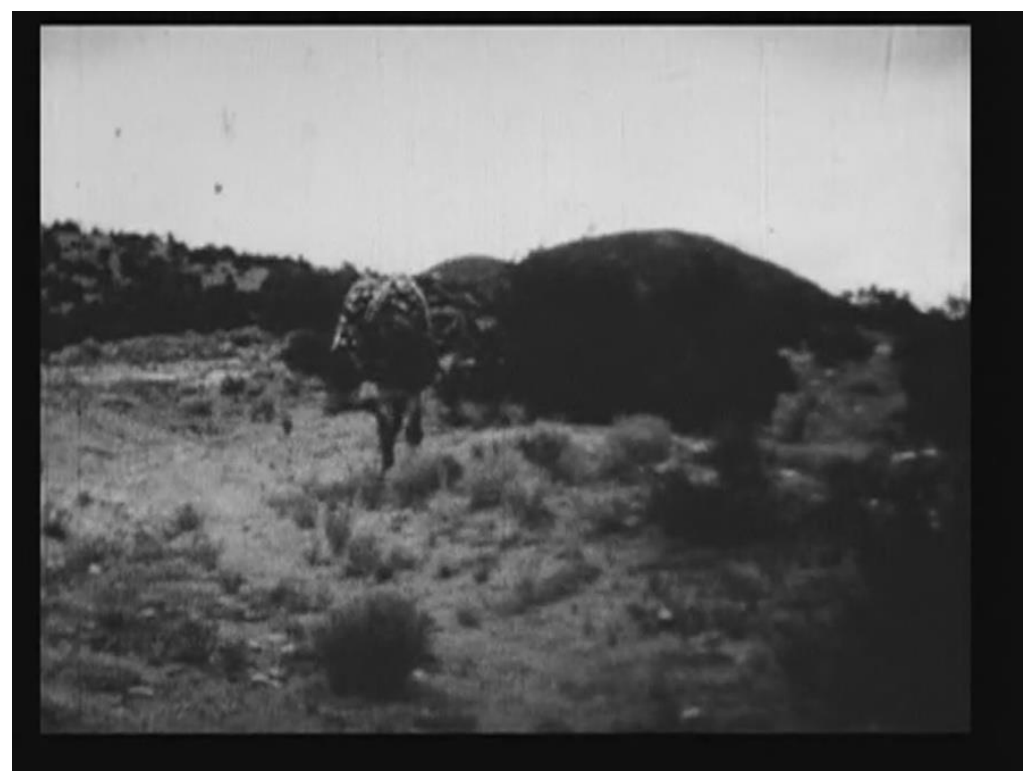

Figura 110

207 Tradução nossa. 
Em 1926, logo após lançar Moana: a romance of the golden age, Flaherty lançou também, após conseguir financiamento privado, o filme 24 dollar island (1926), de 14 minutos de duração, também um tipo de travelogue ou sinfonia da cidade, procurando realizar um retrato maciço, impessoal e retumbante da cidade Nova York. Portanto, se a vanguarda silenciosa dos anos 1920 e 1930 comportava vertentes como o abstracionismo de Grant e Bute, o surrealismo de Florey e Vorkapich e o dadaísmo de Cornell, havia também espaço (silencioso, evidentemente) para leituras poéticas das cidades americanas, mesmo sendo elas tão díspares quanto Santa Fé e Nova York. A respeito de 24 dollar island, Flaherty relata ter filmado 9.144 metros de filme em mais de 24 mil quilômetros percorridos em táxis na cidade de Nova York para liberar estes 14 minutos. "Eu gostaria de gastar muito tempo neste filme - anos. Tenho certeza de alguém o fará em algum momento. Para fazê-lo propriamente, me parece que o trabalho tomaria três anos facilmente." (FLAHERTY, 2001, p. 131) ${ }^{208}$.

Em 24 dollar island, Flaherty, ao contrário do que realizou em seus filmes mais famosos como Nanook, o esquimó, Moana ou Os pescadores de Aran, o foco não está no homem, mas sim na coletividade que subjaz as estruturas sociais. Abusando de recursos como tomadas panorâmicas majestosas (verticais, horizontais, diagonais), close-ups de detalhes arquitetônicos realizados com uma lente grande angular, além de travellings e uma montagem racional e espacializada (FIG. 111 e 112), Flaherty construiu seu próprio monumento à cidade. Poucas pessoas aparecem no filme diante das colossais imagens do porto da Nova York, dos arranha-céus, das máquinas da construção civil, da fumaça saindo das fábricas. De certa forma elaborado para ser uma voz inumana (tal qual A ponte, de Jorens Ivens, analisado no capítulo 4), como se dirigido pelo olhar sóbrio dos próprios prédios, 24 dollar island parte da visão silenciosa das próprias coisas. De certa forma, Flaherty, ao eliminar o humano da porção vital do filme (da mesma maneira que Rodkiewicz vai fazer em Retrato de um homem jovem), vai transformar a relação entre o silêncio e as coisas expressas na tela em uma espécie de circuito autopoiético. Niklas Luhmann argumenta que, nestes circuitos, a partir de certo construtivismo radical, diluem-se as diferenças entre sujeito e objeto no sentido de que a racionalidade sistêmica dos fatos culturais e sociológicos está

208 Tradução nossa. 
sempre trabalhando com impulsos que devolvem a observação ao observador por parte do objeto observado. Este processo é resumido por Ciro Marcondes Filho:

A linha metafísica que vem de Descartes até Kant (e Husserl-Merleau-Ponty) dissolveu a diferença entre sujeito e objeto, mas ela mesma deve ser desconstruída na medida em que se vê que também os objetos podem ser sujeitos, isto é, observações realmente operantes, observações que observam o observador.

A sociologia, assim, descrevendo a sociedade de dentro da sociedade, não operando mais com a distinção sujeito/objeto (ela sendo o sujeito, a sociedade, o objeto), ira abandonar o status de "instância de reflexão", interessada em instruir ou criticar a sociedade, como se fosse algo situado fora dela. Ao contrário, o "objeto" da sociologia, a sociedade, é um objeto que se descreve a si mesmo. E, enquanto observador, vai utilizar as distinções, ou seja, dividir o que irá observar para descrever precisamente isto e não aquilo." (MARCONDES, 2004, pp. 348-9).

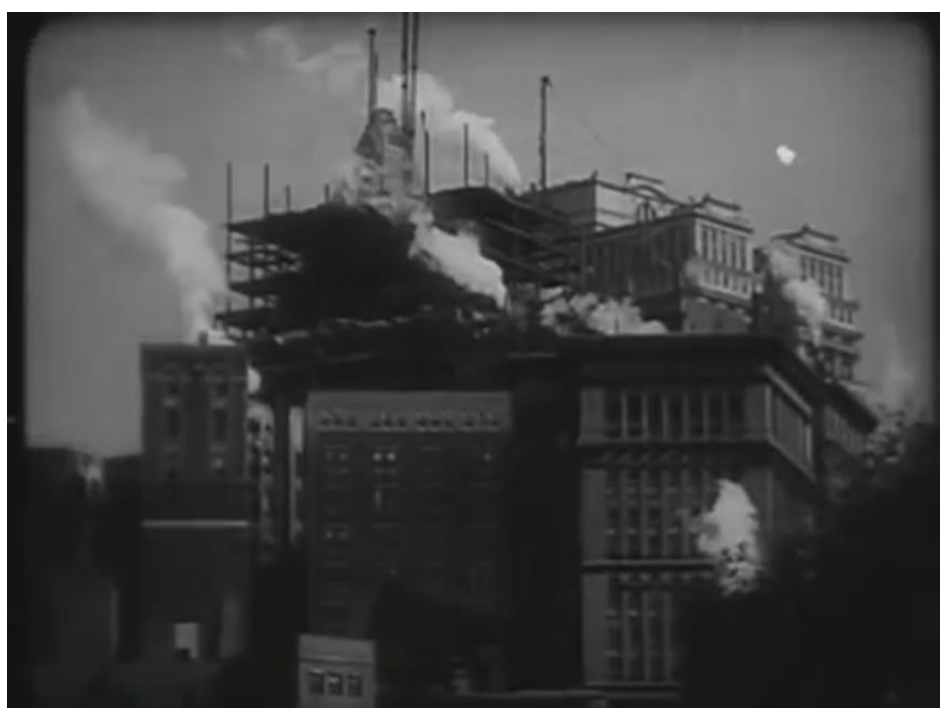

Figura 111

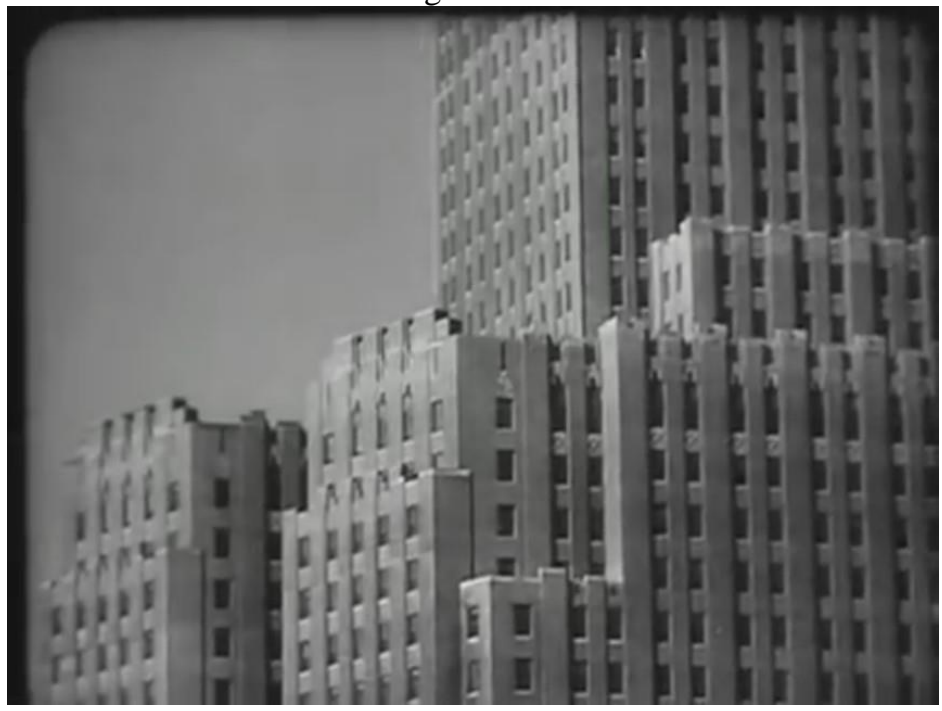

Figura 112

Flaherty, conhecido especialmente por inventar a etnografia fílmica (quiçá até o documentário em si) e apaixonado pelas culturas e diversas manifestações da 
polivalência humana, em 24 dollar island, especialmente, manifesta uma perspectiva inteiramente diferente a respeito do sistema fílmico integrado que comporta observador (o espectador) e observado (o filme). Se um filme como esse pode ser equiparado à sociologia descrita por Marcondes, podemos pensar que, da mesma forma, um filme é um objeto que descreve a si mesmo (mais evidente ainda pelo fato de ser um tipo de comunicação icônica, imagética). Neste caso, o filme é um objeto que se autodescreve a partir de suas próprias contingências, em um processo de fechamento operacional que justifica sua autopoeise. Mas por que este filme especificamente funciona desta forma? Ora, porque, além de ser um objeto que se auto-observa, 24 dollar island é também um filme sobre e composto por objetos. Implacavelmente, ao serem observados, tal qual o princípio de incerteza quântico, estes objetos se modificam e nos olham de volta. E Flaherty, nesta única vez - diferentemente do olhar vertical etnocêntrico que aplicou em suas etnografias fílmicas - aplicou uma antropologia do local de fala não aos humanos, mas sim aos objetos, que, tal qual anuncia Georges Didi-Huberman, modificam o que consideramos como nosso olhar a partir do momento em que eles nos observam de volta. É como ele anuncia em $O$ que vemos, o que nos olha: “O que vemos só vale - só vive - em nossos olhos pelo que nos olha. Inelutável porém é a cisão que separa dentro de nós o que vemos daquilo que nos olha. Seria preciso assim partir de novo desse paradoxo em que o ato de ver só se manifesta ao abrir-se em dois" (DIDIHUBERMAN, 1998, p. 29). Didi-Huberman afirma que a imagem que nos olha nos obriga a olhá-la em sua verdade. O que estamos fazendo aqui, ao associar o construtivismo radical de Luhmann e seus sistemas à fenomenologia do filósofo francês, é procurar entender o local do silêncio tanto na constituição deste objeto observante (como se fosse o corolário do mesmo) quanto na compreensão do papel de uma sintonia com uma frequência poética do pensar para justamente ativar este sistema. É dentro destes parâmetros que avançamos com nosso objeto de estudo, ao comparar a obra final de Monet com o filme de Rodakiewicz.

Henwar Rodakiewicz (FIG. 113), por fim, pertenceu ao grupo que Bruce Posner vai cunhar como provincial americana (POSNER, 2005, pp. 10-15), referindo-se ao mesmo grupo ao redor da cidade de Santa Fé, responsável pela realização do já mencionado A day in Santa Fe. Quem primeiro passa a abordar esta cidade do meiooeste americano, ainda no final da década de 1910, é o talentoso diretor e fotógrafo Paul Strand, que dirigiu o travelogue Manhatta em 1921, filme que tem justamente o mérito 
de ter inspirado Flaherty a realizar 24 dollar island. Ambos têm propostas semelhantes de retratar a cidade de Nova York como personagem, apesar de o filme de Strand ser muito menos arrojado. Dez anos depois, ele realizou o filme experimental Redes (1936), sobre a cidade provinciana de Taos, em proposta documental-poética semelhante à de $A$ day in Santa Fe. Strand foi o nome que coligou toda uma geração de cineastas experimentais e independentes fascinados pela natureza e pelo modo de vida do povo das cidades de Santa Fé e Taos, além dos povos indígenas também presentes nestas cidades e nas cercanias. Além dele, a pintora modernista Georgia O'Keeffe, o diretor de fotografia Leon Shamroy (que realiza em 1928 surpreendente adaptação de Edgar Allan Poe em The telltale heart, em ótima atualização do expressionismo caligarista), a poeta Mary Garland (primeira esposa de Rodakiewicz), Robert Flaherty, Lynn Riggs e o próprio Henwar Rodakiewicz. É dentro deste ambiente, e em inúmeras viagens de caráter diletante que Garland e Rodakiewicz realizaram pelo interior dos Estados Unidos, que Retrato de um homem jovem foi gestado e filmado.

Entre velejar ao redor do mundo com Marie Garland e conversar com Flaherty, Strand e O’Keefe no Novo México, Rodakiewicz estava persistentemente filmando material para o que se tornaria sua obra abstrata, Portrait of a young man. Entre 1925 e 1931, Rodakiewicz filmou e fotografou seu filme nos $16 \mathrm{~mm}$ de um lote em pancromático reverso, longe da linha do horizonte de Nova York, em locações tão exóticas quanto Bermuda, Novo México, Arizona, Colorado e Columbia Britânica. Feito para examinar as nuances do movimento contínuo, o filme combina imagens de água, folhagem, fumaça e máquinas se mexendo em três movimentos sinfônicos que o cineasta insistia em não serem acompanhados por música (POSNER, 2005, p. 13) $)^{209}$.

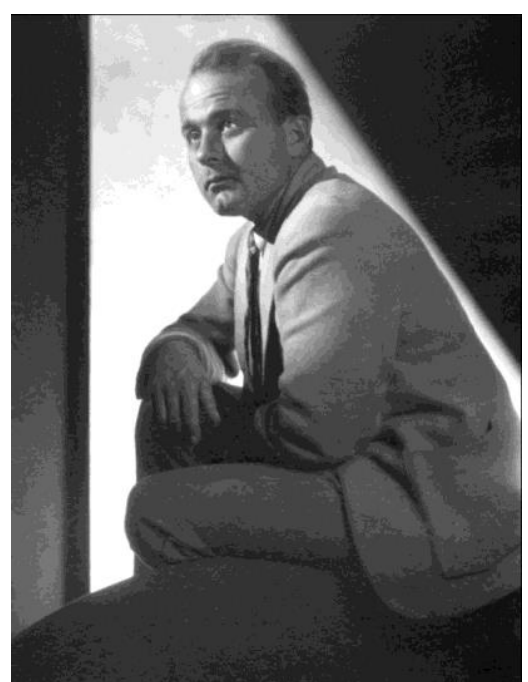

Figura 113

209 Tradução nossa. 
Retrato de um homem jovem, portanto, foi filmado no decorrer de 6 anos à maneira que ficaria característica de Jonas Mekas: material gravado aleatoriamente a partir da sensibilidade e da intuição do diretor, para ser remontado como diário, documentário pessoal ou autorretrato depois. Rodakiewicz tinha 23 quando começou a filmar este material e o título "Retrato de um homem jovem" se justifica dada a idade do diretor. Porém, quando a montagem do filme foi lançada na galeria de arte de Alfred Steiglitz em 1932, o impacto foi de uma realização de visível maturidade. O filme foi até considerado um dos 10 melhores do ano de 1932 pela revista Movie Makers (POSNER, 2005, p. 14.), mas, dado o seu caráter extremamente experimental e seu viés anti-hollywoodiano, evidentemente nunca foi lançado comercialmente. É curioso que este filme possa ser lido como um autorretrato de um homem jovem, enquanto os painéis da Orangerie de Monet possam, de certa forma, serem lidos como o autorretrato da velhice do pintor. Ambos, porém, calcados num flerte com a abstração, acabaram criando obras que vão muito além de uma simples expressão de sensitividade aguçada. É como Rodakiewicz esclareceu, primeiro, em entrevista, e depois em notas sobre o filme:

\begin{abstract}
Tratava-se de uma coleção integrada das muitas coisas que me interessavam como pensamento e sentimento que podiam ser expressos visualmente, e que me acompanhavam. Os temas poderiam ir desde fumaça de cigarro, maquinaria, folhas, nuvens, água (especialmente o mar) - mas não continham pessoas. O trabalho de editar este material foi baseado puramente no sentimento da continuidade apropriada (RODAKIEWICZ apud POSNER, 2005, p. 13$)^{210}$.
\end{abstract}

e

Filmagem esporádica durante seis anos. Locações relevantes somente para o que foi realmente visto lá. Por quase todo o período, sem planos pela continuidade de um filme estruturado. A motivação era inteiramente capturar experiências vívidas sem se importar com o assunto. Uma constante examinação minuciosa pelo detalhe significativo. Eventualmente, ocorreu o pensamento de que o material revelava a pessoa. O filme, assim, de acordo com isso, foi nomeado e editado (Ibidem, pp. 13-14).

A despeito da despretensão relatada pelo próprio diretor, assim como da nãointenção inicial em transformar aquele material em uma obra coesa e unificada em um só filme, Retrato de um homem jovem, montado em três movimentos, em muito se assemelha à série da Orangerie de Monet. Isso se dá não apenas pela tendência ao abstrato, mas sim nas implicações desta escolha, nas motivações poéticas do filme, na

${ }^{210}$ Tradução nossa. 
maneira com que ele nos sintoniza em um tipo de percepção que é um medium em si, e nas relações deste pensamento poético em imagens com o próprio esvaziamento delas mesmas a partir de um princípio que em muito se assemelha à meditação zen. E é seguindo na construção de um pensamento sobre estes temas que damos prosseguimento a este capítulo.

\title{
5.1.4 - Nefelomancia e outras coisas mais em Retrato de um homem jovem, de Henwar Rodakiewicz
}

Retrato de um homem jovem é um tríptico. Rodakiewicz o dividiu em três movimentos e lhe conferiu esta forma de pintura sacra, oriunda das tradições gótica e bizantina, que divide telas e retábulos em dois, três ou mais painéis (sendo o tríptico, evidentemente, o que as divide em três) geralmente dotando as diferentes imagens de uma relação narrativa entre si: diferentes momentos da paixão de Cristo, por exemplo. O retábulo, forma de arte sacra pintada ou esculpida (em pedra, marfim, madeira, etc.) atrás do altar das igrejas e que surgiu no período gótico (século XIII) da história europeia, tornou-se uma das mais fortes vias de expressão medieval e seu modelo sequencial $^{211}$ perdura como referência para formas de expressão modernas como as histórias em quadrinhos e filmes como o de Rodakiewicz. A amplitude do retábulo e sua alta visibilidade explicam, talvez, sua ascendência em relação ao cinema:

\begin{abstract}
Para elevar a religiosidade popular, as ordens mendicantes fomentaram o culto às imagens. Ao mesmo tempo, cresceu o desejo generalizado pela figuração. Em 1264 se introduz pela primeira vez a festa da eucaristia, o Corpus Christi. Nesta época se generalizou a elevação da Hóstia no momento da consagração. Criam-se então custódias e ostensórios que permitem realmente ver as peças sagradas. Entende-se o retábulo também como consequência desta aspiração à visibilidade. O retábulo pintado substitui os mosaicos e afrescos dos absides e destrona os preciosos antipêndios e remates dourados. Se quase sempre é representativo e solene na cena central, frequentemente apresenta em outras partes um muro sobrecarregado, com até meia centena de cenas [...]. (BAUER; BAUR et al, 2005, p. 12) $)^{212}$.
\end{abstract}

Esta menção aos retábulos se dá não apenas pelo fato de Rodakiewicz ter escolhido montar sua coleção de imagens de maneira que remeta a eles, mas também pela primazia da visibilidade e mudança de paradigma que proporcionaram ao iniciarem

\footnotetext{
${ }^{211} \mathrm{O}$ retábulo surge após mudanças na liturgia para a celebração da missa: quando o sacerdote passa a celebrá-la de costas, torna-se necessário um complemento visual rico em proposições narrativas. (BAUER; BAUR et al, 2005, p. 11).

212 Tradução nossa.
} 
o caminho para o Renascimento. Não é um exagero afirmar que, ainda hoje, a imagem do cinema descende da imagem renascentista. Basta pensar na chegada do uso narrativo do primeiro plano na década de 1910 em comparação com a revolução provocada pelo uso do retrato no Renascimento ${ }^{213}$. A diferença aqui é que Rodakiewicz não retrata pessoas, mas coisas, e, tal qual nos autorretratos fotográficos de Monet ou mesmo suas telas de nenúfares, as coisas emanam um excedente de horizontes externos e internos que provocam a projeção e retroprojeção delas mesmas para os fenômenos e para a percepção, a partir da intenção da subjetividade.

Obviamente, o fato de Rodakiewicz montar o seu filme como uma série (o tríptico) remete também às séries de Monet, e este tipo de transposição do imaginário dos media (do retábulo, à pintura moderna, ao cinema) nos interessa porque é preciso investigar o que se preserva nesta transmaterialidade de conteúdos e formas que vão se alojando em diferentes meios, e evidentemente o que é devorado pelo processo de transmediação ou remediação. Retrato de um homem jovem é formado primordialmente por imagens dos quatro elementos: água, terra, ar e fogo. Por mais que o diretor, em suas entrevistas, ratifique a aleatoriedade temática destas filmagens (sendo o enfoque apenas "uma constante examinação minuciosa pelo detalhe significativo"), fica claro que, em sua noção de autorrepresentatividade em filme (que tange a abstração), reside um caráter elemental (e também elementar). A primeira imagem do filme é a de uma superfície aquática plácida, em um preto e branco que facilita abstração da representação da água, com o letreiro que anuncia o título (FIG. 114), e, logo depois, o primeiro movimento. Após esta imagem, temos o único letreiro informativo do filme, que será mencionado adiante, e, após isso, somos convidados ao mergulho no mundo líquido que Rodakiewicz propõe como abertura para sua longa (54 minutos, na projeção em 16 quadros por segundo) e meditativa experiência fílmica. Aparece então a imagem da água do mar batendo insistentemente em uma falésia ou encosta rochosa, que é a própria imagem que Tales de Mileto preconizava para a água, o emolidor universal, arqué que ainda pode ser pensada como origem de tudo em vários filmes realizados na mesma época: H2O (1929), Limite (1931), Os pescadores de Aran (1934). Após este

\footnotetext{
${ }^{213}$ Michaud também estabelece uma ponte entre as primeiras representações cinematográficas e o retrato no Renascimento: "Em 1889, o primeiro filme dirigido por Dickson assumiu, por sua vez, a forma de autorretrato, isto é, de autorreflexão, num fenômeno idêntico ao que Burckhardt - e Warburg, depois dele - diagnosticaria na pintura italiana pré-renascentista como uma consequência do aparecimento do sujeito singular na pintura (MICHAUD, 2013, p. 52).
} 
primeiro plano, aberto, da água do mar, Rodakiewicz vai fechando a visibilidade para o espectador. Apenas utilizando cortes secos (ao contrário do rebuscamento barroco de Limite, por exemplo, que abusa de fusões e sobreimpressões ${ }^{214}$ ), passamos para uma imagem simples do mar aberto e agitado (em ângulo mais próximo), e depois para um plano-detalhe da água sobre uma pedra, criando um universo mais microdinâmico para nossa experiência aquática. Por fim, um detalhe ainda mais próximo do brilho da superfície da água, já desta vez sem outros referentes, nos carrega para o mundo da abstração em movimento. O contraste em preto e branco, com os focos de luz sob a superfície da água parecendo glóbulos aleatórios em sístole e diástole, torna a imagem de Rodakiewicz não muito diferente, por exemplo, de uma tela de André Masson. O diretor cria, neste caso, uma introdução bastante lógica e quase narrativa a algumas das temáticas do filme: o movimento da figuração em direção à abstração; do efeito em direção ao rarefeito; da física à metafísica; do objeto, ao fenômeno, à consciência. É apenas após nos introduzir dentro deste espectro de possibilidade sensitivas que o diretor parte para sua exploração de mundos artificiais, naturais, técnicos, premonitórios, espirituais, e, conforme veremos, até psicanalíticos. Assim diz o letreiro de abertura, assinado pelo próprio Rodakiewicz:

Se o nosso entendimento e simpatia pelas coisas sobre nós mesmos precisa revelar nosso caráter, assim também é o nosso empreendimento em retratar um certo homem jovem nos termos das coisas que gosta e sua maneira de gostar delas: o mar, folhas, nuvens, fumaça, maquinaria, luz do sol, o jogo entre formas e ritmos, e, acima de tudo, o mar (sic).

\footnotetext{
214“A fusão é o ponto de partida para entendermos como Limite também atualiza aideia de montagem proposta por Vertov. De fato, em Limite, não há "desvio teatral” e nem "desvio literário" graças a uma montagem que viabiliza este desvelamento pausado do ser das coisas em relação a um sempre em movimento "vir-a-ser" do ser humano. Não por acaso, se prestarmos atenção à maneira como Mário Peixoto tece esta cena com Olga Breno, perceberemos que, enquanto os objetos são ligados por fusão, a ligação entre os objetos e a própria personagem é feita com cortes secos. Fundir-se, portanto, em Limite, expressa a significação pura, uma resolução poética (e, portanto, um fracasso autorizado) para tentar encontrar a unidade em um eixo sintagmático, ou seja, sequencial.” (MARCONDES, 2008, p. 60).
} 


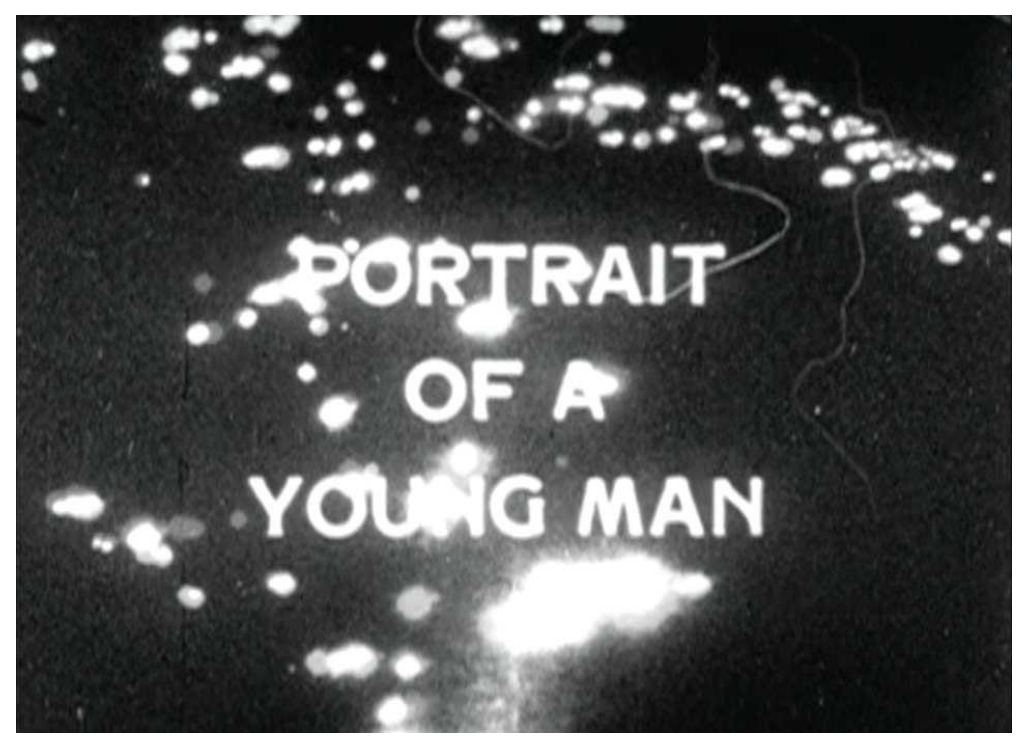

Figura 114

A estas primeiras imagens aquáticas (FIG. 115, 116 e 117), portanto, seguem-se, sempre em corte seco, centenas de planos de coisas que são mostradas sempre a partir de um enquadramento, angulação e composição fotográfica preciosistas: no primeiro movimento, imagens de maquinaria em operação (algo que também fascinou cineastas como Léger, Vertov e Eugene Deslaw), mais reflexos abstratos na água, depois imagens de fumaça (FIG. 118) e fogo, além de outras texturas. No segundo movimento, mais imagens de água (não somente do mar), planos-detalhes de plantas e folhagens (FIG. 119), muitas nuvens (FIG. 120) e imagens em negativo. Por fim, no terceiro movimento, mais variações em torno do tema da água, praias, árvores e máquinas.

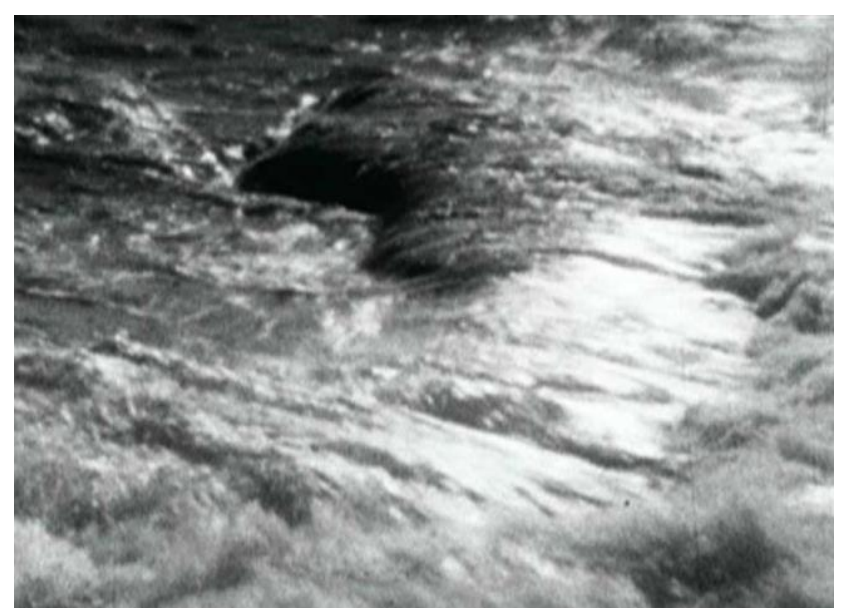

Figura 115 


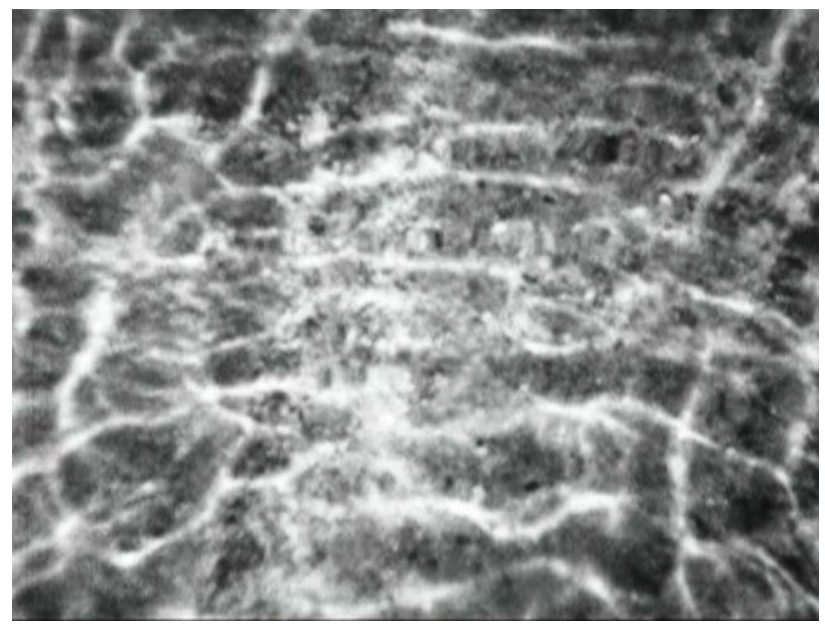

Figura 116

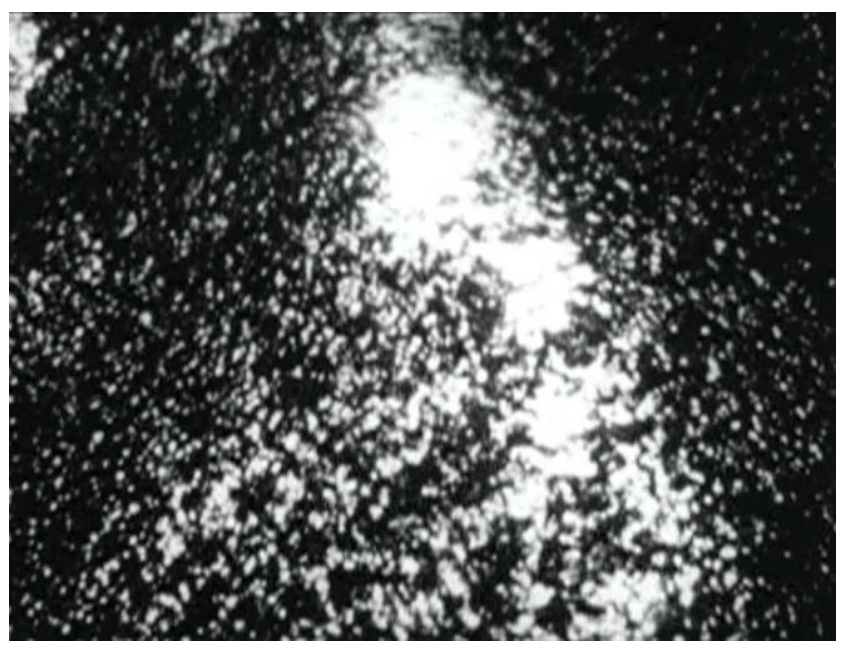

Figura 117

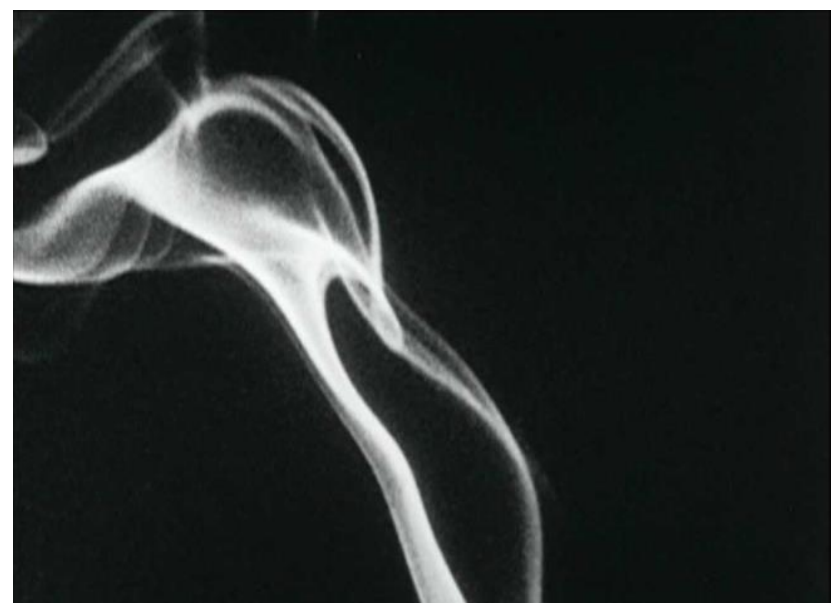

Figura 118 


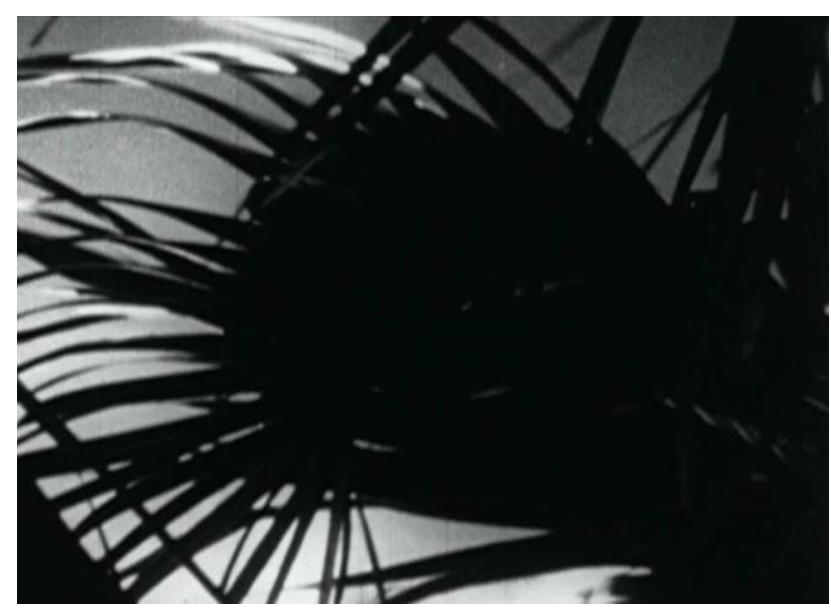

Figura 119

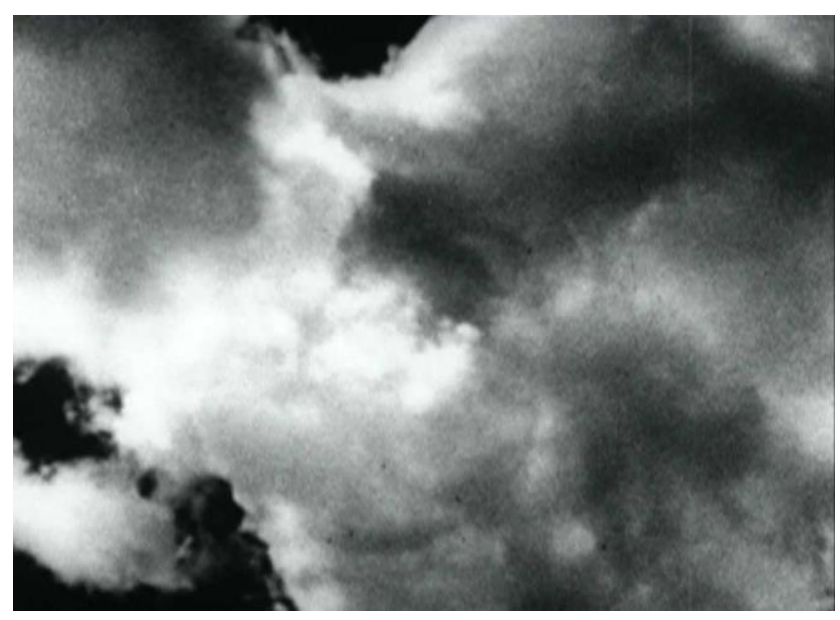

Figura 120

Assim como em Monet, portanto, a superfície da obra de Rodakiewicz pode ser pensada segundo dois pontos que se entrecruzam: a relação do espectador com o objeto e a posterior dissolução deste em meio à abstração. Se, partindo do tema da abstração, conforme veremos adiante a partir do estudo de Susan Sontag, será mais interessante falar em uma dissolução do sujeito (e consequente depósito de toda força expressiva da arte no objeto), aqui, para falar na expectativa dos horizontes produzidos pelos objetos que são mostrados no filme, será necessário recorrer a uma fenomenologia husserliana. Para Husserl, a correlação consciência-objeto é um a priori, ou seja, existe independentemente de quaisquer circunstâncias. Na percepção humana, o objeto é uma ideia que aporta na consciência a partir de um processo de apreensão que o filósofo chamava noose. Este processo faz uma sensibilidade originária amorfa e moldável tomar a forma que o objeto quiser "doar" para a consciência. É isso que ele chama de fenômeno: o momento em que a ideia do objeto sai de sua potência na realidade e, tal 
qual na combinação de uma sequência de DNA, se combina com uma abertura presente na sensibilidade da consciência a partir do fenômeno da intencionalidade. O objeto pode se doar de inúmeras formas diferentes, gerando a complexidade e variabilidade de nossa percepção. Uma música, por exemplo, pode enviar (“doar”) sentidos completamente opostos a duas pessoas diferentes, mas ambos os sentidos opostos estão dentro do horizonte interno de determinações desta música. "É essa variabilidade indefinida das 'perspectivas' sobre um objeto que levará Husserl a apresentar o 'fenômeno' como sendo um modo subjetivo de doação, já que sempre reportado a um 'ponto de vista' parcial e mutável" (MOURA, 2005, p. 12) ${ }^{215}$.

Além deste horizonte interno que se depreende da ideia do objeto, enviando todas as possíveis determinações que o objeto pode levar à consciência (mesmo as não aparentes), existe também um horizonte externo que liga os objetos uns aos outros ${ }^{216}$. Uma folha remete a uma árvore, que remete a uma floresta, que remete a um continente, criando uma rede infinita de projeção e retroprojeção dos horizontes internos e externos dos objetos. A esta rede sistêmica de percepção, Husserl chamava o fluxo:

Portanto, o fluxo é uma entidade coletiva, existem múltiplos vividos reunidos no fluxo. Ele é um tecido, e isso significa que os vividos mantêm entre si relações não indiferentes, características do fluxo. A designação o fluxo, com o artigo definido, evoca o coletivo de vividos em sua totalidade: Husserl nunca cessará de julgar que o tema de sua fenomenologia, seu centro de interesse e campo de investigação, é o fluxo em sua totalidade $\left(\right.$ SALANSKIS, 2006, p. 22) ${ }^{217}$.

Os vividos mencionados pelo estudioso de Husserl Jean-Michel Salanskis são, como se pode ver, os fenômenos já materializados na consciência. Husserl apontava para a possibilidade de realizarmos sínteses fenomenológicas, ou seja, o ato de perceber, a partir de um objeto, todos os objetos. De intuir, a partir de um fenômeno, todos os fenômenos. Estar no fluxo seria participar constantemente destas sínteses, perceber o todo na unidade, intuir o cosmos das coisas que se oferecem a nós a partir de nossa

\footnotetext{
215 Grifo do autor.

${ }^{216}$ Michel Maffesoli, a partir de Levinas, assevera a importância do conceito de "horizonte" para a filosofia moderna: "E como observa Lévinas a partir de Husserl, "a fenomenologia é, integralmente, a promoção da ideia de horizonte que, para ela, exerce o papel do conceito no idealismo clássico. Pode-se prosseguir precisando que, por oposição ao conceito que cerra e encerra, a "ideia de horizonte" fica aberta e, por conseguinte, permite compreender melhor o aspecto idefinido, complexo, das situações humanas, de suas significações entrecruzadas que não se reduzem a uma simples explicação causal" (MAFFESOLI, 1998, p. 117).

217 Grifo do autor.
} 
percepção ordinária. Ora, ao escolher realizar seu autorretrato na forma do objeto, e não do sujeito (sendo "o fenômeno um modo subjetivo de doação"), Rodakiewicz escolhe se alinhar a uma ideia de arte cinematográfica que promulgue este tipo de fenomenologia husserliana. Afinal, "o trabalho de editar este material foi feito baseado puramente no sentimento da continuidade apropriada" (RODAKIEWICZ apud POSNER, 2001). Este tipo de intuição para a montagem no cinema a partir de afinidades morfológicas entre as imagens de alguma forma remonta artificialmente ao fluxo de projeções presente na própria realidade. Não à toa, outros filósofos ligados à fenomenologia como Bergson (2010), Deleuze (1990) e até Pasolini (1983) vão considerar a realidade perceptiva como uma espécie de cinema a priori. Tudo o que a arte cinematográfica faria, com sua sucessão de imagens coligadas por afecções, detalhes morfológicos e narrativos, seria replicar (até grosseiramente) esta complexa realidade da percepção em si.

É por estes motivos, possivelmente, que o filme de Rodakiewicz se concentra nas formas elementais das coisas, procurando reenviar estas relações a uma subjetividade que as acolhe (no caso, a sua própria). Conforme veremos nas ideias de Kandinsky, cada forma geométrica possui uma vibração interna, algo que ela compõe com as outras formas, criando sistemas de crescente complexidade para a emanação de sentimentos, afetos, percepções. É curioso que tenhamos que juntar, neste momento, o construtivismo "espiritual" de Kandinsky à fenomenologia de Husserl, mas o filme de Rodakiewicz nos permite alçar este voo, afinal, ele se trata de uma construção lógica, tijolo por tijolo (ou melhor dizendo: plano a plano), de um sistema de vibrações emocionais emitido pela presença dos objetos na tela. Maquinalmente, a partir da mecânica própria à montagem cinematográfica, e justificado pela artificialidade própria à imagem técnica do cinema em si, o filme erige um painel da sensitividade própria da percepção natural. O fluxo dos fenômenos é recriado pela técnica, o que nos leva a pensar, indo mais longe, que técnica e natureza se imbricam de maneira a uma fazer parte constituinte da outra. A natureza pode ser também uma técnica do mundo. E a técnica, um tipo de natureza.

\subsubsection{Nuvens}

Se há algo que une estes três conceitos representados tanto por Rodakiewicz quanto por Monet - a água onipresente; o fogo do Sol em $O$ Sol se pondo, as nuvens em 
As nuvens, A manhã com salgueiros e Os dois salgueiros; e de maneira mais rarefeita em Manhã e A manhã clara com salgueiros -, é tanto a liquidez quanto a volatilização ou vaporização. Este tipo de instância rarefeita tem sido considerada corolário da modernidade e da pós-modernidade. Susan Sontag (2002) menciona a abstração rarefeita como negação da subjetividade. Siegfried Kracauer (1997) condena explicitamente a tendência à abstração dos processos e o mergulho num mundo rarefeito como algo que nos distancia da natureza e do contato direto com o mundo, buscando no cinema certa redenção da realidade. Zygmunt Bauman fala em modernidade líquida, partindo da ideia de que os processos (culturais, políticos, afetivos, etc.) que engendram as condições da modernidade são instáveis e fluidos, estando em constante transformação, como se situados em lugares apenas probabilísticos, como se fossem um rio heraclitiano. Ora, esta imagem do rio também se aplica a Husserl a respeito de seu fluxo, e vale mencionar:

\begin{abstract}
Mas, se podemos flutuar assim, encontrar a entrada e a saída dos mundos, nos acender e nos apagar, é porque somos um lugar, um campo, é porque há um território de nossas aventuras, de nossas veleidades, de nossos deslizamentos. Uma imanência na qual estamos constantemente perdidos. Durante toda a sua vida, Husserl chamou este lugar de imanência de fluxo heraclitiano dos vividos. É nele que pensávamos ao propor embarcar o leitor no "rio husserliano". A princípio, se Husserl tem razão em querer reconduzir tudo a esse rio, ele não deveria precisar embarcar ali por uma escolha hesitante e contingente, como se se tratasse de tomar o avião para Nova Iorque: antes disso, ele deveria reconhecer que esse é o seu rio, que ele ali nadou desde sempre. A experiência originária da flutuação entre mundos, onde se revela um espaço interno a partir do qual toda coisa ou toda possibilidade se esboça [...], não é incrivelmente a nossa, Husserl não é tão convincente quanto Proust? (SALANSKIS, 2006, pp. 19-20).
\end{abstract}

A volatilidade da filosofia de Husserl, de certa maneira, a partir de sua influência em Heidegger e da semelhança com a filosofia de Bergson, inaugura, através da fenomenologia, esta ideia de que a modernidade e o século XX estão calcados na progressiva demolição de instituições (culturais, políticas, sociais) e na inauguração de um estado impermanente e flutuante de causa e efeito para estes mesmos fatores. Flutuantes também são as nuvens, tão presentes na pintura impressionista (não apenas nos reflexos dos painéis da Orangerie, mas também nos vapores dos trens e estações de Monet, na locomotiva de Manet, nas paisagens celestes de Sisley, etc.), cuja rarefação lembra ao mesmo tempo os pintores e cineastas abstracionistas do século XX, a poesia simbolista do século XIX, e os próprios meios técnicos de comunicação que começam a aparecer nesta mesma época. Não à toa, hoje em dia chamamos de nuvem a base de 
dados virtuais que circula nos cabos de fibra óptica permitindo a livre transmissão e estocagem de dados pela Internet. Porém, a nuvem presente tanto nestes painéis da Orangerie quanto no filme de Rodakiewicz, ligada, de certa forma, tanto ao fluxo husserliano, quanto às remediações do século XIX (pintura-cinema-cinética), quanto à virtualidade do cinema em si, e, por fim, quanto à rarefação do sujeito na cultura do século XX, é, talvez, em sua última instância, um tipo de autorretrato.

Monet e Rodakiewicz são, neste caso, nefelibatas. Habitantes das nuvens na batalha contra os Arismaspos, no Pantagruel de Rabelais, estes seres antropomórficos, oriundos de uma cultura barroca tão distinta tanto da modernidade fin-de-siècle de Monet quanto do experimentalismo do início da era pós-industrial de Rodakiewicz, foram aproveitados, em língua portuguesa, para virarem alcunha para poetas simbolistas herméticos e sem propósito no que diziam. O próprio Manuel Bandeira fez questão de elucidar o significado moderno de nefelibata em uma antologia de poesia simbolista: "os simbolistas foram crismados com tal nome: eram sujeitos que falavam coisas estapafúrdias numa linguagem incompreensível: sujeitos que andavam nas nuvens" (BANDEIRA apud MOREIRA, 2012, p. 3).

Por mais que a imagem do nefelibata se apresente, para as literaturas simbolistas brasileira e portuguesa do final do século XIX, como produto de sonhadores alienados e incapazes de dizer algo efetivo sobre a realidade, não é difícil hoje reverter o ideal dos simbolistas como o prenúncio da imagem da nuvem e do vapor como conceito de modernidade. Evidentemente, Monet e Rodakiewicz não são simbolistas, mas a trajetória da abstração do espaço exterior (feita pelos impressionistas) e a projeção desta deformação para um estado interior (a nuvem como autorretrato; a assunção como nefelibata) leva, possivelmente, ao ideário onírico simbolista. Sem o trabalho de derretimento do mundo visual e aplicação a uma cinética moderna operada pelos impressionistas, a abertura ao sonho que vemos em telas de Maurice Denis ou Gustave Klimt talvez jamais tivesse sido realizada. É como afirma o pesquisador Caio Ricardo Moreira, em defesa do conceito de nefelibata:

Em vez de condenar o "nefelibata", poderíamos tomar a "nuvem" como problema, vendo em seu gesto uma revolução, no entanto, não uma revolução rasteira que seria o resultado de uma concepção utilitarista da poesia; falamos de uma revolução em termos de linguagem. Se por um lado, o sentimento de missão, que foi uma constante na formação da literatura brasileira, perde em 
grande parte seu sentido na poesia fin-de-siècle, por outro não deixa de existir, pois passa a entrar numa zona de indeterminação [...]. Nesse sentido, a nuvem se revistiria também como um corpo político, sendo, assim, não um mero gesto de alienação, mas sintoma da rarefação da matéria" (MOREIRA, 2012, p. 4).

Mais do que nefelibatas, ou seja, habitantes das nuvens - sejam elas nuvens de vapor da indústria do século XIX, nuvens de uma arte individualista na fricção entre a anulação e reivenção do sujeito, ou nuvens da rarefação volátil que caracterizou as operações da modernidade e da pós-modernidade -, talvez o pintor francês e o cineasta experimental americano fossem, na verdade, praticantes da nefelomancia, ou seja, a arte de adivinhar por meio da leitura das nuvens. Conforme veremos adiante, os painéis de Monet e o filme de Rodakiewicz estão integrados em estranho palíndromo mediático em que um reenvia, a partir de um todo cultural que os rodeia, como se fossem efetivamente, parte de um horizonte externo husserliano. Isso não tem a ver com interinfluência entre artistas, mas sim com potências sinalizadas nos ambientes e circuitos culturais, e, em última instância, na própria realidade, que capturam dinâmicas presentes em uma época, dentro de uma relação multifatorial de circunstâncias. Esta relação será abordada adiante, mas nos serve, neste momento, a definição que Sallie Nichols dá, em seu clássico Jung e o tarô, para a projeção, conceito que nos ajuda a compreender aquilo que liga a obra de Monet à de Rodakiewicz:

\footnotetext{
A melhor maneira de alcançar o significado individual das cartas é abordá-las diretamente, como faríamos com os quadros de uma galeria de arte. Como as pinturas, os Trunfos são os chamados detentores da projeção, o que quer dizer simplesmente que são os ganchos para apresar a imaginação. Falando psicologicamente, projeção é um processo inconsciente, autônomo, pelo qual vemos primeiro nas pessoas, nos objetos e nos acontecimentos as tendências, características, potencialidades e deficiências que, na verdade, são nossas. Povoamos o mundo exterior de feiticeiras e princesas, diabos e heróis do drama sepultado em nossas profundezas.

A projeção do nosso mundo interior no exterior não é coisa que fazemos de propósito. É simplesmente a maneira como funciona a psique. Em realidade, a projeção acontece de forma tão contínua e inconsciente que costumamos não dar tento de que ela está acontecendo. Não obstante, tais projeções são instrumentos úteis à conquista do autoconhecimento. Contemplando as imagens que atiramos na realidade exterior, como reflexos de espelho da realidade interior, chegamos a conhecer-nos (NICHOLS, 1980, p. 26).
}

Husserl também afirma que a "doação" dos objetos em direção à formação do fenômeno é inconsciente, e que nossa subjetividade captura a forma com que as coisas a atingem sem que isto seja uma escolha, a despeito da intenção de perceber o fenômeno. A diferença é que a projeção jungiana da qual trata Sallie Nichols funciona como um 
espectro que irradia da subjetividade para as coisas, enquanto Husserl pensa sobre uma irradiação das coisas para a subjetividade ${ }^{218}$. Complementares, as duas ideias nos ajudam a ratificar a porção de nefelomancia em ambos os artistas, considerando a evidente projeção de si próprios que fazem nas nuvens de suas obras, e a irradiação que estas mesmas nuvens proporcionam para todo o mundo de suas vidas, suas épocas e suas culturas.

\section{2 - Abstração e silêncio a partir de Monet e Rodakiewicz}

Todas as coisas, todo lugar é real, Cada partícula constrói o Homem Original. Ainda assim, o absolutamente real não tem voz, O verdadeiro corpo está majestosamente fora da visão.

- Chosha, mestre Zen chinês

\subsection{1 - Silêncio a alucinação}

Monet e Rodakiewicz tenderam à abstração, cada um em seu suporte, mas ambos seguiram, conforme demonstramos, a mesma pulsão cinemática que acompanhou o cinema silencioso, seja na relação entre fotogramas do primeiro cinema, seja na motivação narrativa plano a plano do cinema tableau dos anos 1910, seja invadindo o cinema experimental dos anos 1920 e 1930. Porém, o que o aspecto abstrato destas obras ressalta em relação ao cinema silencioso não é tanto a cinética em si, mas mais especificamente o silêncio inerente tanto ao mundo visual da pintura quanto à apreensão silenciosa de cada filme silencioso. Conforme foi argumentado nos outros capítulos, há controvérsia a respeito da natureza silenciosa destes filmes. Eles não apenas poderiam ser acompanhados por vozes, efeitos sonoros, comentaristas, gritos da plateia e música, como seu mundo sonoro interno poderia ser decodificado e as falas, "lidas" da boca dos personagens. Em suma, o universo dos filmes silenciosos, em

\footnotetext{
${ }^{218}$ Edgar Morin coloca a relação sujeito-objeto em termos de projeções-identificações ou participações afetivas: "Entre a magia e a subjetividade estende-se uma nebulosa incerta, que ultrapassa o homem sem contudo dele se desligar, e cujas manifestações assinalamos ou designamos com as palavras alma, coração ou sentimento. Este magma, ligado a um e a outra, não é nem a magia nem a subjetividade propriamente ditas. É o reino das projeções-identificações ou participações afetivas" (MORIN, 2003, p. 148).
} 
geral, não era "mudo" e nem "surdo" (RAYNAUD, 2001, p. 70), e toda diegese implicava em som e em uma narrativa sonora.

Porém, conforme já argumentamos, nenhuma destas funções sonoras impede que olhemos para o filme silencioso a partir de um truísmo que é seu silêncio técnico. Ora, sabemos que o que se sabe sobre a presença de acompanhamentos sonoros nos filmes silenciosos é inconclusivo. Enquanto Rick Altman argumenta, contrariando a maioria das pesquisas anteriores, que muitas de sessões do cinema silencioso, especialmente do chamado primeiro cinema, não traziam qualquer tipo de acompanhamento sonoro, o pesquisador francês Martin Barnier também traz resultados indeterminados a respeito da natureza e frequência destes acompanhamentos na França até 1914:

\begin{abstract}
A forte imbricação entre o café-concert e o "cinema" nos permite afirmar que as músicas e os cantos, em torno dos filmes, têm uma grande incidência sobre a maneira de se perceber os filmes [...] $\mathrm{O}$ acompanhamento por efeitos sonoros e o comentarista [...] também nos interessa. A frequência de intervenção destes sons e vozes é ainda difícil de acessar. Muito poucos jornais se referem a estes elementos (BARNIER, 2010, p.17) ${ }^{219}$.
\end{abstract}

Além disso, ultrapassando um debate técnico sobre a presença de elementos sonoros nas sessões dos vários estágios do cinema silencioso, a pesquisadora norteamericana Melinda Szaloky argumenta que mesmo que não houvesse nenhum acompanhamento ou sincronização sonora nestes filmes, todo um universo sonoro estaria presente neles através de um tipo de sinestesia metafórica quando intuímos um som (mesmo sendo ele inexistente) através de nossa experiência corporal de derivar um sentido a partir de outro (neste caso, a audição através da visão). "Nós podemos considerar o silêncio do filme do ponto de vista do próprio medium onde o medium é definido não em termos de sua tecnologia material, mas como uma prática representacional direcionada à recepção por parte dos espectadores." (SZALOKY, 2002, p.111) 220 .

Este posicionamento de Szaloky nos permite pensar em duas frentes úteis para compreender o papel do silêncio na obra final de Monet e no filme de Rodakiewicz, além da relação de ambas com status perceptivo e até ontológico do cinema silencioso como um todo. Primeiro, que um medium pode ser definido não em termos de uma

\footnotetext{
219 Tradução nossa.

220 Tradução nossa.
} 
tecnologia material, mas sim de uma prática sensitiva. Isso nos permite pensar a esteira poética da percepção, por exemplo, como um tipo de medium específico para a veiculação de determinados modelos de pensar e perceber. Em segundo lugar, algo que está no avesso do que a pesquisadora americana afirma. Se podemos considerar como som aquilo que não ouvimos, mas intuímos através da sinestesia de um "ouvido interno" que deriva da imagem (se vemos um tiro ser disparado em um filme silencioso, por exemplo, então o "ouvimos" através desta transmutação sinestésica a partir daquilo que nosso olhar processou), então é justo dizer que não há, absolutamente, silêncio no filme silencioso. A partir desta argumentação, porém, poder-se-ia dizer que não há silêncio em instância alguma da realidade, referendando a ideia de John Cage ${ }^{221}$ de que o silêncio é mais uma fantasia humana do que algo tecnicamente verificável na vida como um todo. Ora, nossa ideia é não apenas afirmar o contrário disso (o silêncio está em toda parte), como defender o silêncio dentro do filme silencioso (e dentro de toda imagem silenciosa) como primordial às suas qualidades ontológica e perceptiva. Sendo assim, é importante verificar exatamente a que tipo de silêncio estamos no referindo ao afirmar que, mesmo com o som (ouvidos interno e externo), ao assistirmos a um filme silencioso, estamos tendo uma experiência efetivamente silenciosa, e o que isso implica em nossa recepção perceptiva e cognitiva, especialmente em relação ao filme falado.

Susan Sontag (2002, p.18) classifica o silêncio na arte como "forte" ou "brando". O primeiro tipo, vincado na arte moderna e especialmente no abstracionismo (conforme veremos), é agressivo em suas técnicas e faz questão de "dizer que não diz nada" de uma maneira veemente, autoevidente. Uma pintura de Jackson Pollock, por exemplo, seria um tipo radical de silêncio. Paradoxalmente, um silêncio que grita. $\mathrm{O}$ outro tipo, brando, estaria confinado aos detalhes imperceptíveis do classicismo, ligados a padrões e tipos de ironia que preferem ocultar a falar abertamente. Um silêncio da discrição, por assim dizer. E Sontag não é a única a pensar o silêncio como algo presente dentro de um espectro ou gradação. O filósofo alemão Max Picard, um dos pensadores do silêncio por excelência, fazia uma distinção entre um "verdadeiro" silêncio e o mero vazio, inspirado em uma diferente valorização do mundo mecanizado da indústria (para ele símbolo de uma racionalidade que destrói o mistério e o

\footnotetext{
221 "Eu estou aqui e não há nada a dizer. Se, ao seu redor, estão aqueles que querem chegar a algum lugar, deixe-os ir a qualquer momento. O que nós requeremos é silêncio. Mas o que o silêncio requer é que eu siga falando" (CAGE, 2011, p. 109).
} 
desconhecido da existência) e o do trabalho agrário, carregado de energia espiritual: "Picard chama o silêncio que se segue ao cessar das máquinas mero vazio; o silêncio experimentado depois do trabalho pelo lavrador, por outro lado, é o mesmo silêncio que ele mesmo experimenta enquanto trabalha.” (PUKNAT, 1950, p. 380) 222.

A pesquisadora americana Cheryl Glenn (2004, p. 16) lista nada menos que vinte sentidos potenciais do silêncio em uma interação humana, que vão desde "a pessoa não tem informação o suficiente para falar sobre o assunto" até "o silêncio marca raiva e mau humor." Glenn enfoca fortemente a necessidade de se entender o silêncio como um tipo de retórica, em que o contexto em que ele aparece determina completamente a natureza comunicacional de sua aparição. O silêncio pode ser esperado, respeitado, temido, repentino, carregado de prazer ou de dor, tranquilizador, atormentador, etc.

Como ausência da palavra falada, como presença de uma comunicação nãoverbal, como escolha estratégica, ou como imposição, o silêncio toma muitas formas e serve a muitas funções, particularmente considerando que funções variam de cultura para cultura. De tempos em tempos, por exemplo, usos do silêncio em culturas asiáticas, indígenas americanas ou religiosas foram romantizadas como práticas super-humanas de pessoas especiais (GLENN, 2004, p. 15$)^{223}$.

O conceito de silêncio, portanto, pode ir do grau de comunicabilidade na arte, até algo que inclua uma natureza sociológica (o silenciar das máquinas; o silêncio do lavrador) e a uma estratégia de discurso. Logicamente, nos interessa aqui o silêncio não apenas técnico ou retórico, mas também sua relação com a linguagem, como categoria de percepção e ontologia (assim como a poesia). Neste caso vale mencionar também a leitura holística (por vezes existencialista) do filósofo alemão Karl Jaspers sobre o impacto do silêncio na tomada de posição do ser humano em relação à vida. Para Jaspers, qualquer investigação empírica a respeito da natureza do ser (e, logo, também da realidade) encontrará como obstáculo a configuração aprisionadora do indivíduo, que precisa revelar um ser "verdadeiro" por meio da libertação da consciência. Se o discurso de Jaspers por vezes parece por demais transcendental (certamente não em um sentido kantiano), talvez seja porque ele reconhecia, como Wittgenstein, que há limites para a comunicabilidade humana, mas não para uma apreensão total da realidade. Se o "eu" e a

\footnotetext{
222 Tradução nossa.

223 Tradução nossa.
} 
linguagem são prisões (e sobre isso Kant colocaria um ponto final na questão), é necessário verter-se ao silêncio para buscar um contato diferente com a consciência.

Quando a mente humana se encontra cara a cara com o mistério da existência, explica Jaspers, o silêncio ou a solidão estão lá para a levar a perceber ou entender este mistério. Este entendimento não é uma verdade de conhecimento intelectual ou racional, mas uma verdade do espírito, que é o conhecimento da arte e a estética [...] (CARANFA, 2003, pp. 99-100) 224 $^{224}$

O silêncio, neste caso, conforme veremos também no caso do Zen e do Tao, representa não apenas o esvaziamento de um logos racionalista e ineficaz, incapaz de suprir a demanda do ser para além dos limites de categorias pensantes, mas uma frequência da própria percepção veiculada pelo corpo e pela mente que coloque o ser humano em uma posição assertiva em relação ao que ele é e ao que o rodeia. Aqui, mais do que uma retórica, um tipo de discurso ou um instrumento de poder, o silêncio se torna uma ferramenta para encadear um contato com a realidade de outro modo impossível. Isso se conforma, como veremos, não apenas com a razão poética segundo María Zambrano, mas com a noção de que o silenciamento técnico da fala no filme silencioso importa para a percepção do espectador todos estes vetores de um desenovelar do ser diante da racionalidade, sintonizando-o nesta frequência do silêncio que em muito tem a ver com um estado poético das coisas. Jaspers, de outra maneira, endossa este estado da existência a partir de sua natureza silenciosa:

\begin{abstract}
Assim, para Jaspers, nós não apreendemos ou abarcamos Deus através de nenhum tipo de meditação em um símbolo, ou metáfora, ou analogia, ou imagem, ou alegoria, ou dogma de fé, ou pensamento. Ao invés disso, nós o apreendemos ou o abarcamos através do ato de escutar o que "o mundo como um todo" diz para nós na medida em que viajamos para o silêncio de nosso ser autêntico, onde a existência se torna verdadeiramente sublime ou divina, e onde o pensamento filosófico se transforma naquilo que Jaspers chama de esplendor. (Ibidem, p. 103).
\end{abstract}

Por fim, para além do silêncio ontológico (capaz de desvelar nosso ser autêntico) e até teológico proposto por Jaspers, há o papel do silêncio na forma com que as coisas são comunicadas. "Não se pode imaginar um mundo no qual não há nada além da linguagem e da fala, mas pode-se imaginar um mundo no qual não há nada além de silêncio" (PICARD apud GLENN, 2004, p. 4). É evidente e até natural pensar que o silêncio precede a fala, o som e a linguagem no sentido de que ele, em seu "estado ideal”, existe sem existir, precede a criação ${ }^{225}$, está lá quando nada mais está. O silêncio

\footnotetext{
224 Tradução nossa.

${ }^{225}$ George Steiner, um pensador político do silêncio, aponta as aporias de se pensar que "no começo era o Verbo": "Segundo o ensinamento de São João e a metáfora neoplatônica, no começo era o Verbo: mas se
} 
emerge a cada momento em que a comunicação é encerrada ou interrompida. Está sempre pronto a voltar, como em uma gangorra que nunca cessa, no pronto momento em que uma palavra termina, em que uma vírgula ou um ponto final são colocados. Mais do que isso, cada palavra paradigmaticamente elencada pela linguagem deixa todas as outras possíveis em silêncio, tornando este mundo (o da linguagem) uma pequena ponta de iceberg sobreposta diante de um oceano indevassável de tudo que pode ser dito, escrito, expressado, sempre atrás de um ideal inalcançável, o ideal de preencher a vastidão cósmica deste silêncio. E é talvez especialmente deste silêncio e de sua relação ambígua com a comunicação que falam filósofos ainda metafísicos como Jaspers ou Picard. Eles tratam da capacidade de, em não podendo comunicar nada especificamente (como a linguagem), o silêncio talvez ser a possibilidade de se comunicar todo o resto reunido em uma só experiência:

\begin{abstract}
A fala veio do silêncio, da completude do silêncio. A completude do silêncio teria explodido se não tivesse fluido na forma da fala... Há algo silencioso em cada palavra, como um testemunho permanente da origem da fala. E em cada silêncio há algo da palavra falada, como testemunho permanente do poder do silêncio em criar a fala (PICARD apud GLENN, 2004, p. 4) 226 .
\end{abstract}

A imagem do cinema silencioso apela a este silêncio, já que nos propõe uma espécie de transe, um encantamento que provém da experiência do olhar que percorre os elementos da tela e provoca instantaneamente este estranho efeito de totalidade comunicacional: o silêncio, em um filme silencioso, funciona como um vetor que liga cada imagem a todas as imagens; cada forma a todas as formas; cada sentimento a todos os sentimentos. É como se, graças à sua capacidade de congregar tudo que não é dito em sua ausência prenhe de significado, o silêncio pudesse catalisar a síntese fenomenológica proposta por Husserl: cada objeto presente na potência da realidade, ao oferecer seu horizonte externo à percepção humana, abre o fluxo de todas as coisas e traz à intuição um poder totalizante. Se a linguagem não está necessariamente imersa no fluxo (mas sim em uma semiose ${ }^{227}$ ), o silêncio, como fenômeno oposto e ao mesmo

este Logos, este ato de essência divina representa, em última análise, o grau último da comunicação, uma forma que doa ela mesma seu conteúdo e sua verdade, o que se faz então com o animal falante, do zoom phonanta, do homem? Ele também criou termos, e os criou a partir de termos. Podemos imaginar um modo de coexistência que não seja carregado de rebelião e de sofrimento, entre a totalidade do Logos e os fragmentos vivos, geradores de mundos novos, do discurso humano? A voz, que define o homem, não o ultrapassa, em uma rivalidade grandiosa em direção ao Espírito?” (STEINER, 1969, pp. 58-59).

226 Tradução nossa.

227 "Criada por Lotman, a ideia de semiosfera ajusta-se a tantas outras ali desenvolvidas que ampliaram os estudos de signo para os estudos de texto, não meramente linguístico como também entendido enquanto manifestação artística, cultural, estética e massiva. E, sobretudo, tal ideia dá nova dimensão ao espaço da 
tempo complementar à linguagem, seria uma transfiguração, na realidade, do próprio fluxo. O silêncio é o fluxo.

Retrato de um homem jovem, se seguirmos esta linha de raciocínio, não apenas traz à tona todos estes elementos com muita clareza, como de certa forma serve como imagem originária para todo e qualquer filme silencioso. Em primeiro lugar, há a comunidade de formas e seres que, sozinhos, talvez não provoquem efeito maior do que um filme Lumière: imagens de árvores, de máquinas ou do mar, isoladas, não parecem mais que uma extração pálida da realidade, sem a ambiguidade do acaso (caso da fotografia ${ }^{228}$ ), sem a operação construtiva da montagem (caso do cinema). Ao unificar estes elementos em torno da montagem e do silêncio - lembrando que Rodakiewicz deixou explícita a instrução para que o filme fosse visto sempre em silêncio -, porém, o cineasta americano acabou editando, já de maneira tardia (1932), aquilo que funcionaria como um protofilme silencioso. Sem a pátina de narratividade, sem a preocupação com uma diegese, com um universo sonoro interno ou mesmo com personagens, Retrato de um homem jovem, dentro de sua obsessão pelo fluxo de uma subjetividade projetada no objeto, acaba extraindo tudo aquilo que não importa (ao menos se considerarmos o silêncio como protagonista) em qualquer filme silencioso. Ele retira a sujeira de um mundo diegético e preserva um extrato precioso da experiência de se assistir a um filme desta natureza: o jogo de percepção puro que advém da relação entre imagem, montagem e silêncio no cinema. De certa forma, é esta relação abstrata, de pura virtuosidade, que liga Rodakiewicz a outros cineastas (talvez até mais ousados) como Grant, Bute, McLaren ou Fischinger. Ela está presente, ocultada mas subjacente, no fascínio hipnotizante que é a experiência de se assistir a um filme silencioso, seja na época em que foram produzidos, seja hoje em dia. Trata-se de uma qualidade produzida pela alquimia entre estes elementos (sacramentada pelo silêncio destes filmes) que está introjetada, como uma categoria (ou frequência) de percepção, nesta experiência.

ciência dos signos: 'a semiosfera é o espaço semiótico fora do qual é impossível a existência mesma da semiose"” (ANTONIN, 2009, p. 318).

228 Bonnefoy realiza interessante comparação da fotografia com a pintura por meio do conceito de "acaso": "O acaso está ativo, na imagem fotográfica, ele contorna o espírito do dizer da composição, se é há uma, ele deixa perceber que as coisas existem, então, como tais, em um ser-aí irredutível ao espírito" (BONNEFOY, 2014, p. 21). 
Como não há narrativa a se seguir em um filme como este, nossa mente e percepção se sentem livres para divagar sobre as imagens que se apresentam e desfilam em nossa frente. Somos edulcorados pela sinuosidade da fumaça, pela maleabilidade das superfícies aquáticas ${ }^{229}$, pela existência sólida e singular das plantas, pelo movimento automatizado das máquinas. Em seus quase 60 minutos de duração, Retrato de um homem jovem se reporta especificamente à passagem do tempo, como se procurasse replicar a duração mental de cada instante. Porém, o que nos interessa aqui neste momento não é especificamente a natureza fenomenológica destas imagens, mas sim os voos e as imediações de deriva a que a mente se submete ao entrar em contato com tal silêncio, com estas imagens que se transmutam umas nas outras (tendo as nuvens, a volatilidade e a maleabilidade aquosa como referências), como se fossem caleidoscópios destinados não a nos segurar dentro do filme, mas a escapar por meio dele.

A função logocêntrica da fala e da linguagem em geral, além dos distúrbios provocados pela organização da montagem sonora em um filme sonoro, de certa maneira impedem que este tipo de voo ocorra quando o assistimos. Logicamente, dada a sua radicalidade e seu silenciamento em dois níveis importantes (o silêncio técnico absoluto indicado nas instruções para se assistir ao filme e o silêncio interno provocado pelo grau de abstração), Retrato de um homem jovem é um exemplo paradigmático deste efeito (daí o nosso aprofundamento na experiência que ele provoca). Conforme veremos, nosso estado mental solto ou concentrado nas imagens que aparecem em nossa frente é semelhante a estágios diferentes de um processo de meditação: ora estamos vendo uma multidão de informações se passarem em nossa cabeça, como um rio solto, aleatório e selvagem; ora estamos aprisionados, unificados (como em um único canal ou frequência) pela mudez não apenas do filme, mas de suas imagens: nossos olhos deslindam o fogo, seguem a beleza da fumaça, ondulam como a água. Ora meditamos nas formas do mundo físico reproduzido pelo filme; ora deixamos a mente livre para conectar informações díspares e diversas. Nossa mente sai do filme (tendo ele como base) e cria outras imagens a partir daquelas primordiais elaboradas pelo cineasta.

\footnotetext{
${ }^{229}$ Um filme contemporâneo de abordagem semelhante é o documentário de episódios Cinco (Five, 2003), do cineasta iraniano Abbas Kiarostami. No último episódio, temos uma câmera fixa em uma superfície aquática (provavelmente um lago), que captura, somente à luz da lua e suas variações, por cerca de 20 minutos, as transformações e barulhos da natureza junto a este lago. A experiência é longa e radical, e parece remeter ao mesmo tipo de sensações provocadas por Retrato de um homem jovem.
} 
Este efeito, algo alucinatório, que obviamente pode variar muito de pessoa para pessoa, não é um mérito especial da habilidade cinematográfica de Rodakiewicz. Como já argumentamos, o silêncio é o fluxo, e é o mergulho cego no fluxo husserliano que nos sintoniza nesta frequência. Todo filme silencioso (e mesmo muitos filmes sonoros) guarda em si uma centelha deste fenômeno. O silêncio funciona como um catalisador deste processo de interconexão entre as coisas e as imagens. Conforme vimos a respeito de Bergson e, conforme veremos, argumenta também Pasolini, o cinema investe no mundo de indistintas imagens (que estão entre a coisa e a representação, e que constituem todo o montante de nossa natureza perceptiva), o mundo plasmático da matéria, e o recorta, através da memória, separando as imagens de seu locus indistinto e alojando-as dentro da individualidade do ser. Aqui, curiosamente, por meio da filosofia de Husserl, o processo catalisador é o contrário: um filme como Retrato de um homem jovem ou os painéis da Orangérie de Monet (ou seja: obras que se valem do silêncio) partem do nosso mundo fragmentado e devolvem nossa consciência ao oceano da matéria, colocando-nos, de certa forma, em unidade com o fluxo novamente. E este processo, graças à natureza muda dos filmes silenciosos, se replica, em algum grau, em todos eles, por mais narrativos ou intelectuais que sejam.

A menção às alucinações não foi casual. De certa forma o "transe" a que os filmes silenciosos nos submete se assemelha ao fenômeno das alucinações em si tais quais descritas pelo neurologista Oliver Sacks em seu livro A mente assombrada (2012). Sacks dá especial destaque a um tipo de alucinação conhecida na literatura médica como Síndrome de Charles Bonnet (SCB), em que a pessoa percebe em sua frente imagens (que não emitem sons ou cheiros) perfeitamente visíveis, geralmente de pessoas andando, em diversos tamanhos (muitas vezes multidões), sem que isso seja um produto da imaginação. Ou seja: o cérebro cria aquelas imagens, mas através de uma combinação de áreas diferente daquela responsável pela imaginação:

Houve uma "notável correspondência", escreveram Ffytche et al. em um artigo de 1998, entre as experiências alucinatórias específicas de cada paciente e as porções específicas do trajeto visual ventral no córtex visual em que foram ativadas. Alucinações com rostos, cores, texturas e objetos, por exemplo, ativaram cada qual áreas específicas que sabidamente participam de funções visuais específicas. Quando houve alucinação com cores, ocorreu a ativação de áreas no córtex visual associadas à construção das cores; quando houve alucinações faciais com qualidades caricaturescas ou esboçadas, 
ocorreu a ativação do giro fusiforme. Visões de rostos deformados, desmembrados ou grotescos com olhos ou dentes exagerados vieram associados à intensificação de atividade no sulco temporal superior, uma área especializada na representação de olhos, dentes e outras partes do rosto. Alucinações com texto ocorreram associadas à ativação anormal na área de formação visual das palavras, uma área altamente especializada no hemisfério esquerdo.

Ffichte et al. observaram, além disso, uma clara distinção entre a imaginação visual normal e as verdadeiras alucinações - por exemplo, imaginar um objeto colorido não ativava a área V4, ao passo que uma alucinação colorida, $\operatorname{sim}($ SACKS, 2012, p. 32).

Estas imagens alucinatórias são sempre silenciosas. Alucinações auditivas (SACKS, 2012, pp. 58-75) ocorrem, em geral, separadas das visuais. O mundo de quem sofre com a SCB é sempre invadido por estas imagens clarividentes, límpidas, cristalinas, que caminham e fazem coisas diante de seus olhos, sem que uma interface interfira na outra, ou seja, a alucinação "finge" que o espectador não existe, e viceversa. Ora, de certa forma este distanciamento entre as duas instâncias se assemelha ao cinema, no sentido de que o cinema (ao menos um filme como Retrato de um homem jovem) nada possui de interativo. Alguns teóricos ligados à fenomenologia podem argumentar o contrário, afirmando que há uma permuta perceptiva entre as duas instâncias. Merleau-Ponty ${ }^{230}$ afirma que o cinema ocorre justamente entre as duas instâncias, naquilo que ele envia ao espectador, e naquilo que o espectador envia ao cinema. Edgar Morin (1956) o concebe como uma "máquina de projeção-eidentificação". Mesmo um pioneiro como Hugo Munsterberg ${ }^{231}$ afirma que o fenômeno da espectatorialidade cinematográfica ocorre na replicação das faculdades mentais (em especial a atenção) por meio dos recursos fílmicos. Neste caso ocorre que, em uma experiência cuja proposta epistemológica inclui uma intensa troca intersubjetiva (seja por meio da doação da subjetividade às coisas, ou da doação das coisas à subjetividade), torna-se difícil acreditar em uma não-interferência entre as propriedades de projeção perceptiva do filme e o sujeito espectador. Mesmo assim, estranhamente, ver um filme silencioso (e especialmente algo radical como Retrato de um homem jovem) alcança um tipo de ambiguidade que ultrapassa a mera relação de uma troca perceptiva ou de uma

\footnotetext{
230 "O entrecho cinematográfico tem, por assim dizer, um cerne mais compacto do que o da vida real, decorre num mundo mais exato do que o mundo real. De qualquer forma, é mediante a percepção que podemos compreender a significação do cinema: um filme não é pensado e, sim, percebido" (MERLEAU-PONTY, 2003, p. 115).

231 "Nós temos a realidade em todas as suas verdadeiras dimensões; e mesmo assim o filme continua seguindo, passando uma impressão de superfície sem real profundidade ou preenchimento, tão diferente de uma mera fotografia quanto de uma mera performance de teatro. Ele coloca nossa mente em um estado peculiar e complexo; e devemos perceber que isso interpreta um papel que não é desimportante na maquiagem mental do filme como um todo" (MUNSTERBERG, 1970, p. 24. Grifos do autor. Tradução nossa).
} 
redução fenomenológica. Assim como no caso da meditação, a mente se estabelece em duas frequências: um foco está no rio de imagens e palavras que atravessam o pensamento, sem que se lhes dê atenção; e o outro está na respiração, na ascensão a um estado alinhado a uma ausência, um alinhamento ao silêncio. O filme de Rodakiewicz funciona como alucinação a partir deste duplo anteparo: por um lado é submersão no fluxo, é a experiência de que cada imagem nos carregue a todas as outras do mundo, através destes contatos metonímicos entre os objetos que se impulsionam diante da subjetividade; por outro, assistimos passivamente a um deslizar de imagens separadas de nós que se sequenciam diante de nossos olhos. O filme, assim, produz intensa movimentação interna e ao mesmo tempo restringe-se à distância estabelecida pela separação física entre sujeito e objeto, funcionando como alucinação:

\begin{abstract}
Os sonhos são fenômenos neurológicos além de psicológicos porém diferem muito das alucinações da SCB. O sonhador está totalmente envolvido em seu sonho, e em geral participa dele ativamente, ao passo que as pessoas com SCB conservam a consciência crítica normal da vigília. As alucinações da SCB, embora sejam projetadas no espaço externo, são marcadas pela ausência de interação; são sempre silenciosas e neutras, e raramente transmitem ou evocam qualquer emoção. Restringem-se ao visual; não têm sons, nem odores, nem sensações táteis. São remotas, como as imagens na tela de um cinema em que se entrou por acaso. O cinema está na nossa frente, mas as alucinações não parecem ter relação com a pessoa em nenhum sentido profundamente pessoal (SACKS, 2012, pp. 35-36).
\end{abstract}

O fato de Sacks mencionar o sonho para compará-lo à alucinação não ocorre por acaso quando estamos pensando uma ontologia para o cinema. Buñuel ${ }^{232}$, em seus voos teóricos, comparava o cinema de qualidade poética às propriedades do sonho. Pasolini considerava os eventos do sonho como pré-gramaticais e pré-morfológicos, e, logo, estavam estabelecidos no nível do inconsciente, de onde emergia uma natureza primeira da linguagem do cinema. Já o crítico americano Parker Tyler, autor de uma das obras clássicas a respeito do cinema poético (The three faces of the film, 1960), associa este tipo de cinema diretamente à estética surrealista que, por sua vez, deriva da experiência onírica: “A poesia moderna é especialmente complexa e 'irregular'; sua ordem básica, como aquela dos sonhos, é a ordem psíquica de associação e sugestão. Um 'poema',

\footnotetext{
232 “Nas mãos de um espírito livre, o cinema é uma arma magnífica e perigosa. É o melhor instrumento para exprimir o mundo dos sonhos, das emoções, do instinto. O mecanismo produtor das imagens cinematográficas é, por seu funcionamento intrínseco, aquele que, de todos os meios da expressão humana, mais se assemelha à mente humana, ou melhor, mais se aproxima do funcionamento da mente em estado de sonho" (BUÑUEL, 2003, p. 336).
} 
podemos remarcar, é aquilo que um cine-poema se propõe a ser...” (TYLER apud SITNEY, 2015, p. 4) $)^{233}$.

Torna-se curioso, portanto (e importante para ressaltar a hipótese da ambiguidade perceptiva), notar que a experiência de um filme silencioso como Retrato de um homem jovem se situa entre o sonho, em que a imersão e a troca ocorrem em diversos níveis, e a alucinação, em que a separação entre sujeito e objeto é total. Esta relação serve para nos lembrar que nenhuma proposição a respeito da percepção cinematográfica é absoluta ou desprovida de intensa ambiguidade. Conforme temos argumentado, a mente opera em diversas frequências diferentes em conexão com o mundo externo, muitas delas ao mesmo tempo, algumas anulando os efeitos das outras. No caso do cinema silencioso, o silêncio é um frequência que se desdobra na frequência poética, conforme veremos adiante. Este debate lembra a resposta que o teórico Murray Smith traz ao problema (igualmente ambíguo) da credibilidade da ficção. Afinal, antes de afirmar que "A ficção estimula a imaginação de um determinado cenário; não conduz o espectador a nenhuma espécie enigmática de torpor" (SMITH, 2005, pp. 154-155), ele faz uma proposta intermediária a respeito da imersão que ocorre no cinema, ressaltando especificamente o papel da imaginação (e não da representação projetiva) na relação espectatorial que ocorre com o cinema:

\begin{abstract}
Examinamos, até aqui, os problemas relativos à descrição de respostas à ficção, em termos de uma crença equivocada na realidade do que é representado ficcionalmente. Se rejeitarmos essa explicação, outra se fará necessária para resolver o seguinte paradoxo: enquanto, no cotidiano, para nos sensibilizarmos com algo temos de acreditar que esse algo é real, no que tange à ficção nos deixamos sensibilizar por algo que sabemos não ser real. Para isso, pelo menos duas alternativas se apresentam. Tanto se pode sustentar que 1) o que está implicado na apreensão da ficção é uma forma de fingimento ou faz-de-conta, e não de crença, e que o que parece ser resposta emocional é de fato apenas quase-emoção; ou que 2) não é preciso acreditar em uma série de eventos para a eles responder emocionalmente; basta entreter imaginativamente uma situação ficcional para sentir-se sensibilizado por ela. (Idem, pp. 151-152).
\end{abstract}

A ideia de que haja uma meia-verdade (a "quase-emoção") a respeito do envolvimento do espectador de cinema com a ficção dá uma pista para compreendermos a dupla valência da experiência sensitiva a que somos submetidos ao assistir a Retrato de um homem jovem. Afinal, se existe uma "quase-emoção" na relação do espectador com o filme, existem dois lados neste fenômeno: o primeiro é o da emoção, em que existe o mergulho nos procedimentos sensitivos do filme e a interconexão com sua

\footnotetext{
${ }^{233}$ Tradução nossa.
} 
"verdade"; o segundo é a não-emoção, em que há um distanciamento e perfeita consciência de que filme e espectador estão separados fisicamente, mentalmente, psiquicamente. A experiência fílmica ocorre, especificamente, entre estas duas valências (daí a quase-emoção), o que torna o ato de assistir a Retrato de um homem jovem de alguma forma uma réplica do mundo meditativo: estamos ao mesmo tempo dormindo e despertos. Há um esvaziamento do mundo mental que se dá pelo processamento de imagens e palavras no fluxo da consciência. Estamos, ao mesmo tempo, entre o sonho e a alucinação, e este é o locus do filme silencioso, e talvez somente dele.

\subsection{2 - Silêncio a abstração}

Ainda que Retrato de um homem jovem não seja um filme inteiramente abstrato (imagens de pedaços de plantas, máquinas e nuvens podem ser consideradas abstratas dependendo do conceito de abstração, e a maioria das imagens aquáticas do filme se encaminham nesta direção), é evidente que um apagamento do sujeito neste autorretrato em prol do favorecimento da "doação" do objeto em direção à nossa estrutura perceptiva é favorecido pelo grau de abstração do filme. A abstração não apenas abre espaço para uma projeção intensa e quase totalmente submersa da sujeição na objetificação, como também permite que o silêncio do filme, já favorecido pela ausência

de som, seja também um silêncio da progressiva ausência de formas. É neste sentido que a série de painéis decorativos da Orangérie de Monet antecipa este tropo moderno, que é o silenciamento do discurso de transcendência da arte por meio de uma aniquilação da imagem em si, do assunto, e em última instância do sujeito. A obra final de Monet está engajada não apenas nas modulações silenciosas do fluxo husserliano (significando, estes painéis, tudo - do mundo subatômico aos fenômenos astronômicos - e nada -, mergulhados na pura vacuidade da abstração) e em uma maneira mais puramente cinemática (referendando as novidades tecnológicas e comunicacionais da época) de se criar imagens, mas também naquilo que Susan Sontag considera como um movimento de silenciamento do artista em direção à arte. Um movimento do artista para produzir uma antiarte, ou uma aniquilação da arte.

Em seu famoso ensaio "A estética do silêncio", a filósofa norte-americana procura entender a transformação que o conceito de arte sofre a partir do momento em 
que surge a arte moderna e especialmente o que ficou conhecido como "arte contemporânea", posteriormente. Ela parte do princípio de que, no início da era moderna, "arte" fazia parte de uma mitologia que tinha em sua narrativa a ideia de que este conceito servia como "expressão da consciência humana, ou a consciência buscando conhecer a si própria." (SONTAG, 2002, p.1). Como um tipo de teologia, esta mitologia a respeito da função da arte tem seu decaimento. Ou seja, da mesma forma que o final do século XIX e início do século XX viram ocorrer um esgotamento de certa imagem de Deus e uma resolução deste conflito via o silenciamento desta teologia (a "morte de Deus"), a mesma trajetória narrativa ocorreria com a arte. Sem a possibilidade de transcendência oferecida pelo projeto espiritual da modernidade, caberia ao artista ou abandonar a arte (casos de Rimbaud, Holderlin, Raduan Nassar, etc.), ou agir especificamente contra a arte.

\begin{abstract}
Assim como a atividade do místico precisa terminar em uma via negativa, uma teologia da ausência de Deus, uma ânsia pela nuvem de desconhecimento para além do conhecimento e pelo silêncio para além da fala, a arte precisa tender em direção à antiarte, à eliminação do "assunto" (o "objeto", a "imagem"), à substituição do acaso pela intenção, e à busca pelo silêncio. [...] Praticada em um mundo equipado com percepções de segunda mão, e especialmente confundida pela perfídia das palavras, a atividade do artista está amaldiçoada pela mediação. A arte se torna o inimigo do artista, pois ela lhe nega a realização - a transcendência - que ele deseja (SONTAG, 2002, pp. 1-2).
\end{abstract}

Sontag considera, portanto, que toda forma de negação (a renúncia e o suicídio, por exemplo) seja um tipo de silêncio. E que a impossibilidade de transcendência prometida pelo projeto romântico (e pelo início da era moderna) levaram o artista a desistir da arte, ou ao menos da arte que pretendesse ser propositiva em relação a uma narrativa teleológica. Os diversos tipos de silêncio aplicados à arte (o silêncio técnico, o barulho, as estéticas de destruição como o dadaísmo e o surrealismo e, é claro, a abstração, entre outras formas de expressão) passam a suplantar a representação e as narrativas. "O silêncio é o gesto supramundano seminal do artista; através do silêncio, ele se livra de uma ligação servil com o mundo, que aparece como patrão, cliente, audiência, antagonista, árbitro e detrator do seu trabalho" (Ibidem, p. 2).

Monet e Rodakiewicz não estão ligados de nenhuma forma direta, mas está claro, de acordo com o que argumentamos, que ambos compartilham elementos estéticos, culturais e intelectuais que reafirmam este zeitgeist descrito por Susan Sontag: a cinética (tempo e montagem cinematográficos), os temas e formas (quando existem: nuvens, água), a intenção meditativa, que nos permite um aprofundamento na leitura 
fenomenológica, o entusiasmo com o universo da ciência e da tecnologia (que permitem a leitura intermedial) e, por fim, o apelo ao silêncio trazido pela forte tendência à abstração, ou a constante deformação abstrativa construída no apelo do silêncio. Este último aspecto é extremamente importante porque nos permite realizar uma argumentação mais precisa a respeito de como as frequências de percepção funcionam a partir de emanações conjuntas lançadas tanto pelo sujeito quanto pelo objeto ${ }^{234}$ e como, em cada frequência, sintonizamos nossa percepção e, em última instância, nosso ser, em um tipo específico de leitura e decodificação da realidade. A frequência poética é nosso ponto de chegada nesta trajetória.

A abstração aparece como elemento-chave quando procuramos pontos de convergência entre as estéticas analisadas justamente porque permeia diversos tipos de silêncio: está lá para imprimir visualmente o silêncio ontológico, conforme queriam Picard e Jaspers; é instrumento de linguagem para produzir silêncio como discurso, como preferem Glenn e Sontag; a tela abstrata, sempre como um teste de Rorschach, faz intuir psiquismo ou se assemelha a tipos de alucinação silenciosa SCB, conforme descritas por Sacks. De certa forma, o conceito de abstração conduz ao de silêncio e vice-versa, e um filme como Retrato de um homem jovem, ao optar por forte carga abstrativa, duplica sua proposição silenciosa: é silêncio técnico e ao mesmo tempo silêncio conceitual. A opção de Rodakiewicz por se autorretratar desta forma engendra uma cadeia de silêncios que justamente nos faz mergulhar no "oceano de consciência" (conforme veremos em Lynch) perpetrado pelo fluxo husserliano: do silêncio técnico da tela (sem som), ao silêncio dos objetos solitários (árvores, máquinas, nuvens) vistos emanando de volta seus horizontes internos e externos, ao silêncio propriamente abstrativo das imagens aquáticas (fim da forma), ao estado meditativo conduzido por esta sequência de imagens, até um esvaziamento de si (típico da meditação) que, por fim, revela um estado de autorrepresentação situado fora do próprio sujeito, mergulhado em uma entrega que se coloca entre as frequências meditativa, contemplativa e poética.

\footnotetext{
${ }^{234}$ Warburg pensou relação semelhante para a representação: “[...] durante a viagem ao Novo México, diante das apresentações rituais a que assistira, Warburg havia experimentado ao vivo a profundidade da troca realizada entre a representação e seu objeto. Quando o dançarino mascarado entrava na representação, tornando-se uma figura, ela a carregava de um poder animista. $O$ historiador da arte compreendeu que o universo do saber podia acolher efeitos idênticos" (MICHAUD, 2013, p. 38).
} 
O pintor russo Wassily Kandinsky, famoso por ter sido um dos fundadores da arte moderna abstrata, foi também um inspirado teórico da arte e seus escritos o ajudaram fundamentar a revolução abstracionista que ele viria a capitanear no início da década de 1910. Seu primeiro livro, Do espiritual na arte, escrito em 1909 e publicado em 1912 (com retoques - Cf. ROQUE, 2003, p. 98), aparece antes que o pintor produza sua primeira tela abstrata e traz uma série de relações que hoje podem ser consideradas uma espécie de construtivismo espiritualista, organizando formas, cores e sons em um sistema de vibrações internas capaz de refratar naquilo que ele chamava de "alma" um mundo oculto de sentidos, afetos, sensações ${ }^{235}$. É conhecido o estilo das fases abstratas de Kandinsky, procurando elaborar narrativas entre as formas e as cores de maneira que, ao contrário do que ele temia, a pintura abstrata não se parecesse com um adorno de tapete, mas sim algo "espiritualmente" significativo.

Em Do espiritual na arte, "abstrato" tem constantemente o sentido corrente de isolado, separado da realidade. Assim, por exemplo, em relação à questão da palavra: no ato de repetir uma palavra, como o fazem as crianças, ela acaba por perder o seu sentido, se tornar abstrata, de maneira que não prestamos mais atenção em nada a não ser a sonoridade do significante. Ora, como indica Kandinsky ao se referir explicitamente a Maeterlinck, trata-se de um procedimento literário extremamente forte que constitui "igualmente um exemplo da evolução dos procedimentos artísticos do material em direção ao abstrato" (ROQUE, 2003, p. 100) ${ }^{236}$.

Não iremos nos deter aqui na intrincada disputa pela definição a respeito do que seja a arte abstrata (um termo que o teórico Georges Roque, em seu livro $O$ que é a arte abstrata, evita como algo genérico que significa qualquer tipo de arte que, em algum momento, tenha historicamente sido considerada "abstrata"). Basta distinguir quatro modelos diferentes que se complementam: há a arte abstraída, ou seja, aquela que tem

\footnotetext{
235 Deleuze, ao analisar a pintura abstrata de Francis Bacon - em relação a artistas que se notabilizaram pelo projeto da abstração: a pintura de Mondrian, de Kandinsky e de Pollock, o teatro de Becket e de Artaud ou ainda a literatura de Kafka - afirma haver uma violência relacionada à representação, à emoção, ao sensacional e ao dramático (assim como vimos em Chaplin e Os vampiros). Uma tal violência da imagem figurativa se opõe a uma violência de outra ordem: violência como potência da abstração. À violência do representado, do espetáculo, do sensacional e do clichê se opõe a violência da sensação atingida a partir do irrepresentável do afeto e das forças. É necessário, segundo Deleuze, se renunciar à violência representacional para se atingir a violência da sensação abstrativa. Em Bacon, essa sensação é o ponto de vitalidade, uma espécie de declaração de fé na vida, uma espiritualidade material e formal. (DELEUZE, 1981, p. 32). Não é pois da ordem do sentimento que Deleuze teoriza a sensação na pintura de Bacon. "Não há sentimento em Bacon: nada mais do que sensações produzidas a partir de afetos e forças" (Ibid., p. 21). A força está em relação estreita com a sensação. Para Deleuze, é preciso que uma força se exerça sobre um corpo, na forma de uma onda, para que haja sensação. Esse é um problema comum a todos os campos das artes, em especial as artes visuais: tornar visíveis as forças que não são visíveis. Fazer visíveis as "forças elementares como a pressão, a inércia, a gravidade, a atração, a gravitação" (Ibid., p. 30).

236 Tradução nossa.
} 
como base algo figurativo na realidade (como, por exemplo, os painéis da Orangerie de Monet); há a arte não-objetiva (em que não há base figurativa na realidade para constituí-la conceitualmente, como boa parte da obra de Kandinsky); há a arte nãofigurativa (conceito mais amplo que engloba as duas categorias anteriores e frequentemente é confundido com o de arte abstrata); e, por fim, o próprio conceito de arte abstrata, que, conforme já mencionamos, trata-se de uma categoria histórica, e não estética (Ibidem, pp. 27-29). Importa, neste momento, não uma definição precisa da arte abstrata (talvez nem Monet e nem Rodakiewicz, no nosso caso, se enquadrassem em uma conceituação mais aprisionadora), mas sim os sentidos que, conforme vimos em Sontag, a figuração vai adquirindo na medida em que um processo de abstração se intensifica.

Kandinsky era clinicamente um sinestésico ${ }^{237}$, uma condição muito rara em que, quando regiões específicas do cérebro possuem pontes neurais não-usuais, o estímulo que ocorre em um sentido aparece em outro. Daí o fato de pessoas sinestésicas eventualmente verem cores que aparecem na frente delas quando estão ouvindo determinados sons. Ou pessoas que enxergam as palavras em cores diferentes. Ou cores que deflagram cheiros no nariz e gostos na boca. O pintor russo tinha uma hipersensibilidade a formas e cores e, em uma época em que não havia diagnóstico para a sinestesia, sua intuição o levou a desenvolver uma elaborada teoria espiritual da arte. Para ele, um quadrado, um círculo, uma cor, um ponto, uma palavra etc., possuem uma vibração originária, um tipo de comungação natural com aspectos não-visíveis da realidade e a combinação entre estes elementos produz poderosas novas vibrações, cabendo à arte o controle destes efeitos. "Cada palavra que é pronunciada (árvore, céu, homem) provoca uma vibração interior, e o mesmo ocorre com cada objeto reproduzido em imagem. Privar-se dos meios suscetíveis de provocar esta vibração equivale a empobrecer nossos meios de expressão."238 (KANDINSKY, 1996, p. 81). O pintor,

\footnotetext{
${ }^{237}$ O próprio Kandinsky descreve o processo: "Do ponto de vista estritamente físico, o olho sente a cor. Experimenta suas propriedades, é fascinado por sua beleza. A alegria penetra na alma do espectador, que a saboreia como um gourmet, uma iguaria. O olho recebe uma excitação semelhante à ação que tem sobre o paladar uma comida picante. Mas também pode ser acalmado ou refrescado como um dedo quando toca uma pedra de gelo. Portanto, uma impressão inteiramente física, como toda sensação, de curta duração e superficial. Ela se apaga sem deixar vestígios, mal a alma se fecha” (KANDINSKY, 1996, p. 65).

${ }^{238} \mathrm{O}$ pintor abstrato holandês Piet Mondrian, contemporâneo de Kandinsky, curiosamente, também partilhava de uma visão de certa forma espiritualista (ele havia sido um estudioso da teosofia) da abstração e desenvolveu, através dos anos (e de sua participação na revista de vanguarda De Stijl), os conceitos (análogos) de abstrato real ou neoplasticismo. Mondrian acreditava em certa racionalização
} 
portanto, considerava que formas, cores e palavras possuem um campo de atuação $a$ priori para a emissão destas vibrações, que, recombinadas a partir de outros modelos de formas, cores e palavras, geram dialeticamente novas vibrações (algo remotamente semelhante à primeira teoria de montagem eisensteiniana). Ele chamava a este princípio e estruturação das coisas na realidade o "princípio da necessidade interior", e fica claro (e importante para nós) que cada elemento que acontece no mundo possui uma valência relativa à sua combinação com os outros elementos, e algo como o valor relacional de cada elemento linguístico pensado por Saussure se aplica também a uma "língua escrita da realidade", conforme veremos a partir de Pasolini.

\begin{abstract}
Retomemos, mais uma vez, o exemplo do piano. Substituamos "cor" e "forma" por objeto. Todo objeto (quer tenha sido criado diretamente pela natureza ou produzido pela mão do homem) é um ser dotado de vida própria e que engendra uma multiplicidade de efeitos. O homem está continuamente submetido a essa ação psíquica. Muitas de suas manifestações residem no "inconsciente" (sem que por isso percam o que quer que seja de sua vitalidade ou de sua força criadora). Um grande número de outras atinge o consciente. Para escapar delas, o homem pode fechar-se à sua influência. A "natureza", ou seja, tudo que cerca o homem e muda sem cessar, transforma de maneira constante, por meio das teclas (os objetos), as cordas do piano (a alma) em vibrações (KANDINSKY, 1996, pp. 79-80).
\end{abstract}

Kandinsky estabelece esta analogia da percepção com o funcionamento de um piano (as coisas seriam as teclas; o olho, o martelo; a alma, as cordas do piano) procurando sistematizar o funcionamento dela (ou das relações "espirituais" entre as pessoas e as coisas) a partir de uma estruturação musical. Interessa-nos, para pensar a ideia de frequência, a noção de que cada vibração "musical"239 como esta, alinhada a outras vibrações, vá produzindo padrões perceptivos estimulados por estes recursos visuais originários. Daí configurações elementares como a combinação de formas abstratas (como em um quadro de Kandinsky) ou o mergulho destas formas no silêncio (como em Monet ou Rodakiewicz) carregarem a percepção para um âmbito próximo de

abstrata da sociedade e a arte deveria refletir esta tendência. Uma verdadeira arte abstrata não poderia estar embasada em formas abstraídas da natureza (como havia sido com a abstração desde o século XIX, casos de Turner ou do próprio Monet), mas sim partir de formas e cores elementares (linhas retas e cores primárias). "A nova plástica deve ser nomeada abstrata, não somente porque ela é a expressão direta do universal, mas também porque ela exclui o individual (o concreto natural) da expressão. Nós podemos nomear abstrata a expressão exata de uma relação, por oposição ao ato de transformar em imagem a forma de uma aparência natural, que ela abstrai." (MONDRIAN apud ROQUE, 2003, p. 164. Tradução nossa. Grifo do autor.)

${ }^{239}$ Isso lembra a Teoria das Cordas, divulgada por Stephen Hawking, em que infinitamente minúsculas cordas vibratórias dentro das partículas subatômicas controem o tecido de vários universos no Multiverso (HAWKING, 2016, pp. 74-108); e lembra também a "teoria da harmonia" onde padrões de construção musical se projetam para outras áreas da realidade, conforme explicamos a partir de Berendt na nota 180. 
uma "verdade" mais elementar, e o contato com esta "verdade" produz a consciência poética. Este arranjo configura a sintonia em uma frequência propriamente poética. No fundo o silêncio das coisas, eloquente, produz um tipo intenso de comunicação emanado por esta musicalidade das vibrações do mundo (não é à toa que temos até agora argumentado que a música é também um tipo de silêncio), e que a fala específica das coisas opera neste fluxo (husserliano) silencioso que as formas criam para produzir um encadeamento necessário entre tudo que existe. Os painéis da Orangérie se entremeiam neste processo ao amplificar o aspecto elementar das repetições de nenúfares das séries anteriores de Monet: ao fazer aquelas representações mais largas, mais altas, mais rarefeitas e mais abstratas, o pintor foi abraçando um alcance maior para suas formas (degraus abaixo na percepção) até que seus painéis se parecessem, efetivamente, com vibrações musicais originárias de uma música de outro mundo. Música que, como veremos, se sintoniza na frequência do Zen que, por sua vez, não deixa de abarcar um tipo específico de poesia.

Já Retrato de um homem jovem se estica para este mesmo caráter vibratório ao elaborar imagens da fumaça que se desfaz, do fogo que se incandesce e muda a cada instante, da água moldável segundo as condições a que está submetida. A beleza do filme está justamente em nos fazer perceber um mundo que comunica a todo instante a partir destas emanações, seja efetivamente nas formas mais abstratas produzidas pela fotografia da câmera ou na quietude muda das plantas e máquinas (menos abstratas) operando em silêncio. Em todos os casos, o silêncio é o vetor deste tipo específico de comunicabilidade, conforme nos aponta Adauto Novaes, em texto a partir de MerleauPonty:

\footnotetext{
O filósofo pede que, no esforço do pensamento, esqueçamos a "fala falada" e busquemos a "fala falante": se a tarefa do pensamento é a de dizer, exprimir as coisas do mundo, isto se dá exatamente através da criação permanente da fala (fala falante) que propõe em palavras determinado silêncio que o filósofo escuta. Não existe uma coincidência muda entre as coisas do mundo e a linguagem; o que existe é ao mesmo tempo uma relação de antítese e de cumplicidade. Como observa Merleau-Ponty, não se trata de abandonar as coisas em favor da linguagem, nem de abandonar a linguagem em favor das coisas: "trata-se de fazer falar as próprias coisas. [...] São as coisas mesmas, do fundo do seu silêncio, que (a filosofia) quer conduzir à expressão" (NOVAES, 2014, p. 20).
}

O cinema, neste caso, funciona como um tipo de descolamento da realidade que, de um ponto de vista ontológico, difere da visão impressionista de André Bazin 
(2003), que, considerando a imagem fotográfica como assíntota do real, pensa ela ao mesmo tempo como muito próxima do mundo exterior e ao mesmo tempo infinitamente distante. Aqui, pensando em Bergson, a imagem cinematográfica não difere, propriamente, da imagem transfigurada em matéria, mas sim a transforma em espécie de taxidermia. A imagem muda de um filme como Retrato de um homem jovem tem apenas o trabalho de "empalhar" o material bruto da realidade, recombinando as emanações vibratórias tais quais descritas por Kandinsky. Neste sentido, é importante retomar a semiologia de Pier Paolo Pasolini especialmente no que tange a este "descolamento" de signos "naturais" presentes na realidade que, reconfigurados na forma de cinema, passam a representar uma ponte poética entre autor, personagem (ou coisa) e espectador, caso que é francamente radicalizado na hiperprojeção que Rodakiewicz realiza de si próprio nas coisas em seu "autorretrato". Pasolini considerava a morte como "montagem final" para este "cinema natural" que era a vida e os signos inscritos na realidade. A montagem cinematográfica, o corte, também um tipo de "morte", funciona de maneira semelhante, dotando o filme (assim como a morte dota a vida) de historicidade e narrativa. Daí a ideia de se pensar o cinema como taxidermia, algo que remete à vida, mas está efetivamente morto.

É verdade que Pasolini considerava o cinema experimental (como, por exemplo, o de Jonas Mekas ou Joseph Cornell, e possivelmente Rodakiewicz, se ele o tivesse visto) como um tipo de trapaça de recursividade pirotécnica que nada tinha a dizer. Sua noção de poesia se restringia a um tipo de ponto de vista fílmico que ele nomeou "subjetiva indireta livre" (SIL) a partir do "discurso indireto livre" da teoria literária. A SIL seria como um POV (plano subjetivo) que, além de mostrar aquilo que os olhos de um personagem efetivamente está vendo, privilegia uma permuta entre a emanação própria daquelas imagens (como vibrações kandinskyanas) e aquilo que o personagem é capaz de narrar. Em suma, a SIL representaria este fluxo entre a subjetividade e a objetividade, a permuta entre a doação dos objetos do mundo e aquilo que o sujeito é capaz de formatar enquanto dom ou doação. É como explica, de maneira mais didática, Ismail Xavier:

Evocando o termo tradicional que define a imagem quando esta é produto do olhar da personagem (câmera subjetiva), Pasolini dá um nome especial ao estilo indireto livre cinematográfico: subjetiva indireta livre. Ou seja, durante o filme inteiro estaremos vivenciando uma instabilidade, uma oscilação entre objetivo e subjetivo, na qual o movimento próprio das coisas se mescla ao 
movimento de uma interioridade, um contaminando o outro com seu estilo (XAVIER, 2014, p. 78).

Se Pasolini não considerasse um filme como Retrato de um homem jovem como uma linguagem essencialmente poética, isso se daria talvez por pura teimosia ou uma cegueira temporária para ver os horizontes de sua própria teoria. Se a taxidermia que mortifica a realidade dentro do filme acaba por produzir esta sintonia entre o mundo, o personagem e o espectador, é natural que isso não ocorra apenas em filmes narrativos (conforme ele argumentava), podendo as coisas em si representadas nas imagens fílmicas representarem o papel de permuta entre uma subjetividade e uma objetividade. Como o próprio "autorretrato" de Rodakiewicz (e, expandindo o argumento, até o de Monet) nos faz verificar, a SIL sobrevive à existência de um personagem, desde que este personagem esteja projetado nas coisas e as coisas, nos personagens. O próprio Pasolini, em uma fala inspirada em entrevista a Oswald Stack, reitera estas ideias:

No meu ponto de vista, o cinema é substancialmente e naturalmente poético, pelas razões que coloquei: porque é como um sonho, porque é próximo dos sonhos, porque uma sequência de cinema e a sequência de uma memória ou de um sonho - e não apenas isso, mas também as coisas em si - são profundamente poéticas: uma árvore fotografada é poética, um rosto humano fotografado é poético porque a fisicalidade é poética em si, porque é uma aparição, porque está cercada de mistério, porque é cheia de ambiguidade, porque é cheia de significado polivalente, porque mesmo uma árvore é um signo de um sistema linguístico. Mas quem fala através de uma árvore? Deus, ou a própria realidade. Assim sendo, a árvore como signo nos coloca em comunicação com um falante misterioso. Assim sendo, o cinema, reproduzindo fisicamente e diretamente os objetos, etc. etc., é substancialmente poético (PASOLINI apud SITNEY, 2015, p. 21).

Estas profundas implicações entre cinema, pintura, silêncio, abstração e poesia podem ser recapituladas da seguinte forma: abandonar a subjetividade em prol de um objeto que progressivamente se silencia (através da abstração) em suportes que também deflagram o ocultamento do sujeito na modernidade é também uma forma de subjetividade, uma forma de comunicação mediante o silêncio. Mais profundamente, é uma doação ao fluxo do mundo, uma forma espiritualista (como queria Kandinsky) de processar a subjetividade na realidade. Este tipo de realização, já em potência no protocinema abstrato pensado por Monet nos painéis da Orangérie, se efetiva no cinema de Rodakiewicz, cuja natureza ontológica da medium (o cinema como "língua escrita da realidade") e sua dupla orientação para o silêncio (o técnico e o conceitual) catalisam este processo já presente em cada filme silencioso: o de deixar, por meio do silêncio técnico dos filmes, que cada objeto representado nos sintonize em uma vibração ou 
frequência completamente diferente daquela de uma narrativa em prosa, dominada pelo logocentrismo das palavras. Esta frequência é uma frequência poética, que nasce justamente do contato do silêncio com a imagem nua.

As inferências pensadas a partir de Monet e Rodakiewicz são, efetivamente, condições extremas de posicionamento dos conceitos pensados até aqui a respeito de cinema, pintura, silêncio, abstração e poesia. O que é colocado como grau máximo de escalonamento destas relações no filme de Rodakiewicz pode ser pensado como prosaico e recorrente não apenas em toda manifestação silenciosa no cinema (seja um filme silencioso ou não, conforme vimos no caso de $O$ boulevard do crime no Capítulo 3) como também em toda manifestação silenciosa em tela ou na tela que prefigure o silêncio representado (conforme vimos em Magritte ou Monet). A tendência à abstração, e, portanto, a tendência em replicar o silêncio em camadas cada vez mais profundas de silêncio, nos leva a um direcionamento final a respeito de que tipo de experiência o silêncio nos proporciona. Se há várias frequências poéticas da percepção e o silêncio técnico do filme silencioso dispara uma delas (a poesia da tela muda - uma poética silenciosa), a duplicação do silêncio na tela muda por meio da rarefação do sujeito (por meio da abstração) em sua submersão no objeto nos leva ainda a uma nova frequência, a da contemplação.

\begin{abstract}
O silêncio é uma metáfora para uma visão purificada e não-interferente, na qual alguém pode visionar a produção de obras de arte que não fornecem respostas mesmo antes de serem vistas, invioláveis, em sua essencial integridade, pelo escrutínio humano. Uma paisagem não demanda de seu espectador o seu "entendimento", suas imputações de significação, suas ansiedades e simpatias; ela demanda, ao invés disso, sua ausência; demanda que ele não adicione nada a ela. A contemplação, falando estritamente, encadeia o autoesquecimento por parte do espectador: um objeto digno de contemplação é um objeto que, efetivamente, aniquila o sujeito perceptivo (SONTAG, 2002, p. 8) 240. $^{24}$
\end{abstract}

Esta é não apenas a conclusão de Sontag na argumentação a respeito de seu silêncio "brando", como também funciona como nosso desembocadouro, a última e mais cristalizada manifestação de uma poesia silenciosa. Trata-se da contemplação Zen, do esvaziamento tao, de uma poética silenciosa por meio da mais completa entrega do sujeito ao mundo. Tanto os painéis da Orangérie quanto Retrato de um homem jovem se encaminham para estacionar nesta direção, e é para este tema que reservamos nosso último núcleo reflexivo.

\footnotetext{
240 Tradução nossa.
} 


\subsection{3 - Zen e razão poética}

A contemplação, radicalmente designada por Sontag como "aniquilamento do sujeito perceptivo", é particularmente importante para nós. Monet e Rodakiewicz certamente a tinham em mente ao elaborar suas obras. Monet pensava, com os painéis da Orangérie, em construir uma instalação de imersão, em que a fronteira entre sujeito e objeto fosse abolida, em que, de maneira ideal, os sentidos fossem obliterados por uma totalidade que fosse do micro (mundo subatômico) ao macro (mundo astronômico). Em uma experiência como esta, silêncio, poesia e contemplação já não são categorias intercambiáveis com uma estética, e sim exclusivamente com uma ontologia. São frequências de percepção que se alternam uma com a outra, se complementam, colocam a mente em estados de completa substituição das faculdades ordinárias. Mergulhar na intencionalidade de Monet nos painéis funciona, desta forma, como um laboratório para a noose husserliana: os estímulos são enviados e a consciência vai processando a abstração como um salto sem volta em um objeto fluido e amorfo. Nossas entradas cognitivas, acostumadas a receber a doação de objetos definidos e simples (casas, pessoas, animais), passam a receber, enquanto fenômeno, a constante maleabilidade da abstração. É como podemos dizer através do pensamento de Ernst Jünger: "não se fala do objeto, mas sim através dele." (JÜNGER apud MAFFESOLI, 1998, p. 125). As frequências da percepção são linhas que se entrecruzam, como sistemas em circuitos que, a cada novo nó dado em seus caminhos percorridos, provocam uma mutação na relação com que interpretamos sujeito e objeto. Merleau-Ponty situaria a consciência entre sujeito e objeto. Peirce a colocaria na instância do interpretante. Chantal Maillard, aludindo-se a María Zambrano e se utilizando de terminologia de Lapierre (e também de Heidegger), separa a consciência (neste caso, o próprio ser) em dois:

Para utilizar a terminologia de André Lapierre, instaurador das técnicas de psicomotricidade relacional, diríamos que um homem participa tanto do desejo de fusão como do desejo de identidade. O desejo de fusão pertence ao inconsciente, é desejo de harmonia, de acordo, necessidade de regressão, em certo aspecto, ao ventre materno; o desejo de identidade, pelo contrário, está ligado ao domínio do consciente. Esta relação alcança às vezes, para alguns, níveis trágicos quando se empenham em aludir a uma de ambas as tendências. E isto é precisamente o que ocorre, enquanto figuras-limite, ao poeta e ao filósofo, nos extremos da regressão e da decisão, do ser-com e do ser-aí (MAILLARD, 1992, p. 41) ${ }^{241}$.

${ }^{241}$ Tradução nossa. 
Neste caso, a relação com o objeto é cindida em possibilidades diferentes de ser, tais quais anunciadas por Heidegger. Não seria exagero pensar que a simultaneidade de manifestações do ser (solo; junto) é também sinal da multitude fatorial das frequências de percepção tais quais temos anunciado aqui. Cada faixa de frequência é um feixe de sintonia com uma abertura, dada à percepção, que o objeto (a sensibilidade originária amorfa e moldável) doa ao sujeito. A contemplação, que parte do silêncio e abre à frequência poética, é uma das formas mais poderosas com que estas frequências se manifestam. María Zambrano, considerava a contemplação como atributo fundamental ao seu conceito de razão poética. Para ela, filosofia e poesia possuem um espectro oposto de atuações justamente porque o pensamento, em sua busca emergencial por respostas positivas (pensando em um logos aristotélico), repousa sobretudo em uma violência. Já a poesia, baseada não em um aspecto emergencial, mas sim imersivo, é um saber de reconciliação, baseado na contemplação e não na violência.

O saber de experiência, segundo descreve Zambrano, é, sobretudo, contemplação, e é ao mesmo tempo visão e escuta. Penetra na vida sem a violência que pretende exercer a razão, sem forçar a realidade a adaptar-se a um certo modo de olhar e/ou a um certo modo de dizer. Violentar a realidade é não deixá-la aparecer antes da palavra, não deixar que seu corpo - sua matéria - seja plenamente antes que adquira significado para aqueles que nela e com ela vivem. Pois a realidade, pensa Zambrano, somente se oferece quando não se a força, e o saber que então se recebe é "verdade presenteada." (MAILLARD, 1992, p. 19) 242. $^{2}$

Este tipo de saber, nomeado "razão poética", cujo efeito é justamente receber certa verdade com "suavidade", baseada no transe da contemplação, e em que a revelação desta verdade venha "como um presente", lembra o "saber erótico" (que ama o mundo que descreve) proposto por Michel Maffesoli (1998, p. 14), para quem também a contemplação "é uma forma de criação" (Ibidem, p. 15). O que interessa neste momento é que a contemplação, seja ela aniquilação do sujeito perceptivo, transformando-nos em puro objeto (conforme argumenta Sontag); seja ela saber da experiência que leva ao "acariciamento" da razão poética (segundo Zambrano); ou seja ela uma própria forma de criação (Maffesoli), é um vetor fundamental da relação entre os painéis da Orangérie, Retrato de um homem jovem e as frequências do silêncio e poética que são desencadeadas por nossas experiências com estas obras de arte.

Este debate a respeito de uma liquefação da consciência através do objeto por meio da contemplação é útil para se introduzir o assunto do Zen a este trabalho

242 Tradução nossa; grifos da autora. 
justamente porque, sendo o Zen uma prática e não propriamente uma filosofia ou algo de substância intelectual, há dificuldade e ambiguidade na hora de defini-lo. E é importante frisar que, se obras como as de Monet e Rodakiewicz nos fazem encadear três tipos de frequências (silenciosa-contemplativa-poética), como se uma derivasse perceptivamente da outra, chegar ao tipo de enxugamento da consciência tal qual propõe o Zen requer um outro estágio de preparo e abertura perceptiva. Os painéis da Orangérie e Retrato de um homem jovem sugerem o Zen, que apenas se realiza na prática, conforme veremos. É como sugere o mestre Zen Taigan Takayama, do templo Nanzenji, em Kyoto, um dos mais importantes santuários do Japão:

\begin{abstract}
A coisa mais importante no Zen é, conforme apontado por Daruma, o despertar para o seu Eu Verdadeiro [Real Self]. É se tornar consciente do Eu Sem Forma [Formless Self]; o que significa ir além não apenas de formas materiais ou espaciais, mas também formas conceituais ou psíquicas, isto é, verdade/falsidade, beleza/feiura, bem/mal, etc. Este tipo Zen de autoconsciência não pode ser tratado como um objeto, como ocorre na psicologia ou na metafísica. A autoconsciência ordinária, que pode ser tratada desse jeito, é diferente e limitada, possuindo uma forma. A autoconsciência do Zen é aquilo que não pode de maneira alguma ser objetificada ou diferenciada, porque ela invariavelmente se mantém sujeito ao invés de se tornar objeto. (TAKAYAMA, 1973, pp. X-XI) ${ }^{243}$.
\end{abstract}

Para o mestre Zen, portanto, a autoconsciência Zen se desdobra sobre a perfeição do sujeito, que é transfigurada na ausência de forma para um self, estado flutuante livre de divagações morais, políticas, estéticas. Porém, se nos atermos às palavras de outro mestre Zen, desta vez do século XIII, há uma inversão na maneira com que a experiência do Zen é encarada do ponto de vista da sujeição/objetificação:

\footnotetext{
"Aprender o caminho de Buda é aprender algo sobre si-mesmo. Conhecer-se é esquecer-se. Esquecer-se é experimentar o mundo como puro objeto. Experimentar o mundo como puro objeto é deixar sucumbir o próprio corpo e mente, e o corpo e a mente do 'outro eu'." (DOGEN-SENJI apud KAPLEAU, 1978, p. 33).
}

Dogen-Senji, por meio de um ensinamento que lembra um koan (espécie de parábola Zen budista que não deixa de ter em seu âmago uma semente de poesia), portanto, interpreta a liberdade do Zen como experimentar o mundo como objeto, precisamente o contrário do que pregou Takayama. Esta dificuldade advém justamente da incapacidade de ser definir o Zen enquanto algo que possa ser traduzido em linguagem. O teórico da poesia Zen Lucien Stryk escreve a respeito de um estado

243 Tradução nossa. 
encontrado neste tipo de Literatura chamado Yugen (o quarto estágio de um conjunto de estados formados também pelo Sabi - o sentimento do isolamento -, Wabi - a apreciação das coisas simples -, e Aware, a consciência da transitoriedade das coisas). Representando o profundo mistério presente na existência da própria natureza, o Yugen é um sentimento que se localiza na arte zen mais depurada, aquela que faz transparecer com mais clarividência a ambiguidade do mundo e a total ausência de formas tanto para as coisas externas (o objeto) quanto para os construtos da mente (ideologias, ideias, linhas de raciocínio). A contemplação e a placidez estão também contidos neste sentimento: "Yugen é o senso de calma mística nas coisas." (STRYK, 1973, p. XLIV) ${ }^{244}$. Ultrapassando os sentidos mais precisos dos outros "moods" (Sabi, Wabi e Aware), o Yugen traz à tona aquilo que temos discutido a respeito do "mergulho no fluxo" husserliano (provocando uma reação em cadeia entre todos os elementos do cosmos, como se energizada por uma rede invisível de percepção) desencadeado pelo silêncio e pela abstração. Stryk cita o mestre japonês Soto Rosen Takashina para elucidar o Yugen com palavras que resplandeçam seu sentido:

\begin{abstract}
A verdadeira base do universo é a quietude. É a sua verdadeira condição, pois é dela que advém toda atividade. O oceano, quando o vento para, está calmo de novo, assim como estão as árvores e a grama. Estas coisas retornam para a quietude, sua forma natural. E este é o princípio da meditação. Há a noite, há o dia. Quando o sol se põe há uma calmaria e então a noite escura, quando tudo está parado. Esta é a meditação da natureza (TAKASHINA apud STRYK, 1973, p. XLIV) ${ }^{245}$.
\end{abstract}

Compreender o sentido misterioso do Yugen ajuda a perpassar um pouco o sentimento que Monet e Rodakiewicz procuram transmitir com suas obras, mas é importante verificar mais profundamente o próprio sentido do Zen budismo no contexto japonês para que possamos identificar qual o silêncio que existe neste contexto e ao mesmo tempo como este silêncio se torna também frequência, plataforma ou medium, e para que tipo de experiência. A palavra japonesa Zen vem do chinês ch'an, que por sua vez vem da palavra indiana (do sânscrito) dhyana, e significa "ensinar", "conhecimento" e "meditação" (BERENDT, 1991, p. 185). Estes significados arcaicos, mesmo que ainda façam algum sentido, podem enganar. Dentre as inúmeras formas de Zen que se espalharam secularmente pela Índia, China e Japão (e basicamente por toda Ásia), o Zen-budismo japonês se tornou famoso por duas premissas fundamentais: a

\footnotetext{
244 Tradução nossa.

245 Tradução nossa.
} 
busca pelo satori (iluminação) e a prática da meditação zazen (a meditação sentada, de olhos abertos, centrada na respiração, que pode eventualmente evoluir para o kinhin, tipo de caminhar meditativo que sucede o zazen). No budismo japonês, não há "Zen" sem esta linha reta que personifica uma prática que, no plano das ideias, é muito simples: intenso treinamento no zazen leva ao satori. Não há caminho intermediário, não há explicação de ordem racional ou intelectual ${ }^{246}$. O Zen budismo não se assume como filosofia ou prática de um pensamento lógico; ele nunca se abstém de se assumir enquanto prática exclusivamente espiritual. Esta prática reside também em um ambiguidade muito difícil de ser compreendida a não ser pelos próprios praticantes do zazen: você deve parar o pensamento discursivo durante a prática, mas isso não impende que o fluxo de imagens e palavras na mente continue seguindo seu curso. De certa forma, a prática silenciosa do zazen encontra eco no mergulho transcendental, por meio da arte abstrata, no fluxo husserliano. A consciência consegue tocar coisa alguma e todas as coisas ao mesmo tempo. É um fenômeno paradoxal, mas perfeitamente visível em um filme de qualidade meditativa como Retrato de um homem jovem ou em uma estrutura de imersão (diria submersão) no mundo aquático, plácido e perdido em um emaranhado de abstração que é a proposta de Monet para os painéis da Orangérie. Em seu clássico livro sobre o Zen, Os três pilares do Zen, Philip Kapleau dá voz às conferências do mestre Zen Yasutani-Roshi, que viajou aos Estados Unidos nos anos 1960 para difundir e ensinar a prática do zazen. As preciosas conferências foram transcritas por Kapleau em seu livro:

Como poderemos trazer a lua da verdade para iluminar plenamente nossa vida e personalidade? Precisamos, primeiramente, de purificar esta água, acalmar as ondas encapeladas fazendo parar os ventos do pensamento discursivo. Em outras palavras, precisamos esvaziar nossas mentes daquilo que as sutras kegon chamam de "pensamento conceptual do homem". A maioria das pessoas dá um alto valor ao pensamento abstrato, mas o budismo demonstrou claramente que o pensar discriminativo jaz na raiz da ilusão. Certa vez ouvi alguém dizer: "O pensamento é a doença da mente humana" (YASUTANI-ROSHI, 1978, p. 45).

\footnotetext{
${ }^{246}$ Neste sentido o princípio do Zen Budismo japonês se aproxima muito do Tao, "um princípio impessoal, invisível mas onipresente, que gera, alimenta, transforma e destrói o conjunto das realidades sem seguir plano nem intenção" (GRAZIANI, 2014, pp. 314-315). Este sentido de caos criador e devorador silencioso do Tao é revertido em pura ausência entorpecida no Zen, ainda que os princípios se aproximem muito. "O elogio prolixo do silêncio serve de crítica à linguagem e ao conhecimento. $\mathrm{Na}$ perspectiva taoísta [...], a ideia de compreensão última das coisas é concebida não como o resultado de uma construção intelectual a partir de dados sensoriais, mas como uma decantação progressiva do espírito, que extingue dentro dele o rumor excitante do mundo, os clamores intempestivos da ambição e do desejo. A forma de passividade que define o não agir é uma conquista e requer uma longa ascese, um repouso do intelecto e da linguagem" (Ibidem, p. 332).
} 
Por mais que possamos pensar em uma indistinguibilidade entre sujeito e objeto dentro de um ambiente Zen (o que nos leva necessariamente a processar, para ele, um tipo de fenomenologia), está claro que, para os praticantes do Zen budismo, toda formulação intelectual é falsa, ilusória, trapaceira. O Zen é gestado no silêncio. E é deste silêncio que provém a substância para se atingir o satori, e "não há Zen onde não há satori” (STRYK, 1973, p. XVIII). Se a iluminação efetivamente ocorre, não nos cabe discutir. A questão é que, para se compreender o efeito que o silêncio traz à percepção a partir do cinema silencioso, é preciso cavar escalas cada vez mais densas deste silêncio. Toda a cultura do Zen é cuidadosamente posicionada em torno deste silêncio, e útil para se compreender quando ele muda de plataforma ou medium (como, por exemplo, da consciência para o filme). Como vimos, o taoísmo chinês prevê um princípio cuja acepção ou mesmo a compreensão mínima depende de completo silêncio. "Quem responde a quem interroga sobre o Tao, não o conhece; quem interroga sobre o Tao, nunca ouvirá falar dele. Não há questões ao Tao e nenhuma resposta a estas questões" (GRAZIANI, 2014, p. 316). O paradoxo em relação a tais conceitos é tão elevado que podemos ao mesmo tempo considerá-los como extremamente herméticos e complexos, praticamente inacessíveis a um campo que não seja a absoluta espiritualidade; e espantosamente simples, captados pela mais treinada intuição, de uma vacuidade que todos pressentem e sabem desde o início de suas vidas.

\footnotetext{
$\mathrm{Na}$ prática do daijo-Zen ${ }^{247}$ o objetivo inicial é despertar para a sua Verdadeira-natureza mas, quando chegam à iluminação, vocês compreendem que o zazen é mais do que um meio de iluminação - é a atualização de sua verdadeira-natureza. Neste tipo de Zen, que tem como objetivo o despertarsatori, é fácil olhar erradamente o zazen como sendo apenas um meio. Um mestre sábio, entretanto, procurará salientar desde o início que o zazen é de fato a atualização da natureza-Buda inata e não apenas uma técnica de atingir a iluminação. Se o zazen fosse nada mais que uma técnica, poder-se-ia concluir que depois do satori o zazen seria desnecessário. Mas, como o zenjiDogen mesmo salientou, a verdade é exatamente o contrário, quanto mais profunda é a experiência do satori, mais vocês compreendem a necessidade da prática. [...] Nesta forma mais sublime os meios e o fim fundem-se (YASUTANI-ROSHI, 1968, p. 60).
}

\footnotetext{
${ }^{247}$ É fato que um verdadeiro mestre Zen não considera Zen nada que não seja absolutamente direcionado ao satori. Mesmo assim, Yasutani-Roshi (1968, pp. 56-61) enumera, especialmente para fins didáticos, cinco variedades do Zen adaptáveis às finalidades particulares dos indivíduos: O Zen bompu é a prática ordinária, sem finalidade espiritual, feita para a saúde física e mental; O Zen gedo compreende uma busca espiritual que ainda não é a budista. Práticas de meditação hindus, confucionistas ou cristãs são Zen gedo. O Zen shojo já é um veículo Zen budista em que a pessoa passa do estado mental para o da iluminação, mas é ainda um caminho individual; O Zen daijo já é uma forma profunda de Zen, em que, atingida a iluminação, as práticas não cessam, e a verdadeira-natureza do indivíduo é sempre atualizada; por fim, o Zen saijojo é o cume do Zen budismo. É a expressão da Vida Absoluta, e não envolve qualquer esforço pelo satori, que ocorre com naturalidade. Todos os Budas praticam o Zen saijojo.
} 
Talvez a grande dificuldade, tanto por parte dos mestres zen, quanto por parte do pensamento ocidental, em discernir a passagem do zazen (a prática do sentar meditativo) para a meditação em si, e por fim à iluminação (satori) seja uma inevitável diminuição do potencial desta prática enquanto meio. Apesar de Yasutani afirmar que, nas práticas avançadas do Zen, como o daijo e o saijojo, meios e fins se fundem, há ainda a prevalência da ideia de que o meio é uma técnica (e ele recusa dizer que o zazen seja apenas isso). O meio, o zazen, seria mais do que isso. A dificuldade em definir o que isso seria advém da ambiguidade da prática e do intenso contato desta prática com o silêncio. Yasutani faz questão de frisar a necessidade iminente de se continuar a prática do zazen mesmo após o satori. Está claro que o próprio satori está umbilicalmente ligado a esta prática, a este meio. Parece haver, essencialmente, uma indistinguibilidade entre a iluminação e a prática em si, como ocorre nos fenômenos de comunicação. Pensando em Wittgenstein (1999), ou, como veremos, em Flusser, o mundo da linguagem encerra a realidade e transforma um universo de pura virtualidade que não podemos tocar também em linguagem. Portanto, transforma virtualidade em mundo. $\mathrm{O}$ mundo da não-linguagem (mundo do silêncio) pode funcionar da mesma maneira. Em se praticando a não-linguagem (o exercício treinado do silêncio), verte-se também o mundo em não-linguagem. Temos aqui também um mundo contaminado pelo silêncio que se verte efetivamente em silêncio. O satori é este antípoda da linguagem. São espelhos invertidos, faces da mesma moeda que compõe a construção de mundos pela percepção. A questão é que, assim como a linguagem não é meio, tampouco é o zazen que leva ao satori. A linguagem é medium, e assim também deve ser interpretado o zazen.

A meditação é uma atividade que também contém seu grau de paradoxo. Todo ato de meditar se inicia em um confrontamento de si próprio. Uma guerra para domar não apenas o universo da mente, mas do corpo. Para os mestres do Zen budismo, o ato de sentar em posição de lótus, girar o corpo em direção a uma posição o mais alinhada possível, iniciar o processo com respirações longas e depois encadeá-las em outras mais curtas, assim como o controle da atenção fixado em algum ponto na linha de visão ou mesmo em nada específico, tudo isso faz parte de uma operacionalidade quase mecânica em direção à produção do satori em si. Como vimos, porém, a meditação não é um domínio exaustivo e hierárquico da mente. Não se diz para a sua própria mente: "agora 
você está sob meu controle". Não se separa o eu em mais segmentos produtores de neurose. O sentido do meditar é justamente apagar estas zonas compartimentadas da mente. $\mathrm{O}$ "eu" que questiona, procurando controlar a mente, deve ser o mesmo "eu" questionado, que se submete ao controle. É difícil evitar a tautologia quando se pensa neste mecanismo, justamente porque ele reside fora da linguagem e as palavras batem neste limite e voltam, como se não pudessem fazer nada além de circundar este limite e olhar um mundo fora da linguagem apenas por uma janela intransponível. A sensação de transe e mergulho no fluxo que temos quando assistimos a um filme silencioso (e em escalas maiores quando os filmes se aproximam da abstração, como no caso de Retrato de um homem jovem) ocorre quando nossa consciência muda de frequência e vira a chave da linguagem para a imagem e o silêncio, única maneira com que esta janela pode ser ultrapassada. Porém, isso requer sair da linguagem e ativar outra modulação da mente.

Este tipo de relação com a própria mente (a meditação) não é simples. É preciso estimular o corpo para que o sangue circule e a própria irrigação do cérebro seja transformada pelo processo. Nos primeiros minutos, o rio mental é caudaloso, o corpo está quente; os nervos tensos; as juntas, tesas. Porém, muitas vezes, a virada de chave ocorre como em um passe mágica, de instante a outro. $\mathrm{O}$ rio se acalma (mas nunca para), continua fluindo e em contágio com a frequência do próprio corpo. Uma multitude de palavras e imagens continua ocorrendo dentro do espaço da mente, mas neste momento a pessoa que medita está em uma modulação diferente. Não há controle sobre a mente (como se supõe no senso comum), mas sim uma modificação na natureza da consciência. Os objetos mentais, nesta frequência, deixam de oferecer qualquer risco, angústia ou satisfação. Eles existem fora da esfera dos afetos. É difícil dizer que ainda persiste qualquer tipo de julgamento moral ou estético ${ }^{248}$. sobre o que se passa na mente dentro desta modulação. A sensação é pacífica, mas isso não é uma aferição de bemestar. Os objetos mentais não importam não porque eles deixem de representar algo com importância, mas sim porque a atribuição de importância a qualquer coisa deixa de fazer sentido. De certa forma, estas imagens e palavras são o outro mundo visto do outro lado da janela, em uma perspectiva reversa, e funcionam um pouco como as alucinações

\footnotetext{
${ }^{248}$ Contradizendo o que diz Kant, que considera a priori os juízos sintéticos e reflexivos que norteiam o
} gosto e a estética (KANT, 2005, pp. 23-25). 
SCB descrita por Oliver Sacks. Elas existem, mas não têm olhos para te enxergar, e você não tem olhos para enxergá-las com qualquer atribuição de afecção.

O cineasta David Lynch, praticante da meditação transcendental, tem uma definição interessante para este fenômeno: "É assim que funciona: dentro de cada ser humano está um oceano de pura, vibrante consciência. Quando você 'transcende' na Meditação Transcendental, você mergulha neste oceano de pura consciência" (LYNCH, 2007 , p. 27 ) $^{249}$. Ora, a definição do cineasta americano (não por acaso alguém que confecciona imagens oníricas, sempre apontando para um logos fora do perímetro artistotélico) é extremamente simples, mas profundamente eficiente. Oceano de consciência. Pouco precisa ser explicado e toda a experiência meditativa é apreendida em um relance bastante intuitivo. "Ela te leva a um oceano de consciência, o puro conhecimento. Mas é familiar: é você. E logo um senso de felicidade emerge - não uma felicidade pateta, mas uma beleza espessa" (Ibidem, p. 4).

Um dos postulados de Kant em sua Crítica da faculdade de julgar é justamente a ideia de que "o belo apraz desinteressadamente" (sem uma finalidade). Ora, dentro de uma filosofia baseada em categorias que procuram propor limites a priori à razão, à imaginação e ao entendimento, Kant (2005, p. 49) possivelmente não encontraria vínculo entre sua famosa proposição e a experiência meditativa, mas há um grão de "oceano de consciência" (esta "beleza espessa" descrita por Lynch) dentro da gratuidade da beleza proposta pelo filósofo. São muitas as portas abertas pela frequência do silêncio. A arte e a poesia são outros feixes e frequências que se desdobram a partir dela. Mais interessante do que pensar na cerrada proposição de Kant talvez seja retornar ao conceito de Aberto heideggeriano. Conforme vimos, dentro deste conceito reside o mundo intangível, tecido no caos que alinha toda a complexidade da aparência, das imagens, do ente, das formas de ser, do tempo. A busca pelo ser que nunca está lá (devir) às vezes funciona como uma pequena lanterna, e é nestes pontos delicados de contato que conseguimos vislumbrar um rastro de luz na incomunicabilidade do Aberto. É aí que a frequência do silêncio tange a arte e a poesia. O silêncio muta. Passa a dizer. Uma frequência se converte na outra. O Aberto se torna visível, ao menos em uma

${ }^{249}$ Tradução nossa. 
ínfima parte, e passa a circundar a consciência, conforme esta precisa descrição de Castro e Dravet:

Segundo Heidegger, somente a poesia é criadora de verdade na medida em que somente ela é capaz de criar na linguagem, ultrapassando os limites do conhecido, do representado, ou de efetuar uma clareira no Aberto. O Aberto: aquilo que não restringe, não impede, não tem limite; a grande totalidade de tudo o que não está restringido. A noção de Aberto é ambígua, porque tanto significa a totalidade dos nexos ilimitados da conexão pura, como também a abertura no sentido da ilimitação em que tudo vigora. O Aberto é também o círculo mais vasto, aquilo que circunscreve tudo o que é ; a circunscrição que circun-une todo ente. Ao efetuar uma clareira no Aberto, o poeta traz a verdade que se encontrava oculta (CASTRO e DRAVET, 2014, p. 76).

O mergulho no "oceano de consciência" através da meditação é, de certa forma, um mergulho no Aberto heideggeriano. Talvez Heidegger não estivesse pensando em meditação, mas afirmou que a verdade acontece por meio da arte (NUNES, 2007, pp. 20-21). “A comunicação das possibilidades existentivas do encontrar-se, isto é, o abrir à existência, pode tornar-se o próprio fim do discurso poético" (HEIDEGGER apud NUNES, 2007, p. 20). Ele estava pensando na arte e na poesia. Porém, por mais que o próprio discurso oriental renegue a poesia como um tipo atividade que leve ao satori ${ }^{250}$, é importante retirá-la de seu locus tradicional tanto no que diz respeito a Heidegger quanto ao budismo. O filósofo alemão acreditava sim em um pensamento poético, algo semelhante a uma frequência, e no poder da arte em abrir frestas no Aberto, ou seja, em fazer a verdade acontecer por meio dela. É a partir desta ideia que Zambrano vai desenvolver sua formulação a respeito da "razão poética". Ora, se a poesia é, como prefere Heidegger, um tipo de ontologia e se, conforme temos argumentado, ela advém deste contato com o silêncio que se confunde com o Aberto, ela é algo muito próximo da frequência que alcançamos ao meditar. Aberto, silêncio e poesia tornam-se um fenômeno unificado, e aquilo que Heidegger enxergava apenas como uma clareira torna-se experiência efetivamente transcendental. Logicamente a poesia prescinde de palavras ou formatos porque ela própria é o formato. Como o silêncio dos budistas, a poesia é um medium. E é deslizando na esteira deste medium, a partir da porta aberta pelo silêncio (zazen) é que podemos mergulhar no oceano de consciência.

É interessante que, assim como o cinema de Rodakiewicz (que já afirmamos ser a imagem primordial do cinema silencioso; um protocinema que dispara emanações

\footnotetext{
250“Poesia é uma expressão do pensamento. O que está na mente é pensamento; expresso em palavras, ele se torna poesia." (CONFÚCIO apud TAKAYAMA, 1973, p. XIV. Tradução nossa). O pensamento, qualquer que seja ele, logicamente está fora do raio de determinação do satori.
} 
primevas a todos os outros filmes silenciosos), a meditação também se vale de imagens que se dissolvem e se abstraem na medida em que o processo se torna mais intenso. Muitas pessoas se focam em imagens verdadeiras, do mundo fenomênico, para se concentrar no ato de meditar. Pontos na parede, padrões de desenhos, pequenas luzes, etc., qualquer motivo pode ser o gatilho para o processo meditativo. Depois, quando a maturidade alcança a pessoa que medita, bastam imagens mentais, que podem ser também auditivas: imaginar o Buda, contar até dez, entoar um mantra, tudo funciona como um parâmetro sobre o qual o ato de meditar pode circundar. Até chegar o momento em que imagens e subterfúgios não apenas deixam de se tornar úteis, mas torna-se imprescindível evitá-las. Yatsutani fala em verdadeiras alucinações (semelhantes à SCB de Sacks) que ocorrem após sessões de meditações muito intensas:

\begin{abstract}
Makyo são os fenômenos-visões, alucinações, fantasias, revelações, sensações ilusórias - que as pessoas que praticam o zazen são capazes de experimentar num estágio particular de seu sentar-se. Ma significa "diabo" e kyo "o mundo objetivo". Portanto, o makyo são fenômenos perturbadores ou "diabólicos" que surgem em alguém durante o zazen. Estes fenômenos não são em si mesmo ruins. Tornam-se sérios obstáculos à prática somente se alguém ignorar sua verdadeira natureza e for iludido por eles (YASUTANIROSHI, 1978, p. 53).
\end{abstract}

A progressiva dissolução e posterior combate às imagens na meditação, portanto, faz parte da estratégia para se abrir a porta para a frequência poética. A escala é a seguinte: primeiro, oblitera-se a palavra (como na poesia escrita) para fazê-la remeter à sua imagem originária (a metáfora); depois passa-se da metáfora à própria imagem sem palavra, como em um filme silencioso qualquer; por fim, oblitera-se também esta imagem silenciosa em busca da abstração, como nos casos das imagens de Monet e Rodakiewicz. Neste sentido, Retrato de um homem jovem seria um último tipo de cinema, um cinema sem imagens, feito de silêncio.

Estas relações traçadas entre zen, silêncio e poesia encontram eco nas formulações de um jovem Vilém Flusser, desenvolvidas em seu primeiro livro Língua e realidade. Ali, em uma engenhosa e ousada formulação (o livro foi publicado originalmente em 1963), Flusser estabelece, a partir principalmente de Wittgenstein e Heidegger (mas também da filosofia insular) que a língua é a verdadeira construção da nossa realidade, já que todo "dado bruto" transformado em língua não está em contato direto conosco, mas existe apenas como virtualidade a ser convertida. O fato de existirem várias línguas diferentes (com proposições e estratégias diferentes para o 
processamento destes "dados brutos") determina que a análise do real só pode partir da língua. O dado bruto é inacessível e a regra de cada língua seria a primeira premissa sobre a qual se pode partir para considerar algo como "realidade". Seria o seu "grau zero".

Há um abismo intransponível ao intelecto entre o dado bruto e a palavra. Ele pode mergulhar introspectivamente dentro das suas próprias profundezas na ânsia de alcançar as raízes; entretanto, lá onde acaba (ou começa) a palavra, ele para. Ele sabe dos sentidos e dos dados brutos que colhe, mas sabe deles em forma de palavras. Quando estende a mão para apreendê-los, transformam-se em palavras. Isso justamente caracteriza o intelecto: ele consiste de palavras, compreende palavras, modifica palavras, reorganiza palavras, e as transporta ao espírito, o qual, possivelmente as ultrapassa. O intelecto é, portanto, produto e produtor da língua, "pensa" (FLUSSER, 2007, pp. 46-47).

A continuidade da trajetória intelectual de Flusser iria modificar substancialmente suas ideias a respeito deste conteúdo. A inserção dos termos "medium" e "imagem" vão adicionar elementos que levarão o pensador tcheco a expandir suas possibilidades de mediação da realidade, especialmente a partir do desenvolvimento das premissas do "pensamento em linha" e do "pensamento em superfície". O que primeiro Flusser pensou como "língua" vai pensar como "medium" em seus escritos posteriores. Aqui, porém, em seu primeiro livro, encontramos algumas soluções que ajudam a engendrar um pensamento que unifique (ainda que, como sempre, dentro do paradoxo) este estado meditativo que associamos ao Aberto heideggeriano (o "oceano de consciência") e a uma frequência poética da percepção. Aquilo que Flusser chama "dado bruto" remete ao que Bergson chamou matéria (que, segundo ele, processada pela memória através da imagem, chega à consciência) e ao que Pasolini chamou Im-signo, ou seja, a imagem descolada da realidade que na verdade é a própria realidade. Flusser considerava duas fronteiras entre esse "dado bruto" (um "nãoeu” inatingível) e o horizonte do intelecto que processa a língua (um “eu”). Para ele, a língua possui um limite em seu poder de incidir sobre o dado bruto. Existe o indizível, o incomunicável. Existe o silêncio. Da mesma forma que a linguagem "bate e volta" no paradoxo da mente que controla e é controlada no estado meditativo (podendo perceber este fenômeno apenas por uma metafórica "janela"), aqui a mesma linguagem (e Flusser especifica como "a língua"), quando confrontada com sua própria e natural tautologia, pode chegar ao silêncio por duas frentes: pode recair sobre um abismo em que o "nada indizível” emana para a linguagem apenas caos e fragmentação (a fronteira de baixo), produzindo a linguagem dos loucos (que ele chama de "salada de palavras"); ou pode 
concentrar-se sobre si própria adensando-se até o grau máximo de expressividade, gerando a linguagem poética (a fronteira de cima).

\begin{abstract}
Essas regiões, por serem anteriores ou posteriores à língua, são irreais, são nada. Mas é aquela irrealidade, aquele nada, que estabelece a realidade, e neste sentido é uma realidade mais básica, ou superior à realidade. Ao realizar-se na língua, o intelecto perdeu esta irrealidade superior à realidade e procurou reconquistá-la, superando a língua. Sendo intelecto realizado, entretanto, somente um nome subjetivo da língua, devemos dizer que a língua, como um todo, é um processo de realização que tende a superar-se a si mesmo. A língua, essa realização do potencial, expande-se na direção do supra-real e deixa de ser língua neste avanço. [...] Trata-se de dois silêncios diferentes, embora ambos signifiquem nada. É, de um lado, o silêncio do ainda não articulado, o calar-se do animal e do cretino, e, do outro lado, o silêncio do já não mais articulável, o calar-se de um S. Tomás, de um Wittgenstein, do Buda. Se encararmos a língua como um processo de realização, devemos vislumbrá-la como algo que se condensa, gradativamente, a partir do calar-se animalesco, para evaporar-se de novo, dentro do calar-se supraintelectual (Ibidem, pp. 133-134).
\end{abstract}

Como se pode ver, Flusser equipara o silêncio supraintelectual (além dos limites da fronteira superior da língua) a duas coisas: o esforço (de alguma forma um fracasso assumido) da poesia em atingir este "nada indizível"; e o silêncio dos santos. O que procuramos dizer aqui é, como já deve estar claro, que ambos os silêncios são o mesmo. Flusser coloca a poesia e a oração em escala (sendo a oração mais próxima da fronteira com o "nada indizível" que a poesia). Porém, esta formalização não nos interessa muito aqui. Já deve estar claro que a poesia é um tipo de ontologia que pode ser alcançada a partir do silêncio (que corresponde ao "dado bruto", ao "nada indizível", enfim, a tudo aquilo que o fluxo husserliano comunica de uma vez. Percebemos em um átimo, que é processado pelo silêncio e pela imagem, mas que foge da linguagem). Portanto, a partir da frequência do silêncio podemos chegar à frequência poética, que contempla um pensamento poético (ou uma razão poética), presente a cada momento em que chegamos ao limite da comunicabilidade. É o momento em que vislumbramos o outro mundo pela janela, em que molhamos nossos pés no oceano de consciência.

De certa forma, como estágios finais de suas estéticas (o esgotamento do impressionismo; o esgotamento do cinema silencioso), os painéis da Orangérie e Retrato de um homem jovem estão umbilicalmente ligados, não se limitando a uma simples trajetória de interinfluência de época e estética de um e outro. Estas obras estão ligadas porque estão penduradas nesta fronteira. O limite da arte é não apenas o limite da linguagem, mas o limite da realidade, ou ao menos da realidade de nossa frequência 
perceptiva ordinária, de "prosa". Quando passamos à frequência da poesia - e a imagem muda e abstrata é um ótimo trampolim para isso -, o espelho se inverte, estamos dentro de outro "mundo", e a fronteira passa a ser o contato com o limite do silêncio para com a linguagem. Entre a abstração e a concretude, com suas imagens borradas e referências ao mundo natural, as obras de Monet e Rodakiewicz funcionam como portais que atravessam e voltam desta janela, como um elétron ou um fóton que não se definem, em instante algum, como matéria ou energia, mas ao mesmo tempo são as duas coisas o tempo inteiro. A razão poética funciona neste ínterim.

María Zambrano, discípula de Heidegger e Ortega y Gasset, dona de um pensamento extremamente original, cunhou esta expressão para funcionar como corolário de uma série de ideias a respeito de filosofia, poesia, razão e até da divindade. Para Zambrano, a razão poética é sobretudo um método, uma rearticulação do pensar que parte justamente de algo como o "não-eu", o "dado bruto" ou o "nada indizível" propostos por Flusser para gerar um outro tipo de logos, desta vez poético ${ }^{251}$. A diferença é que Zambrano, ao contrário da prosa calculada de Flusser, não se omite em aplicar este logos poético em sua própria escrita, e o mergulho no absurdo analítico do "nada indizível" (uma proposição técnica) aqui se transforma no "mistério" e o "sagrado" de uma realidade confusa ("dado bruto"). Este logos se alimenta desta fonte também indizível e processa uma oposição entre pensamento e poesia que a filósofa faz questão de frisar como irrevogável e cada vez mais marcada. O principal argumento é que a filosofia é um tipo de violência positiva (no sentido de presença), ativa, de busca incessante. Já o poeta não precisa buscar nada, pois já o tem: seu polo é o negativo, da não-violência, de uma feminilidade (no sentido de ser cálice que recebe) e uma aceitação contemplativas. Aqui, a razão poética de Zambrano não apenas se encontra em todas as formulações que realizamos sobre o Zen, como também no pensamento "acariciante" de Maffesoli. Tanto para Zambrano quanto para o pensador francês, este poético funciona como um pensamento de sombras e frestas, de ambiguidades e paradoxos, de fantasmagorias e alucinações. Neste sentido, mais ainda do que uma ontologia (conforme vemos afirmando), a razão poética é um tipo de deontologia conforme proposta por Maffesoli:

\footnotetext{
251“'A comunicação entre o logos poético e a poesia concreta e viva é mais rápida e mais freqüente; o logos da poesia é de um consumo imediato, cotidiano; descende diariamente sobre a vida, tão diariamente, que, às vezes, se confunde com ela. É o logos que se presta a ser devorado, consumido" (ZAMBRANO, 1996, p. 23. Tradução nossa).
} 
Totalmente outro é o caminhar incerto do imaginário. Isso culmina num saber raro; um saber que, ao mesmo tempo, revela e oculta a própria coisa descrita por ele; um saber que encerra, para os espíritos finos, verdades múltiplas sob os arabescos das metáforas; um saber que deixa a cada um o cuidado de desvelar, isto é, de compreender por si mesmo e para si mesmo o que convém descobrir; um saber, de certa forma, iniciático (MAFFESOLI, 1998, p. 21).

A força deste saber proposto por Maffesoli e Zambrano de certa maneira é um passo além em relação à proposição analítica de Flusser, já que o pensador tcheco considera, em Língua e realidade, como uma natureza ontológica da realidade o fato de que não podemos sair dos limites do indizível (podemos apenas traduzi-lo em língua), estando todos nós presos dentro da tautologia do mecanismo do mundo. Maffesoli, por outro lado, fala em deontologia. Ele fala em se servir do indizível para produzir um novo logos. Flusser anunciava isso como a linguagem poética, mas ele não pensava nela como logos. Zambrano e Maffesoli propõem que todo um sistema de realidade parta desta fonte, deste logos. Isto é, como temos tentado demonstrar, característica da frequência poética: ela te coloca do outro lado, os espelhos se invertem, você pode observar pelo vidro oposto da janela. A frequência é um cosmos. Beber deste cosmos (por meio do silêncio) ativa este cosmos, você passa a se tornar parte dele. É como coloca a pesquisadora e poeta belga (especialista em Zambrano) Chantal Maillard:

Para afirmar esta identidade, a razão insiste em criar algo "outro" com que diferenciar-se, e a matéria moldável para formá-lo é o fundo oculto que toda vida humana abriga, aquilo que por ser original e desconhecido foi denominado como "o sagrado". Transformar "o sagrado" em "o divino" é dar luz às trevas, fazê-las compreensíveis (MAILLARD, 1992, p. 23$)^{252}$.

Esta "matéria moldável” a que se refere Maillard corresponde aos sentidos do "nada" e do "silêncio" 253 propostos por Flusser. E, também como pensa Flusser a respeito da própria realidade, a razão poética é um método. Ou melhor, um medium que, tal qual o zazen, é um fim em si mesmo. Um medium que abre um mundo. Um medium que é o próprio novo mundo. Desembocar na poesia, após tão extensiva argumentação, na realidade confere um alívio diante da brutalidade (a violência da filosofia) que é desembaraçar a complexidade (tal qual proposta por Morin) das relações entre arte, mundo e frequências da percepção (ou, mais que isso, mundos que se tocam pela tangente). Isto confere um sentido profundo ("deontológico") à velha máxima macluhaniana "o meio é a mensagem", e a desnuda de sua simplicidade quase

\footnotetext{
252 Tradução nossa.

253 "Mas esta palavra original a que acude Zambrano como um âmbito sagrado pertence em última instância ao silêncio" (MAILLARD, 1992, p, 13. Tradução nossa).
} 
mentecapta que a faz ser repetida como mantra da comunicação rasa em todo lugar. $\mathrm{O}$ meio é o mundo, e a poesia não chega a ser uma lente de leitura do mundo (pois não há nada por trás da lente), mas a leitura em si, o próprio intelecto proposto por Flusser.

\begin{abstract}
A poesia, na verdade, vive alijada disto. Poder e vontade não a interessam, e nem entram em seu âmbito. A consciência nela não significa poderio. E esta é a maior diferença. Quando a poesia falar de ética, falará de martírio, "de sacrifício". A poesia sofre o martírio do conhecimento, padece pela lucidez, pela vidência. Padece, porque poesia segue sendo mediação e nela a consciência não é signo de poder, senão necessidade ineludível para que uma palavra se cumpra. Claridade precisa para que o que está desenhado, não mais na névoa, se fixe; adquira "número, peso e medida" (ZAMBRANO, 1992, p. 88) $)^{254}$.
\end{abstract}

As obras de Monet e Rodakiewicz, conforme processamos nesta longa argumentação, estão interligadas por vários fios que conduzem a este universo.Ele inclui o papel do zeitgeist tecnológico e comuniciacional, da abstração enquanto obliterador da palavra e da imagem, da própria imagem enquanto condutor de silêncio, do próprio silêncio pensado como meditação, e da meditação enquanto esteira para um pensamento poético. Logicamente, não são obras necessariamente iniciáticas e exclusivas. Todo o cinema silencioso, como pensamos durante todo este trabalho, se reporta a estas relações. E toda pintura carrega em si seu cinema silencioso, conforme vimos também em Magritte. O mais importante é trazer uma situação minuciosamente local que engatilhe um desbaratar da complexidade, mesmo que vista sob ângulos e posições arbitrárias. Chegar à razão poética não é o fim de um percurso total, mas apenas o fim de um começo. É a porta que se abre para uma nova exploração do mundo:

Fazendo-se tal conjunção entre o estático e o dinâmico, entre o tempo e o espaço, encontra-se a antiga intuição dos alquimistas medievais, sempre no encalço do espírito. Aí está todo o simbolismo da pedra filosofal. Em outras palavras, aquilo que chamamos de "própria coisa" está carregada de forças que a ultrapassam. O universo está povoado de símbolos cujo sentido não se consegue esgotar mas cujas significações não valem senão por suas intenções, vividas dia a dia sem que isso seja "conscientizado" ou verbalizado. É isso, propriamente, que permite compreender o "giro" que pode ser observado desde o ativismo moderno até à moleza ou ao hedonismo pós-moderno. À penetração do mundo vai, portanto, suceder a contemplação do mundo. Retomando as categorias de Gilbert Durand, o símbolo do gládio, instrumento ativo, cede lugar ao da taça, do oco, da vacuidade. Talvez seja assim que convém compreender o que chamei de feminização do mundo. Isto é, o retorno de um outro modo de referir-se ao mundo, de outra maneira de ver a criação. Algo que não tenha a brutalidade da razão instrumental, mas se

${ }^{254}$ Tradução nossa. 
contente com acompanhar aquilo que cresce lentamente em função de uma razão interna (ratio seminalis) (MAFFESOLI, 2007, p. 116) ${ }^{255}$.

É importante frisar que, se desembocamos finalmente na razão poética, começamos esta argumentação no embate entre palavra e imagem a partir de um conflito entre o filme falado e o filme silencioso, como foi longamente discutido no capítulo 2 e no capítulo 3, especialmente na discussão a respeito de $O$ boulevard do crime. Este conflito atávico, presente em Platão, nos escritos de Da Vinci, em Lessing e em tantos outros, é o disparador inicial que Zambrano arma como uma oposição entre pensamento e poesia. Neste sentido, a ideia de se pensar que o filme silencioso obedece a um paradigma poético (mesmo narrativo) e o filme falado a um paradigma de prosa (pensamento instrumental), ainda que não possa ser pensada em termos totalizantes, funciona como belo corolário para se refletir sobre os meios de se decodificar a realidade que nos cerca e que está dentro de nós.

Chega a ser curioso imaginar que um tipo de pensamento de reconciliação como a razão poética nasça de um embate irreconciliável entre pensamento e poesia; entre palavra e imagem; entre silêncio e linguagem. Mais do que de uma dialética universal, como espécie de semiose infinita que produz elementos que vão se destruir mais adiante, é importante lembrarmos do princípio do Tao: "não há questões ao Tao e nenhuma resposta a estas questões". O logos poético parte de aferições ao silêncio e ao vazio; ao indizível. Ao tentar evitar o paradoxo com dialética, este logos se desfaz. O conflito entre estas oposições existe para que elas possam naturalmente se dissolver no "oceano de consciência" (por meio da meditação ou não) a que nos submetemos quando nos sintonizamos nesta frequência. Monet e Rodakiewicz trabalharam anos de suas vidas para construir obras que remetessem (intuitivamente ou não) a este oceano, que fossem capazes de disparar esta consciência poética. Seus autorretratos são, mais do que visões da singularidade individual, retratos da caixa preta do mundo. Um mergulho de cabeça neste oceano. Eles fazem o silêncio gritar que existe, preenchendo a consciência com a placidez de seu atordoante entorpecimento.

${ }^{255}$ Grifo do autor. 


\section{CONSIDERAÇÕES FINAIS}

O intelecto carrega sobre os ombros, como Atlas, um mundo de silêncio, para dentro do qual os pensamentos (as frases) desembocam e dentro do qual evaporam. - Vilém Flusser

Retira-se uma tecnologia de um medium e ele se transforma em outro medium. Retira-se o som do cinema e ele se transforma numa máquina poética. Retira-se a fala de uma encenação e ela recorre à imagem. Adiciona-se música a esta imagem e ela se torna esteira para uma reconfiguração da percepção. Adiciona-se o silêncio à imagem, e ela vira janela para um deslizar profundo da cognição em outra sintonia. Adiciona-se o fluxo à consciência e entramos em contato, via horizontes interno e externo, com uma totalidade de fenômenos que ocorrem entre a mente e as coisas. A rede de relações entre este tipo de troca sistêmica poderia estender-se longamente. Os elementos comunicacionais encontram seus media por toda parte. Em um princípio mais elementar, um medium é efetivamente um meio (o "meio físico por onde passa o sinal comunicacional"). O medium da voz é o ar por onde ela passa. O medium da TV a cabo são cabos de fibra óptica. O medium da escrita computacional são emulsões eletrônicas via microchip. Porém, é difícil desconsiderar que o computador em si seja um medium. Que a televisão seja um medium. Ou que nosso próprio corpo seja um medium. Nosso cérebro, seria ele também um medium? O que torna um meio qualquer (como um trem, meio de transporte) diferente de um meio que veicula informação (um medium)? Pode a informação ser veiculada sem um medium? Quando nos comunicamos, a palavra se torna um medium? E quando nos comunicamos por imagens? E imagens dentro da nossa mente, como são comunicadas para nós? Talvez este medium sejam as redes neurais do cérebro. Mas isso seria apenas um hardware para o software representado pela percepção. Os media podem começar como meios, sendo eles dados físicos de transporte e veiculação de informação. Porém, quando eles saem da materialidade física e se transportam para a percepção, mantêm a ordem de seu funcionamento, mas já não são media (ao menos no sentido tradicional) para se transformarem em frequências.

A poesia é uma destas frequências. Como sabemos, o medium altera as configurações da comunicabilidade, e o medium da tecnologia a tem prevista em seu programa. Uma língua está prevista em sua sintaxe, que, de certa forma, a ancora na materialidade. O que ocorre então quando os media não possuem esta ancoração e se 
tornam frequências? Podemos assumir que, assim como os media reconfiguram, a partir de sua forma ou de seu programa, a natureza da comunicação (e o sentido dela), também quando ocorrem na percepção cada medium resulta em um arranjo mental/perceptivo/cognitivo diferente. Se, conforme argumentamos, a meditação é um desses arranjos, a poesia também é um deles. Ou melhor, o poético. O milagre da correspondência entre os media e as frequências é a comunicabilidade direta entre eles. Se o medium filme é capaz de transmitir uma frequência poética, é porque temos receptores na percepção para receber e vibrar nesta frequência. $\mathrm{O}$ estado poético é ativado, estamos em sintonia com a forma de comunicar do filme.

Durante todo este trabalho, procuramos pensar em como a poesia deságua em determinados media, e o que especificamente a dispara neles. A relação do cinema silencioso com a poesia possui algumas peculiaridades que nos ajudaram a pensar este caso mais geral. Olhando por um determinado ponto de vista, a poesia está presente em todos os filmes silenciosos (sejam da era silenciosa ou não) porque o silêncio já seria uma frequência em si, e capaz de disparar outras frequência a partir do desdobramento natural dela. Portanto, assim como o cinema está na TV, que está na Internet (e assim sucessivamente), silêncio, poesia, alucinação, etc., se imiscuem, podem existir simultaneamente, podem ocultar um a existência do outro, ou podem potencializá-la. A percepção, neste caso, funcionaria como ondas de rádio. Nossa cabeça poderia, neste modelo, estar sendo cruzada por inúmeras frequências em posições e direções diferentes, e o desdobramento entre elas próprias funciona como percebemos os media no mundo material.

Desde o início, dentre os objetivos deste trabalho, ainda em seu projeto, estava no horizonte esta possibilidade: "Investigar a possibilidade de se entender a poesia como frequência ou modalidade do pensar". É lógico que as condições desta investigação se mostraram bastante complicadas, pois exigem um cruzamento entre os campos da fenomenologia, da teoria dos media e da cognição que está além de uma tese somente. Porém, foi possível pensar inúmeras relações, formular um pensamento. $\mathrm{O}$ poético é uma frequência da percepção e se comporta como os media, mas fora da materialidade. Quando em contato com um medium, ele provoca uma síntese entre sua própria natureza ontológica e a natureza destes media. A frequência poética está intimamente ligada ao silêncio, porque, mesmo quando investe na palavra, ela procura 
seu limite, procura caminhar em direção ao silenciamento dela. É por isso que o cinema silencioso dispara um componente poético automaticamente, já que está tecnicamente inserido no silêncio. A fala e a palavra, por outro lado, aprisionam o poético em sua narrativa, sua vetorização, na construção de seu caráter histórico. A imagem, por sua vez, pode servir às duas coisas, mas seu silêncio inerente (e isso vale também para a pintura e outros media silenciosos que dispensam a palavra) é potencializado pela ausência de som e fala destes filmes. O estado disparado por eles vai variar em cada experiência individual e com cada filme, pois transitória é a natureza ontológica da poesia. Mas, em determinados casos, o poético que emerge a partir do silêncio da imagem nos leva a uma redução fenomenológica: mergulhamos no fluxo dos fenômenos e nos sentimos em contato com uma totalidade de coisas por associação metonímica entre estes fenômenos. É este o mergulho no estado poético. As coisas do mundo aportam à consciência por meio de uma doação, mas a mente precisa estar em determinada frequência para que um também determinado tipo de noose ocorra. $\mathrm{O}$ estado poético é amorfo, pode se dividir em mil manifestações diferentes, ele obedece às propriedades dos media. É por isso também que o pensamos como um tipo de ontologia: ele é esteira para a manifestação do ser. De uma certa maneira, é um dos media para a emergência do ser.

Poesia, imagem, silêncio, movimento, montagem, narrativa, abstração e outros fizeram parte de uma constelação de conceitos que permitiram erigir um pensamento sobre como eles se entrelaçam a partir de padrões de complexidade. A imagem estava também nos objetivos originais: "Investigar a natureza da imagem cinematográfica enquanto signo (ícone) e os efeitos de sua incidência sobre a cognição". Aqui é importante ressaltar que a imagem foi, sim, intensamente investigada, especialmente em sua relação com outros modos de discurso (a palavra, a fala, o som), mas a abordagem semiótica, apenas pontual neste trabalho, deu lugar à teoria dos media e a aspectos fenomenológicos. Foi importante pensar a imagem tradicional, a imagem técnica e maneira como produzem representação. Sendo uma das primeiras imagens técnicas (produzidas através de um aparelho, digamos, ainda rudimentar em relação à tecnologia contemporânea), a imagem do cinema silencioso procura ainda uma permuta com um mundo "magicizado" não porque capture qualquer tipo de essência da natureza, mas sim porque faz eclodir justamente a frequência poética. A poesia, conforme temos argumentado, é sim ontologia, mas, conforme podemos pensar aqui, é também dado 
técnico, e a investigação do cinema enquanto manifestação técnica (e tecnológica) também fazia parte dos objetivos pensados inicialmente para esta tese. Tudo isso nos leva a pensar que o tipo de operacionalidade que existe na intermedialidade pode ser aplicado a uma teoria mais ampla sobre as relações entre tudo que é percebido, comunicado e veiculado. É por isso que a ideia de ícone, por problematizada que seja, ainda persistiu no trabalho, já que ela representa muito bem a fase de operacionalidade a que a imagem se submete na cadeia de percepção quando neste estágio.

No corpo deste texto, imagem, poesia e silêncio nem sempre aparecem de maneira conclusiva e articulada como estamos fazendo aqui. As valências de manifestação e significação (ou ausência mesma do sentido) para estes conceitos são muitas, e foi preciso criar um método dispersivo para conter esta miríade de possíveis leituras deles. Foi preciso, efetivamente, aproximar-se deles em espiral, circundando-os aos poucos, semeando-os com ideias e análises, para que um pensamento mais encerrado em associações propriamente sistemáticas pudesse surgir. O silêncio, conceito mais arredio e profundamente ambíguo, teve de ser inúmeras vezes pensado em prismas diferentes para que se o compreendesse com um mínimo de abrangência sem perder um sentido comum a todos eles. Aqui foi importante pensar a natureza do cinema silencioso enquanto silêncio, já que este é um tópico usual (e controverso) de discussão na teoria do cinema. Como ficou claro no corpo do texto, optamos por valorizar a manifestação do silêncio neste cinema, mesmo sendo ele acompanhado por tipo de tipo de intervenções sonoras, falas, textos, intertítulos, letreiros, música, etc. O silêncio é um conceito que ultrapassa este tipo de definição técnica. É por isso que a presença dos pintores (notadamente Magritte e Monet) foi tão importante para a consolidação das ideias deste trabalho. O cinema silencioso não existe apenas no cinema. O nível de conhecimento e a forma que ele perpetua pode ser totalmente dialógica em relação aos outros media. Sem o auxílio da operacionalidade no pensamento visual de Magritte e da abstração (cinética) em direção ao mergulho no fluxo em Monet, ou seja, pensando por uma via negativa (daí também a importância do estudo do som, da fala e da palavra), certamente não teríamos chegado às conclusões que estamos apresentando aqui.

Por fim, também estava em nossas intenções "procurar entender o cinema silencioso a partir das próprias diferenças estéticas, expressivas e narratológicas que ele 
possui em relação ao cinema sonoro". É claro que este cinema (o sonoro) esteve em nosso horizonte a todo momento. Uma das principais aporias deste trabalho certamente é a possibilidade de que o que foi argumentado para o cinema silencioso também tenha validade para os filmes sonoros, desde que estejam submetidos a determinadas condições. A poética silenciosa não se submete a gêneros fílmicos ou modalidades historicamente constituídas. Não é um pensamento generalizante. A poesia, enquanto frequência que aporta nos media, pode surgir a qualquer instante, em um filme ou pintura, e se esvanecer no instante seguinte. Mais importante, porém, talvez tenha sido comparar os filmes silenciosos entre si, entendê-los como sistemas (o porco-espinho de Schlegel) que funcionam em contingências específicas, mas que trocam reminiscências que se tornam modificações poderosas quando o fechamento operacional destes sistemas é aberto à intermedialidade.

É por isso que um aprofundamento na teoria dos sistemas é uma necessidade para avançar nas ideias semeadas neste trabalho. O próximo passo, após uma abordagem calcada quase inteiramente na filosofia, na história e teoria do cinema, assim como na teoria dos media, será incluir um contingente maior de neurociências e cognitivismo, campos que vêm se aproximando cada vez mais do cinema nos últimos anos. A percepção, por mais que possa ser entendida a partir da elaboração da filosofia (e daí inúmeros modelos surgem a partir de pura especulação), não pode se limitar a ser pesquisada como software. O mundo dos fenômenos, por mais que à percepção pareça uma indistinguível variação de modelos de imagem se inoculando e sendo processados pelo sujeito, possui também sua contrapartida matemática, abstrata, física. A operacionalidade dos fenômenos no cérebro é a última fronteira da fenomenologia, e há estudos contundentes nesta direção sendo realizados na contemporaneidade. A própria abordagem da meditação como um tipo de percepção que de alguma forma se associa à do cinema (ainda que sejam animais diferentes) carece de verificação empírica (como tem sido realizado no campo da neurociência). Uma pesquisa deste tipo precisa de um cruzamento ainda mais aberto de conhecimentos, não necessariamente para chegar a alguma verdade, mas sim para abrir fronteiras, clareiras, desbastar universos que continuam encerrados em si próprios. Sem este passo além, a ideia de um pensamento complexo não cumpre com o que anuncia. 
A poética silenciosa foi pensada como um modelo policêntrico para se refletir sobre a poesia. Como toda poética, não deixa de ter seu lado "prescritivo" (principal característica das poéticas clássicas). Em determinados momentos, foi inevitável recair sobre certos dogmatismos. "O cinema silencioso funciona assim", "a poesia aporta na percepção desta maneira", "a música tem este papel na constituição do silêncio", etc. Logicamente, a imensa variação de possibilidades de abordagem e de sentidos inerentes a estes temas tornou a tarefa de encerrar um modelo imediatamente aplicável mais difícil. Portanto, é importante pensar esta tese como uma estrutura ainda em concepção na cabeça do arquiteto do que algo já presente nos andaimes que vão compor o prédio. Isso não significa, é claro, que precisamos algum dia construir este prédio, com suas bases sólidas e pilastras vigorosas. As frestas e porosidades nas paredes de pedra-pomes do nosso edifício são na verdade os alicerces que permitem justamente que esta estrutura seja alterada a qualquer momento, por qualquer pesquisador. É como diz mais um fragmento de Schlegel: "Muitas obras dos antigos se tornaram fragmentos. Muitas obras dos modernos já o são ao surgir" (SCHLEGEL, 1997, p. 51). Procuramos, portanto, pensar este trabalho como grande fragmento cujas frestas podem atrair a atenção de outras pessoas (muitas vezes de outros campos) que queiram complementálo, expandi-lo. Mais que um edifício sólido como as poéticas antigas, esta tese já nasce como ruína submersa, para ser descoberta e recuperada a partir de sua natureza de fragmento.

Assim, para os estudos de cinema e cinema silencioso, esta poética traz um modelo para se arriscar a pensar sobre obras ainda mais sofisticadas, invadir as obrasprimas e se ramificar em muitos outros estudos, seja do ponto de vista da historiografia do cinema, da percepção do cinema, nos estudos de som e silêncio no cinema e na estética do cinema. Seria ainda interessante aplicar o modelo da poética para o cinema sonoro, ou o cinema expandido, ou o chamado cinema experimental e de vanguarda, coisas que apenas tangenciamos aqui. O mesmo ocorre à possibilidade de se aplicar o modelo da poética (um pensamento a partir da linguagem do cinema) em outros media e formas de arte. Uma poética silenciosa para a música, ou para as histórias em quadrinhos, ou para a realidade virtual, por exemplo. Para o pensamento sobre o silêncio, esta poética abre um espaço de diálogo entre tecnologia e este silêncio, procurando entender como se dão as permutas entre um e outro, saindo de um silêncio somente filosófico para adentrar na maneira com que ele está presente em todas as modalidades de comunicação, inclusive do ponto de vista técnico. Um horizonte 
próximo é o silêncio político dentro do cinema, as modalidades de discurso, maneira como o silêncio prioriza maneiras de dizer em detrimento de outras, etc. Por fim, para a continuidade sobre os estudos sobre poesia, este trabalho procura pensá-la de maneira aberta e abrangente (tal qual é a natureza da própria poesia), para que o campo se expanda em tudo aquilo que a frequência poética atinge: os campos das artes, da comunicação, das ciências da natureza, das ciências sociais, etc. $\mathrm{O}$ objetivo é chegar à poesia como inoculada no próprio pensar filosófico. Paradigmas sobre qual pode ser a natureza do pensamento têm convergido em direção à poesia há décadas, e fica cada vez mais premente a sua função construtora de mundos e a necessidade com que as relações entre as funções organizadoras das sociedades (a ética, a política, a justiça, etc.) enverguem para uma estética e se sintonizem também na frequência poética. A maré, enfim, está cheia novamente. É hora de lançar mais e melhores redes na vastidão inesgotável do oceano. 


\section{REFERÊNCIAS}

ABEL, Richard; ALTMAN, Rick. The sounds of early cinema. Bloomington e Indianapolis: Indiana Univserdity Press, 2001.

AGAMBEN, Giorgio. "Notas sobre o gesto". In: IANNINI, Gilson. (Org.). Artefilosofia. No 4. Ouro Preto: IFAC, 2008.

ALLEN, Richard; SMITH, Murray. "Teoria do cinema e filosofia".Trad. De Fernando Mascarello.In: RAMOS, Fernão (Org.). Teoria contemporânea do cinema. Pósestruturalismo e filosofia analítica.São Paulo: Editora Senac, 2005. Volume 1.

ALTMAN, Rick. Silent film sound. New York: Columbia University Press, 2004.

ANDRADE, Carlos Drummond de. A rosa do povo. Rio de Janeiro: Record, 2002.

ANDREW, J. Dudley. As principais teorias do cinema: uma introdução. Trad. deTeresa Ottoni. Rio de Janeiro: Jorge Zahar, 2002.

ANTONIN, Eliana Pibernet. Semiótica. In: MARCONDES FILHO (Org.). Dicionário de comunicação. São Paulo: Paulus, 2009.

ARISTÓTELES. Poética. Organon. Política. Trad. de Baby Abrão, Pinharanda Gomes e Therezinha M. Deutsch. São Paulo: Nova Cultural, 2000. (Os Pensadores)

ARNHEIM, Rudolf. Film as art. Berkeley e Los Angeles: University of California Press, 1960.

AUMONT, Jacques. $O$ olho interminável [cinema e pintura]. Trad. de Eloisa Araújo Ribeiro. São Paulo: Cosac Naify, 2004. (Coleção cinema, teatro e modernidade)

; MARIE, Michel. Dicionário teórico e crítico de cinema. Trad. De Eloisa Araújo Ribeiro. Campinas: Papirus, 2003.

BARNIER, Martin. En route vers le parlant. Histoire d'une evolution technologique, économique et esthétique du cinema (1926-1934). Liège (Bélgica): Céfal, 2002.

. Bruits, Cris, musiques de films. Les projections avant 1914. Rennes: Presses Universitaires de Rennes, 2010.

BARTHES, Roland. A câmara clara. Trad. de Júlio Castañon Guimarães. Rio de Janeiro: Nova Fronteira, 1984.

BAUDRILlARD, Jean. A ilusão vital. Trad. de Luciano Trigo. Rio de Janeiro: Civilização Brasileira, 2001. 
BAUER, Hermann; BAUR, Eva-Gesine et al. Los maestros de la pintura occidental. Uma historia de arte em 900 análisis de obras. Tomo I. Del gótico al neoclasicismo. London: Taschen, 2005.

BAZIN, André. Charlie Chaplin. Trad. de André Telles. Rio de Janeiro: Jorge Zahar, 2006.

. Ontologia da imagem fotográfica. In: Ismail Xavier (Org.). A experiência do cinema. Rio de Janeiro: Edições Graal, 2003.

BENJAMIN, Walter. Magia e técnica, arte e política: ensaios sobre literatura e história da cultura. Tradução de Sérgio Paulo Rouanet. 7. ed. São Paulo: Brasiliense, 1994.

(Obras escolhidas; v. 1).

BERENDT, Joachim-Ernst. The world of is sound: Nada Brahma. Music and the landscape of consciousness. Rochester: Destiny Books, 1991.

BERGSON, Henry. Matéria e memória. Ensaio sobre a relação do corpo com o espírito. Trad. de Paulo Neves. São Paulo: Martins Fontes, 2010. (Biblioteca do pensamento moderno)

BONNEFOY, Yves. Poésie et photographie. Paris: Galilée, 2014.

BORDWELL, David. "O cinema clássico hollywoodiano: normas e princípios narrativos" Trad. de Fernando Mascarello. In: RAMOS, Fernão (Org.). Teoria contemporânea do cinema. Documentário e narratividade ficcional. São Paulo: Editora Senac, 2005. Volume 2.

How to watch FANTÔMAS and why. Disponível em: <http://www.davidbordwell.net/blog/2010/11/11/how-to-watch-fantomas-and-why/>. Acesso em: 15 Dez. 2013.

BORDWELL, David; THOMPSON, Kristin. Film art: an introduction. New

York: Alfred A. Knopf, 1986.

BOWSER, Eileen. The transformation of cinema. 1907-1915. Berkeley e Los Angeles: University of California Press, 1990. (History of the American cinema; volume 2)

BROWNLOW, Kevin. The parade's gone by... Berkeley e Los Angeles: University of California Press, 1994.

"Introduction". In: KOBEL, Peter. Silent movies, the birth of film and triumph of movie culture. New York: Hachette Book Group, 2008.

BUÑUEL, Luís. "Cinema: instrument de poesia". In: XAVIER, Ismail (Org.). A experiência do cinema. Rio de Janeiro: Edições Graal, 2003.

BÜRGER, Peter. Theory of the avant-garde. Trad. de Michael Shaw. Minneapolis: University of Minnesota Press, 1994. 
BURNET, Éliane. "Du cri du silence au silence du cri". In: La bande sonore: esquisse d'une théorie de l'oralité dans la littérature et au cinema. Paris: Éditions Aleph, 2002.

CAGE, John. Silence. Middletown: Wesleyan University Press, 2011.

CALVIN, William H. "A evolução do pensamento" In: Scientific american Brasil edição especial. São Paulo, Duetto Editorial, n. 17, fev. 2005.

CALVINO, Italo. Palomar. Trad. de Ivo Barroso. São Paula: Cia. Das Letras, 1994.

CAMPAN, Véronique. L'Écoute filmique. Écho du son em image. Paris: Presses Universitaires de Vincennes, 1999.

CAMPBELL, Joseph. O herói de mil faces. Rio de Janeiro: Cultrix/Pensamento, 1995.

CARANFA, Angelo. Philosophical Silence and Spiritual Awe. Journal of Aesthetic Education, Vol. 37, No. 2, pp. 99-113, 2003.

CARNÉ, Marcel. La vie à belles dents. Paris: Juan Vuarnet, 1979.

CASTANT, Alexandre. Planètes sonores. Radiophonie, Arts, Cinéma. Paris: Monographique, 2010.

CASTRO, Gustavo de; DRAVET, Florence. Comunicação e poesia. Brasília: Editora da UnB, 2014.

CASTRO, Gustavo de (Org.). Mídia e imaginário. São Paulo: Annablume, 2012.

Ítalo Calvino - Pequena cosmovisão do homem. Brasília: UnB, 2007.

CHARNEY, Leo; SCHWARTZ, Vanessa. (Org.) $O$ cinema e a invenção da vida moderna. São Paulo: Cosacnaify, 2004.

. "Introdução". In: In: CHARNEY, Leo; SCHWARTZ, Vanessa. (Org.) $O$ cinema e a invenção da vida moderna. São Paulo: Cosacnaify, 2004.

CHAPLIN, Charles. Minha vida. Trad. de Rachel de Queirós, R. Magalhães Júnior e Genolino Amado. Rio de Janeiro: José Olympio, 1989.

CHEVALIER, Jacques (Org.). Regards neufs sur le cinéma. Paris: People et Culture, 1953.

CHION, Michel. L'audio-vision. Son et image au cinéma. Paris: Armand Colin, 2005.

CLEMENTE, José. Robert Flaherty. Madrid: ediciones Rialp, 1963.

COSTA, Flávia Cesarino. "Primeiro cinema". In: MASCARELLO, Fernando. (Org.) História do cinema mundial. Campinas: Papirus, 2006. 
DA VINCI, Leonardo. Textes choisis. Pensées, théories, préceptes, flabes et facéties. Trad. de Joseph Péladan. Paris: Societé du Mercure de France, 1907.

DAWKINS, Richard. The god delusion. London: Black Swan, 2007.

DELEUZE, Gilles. A imagem-movimento: Cinema 1. Trad. de Stella Senra. São Paulo: Brasiliense, 1983.

. A imagem-tempo: Cinema 2. Tradução de Eloisa de Araújo Ribeiro.

São Paulo: Brasiliense, 1990.

. Francis Bacon: lógica da sensação. Rio de Janeiro: Jorge Zahar, 1981

DELLUC, Louis. "Photogénie". In: CHEVALIER, Jacques (Org.). Regards neufs sur le cinéma. Paris: People et Culture, 1953.

DERRIDA, Jacques. A escritura e a diferença. Trad. de Maria Beatriz Marques Nizza da Silva. São Paulo: Perspectiva, 2002. (Debates)

. Gramatologia. São Paulo: Perspectiva, 2011. (Estudos)

DIDI-HUBERMAN, Georges. A sobrevivência dos vaga-lumes. Trad. de Vera Casa Nova e Márcia Arbex. Belo Horizonte: Editora UFMG, 2011.

. O que vemos, o que nos olha. Trad. de Paulo Neves. São Paulo: Ed. 34, 1998.

. Prefácio. In: MICHAUD, Philippe Alain. Aby Warburg e a imagem em movimento. Trad. de Sibylle Muller. Rio de Janeiro: Contraponto, 2013.

DOANE, Mary-Ann. "A voz no cinema: a articulação de corpo e espaço". Trad. de Luciano Figueiredo. In: XAVIER, Ismail (Org.) A experiência do cinema. Rio de Janeiro: Edições Graal, 1983.

DORIA, Francisco Antônio; KATZ, Chaim Samuel; LIMA, Luiz Costa. Dicionário crítico de comunicação. Rio de Janeiro: Paz e Terra, 1971.

EAGLETON, Terry. Teoria da literatura: uma introdução. Tradução de Waltensir Dutra. 4. ed. São Paulo: Martins Fontes, 2001.

EISENSTEIN, Sergei. $O$ sentido do filme. Tradução de Teresa Ottoni. Rio de Janeiro: Jorge Zahar, 2002.

Dickens \& Griffith. Genèse du gros plan. Trad. de Marina Berger. Paris: Stalker Éditeur, 2007.

EISNER, Lotte H. A tela demoníaca. As influências de Max Reinhardt e do expressionismo. Rio de Janeiro: Paz e Terra, 2002.

ELSAESSER, Thomas. Weimar cinema and after. Germany's historical imaginary. Abingdon: Routledge, 2000. 
EPSTEIN, Jean. "O cinema e as letras modernas". In: Ismail Xavier (Org.). A experiência do cinema. Rio de Janeiro: Edições Graal, 2003.

ESCHENBURG, Barbara; ESSERS, Volkmar et al. Los maestros de la pintura occidental. Uma historia de arte em 900 análisis de obras. Tomo II. Del romanticismo a la época contemporánea London: Taschen, 2005.

EVERSON, William. American silent film. New York: Da Capo Press, 1998.

FELDSTEIN, Richard; FINK, Bruce; JAANUS, Maire (Org.). Para ler o seminário 11

de Lacan. Trad. de Dulce Duque Estrada. Rio de Janeiro: Jorge Zahar, 1997.

FELINTO, Erick. A imagem espectral. Comunicação, cinema e fantasmagoria tecnológica. Cotia: Ateliê Editorial, 2008.

. Silêncio de Deus, silêncio dos homens. Babel e a sobrevivência do sagrado na Literatura moderna. Porto Alegre: Sulina, 2008.

FISCHER, Lucy. Sunrise. A song of two humans. London: British Film Institute, 1998.

FLAHERTY, Robert. Making twenty-four dollar island. In: POSNER, Bruce (Org.). Unseen cinema. Early American avant-garde film 1893-1941. New York: Anthology Film Archives, 2001.

FLUSSER, Vilém. O universo das imagens técnicas. Elogio da superficialidade. São Paulo: Annablume, 2008. . Língua e realidade. São Paulo: Annablume, 2007.

Filosofia da caixa preta. Ensaios para um futura filosofia da fotografia. São Paulo: Annablume, 2011.

FOUCAULT, Michel. Isto não é um cachimbo. Trad. de Jorge Coli. Rio de Janeiro: Paz e Terra, 1988.

GALLEZ, Douglas W. Theories of film music. Cinema journal, Houston, University of Texas Press, Vol. 9, n. 2, Spring. 1970.

GARNCARZ, Joseph. "Art and industry. German cinema of the 1920s". In: GRIEVESON, Lee; KRÄMER, Peter. (Org.) The silent cinema reader. Routledge: NewYork, 2004.

GAUDREAULT, André; JOST, François. A narrativa cinematográfica. Trad. de Ciro Inácio Marcondes, Adalberto Müller e Rita Jover-Falleiros. Brasília: Editora da UnB, 2009.

GLENN, Cherryl. Unspoken. A rhetoric of silence. Carbondale: South Illinois University Press, 2004. 
GORBMAN, Claudia. "Narrative film music". In: .Yale french studies, New Haven, Cinema/Sound, n. 60, 1980.

GRAVETT, Paul. Mangá. Como o Japão reinventou os quadrinhos. São Paulo: Conrad, 2006.

GRAZIANI, Romain. "Os recursos éticos do silêncio e o 'ensinamento sem palavras' (wu yan zhi jiao) no taoismo antigo". In: NOVAES, Adalto (Org.). O silêncio e a prosa do mundo. São Paulo: Edições SESC São Paulo, 2014.

GRIEVESON, Lee; KRÄMER, Peter. (Org.) The silent cinema reader. Routledge: New York, 2004.

GROENSTEEN, Thierry. "The impossible definition”. In: HEER, Jeet; WORCESTER, Kent (Org.). A comics studies reader. Jackson: University Press of Mississipi, 2009.

GUMBRECHT, Hans Ulrich. Production of presence. What meaning cannot convey. Stanford: Stanford University Press, 2003.

GUNNING, Thomas. Présence du narrateur: l'héritage des films Biograph de Griffith. In: MOTTET, Jean (Org.). David Wark Griffith. Etudes sous la direction de Jean Mottet. Paris: Editions L'Harmattan, 1984.

. "Doing for the eye what the phonograph does for the ear". In: ABEL, Richard; ALTMAN, Rick. The sounds of early cinema. Bloomington e Indianapolis: Indiana Univserdity Press, 2001.

HAWKING, Stephen. O universo numa casca de noz. Trad. de Cássio de Arantes Leite. Rio de Janeiro: Intrínseca, 2016.

HEER, Jeet; WORCESTER, Kent (Org.). A comics studies reader. Jackson: University Press of Mississipi, 2009.

HEIDEGGER, Martin. Explicações da poesia de Hölderlin. Trad. de Claudia Pellegrini Drucker. Brasília: Editora da UnB, 2013.

A origem da obra de arte. Tradução de Maria da Conceição

Costa. Lisboa: Edições 70, 2005. (Biblioteca de filosofia contemporânea).

HEINRICH, Christophe. Claude Monet. Trad. de Jorge Manuel Pinheiro Valente.

London: Taschen, 2000.

HERSCOVICI, Charly (Org.). Magritte en poche. 400 ouvres d'art par le maître du surréalisme. Paris: Ludion Anvers, 2009.

HERTZ, Constança. Mário Peixoto, cinema e poesia: imagens de permeio com o mar. 2001. Dissertação (Mestrado em Literatura Comparada) - Faculdade de Letras,Universidade Federal do Rio de Janeiro, Rio de Janeiro, 2001. 
HOOG, Michel. Les nymphéas de Claude Monet. Paris: Musée de l'Orangerie, 2006.

HUGHES, Robert. "Rien q'un critique". In: HERSCOVICI, Charly (Org.). Magritte en poche. 400 ouvres d'art par le maître du surréalisme. Paris: Ludion Anvers, 2009.

HUSSERL, Edmund. Investigações lógicas. Sexta investigação. Trad. de Zeljko Loparic, Andréa Altino de Campos Loparic. São Paulo: Nova Cultural, 2000.

IKEMOTO, Takashi; STRYK, Lucien; TAKAIAMA, Taigan. Zen poems of China and Japan. The crane's bill. Trad. de Lucien Stryk e Takashi Ikemoto. New York: Anchor Books, 1973.

JAMES, David E. Hollywood extras: one tradition of "avant-garde" film is Los Angeles. In: POSNER, Bruce. Unseen cinema. Early American avant-garde film 18931941. New York: Anthology Film Archives, 2001.

JOHNSON, Christopher. Derrida. A cena da escritura. Trad. de Raul Fiker. São Paulo: editora UNESP, 2001.

JOST, François. Sous le cinéma, la communication. Paris: Vrin, 2014.

. "The voices os silence". In: ABEL, Richard; ALTMAN, Rick. The sounds of early cinema. Bloomington e Indianapolis: Indiana Univserdity Press, 2001.

JUARROZ, Roberto. Poesia e realidade. Trad. de Gustavo de Castro e Florence Dravet. Brasília: Casa das Musas, 2009.

JULLIER, Laurent. Les sons au cinema et à la télévision. Paris: Armand Colin, 1995.

KACTUZ, Flávio (Org.). Pasolini ou quando o cinema se faz poesia e política do seu tempo. Rio de Janeiro: Uns Ente Outros, 2014.

KAMPER, Dietmar. A imagem. Trad. de Lília Lustosa. In: CASTRO, Gustavo de (Org.). Mídia e imaginário. São Paulo: Annablume, 2012.

KANDINSKY, Wassily. Do espiritual na arte e na pintura em particular. Trad. de Álvaro Cabral. São Paulo: Martins Fontes, 1996.

KANT, Immanuel. Crítica da faculdade do juízo. 2.ed. Tradução de Valério Rohden e António Marques. Rio de Janeiro: Forense Universitária, 2005.

KAPLEAU, Philip. Os três pilares do zen. Ensinamento, prática, iluminação. Trad. de Abadia de Nossa Senhora das Graças. Belo Horizonte: Editora Itatiaia Limitada, 1978.

KATZ, Chaim Samuel. "Imagem". In: DORIA, Francisco Antônio; KATZ, Chaim Samuel; LIMA, Luiz Costa. Dicionário crítico de comunicação. Rio de Janeiro: Paz e Terra, 1971.

KITTLER, Friedrich. Gramophone, film, typewriter. Trad. de Geoffrey WinthropYoung e Michael Wutz. Stanford: Stanford University Press, 1999. 
KURY, Mário da Gama. Dicionário de mitologia grega e romana. 5.ed. Rio de Janeiro: Jorge Zahar, 1999.

KOBEL, Peter. Silent movies, the birth of film and triumph of movie culture. New York: Hachette Book Group, 2008.

KOVADLOFF, Santiago. O silêncio primordial. Trad. de Eric Nepomuceno e Luís Carlos Cabral. Rio de Janeiro: José Olympio, 2003.

KRACAUER, Siegfried. De Caligari a Hitler. Uma história psicológica do cinema alemão. Trad. de Tereza Ottoni. Rio de Janeiro: Jorge Zahar, 1988.

. Theory of film, the redemption of physical reality. New Jersey: Princeton Paperbacks, 1997.

LACAN, Jacques. O seminário. Livro 11. Os quatro conceitos fundamentais da psicanálise. Trad. de M.D. Magno. Rio de Janeiro: Jorge Zahar, 1988.

LHERMINIER, Pierra. Louis Delluc et le cinéma français. Paris: Ramsay, 2008.

LEVINE, Steven Z. Monet, Lumière and cinematic time. The Journal of Aesthetics and Art Criticism, The American Society for Aesthetics, Vol. 36, No. 4, pp. 441-447, 1978.

LUHMANN, Niklas. Introdução à teoria dos sistemas. Trad. de Ana Cristina Arantes Nasser. Petrópolis: Vozes, 2009.

Speaking and silence. New german critique. Durham, Duke University Press, n. 61, Winter, 1994.

LYNCH, David. Catching the big fish. Meditation, counciousness, and creativity. New York: Bookind, 2007.

MACHADO, Arlindo. Pré-cinemas \& pós-cinemas. Campinas: Papirus, 1997.

MCCLOUD, Scott. Desvendando os quadrinhos. Trad. de Helcio de Carvalho e Marisa Nascimento Paro. São Paulo: M. Books do Brasil, 2005.

MAFFESOLI, Michel. Elogio da razão sensível. Trad. de Albert Christophe Migueis Stuckenbruck. Petrópolis: Vozes, 1998.

MAGRITTE, René. Les mots et les images. Choix d'escrits. Tournai: Labor, 1994.

MAILLARD, Chantal. La creación por la metáfora. Introducción a la razón-poética. Barcelona: Anthropos, 1992.

MARCONDES FILHO, Ciro (Org.). Dicionário de comunicação. São Paulo: Paulus, 2009. 
O escavador de silêncios. Formas de construir e de desconstruir sentidos na Comunicação. Nova teoria da Comunicação II. São Paulo: Paulus, 2004.

“Acontecimento". In: MARCONDES FILHO (Org.). Dicionário de comunicação. São Paulo: Paulus, 2009.

. "Mass media". In: MARCONDES FILHO (Org.). Dicionário de comunicação. São Paulo: Paulus, 2009.

. "Media”. In: MARCONDES FILHO (Org.). Dicionário de comunicação. São Paulo: Paulus, 2009.

MARCONDES, Ciro Inácio. Limite: o poema em filme. $124 \mathrm{f}$. Dissertação (mestrado). Departamento de Teoria Literária e Literaturas, Universidade de Brasília, 2008.

. Charles Sanders Peirce. In: MARCONDES FILHO (Org.). Dicionário de comunicação. São Paulo: Paulus, 2009.

Sergei Mikhailovitch Eisenstein. In: MARCONDES FILHO (Org.). Dicionário de comunicação. São Paulo: Paulus, 2009.

MARTIN, Marcel. A linguagem cinematográfica. Trad. de Lauro António e Maria Eduarda Colares. Lisboa: Dinalivro, 2005.

MALAND, Charles J. "A star is born: american culture and the dynamics of Charlie Chaplin's star image, 1913-1916”. In: GRIEVESON, Lee; KRÄMER, Peter. (Org.) The silent cinema reader. Routledge: New York, 2004.

MASAGÃO, Andrea Menezes. Habitats. Livro II. A casa assombrada - ensaio sobre o olhar. Campinas: Mercado das Letras, 2013.

MASCARELlO, Fernando. (Org.) História do cinema mundial. Campinas: Papirus, 2006.

MATURANA, Humberto. Cognição, ciência e vida cotidiana. Trad. de Cristina Magro e Victor Paredes. Belo Horizonte: Editora da UFMG, 2001.

MCLUHAN, Marshall. Os meios de comunicação como extensões do homem. Trad. de Décio Pignatari. São Paulo: Cultrix, 1964.

MERLEAU-PONTY, Maurice. O cinema e a nova psicologia. In: Ismail Xavier (Org.). A experiência do cinema. Rio de Janeiro: Edições Graal, 2003.

. Textos selecionados. Trad. de Marilena Chauí, Nelson Alfredo Aguilar, Pedro de Souza Moraes. São Paulo: Abril Cultural, 1980. (Os pensadores)

METZ, Christian. A significação no cinema. Tradução de Jean-Claude Bernardet. 2. ed. São Paulo: Perspectiva, 2004. (Debates). 
MILLER, Ann. Reading bande dessinée. Critical approaches to French-language comic strip. Bristol/Chicago: Intellect Books, 2007.

MICHAUD, Philippe Alain. Aby Warburg e a imagem em movimento. Trad. de Sibylle Muller. Rio de Janeiro: Contraponto, 2013.

MITCHELL, W.J.T. "Beyond comparison". In: HEER, Jeet; WORCESTER, Kent (Org.). A comics studies reader. Jackson: University Press of Mississipi, 2009.

MOREIRA, Caio Ricardo Bona. O encontro entre chuvosos e nefelibatas: a nuvem política. Revista de Letras da UTFPR, n.15, 2012.

MORIN, Edgar. O método 3. O conhecimento do conhecimento. Trad. de Juremir Machado da Silva. Porto Alegre: Sulina, 1999.

. Ciência com consciência. Trad. de Maria D. Alexandre e Maria Alice Araripe de Sampaio Doria. Rio de Janeiro: Bertrand Brasil, 2014.

. "A alma do cinema". In: Ismail Xavier (Org.). A experiência docinema. Rio de Janeiro: Edições Graal, 2003.

. Le cinema ou l'homme imaginaire. Essai d'anthropologie. Paris: Les Editions de Minuit, 1956.

MOTTET, Jean (Org.). David Wark Griffith. Etudes sous la direction de Jean Mottet. Paris: Editions L'Harmattan, 1984.

MOURA, Carlos Alberto Ribeiro de. "Husserl. Intencionalidade e fenomenologia". In: Mente Cérebro Filosofia. São Paulo, Duetto Editorial, n. 5, mar. 2005.

MOUSSINAC, Léon. "Mon ami Delluc". In: LHERMINIER, Pierra. Louis Delluc et le cinéma français. Paris: Ramsay, 2008.

MÜLLER, Adalberto. Manoel de Barros in film: the nature of language and the language of nature. Studies in Spanish \& Latin American Cinemas, Intellect Limited, Vol. 11, N. 2, pp. 193-202. 2014.

. Linhas imaginárias: poesia, mídia, cinema. Porto Alegre: Sulina, 2012.

MÜNSTERBERG, Hugo. The Film: a psychological study. Mineola, New York: Dover, 2004.

MUSSER, Charles. At the beggining: motion picture production, representation and ideology at the Edison and Lumière companies. In: GRIEVESON, Lee; KRÄMER, Peter. (Org.) The silent cinema reader. Routledge: New York, 2004.

NICHOLS, Sallie. Jung e o tarô. Uma jornada arquetípica. Trad. de Octavio Mendes Cajado. São Paulo: Cultix, 1980. 
NIETZSCHE, Friedrich W. A gaia ciência. Trad. de Antônio Carlos Braga. São Paulo: Escala, 2006.

Assim falou Zaratustra. Um livro para todos e para ninguém. Trad. de Mário da Silva. Rio de Janeiro: Civilização Brasileira, 1977.

NOVAES, Adalto (Org.). O silêncio e a prosa do mundo. São Paulo: Edições SESC São Paulo, 2014.

. "Treze notas sobre $O$ silêncio e a prosa do mundo". In: NOVAES, Adalto (Org.). O silêncio e a prosa do mundo. São Paulo: Edições SESC São Paulo, 2014.

NUNES, Benedito. Hermenêutica e poesia. O pensmento poético. Belo Horizonte: Editora da UFMG, 2007.

PAZ, Octavio. El arco y la lira. Lengua y estúdios literários. Mexico DF: Fondo de Cultura Economica, 2003.

PAQUET, Marcel. Magritte. O pensamento tornado visível. Trad. de Lucília Filipe. Köln: Taschen, 1992.

PASOLINI, Pier Paolo. Empirismo hereje. Tradução de Miguel Serras Pereira. 152. ed. Lisboa: Assírio e Alvim, 1982.

PIGUET, Philippe. Claude Monet prospectif. Les Nymphéas une ouvre in situ. Paris: L'Échoppe, 2010.

PLATÃO. A república. Trad. de Enrico Corvisieri. São Paulo: Nova Cultural, 1999.

POLET, Jacques. "Early cinematography spectacles: the role of sound accompaniment in the reception of moving images". In: ABEL, Richard; ALTMAN, Rick. The sounds of early cinema. Bloomington e Indianapolis: Indiana Univserdity Press, 2001.

POSNER, Bruce (Org.). Unseen cinema. Early American avant-garde film 1893-1941. New York: Anthology Film Archives, 2001.

. The grand experiment. In: POSNER, Bruce. Unseen cinema. Early American avant-garde film 1893-1941. New York: Anthology Film Archives, 2001.

(Org.). Where the buffalo roamed... Relative histories of an early american avant-garde film. New York: Image Entertainment, 2005.

PUDOVKIN, Vsevolod. Os métodos do cinema. In: XAVIER, Ismail (Org.). A experiência do cinema. Rio de Janeiro: Edições Graal, 2003.

PUKNAT, Siegfried B. Max Picard and Ernst Wiechert. Monatshefte, University of Wisconsin Press, Vol. 42, No. 8, pp. 371-384, 1950.

RAMOS, Fernão (Org.). Teoria contemporânea do cinema. Pós-estruturalismo e filosofia analítica. São Paulo: Editora Senac, 2005. Volume 1. 
Teoria contemporânea do cinema. Documentário e narratividade ficcional. São Paulo: Editora Senac, 2005. Volume 2.

RANCIÈRE, Jacques. Le destin des images. Paris: La fabrique éditions, 2003.

RAYNAUD, Isabelle. Dialogues in Early Silent Screeplays: What Actors Really Said. In: ABEL, Richard; ALTMAN, Rick. The sounds of early cinema. Bloomington e Indianapolis: Indiana Univserdity Press, 2001.

RÉE, Jonathan. Heidegger. História e verdade em Ser e Tempo. Trad. de Oscar de Almeida Marques e Karen Volobuef. São Paulo: Unesp, 2000.

ROQUE, Georges. Qu'est-ce que l'art abstrait? Paris: Gallimard, 2012.

ROUBINE, Jean-Jacques. Introdução às grandes teorias do teatro. Rio de Janeiro: Jorge Zahar, 2003.

SACKS, Oliver. A mente assombrada. Trad. de Laura Teixeira Motta. São Paulo: Cia. das Letras, 2013.

SADOUL, Georges. História do cinema mundial: I volume. Tradução de Sônia Salles Gomes. São Paulo: Livraria Martins Editora, s/d.

SAFATLE, Vladimir. Lacan. São Paulo: Publifolha, 2007.

SALANSKIS, Jean-Michel. Husserl. Trad. de Carlos Alberto Ribeiro de Moura. São Paulo: Estação Liberdade, 2006.

SCHELliNG, F.W.J. Filosofia da arte. Trad. de Márcio Suzuki. São Paulo: Editora da Universidade de São Paulo, 2010.

SCHULTE-SASSE, Jochen. Foreword: theory of modernism versus theory of the avantgarde. In: BÜRGER, Peter. Theory of the avant-garde. Trad. de Michael Shaw. Minneapolis: University of Minnesota Press, 1994.

SCHWARTZ, Vanessa R. "O espectador cinematográfico antes do aparato do cinema: o gosto do público pela realidade na Paris fim-de-século”. In: CHARNEY, Leo; SCHWARTZ, Vanessa. (Org.) O cinema e a invenção da vida moderna. São Paulo: Cosacnaify, 2004.

SODRÉ, Muniz. “Apresentação”. In: FELINTO, Erick. Silêncio de Deus, silêncio dos homens. Babel e a sobrevivência do sagrado na Literatura moderna. Porto Alegre: Sulina, 2008.

SONTAG, Susan. Styles of radical will. London: Picador, 2002.

SOUZA, José Cavalcante de (Org.). Os pré-socráticos. Fragmentos, doxografia e comentários. Trad. de José Cavalcanti de Souza, Anna Lia de Almeida Prado et al. São Paulo: Nova Cutural, 2000. 
SITNEY, P. Adams. The cinema of poetry. Oxford/New York: Oxford University Press, 2015.

SMITH, Murray. Espectatorialidade cinematográfica e a instituição da ficção. In: RAMOS, Fernão (Org.). Teoria contemporânea do cinema. Pós-estruturalismo e filosofia analítica. São Paulo: Editora Senac, 2005. Volume 1.

STARR, Cecile. Busby Berkeley and America's pioneer abstract filmmakers. In: POSNER, Bruce. Unseen cinema. Early American avant-garde film 1893-1941. New York: Anthology Film Archives, 2001.

STEINER, George. Language et silence. Trad. de Lucienne Lotringer. Paris: Éditions du Seuil, 1969.

STRYK, Lucien. "Preface: zen poetry". In: IKEMOTO, Takashi; STRYK, Lucien; TAKAIAMA, Taigan. Zen poems of China and Japan. The crane's bill. Trad. de Lucien Stryk e Takashi Ikemoto. New York: Anchor Books, 1973.

SUZUKI, Márcio. FIlosofia da arte ou arte de filosofar? In: SCHELLING, F.W.J. Filosofia da arte. Trad. de Márcio Suzuki. São Paulo: Editora da Universidade de São Paulo, 2010.

SZALOKY, Melinda. Sounding Images in Silent Film: Visual Acoustics in Murnau's "Sunrise". Cinema Journal, Vol. 41 no. 2 (Winter), pp. 109-131, 2002.

TAKAYAMA, Taigan. "Foreword". In: IKEMOTO, Takashi; STRYK, Lucien; TAKAYAMA, Taigan. Zen poems of China and Japan. The crane's bill. Trad. de Lucien Stryk e Takashi Ikemoto. New York: Anchor Books, 1973.

TARKOVSKY, Andrei. Esculpir o tempo. São Paulo: Martins Fontes, 1998.

TATTERSAL, Ian. "Como nos tornamos humanos". In:Scientific american Brasil edição especial. São Paulo, Duetto Editorial, n. 17, fev. 2005.

TRUFFAUT, François. "Prefácio". In: BAZIN, André. Charlie Chaplin. Trad. de André Telles. Rio de Janeiro: Jorge Zahar, 2006.

WARBURG, Aby. "Recordações de uma viagem à terra dos pueblos". In: MICHAUD, Philippe Alain. Aby Warburg e a imagem em movimento. Trad. de Sibylle Muller. Rio de Janeiro: Contraponto, 2013.

. "Projeto de viagem à América". In: MICHAUD, Philippe Alain. Aby Warburg e a imagem em movimento. Trad. de Sibylle Muller. Rio de Janeiro: Contraponto, 2013.

WONG, Kate. O despertar da mente moderna. Scientific american Brasil edição especial. São Paulo, Duetto Editorial, n. 17, fev. 2005.

WITTGENSTEIN, Ludwig. Investigações filosóficas. Trad. de José Carlos Bruni. São Paulo: Nova Cultural, 1999. 
XAVIER, Ismail (Org.). A experiência do cinema. Rio de Janeiro: Edições Graal, 2003. O discurso cinematográfico. São Paulo: Paz e Terra, 2005.

. O cinema moderno segundo Pasolini. In: KACTUZ, Flávio (Org.). Pasolini ou quando o cinema se faz poesia e política do seu tempo. Rio de Janeiro: Uns Ente Outros, 2014.

YASUTANI-ROSHI. “As conferências: 1 - teoria e prática do zazen”. In: KAPLEAU, Philip. Os três pilares do zen. Ensinamento, prática, iluminação. Trad. de Abadia de Nossa Senhora das Graças. Belo Horizonte: Editora Itatiaia Limitada, 1978.

ZAMBRANO, María. Filosofia y poesia. Cidade do México: FCE, 1996. 


\section{FILMOGRAFIA INCLUÍDA NO PEN DRIVE}

\section{Capítulo 2}

Na farra (The Rounders, Charles Chaplin, 1914)

Carlitos e Mabel se Casam (Mabel's Married Life, Charles Chaplin, 1914)

Dois Heróis (The knockout, Mack Sennet, 1914)

Carlitos e as Salsichas (Mabel's busy day, Mabel Normand, 1914)

Rua da paz (Easy Street, Charles Chaplin, 1917)

O vagabundo (The tramp, Charles Chaplin, 1915)

Os vampiros, episódio 1 - A cabeça decepada (Les vampires - La tête coupée, Louis

Feuillade, 1915)

Os vampiros, episódio 2 - O anel que mata (Les vampires - La bague qui tue, Louis

Feuillade, 1915)

Os vampiros, episódio 3 - O criptograma vermelho (Les vampires - Le criptogramme rouge, Louis Feuillade, 1915)

Ivan, o terrível, Parte 1 (Ivan Grozniy, Parte 1, 1944, Sergei Eisenstein)

Moana (Robert Flaherty, 1926)

\section{Capítulo 3}

Nanook, o esquimó (Nanook of the North, Robert Flaherty, 1922)

O boulevard do crime (Les enfants du paradis, Marcel Carné, 1945)

O gabinete das figuras de cera (Das wachsfigurenkabinett, Paul Leni, 1924)

O gabinete do Dr Caligari (Das Cabinet des Dr. Caligari, Robert Wiene, 1919)

\section{Capítulo 4}

O grande assalto de trem (The great train robbery, Edwin S. Porter, 1903)

The big swallow (James Williamson, 1901)

A ponte (De brug, Joris Ivens, 1928)

Fantômas I: À l'ombre de la guillotine (Louis Feuillade, 1913)

\section{Capítulo 5}


Retrato de um homem jovem (Portrait of a young man, Henwar Rodakiewicz, 1931) The life and death of 9413 - A Hollywood extra (1928, Slavo Vorkapitch e Robert Florey)

Rose Hobart (Joseph Cornell, 1936)

Children's party (Joseph Cornell, 1938)

Cotillion (Joseph Cornell, 1938)

The midnight party (Joseph Cornell, 1938)

24 dollar island (Robert Flaherty, 1926)

H20 (Ralph Steiner, 1929)

A Day in Santa Fe (Lynn Rigs, 1931) 